doso en la 1

ar ejemplos a

is funcionalidac uso, dependiende encarnan los conceptos detr por e $\Lambda$ influ
$\mathrm{Pe}$ infin:

Las formas $d r$ oceso de sig ialidad .

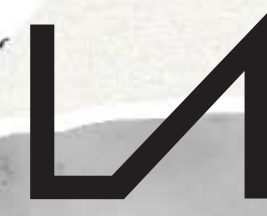

R E V I S A
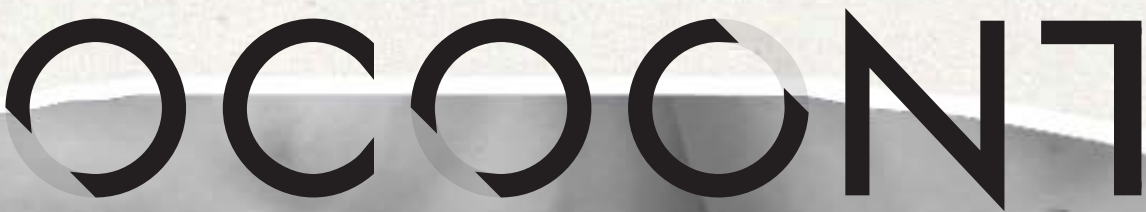

D $E$

No $6 \cdot 2019 \cdot$ ISSN 2386-8449

"El producto del diseñador es un proyecto, el estado previo de un objeto", Entrevista con Norberto Chaves, por Fernando Infante

El papel de la investigación y la teoría en diseño. Una conversación abierta, por Fernando Infante y María Jesús Godoy

UT PICTURA POESIS

Abandonar la escritura. Poesía experimental y manifiesta, Ignacio Gómez de Liaño

PANORAMA: FILOSOFÍA DEL DISEÑO Sección coordinada por Fernando Infante y María Jesús Godoy

Pensar el diseño, Fernando Infante y María Jesús Godoy (Coordinadores)

TEXTOS INVITADOS

Estatus y estado del điseño más allá del objeto, Pedro Medina Reinón

Mar de Nubes, Cuerpo de Cristal, Dionisio González

ARTÍCULOS

Understanding Design Aesthetics beyond Functional Beauty accounts, Lucía Jiménez Sánchez

Estética y diseño industrial: debates y controversias, Joan M. Marín

Del ornamento al delito. El diseño y la sociedad en Charles Baudelaire y Adolf Loos, Jorge López Lloret

When is Architecture not Design? Saul Fisher

Diseño y habitabilidad: una aproximación basada en los lenguajes de patrones, Antonio Hidalgo Pérez

Marcel Breuer: un diseñador global. Experiencias en el ámbito de la vivienda prefabricada, Salvador J. Sanchis, Ignacio Peris y Pedro Ponce Diseño y artes escénicas: el papel de Oskar Schlemmer en Das Triadische Ballett y la actualidad de la Bauhaus, Milagros García Vázquez Lo performativo en prácticas de arte y diseño actuales vinculadas a procesos de innovación social. El caso de La Venezia che non si vede y de La borda, Tània Costa Gomez

Articulaciones de la estética y el diseño. El caso de la evaluación a partir de la investigación dirigida en la carrera de diseño escénico de la Universidad de las Artes de Cuba, Mara Rodríguez Venegas y Xiomara Romero Rojas

SUPLEMENTO

El diseño, la ciudad y un lápiz de labios, Mercedes Espiau, Mar García Ranedo y Alejandro Rojas mas. 


\section{UつCつCNTE}

No $6 \cdot 2019 \cdot \operatorname{ISSN} 2386-8449 \cdot$ DOI 10.7203/LAOCOONTE.5.15381

https://ojs.uv.es/index.php/LAOCOONTE/index

COORDINACIÓN EDITORIAL

Anacleto Ferrer (Universitat de València)

Francesc Jesús Hernàndez i Dobon (Universitat de València)

Fernando Infante del Rosal (Universidad de Sevilla)

SECRETARÍA DE REDACCIÓN

Lurdes Valls Crespo (Universitat de València)

Vanessa Vidal Mayor (Universitat de València)

COMITÉ DE REDACCIÓN

Tamara Djermanović (Universitat Pompeu Fabra), Rosa Fernández Gómez (Universidad de Málaga), Anacleto Ferrer (Universitat de València), Ilia Galán (Universidad Carlos III), Ana María García Varas (Universidad de Zaragoza), María Jesús Godoy (Universidad de Sevilla), Fernando Infante del Rosal (Universidad de Sevilla), Miguel Ángel Rivero (Universidad de Sevilla), Miguel Salmerón (Universidad Autónoma de Madrid), Gerard Vilar (Universitat Autònoma de Barcelona).

COMITÉ CIENTÍFICO INTERNACIONAL

Rafael Argullol* (Universitat Pompeu Fabra), Luis Camnitzer (State University of New York), José Bragança de Miranda (Universidade Nova de Lisboa), Bruno Corà (Università di Cassino), Román de la Calle* (Universitat de València), Eberhard Geisler (Johannes Gutenberg-Universität Mainz), José Jiménez* (Universidad Autónoma de Madrid), Jacinto Lageira (Université Paris 1 Panthéon-Sorbonne), Bernard Marcadé (École Nationale Supérieure d'Arts de Paris-Cergy), Elena Oliveras (Universidad de Buenos Aires y Universidad del Salvador), Pablo Oyarzun (Universidad de Chile), Francisca Pérez Carreño* (Universidad de Murcia), Bernardo Pinto de Almeida (Faculdade de Belas Artes da Universidade do Porto), Luigi Russo (Università di Palermo), Georges Sebbag (Doctor en Filosofía e historiador del surrealismo), Zoltán Somhegyi (University of Sharjah, United Arab Emirates), Robert Wilkinson (Open University-Scotland), Martín Zubiria (Universidad Nacional de Cuyo). *Miembros de la Sociedad Española de Estética y Teoría de las Artes, SEyTA

\begin{tabular}{lll}
\hline DIRECCIÓN DE ARTE & REVISIÓN DE TEXTOS & TRANSCRIPCIÓN DE TEXTOS \\
El golpe. Cultura del entorno & Antonio Cuesta & Álvaro G. Serna
\end{tabular}

(cc) BY Excepto que se establezca de otra forma, el contenido de esta revista cuenta con una licencia Creative Commons Atribución 3.0 España, que puede consultarse en http://creativecommons.org/licenses/by/3.0/es/deed.es

EDITA

\section{SEyTA.}

CON LA COLABORACIÓN DE

\begin{tabular}{|c|c|c|c|}
\hline $\begin{array}{l}\text { VNIVERSITAT } \\
\text { ID VALENCIA } \\
\text { Institut a Creativitat } \\
\text { i|nnovacions Educatives }\end{array}$ & $\begin{array}{l}\text { VNIVERSITAT } \\
\text { IE ÖVALENCIA Departament de Filosofia }\end{array}$ & 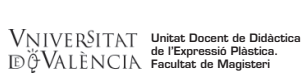 & \\
\hline $\begin{array}{l}\text { DEPARTAMENTO DE ESTÉTICA } \\
\text { E HISTORIA DE LA FILOSOFIA }\end{array}$ & $\frac{\text { UAW }}{\frac{\text { UNIVERSIDAD AUTONOMA }}{\text { DE MADRID }}}$ & $\begin{array}{l}\text { AB } \\
\text { Universitat Autònoma } \\
\text { de Barcelona }\end{array}$ & 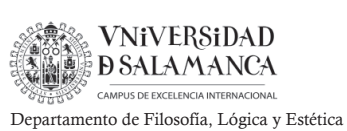 \\
\hline
\end{tabular}

LAOCOONTE aparece en los catálogos: 


\section{LつCつCN7E}

"Cuanto más penetramos en una obra de arte más pensamientos suscita ella en nosotros, y cuantos más pensamientos suscite tanto más debemos creer que estamos penetrando en ella".

G. E. Lessing, Laocoonte o los límites entre la pintura y la poesía, 1766.

Vo hay cól.

létodo, de pen.

:ión en general. Ith

zar la forma para el $\mathrm{n}$.

eptual por las orígenes

la, el objeto, la exposición

storia, porque existe en el $\mathrm{m}$

das sus raíces. Desde alli cc _. panoram

n conceptual y donde el émencia del con 'iseñado, como es el a al objeto y el di $\begin{array}{ll}\text { igen } \mathrm{de}^{\text {to }} \text { la inmer } & \text { tolvidada, o comc } \\ \text { trozo de madera ar }\end{array}$ a manera dorm comunicar ene nundo. Seguin? sngo en manos te el método $C$ les. A partir c teria prima $\mathrm{p}_{\mathbf{c}}$

'xto se puede:

¿ño, en proyea

amientos de $\mathrm{u}$

a conscie-

.)

en la publicación jue "plos de la impor te las nalidades porqu ura un ${ }^{2}$ diendo de qui zenerar $\mathrm{u}$ ción de nr? lne

in-

n-

is.

le http:,

le crear visualidades. A partir de.

ellas la propia materia prima para un en que desde un texto se puede generar $u_{11}$ i

Pensar en diseño, en proyección de nue

posibles comportamientos de una colecti

presente como una consciencia del hecho que estamos elaborando, significac

nuestro entorno (..)

Cardoso, R. C. Rafael. (2014). Design para um mundo complexo. Sãc asil: Cosac Naify. 


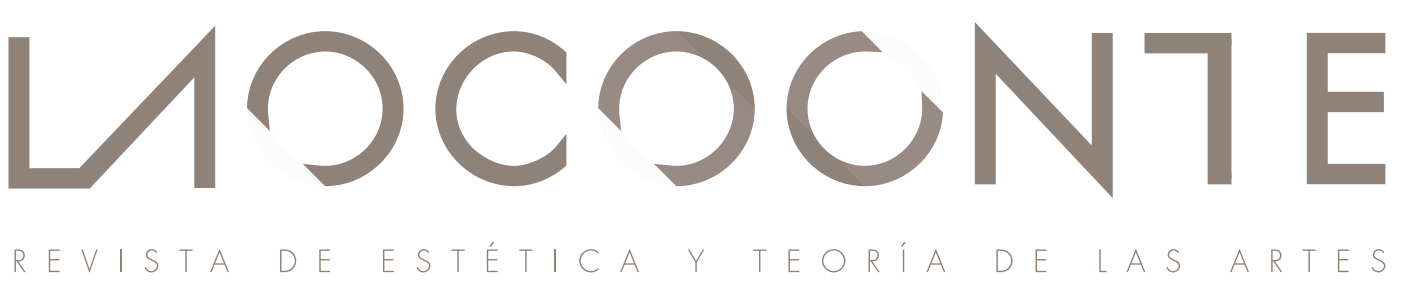

$\mathrm{N}^{\circ} 6 \cdot 2019$

PRESENTACIÓN

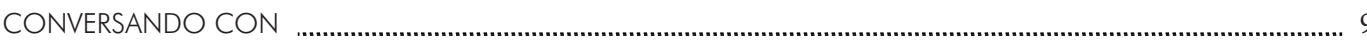

"El producto del diseñador es un proyecto, el estado previo de un objeto", Entrevista con Norberto Chaves,

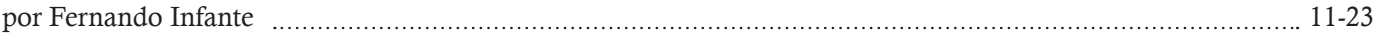

El papel de la investigación y la teoría en diseño. Una conversación abierta, por Fernando Infante

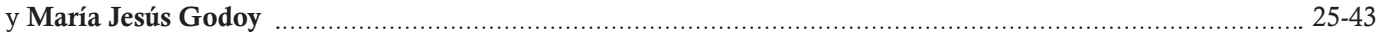

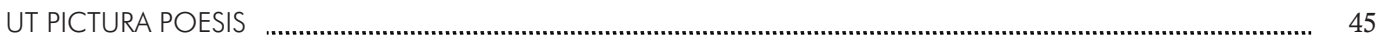

Abandonar la escritura. Poesía experimental y manifiesta, Ignacio Gómez de Liaño ................................................ 47-95

Imágenes de Laocoonte n. 6, de Isadora Gonzaga ................................................................................................... 96-97

PANORAMA

FILOSOFÍA DEL DISEÑO

Pensar el diseño, Fernando Infante y María Jesús Godoy (Coordinadores) .............................................. 101-105

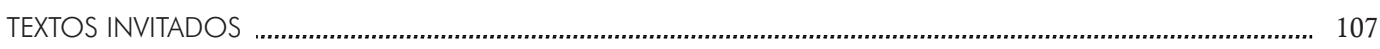

Estatus y estado del diseño más allá del objeto, Pedro Medina Reinón . ................................................... 109-125

Mar de Nubes. Cuerpo de Cristal, Dionisio González .............................................................................. 127-133

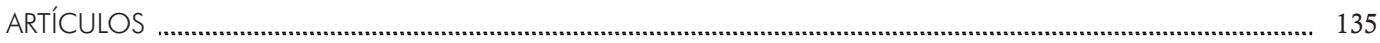

Understanding Design Aesthetics beyond Functional Beauty accounts, Lucía Jiménez Sánchez ................. 137-149

Estética y diseño industrial: debates y controversias, Joan M. Marín _...................................................... 150-164

Del ornamento al delito. El diseño y la sociedad en Charles Baudelaire y Adolf Loos, Jorge López Lloret ... $165-182$

When is Architecture not Design? Saul Fisher ……............................................................................. 183-198

Diseño y habitabilidad: una aproximación basada en los lenguajes de patrones, Antonio Hidalgo Pérez ...... 199-215

Marcel Breuer: un diseñador global. Experiencias en el ámbito de la vivienda prefabricada,

Salvador José Sanchis, Ignacio Peris y Pedro Ponce

Diseño y artes escénicas: el papel de Oskar Schlemmer en Das Triadische Ballett y la actualidad de la Bauhaus, Milagros García Vázquez

Lo performativo en prácticas de arte y diseño actuales vinculadas a procesos de innovación social.

El caso de La Venezia che non si vede y de La borda, Tània Costa Gomez

Articulaciones de la estética y el diseño. El caso de la evaluación a partir de la investigación dirigida en la carrera de diseño escénico de la Universidad de las Artes de Cuba, Mara Rodríguez Venegas

y Xiomara Romero Rojas

SUPLEMENTO 
Walter Gropius. La vida del fundador de la Bauhaus, Jorge Martínez Alcaide

¿Qué significa pensar la política desde la estética? Àger Pérez Casanovas

Ideologías estéticas en los orígenes de la pintura moderna, José Luis Plaza Chillón 300-303

Sobre a estética, Luis Carlos Pereira

Músicas populares. Sociedad y territorio: Sinergias entre investigación y docencia, Mar Aleixandre Badenes.

307-309

La necesidad de la mirada antropológica sobre la literatura, Pablo de Benito David

A propósito de Chandler, o la novela policíaca como tratado filosófico, Juan Evaristo Valls Boix

Videre aude!, Anacleto Ferrer

La inaplazable memoria del dolor y el sufrimiento, Antonio Notario Ruiz

La alargada sombra de la pintura, Raquel Baixauli

Sondear la maravilla, Juan Evaristo Valls Boix

... Y lo sabes, Marc Hernández Montoro

Arqueologías de la modernidad en las artes. Ensayo estético, Carlota Fernández-Jáuregui Rojas

Estética de la Instalación, Luis Cemillán Casis

La Herencia de otra época, María Jesús Godoy Domínguez

Del Theatrum Mundi al Gran Vidrio, Miguel Salmerón Infante

Imágenes de Isadora Gonzaga.

Fotografía de portada de Tamara Djermanovic intervenida por Isadora Gonzaga.

Los coordinadores de la sección Panorama: Filosofia del diseño agradecen

a Antonio Molina Flores su colaboración. 
_ estan sobres

al hace surgir la form:

escifra una lengua olvidada

1 ea forma fara el mundo ....m.nim ju una unestigación coucupe o de los rignificados: dur. 'la, lactposicion, el ' porque, cual is su ho 'e o aun

- Descle

x la ovi buto quer i ngúi,ge enste ua poinco anime uin co rents iral. I ueco la ex ca olv adc, oc nay $x$ la aple wi w ia fus juso, cormer ualcias is J Jielige

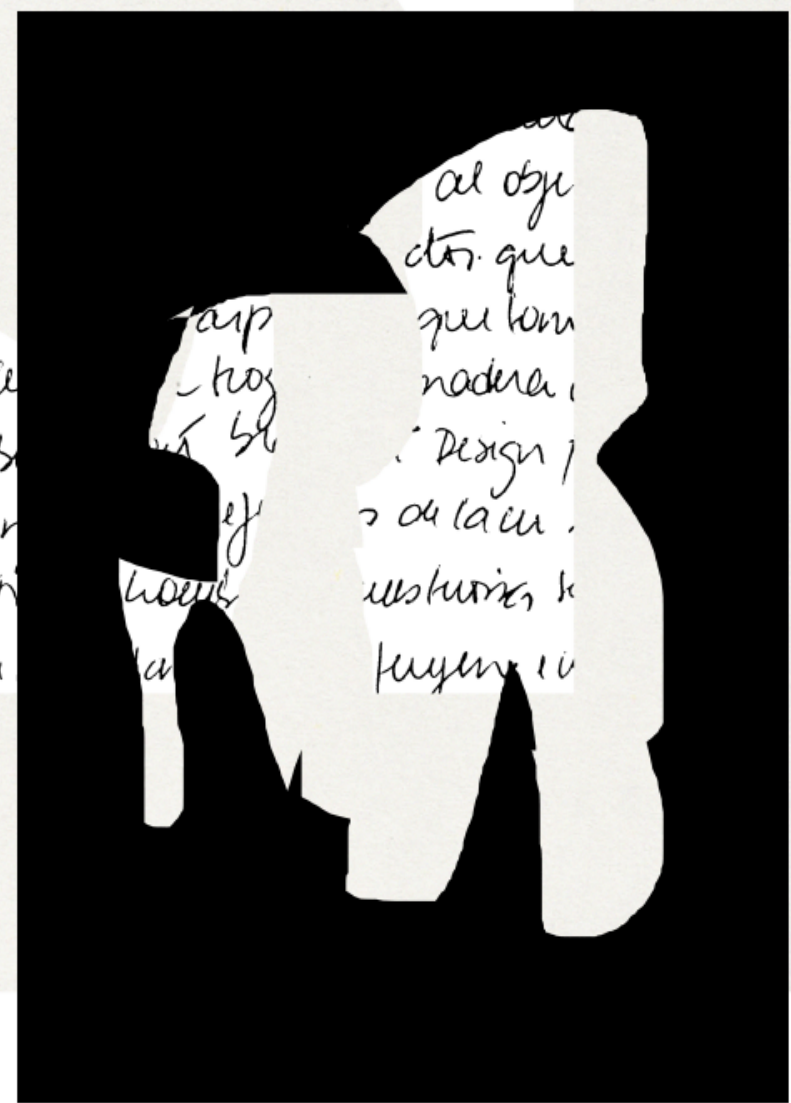


Según la tradición numerológica del judaísmo, la estrella de seis puntas, o Sello de Salomón, da cuenta de la conjunción de dos opuestos. El triángulo erguido expresa la naturaleza divina y el invertido la condición humana. El seis, que también es el número de días en que según la Biblia fue creado el mundo, simboliza, por esta razón, el encuentro, no siempre feliz, entre el cielo y la tierra, entre lo de arriba y lo de abajo: entre nuestros deseos y los imperativos materiales que los limitan.

Valga este breve preámbulo esotérico de excusa que justifique por qué a partir de esta sexta entrega desaparece la sección miscelánea de Laocoonte: después de seis años, la revista ha necesitado un reajuste, so pena de morir de éxito. "Se puede caer en la altura, como en el abismo", advertía ya Hölderlin. Y sabía bien lo que decía. Desde nuestra exigua redacción, no podíamos gestionar la cantidad de artículos que nos llegaban para evaluar y decidimos ya en diciembre del año pasado limitar la recepción de textos a la sección monográfica panorama. Así fue comunicado en la presentación del número cinco de Laocoonte y, después, en febrero de este año, a la comunidad científica de los estetas y teóricos de las artes a través de la página web de SEyTA (www.seyta.org).

Nuestra publicación ha recibido en esta ocasión quince trabajos redactados en español, portugués e inglés; de los cuales, tras un exigente proceso de evaluación y selección, solo nueve verán la luz. Laocoonte sale, una vez más, al encuentro de los lectores cargada de propuestas sugerentes en su amplio bloque no sometido a arbitraje, que alberga un apartado de creación (con una gavilla de textos inéditos del filósofo, narrador y poeta Ignacio Gómez de Liaño), dos entrevistas (una al docente, teórico y crítico de la arquitectura y el diseño Norberto Chaves; otra a varios filósofos y estetas con una dedicación disciplinaria a ese mismo ámbito de interés), dos textos invitados (uno de Pedro Medina, Director del Área Cultural del Istituto Europeo di Design de Madrid y otro del artista Dionisio González, "una especie de sanador de ciudades, arquitecto de los deseos o mago de la habitabilidad", según el periódico El País), una sección especial en la que Mecha Espiau (historiadora del arte), Mar G. Ranedo (artista) y Alejandro Rojas (diseñador) escriben sobre el impacto de la barra de labios Margaux en la ciudad, desde los diferentes puntos de vista de sus respectivas formaciones, $y$, finalmente, una variada panoplia de reseñas de libros. La parte gráfica esta vez ha corrido a cargo de la diseñadora brasileña Isadora Gonzaga. El otro bloque, estrictamente académico, de Panorama, está dedicado a la Filosofía del diseño. A propósito del centenario de la Bauhaus y ha sido coordinado por María Jesús Godoy y Fernando Infante del Rosal, del Departamento de Estética e Historia de la Filosofía de la Universidad de Sevilla, autores también del texto introductorio "Pensar el diseño". Siguiendo las rutinas de las revistas académicas al uso, cada uno de los trabajos recibidos en esta sección ha sido sometido a un proceso de arbitraje ciego por dos informantes, los cuales se han ocupado de evaluar el contenido y la metodología del artículo. Los autores han recibido los informes redactados por los 
revisores, indicándoles -si así era el caso-la manera de subsanar deficiencias o realizar los cambios solicitados. Los informantes externos han sido seleccionados de acuerdo a un criterio de excelencia académica e investigadora, y tomando en consideración que su ámbito de especialización se correspondiese con las temáticas abordadas en cada uno de los artículos.

El asesinato de los líderes de la Liga Espartaquista, Karl Liebknecht y Rosa Luxemburg, por los cuerpos francos de voluntarios ultraderechistas, en enero de 1919, y la quema de libros, que antecedió a la generalizada persecución de sus autores, en la Bebelplatz de Berlín, en mayo de 1933, marcan simbólicamente el alfa y omega de la República de Weimar. Este período de entreguerras supuso un despliegue cultural tan impresionante que centró la atención mundial sobre la desvencijada Alemania en los ámbitos de la literatura, la filosofía, el periodismo, el cine, la pintura, la música, las artes escénicas, la arquitectura y el diseño.

Ante tan extraordinaria situación, el sociólogo Karl Mannheim, uno de sus supervivientes, pronosticó en 1947, antes de morir en Londres, donde se había exiliado, que en los años venideros Weimar sería considerada como una nueva época de Pericles. Eso sí -cabe añadir- mucho más breve: duró la mitad (apenas quince años) $\mathrm{y}$, a diferencia de la democrática Atenas de la edad de oro, fue profundamente inestable.

En los terrenos de la actividad cultural y de la creatividad artística, Weimar vivió una efervescencia sin precedentes. Tanto en las ciencias físico-naturales, con un Einstein a la cabeza que había celebrado la llegada de la República, como en el psicoanálisis o la teoría social, gracias a la Escuela de Fráncfort, se desarrollaron nuevas ideas. Pero fue, sobre todo, en el ámbito de las diferentes artes donde se produjo la eclosión más llamativa. En arquitectura, la escuela de la Bauhaus, bajo la dirección de Walter Gropius, combinó criterios estéticos y utilitarios para crear estilos arquitectónicos, de decoración de interiores y de mobiliario que eludían lo ornamental en su búsqueda por lo esencial. Su ascetismo, del que arranca el nuevo espíritu del "menos es más", es heredero de Adolf Loos.

A la comprensión de los cambios estéticos y sociales propiciados por la Bauhaus, sus derivas, consecuencias y contrapuntos actuales en el campo del diseño hemos querido dedicar este sexto número de Laocoonte, ahora que los centenarios vientos de Weimar parecen soplar de nuevo en más de un sentido.

A los sellos de calidad de Laocoonte hay que añadir uno nuevo: el de REDIB (Red Iberoamericana de Innovación y Conocimiento Científico), la plataforma de agregación de contenidos científicos y académicos en formato electrónico, formada conjuntamente por el Consejo Superior de Investigaciones Científicas y Universia, la mayor Red de Universidades Iberoamericanas, cuyo objetivo primordial es la "Difusión de la Ciencia Iberoamericana". Al patrocinio económico de SEyTA, la Universitat de València, la Universidad Autónoma de Madrid, la Universitat Autònoma de Barcelona y la Universidad de Sevilla, se suma, a partir de este número, el de la Universidad de Salamanca.

Tanto la información de las actividades que organiza o en las que participa SEyTA (Sociedad Española de Estética y Teoría de las Artes) como el Call for Papers del número siete de Laocoonte (dedicado a La actualidad de la estética de Theodor W. Adorno y coordinado por las profesoras Rosa María Benéitez, de la Universidad de Salamanca, y Vanessa Vidal, de la Universitat de València) se hacen públicos en la página web de SEyTA [www.seyta.org]. 
un proceso de significado, es

origen $\mathrm{Cc}$ allí cojo el hilo del

a ser diser

el está ubicado. Cuć

materialidad y lo que nuestra

sobrevolana

1 panorama político, encarnan los conceptos detrás

hace

:- e surgn

Hablo también de una construc c y se tescifra una le y se la aplica a

Así, Card comienza a da y cuestiona sus significado y us

use:

"I un pro materia encarn

Hablo tam en conjunto co entrelazan en

Pensar pa infinitamente encontrar su $\mathrm{p}$ hacer conscien de las formas $\mathrm{c}$ hago con lo qu haciéndose pre de crear $r$ e"

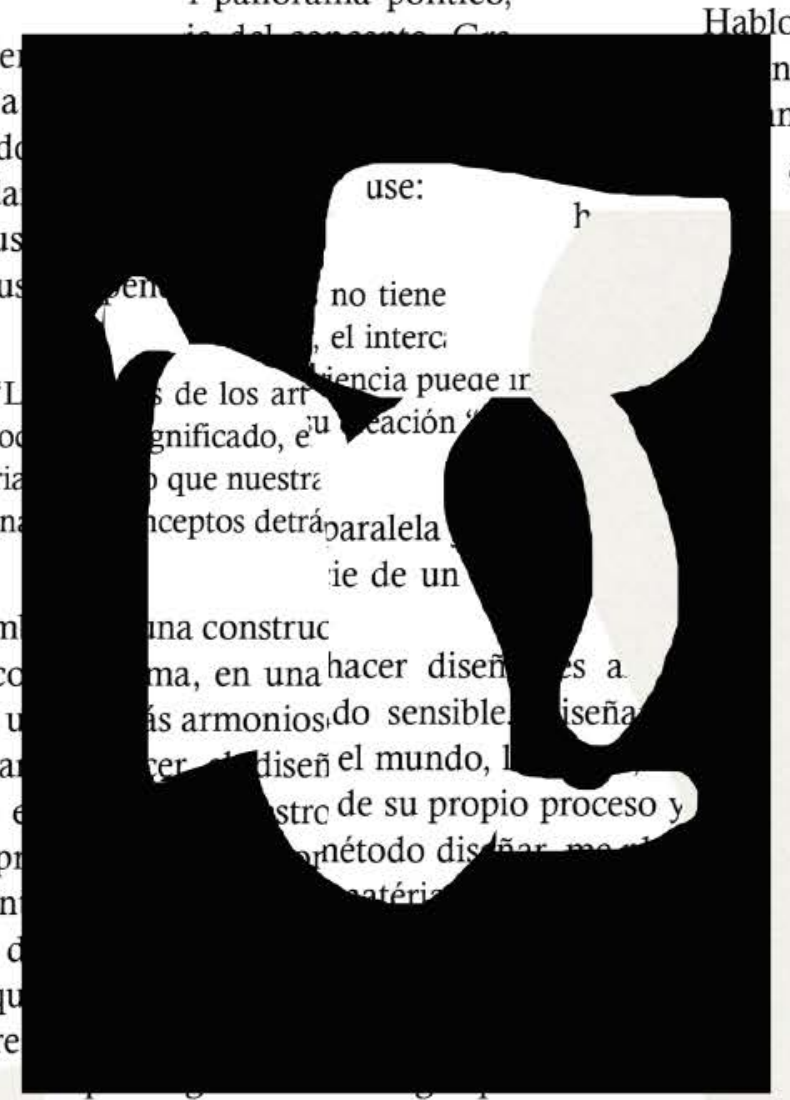

en proyección de nuevas o antiguas formas. tos de una colectividad. La responsab riencia del hecho que estamos elaborar ${ }^{\text {2n }}$ nto con la forma, en 1 . n en un compás -del mundo. Sc tengo en má te el método 's. A partir d ia prima par. ; rormas

\section{uerpo}

1 historia, porq ncadas sus raí rigen conceptu a ser diseñado, sobrevolando 1 : hace surgir la descifra una ${ }^{\prime}$ y se la aplir Así, ' comien

.. $\mathrm{d}$ a dar eje $\mathrm{e}_{\text {. }}$ y cuestiona sus funcic significado y uso, dep

\section{MDCOCN7E "Design para um $r$}

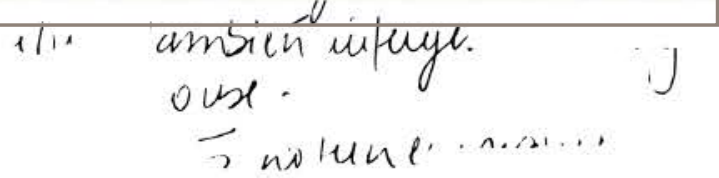


. $\mathrm{ncaa}_{4}$

origen $\mathrm{Cc}$

a ser diser

sobrevolana el mundo sensible c

allí cojo el hilo del

el está ubicado. Cú

un proceso de significado, es materialidad y lo que nuestra encarnan los conceptos detrás

1 panorama político,

hace

d

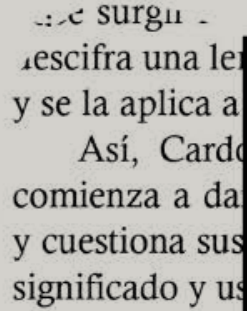

- : c surg -escifra una le y se la aplica a

Así, Card comienza a da y cuestiona sus significado y us

un prod
materia
encarn
Hablo tam
en conjunto co
entrelazan en y
Pensar pa
infinitamente
encontrar su pr
hacer conscien
de las formas o
hago con lo qu
haciéndose pre
de crear r.
on

Hablo también de una construc nto con la forma, en $r$ n en un compás -.del mundo. Sc tengo en má te el método 's. A partir d ia prima par. i rormas

\section{uerpo}

1 historia, porq ncadas sus raí rigen conceptu a ser diseñado, sobrevolando 1 : hace surgir la descifra una ${ }^{\prime}$ y se la aplir Así, ' comien

. d a dar eje..

en proyección de nuevas o antiguas formas. tos de una colectividad. La responsab. siencia del hecho que estamos elaborar ${ }_{\text {es }}^{\text {?n }}$ y cuestiona sus funcic significado y uso, dep ilida

1) Design para um $r$

$$
\begin{aligned}
& \text { 11. ambien infuye. } \\
& \text { ove. } \\
& \rightarrow \text { notume'.n..... }
\end{aligned}
$$




\section{"El producto del diseñador es un proyecto, el estado previo de un objeto"}

\section{Entrevista con Norberto Chaves}

\section{por Fernando Infante del Rosal ${ }^{*}$}

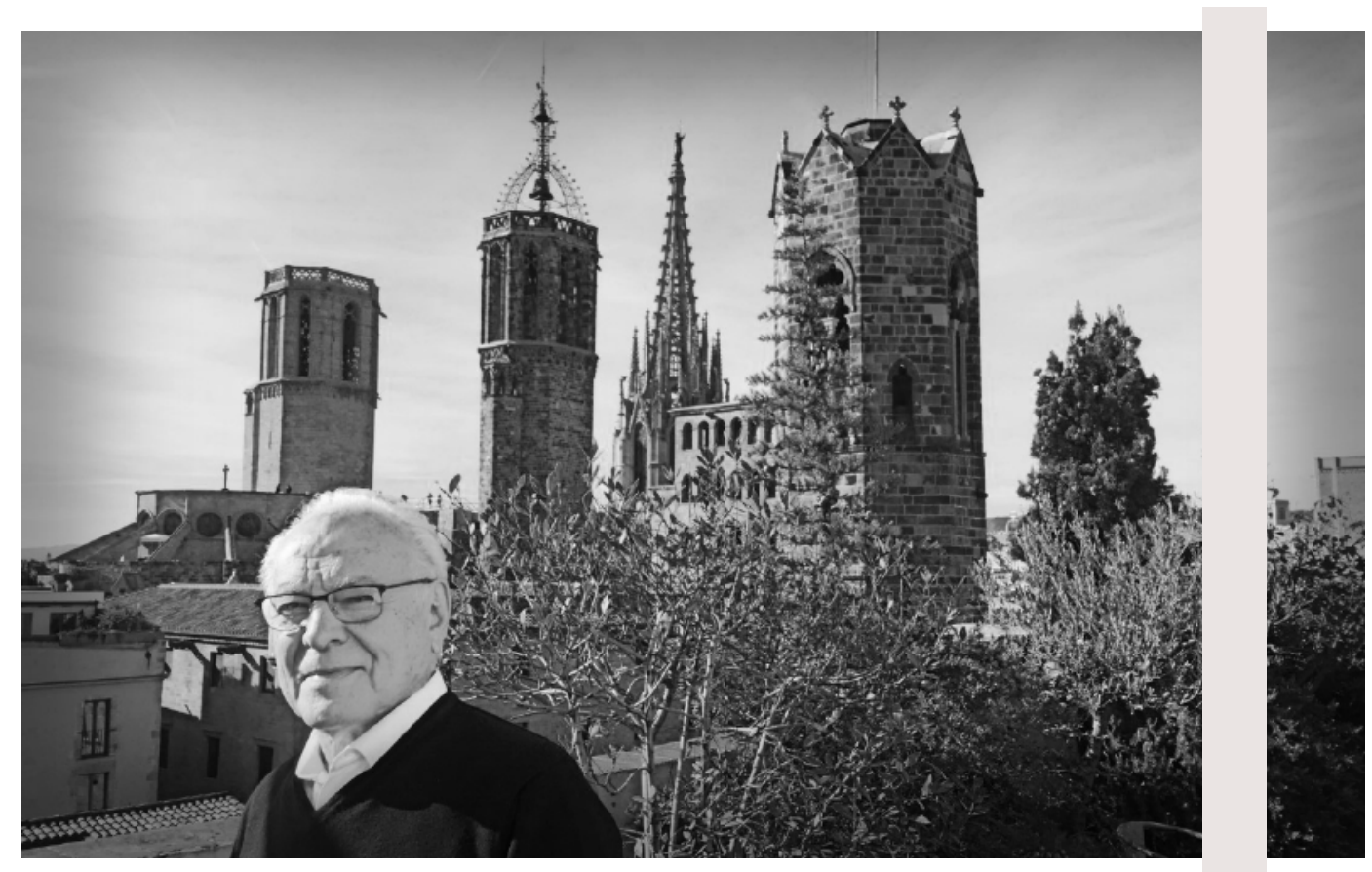

Norberto Chaves nació en la ciudad de Avellaneda, provincia de Buenos Aires, en 1942. En 1976 emigró huyendo de la dictadura y vive en Barcelona desde 1977. Se siente representante fiel de la generación del 68 y "subproducto de la transición democrática española". ${ }^{1}$ Desde entonces ha sido uno de los principales consultores y asesores en imagen y comunicación de nuestro país. Su actividad docente sigue siendo intensa en el ámbito internacional, y su experiencia y sus ideas son reclamadas tanto en contextos académicos como profesionales. Es autor de obras fundamentales sobre diseño, algunas de ellas son referentes en la enseñanza y en la profesión, especialmente las que tratan sobre identidad corporativa. Pero su escritura también se ha extendido regularmente al ensayo, a la reflexión cultural y social, a la poesía, y, de una manera muy sustanciosa, al aforismo. Llama la atención su capacidad -gráfica- para aprehender verdades en lo

1 Norberto Chaves. 2015. Desafueros. Literatura de emergencia para una época sin tiempo, Madrid: Punto de vista Editores, p. 4. 
breve: "Toda estética es una lectura de la estética"2 dice en uno de sus aforismos.

$\mathrm{Su}$ perspectiva es amplia porque ha convivido durante mucho tiempo con la profesión del diseño, con la docencia en diseño, con la industria, el mercado, la reflexión. Como él mismo cuenta en esta entrevista, sus inicios estuvieron unidos a la semiología de la arquitectura. De aquel contexto semiótico conserva su preferencia por la exactitud y el rigor, frente a las formulaciones laxas y excesivamente ambiguas ("Hay dos tipos de idealismo: el que desprecia la realidad y el que pretende explicarla"3). En su profesión y en sus escritos ha mostrado siempre dos compromisos, que a una mente simple podrían parecerle antagónicos: con el programa al que debe ajustarse todo diseño, un programa determinado por el encargo y un contexto que es el del mercado; y con una "voluntad de despejar lo ideológico" que lo ha llevado siempre a militar por las causas sociales.

En su casa de Barcelona, a las doce, se alternan las puntuales campanas de la Catedral con el sonido intermitente del trasiego de Via Laietana. Tras hablar de América Sánchez, de Yves Zimmermann, que, como él, hacen una parte significativa de la historia real del diseño -invisible para quienes viven en las nuevas y pancistas consignas del diseño-, empezamos la entrevista.

- Fernando Infante: El diseño es una realidad amplia que media en la manera en que accedemos al entorno, a los objetos, a las imágenes y al conocimiento de los demás. Puede entenderse, por eso, como un modo de conformación de la realidad, como la manera en que hacemos el mundo y nos hacemos nosotros mismos en él. Teniendo en cuenta esta extensa presencia y acción del diseño, ¿considera que el pensamiento que se le ha dedicado por parte de la filosofía refleja esa importancia?

- Norberto Chaves: No me consta que la filosofía, en sentido estricto, haya asumido al diseño como objeto de reflexión, ni creo que le competa hacerlo. Sí lo han hecho la sociología, la antropología y la semiología, con distinto grado de profundidad. Yo inicié esta fusión justamente con la materia semiología arquitectónica; venía de una formación en humanidades, y luego en arquitectura, y ahí se produjo el click.

En la sociedad industrial, la mayor parte del entorno objetual es fruto del diseño, en tanto instrumento inevitable de la producción, $\mathrm{y}$, por lo tanto, como instancia en la que se define la forma de las cosas, no sólo su aspecto o estética sino la totalidad de sus características. En tanto objeto de análisis, al diseño le compete un abordaje socioeconómico, sociológico, o antropológico: una suerte de etnografía de lo industrial.

Me parece que queda claro. La filosofía -yo tengo cierta formación- tiene otros interrogantes que formular. Un abordaje filosófico sería excesivo, es querer asignarle al diseño una dimensión de la que carece. En cambio, un estudio etnográfico sería de desear, algo como, pongamos, "la etnografía de la sociedad industrial". Sería un enfoque original. Yo entré por el lado de la semiología, cuando descubrimos, joh, sorpresa!, la revolución ideológica de que todo significa, y que la arquitectura porta un significado. (Por aquella época, en la Universidad de Buenos Aires tuvimos el privilegio de recibir la visita de Umberto Eco, y yo, que era muy jovencito, hablé por parte de los estudiantes).

2 Ibid. p. 74.

3 Ibid. p. 141. 
- Fernando Infante: En el caso de las artes, la teoría ha servido siempre para consolidar el espacio de dichas artes y para darles presencia en otro espacio, el de la reflexión estética o filosófica. Aunque se ha dicho muchas veces que el arte no necesita de la teoría para darse, parece cierto que la teoría estética ha venido a reforzar la acción del arte sumando su acción propia. Esto ha favorecido, entre otras cosas, la configuración del arte como ámbito simbólico de la libertad. ¿Confía en que la teoría del diseño puede alcanzar alguna vez una dimensión similar?

- Norberto Chaves: Yo creo que no, por lo siguiente: en el caso del diseño, que no es una forma de arte sino una etapa en el proceso de producción, la teoría tiene varias dimensiones, cada una con su función específica.

En la primera, podríamos hablar de una teoría normativa. Aunque, en rigor, la palabra "teoría" resulta aquí excesiva; son más bien sistemas de normas, desarrolladas en el seno de la disciplina, que regulan la labor proyectual con el fin de potenciar la calidad de los resultados en todos los planos: funcional, estético, tecnológico, económico, cultural, etc.

Luego disponemos de ciertas metodologías también desarrolladas en el campo del diseño cuyo objetivo es regular los procesos o secuencias proyectuales a fin de garantizar el fluidizarlos, evitando callejones sin salida y vueltas atrás. Estamos siempre dentro del pensamiento del diseño. A la metodología -o las metodologías, porque no hay una universal, no hay nada universal en el diseño- podríamos asignarle el carácter de teoría.

En el tercer nivel hablamos de una ideología (que tampoco se puede decir que sea una teoría, pero podríamos tolerarlo). Se trata de sistemas de valores, siempre específicos -no hay una ideología del diseño, nunca universal- que orientan los programas de diseño y sus objetivos conforme a unos principios éticos, estéticos y sociales determinados.

Ahora bien, aquí hay un salto cualitativo: una auténtica teoría del diseño, es decir, una teoría explicativa, que no serviría para nada más que para explicar -como, por ejemplo, una semiótica-, una teoría pura del diseño, pues, tendría como función explicar objetivamente qué es lo que el diseño es, su estructura y su modo de relación con la sociedad. Como diría Saussure en el caso del signo, "la vida del signo en el seno de la vida social". Pues aquí sería: "la vida de esta praxis dentro de la práctica social". Eso es una teoría del diseño en sentido estricto, que define a su objeto, el diseño, sus características estructurales universales, independientemente de sus variantes temáticas y axiológicas.

Y, finalmente, de manera absolutamente externa, está la ciencia, como la citada semiología de la arquitectura. Son ciencias -ciencias sociales normalmente-que toman el diseño como objeto de análisis y producen conocimientos objetivos sobre alguno de sus planos, con lo que nunca hay un conocimiento global.

- Fernando Infante: Es evidente que el diseño es una práctica que requiere gran capacidad de observación, de análisis y de articulación conceptual por parte de quienes se dedican a él profesionalmente. Cualquier diseñador o diseñadora genera, con el tiempo, sus propias "poéticas" y sus propios "discursos", aunque muy pocos se han dedicado a dar a estos modos reflexivos la forma de la escritura. ¿Es responsabilidad de los diseñadores proyectar una mayor reflexión acerca del diseño?, ¿han de dedicar esfuerzo a la expresión escrita de esas "poéticas" y de esos "discursos" en los que se desenvuelven (como sí hacen, por tradición, una parte de los diseñadores: los arquitectos)? 
- Norberto Chaves: El diseño es una artesanía. Su lugar es el taller y su reflexión específica se concentra, como toda artesanía, en los tres primeros niveles de teoría que he citado. Sólo anecdóticamente, y en función de apetencias y capacidades individuales ajenas a la praxis concreta, algunos diseñadores, minoritarios, asumen la tarea teórica propiamente dicha. Pero por decisión propia, pues la calidad del diseño no depende en absoluto del desarrollo científico, de la reflexión, sino fundamentalmente del desarrollo cultural del profesional. No es la teoría la que enriquece al diseño sino la cultura, tema al que todo el mundo le tiene pánico, porque como está en extinción... Lo que alimenta al diseño no es la teoría sino la cultura. La amplia mayoría de los grandes maestros del diseño lo han sido por satisfacer este requisito. Charles Eames para mí es la metonimia de todo el sistema. Y muy pocos han escrito algo que valga la pena.

Tampoco los arquitectos se han destacado por ello; salvo excepciones, su discurso es pura ideología. Yo procedo de la arquitectura y me consta. Venía de filosofía, pasé a arquitectura, y cuando leí el primer texto de Le Corbusier me pareció de una absoluta falta de rigor, pura voluntad, con mucha importancia desde el punto de vista de la orientación de la práctica, pero sin llegar a explicar nada. Y todas sus hipótesis eran desmentidas por su propia obra, eran fantasías ideológicas. ¿La machine à habiter? La machine à habiter... depende.

La formación teórica del diseñador suele ser muy baja o incluso nula, basta mirar los planes de estudio. El que haya logrado cierta formación teórica lo ha hecho de forma autodidacta -que los hay, afortunadamente-.

\section{(6}

No es la teoría la que enriquece al

diseño sino la cultura, tema al que todo el mundo le tiene pánico porque como está en extinción... Lo que alimenta al diseño no es la teoría sino la cultura. La amplia mayoría de los grandes maestros del diseño lo han sido por satisfacer este requisito.

- Fernando Infante: En uno de sus escritos habla de la banalización de la noción de diseño que han promovido en parte esas construcciones del imaginario mediático ("originalidad", "novedad", "transgresión", "modernidad" "nueva estética") que "se instalan en la opinión pública antes de que las personas logren pensarlas por sí mismas". ¿En qué medida es posible recuperar otra noción de diseño para la opinión pública y para el conocimiento social?

- Norberto Chaves: La banalización del diseño es un efecto sistémico de la sociedad del espectáculo, o sea, de la posmodernidad. En tanto tal no es reversible, sólo el propio desarrollo de la sociedad podrá introducir cambios, pero estos nunca serán regresivos, sino adaptativos a futuros e imprevisibles escenarios. El pasado ha pasado. A su vez el concepto estricto de diseño, latente incluso detrás de sus formas banales, carece de reflejo en la opinión pública. El diseño no es un producto, ni un lenguaje, ni una estética, sino un proceso productivo y ese proceso es inaccesible a la conciencia social, que sólo ve imágenes de los productos. 

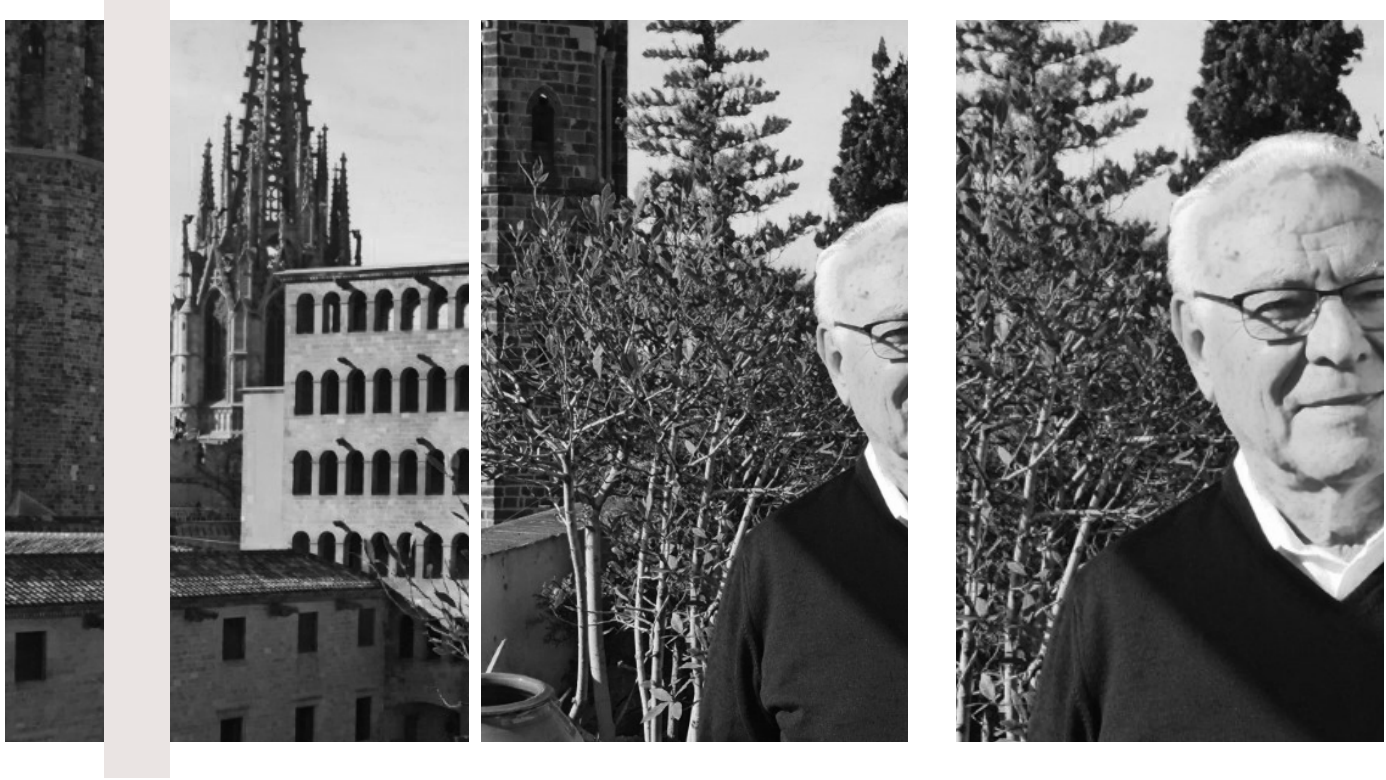

Ningún hipotético operativo de reposicionamiento del diseño ante la opinión publica podrá contrarrestar su instrumentación como simple argumento de venta a cargo de los medios de masas, y básicamente la publicidad, incluida la de las escuelas de diseño. Y, además, no hace falta que el público domine un concepto riguroso de diseño, bastaría con que lo dominen las escuelas de diseño, tarea pendiente e indispensable.

\section{6}

El diseño no es un producto, ni un lenguaje, ni una estética, sino un proceso productivo y ese proceso es inaccesible a la conciencia social, que sólo ve imágenes de los productos.

- Fernando Infante: En algunas ocasiones ha afirmado que tras la reivindicación de la "función social del diseño" se han instalado un sentido del compromiso y una crítica más bien superficiales, ya que estos no se adentran en el origen profundo de los usos antisociales del diseño que denuncian, y se conforman, más bien, con escenificar -en sus palabras- "un escándalo por los síntomas que tolera la enfermedad". ¿De dónde vendría el conocimiento de esa lógica que permitiría acceder al centro de la relación entre el diseño y la sociedad actual? ¿Cómo puede el diseño mismo reconocer esa lógica y controlarla?

- Norberto Chaves: La relación estructural del diseño con la sociedad real, o sea, con el consumo, sólo es accesible a una actividad intelectual centrada en el análisis socioeconómico y sociocultural. El diseño no es una disciplina analítica y como tal no puede acceder a esa lógica, y mucho menos controlarla. No es el diseño sino diseñadores individuales motivados por el autoconocimiento, quienes pueden saltar fuera del diseño y analizarlo desde ese afuera, munidos de las correspondientes herramientas teóricas, que no las provee el diseño sino las ciencias sociales. De hecho, hay diseñadores que lo hacen e incluso escriben libros, pero su número dentro del sector es imperceptible. 
- Fernando Infante: El diseño, en todas sus áreas y facetas, posee la capacidad de definir el entorno, lo próximo, lo cotidiano, lo consuetudinario. Conforma la manera en que nos desenvolvemos en un medio que es él mismo, pero, como sucede con nuestro propio cuerpo, solo se nos hace patente algunas veces, otras se vuelve transparente a nuestra experiencia. De entrada, parece que esa cercanía, esa continuidad y esa eventual transparencia dificultan la realización de acciones transformadoras de lo social de manera ostensible por parte del diseño, permitiendo solamente reformas y conquistas silenciosas, al modo de una ideología. Si esto es cierto, ¿cómo es posible trazar nuevas utopías en diseño?

- Norberto Chaves: Trazar nuevas utopías de diseño es lo más fácil del mundo. Diseño social, diseño ecológico, etc. Yo tengo una: su desaparición. Pero por el propio concepto, una utopía es aquello que carece de topos. El lugar del diseño no lo definen los diseñadores, sino las demandas de servicios del sistema socioeconómico. Y la transparencia del diseño no es una limitación, sino una virtud. Vivir las cosas espontáneamente, como extracuerpos y no fetiches de la moda, es una señal de salud. (Precisamente, uno de mis libros tiene como título El diseño invisible ${ }^{4}$ ).

Y reitero, el diseño no puede per se realizar acciones transformadoras. Sólo las realiza cuando, desde la demanda, se emiten programas transformadores. Y esa demanda no proviene de los usuarios, sino de los actores económicos del diseño que son quienes interpretan y reconducen las expectativas del público; básicamente, las empresas.

Hay una idea parecida en una de las consideraciones que hace Nietzsche: cultura es exactamente aquello que no sentimos que sea cultura. Cuando estoy bailando, cuando estoy cantando, cuando estoy comiendo como un dios, no estoy pensando que esté haciendo cultura, estoy bailando, estoy cantando,... es decir, la cultura es aquello que no se llama cultura. Si deviene visible, se transforma en parodia. Es lo que denunciaba Nietzsche, en las Consideraciones intempestivas, no es auténtica cultura. El diseño, al revés, se ha hecho tan evidente que hasta decimos "esto es un diseño". No, esto es una mesa, que lo haya diseñado alguien es otra cosa, pero esto es una mesa. Lo siento mucho, no es un diseño. Pero claro, se le da la vuelta, y el medio es ahora el mensaje -todo aquello que sabemos-, se le da la vuelta como un guante y la gente ve una cosa novedosa en lugar de ver una cosa que está bien.

\section{(6}

Trazar nuevas utopías de diseño

es lo más fácil del mundo. Diseño social, diseño ecológico, etc. Yo tengo una:

su desaparición.

- Fernando Infante: Como ha escrito en alguna ocasión, el concepto circulante de diseño ha quedado indisolublemente asociado a una idea de mercado y "a la reproducción del consumidor en tanto subjetividad centrada en la pulsión de cambiodescarte", antes que al de los intercambios culturales y los usos de la cultura. Al

4 Norberto Chaves. 2005. El diseño invisible. Siete lecciones sobre la intervención culta en el hábitat humano, Buenos Aires: Paidós, Estudios de Comunicación. 
margen de esa asociación al mercado y al consumo, y teniendo en cuenta la propia industrialización de la cultura, ¿de qué otra manera conforma el diseño la cultura?, ¿es el diseño un modo de cultura?, e, incluso, podría decirse que es el modo de la cultura característico de nuestro tiempo?

- Norberto Chaves: El diseño no es un área de la cultura sino una etapa del proceso de producción. Como tal, puede inscribirse en todos los sectores de la cultura, y, por lo tanto, generarla. Pero la iniciativa cultural está en los programas que se le presentan a la profesión. Esta, sólo marginal y anecdóticamente, puede liderar procesos de cambio cultural, pues el actor estratégico del diseño no es el diseñador sino el cliente. Y sin cliente, no hay diseño posible. Lo que es el modo cultural característico de nuestro tiempo no es el diseño sino el consumo de sus objetos, que es el sustituto de la cultura, actualmente en extinción.

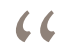

El diseño no es un área de la cultura sino una etapa del proceso de producción. Como tal, puede inscribirse en todos los sectores de la cultura, y, por lo tanto, generarla.

- Fernando Infante: También ha afirmado que esa noción del diseño como algo indisociable del mercado y de sus valores se ha instalado en las escuelas y organismos de promoción. Hablar de una alternativa humanista no deja de ser algo así como reclamar lo que ya es propio, pero ¿cómo es posible hacer ver esa dimensión del diseño que excede el mercado? y, según su experiencia, ¿hacía dónde debería dirigirse la educación en diseño en la actualidad?

- Norberto Chaves: La educación no puede crear un mundo que contravenga el modelo socioeconómico en que ha de insertarse la práctica profesional. La educación en diseño debe formar profesionales capacitados para subvenir a todas las demandas de servicios provenientes de los clientes. Pero lo que también debe hacer, y no hace, es instruir a sus educandos acerca del mundo en que han de insertarse, incentivando una motivación por el conocimiento objetivo de la realidad. La educación en diseño elude ese compromiso y transmite una visión exitista colaboracionista. Una educación alternativa debe formar posiciones técnicamente útiles e intelectualmente libres. Seres desdoblados, o sea, sanos, no alienados. La dimensión del diseño que excede el mercado es su autoconciencia como parte del aparato productivo. El diseño fuera del mercado es pura fantasía compensatoria de una culpa.

Una vez, en una conferencia, una chica intervino diciendo que ella se resistía a trabajar para el mercado, que ella no colaboraba. Yo le expliqué que indirectamente sí. Como insistía, tuve que contestarle: "te lo acepto, tú no trabajas para el mercado; pero cuando vayas al mercado a comprar, invítame y te voy a demostrar que sí estás trabajando para el mercado". Colaborar con el mercado no sólo se hace diseñando, produciendo, se hace consumiendo.

- Fernando Infante: Quienes diseñan saben que el tiempo que define la funcionalidad de un objeto o una imagen, su vida útil, no es el único sentido temporal que pueden aplicar, y al crear y proyectar exceden el contexto de tal función. ¿En qué medida toma conciencia del tiempo el diseño? 

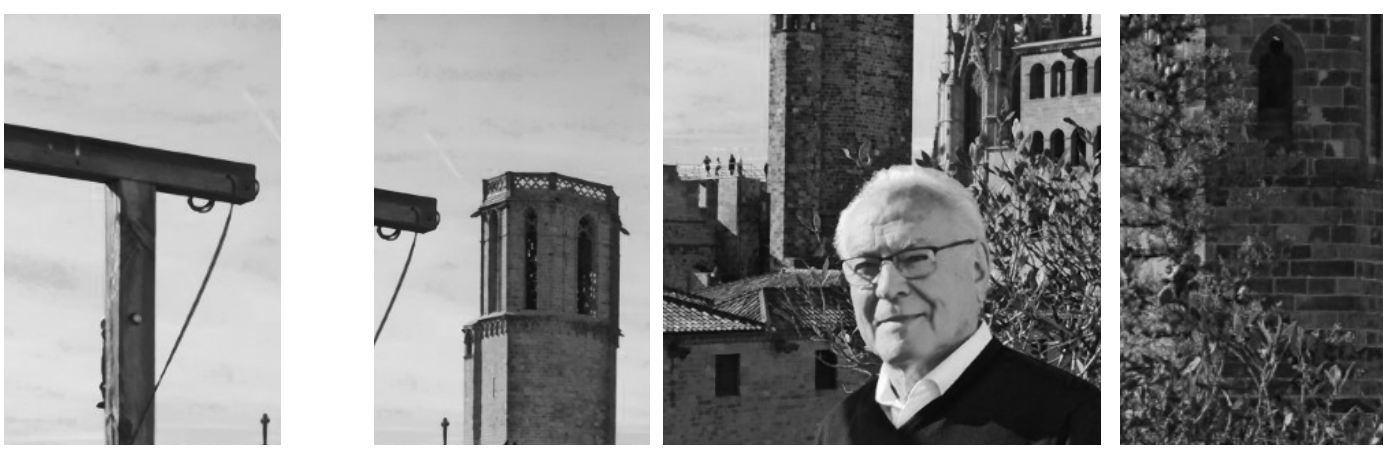

\section{(6}

Hay diseño para el instante y diseño para la eternidad. El programa -concepto más estratégico que el de diseño-contiene expresa o tácitamente la indicación del tiempo de vigencia óptimo.

- Norberto Chaves: (Justamente tengo un texto, una serie de conferencias sobre diseño y tiempo ${ }^{5}$ ). Hay diseño para el instante y diseño para la eternidad. El programa -concepto más estratégico que el de diseño-contiene expresa o tácitamente la indicación del tiempo de vigencia óptimo. La moda, un área del diseño, "género cultural" contemporáneo por excelencia, es pura obsolescencia programada. La exigencia de recambio permanente obliga a la fugacidad, hay que descartar productos o incluso costumbres que están en perfecto estado.

Sólo grandes diseñadores saben crear productos que satisfagan perfectamente el programa y, a la vez, sobrevivan al torbellino del cambio, mostrándose como permanentemente jóvenes, o sea, vigentes. Pero esa producción no es la predominante en el modelo socioeconómico y cultural de la posmodernidad. Como se sabe, lo propio de hoy es lo líquido.

La famosa lámpara de Miguel Milá festejó cincuenta años hace unos cuantos, y en la exposición, en una sala, había 50 lámparas, todas ordenadas de la primera a la última de forma que se observaba muy hermosamente cómo ha ido evolucionando la tecnología. Pero la lámpara es la misma, la primera y la última son la misma. La inicial es prácticamente artesanal, y la última tiene ya otros ajustes. Cincuenta años de vida y la gente la compra pensando que fue diseñada ayer. Este es Miguel Milá, para mí uno de los más grandes diseñadores, por lo menos en el país.

La fugacidad, por lo líquido, tiene prioridad sobre lo longevo. Hoy vi una publicidad en el metro muy inteligente, porque era una colección de películas anteriores, no actuales; y decía "no son viejos, son clásicos". Por fin un publicitario que tiene dos dedos de frente. No son viejos, son clásicos, los sin-tiempo.

5 Norberto Chaves, "Diseño y tiempo. La vigencia como dato de programa". Lección en el Seminario Docente CBC. Cátedra Arq. Flora Manteola, FADU-UBA, Buenos Aires. Puede leerse en https://www.norbertochaves. com/articulos/texto/diseno_y_tiempo [consultado el 25 de noviembre de 2019]. 
- Fernando Infante: En uno de sus textos ha hablado de los cuatro mitos en la cultura del diseño refiriéndose a la jerarquía científica, a la creatividad artística, a la función comercial, y a la misión redentora o a la comprensión del diseño como panacea de los males de la humanidad. En el caso de la creatividad, en diseño, esta suele estar convocada en un espacio compartido con la función y el encargo, ¿cómo ajusta el diseño ese mito de la creatividad?

- Norberto Chaves: La creatividad ha quedado perfectamente definida por el filósofo estadounidense Douglas R. Hofstadter. Él dice -leo-: "La creatividad es la habilidad para encontrar soluciones insospechadas para problemas aparentemente insolubles. Carece de toques mágicos o misteriosos: creatividad no es más que inteligencia, una inteligencia en cierta medida cultivable y desarrollable, que en medio de una gran cantidad de información aparentemente desconectada y caótica puede descubrir semejanzas que otros no descubren, ver opciones que otros no ven, establecer conexiones que otros no establecen y, consecuentemente, puede producir síntesis nuevas y sorprendentes". Deja todo resuelto.

Y a otro grande, Gerard Unger, el tipógrafo, en un cuestionario le hacen una pregunta que dice “¿cómo es su proceso creativo?”. Escucha esto -un tipógrafo grandísimo-: "soy más creativo cuando tengo limitaciones. Cuando me inhiben y me restringen, entonces soy realmente creativo". Coincide con lo de Hofstadter. "Mi caso se podría comparar con el de un escapista. Hay artistas que logran su máxima creatividad cuando gozan de plena libertad, pero para otros es a la inversa: son creativos cuando no tienen otra salida. Esto me da placer y es lo que considero creatividad. Soy como una especie de Houdini gráfico. Encontrarme en una posición desesperada y luego salir triunfante".

Me parecen excelentes las dos. Se trata de riqueza de paradigmas y capacidad sintagmática. O sea, libertad asociativa y talento combinatorio. Ahora bien, esa capacidad puede ponerse al servicio de cualquier encargo, desde una silla de ruedas hiperfuncional hasta el abalorio más estúpido. La creatividad es un instrumento y no un fin, el fin lo pone el encargo. Precisamente, el mito de la creatividad la eleva como un tótem autónomo: la creatividad por la creatividad misma. Se trata de un mito creado por el narcisismo profesional. Se perdona.

- Fernando Infante: La arquitectura posee una historia propia, con numerosos episodios que la han situado entre las arti del disegno o como una de las bellas artes. ¿Cómo se ubica hoy la arquitectura dentro de una categoría amplia de diseño? ¿y cómo convive con el resto de disciplinas o áreas del diseño dentro de eso que se ha llamado la cultura del proyecto?

- Norberto Chaves: Arquitectura es hábitat. O sea, uno de los pilares antropológicos junto al lenguaje o la gastronomía. Su producción ha sido milenariamente artesanal, como un cuenco de cerámica. Sólo muy tardíamente devino arte. Jerarquía impuesta en la sociedad de clases por la clase dominante: el monumento. Con la sociedad de masas su producción deviene diseño, como el automóvil. La arquitectura hoy es un gran electrodoméstico. Cultura de proyecto es una hipérbole, se trata simplemente del oficio proyectual, que está presente en múltiples sectores, dado que la producción contemporánea, o sea industrial, requiere de esa etapa como inexcusable.

La arquitectura convive perfectamente con el resto de las disciplinas del diseño, pues en el fondo son lo mismo. Lo prueba la frecuente migración de los profesionales de una a otra especialidad. O más aún, profesionales que ejercen regularmente más 
de una especialidad de diseño. Hay diseñadores muy interdisciplinares, absolutos no; yo no creo que Charles Eames, que hemos citado, haya hecho moda, pero ha hecho arquitectura, ha hecho gráfica y, básicamente, diseño industrial. Es uno de los que más admiro, por su sobriedad intelectual y su falta de arrogancia, que no la tiene, por ejemplo Le Corbusier, que es un pedante, o Mies, que es otro genio, pero cuando habla... Eames, en cambio, es tan discreto..., yo lo doy mucho en las clases. Y mucha gente ya ni se acuerda de quién es.

- Fernando Infante: Este año hemos celebrado el centenario de la Bauhaus, un acontecimiento crucial en la historia del arte moderno y el diseño, pero más allá del hito y la efemérides, ¿qué significa para usted la palabra Bauhaus? ¿De qué manera aquel espíritu y sus logros perviven en la actualidad?

- Norberto Chaves: Este es un tema bastante complicado. Para mí la Bauhaus significa la voluntad de un renacimiento de la cultura del hábitat. En el doble sentido del término "renacimiento": pensamiento renacentista, y volver a nacer. Implica una depuración cultural, la Bauhaus es como una profilaxis. De ella rescato, más que un simple lenguaje, su vocación de servicio a la vida. Cierta recuperación antropológica, de allí su reivindicación de lo etnográfico. Especialmente los racionalistas españoles, el GATEPAC, se inspiraban mucho en la arquitectura vernácula, donde no hay nada superfluo, porque no había posibilidad. Hoy, este racionalismo ha devenido casi lo contrario: un manierismo minimalista que se regodea en la esterilidad. Parece gente que no va de cuerpo ni come, la que vive ahí. Basta ver las revistas de interiorismo, son una especie de escaparates de cristal y nunca hay nadie adentro. Esta todo limpísimo.

Afortunadamente hay sectores de la producción que sólo pueden abordarse mediante los criterios de racionalidad y funcionalidad reivindicados por la Bauhaus. Sectores que garantizan la vigencia de sus planteamientos. Como digo en otro texto: "a la Bauhaus le encantaban los laboratorios". La gráfica de los laboratorios es absolutamente Bauhaus. Además - cosa curiosa-, una parte significativa de los más grandes laboratorios son suizos. Y la escuela suiza bebe de ahí. Mi gran amigo Yves Zimmermann, por ejemplo, trabajó cuando era joven para Ciba Geigy. Así que hay una relación entre el lenguaje bauhausiano o racionalista, si queremos, y determinadas áreas de la producción.

El error para mí fue pretender -que sí lo pretendían- que esos valores eran universales, no sólo en todos los temas, sino en todo el mundo. Le Corbusier hizo una casa en la ciudad de La Plata para un cirujano, Curutchet; ahora es Monumento Histórico Nacional, pero, como saben los platenses, aunque nadie lo quiere escribir, el médico odiaba esa casa. Y es una casa muy bella, por cierto.

- Fernando Infante: Las historias escritas de la Vanguardia histórica han aminorado u ocultado durante mucho tiempo ciertas acciones de los artistas de ese tiempo, quizá por considerarlas meras transposiciones de los hallazgos ocurridos en el arte (la pintura, básicamente) a los medios de lo que tiempo más tarde sería identificado como diseño. En los últimos años esta visión parece cambiar, y empezamos a ver cómo cobran presencia los textiles y la cerámica de Malevich o los diseños de Sonia Delaunay-Terk. ¿Piensa que es acertada la manera en que historia del arte ha integrado el diseño en su relato?

- Norberto Chaves: Carezco de formación en los textos de historia del arte, pero me consta que la bajada de la estética desde la plástica a los usos cotidianos es muy positiva. Siempre dije - por tocar las narices- que Mondrian era un excelente diseñador 

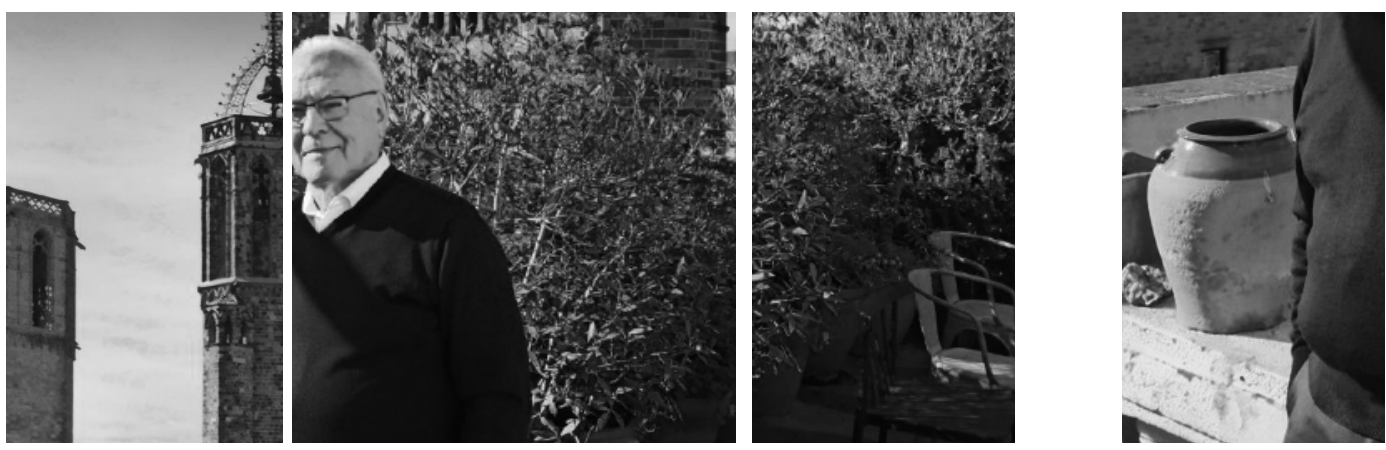

\section{(6}

El artesano produce el objeto de modo

directo, amasa el barro; el diseñador diseña

para que luego la industria fabrique el cuenco.

Es decir, el producto del diseñador es un

proyecto, el estado previo de un objeto.

de estampados textiles, y que una cortina neoplástica es más válida culturalmente que un cuadro suyo en casa de un millonario o en un museo. Si estas vanguardias supieron saltar el cerco del arte por el arte, plasmando sus estéticas al servicio de los objetos de uso, no casualmente fueron testigos y actores de los orígenes del diseño -la Bauhaus- y realizaron el giro que enlaza el diseño con la artesanía. El artesano produce el objeto de modo directo, amasa el barro; el diseñador diseña para que luego la industria fabrique el cuenco. Es decir, el producto del diseñador es un proyecto, el estado previo de un objeto.

- Fernando Infante: En muchas escuelas de arte y diseño, y en algunos centros de difusión, se ha instalado la noción de diseño experimental como una práctica ajena a la lógica de la función y el encargo, y revestida del aire simbólico del arte autónomo, ¿qué piensa de esta caracterización?

- Norberto Chaves: Tiendo a pensar que un experimento sin meta no es más que un entretenimiento de la clase ociosa. Las personas trabajadoras no tienen tiempo para experimentos. Experimentan a través de la optimización de su trabajo. Un experimentalismo ajeno a la lógica de la función y el encargo es una suerte de arte degenerado, por citar a dos grandes tiranos (los dos, tanto Hitler como Stalin, usaron curiosamente la misma expresión). Una expresión que paradójicamente acuñó una represión muy injusta en su época (porque ellos lo aplicaron contra auténticos artistas), pero que hoy sería válida. Por otra parte, también hay que revisar el desgajamiento de las vanguardias respecto del pueblo, la sociedad sencilla, el hombre de la calle, porque creo que dieron la espalda, con desprecio incluso, a las apetencias simbólicas de la gente sencilla. Una prueba es la famosa demolición de la Unidad de Habitación de San Luis, porque la gente no quería vivir en cajas de zapatos, que es la famosa metáfora que siempre se usa para el racionalismo. No sé que pensador lo dijo: es muy entendible que los obreros no quieran vivir en casas que se parecen a las fábricas donde los explotan ¡Pam! El racionalismo está bien para una fábrica, pero la casa, con el niño, el bebé, la vida real... Otra cosa es el eclecticismo de la burguesía secular, pero a la gente también le gusta el moñito. Esto es algo que hay que pensar con mayor humildad. 
- Fernando Infante: ¿Se puede hablar propiamente de criterios en diseño?

- Norberto Chaves: Me gusta la palabra criterio más que norma. El criterioso, siguiendo a Hofstatder y a Unger, sabe prestar mucha atención al programa. Antes de dibujar nada, antes de pensar nada, está pensando el problema o la necesidad. Este es un criterio básico, si yo tuviera una escuela de diseño -cosa que no quisiera bajo ningún punto de vista- no los dejaría diseñar durante dos años. Y durante esos dos años los haría conocer el diseño: la obra de los grandes maestros, materia uno, y analizar o redactar los programas, materia dos. O sea, usted no va a diseñar, usted va a elaborar el programa. ¿Qué hace falta para una silla de oficina? Que sea basculante, giratoria, muy estable, etc. No van a diseñar, primero tienen que entender el problema, pero muy obsesivamente. Y para eso se requiere no sólo ser racional, sino tener una altísima sensibilidad, oír los sonidos pequeñitos para dar una respuesta sustanciosa. Por eso creo que criterio es obediencia al programa. Obediencia no como sumisión, sino como exaltación, es decir, llevar ese programa hasta las últimas consecuencias, sacarle el jugo al programa. Pero no darle la espalda, que eso es lo grave.

Otra cosa, los programas son heterogéneos: en la época de la Bauhaus no iban mucho más lejos de los muebles de la casa, pero ahora todo, hasta un misil, es diseño. Por eso, en esa imaginaria escuela de diseño de la que hablaba, una vez pasaran los alumnos a la etapa de diseño, los haría diseñar cosas absolutamente heterogéneas, saltando de una señalización de aeropuerto -suponiendo que fuera diseño gráfico- a un festival de rock duro, donde todo es neogótico. Y con gran libertad.

La heterogeneidad no puede conseguirla todo el mundo, pero hay que proponérsela, para soltar, no la mano, la cabeza. Cuando hay que hacer un garabato, se hace el dibujo y cuando hay que hacer una cosa ortodoxamente suiza, hay que hacerlo y no tener miedo. Este sería un concepto fundamental en nuestra escuela de diseño, en cada especialidad, ser un dibujante de primera.

En el diseño no hay una metodología ni un sistema de normas. Al principio podría haberla, pero en la medida en que el diseño se expande, lo hace temáticamente, empieza a cubrir todo, y se desparrama geográfica y sociológicamente. Queda todo ahí, queda toda la sociedad. El diseño está en la sociedad en su conjunto. Pobres, ricos, clase media, alta tecnología, ... todo entra. Por eso es materialmente imposible dar con una metodología única, un sistema de normas único, etc.

Un filósofo importante, Xavier Rubert de Ventós, muy vinculado a la estética, me hizo el honor de escribirme un texto para mi libro sobre André Ricard. En él habla sobre la característica fundamental del diseño: la heteronomía. Ahora bien, tú le dices esto al diseñador y puede parecer que su ego se pone en entredicho: "¿cómo que no tengo principios propios?" El asunto es que no tiene propiamente principios, los principios los toma según convenga de la sociedad. Principios estéticos, normas funcionales, tecnológicas,... todo viene de fuera. Heteronomía, no autonomía: la presunta autonomía del diseño es una cosa narcisista, cuando la enorme virtud de la disciplina está precisamente en su heteronomía. Es de goma el diseño, puede estirarse a los temas que quiera, ahora bien, en cada caso debe ser muy respetuoso con el programa, si pide $A$, no venderle $Z$. No hay que violentar el programa, hay que exaltarlo. Si el tema es un envase de yogur, exaltarlo, que sea yogur yogur yogur, que de ganas de comerlo, que cumpla con todas las normas de marketing, pero que además pueda ir a parar al MoMA, 
- Fernando Infante: En referencia a ese desparramarse geográfica y sociológicamente, ¿se habla acertadamente cuando se habla de diseño mexicano, diseño argentino, diseño español?

- Norberto Chaves: Esto es un tema que aparece siempre. Otra vez vuelvo a los programas: hay algunos programas, en gráfica, o incluso en hábitat, o en indumentaria, que deben incorporar de alguna manera atributos locales. He visto un pase de moda en México donde los diseñadores trabajaron sobre texturas y colores indígenas, pero con ropa de hoy. Y aquello respiraba mexicaneidad. Si haces un tequila, conviene que parezca tequila y no alcohol de quemar. Ahora bien, hay temas que tienen prohibida la localía, que requieren internacionalidad o universalidad. Y ahí vuelve a estar la sensibilidad del diseñador para entender el programa: aquí hace falta que respire mediterraneidad, y aquí tiene que ser nórdico. Este sentido de la contextualidad no lo tienen todos los diseñadores.

Viniendo para aquí, vi que están demoliendo e interviniendo el Palau Moxó, un bellísimo palacio del siglo XVIII. Tengo cierta desconfianza por lo que los arquitectos puedan hacer, porque lo primero en que piensan es en meter cristal templado o acero. Duele ver esas intervenciones que son tan poco respetuosas con el patrimonio, tan arrogantes, en las que el arquitecto se lleva todo por delante.

- Fernando Infante: Para terminar, una parte significativa de sus libros están dedicados a la teoría y la crítica cultural o social, como el reciente Ser Posmoderno. Dilemas culturales del capitalismo financiero. ¿De qué manera se une en su trayectoria personal este tipo de escritura con su labor como consultor y como profesor?

- Norberto Chaves: Es muy importante esa pregunta, porque nada es casual. Yo desde muy jovencito -nunca se podrá saber por qué, ni Freud ni nadie puede explicar ciertas orientaciones- tuve una gran preocupación por lo social y por lo ideológico. Esta es una anécdota divertida: segundo grado, tendría ocho años, o siete, y dice el maestro "Hoy vamos a hablar sobre los tres reinos, el reino mineral, el reino vegetal y el reino animal; a ver, Fulanito, danos un ejemplo del reino animal". Y el niño, compañerito, va y dice: "la mariposa". Y el primero de la clase, bastante pedante, replica: "ja, ja, la mariposa un animal". Entonces, ahí sale Jaimito, y le contesto: "seguro que para ti es un vegetal". Lo que el primero de la clase esperaba decir es la vaca, que es la animalidad total. Esta voluntad de despejar lo ideológico, los ideologemas turbios y ver la luz, y por otro lado, muy relacionada, la preocupación por lo social, eso lo llevo desde la escuela primaria. En la escuela secundaria ya militaba porque hubo una política muy reaccionaria de no se qué gobierno que quería avanzar en la privatización de la enseñanza, cuando en Argentina la educación pública tiene un prestigio enorme con la UBA a la cabeza. Todos mis compañeros, escritores, teóricos, todos fueron a la escuela pública. No íbamos a las de pago, que eran malas en general.

Siempre tuve una actitud militante, tanto en lo social como en lo ideológico o en lo teórico. Por eso me matriculé en filosofía. Luego, por incorporar elementos sensibles me pasé a arquitectura y allí se produjo el link entre arquitectura y semiología. Mientras tanto, yo iba militando en la izquierda revolucionaria, es decir, siempre estuve muy preocupado. Y a esta edad estoy preocupado de estar preocupado. Quisiera estarlo un poquito menos. No puedo esperar... lo de Evo Morales, a mí me ha hecho mucho daño, me duele en el alma. El pobre pueblo boliviano, muy cercano al argentino, esa línea andina, que es el epicentro de la cultura latinoamericana... 
ruea conceptual y donde $\mathrm{el}^{\text {11 }_{1} \ldots}$

,..tilcados: de que surado, como es el ptual por. onde surgió, que es, quien ¿ inmanencia d, el objeto, la mundo sensible o aún, por qué llar. a al objetotoria, porque e allí cojo el hilo del pensamiento y inte ${ }_{\text {lvidada, }}$ las sus raíces.

Lestá ubicado. Cual es el ambiente que, de $m \dot{c}_{\mathrm{p}}$ conceptual

rama político, cuáles son los símbo

, uc la perspectiva de li

$\therefore$ proceso de un labor íntimo, un camino dı sible. Todo puede empezar por una investigació risnifiradne. de me ce trata ol lihrn ol monto, li rómo no hablar de una filosofía del di uál e:

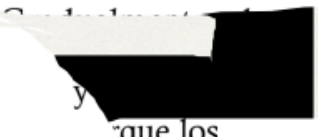

que los

conuién lo

$\mathrm{y}^{\prime}$ - ^miento de construcción de forr está

$/ 351 /$

los artefactos nc

icado, es decir, el

Jfía del diseño, si ${ }_{\text {ues. }}$ teria prima para un colla ón de formas $\mathrm{y} \mathrm{d}_{\text {exto se puede generar un }}$ vado amnezar

il pensalmumiu

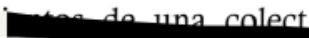

ual es el ambier

o, cuáles son $\mathrm{lc}_{\mathrm{C}}$

radualmente, el ly.

encarna el papt

intero que toma ${ }_{1}$ Santos, C. T. S. Célio. (2009, 21 agosto). Signif

Rafael. (2014). Desig
No hay cómo no hablar de de método, de pensamiento de creación en general. Intenta a sus iuncionanuaucs tr significaao y uso, dependiendo dt 


\section{El papel de la investigación y la teoría en diseño. Una conversación abierta}

\section{The role of Research and Theory in Design. An open conversation}

por Fernando Infante del Rosal ${ }^{*}$ y María Jesús Godoy Domínguez ${ }^{* *}$

Al plantear un número de Laocoonte dedicado a la Filosofía del diseño tomamos como objetivo mostrar el trabajo reflexivo de quienes se han acercado al diseño desde la estética o desde disciplinas afines. Para ello elaboramos un breve cuestionario de cuatro preguntas e invitamos a participar a algunos de esos investigadores. No todos han podido hacerlo, pero la conexión entre quienes trabajan sobre la teoría y la estética del diseño hace que muchos de los que no estén aparezcan de alguna manera.

No existe una tradición en la reflexión sobre el diseño en España, si bien algunos nombres están muy vinculados a una primera apertura hacia el diseño: Román de la Calle, Francisco Jarauta, Wenceslao Rambla, Anna Calvera, Juan Antonio Ramírez. En todos ellos, esa apertura no se da bajo la forma de una integración, porque "integrar" implica asimilar hechos y objetos a un supuesto marco legítimo y puro; su reflexión nació más bien de la inquietud y el interés planteados por unas formas, objetos e intencionalidades que ponían en tela de juicio las normatividades estéticas y que interpelaban de una manera diferente. Después de ellos, la conveniencia de la Estética en los estudios de diseño (en Diseño Industrial, Arquitectura, Comunicación, Publicidad, etc.) empezó a hacerse patente. Muchos de los que han participado en esta conversación abierta son docentes en estas especialidades y pertenecen, excepto Rambla, a una segunda generación que está consolidando la investigación estética en diseño.

En la actualidad, una parte importante de la reflexión sobre el diseño tiene lugar en América Latina, donde los estudios de esta disciplina conviven con mayor naturalidad con los de arte y donde se incide en la carga social y crítica de la práctica del diseño. En España es muy destacable la proliferación de revistas académicas dedicadas a la cultura del diseño que completan con la investigación y la teoría la repercusión de las revistas de difusión de carácter profesional. En estos medios, los textos sobre diseño empiezan a conformar un tejido que, poco a poco, refuerza su urdimbre. La presente conversación abierta muestra esa fuerza, y refleja también un hecho cada vez más patente: el universo de discurso de la teoría del diseño, con sus problemas, su terminología, sus valores, sus sensibilidades, sus discusiones, constituye ya una realidad dentro del universo de discurso de la disciplina estética.

* Universidad de Sevilla, ADG-FAD, España.finfante@us.es ADG-FAD

** Universidad de Sevilla, España.godoydom@us.es 


\section{Primera cuestión}

\section{"Diseño" es un término que ha designado diferentes realidades y que ha sido objeto de muy distintas valoraciones durante el pasado siglo, ¿cómo podemos definir "diseño" en nuestros días?}

Fernando Broncano es catedrático de Filosofía de la Ciencia en la Universidad Carlos III de Madrid. Su extenso trabajo traza una unión entre la cultura científica y la humanística, trascendiendo las dicotomías entre lo natural y lo artificial. Entre sus obras destacan Entre ingenieros y ciudadanos. Filosofía de la técnica para días de democracia (Montesinos, 2006), La melancolía del ciborg (Herder, 2009) y Mundos Artificiales. Filosofía del cambio técnico (Paidós, 2000). Estas obras giran alrededor de la filosofía de la técnica en el marco de la teoría de la acción, que, según él, sería el ámbito natural para reflexionar sobre la tecnología como objeto filosófico.

- Fernando Broncano: El diseño ha mantenido siempre una situación ambigua prácticamente desde que William Morris iniciase la tradición del diseño. El término así como el concepto capturan dos ámbitos diferentes: el de la producción y el del producto. En el segundo sentido, diseño es el hecho objetivo de un conjunto de materiales que se articulan mediante diversas formas para cumplir ciertas funciones y permitiendo por ello el uso del artefacto. En el segundo sentido, diseño es un plan de representación y acción que conduce a la producción dirigida por él de un artefacto. Aquí intervienen las elecciones que hace el diseñador (o diseñadora) de materiales, formas y, por supuesto, funciones designadas y usos apropiados del artefacto. Poco a poco ha ido creciendo el uso del segundo sentido de tal ma- nera que señala los elementos personales o intencionales y deja en segundo plano el resultado. Especialmente han ido sobresaliendo las intenciones estéticas y se han ido ocluyendo las funcionales. Desde el comienzo fue así, pues William Morris, y después las varias escuelas que definen el tiempo del Art Nouveau, hicieron que el diseño se dirigiese a resaltar estos aspectos. Pero no puede olvidarse que el diseño es también diseño industrial en el que la anticipación de las funciones, también de los usos y, con ellos, de los aspectos más ergonómicos predominan sobre los estéticos. Esta tensión entre lo ornamental y lo funcional ha definido la historia del diseño. Ahora quizás las consideraciones comerciales hayan invadido aún más la anticipación del usuario con la intención de que el objeto sea tan seductor como útil, haciendo que los elementos simbólicos sean más prominentes. En definitiva, creo que definir diseño implica siempre entrar en esta dialéctica irresoluble.

\section{6}

Poco a poco ha ido creciendo el uso del sentido del diseño como plan de representación y acción de tal manera que señala los elementos personales o intencionales y deja en segundo plano el resultado.

\section{Fernando Broncano}


Jorge López Lloret es profesor titular de Estética y Teorías de las Artes en la Universidad de Sevilla, donde imparte "Estética del Diseño Industrial" en la Escuela Politécnica Superior. Su investigación se centra en el pensamiento de los siglos XVIII y XIX y en cómo se configura en él la apreciación del diseño y de los objetos. Entre sus publicaciones más relevantes, destacan: La ciudad construida: Historia, estructura y percepción en el conjunto histórico de Sevilla (Diputación de Sevilla, 2003), "Jean-Jacques Rousseau y la cultura del diseño" (Ágora. Papeles de Filosofia, 2014) y "De la utilidad de la belleza: Argumentos sobre el Clasicismo en la estética de David Hume" (Daimon. Revista Internacional de Filosofia, 2003).

- Jorge López Lloret: Así, sin más especificación, el diseño es el producto del acto de diseñar. Es diseñado todo lo que no es natural, es decir, todo lo que es proyectado. Diseño es lo que resulta del "dibujo" (disegno) de "designios" (designs), un mundo planificado de objetos, experiencias y emociones que tienen su razón de ser en su significado. Actualmente abarca no solo los objetos que utilizamos, las obras que experimentamos, las ciudades que habitamos o los territorios por los que nos movemos, sino los alimentos que comemos, los políticos a los que votamos, parte de los órganos que nos hacen vivir, el aspecto físico con el que nos identificamos e, incluso, las aspiraciones y sueños que nos dirigen. El diseño, al menos en este planeta y ahora, es casi todo.

$\mathrm{Si}$, en lugar de diseño sin más, me refiriese al diseño industrial de producto, que es donde desempeño mi tarea docente, diría que el diseño es el resultado de una actividad humana compleja que consiste en la producción masiva, con medios técnicos avanzados (no necesariamente complejos), de objetos de uso que generan un alto grado de identificación personal.

\section{6}

El diseño -al menos el buen diseño- es una actividad creativa (multi)funcional, puesto que busca la innovación pertinente que satisfaga nuestras necesidades más diversas, desde las mecánicas a las simbólicas y emocionales.

Joan M. Marín y Rosalía Torrent

Rosalía Torrent Esclapés es Catedrática de Estética y Teoría de las Artes en la Universidad Jaume I de Castellón. Entre sus publicaciones más relevantes, sobresalen: Historia del diseño industrial (Cátedra, 2005), escrito en colaboración con Joan M. Marín Torres, al igual que Breviario de diseño industrial: Función estética y gusto (Cátedra, 2016). En solitario, es autora también de numerosos artículos, como "Arte y Diseño industrial. Hibridaciones y conflictos" (Keples, 2018).

Joan M. Marín Torres es profesor titular de Estética y Teoría de las Artes en la Universidad Jaume I de Castellón, donde imparte la asignatura "Estética" en el Grado de Ingeniería del Diseño Industrial y Desarrollo de Productos. Además de los libros publicados junto con Rosalía Torrent, es autor asimismo de artículos como "Ars, design et engagement éthique" (Nouvelle Revue d'Esthétique, 2016) y "Artesania i Disseny industrial: una confluència creativa" (en Ceràmica: la metamorfosi de la terra, MACVAC, 2018).

- Joan M. Marín y Rosalía Torrent: Estamos totalmente de acuerdo con la afirmación que antecede a la pregunta. E1 término "diseño" ha servido para designar actividades muy diferentes, por lo que todo intento de definición acaba siendo insatisfactorio para alguna de las múlti- 
ples perspectivas y disciplinas desde las que se puede abordar. El diseño -al menos el buen diseño- es una actividad creativa (multi)funcional, puesto que busca la innovación pertinente que satisfaga nuestras necesidades más diversas, desde las mecánicas a las simbólicas y emocionales. Es una techné o ars, en tanto que es un conocimiento cuyo objetivo es materializarse en un objeto o aplicación práctica. Es comunicación, ya que busca establecer lazos entre el producto y el usuario. Es el punto de confluencia entre la competencia tecnológica, la creatividad artística y la cultura humanística. Es... una realidad multidisciplinar con estancias intercomunicadas, techos abiertos y paredes trasparentes.

María Aguilar Alejandre es profesora del Departamento de Ingeniería del Diseño en la Escuela Politécnica Superior de la Universidad de Sevilla. Es arquitecta y especialista en diseño industrial y en danza. También pertenece a la junta directiva de la aad (Asociación Andaluza de Diseñadores). Entre sus publicaciones, se encuentran: "Pensamiento espacial en la obra de William Forsythe" (en La investigación en danza en España, 2010) y "Ordenación urbana en el Arenal de la Fuensanta de Córdoba" (en Curso de Proyectos 2002-2003 Córdoba, 2003).

- María Aguilar: Se trata de una cuestión difícil pero me siento muy cercana a la definición de Miquel Milá cuando dice que el diseño es la organización de los elementos que componen un todo. Efectivamente, se trata de una definición muy generalista pero resulta que el diseño atañe a todos los sectores, ya que prácticamente todo necesita ser diseñado, pensado, organizado en todas sus facetas. De ahí la multitud de especialidades que están surgiendo en este ámbito: gráfico, producto, entorno, digital, UX, etc.

\section{6 \\ Me siento muy cercana a la definición de Miquel Milá cuando dice que el diseño es la organización de los elementos que componen un todo.}

\author{
María Aguilar
}

Wenceslao Rambla Wenceslao Rambla Zaragoza es Catedrático de Estética y Teoría de las Artes en la Universitat Jaume I de Castellón, en la que ha sido también Vicerrector de Cultura, Extensión Universitaria y Relaciones Institucionales. Artista autodidacta, trabaja en los campos de la pintura, la fotografía, el dibujo y el grabado. Académico correspondiente de la Real Academia de Bellas Artes de San Carlos de Valencia. Entre la veintena de libros publicados destacan Principales itinerarios artísticos en la plástica y arquitectura del siglo XX (Publicaciones Universitat Jaume I, 2008) y Estética y Diseño (Publicaciones Universidad de Salamanca, 2018). Ha sido director de la colección Dissenyadors valencians (DISVA XXI). Como artista ha realizado 122 muestras entre exposiciones individuales y colectivas dentro y fuera de España.

- Wenceslao Rambla: Terminológicamente se entendía por "diseño" el boceto, esbozo, esquema preparatorio... apto para desarrollar una obra en el terreno artístico (disegno). Modernamente pasó a entenderse, bajo la denominación de design, como tarea proyectual con vistas a resolver un problema de tipo utilitario, asumiendo en su propio ámbito toda la serie de implicaciones conceptuales, sociales y económicas que lo envolvían. A partir de ahí, y conforme ha evolucionado su reubicación en el panorama de la creación humana, ha transitado desde querer quedar anclado en la mera funcionalidad, 
según un enfoque ingenieril, hasta el deseo de identificarse con lo artístico; lo que ha llevado a graves imprecisiones por pretender reducir diseño a arte, pues aun cuando sea cierto que el diseño es algo próximo o "familiar" a lo artístico, estrictamente hablando no lo es.

Actualmente, superados estos enfoques, el diseño tiende a cumplir la tarea de "in-formar" sobre lo que puede ser resuelto; entendiendo esto como un "modo-otro" de conocer el mundo (Welt) aportando soluciones (sin condicionantes previos ya cerrados o dados indiscutiblemente por válidos) que incidan en la sostenibilidad del sistema de producción y consumo y sin menoscabo de su capacidad como generador de efluvios estéticos. Máxime cuando en el mundo de hoy, en plena era de las TICs, se están sobrepasando las miradas ya anticuadas relativas al binomio forma-función y donde el diseño de lo inmaterial (que es un modo de hablar, pues lo inmaterial energético o cibernético es real) se está expandiendo hacia una nueva interacción, al menos como posibilidad, entre lo real fenoménico y lo nouménico.

\section{6}

Actualmente, el diseño tiende a cumplir la tarea de 'in-formar' sobre lo que puede ser resuelto; entendiendo esto como un 'modo-otro' de conocer el mundo (Welt) aportando soluciones que incidan en la sostenibilidad del sistema de producción y consumo y sin menoscabo de su capacidad como generador de efluvios estéticos.

Wenceslao Rambla
Tània Costa es profesora de "Últimas tendencias del diseño y del arte" en el Grado de diseño de la EINA en Barcelona y coordinadora del Programa de Doctorado de dicho centro. Entre sus últimas publicaciones, figuran: "Analysis of Ongoing Transition Projects in Barcelona. An approach to Transition Design from a Southern Perspective" (Cuadernos del Centro de Estudios de Diseño y Comunicación, n. 73, Argentina, 2019) y "Learning through Experience and Teaching Strategies outside the Classroom at Design University Studies" (Procedia-Social and Behavioral Sciences, 2015).

- Tània Costa: Me interesa particularmente una concepción del diseño que tiene mucho que ver con la elaboración que propuso Guy Julier en su libro $\mathrm{La}$ cultura del diseño (2010: 246), y cuyo eje esencial resumiría en una sola frase de su texto: "Se trata de que el diseño sea un proceso de transformación, que reconfigure las rutinas y los puntos de vista". En efecto, me parece prioritario entender que actualmente el diseño es un agente de cambio en el sentido de transformación contextual, y que no solo afecta a la cultura material. Y considero un elemento clave de esta perspectiva que la intención del diseñar sea incidir en los hábitos de lo cotidiano así como en las subjetividades de los individuos y colectivos implicados. Es el enfoque que desde el Transition Design se describiría como "cultivo de formas de vida" o diseño de maneras de vivir alternativas, en relación a su adecuación a la visión de un escenario de futuro determinado.

Ciertamente, para elaborar una definición de diseño rigurosa deberíamos vincular este eje principal a otros aspectos relevantes de la contemporaneidad como la co-creación, la perspectiva sistémica, la in-disciplina, etc. Aquí no disponemos de la extensión necesaria, pero no quiero de- 
jar de subrayar un elemento que no suele aparecer como imprescindible en el breafing del proyecto de diseño aunque a mí me parece primordial. Me refiero a la idea que Hillary Cottam lleva desarrollando desde hace más de una década bajo el calificativo de "bienestar relacional", y que ha culminado recientemente con la publicación Radical help: How we can remake the relationships between us and revolutionise the welfare state (2019). Desde mi punto de vista, todo proyecto de diseño de orientación contextual debería tener en cuenta que el fortalecimiento o creación de redes relacionales entre personas soluciona parte del problema a abordar y, tal como apunta Cottam, convendría trabajar con las capacidades de los agentes implicados en lugar de focalizarse únicamente en sus "necesidades".

Sólo decir, para acabar, que felizmente el diseño hoy en día se ha desprendido de una única definición -tradicionalmente ligada a la idea moderna del buen diseño- y ahora mismo se atreve a acoger distintas narrativas que le describen de maneras diversas. $\mathrm{Y}$ precisamente esta aceptación de la diversidad permite al diseño adoptar diferentes formatos e hibridarse con otros campos de conocimiento para dar paso a nuevos paradigmas de las formas del diseñar.

\section{6}

En efecto, me parece prioritario entender que actualmente el diseño es un agente de cambio en el sentido de transformación contextual, y que no solo afecta a la cultura material.

Tània Costa
Pedro Medina Reinón es curador, crítico de arte, profesor, investigador y editor de cultura contemporánea, especialmente diseño, videocreación y medios digitales. Desde 2006 ha sido Director del Área Cultural del Istituto Europeo di Design en Madrid, donde también enseña Estética. Dirige la Editorial IED y IED Sapere (2016-, Italia, España y Brasil). Ha coordinado el número sobre "Arte y Diseño" de la revista Artecontexto (2011) y el de "Diseño de Procesos" de Cuadernos de Diseño, este último junto a Francisco Jarauta (2014).

- Pedro Medina: El diseño es esa disciplina dentro de la cultura del proyecto que considera estética, productiva y comunicativamente cada producto, dentro de un sistema de relaciones creativas, sociales y empresariales, que debería buscar siempre situaciones más deseables en un contexto de sostenibilidad medioambiental y económica.

Claudia Mosqueda Gómez es doctora en filosofía y profesora en los estudios de Arte y Comunicación Digitales de la Universidad Metropolitana Unidad Lerma de México. Especialista en arte y diseño digitales, su investigación se centra en las relaciones entre humanismo, tecnología y sociedad. Entre sus publicaciones destacan el reciente libro "Interpelaciones del arte, el diseño y la sociedad" (Juan Pablos, 2019) o "Un re-pensamiento de la noción de práctica profesional" (Veredas, 2015).

- Claudia Mosqueda: La era de la información, como la denominaría Manuel Castells, ha renovado las prácticas de consumo, interacción social, la producción del conocimiento, de las artes y del diseño, las relaciones sociales, la producción y difusión de la información. Desde finales del siglo XX y en los inicios del siglo 
XXI hemos observado que la formación profesional y producción de los objetos de diseño son atravesados por el vertiginoso desarrollo tecnológico y los cambios epistemológicos de las disciplinas a la interdisciplina y transdisciplina.

Pienso que los desarrollos de procesos tecnológicos cada vez más sofisticados, el desarrollo de nuevas condiciones materiales informáticas y el despliegue crítico y dinámico de nuevos espectadores en el siglo XXI, permiten que los diseñadores repiensen la creación, producción y circulación de sus objetos.

El avance tecnológico y las novedosas formas de emplear los artefactos o soportes de diseño conducen a estas disciplinas $\mathrm{y}$ a sus creadores a generar formas emergentes de composición en los lenguajes del diseño que inciden productivamente en el re-pensamiento de su proceso creador.

Considero que el diseño, históricamente, ha establecido una relación estrecha con la tecnología, pero en el contexto del siglo XXI la producción de los objetos diseñados supone cualidades novedosas, efímeras, abiertas, colectivas porque la vertiginosidad con la que se mueven el contexto y la producción tecnológica modifica, en todo momento la producción de los diseños.

En este sentido, creo que el diseñador o los creadores con formación afín están condicionados y determinados por la velocidad de los cambios socioculturales y tecnológicos, o lo que es más, estos creadores requieren atributos que les hagan ser creadores capaces de aprender a diseñar en la vertiginosidad y vorágine de sus tiempos. Los complejos perfiles de los diseñadores ya no se reducen a ser unidisciplinares, sino inter o transdisciplinares: desarrolladores de tecnología, industriales, programadores, músicos, matemáticos, biólogos, filósofos, antropólogos, ingenieros, arquitectos, diseñadores, físicos; etc. Se desplazan como técnicos, armadores, artesanos, inventores o creativos. Los diseñadores que emplean los nuevos medios tecnológicos se despliegan como hombres de su tiempo.

Por estas razones pienso que, frente a estos cambios estructurales, los nuevos creadores tendrían que atender a las velocidades con que se producen y circulan los rápidos procesos del avance tecnológico, la producción creativa dentro del espacio de la información global o la ruptura de fronteras disciplinares para trabajar en los umbrales de una revolución material y la expansión de sus competencias.

Manuel Fernando Mancera Martínez es profesor de "Arte, Diseño y Comunicación" en la Facultad de Bellas Artes de la Universidad de Sevilla. Dirige SinSerifa Revista Andaluza de Diseño. Su trabajo se centra actualmente en la producción digital (serie Cirque DuMal, LaVozDeSuAmo). Sus publicaciones más relevantes en materia de diseño comprenden los cinco volúmenes sobre Arte y diseño: la decoración mural de interiores a través de la Historia (Padilla Libro, Sevilla, 2005).

- Manuel F. Mancera: Desde el día a día, no parece haber cambiado mucho ese ecléctico posicionamiento del "vale para todo" en las mil y una variantes del referente parcelario en el que se ha ido acomodando y diluyendo para impregnarlo todo.

Más allá de las eruditas disertaciones sobre "arte" y "técnica", "diseño" sigue siendo usado a troche y moche, y se estandariza en el uso indiscriminado de cualquier planteamiento en el que se genere algo, que no existía, o que ha resurgido desde una interpretación de lo ya creado previamente.

Más que decir qué es "diseño" en nuestros días, me atrevería a decir qué no debería ser "diseño" (apoyándonos en Platón): 
- Un comodín rutilante que pretenda empoderar una acción meramente creativa.
- Un disfraz histriónico dentro de una producción nimia.

- Una adjetivación legitimaria.

\section{Segunda cuestión}

\section{La teoría ha cumplido una función fundamental en la conformación del arte como una realidad, o, al menos, como un sistema. En este sentido, la estética y la teoría del arte jugaron durante mucho tiempo un papel determinante. Esto ha hecho que el arte haya sido pensado, especialmente desde su conformación como ámbito autónomo, ¿consideras que el diseño ha sido pensado de igual manera?, o visto de otra forma, ¿la filosofía ha dedicado su reflexión al diseño?}

- Fernando Broncano: Bien, ciertamente la teoría ha tenido un papel muy importante, aunque no deberíamos olvidar el papel que tuvieron nuevas instituciones como las galerías, los museos, las exposiciones y, sobre todo, la constitución de un mercado amplio del arte, más allá de los tradicionales mecenas. En particular los coleccionistas fueron centrales en la conformación de este mercado. Todo esto dio alas a las dinámicas que ha estudiado Bourdieu que conducen a las constitución de campos culturales identificados como "arte". Respecto al diseño, en tanto que está en un territorio intermedio entre la industria y el arte, no ha habido un proceso tan claro, pero es cierto que podemos identificar ya escuelas, tradiciones $\mathrm{y}$, por ello, dinámicas muy similares a las que han dirigido el arte. Volviendo al papel de la teoría, hay que reconocer que ha faltado mucha atención al diseño y demasiada a los aspectos más estéticos de la obra. Salvo algunas reflexiones ya en la segunda parte del siglo pasado, y en particular en el ámbito de la filosofía de la posmodernidad, no encontramos demasiada literatura sobre el tema. Menos aún que combine la filosofía de los artefactos con la estética, pues los artefactos han quedado en el margen de la ontología, como si las pocas consideraciones de Heidegger bastasen para cubrir las necesidades teóricas.

- Jorge López Lloret: La filosofía ha dedicado su reflexión a todo $\mathrm{y}$, por supuesto, también al diseño. Por ejemplo, Ser y tiempo de Martin Heidegger trata ante todo sobre el diseño. Cuando afirma que el ser humano es un ser arrojado que tiene que hacerse y al que, por eso, en cada caso le va su ser, está afirmando que nuestra existencia consiste en proyectarnos. El proyecto es lo que nos define antropológicamente. Por eso Heidegger concedió tanta importancia a nuestro "trato procurante" con las cosas.

Podemos poner más ejemplos, como el Kallías de Schiller, con su recurso al diseño de producto como imagen de la libertad en la apariencia; o la romantización del mundo de Novalis, pues el diseño anticipa que seremos lo que ahora nos parece maravilloso llegar a ser. Cualquier habitante del siglo XVII se maravillaría ante nuestro mundo, que es producto de la cotidianización de la técnica, tarea del 
diseño (industrial de producto).

Concluyendo, afirmaría que la filosofía solo se ha ocupado del diseño: de cómo Alguien ha hecho nuestro mundo o, si no nos permitimos esa hipótesis, de cómo nosotros hemos hecho, estamos haciendo o podríamos hacer nuestro mundo.

\section{6}

También las artes decorativas sufrieron cierto menosprecio general por parte de la reflexión estética que, bajo los prejuicios de una concepción aristocrática del saber, prefería dedicar su atención a temas -supuestamentemás elevados que los objetos cotidianos y las creaciones utilitarias.

Joan M. Marín y Rosalía Torrent

- Joan M. Marín y Rosalía Torrent: La reflexión estética -y en general, la filosofía- no han dedicado al diseño la atención que se merece. En parte esto resulta comprensible porque, prácticamente, hasta inicios del siglo XX el diseño no empieza a adquirir una personalidad propia, diferenciada de las artes aplicadas o decorativas. Dicho sea de paso, también las artes decorativas sufrieron cierto menosprecio general por parte de la reflexión estética que, bajo los prejuicios de una concepción aristocrática del saber, prefería dedicar su atención a temas -supuestamente- más elevados que los objetos cotidianos y las creaciones utilitarias. Ahora bien, persistir en este menosprecio constituye una actitud anacrónica que se desvincula de nuestro mundo contemporáneo. La actividad multidisciplinar que se agrupa bajo el término "diseño" no sólo es la productora de gran parte de la creatividad cultural actual, sino que es simple y llanamente la principal artífice del mundo en el que vivimos.
- María Aguilar: Considero que desde la filosofía se ha dedicado muy poca reflexión al diseño y creo que no es comparable al papel que ésta ha jugado en la conformación del arte. Bajo mi punto de vista, esto tiene que ver también con una cuestión de tiempo. Tengamos en cuenta que el diseño es una disciplina relativamente joven, especialmente en nuestro territorio, esto hace que su propia historia y el mapa de sus referentes estén aún en construcción y que, por tanto, el campo de la reflexión tenga más dificultades para acercarse a él.

\section{C6}

El diseño es una disciplina relativamente joven, especialmente en nuestro territorio, esto hace que su propia historia y el mapa de sus referentes estén aún en construcción y que, por tanto, el campo de la reflexión tenga más dificultades para acercarse a él.

\section{María Aguilar}

- Wenceslao Rambla: Ciertamente el arte pronto se posicionó como algo más o "algo otro" que la artesanía, si bien en un principio tenían bastantes puntos en común. Cuando al hacedor de arte se le otorgó el papel de creador, comportando un estatus social relevante, comenzó a jugar un papel, digamos, "superior". Por su parte la reflexión estética viene de mucho antes: su papel iniciático aparece en los comienzos de la filosofía como sistema de pensamiento, sazonando las reflexiones y cuestionamiento que al respecto fue generando la filosofía del arte. En cambio, la filosofía "a secas" apenas ha dedicado un espacio de discusión al diseño, si lo comparamos con lo anteriormente dicho. Cuando a mediados del pasado siglo se 
admitió que otros campos distintos al arte -como la publicidad y el desarrollo de los objetos más allá de la artesanía, es decir, de factura industrial- podían generar extensivamente una corriente de apreciación estética y ser degustados como si estuviéramos intensivamente frente a obras artísticas, es cuando, creo yo, empieza la filosofía a interesarse por el estatus del diseño.

- Pedro Medina: Dedico toda la primera mitad de mi artículo a esta cuestión. ${ }^{1}$ Como resumen, enfatizaría que la historia del diseño nunca ha sido autónoma y, por ello mismo, siempre ha estado "tutelada" por otras disciplinas como la arquitectura y las artes visuales, quedando relegada a un segundo plano, tanto académica como teóricamente. Sin embargo, sus capacidades proyectuales y de conexión entre ámbitos han demostrado su carácter transformador de nuestra cotidianidad, lo que ha llamado la atención de la teoría, sobre todo a partir de los años sesenta, con pensadores como Gillo Dorfles, Roland Barthes, Ezio Manzini,... Su origen ha hecho que su relación con la teoría haya sido menor, pero, precisamente por su potencial práctico y expresivo, además del método que establece, se propone hoy día como un campo fértil y crucial capaz de influir con fuerza en los otros ámbitos an-

\section{6}

La historia del diseño nunca ha sido autónoma y, por ello mismo, siempre ha estado 'tutelada' por otras disciplinas como la arquitectura y las artes visuales, quedando relegada a un segundo plano, tanto académica como teóricamente.

Pedro Medina

1 “Estatus y estado del diseño más allá del objeto", Texto invitado en este número. tiguamente dominantes; por tanto, como ámbito por explicar sobre el que hay que generar necesariamente teoría.

- Claudia Mosqueda: Estoy convencida de que el diseño ha sido pensado desde la filosofía, quizá una de las contribuciones más potentes es la de Wenceslao González, filósofo español que desde la filosofía de la ciencia eleva el estatus científico de esta práctica profesional mediante una nueva taxonomía del conocimiento que propone asumir el carácter disciplinario del diseño como una ciencia.

Ciencias del diseño designan conocimientos específicos que son elaborados para resolver, de manera articulada, problemas concretos que surgen en el entorno humano. Es una actividad científica en cuanto que -al hacer diseños- está encaminada a metas relacionadas con lo hecho por los humanos (human-made).

González analiza las ciencias del diseño desde una mirada filosófica-epistemológica y argumenta que estas ciencias están delimitadas por rasgos: semánticos, epistemológicos, metodológicos, ontológicos y también, podríamos añadir estéticos. En estas ciencias hay una actividad creativa humana de fondo, que formula sucesivos pasos como ciencias porque implica la elaboración de objetivos, procesos y resultados.

Coincido completamente con el epistemólogo español cuando dice que el diseño mira hacia algo posible y alcanzable de modo que, mediante unos procesos bien articulados, puede llevar al resultado anticipado a una mejor planificación social, la composición de un producto.

Crear los artefactos, dice González requiere de racionalidad, tanto en el plano de la actividad científica en sí misma considerada como en el ámbito de los agentes que la originan. De este modo, el diseño está orientado a fines y surge de una racionalidad de los agentes. Quizá este argumento se sostiene desde que asume que 
las ciencias del diseño ocupan un lugar cercano a la tecnología y, en este sentido, sería prudente citarlo directamente:

Originalmente, las ciencias del diseño pueden estar engarzadas a diversas posibilidades: una práctica artística, un saber técnico -o, incluso, tecnológico-, un comportamiento de gestión (empresarial, política), un planteamiento para desarrollar aspectos humanos en un entorno social, etc. Ante esta pluralidad temática, el diseño científico proporciona un plan articulado, donde hay pautas de actuación para lograr resultados. Y, aunque el "diseño" puede ser también un producto, aquí importa más el componente conceptual que, tras el proceso adecuado, puede propiciar un producto. Esta dinámica aplicada lleva a solucionar problemas concretos con resultados que pueden ser tangibles. Por tanto, la ubicación de las ciencias de diseño difiere de las esferas del arte y se distingue del territorio de la tecnología, aunque se conecte con ambas (González; 2007).

Se puede afirmar entonces, que la función de diseñar no se reduce a la mera dimensión técnica, estética, metodológica, científica, las reúne a todas y va más allá porque está guiado por un proceso de creación que imbrica saberes de distintos órdenes epistemológicos, metodológicos o estéticos.

- Manuel F. Mancera: A la primera pregunta: Rotundamente no.

Para la Filosofía, el "diseño" es, aún, el púber difícil de manejar. Incontrolable y cuestionable, inabarcable y cambiante, descarado y petulante.

Afrontar la realidad de un devenir insustancial, que no es todavía aplicado conscientemente, problematiza la proyección sistémica.

Bauhaus nos lo constata como un maridaje entre funcionalidad y significación.

En el consumismo, Baudrillard nos lo presenta como un identitario.

Vilém Flusser desde el mirar teorético lo identifica como sabiduría.

Pero "Diseño" es más aún que sesgadas realidades de la tecno-multi-realidad que nos circunda. Y dilucidar la esencia del vocablo y su aproximación a la constatación de su pre-forma están aún litigiadas en el misceláneo planteamiento del pensamiento tierno, aproximativo...

\section{6}

'Diseño' es más aún que sesgadas realidades de la tecno-multi-realidad que nos circunda. Y dilucidar la esencia del vocablo y su aproximación a la constatación de su pre-forma están aún litigiadas en el misceláneo planteamiento del pensamiento tierno, aproximativo...

Manuel F. Mancera

\section{Tercera cuestión}

\section{¿Qué aspectos del diseño pueden ser abordados por la estética como disciplina?}

- Fernando Broncano: En primer y en último lugar, creo que la estética debe situarse en la dialéctica de producción/ producto. Lo peor que podría ocurrirle a la estética es que se centrase en los aspectos ornamentales o, peor aún, comer- 
ciales del objeto. Adolf Loos se removería en su tumba. En tanto que se ocupa, para decirlo con la frase ya estándar, del "reparto de lo sensible", la estética debe tratar el cómo el objeto anticipa los usos, pero también cómo los usos (simbólicos, funcionales) transforman el objeto y lo resignifican. Del mismo modo que no se puede hacer estética sin una filosofía de las imágenes, tampoco se puede hacer sin una teoría de los artefactos. Lo estético comienza en el entredós entre la función (técnica y simbólica) y la intelección, y transformación, que el usuario hace el objeto.

\section{6 \\ Del mismo modo que no se puede hacer estética sin una filosofía de las imágenes, tampoco se puede hacer sin una teoría de los artefactos.}

Fernando Broncano

- Jorge López Lloret: Básicamente, depende de lo que se entienda por "estética" y a qué variante del "diseño" nos refiramos. Si pensamos en el diseño industrial de producto e interpretamos el término "estética" de una manera amplia, incluyendo tanto los recursos perceptivos como los formales y semánticos, prácticamente cualquier aspecto del diseño puede ser potenciado por la reflexión estética.

El diseño industrial de producto proyecta objetos de uso que generan identificación personal. En su dimensión de uso, estos objetos desarrollan un trabajo, lo cual requiere fijarse en cuestiones físicas, estructurales y ergonómicas; en su dimensión de generadores de identidad, tratan con dimensiones psicológicas $\mathrm{y}$, sobre todo, sociales. La identidad se desarrolla a través de la estilización del producto, lo

\section{6}

La estética hace que la cultura del diseño resulte simbólicamente sostenible.

\section{Jorge López Lloret}

que a su vez revierte en la estructura que se elige y, con ella, en el tipo de gestión que se requiere de los requisitos físicos básicos. En este complejo disciplinar y partiendo del respeto absoluto por la ergonomía, la estética se extiende al trabajo con los datos perceptivos (colores, texturas, luminosidad, temperatura, dureza, sonido, olor y peso) y a su integración formal, explotando todas las posibilidades de la sintaxis espacial para, con ello, lograr transmitir con la mayor claridad posible los aspectos semánticos o comunicativos del producto, desde el significado más básico, el de su funcionalidad operacional, hasta los más complejos, como su sentido exhibitorio y simbólico. Al analizar, dentro de una trama de valores definida por los extremos del minimalismo y el maximalismo, las dimensiones perceptiva, sintáctica, semántica y pragmática, la estética permite que los diseñadores se sitúen conscientemente en el momento histórico para el que diseñan. La estética hace que la cultura del diseño resulte simbólicamente sostenible.

- Joan M. Marín y Rosalía Torrent:

Los mismos, o similares, aspectos que la disciplina estética investiga en torno al arte puede abordarlos también en el campo del diseño con igual competencia: ya sea una reflexión sobre la creatividad, o el análisis de las diferentes dimensiones del producto -formal, funcional, simbólica, emocional-; el estudio de las relaciones o tensiones que se establecen entre las distintas funciones; la reflexión sobre la 
problemática en torno a la recepción del producto por parte del usuario o el mercado; estudios sobre el compromiso social del diseño; etc. En definitiva, la tarea de la reflexión estética en el ámbito del diseño no es menos extensa que en el ámbito del arte. Sería un error considerarlo un tema menor o tangencial.

- María Aguilar: Creo que hay muchos aspectos del diseño que pueden ser abordados por la estética como disciplina, me interesan especialmente aquellos que se distancian del tratamiento del diseño como una parte del arte. Evidentemente arte y diseño están íntimamente relacionados y se necesita que se piense también esta cuestión, pero quizá sea la que más se ha explorado hasta ahora. En este sentido, me parece que merecería la pena reflexionar sobre el papel del diseño en la sociedad y en el medio ambiente haciendo especial hincapié en la relación entre diseño y modelos de consumo. También considero muy necesario abordar temas como las políticas del diseño y la docencia de la filosofía del diseño.

- Wenceslao Rambla: En el momento en que nos hallamos, con apremiantes confrontaciones ideológicas surgidas por mor de la globalización, con el desarraigo que el ser humano manifiesta suicidamente con respecto a la naturaleza poniéndola en peligro, es apremiante, ante todo, poner el acento en una comprensión y defensa ética del diseño. La sostenibilidad y preservación de materiales que impidan obsolescencias programadas, evitar cambiar por cambiar antes que reciclar. Y ya en la dirección de implementar procesos comunicativos, el tener muy en cuenta el peligro que supone la brecha digital (cuyo manejo es indispensable en el modo actual de articular los propios procesos de diseño, sea gráfico, objetual o de servicios), pues de no enmendarse, se impedirá que todo el mundo pueda beneficiarse de esa nueva forma de enfocar el diseño como disciplina. De ahí que todo este panorama haya de repensarse, si es que realmente queremos resolver las antiguas necesidades -vamos, las de siemprey ser capaz de encarar las nuevas que van surgiendo.

Así como en el terreno sanitario es mucho mejor prevenir que curar, aquí creo, mutatis mutandis, que es mejor reflexionar de modo anticipatorio los problemas que están ya apareciendo y ajustar en esta tesitura las metodologías pertinentes. Es por esto por lo que, para llegar a formar (construir) aquello que vayamos a necesitar, ha de propiciarse antes una información no sólo para resolver las viejas necesidades de otro modo, sino para alumbrar las nuevas. Bien entendido que no se trata de crear aprioris, cual nuevas y artificiosas necesidades (como tan bien sabe promover el capitalismo más desaforado) para dotarlas de falsamente novedosas ofertas resolutorias, sino analizar muy críticamente, desde una auténtica consideración ética, las futuras proyecciones y prácticas, que han de ser ya presentes, en el diseño de nuestra contemporaneidad.

- Pedro Medina: La creación de algo nuevo atañe a formas, usos y procesos, siendo una reflexión que, si bien podemos encontrar en más ámbitos, la estética puede hacer suyos, para hablar de "proyecto logrado". Para ello deberá atender aspectos de carácter formal, es decir, debe activar análisis de tipo epistémico, que describa y explique el valor propiamente estético del proyecto; pero también debe considerar esta perspectiva en correspondencia con la incidencia que tiene el proyecto en el ámbito social y político, considerando también su capacidad simbólica y comunicativa, en definitiva, el valor moral y cognitivo del proyecto.

- Claudia Mosqueda: Históricamente, el diseño ha sido caracterizado por conceptos que definen la ejecución de sus saberes. Pero tales conceptos, son 
construcciones epistémicas, discursivas $\mathrm{y}$ bidireccionales que fundamentan $\mathrm{y}$ conceptualizan la producción del diseño en momentos históricos específicos; de modo que el diseño puede ser comprendido por las construcciones estéticas que en todo momento representan formaciones discursivas específicas.

En mi opinión, una estética del diseño podría responder a formaciones discursivas propias, esquemas estéticos-conceptuales que partan de una lectura de la realidad y que al mismo tiempo pueda explicarlas, no sólo desde enfoques y propuestas teóricas, sino con la producción de objetos de diseño que inciden, permean, construyen y configuran las realidades disímbolas y complejas que ordenan los discursos epistémicos del diseño.

Estos conceptos se inscriben dentro de estructuras y formaciones discursivas del campo del conocimiento del diseño capaces de regular y ordenar los modos en que los objetos son percibidos, agrupados, definidos.

Una estética del diseño requiere comprender los modos en que la realidad se transforma y con ello las prácticas del diseño. De tal manera que no podría pensarse sólo en conceptos de época, sino en como estos responden a momentos específicos y son trascendidos en la medida en que dejan de responder a la realidad en la que fueron producidos y recibidos. Diseñar es llevar a cabo un proceso de conceptualización que sintetiza la época o los procesos socio-históricos y culturales específicos en los que se produce, pero la base de la proyectación del diseño también incorpora a este entorno elementos formales, conceptuales, materiales, técnicos, teóricos, prácticos, metodológicos y tecnológicos ordenados de manera integral.

- Manuel F. Mancera: - Eficacia y eficiencia del modelo.

- Adaptación del medio.

- Concreción de la idea.

\section{6}

En mi opinión, una estética del diseño podría responder a formaciones discursivas propias, esquemas estéticos-conceptuales que partan de una lectura de la realidad y que al mismo tiempo pueda explicarlas.

\section{Claudia Mosqueda}

\section{Cuarta cuestión}

\section{¿Qué momentos de tu trabajo reflexivo han implicado un acercamiento al diseño? ¿En qué ha consistido esa reflexión sobre el diseño?}

- Fernando Broncano: Yo comencé a preocuparme del diseño cuando empecé a pensar en la acción humana de carácter complejo, es decir, de los planes para transformar el mundo. Una teoría del diseño es, para mí, una teoría de la acción, del mismo modo que una teoría del significado es una teoría de la intencionalidad.
Ello me llevó rápidamente a la filosofía de la técnica y de ahí, cada vez más a una teoría de los artefactos como mediaciones de la acción humana, que es al fin y al cabo, lo que constituye el diseño como una actividad normativa, el que se dirige a crear un espacio de posibilidades de acción. 


\section{6}

El diseño industrial de producto, como factor potenciador de la identidad personal, ha sido importante desde el principio, aunque de una manera creciente hasta la actualidad.

Jorge López Lloret

- Jorge López Lloret: Casi todo mi trabajo reflexivo ha girado en torno a la historia de las ideas estéticas en el siglo XVIII, vista desde lo que se podría definir como "cultura del diseño". Las transformaciones sociales que tuvieron lugar en el paso del Clasicismo al Rococó condujeron a que, como dijo John Gloag, una cultura que daba más importancia a la comodidad sustituyera a otra basada en la dignidad. El surgimiento de la individualidad moderna dio una importancia creciente a la imagen personal, a la que vinculaba con los objetos que usaba y exhibía. La búsqueda de una nueva identidad personal en entornos, como los urbanos, crecientemente anómicos, en el marco, además, de la consolidación de la Revolución Industrial y del asentamiento de la burguesía como clase dominante, definió una situación que ha durado hasta nuestros días. En ella el diseño industrial de producto, como factor potenciador de la identidad personal, ha sido importante desde el principio, aunque de una manera creciente hasta la actualidad. La indagación de los efectos de esta situación sobre el pensamiento ilustrado, especialmente el francés y el escocés, ha definido el grueso de mi vida reflexiva.

- Joan M. Marín y Rosalía Torrent: Desde hace años la investigación sobre la historia del diseño y su estética ocupan la mitad de nuestras investigaciones.

- María Aguilar: Dentro del diseño, a la parte que dedico más tiempo es a mi labor docente. En este ámbito, reflexiono de forma recurrente sobre cómo hacer que los futuros diseñadores se planteen constantemente las implicaciones de su trabajo y su papel como agente social, cultural y económico. Podríamos decir que me preocupa especialmente la ética del diseño desde un punto de vista profesional y cómo inculcarla en los estudiantes.

- Wenceslao Rambla: Así como tú, Fernando, eres profesor y diseñador gráfico, yo soy profesor de Estética pero me dedico a las artes plásticas. Desde muy joven me atraía la filosofía además de apasionarme también la pintura y el dibujo, a lo que se añadieron la fotografía y el grabado. Precisamente este año cumplo 50 años de trayectoria artística y 30 de profesor universitario en los que impartí desde Antropología filosófica hasta Estética en Diseño Industrial y, por supuesto, Estética y le Teoría del Arte Contemporáneo en Historia del Arte.

Cuando elaboraba mis particulares "objetos" (mis cuadros) ya entonces me preguntaba por esa otra clase de objetos (lo que entendemos por cosas, vamos) tales como herramientas, locomotoras, envases, mobiliario, luminarias,... también los edificios e instalaciones fabriles, y por supuesto los grafismos y las tipografías que conforman (ilustran, apelan y señalan) nuestro universo comunicativo.

Para empezar diré que pronto me percaté, y sigo pensándolo, de la existencia de un gran analfabetismo visual en nuestra sociedad. Sí, todo el mundo sabe leer, escribir, hacer cuatro cuentas y desde hace no mucho también procura ser ducho en el campo de la informática básica. Pero la gente, ¿realmente sabe leer una imagen, conoce el valor de la tipografía en un cartel, su importancia en la maquetación de un libro o en la señalética que nos rodea? ¿Entiende cómo se articulan y dialogan entre sí cromatismos y formas, 
significantes y significados? ¿Comprende por qué un color "pesa" más que otro, el valor de la letra como imagen más allá de su codificación lingüística, y cosas así? Creo que no, o apenas. Todavía hace falta mucho por superar estas lagunas desde luego.

Y claro, desde mi práctica artística y desde la teoría estética - a donde me dirigí posteriormente en mis estudios- es cuando me interesó vivamente indagar en todo ese universo objetual entendido en sentido amplio -objetual como contraposición al sujeto creador, lo objetual físico, icónico, gráfico, digital, o como queramos 1lamarlo- y que, en definitiva, viene a configurar nuestra Weltanschauung, a construir el universo de entes entre que los vivimos $\mathrm{y}$ con-vivimos y estar abierto a hacer nuestra vida más amable y mejor en esa vocación de acercar el arte a la vida. Y así es cuando me reafirmé en que era precisamente la esfera del diseño en y desde donde debía abordar el entendimiento entre el ámbito intensivo de la estética (arte-teoría) y el que por extensión acoge el diseño. Y en consecuencia el que personalmente me lanzara a la investigación en este terreno, el de la disciplina proyectual y poder desarrollar así cierta teorización en el ámbito académico. Y todo ello, dándome cuenta, por un lado -y como decía el diseñador británico Neville Brody- de que "hay cientos de maneras de trabajar, todas ellas modernas, y concentrarse en una es un error"; y por otro lado -como sostiene el diseñador y académico japonés Naoto Fukasaw- que "el diseño puede verse como un proceso que no sólo procura la primera función del objeto, sino que facilita funciones alternativas que pueden descubrirse dentro del entorno activo del objeto". Aseveración a la que personalmente yo añadiría que "según un peculiar avant la lettre: anticipo visual de lo que todavía empíricamente no es, o de proponerle qué resultados desearía ver plasma- dos (hechos) en el ciberespacio antes de su "concreción extrapantalla", y no tanto por lo que a sus aspectos pre-materiales y funcionales respecta, sino también en cuanto a su "acabado artístico".

\section{6}

Pronto me percaté de la existencia de un gran analfabetismo visual en nuestra sociedad. Sí, todo el mundo sabe leer, escribir, hacer cuatro cuentas. Pero, la gente, ¿realmente sabe leer una imagen, conoce el valor de la tipografía en un cartel, su importancia en la maquetación de un libro o en la señalética que nos rodea?

\section{Wenceslao Rambla}

- Tània Costa: Respondiendo a la pregunta anterior y a esta, diría que uno de los focos de reflexión sobre el diseño que me ocupa actualmente tiene que ver con su relación con la estética aplicada y con la investigación artística. Este interés se deriva de mi labor como coordinadora de la línea de doctorado de EINA, centro Universitario de diseño y arte de Barcelona, y del seminario de doctorado de la facultad de Filosofía de la UAB, GEARAD (Grupo de Estética Aplicada de Investigación en Arte y Diseño), junto con la profesora Jèssica Jaques. También mi implicación en la coordinación del EEES, Máster Universitario de Investigación en Arte y Diseño (MURAD), dirigido por Gerard Vilar, y en Proyectos de investigación afines fomenta que gran parte de mis actividades de investigación se muevan en espacios de pensamiento y de acción que abordan el diseño, el arte y la estética como disciplinas interrelacionadas que, cuando actúan conjuntamente, generan campos de conocimiento comunes.

En este marco de reflexión destacaría 
la idea de "pensamiento ejercitante" que Peter Sloterdijk plantea en Muerte aparente en el pensar. Sobre la filosofia y la ciencia como ejercicio (2009). El filósofo apunta que entre el pensamiento contemplativo y el productivo existe el pensamiento ejercitante. Desde mi punto de vista, éste último se correspondería precisamente con el de la investigación artística o, mejor dicho, con la investigación de las artes basada en la práctica (entendiendo el diseño como una de las artes, junto con la música, la danza, las artes visuales, etc.). Se trata de aquel pensamiento que se desarrolla a través del ejercicio entendido como ensayo, prueba, acción, y que facilita la integración y aprehensión del conocimiento a través de la experiencia... de la misma manera que aprendemos a ir en bicicleta montando en bicicleta, ejercitando, hasta que el conocimiento finalmente sucede. Y, si me permitís, en este punto le robaremos el verbo al poeta Jorge Luis Borges cuando en su Arte poética dice que el arte sucede; no se manifiesta, aparece, es o será, sino que sucede. Y no puedo estar más de acuerdo ante ciertas prácticas de arte y diseño que son claramente investigación en tanto que su suceder deviene y se constituye como un acontecer de conocimiento.

Tal vez podría describirse esta perspectiva como la de un modelo performático de la investigación a través de las artes y el diseño. Pero debemos precisar que la performatividad a la que nos referimos no apunta únicamente al hecho de la acción, el movimiento y el proceso, sino que evidencia la capacidad de esta práctica para generar transformaciones una vez la intervención de diseño y/o arte ya ha finalizado. En el caso de su incidencia en territorios de innovación social nos estaríamos remitiendo a su capacidad de continuidad para empoderar a los agentes implicados a transformar su contexto de manera autónoma y emancipada. En el ámbito de la investigación aludimos a su capacidad para producir el efecto de transferencia de un "conocimiento ejercitante" que revierta en una comunidad investigadora, social y cultural, de manera que pueda ser empleado para iniciar o reanudar proyectos autónomos, críticos y emancipados.

En este sentido, aunque la estética ha de abordar de maneras distintas algunos aspectos del diseño y del arte, sí pienso que comparte discurso en el espacio de la investigación basada en la práctica en la que se encuentran las dos disciplinas. Sobre todo, respecto a la vía de trabajo que pretende revertir la investigación en el contexto trabajado con el fin de resultar una investigación con sentido aplicado y alcanzar un objetivo ciertamente transformador.

\section{6}

Peter Sloterdijk apunta que entre el pensamiento contemplativo y el productivo existe el pensamiento ejercitante. Este último se correspondería precisamente con el de la investigación de las artes basada en la práctica (entendiendo el diseño como una de esas artes).

\section{Tània Costa}

- Pedro Medina: Mi relación con el diseño ha conocido distintos puntos de vista: como docente, como coordinador de estudios, gestor, crítico y comisario de exposiciones. Esto me ha permitido apreciar -en paralelo a lo que ocurre dentro de las artes visuales- que existe un "Diseño", es decir, una disciplina general que construye un discurso sobre sus prácticas, y un "diseño", o sea, cada proyecto individual como resultado de un proceso creativo y productivo. Esto nos lleva a la siguiente reflexión: se suele tender al posicionamiento polar, situándose cada agente en un ámbito en mayúsculas o en mi- 
núsculas, como si fueran compartimentos estancos. Mi trabajo me ha situado más en el primer ámbito, pero he aprendido mucho del segundo, lo que me ha llevado a la convicción de la necesidad de generar discursos que permitan la permeabilidad entre estos espacios, para generar una reflexión más cercana a los desafíos y prácticas actuales del diseñador.

\section{(6}

Existe un 'Diseño' es decir, una disciplina general que construye un discurso sobre sus prácticas, y un 'diseño"' o sea, cada proyecto individual como resultado de un proceso creativo y productivo.

Pedro Medina

- Claudia Mosqueda: Las reflexiones teóricas que he orientado al diseño versan como propuestas teóricas de frontera que intentan construir un pensamiento original para dar cuenta de un presente a partir de conceptos radicantes móviles y dinámicos que expresen la posible realidad de las prácticas del diseño. La filosofía, la sociología, la antropología, la historia, el arte y el diseño son campos de conocimiento importantes a partir de los cuales se pueden proyectar perspectivas teóricas intersticiales que vinculen el pensamiento de diferentes saberes; que busquen aquellos recovecos y hendiduras en donde se hallan los conceptos que dan la posibilidad de establecer relaciones complejas de pensamiento desde el concepto de interpelación.

Este concepto me condujo a revisar el pensamiento del diseño del límite, asumido por mí como un pensamiento potente y productor que nutre de vida la posibilidad de reflexionar el diseño como un instante perpetuo, que aprenda de sí, por sí mismo y para sí mismo y que se recree en cada uno de sus saberes categoriales y vaya siempre más allá de su práctica misma. El pensamiento del límite edifica una propuesta para la configuración de una práctica profesional del diseño del límite. En este sentido es importante recuperar las ideas filosóficas de Eugenio Trías, las categorías del pensamiento del límite, para proponer un repensamiento del diseño como un instante eterno, siempre pensante desde sí mismo y para sí mismo.

Pienso que el saber del diseño como práctica profesional requiere de aprender a hacerse consciente de su existencia a través de la mirada de todas aquellas condiciones sociales, culturales, artísticas, educativas, ambientales, económicas, materiales y de diseño mismo que lo enfrentan a pensarse a sí y para sí mismo, con los otros saberes o condiciones que ensanchan, transgreden y sensibilizan su existencia en tanto saber. Pero, ¿por qué pensar el diseño desde la filosofía? o, mejor dicho, ¿por qué pensar el diseño desde la filosofía del límite? ¿Qué preocupación flota en el contexto social, cultural económico, educativo o artístico para detenernos a ver el diseño con la mirada sensible del filósofo? ¿Qué hay en el diseño mismo para problematizar la existencia contemporánea y sociocultural de los saberes y prácticas del diseño?

Evocando a Micieli, yo aseveraría, que si la filosofía tiene que poder problematizar su propia actualidad, la tendría que interrogar como acontecimiento desde el que da sentido, valor. En este aspecto, la filosofía del límite de Eugenio Trías se refleja en el arte o la ética, el saber del diseño puede desprenderse o emerger como una filosofía del límite. De tal manera que, los saberes, las prácticas y los sujetos-diseñadores ajusten su máxima de conducta o acción a su propia condición humana, es decir a su condición de diseñadores forjadores y habitantes pro- 
ductores del mundo y de su propio mundo. Que el diseño se conozca a sí mismo, para dejarlo actuar en consecuencia de su propia máxima de conducta. Es decir, que aprenda a vivir en el instante de su propia existencia y experiencia.

\section{6}

Es importante recuperar las ideas filosóficas de Eugenio Trías, las categorías del pensamiento del límite, para proponer un repensamiento del diseño como instante eterno, siempre pensante desde sí mismo y para sí mismo.

\section{Claudia Mosqueda}

Me parece pertinente y preciso el pensamiento de la filosofía del límite para la práctica del diseño si se asume que el límite siempre está abierto a la generación de nuevos modos de pensar lo comunitario de los saberes, las prácticas y lo personal del sujeto; introduciendo inflexiones conceptuales que pueden tener verdadera relevancia en el ámbito de las ideas de cualquier saber, en este caso el diseño.

De esta manera, pensar el diseño como una práctica del límite podría ser -siguiendo a Eugenio Trías- una invitación a ser traspasado, transgredido o revocado. La filosofía del límite, a la que aspiraría el diseño, es una forma de incitación a la superación, en esta incitación pierde su identidad pura y dura de carácter originario, agreste o natural y será el sujeto diseñador, el hombre fronterizo, el portador de la razón que en él se constituye.

Pensar el diseño desde la filosofía del límite tiene sentido como pensamiento propositivo que intenta en todo momento volver la vida del ser productiva. Cuando se dice que es una respuesta de época quizá es porque se trata de repensar la voluntad de poder del sujeto como un creador que siempre procura recrearse, no materializarse en su obra sino revivir en el pulso creativo y creador.

Pienso que el límite combate la pasividad del nihilismo que conduce a una vida reactiva, sin un sentido productivo de vida, porque la voluntad de poder se parece a la de un esclavo que no se compara con la actitud de vida y creadora de la de un artista. Uno pasivo y reactivo es lo opuesto a un creador y a eso aspira el sujeto-diseñador, el ser del límite. El sujeto-diseñador, en tanto ser del límite, se hace en el límite, se hace en la plena conciencia de su actividad productiva y creadora.

\section{6}

Se puede decorar desde la imaginación. Se diseña desde el intelecto.

\section{Manuel F. Mancera}

- Manuel F. Mancera: En la sociedad diseñada en la que vivimos, aún quedan muchos planteamientos por abordar para que, la maquinaria que la echa a andar, funcione correctamente. Abordar algunas cuestiones de eficiencia en ese modelo constructivo-ejecutor, desde dentro de la técnica, como recurso pragmático de la construcción actual, es un punto de inflexión importante para profundizar en la idea de su esencia.

Mejorar o adaptar los recursos, para apuntalar y/o construir un elemento referente que gestione, desde la eficacia, el uso de lenguajes propios y diferenciadores para el nicho de mercado en cuestión al que vaya destinado.

Instruir a los hacedores del ámbito tecno-creativo en una suerte de libertades conceptuales desde la aproximación al conocimiento de la técnica aplicada.

Se puede decorar desde la imaginación. Se diseña desde el intelecto. 
sna sus tu. nportancia de los bienes producidos por el .cado y uso, dependiendo de quién lo use:

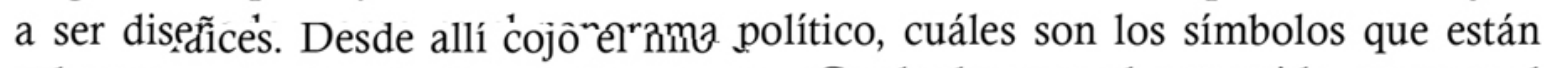
sobrevseptual y donde el está ubicado. Cual êsadualme:

hace ñado, como es el panorama político, cuálesirna $\epsilon$ to la inmanencia del concepto. Gradualmes jur. la forma al objeto y el diseñador encarna $\epsilon$ ira u. engua olvidada, o como un carpintero que a apli $a$ un trozo de madera amorfo.

ssí, Cá oso en la publicación brasileña Design enza a c $r$ ejemplos de la importancia de los bient stiona su. funcionalidades porque los factores subje

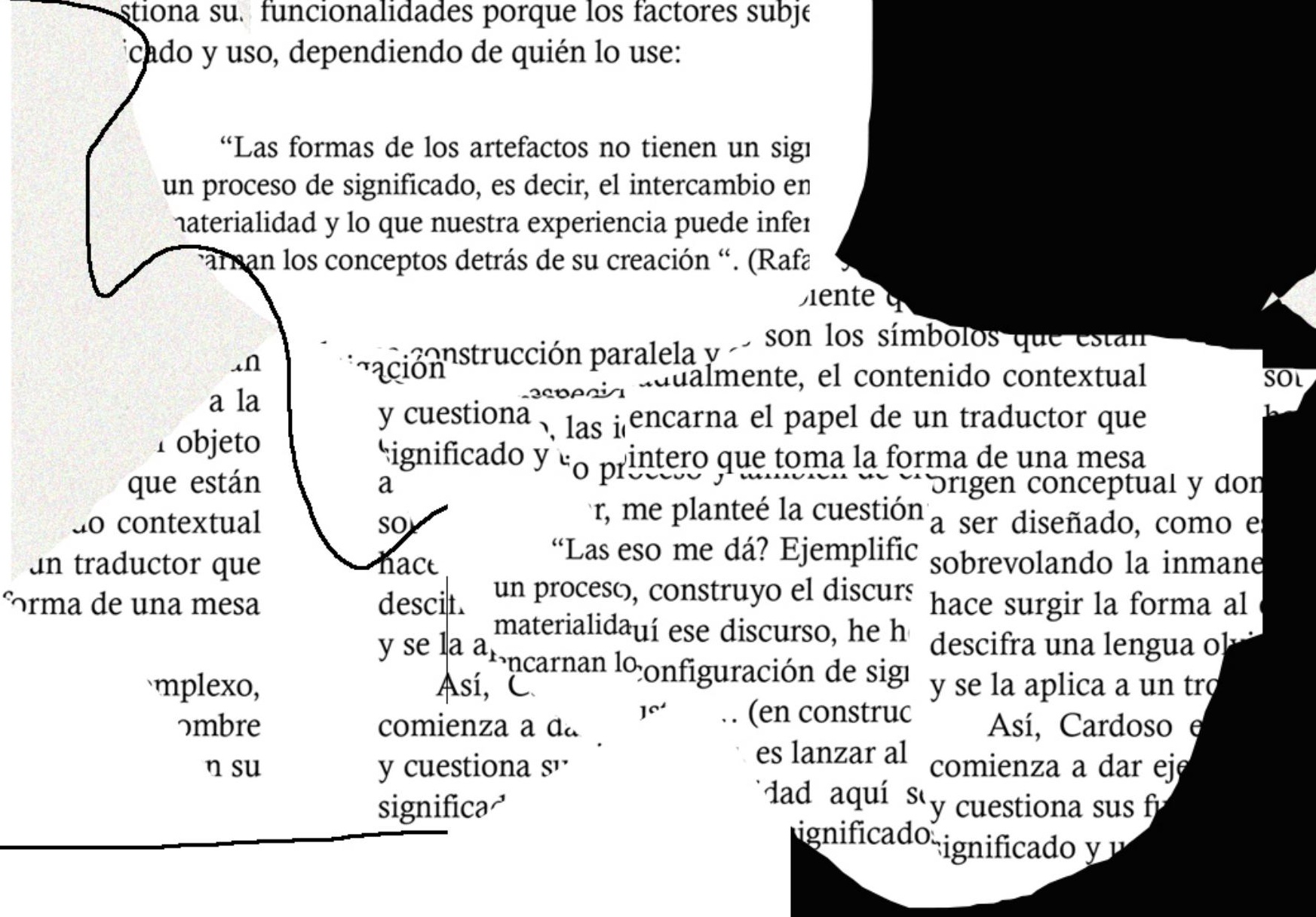
comienza a dar ejempl

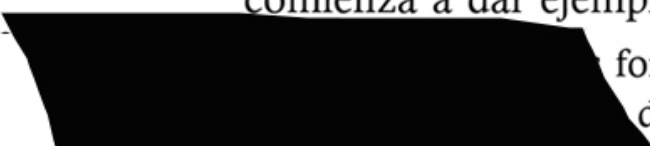




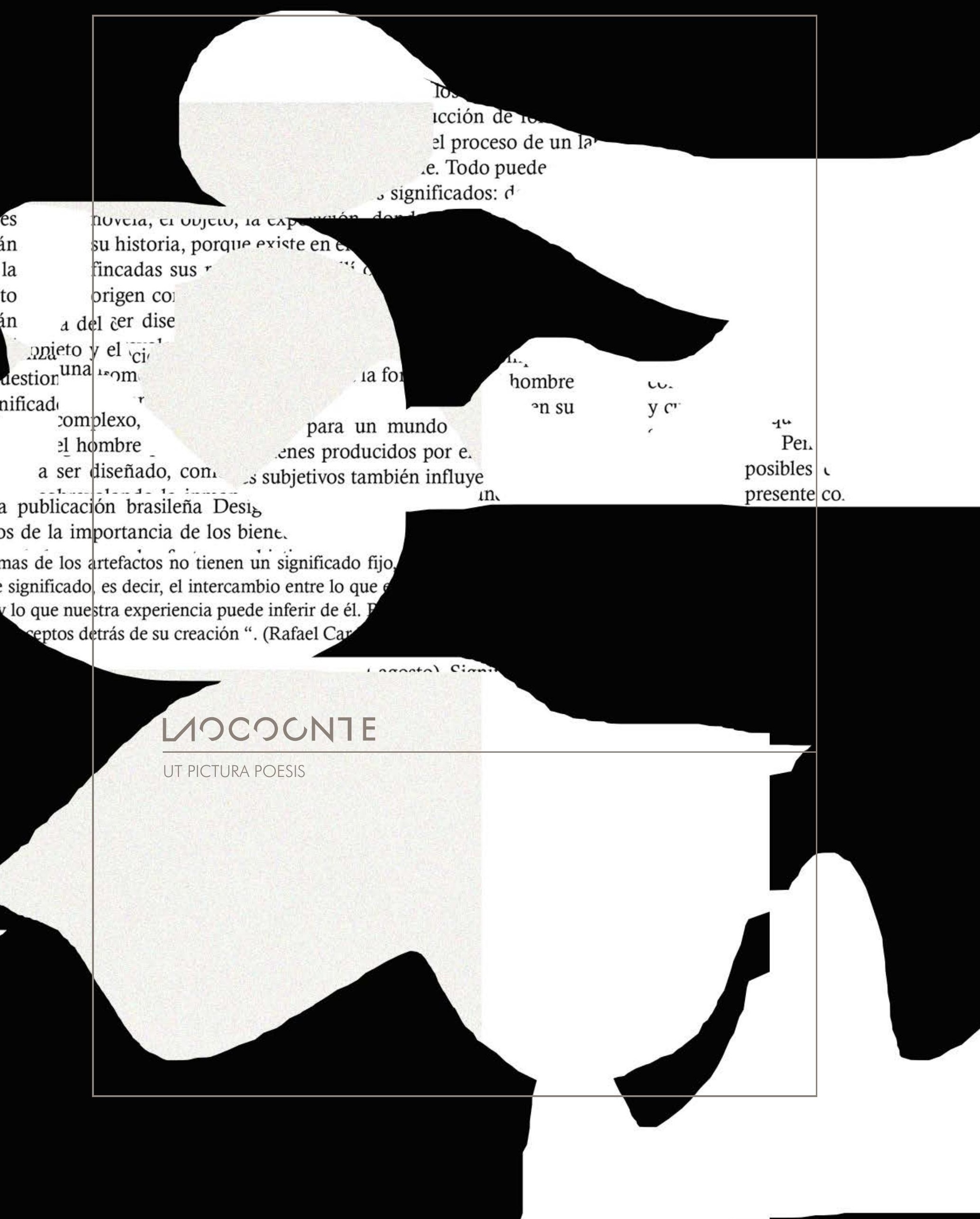




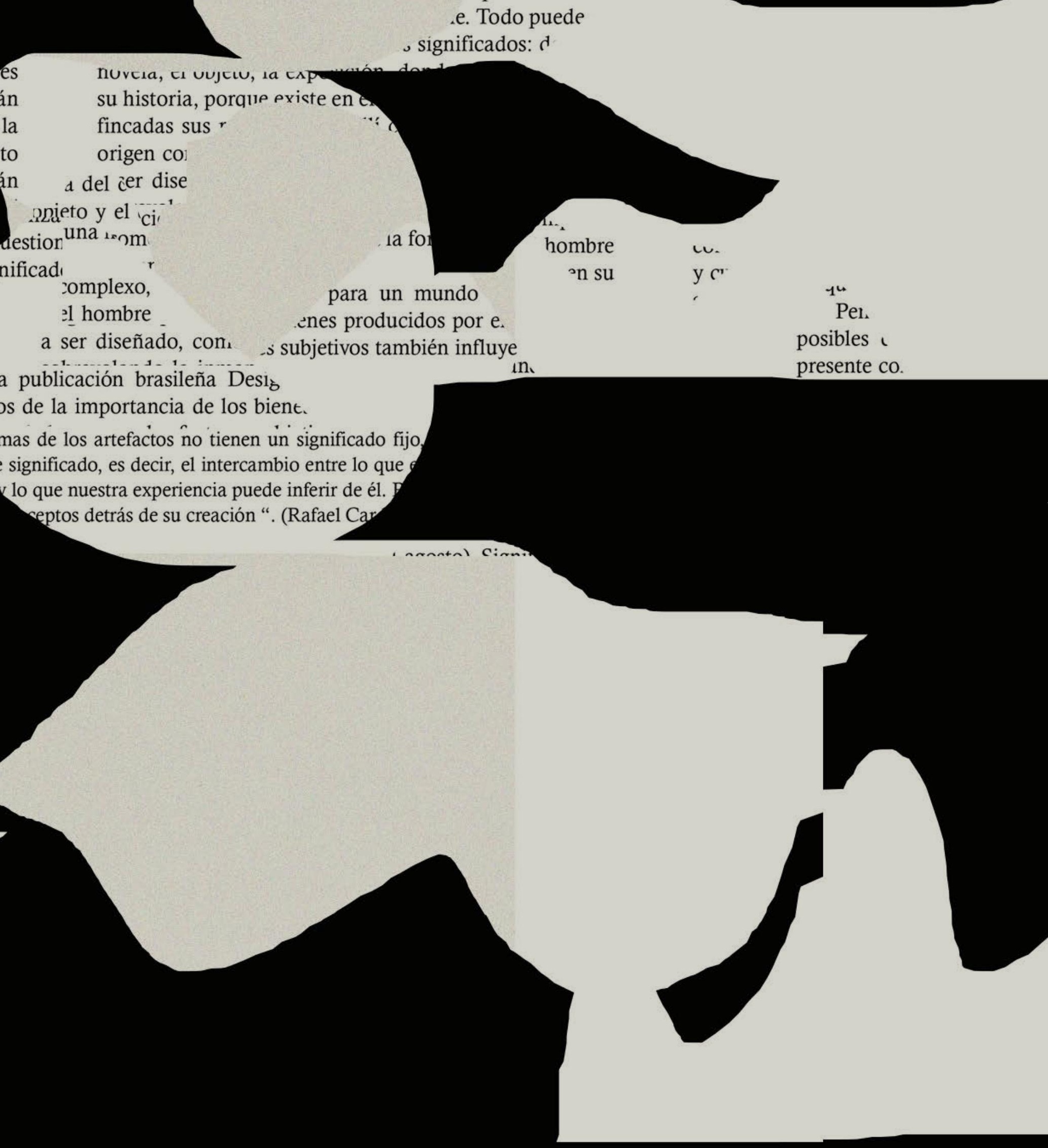




\title{
Abandonar la escritura. Poesía experimental y manifiesta
}

\author{
Ignacio Gómez de Liaño*
}

\section{A BAN DO NN E R $L^{\prime} E C R \quad$ I TU R E}

* Doctor en Filosofía, Ignacio Gómez de Liaño (Madrid, 1946) ha sido profesor en los campos de la Sociología, la Estética y la Filosofía Oriental, en la Escuela Técnica Superior de Arquitectura de Madrid (1969-1972), el Centro de Cálculo de la Universidad Complutense (CCUM, 1970-1971), la Facultad de Ciencias Políticas y la Facultad de Filosofía de esa Universidad (1976-2007), y en las Universidades de Estudios Extranjeros de Osaka (1984-1985) y de Pekín (1989-1990). Ha dado conferencias en España, Francia, Italia, Gran Bretaña, Alemania, Grecia, Rumanía, Bélgica, Estados Unidos, Puerto Rico, Cuba, Perú, Brasil, Chile, Argentina, Rusia, China, Japón, Marruecos, Argelia, Túnez, Siria, Jordania, Turquía y Líbano.

En junio de 2004 la Fundación Bartolomé March dedicó un simposio a "La obra de Ignacio Gómez de Liaño" con el título de "Arte, memoria y filosofía", en el Palacio-Museo March, de Palma de Mallorca. En mayo de 2008 la Fundación Juan March, de Madrid, invitó a Ignacio Gómez de Liaño a dar dos conferencias y un seminario con el título de "Filosofía práctica", "Autobiografía intelectual" y "Yo y el mundo".

Pionero, desde 1964, de la poesía experimental (concreta, espacialista, fonética, semiótica, de acción, pública...), sobre la que da conferencias y organiza exposiciones. Desde 1965 trata a poetas experimentales de varios países, como Alain Arias-Misson, Julien Blaine, Henri Chopin, Jean-François Bory, Arrigo Lora-Tottino, Carlo Belloli y Adriano Spatola. A finales de 1966, funda la Cooperativa de Producción Artística y Artesana (CPAA) con los pintores Manolo y Enrique Quejido, Herminio Molero, Julio Plaza, Elena Asins, Lugán, Julián Gil, Tomás García, el filósofo Fernando Carbonell y la recitadora Lily Greenhan, además de Francisco Salazar y Fernando López Vera. En sus tres años de existencia la CPAA realiza diversas exposiciones de la nueva poesía, la más importante de las cuales fue Concordancia de artes - Exposición rotor internacional, que fue a varias ciudades españolas y cuyo catálogo (1967) viene a ser la primera antología de poesía experimental publicada en España. Gracias a la relación que establece I. G. de L. con el Instituto Alemán, a través de Helga Drewsen, la C. P. A. A. organiza, entre 1967 y 1969, ciclos de conferencias sobre las "Nuevas Tendencias" en poesía, arte y filosofía, en los que intervienen Eugen Gomringer, Max Bense, entre otros.

Autor de los manifiestos Abandonner l'écriture (1968-1969) y ANTIPRO (1971), realiza entre 1969 y 1973 trabajos sobre pintura y perceptrónica (inventando, junto con Guillermo Searle, la "pixelización") y aplica la gramática generativo-transformacional a la arquitectura en el CCUM. En los Encuentros de Pamplona de 1972 se encarga de la sección de poesía experimental y realiza poemas aéreos. De julio a noviembre de ese año culmina en Ibiza sus 
experimentaciones poéticas, teniendo al poeta Villamediana y al filósofo Giordano Bruno como figuras tutelares. Una evocación de esos juegos poéticos y filosóficos se encuentra en sus novelas Extravios (2007) y El Juego de las Salas de Salas (2019). A partir de 1973 se relaciona con los artistas de la llamada Nueva Figuración Madrileña o "Los Esquizos".

Figura en diversas antologías de la literatura española, como Ein Schiff aus Wasser - Spanische Literatur von Heute, Herausgegeben von Felipe Boso und Ricardo Bada (Kiepenheuer \& Witsch, Colonia, 1981). Y desde 1993 hasta 1999, edita diez números de la revista literaria Inventario en colaboración con V. Ferrán Martinell y Alfonso Lucini. Y ha traducido obras del francés, inglés, italiano y latín.

En 2016 el Museo de Arte Contemporáneo de Ibiza realiza una exposición de la poesía experimental de Ignacio Gómez de Liaño con el título de 1972. Los Juegos del Espinario. El FRAC Centre-Val de Loire realiza, en la ciudad francesa de Orleans, otra del mismo género en 2018. Y en diciembre de 2019 el Museo Nacional Centro de Arte Reina Sofía de Madrid abrirá una exposición dedicada a la obra poético-experimental Ignacio Gómez de Liaño con el título de Abandonar la escritura.

Tras su primera fase de poeta experimental, I. G. de L. será el autor de numerosos libros dedicados a la filosofía, la Historia de las ideas, la narrativa, el teatro y el diario, además de la "poesía discursiva". El conjunto de su obra viene a ser una composición polifónica en la que los conceptos y los razonamientos cantan al unísono con las figuras y los lugares. Esta condición polifónica explica la forma como I. G. de L. ha llevado a cabo el proyecto de refundar la filosofía en Iluminaciones filosóficas (2001), Sobre el fundamento (2002) y Breviario de filosofia práctica (2005). Es una refundación que consiste, esencialmente, en complementar el raciocinio con la imaginación, los conceptos con los afectos, el "discurso lógico" con el "decurso mnemónico". Sólo sobre esa base, filosófica a la vez que poética, se puede contribuir a la formación plena de la persona. Esa refundación de la filosofía explica también los cientos de páginas que I. G. de L. ha dedicado al estudio de los métodos diagramáticos y mandálicos utilizados desde la Antigüedad hasta el Renacimiento (tanto en Occidente como en Oriente) a modo de herramientas complementarias de las lógico-discursivas para ayudar a la memoria y a la inteligencia en sus funciones respectivas y, globalmente, a la configuración de la psique.

\section{Bibliografía (sólo libros)}

1968: Poesía experimental. Estudios y teoría, libro conjunto con Eugen Gomringer y Reinhard Döhl, editado por el Instituto Alemán y la Cooperativa de Producción Artística y Artesana, Madrid.

1973: Mundo, magia, memoria, selección de textos de Giordano Bruno (edición de Ignacio Gómez de Liaño), Taurus, Madrid. Reditado en Biblioteca Nueva.

1975: Los juegos del Sacromonte, Editora Nacional, Madrid. Premio de la Nueva Crítica para Ensayo. Reeditado en facsímil por la Universidad de Granada en 2005.

La sensorialidad excéntrica - Rúbricas marginales, de Raoul Hausmann e Ignacio Gómez de Liaño -con una composición gráfica de Henri Chopin y varias obras gráficas de Raoul Hausmann-, Ed. Tres. Catorce. Diecisiete, Madrid.

1980: Nauta y estela (poesía), editado por Entregas de la Ventura, Madrid. La segunda edición, ampliada, aparecerá al año siguiente en Hiperión, Madrid.

Regreso del abismo (poesía), con grabados iluminados a mano de Carlos Forns Bada, Taller de la Galería Estampa, Madrid. Edición limitada.

1981: Arcadia (novela), Alfaguara, Madrid. La tercera edición aparecerá en enero de 2017 en la editorial Huerga y Fierro, Madrid.

1982: Dalí, Polígrafa, Barcelona. Hay ediciones en francés -Albin Michel-, inglés, alemán, italiano -Rizzoli-, portugués, japonés y catalán.

Arquitecturas modernas, libro catálogo, en colaboración con el arquitecto Antón González Capitel, Pronaos, Madrid.

1983: El idioma de la imaginación - Ensayos sobre la memoria, la imaginación y el tiempo, Taurus, Madrid. Reeditado en Tecnos.

1984: Mi tiempo - Escritos de arte y literatura, Ed. Libertarias, Madrid. Jardines (poesía), con cinco serigrafías de Guillermo Pérez Villalta, Ediciones de la Galería Sen, Madrid. Edición limitada. 
La caza de Acteón (poesía), editado por la Diputación de Santander.

1986: Athanasius Kircher. Itinerario del éxtasis, o las imágenes de un saber universal (dos volúmenes), Siruela, Madrid. Premio Nacional a la mejor edición del año. Reeditado en un solo volumen en 2001.

1987: Palabra y terror, La Idea, Madrid.

1989: La mentira social - Imágenes, mitos y conducta, Tecnos, Madrid. Reeditado con nuevos capítulos y revisado en 2018.

1990: Paisajes del placer y de la culpa, Tecnos, Madrid.

1993: Cuadrados (poesía), con grabados del pintor Julián Gil. Galería Víctor Martín, Madrid. Edición limitada. Trazado de estrellas, con grabados de Guillermo Pérez Villalta, Ediciones de la Galería Sen, Madrid. Edición limitada.

1998: El círculo de la sabiduría, I volumen - Diagramas del conocimiento en el mitraísmo, el gnosticismo, el cristianismo y el maniqueísmo, Siruela.

El círculo de la Sabiduría, II volumen - Los mandalas del budismo tántrico, Siruela.

Esos dos volúmenes han sido reeditados en uno solo en 2019 por Siruela.

1999: Musapol (novela), Seix-Barral, Barcelona.

Hinduismo y budismo. Introducción filosófica, libro conjunto con Mónica Cavallé, Abraham Vélez y Marisol Catena, Etnos, Madrid.

2000: Filósofos griegos, videntes judios, Siruela.

Domus Aurea (poesía), con grabados de J. A. Vargas, Arte y Naturaleza, Madrid. Edición limitada.

2001: Iluminaciones filosóficas, Siruela.

2002: Sobre el fundamento, Siruela. Edición italiana en Bruno Mondadori.

2003: El diagrama del Primer Evangelio, Siruela. Edición italiana en Bruno Mondadori.

2004: El camino de Dali (Diario personal, 1978-1989), Siruela, Madrid.

2005: Breviario de filosofia práctica, Siruela, Madrid.

Dali. Noves fronteres de la ciència, l'art i el pensament, libro conjunto con J. Wagensberg, P. T. Landsberg, G.

Herralde, Roy Ascot, Semir Zeki, Gavin Parkinson y Joan Úbeda, Generalidad de Cataluña, Barcelona.

2007: Extravíos, Siruela, Madrid.

2008: Hipatia, Bruno, Villamediana. Tres tragedias del espiritu, Siruela, Madrid.

Recuperar la democracia, Siruela, Madrid.

2009: La variedad del mundo, Siruela, Madrid.

2010: Carro de noche. Poesía 1972-2005, Libros del Aire, Madrid. Reeditado por Ars Poética, en 2017.

2013: En la red del tiempo 1972-1977. Diario personal, Siruela, Madrid.

2014: La mer, Éditions Arichi, París. Con dibujos de Nicolai.

2014: Contra el fin de siglo, Siruela, Madrid.

2015: El reino de las luces. Carlos III entre el Viejo y el Nuevo Mundo, Alianza Editorial, Madrid.

2016: Libro de los artistas (1977-2015), ediciones asimétricas, Madrid. Edición preparada por J. L. Gallero.

2017: 8 ESCRITOS (1993-2016) sobre la poesía de Eduardo Scala, Turpín Ediciones, Madrid.

2018: El Juego de las Salas de Salas, Siruela.

2018: Democracia, islam, nacionalismo, Editorial Deliberar, Madrid.

2019: Sintaxis informática de la arquitectura plateresca (Lógica de la arquitectura). Libro realizado por la colaboración de Guillermo Searle Hernández y correspondiente a las investigaciones hechas por los autores en el Centro de Cálculo de la Universidad de Madrid, entre 1969 y 1973. 

$i$ (1964-1965).

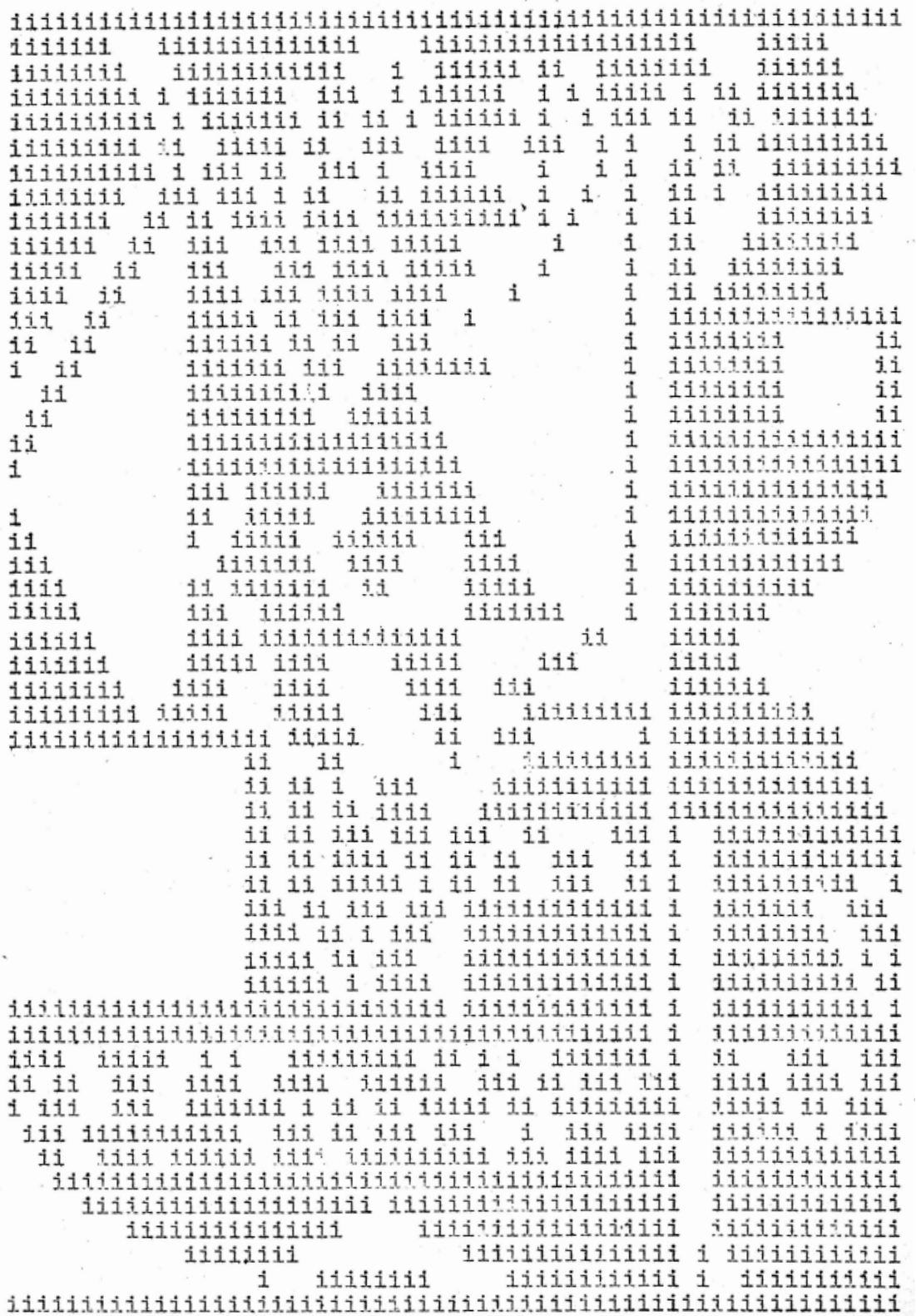


Poema visual negro (1965-1966).

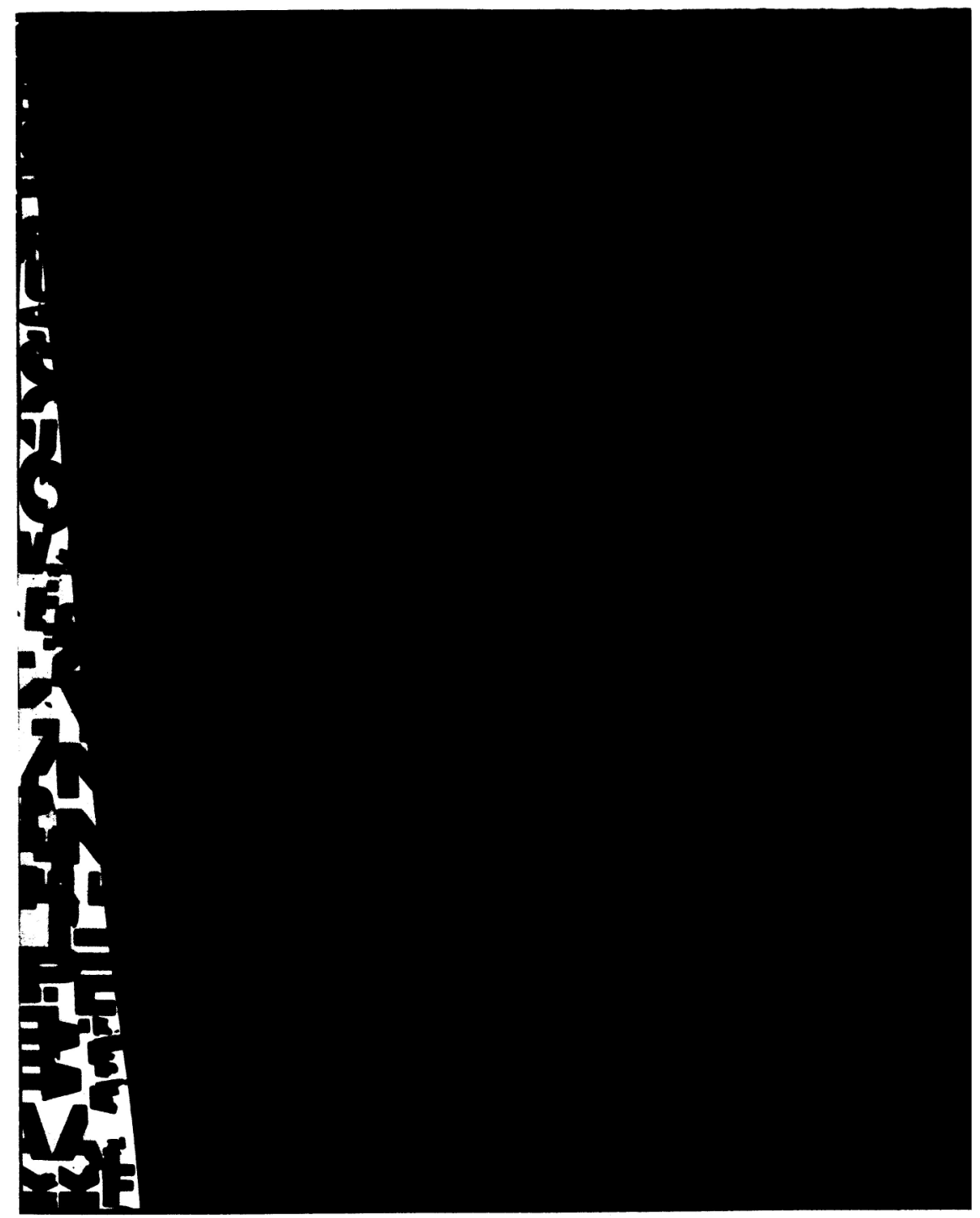


Pájaro geométrico (1965-1966).

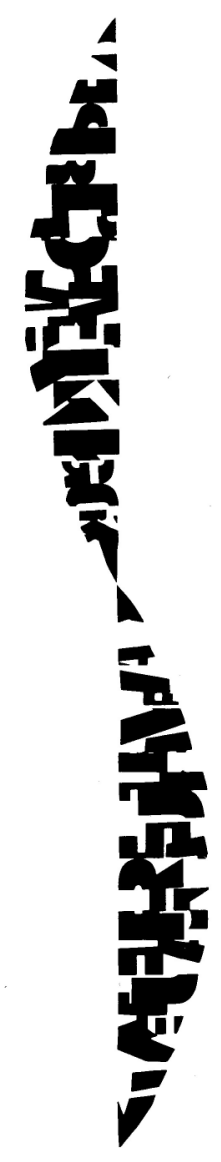


est-mors (1965-1967).

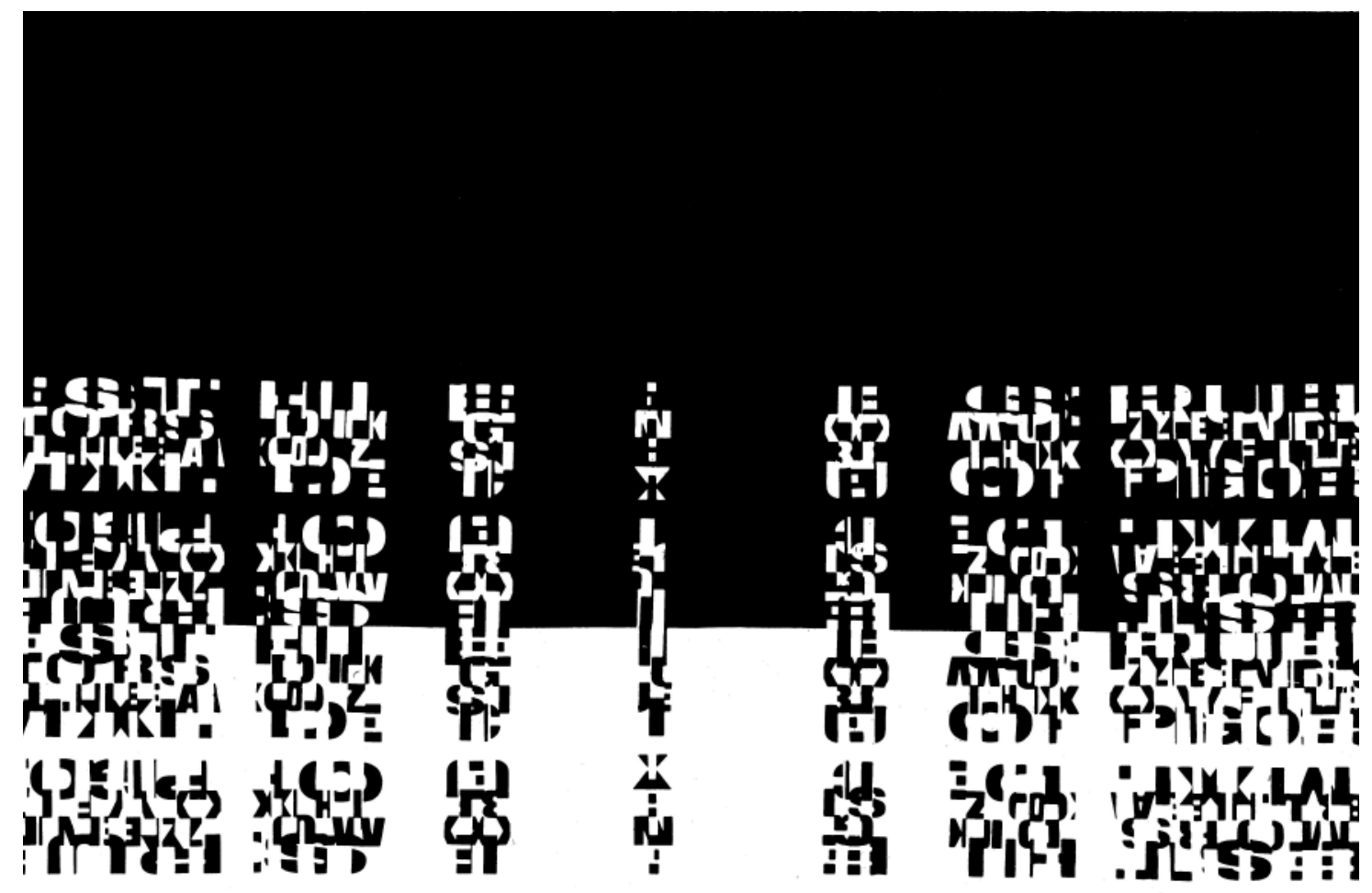


est-mors/letras-libros (1965-2017).
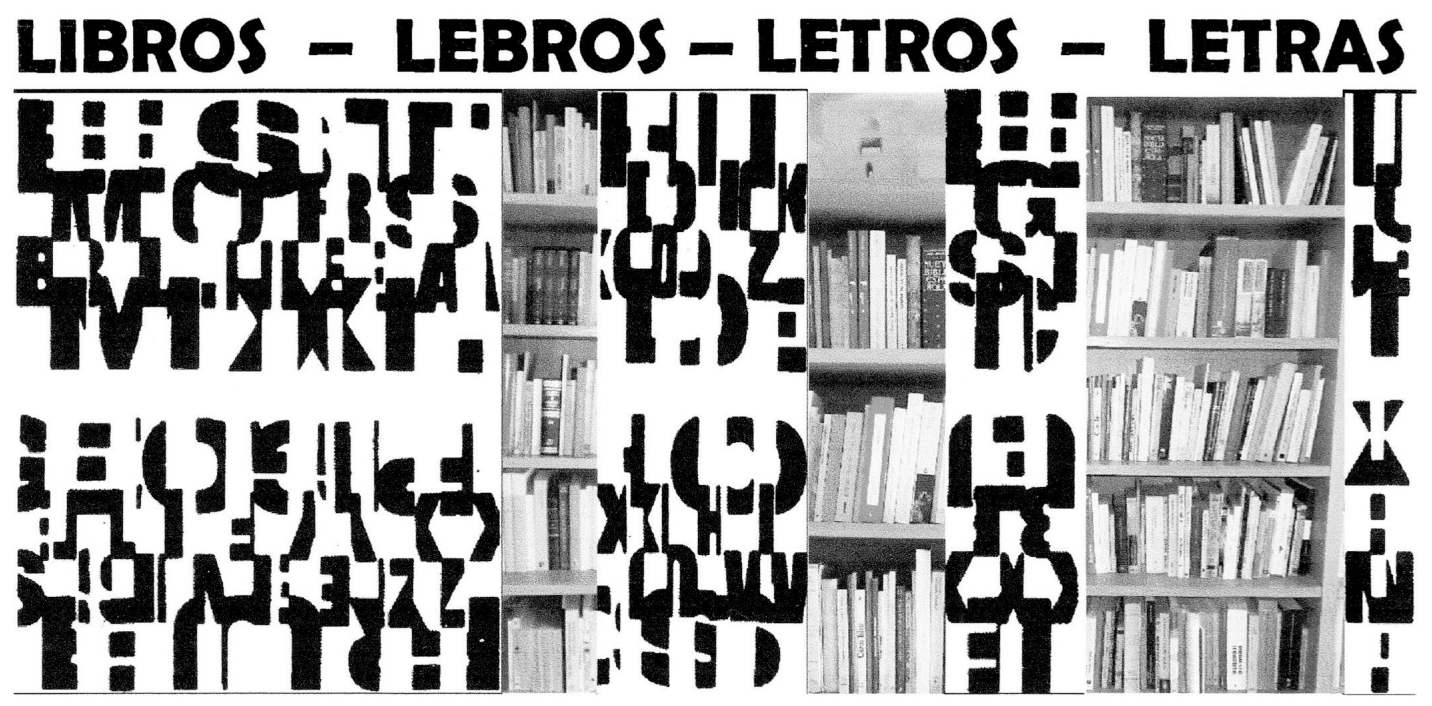

LETRAS - LITRAS - LIBRAS - LIBROS 
Manifiesto Abandoner l'écriture (1968-1969).

\section{A BAN DO NN E R}

1. Vn essei sur l'horme et sur un de ses produits - l'écriture - no peut être un essai humaniste.

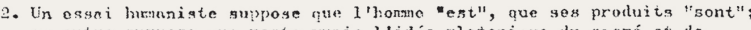
en outre suypoge que reste vrnio l'idte platonique du secré et de l'ismuable, ici substance ariatotélíque.

3. Mais le sncró ot l'imasble ne donnent de suretí qua'ti la race qui dé-

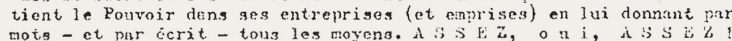

4. Les solutions (prétendues) hunenistes, en tout état ic cruse trompent. - falsifient - lo culture, en lo fixant. Lles sont au service de l'0rdre cul turel tabli, pro
les nouroirs nveumles.

5. Contre ces pouvoirs, j'aime les nota-valeurs : essayer, chercher, cor derrière eux il $y \mathrm{n}$ : re pas nccepter l'oripine, l'inguable, de la

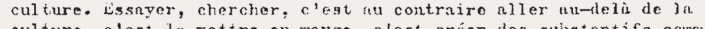

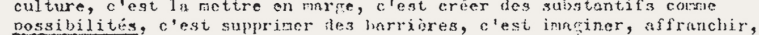
oni, nffranchir et couscicid: i vive.

3. Ahandonner l'ocriture. Oui! il trut nbandonner l'bcriture, telle qu'elle existe, telle que nous la subissons, la nôtre enfin, quiu est contune nu point qu'elle est atilisnble par lo Burcoucratic!!! laguelle est

7. 1.'écriture actuelle n'est plus celle ọui put répondre it I'hotrae, an

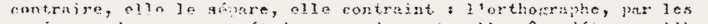
nunies perdues que ses etudes nous tonnent, elle-rêne dítourne l'hnme de ses iasuintions

- Lecriture telle que nous l'nvons fife toui, y compris la culture, elle

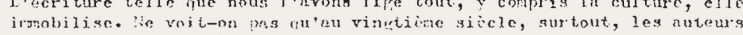
en inventant tonses les fornes possibes, ne purent se contenter de lo

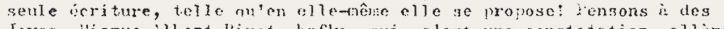

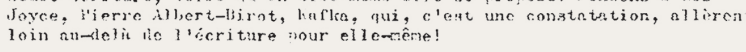

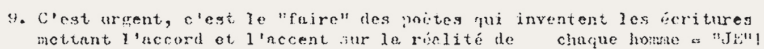

10. C'est le trnvail des poètes : inventer des Ecritures oui ne soient pas répertoires de prétenilues comnissances. tui, les noètes doivent inventer les moyens flli crient le monte, car le vontie se fint, il ne se connat pos.

11. Vne remarque : c'egt un lieu corrum de dire que les hićroslyphes ou les ideogrannes ont init une race, celle des scrihes, métres, mantarins... Je pense tout le contraire. c'est in renire utilitaire, flu sens oi elle devient l'orilre, et biem sûr l'irdre ìs-exjloitations.

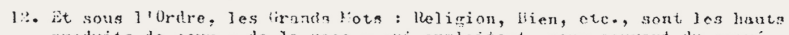
produits de coux - de la race - qui exploitent, sous couvert du sacré, du formelisme, de la mornle. 2. pendant ce tomps, les exploitis cons-

\section{IGNACIO G. DE LIANO}

13. Bref, l'ilphabétiane n'egt plus dísoranis qu'une exploitution. linest de lus une poudo-culture, avec ses rifirences fincienent totalituires. Wt, ce sous couvrrt dure, sacrec sour lerinel il est dinositaire.

14. Contre celn, il y a la rénlité de l'inagination. Suns cesse nouvelle sans cesse contrealite, diverse toujours, tonjours insaisissable.

1: C'est l'imurinntion selle, ses ondes, ses movenants, ses receptions, ses mrojoctions, zes cris, ses refus, ses pensces, ses libertés, qui ost le pararètre un tems et de l'espnce. C'est l'inn inntion, qui se cherge,

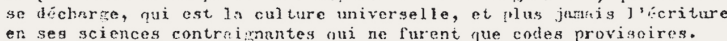

16. Vouloir des ceritures, c'egt vouloir se détruire. Crúer un texte, c'est ge détruire.

$$
\begin{aligned}
& \text { (extraits) } \\
& \text { dive }
\end{aligned}
$$

\section{$L^{\prime} \quad E \quad C R \quad$ I TU RE}


1.- Un ensayo sobre el hombre y sobre sus productos -la escritura- no puede ser un ensayo humanista.

2.- Un ensayo humanista supone que el hombre es, que sus productos son; en otras palabras, supone que continúa siendo verdadera la idea platónica de lo sagrado y de lo inmutable; la substancia aristotélica.

3.- Pero no sagrado y lo inmutable solamente sirven para dar seguridad a la casta que detenta el Poder; y le entrega todos los medios para la realización de sus empresas y cometidos con la palabra y con la escritura. ¡BASTA, sí, BASTA!

4.- Las (pretendidas) soluciones humanísticas en todas las circunstancias falsifican -engañan- la cultura, fijándola, vegetalizándola. Están al servicio del Orden cultural establecido, producto del estatuto socio-económico; los poderes ciegos.

5.- Contra estos poderes, las palabras-valor: ensayar, buscar, porque detrás de ellas está: no aceptar lo original, lo inmutable de la cultura. Ensayar, buscar, es, por el contrario, ir más allá de la cultura, es ponerlas al margen, es crear substantivos como posibilidades, es suprimir fronteras, es imaginar, franquear, sí, franquear y COMENZAR a vivir.

6.- Abandonar la escritura. ¡Sí! ¡Se hace necesario abandonar la escritura, tal como existe, esta escritura que nos vemos obligados a soportar, que es la utilidad de la Burocracia! ¡Y Depósito de lo sagrado!

7.- La escritura actual no puede ya responder al hombre; por el contrario, lo separa, lo constriñe -la ortografía, años perdidos-; aparta al hombre, lo aleja de sus imaginaciones.

8.- La escritura tal como la tenemos lo fija todo, incluida la cultura, inmoviliza. ¿Es que no se advierte cómo, sobre todo en el siglo XX, los escritores que se han puesto en el camino de la invención de todas las formas posibles, no pudieron contentarse con la escritura en la forma en que ésta se presenta a sí misma? Pense- mos en los Joyce, Albert-Birot, Kafka,..., que emprendieron el camino que aleja de la escritura -es una comprobación- en gracia a jla propia escritura!

9.- Es urgente. Es el "hacer" de los poetas: inventar escrituras que pongan el acento y acuerdo sobre la realidad de cada hombre: YO.

10.- Es trabajo de poetas: inventar escrituras que no sean repertorios de pretendidos conocimientos. Sí, los poetas deben inventar los medios con que crear el mundo, porque el mundo se hace, no se conoce.

11.- Nota: Es un lugar común decir que los jeroglíficos o los ideogramas han dado lugar a una casta, la de los escribas, sacerdotes, mandarines... Pero es el hombre quien hace aparecer la casta, él es el dueño de la escritura... Darle a ésta toda prioridad es hacerla utilitaria, en el sentido de que se vuelve al Orden y, ciertamente, al Orden de las explotaciones.

12.- Y bajo el Orden, las Grandes Palabras: Religión, Bien, etc. He ahí los altos productos de la casta que explota, bajo la cobertura de lo sagrado, del formalismo, de la moral. Mientras tanto, los explotados levantan las pirámides.

13.- Resumiendo, el alfabetismo no es más que una explotación. Es también una pseudo-cultura, con sus referencias fundamentalmente totalitarias. Y ello bajo la cobertura de lo sagrado, de lo que es su depósito.

14.- Contra todo esto está la realidad de la imaginación. Nueva sin cesar, sin cesar contradictoria, diversa siempre, siempre inaprehensible.

15.- Es solamente la imaginación, sus ondas, sus movimientos, sus recepciones, sus proyecciones, sus gritos, sus rechazos, sus pensamientos, sus libertades, es sólo la imaginación, que se carga, se descarga, la cultura universal, y nunca la escritura y sus ciencias auxiliares que no fueron sino códigos provisionales.

16.- Querer escrituras es querer destruirse. Crear un texto es destruirse. 
Manifiesto ANTIPRO (1970).

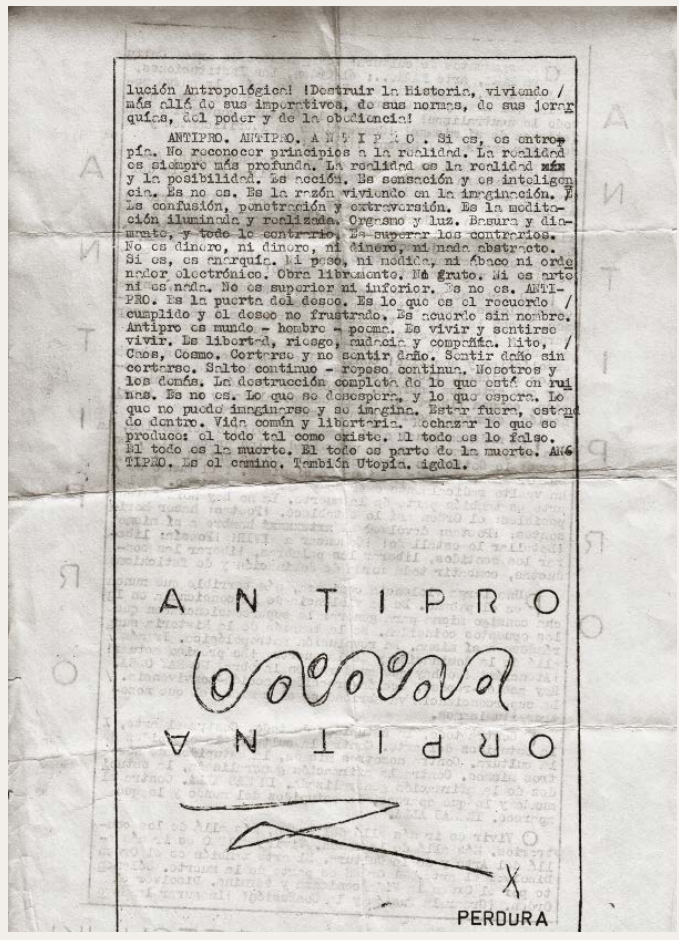

¡Cargamentos de cultura! ¡Cargamentos de arte! Cultura PARA, arte PARA...: el Orden, las Instituciones, la Autoridad, la miseria del Poder. He ahí a la nueva policía: ¡El Arte y la Cultura que todo lo justifican, que todo lo neutralizan! ¡El Arte y la Cultura convertidas en fetiches de sí mismas! ¡Convertidas en lubrificantes y en seductor envase del Orden! ¡BASTA!!

Ha llegado el tiempo de actuar con consecuencia. Actuar contra un arte convertido en firme garantía del Orden y la Miseria existentes. Al igual que el sexo. El erotismo creador y libertario al convertirse en producto mercantil ha pasado a ser la más firme garantía del Orden y la Miseria sexuales existente. La negación y enajenación de toda autonomía y libertad. ¡Es preciso actuar! ¡El todo social y

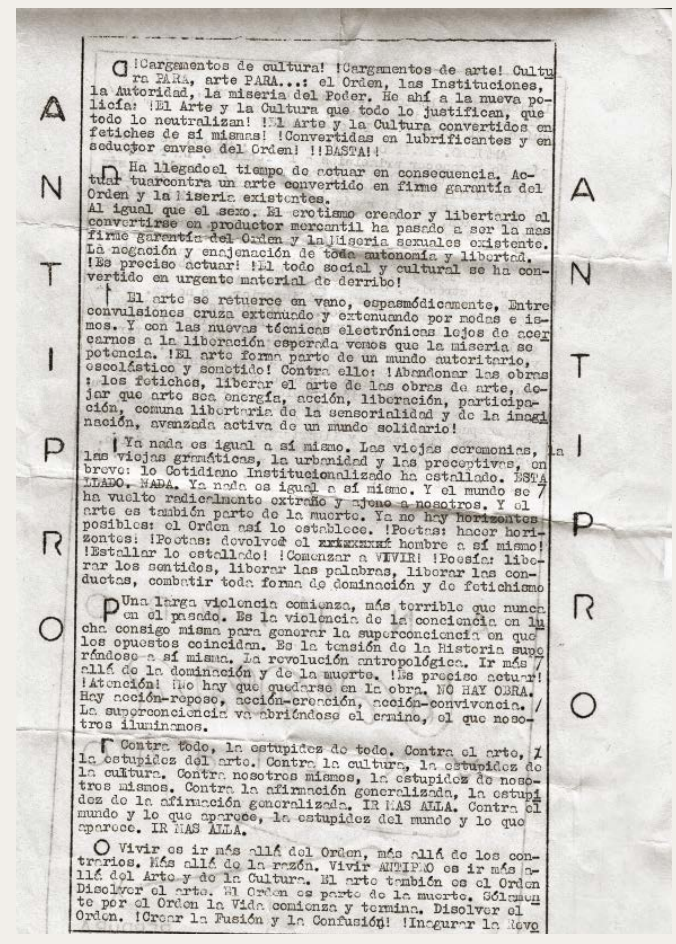

cultural se ha convertido en urgente material de derribo!

El arte se retuerce en vano, espasmódicamente. Entre convulsiones cruza extenuado y extenuando por modas e ismos. Y con las nuevas técnicas electrónicas, lejos de acercarnos a la liberación esperada, vemos que la miseria se potencia. ¡El arte forma parte de un mundo autoritario, escolástico y sometido! Contra ello: ¡Abandonar las obras: los fetiches, liberar el arte de las obras de arte, dejar que arte sea energía, acción, liberación, participación, comuna libertaria de la sensorialidad y de la imaginación, avanzada activa de un mundo solidario!

Ya nada es igual a sí mismo. Las viejas ceremonias, las viejas gramáticas, la urbanidad y las preceptivas, en breve: lo 
Cotidiano Institucionalizado ha estallado. ESTALLADO, NADA. Ya nada es igual a sí mismo. Y el mundo se ha vuelto radicalmente extraño y ajeno a nosotros. Y el arte es también parte de la muerte. Ya no hay horizontes posibles: el Orden así lo establece. ¡Poetas: hacer horizontes! ¡Poetas: devolved el hombre el hombre a sí mismo! ¡Estallar lo estallado! ¡Comenzar a VIVIR! ¡Poesía: liberar los sentidos, liberar las palabras, liberar las conductas, combatir toda forma de dominación y de fetichismo.

Una larga violencia comienza, más terrible que nunca en el pasado. Es la conciencia en lucha consigo misma para generar la superconciencia en que los opuestos coincidan. Es la tensión de la Historia superándose a sí misma. La revolución antropológica. Ir más allá de la dominación y de la muerte. ¡Es preciso actuar! ¡Atención! ¡No hay que perderse en la Obra. NO HAY OBRA. Hay acción-reposo, acción-creación, acción-convivencia. La superconciencia va abriéndose el camino, el que nosotros iluminamos.

Contra todo, la estupidez de todo. Contra el arte, la estupidez del arte. Contra la cultura, la estupidez de la cultura. Contra nosotros mismos, la estupidez de nosotros mismos. Contra la afirmación generalizada, la estupidez de la afirmación generalizada. IR MÁS ALLÁ. Contra el mundo y lo que aparece, la estupidez del mundo y lo que aparece. IR MÁS ALLÁ.

Vivir es ir más allá del Orden, más allá de los contrarios. Más allá de la razón. Vivir ANTPRO es ir más allá del Arte y de la Cultura. El arte también es el Orden. Disolver el arte. El Orden es par- te de la muerte. Solamente por el Orden la Vida comienza y termina. Disolver el Orden. ¡Crear la Fusión y la Confusión! ¡Inaugurar la Revolución Antropológica! ¡Destruir la Historia, viviendo más allá de sus imperativos, de sus normas, de sus jerarquías, del poder y de la obediencia.

ANTIPRO. ANTIPRO. ANTIPRO.

Si es, es entropía. No reconocer principios a la realidad. La realidad es siempre más profunda. La realidad es la realidad y la posibilidad. Es acción. Es sensación y es inteligencia. Es no es. Es la razón viviendo en la imaginación. La confusión, penetración y extraversión. Es la meditación iluminada y realizada. Orgasmo y luz. Basura y diamante, y todo lo contrario. Es superar los contrarios. No es dinero, ni dinero, ni dinero, ni nada abstracto. Si es, es anarquía. Ni peso, ni medida, ni ábaco, ni ordenador electrónico. Obra libremente. Ni fruto. Ni es arte ni es nada. No es superior ni inferior. Es no es. ANTIPRO. Es la puerta del deseo. Es lo que es el recuerdo cumplido y el deseo no frustrado. Es acuerdo sin nombre. ANTIPRO es mundo - hombre - poema. Es vivir y sentirse vivir. Es libertad, riesgo, audacia y compañía. Mito, Caos, Cosmos. Cortarse y no sentir daño. Sentir daño sin cortarse. Salto continuo - reposo continuo. Nosotros y los demás. La destrucción completa de lo que está en ruinas. Es no es. Lo que se desespera, y lo que se espera. Lo que no puede imaginarse y se imagina. Estar fuera, estando dentro. Vida común y libertaria. Rechazar lo que se produce: el todo tal como existe. El todo es lo falso. El todo es la muerte. El todo es parte de la muerte. ANTIPRO. Es el camino. También Utopía. 
Escritos inéditos (1971)*.

\section{El poema público}

— ¿Es ahí el almacén de plásticos? Mire, desearía 24 metros de cinta plástica transparente de 3 metros de ancho; el nombre es polietileno $005 \ldots$ Sí, 12 pesetas el metro.

Con estas palabras puede decirse que se iniciaba el poema público palabras frágiles. Las decía un amigo del poeta, Ignacio Gómez de Liaño. Pues el autor, Alain Arias-Misson, se encontraba en Bruselas, y aún tendría que pasar por Ginebra (¡dos ciudades verdaderamente poéticas!) antes de llegar a Madrid para animar esas palabras frágiles que se desplegarían polietilénicamente en la calle de Santa Catalina, junto a la Galería Seiquer. (Con palabras por teléfono a un almacén de plásticos se iniciaba el poema).

Todos los tratadistas coinciden en que una de las características de los poemas públicos es la de dejar extenuados y exhaustos a los que los practican. Arias-Misson, principal pionero de esta modalidad, escribía recientemente: "La transferencia de la energía poética sobre el público exige un tremendo gasto de esfuerzo físico privado" (Tafelronde, XV - 3 en 4 , Antwerpen). La poesía, particularmente la pública, es como una ventosa, es absorbente, lo quiere todo de nosotros, para con renovada alquimia obrar la metamorfosis, el gran salto. Veremos.

La noche anterior a la sesión "pic", el poema público seguía su marcha, nunca más exacto, pues el segundo paso estaba efectuándose en un garaje. Allí, recién lle-

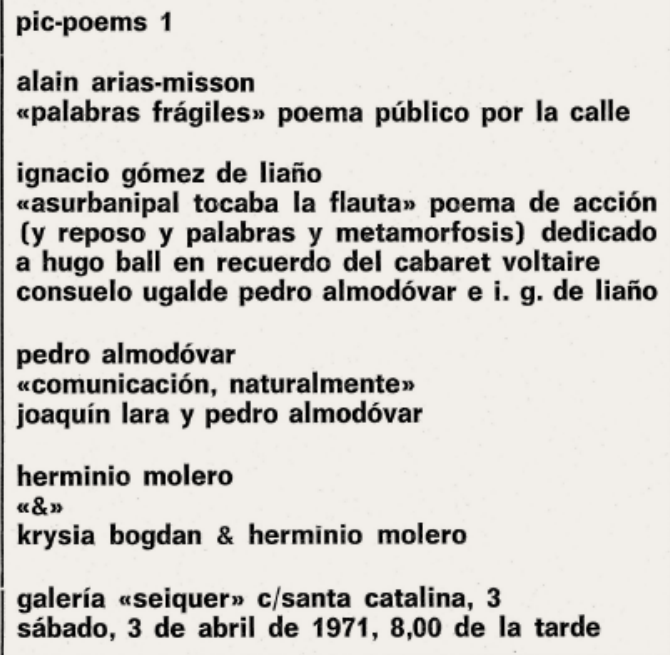

Programa de pic-poems 1

gado Alain Arias-Misson procedente de círculos hiperbóreos, estaban reunidos la pintora Nela Arias-Misson, los poetas $\mathrm{H}$. Molero e I. G. de Liaño, y con ellos Virginia Careaga. El objetivo que les congregaba era el de pintar con gruesas letras las expresiones mágicas PALABRAS FRAGI$L E S$ sobre las dos desmesuradas bandas de polietileno respectivamente, que, una detrás de otra, se extendían sobre el piso del garaje. Alrededor, los automóviles esbozaban muecas fraternas. Lo que nadie sabrá es la sorpresa del sereno que vino a aparecer en el garaje justo en el momento en que, como conspiradores, entraban en él nuestros amigos. A Nela, como tratando de explicar, en ropa de faena, con pinceles y pintura en ristre, se le ocurrió decir:

* $\quad$ Estos textos, escritos con el pseudónimo de Karma DURBIMA, han permanecido inéditos hasta ahora. Tienen la virtud de reflejar el espíritu del momento, además de relatar aquellas horas tan especiales de poesía "pic" (así se nos antojó llamar a las acciones poéticas que entonces llevamos a cabo). 
-Ya ve usted, vamos a hacer un poema.

A las tres y media de la madrugada, extenuada, la improvisada comunidad poética se retiraba a descansar.

Unas horas después, a las ocho de la tarde del sábado, se desplegarían transversalmente las dos cortinas del plástico de uno al otro lado de la calle. El viento agitaba las expresiones mágicas $P A L A$ $B R A S$ FRAGILES colgadas al aire. ¿Interrumpir el tráfico? ¿Desalojar el espacio entre las dos cortinas, e invitar a que una pareja, hundiendo la cinta transparente, rompiendo las frágiles letras, se situase en el centro vacío del extraño y público receptáculo, y allí, se abrazase o, desnudos, se reconociesen en el coito recordando el Asno de oro de Apuleyo? Esto pudo ser el plan. ¡Bello plan! Pero lo real y aún realista fue dejar que el poema lo activase el propio tráfico. Los automóviles, especialmente los taxis, desbarataron los planes con la fuerza de sus chapas. Sí, dejar que

\section{El poema de Asurbanipal}

Era el momento de entrar en la galería para continuar, ya entre cuatro paredes, la sesión "pic". Allí esperaba, voluble, un Poema de acción (y reposo y palabras y metamorfosis), de Ignacio Gómez de Liaño, titulado Asurbanipal tocaba la flauta, con dedicatoria a Hugo Ball en recuerdo del Cabaret Voltaire, según se anunciaba en el programa de mano. La sombra de Asurbanipal y su flauta no tardarían en proyectarse grotesca y espasmódica sobre los concurrentes.

Paralelos a la pared, sobre la moqueta, se hallaban tendidos boca arriba e inmóviles, dos personajes -hombre él y mujer ella-, conectados el uno al otro por las plantas de los pies. Momentos después aparecía I. G. de Liaño preguntando a la sala: "¿Qué es un poema de acción? ¿Qué es un poema de acción?" Por esta vez, no se extendió hablando de sus experiencias los automóviles fuesen penetrando, horadando las cortinas, no sin vacilaciones, no sin que fuesen requeridos a ello por los circunstantes, no sin que fuesen burlados. Los vehículos se encargaron de sustentar el poema, rompiéndolo. Ellos rompieron el himen.

Entre tanto, la energía poética iba desplegándose por la calle, procedía de todos, tomaba la forma de miradas expectantes, de gritos, o era energía mecánica que trataba de apuntalar el polietileno poético, tras los embates de los coches. El poema se consumía, las cortinas caían definitivamente hechas jirones, las letras, convertidas en blancos fragmentos, estaban esparcidas sobre el alquitrán. Media hora antes podíamos leer: PALABRAS FRAGILES. Media hora antes. (¿Qué quiere decir "media hora antes"?) Lo legible, al ser destruido, había realmente generado intemporal y poética lectura.

de poesía de acción por correspondencia, nada nos dijo sobre la resistencia pasiva de la mujer, frente al poema de acción por correspondencia. Esto pertenece, sin duda, a los prolegómenos. El poema de acción -síntesis en cierto modo del Yin y del Yang-, es un rito, pero téngase en cuenta que es un rito único, efímero y estético. Asume la vida como rito, no como palabras estándar, sino como acción y como palabras-movimiento. Se desglosa en gestos, fonemas, palabras, pasos, saltos... Liaño inició la primera fase - poema de participación- haciendo trizas algunos ejemplares de La Gaceta Regional (números atrasados, diario de Salamanca); entregó generosamente los recortes a los asistentes; y entonó: "RAWALPINDI, 28: A la luz de los últimos acontecimientos...". Y de todos los labios empezó a surgir una amplia, efusiva e informativa columna 
sonora. Minutos después: ¡STOP! ¡STOP! Cesaba la algarabía, y en el silencio aún se desgajaban, individualizados, retazos de ir-realidad periodística. Como en un coro, la boda de Laura Valenzuela-Dibildos respondía a los incidentes de Sierra Leona, el anuncio de un jabón contrapuntaba el boletín de información religiosa... En ese momento Ignacio G. de Liaño, que estaba de pie junto a los dos personajes tendidos en el suelo y en medio de ellos, se ajusta a la cabeza una máscara grotesca de goma, con adherencias de papel higiénico, llavecitas mohosas, etc., y, operada la metamorfosis, deja caer, estruendoso, el recitativo dada Asurbanipal tocaba la flauta -la flauta tocaba Asurbanipal. Una de las estrofas decía:

Fiebres antropoides bielas vertederos machacan trituran se hunden la calle se quema desempavimento saltan ampollas de brea y bacilos de Koch avanza entre mallas de junglas perdidas y

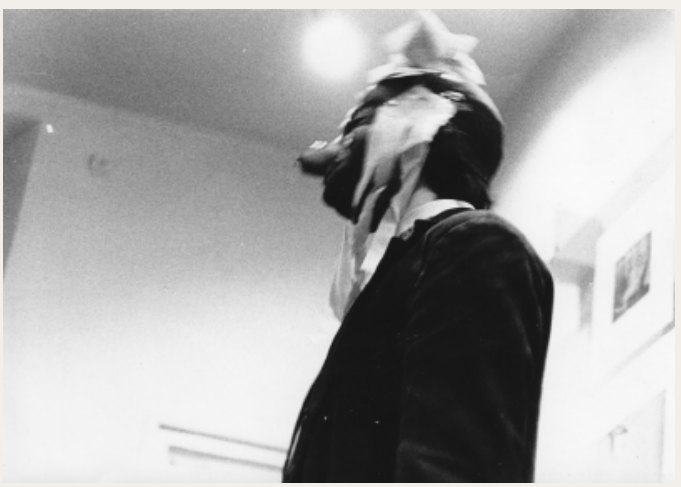

balas RON RON RON FFFFFFFF ZUZUZI ZEZO TANKA RALAKA ZIZARA ZARAKA ASIMO ASAMO KURU y los exitistas y los extintores arañas gigantes de hierro arañas volantes ¡Wellcome Mr Nixon! Barquillos obleas cornflakes y boniatos para Superman y para Mr Freedom un cielo de nylon y papel de prensa ilustrada exuda licores y slogans.

Leído el poema grotesco, el recitador se despoja de su máscara, da la espalda al público, traza un amplio gesto circular con los brazos invitando a los compañeros yacentes para que se levanten. Se yerguen lentamente. Los tres se abrazan. E1 frenesí fusionista va creciendo, y los tres, confundidos, se desploman. Alguien salta de entre el público y se abalanza con furia participadora. En tanto, Asurbanipal tocaba la flauta -la flauta tocaba Asurbanipal.

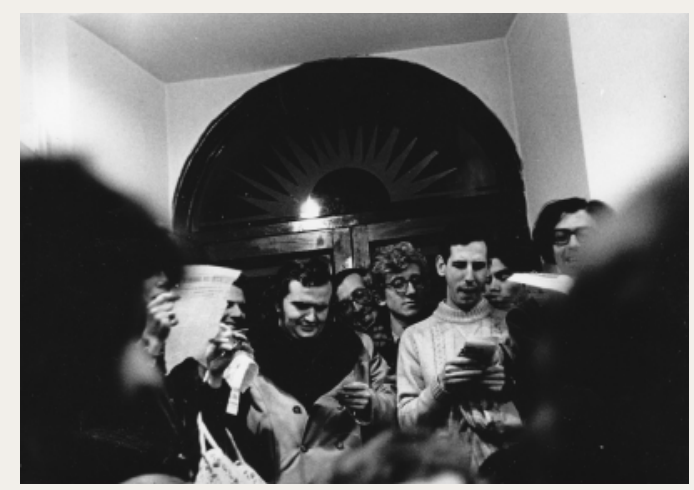

Dos vistas de la acción poética Asurbanipal tocaba la flauta... En la segunda imagen se distinguen, entre otros asistentes-participantes, a Juan Navarro Baldeweg, Fernando López Vera y Alain Arias-Misson

\section{Comunicación "\&" comunicación}

Los dos poemas restantes comunicación, naturalmente y \&, de Pedro Almodóvar y Herminio Molero, respectivamente, se iniciaban a la luz de claras constelaciones lúdicas, y estuvieron a punto de terminar en el mejor y más extremoso estilo "pic". Comunicación, naturalmente consistía en dos focos (Pedro Almodóvar y Joaquín Lara) emisores-receptores de mensajes que yendo de mano en mano por toda la sala paraban, y allí eran leídos, en uno de los dos focos. Se oía: "Sesenta mil pesetas, cuarenta mil pesetas, veinte mil pesetas...", o "Es una fase coyuntural del comercio norteamericano", o "¿De qué color eres tú?", etc. 
A continuación, penetró en la sala $\&$, poema de Herminio Molero, que fue activado por el propio autor y la bella bailarina polaca Krysia Bogdan. Contrapuntados, y como en un collage, alternaban los fonemas emitidos por Molero, las conexiones musicales y los movimientos del cuerpo de Krysia.

En realidad, esto me lo estoy imaginando, ya que no pude asistir a esta úl-

\section{Happy end}

Un coche patrulla de la policía armada estaba apostado enfrente de la galería. Sus contingentes -de uniforme y de paisano- merodeaban intentando sorprender pistas en los restos del polietileno, la pintura plástica o los recortes de La Gaceta Regional, tratando de descifrar lo de las "sesenta mil pesetas, cuarenta mil pesetas..." o "... el comercio norteamericano”. ¡Buenos chicos! Expectación, explica-

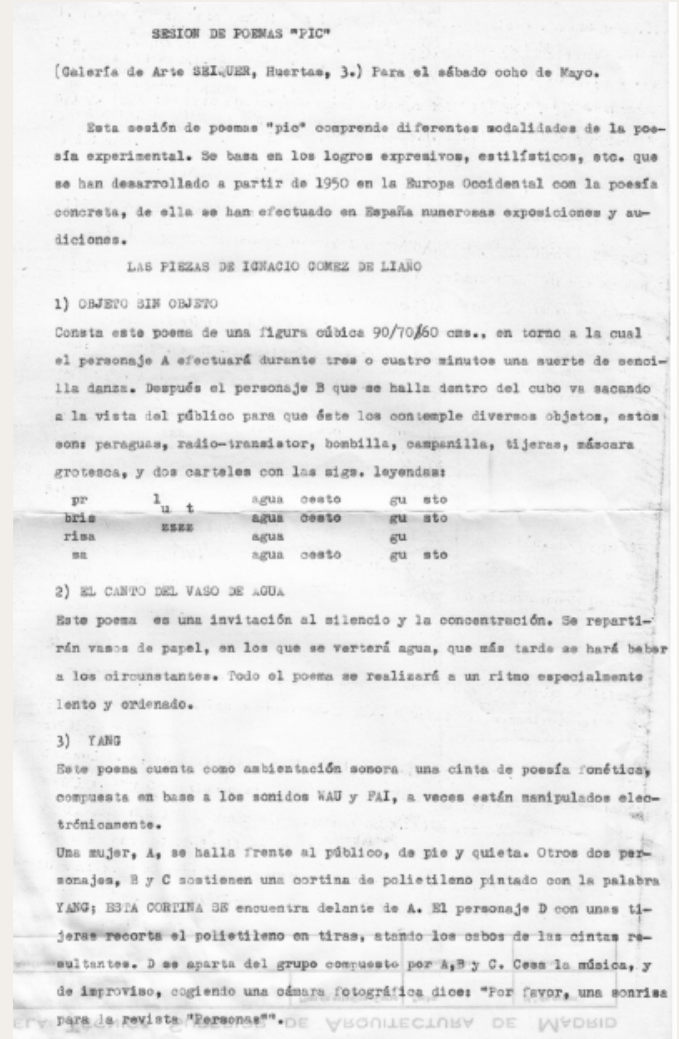

Hoja original con el guión de los poemas de acción de

I. Gómez de Liaño en la sesión de pic-poems 2 tima parte de la sesión. Algo en la calle reclamaban mi atención. He ahí que una circunstancia que no dudaba en calificar de extremosamente "pic", se desplegaba profusamente a las puertas de la galería desde hacía unos minutos. Teníamos invitados. Vi que Josefa Seiquer e Ignacio G. de Liaño salían a hacer los honores. (Yo les acompañaba).

ciones; presencia de ánimo en Josefa Seiquer, elocuencia en Gómez de Liaño. Los reunidos allí dentro, los amontonados allí dentro, ¿no serían una pandilla de excéntricos, de locos fraternos, pero inofensivos, de gente pic, pic ... y nada más? El juicio se suspende. (Consejo de Bertrand Russell). La locura es una actitud política.

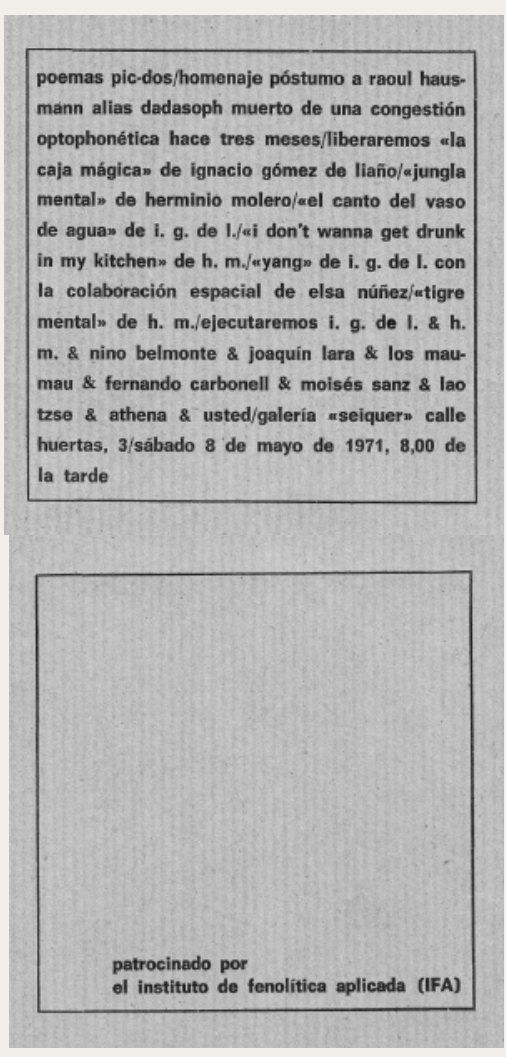

Programa de pic-poems 2 
Poema de la destrucción (1972 - abril).

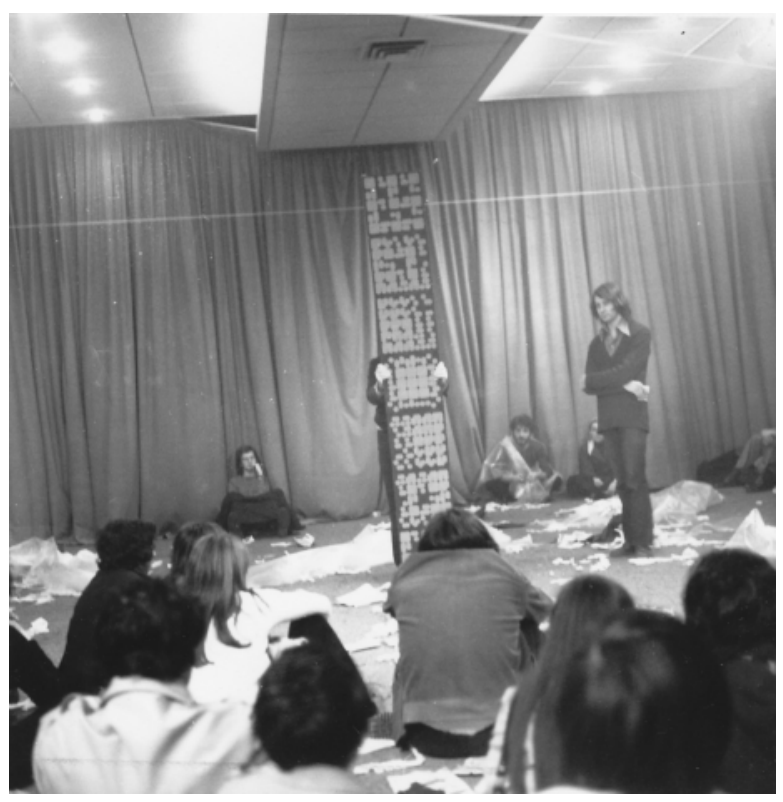


Laberinto de aire (1972 - mayo).

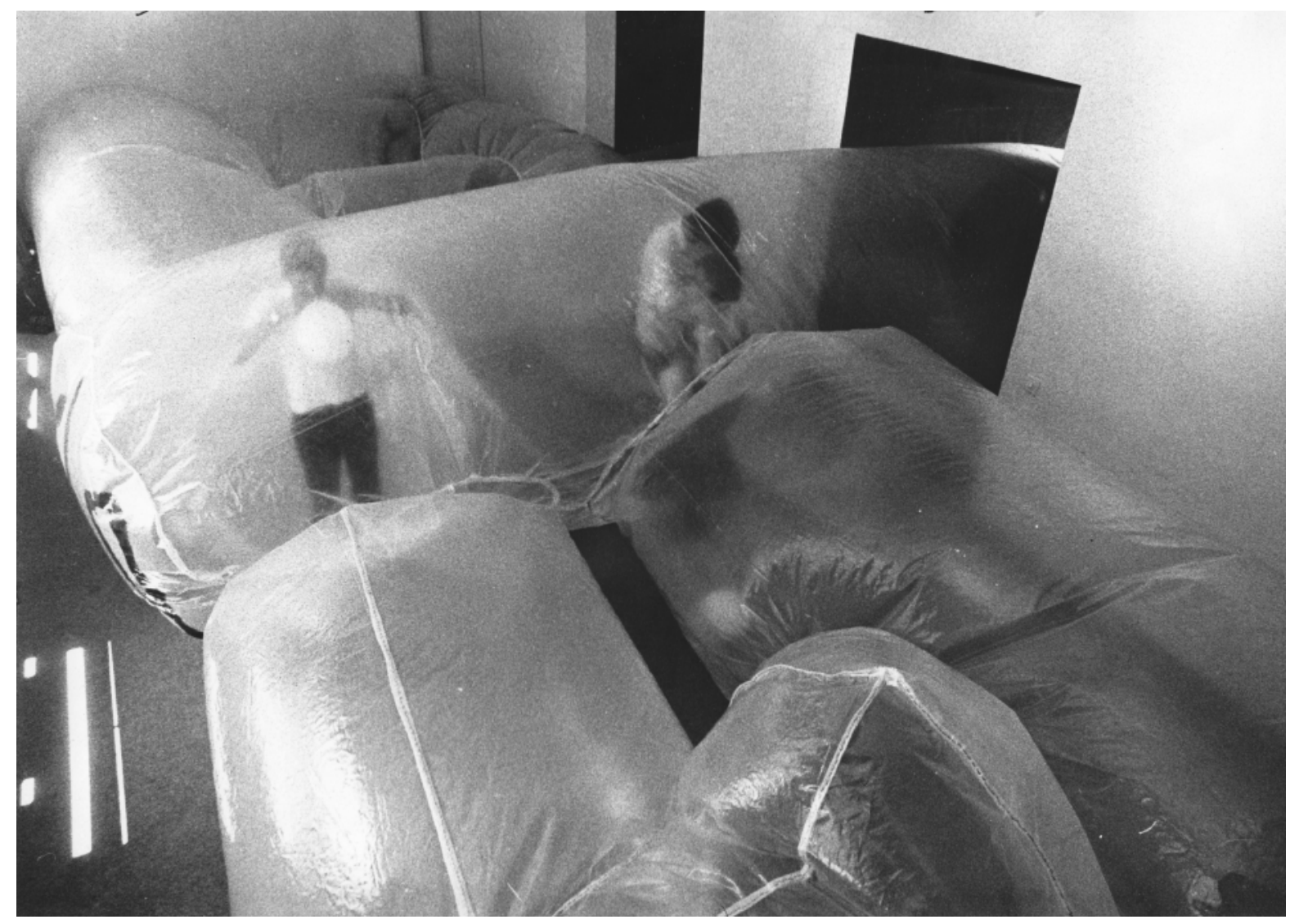




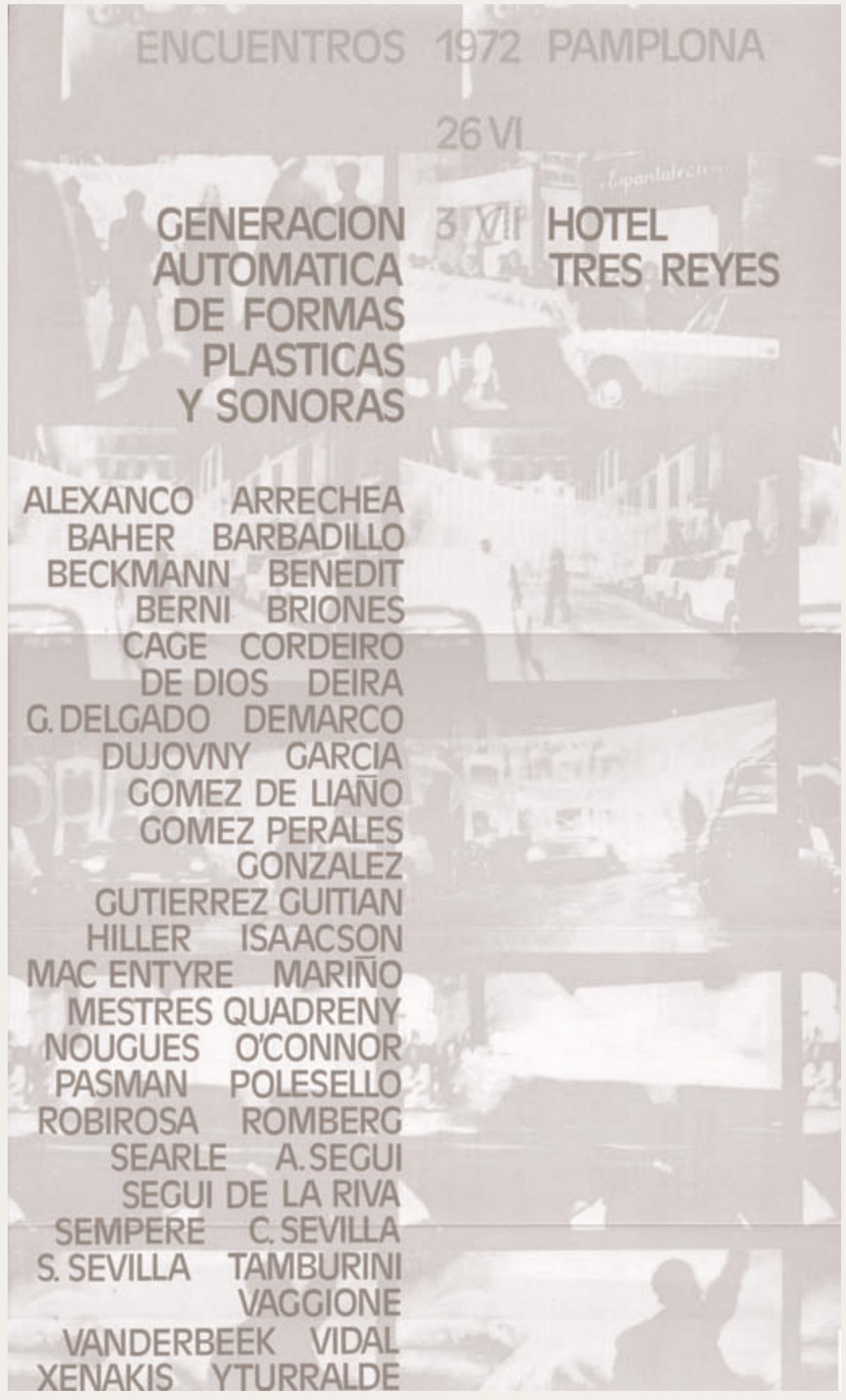


Agitadores (1972 - junio)*

\section{ACCIÓN POÉTICA}

Reúnete con algunos amigos. Respirad siete veces consecutivas lentamente. Al inspirar el aire concentraos en una palabra. Al expirar el aire pronunciad la palabra pensada. Lentamente. Tomad después rotuladores de colores y pintad en el cuerpo las palabras que recordéis entre las que se han pronunciado. Miraos al espejo. Bañaos.

La semioesfera poética se introduce en las cosas cuando se relega al silencio a las reglas, cuando se disuelven los principios, las conveniencias, la lógica que sitia a las cosas. Por el contrario la semioesfera en que vivimos es esa ciudad-escrita, esa conducta escrita, la escritura excrecencia del orden, la marca y señal de tránsito inexcusables. Las reglas del juego no tienen que ver con el juego. La semioesfera poética se hace con el juego libre: Eros, imaginación, ver.

En "De ibero arbitrio", leemos: "La Palabra, convertida ya en garantía del orden, define y categoriza el sentido de todo; impone sobre las cosas su ley marcial. Las cosas allanadas, los signos acometen la ocupación efectiva. Desde las poesías concretas a las poesías públicas y de acción se ha intentado curar la frigidez en que han dejado a la palabra ciencia, filosofia, periodismo, etcétera. Surgen como incursión liberadora sobre las realidades escondidas que se nos han sustraído de las cosas. Se lanzan contra un medio erizado de rutinas, usos establecidos y códigos aletargadores".

Sal a la calle llevando de la mano, atada de una cuerda, una letra mayúscula. Paséala por la ciudad. Acércate a Correos. Mete la letra en un paquete y envíala a la Real Academia de la lengua.

Kacy Lee aconsejaba a los poetas silencio, después de llamar la atención sobre el antibiótico de acción verbal que recientemente ha preparado el doctor Tarratt. La logomicina -nombre del antibiótico citado- proporciona saludables efectos en los casos de afección logicista aguda. Se recomienda a los tecnócratas, burocraticistas y a la mayoría de los sometidos a las profesiones reconocidas. El preparado del doctor Tarratt sirve también como emético después de conferencias o lecturas poéticas. Estos son algunos de sus experimentados efectos poéticos.

Cuando a Kacy Lee le preguntaron: “¿Qué entiende usted por poesía experimental?" se limitó a contestar: "La verdad es que no entiendo nada, señorita. ¿Qué quiere usted que le haga?"

* Texto que acompaña al cartel que diseñé para mi participación en los Encuentros de Pamplona (Junio de 1972), bajo el título de "Agitadores". 
Poema aéreo (1972 - junio).

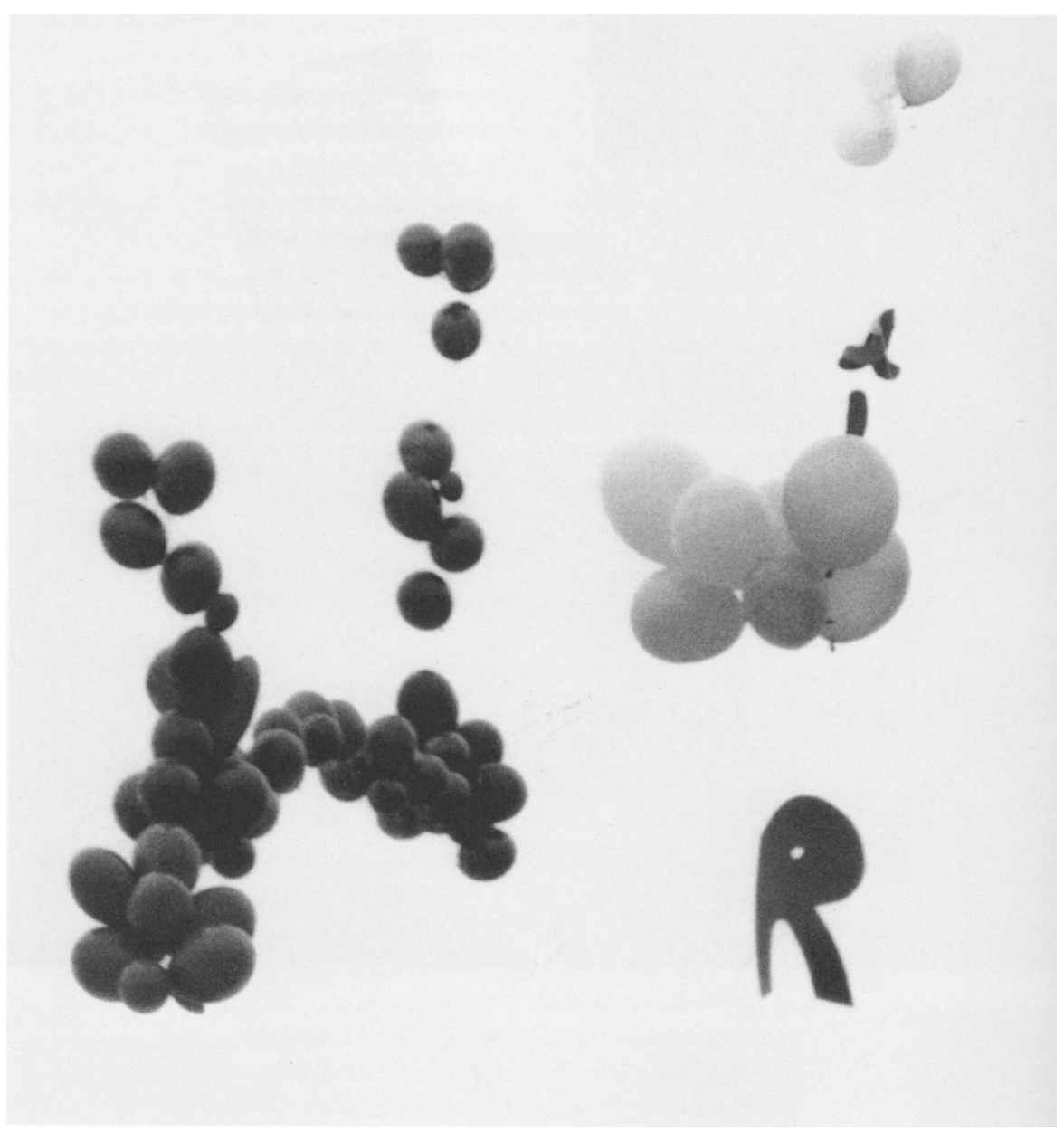


peñaranda... (1972 - julio).

\section{pen̄aranda...}

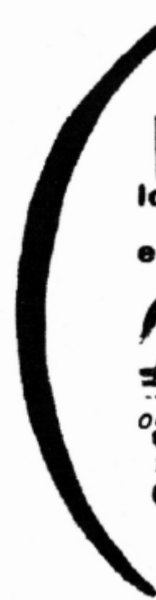

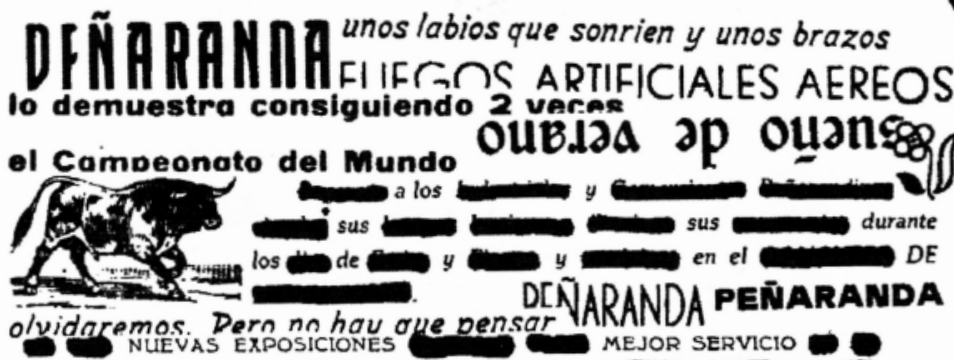
DISTINGUIDA Clientela PUBLICO EN GENERAL.

T TRESILlOS DORMITORIOS. CLASICOS, MODERNOS Y CASTEL,LANOS.
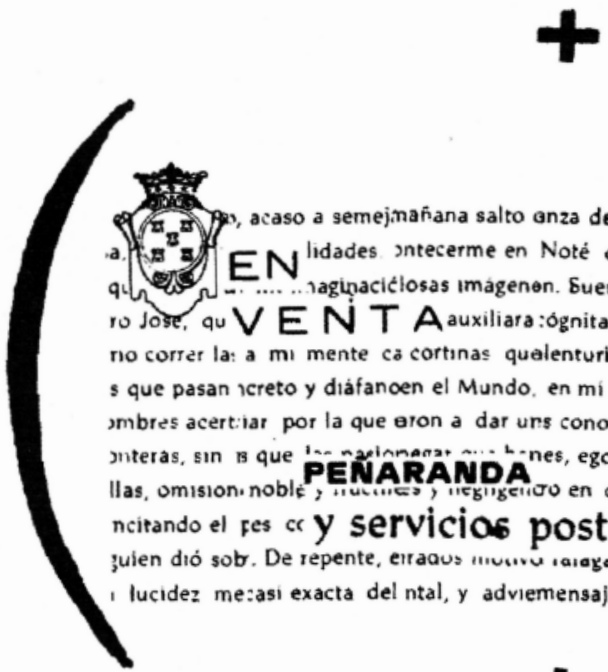

\section{4:}

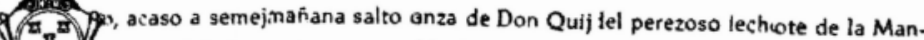

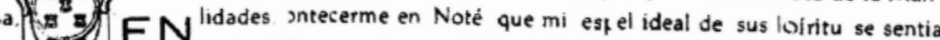

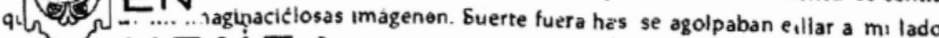
ro Jose, au $V \in N T A$ auxiliara :ógnita de mı sue como al Faraón rño. Era nece. no corret la: a mi mente cácortınas qualenturienta Que privaban de luz ria ver las co. s que pasan icreto y diafancen el Mundo. en mi Peñaranda y de un modo col, a quien unos mbres acertiar por la que eron a dar uns conocida allenia fisonomia pecu le de nuestras

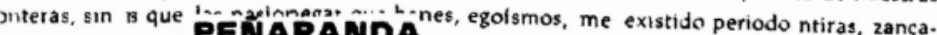
llas, omision. noble, Hit... ncitando el pes " y servicios postventa garantizados. orque suien dió sob. De repente, erraaus ...u....u raragas intermitis por su mal naceentes aparece lucidez mesasi exacta del ntal, y adviemensaje de mi sto una magnitud ueño... Una

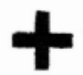


peñaranda... (1972 - julio).

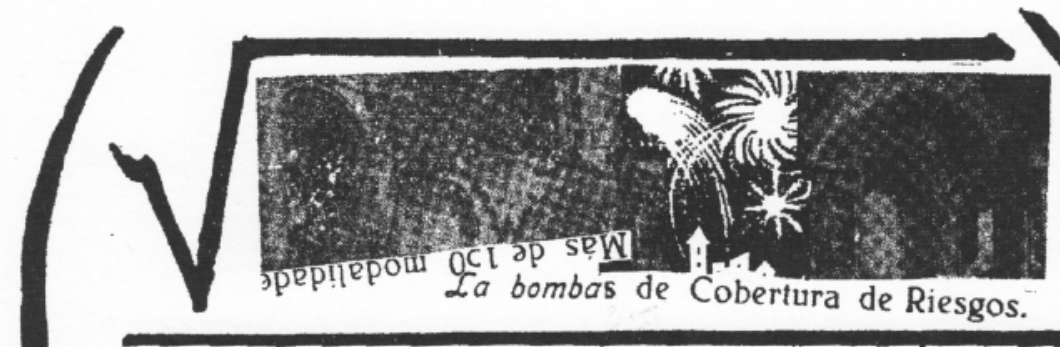

Lo cual es una suerte para usted. inchainton hoemas cabeu ne feñarande?

Porque está hecho con el mismo afáno se monta una central eléctrica. Ades. To en tam.

de perfección con que en GeneralGracias, sencillamente, a su famosa pi "S Mtar,

Elèctrica se hace una locomotora. Asi que, si su programa preferido se te 8 e eurmm-

$P_{2} \bar{n}$ a $x$ Uama $\mathbf{P} \mathbf{E} \tilde{\mathbf{N}} \mathbf{A} \mathrm{Y}$ podrá ver también que,

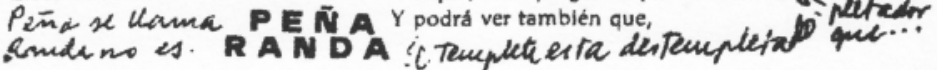
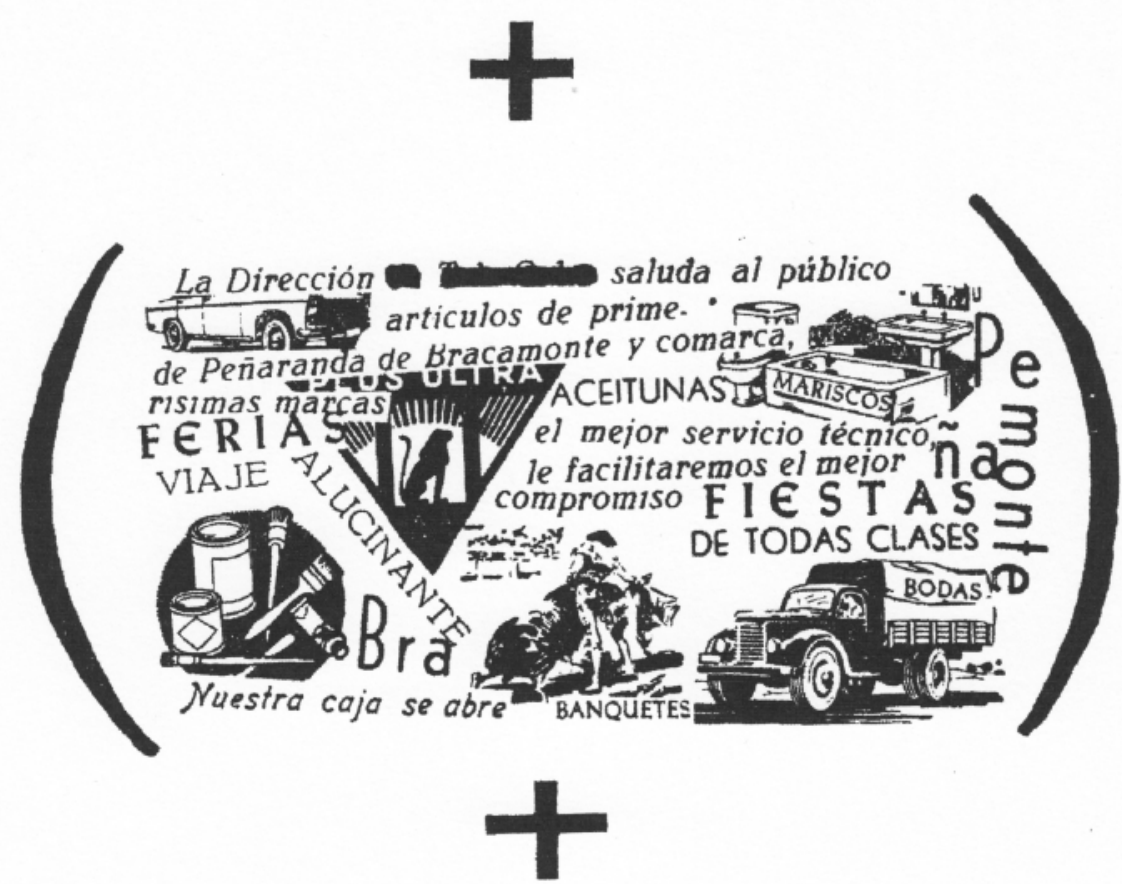

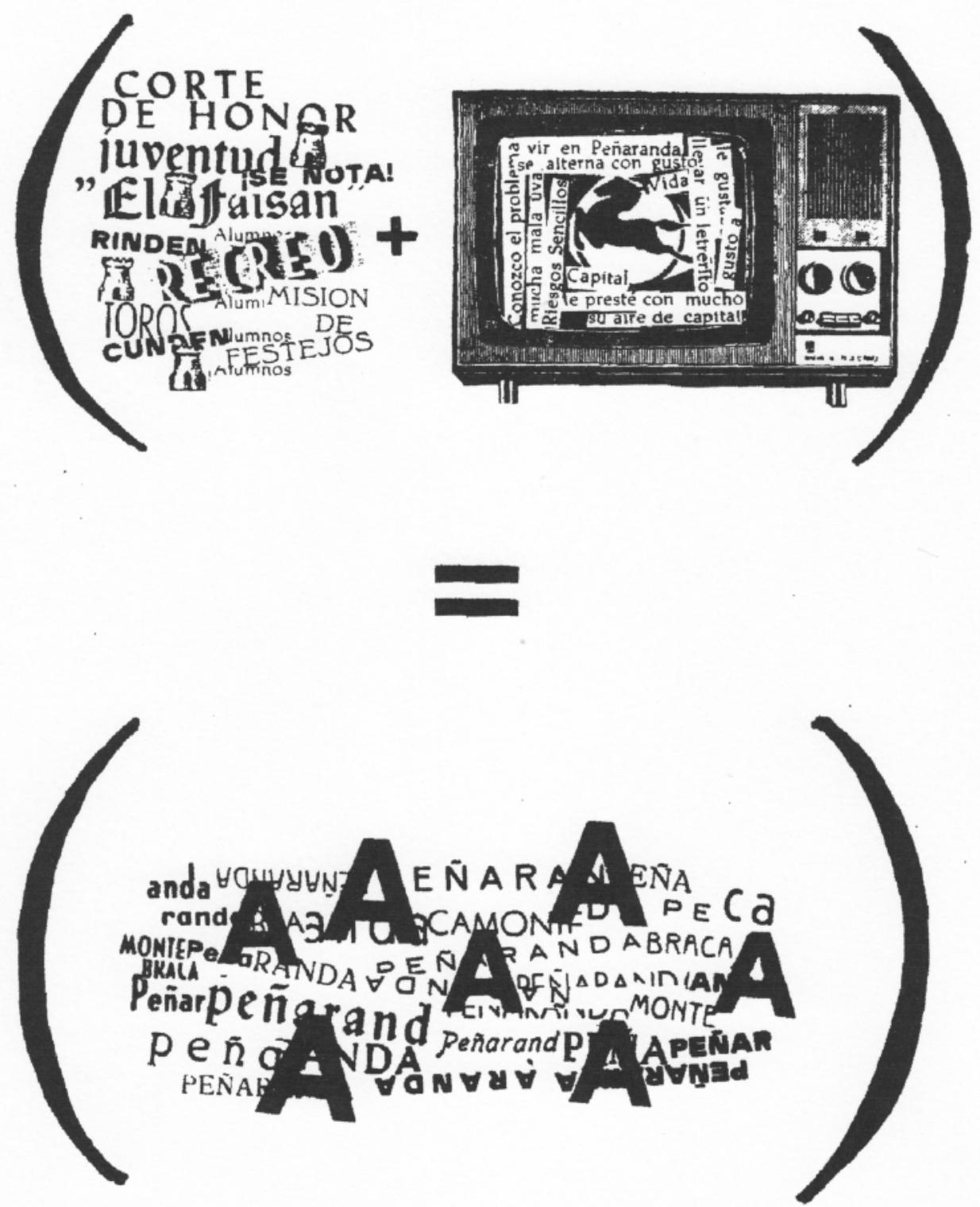
Yantra de Ibiza (1972 - julio).

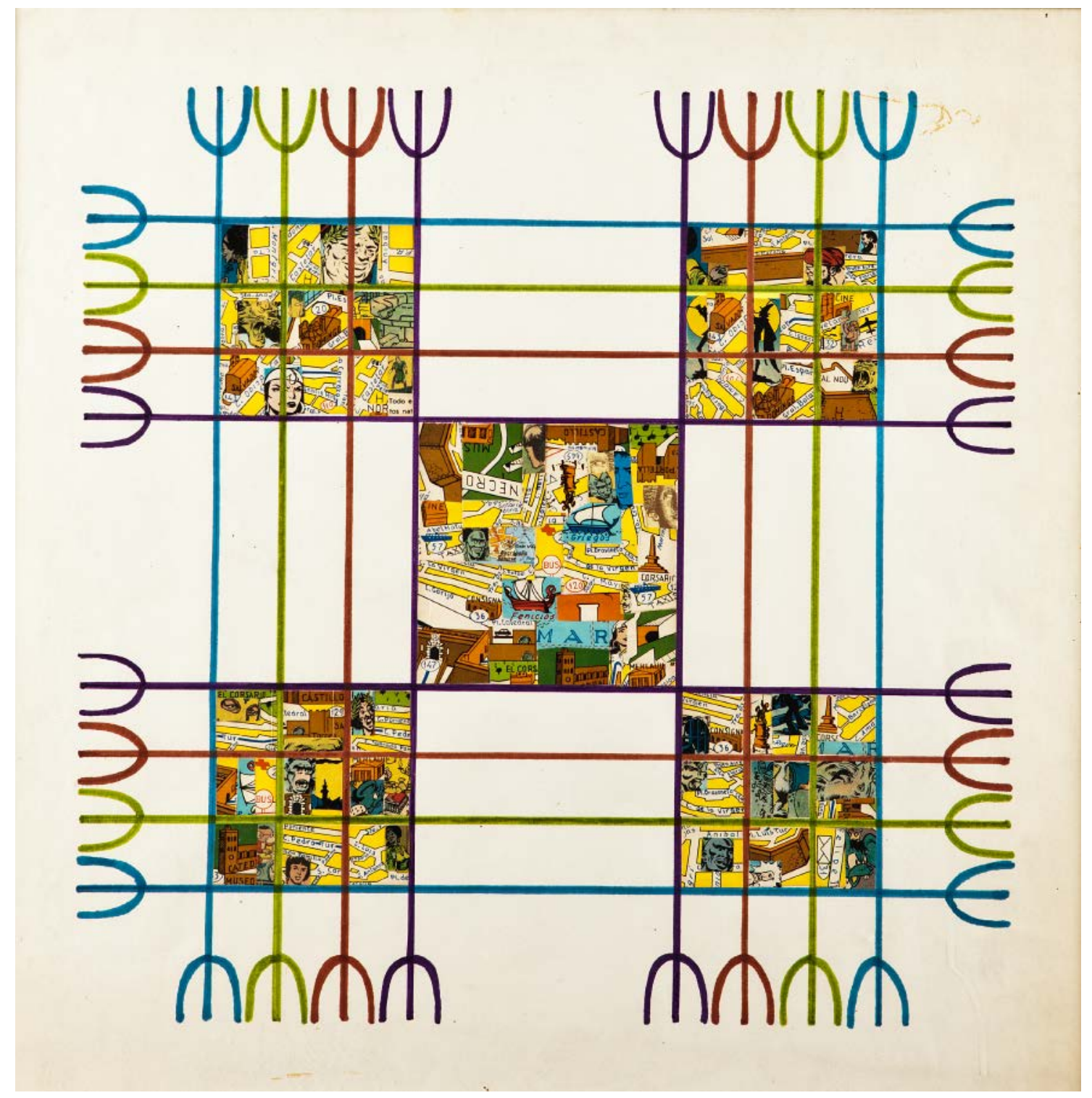


El Juego del Correo (1972 - agosto).

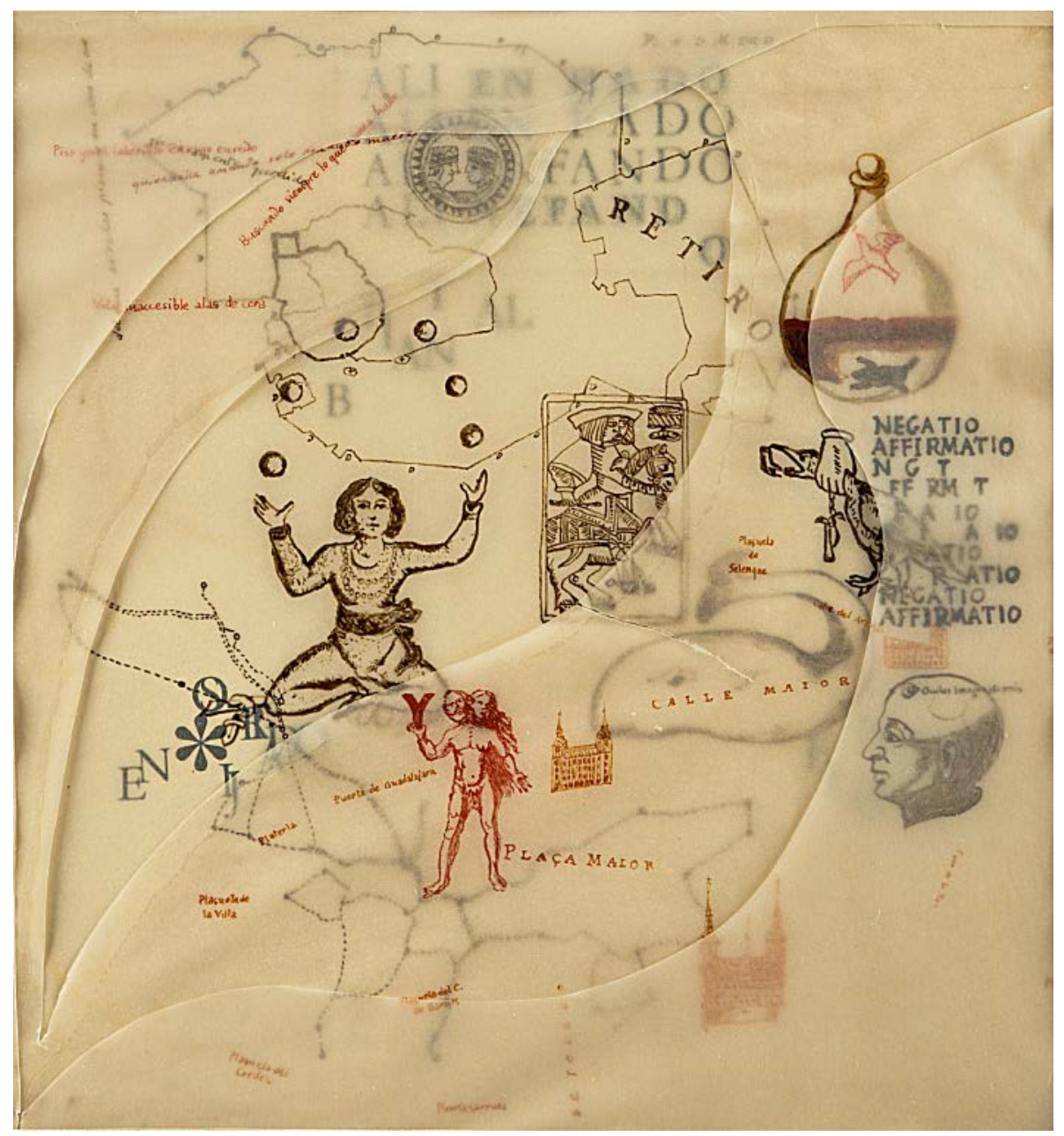


Ruedas de la Fortuna (1972 - agosto).

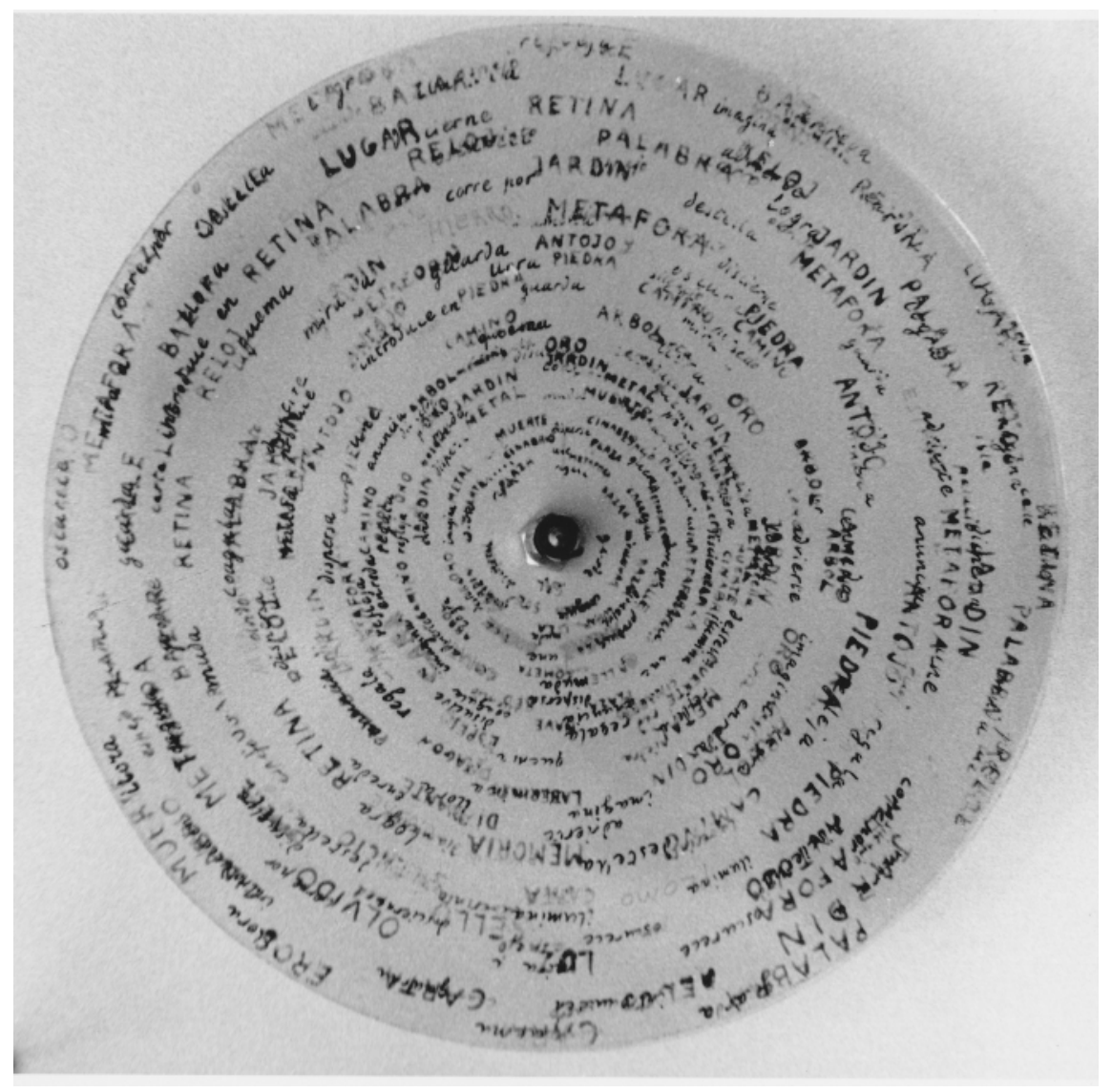


Teatro del Olvido (1972 - agosto).
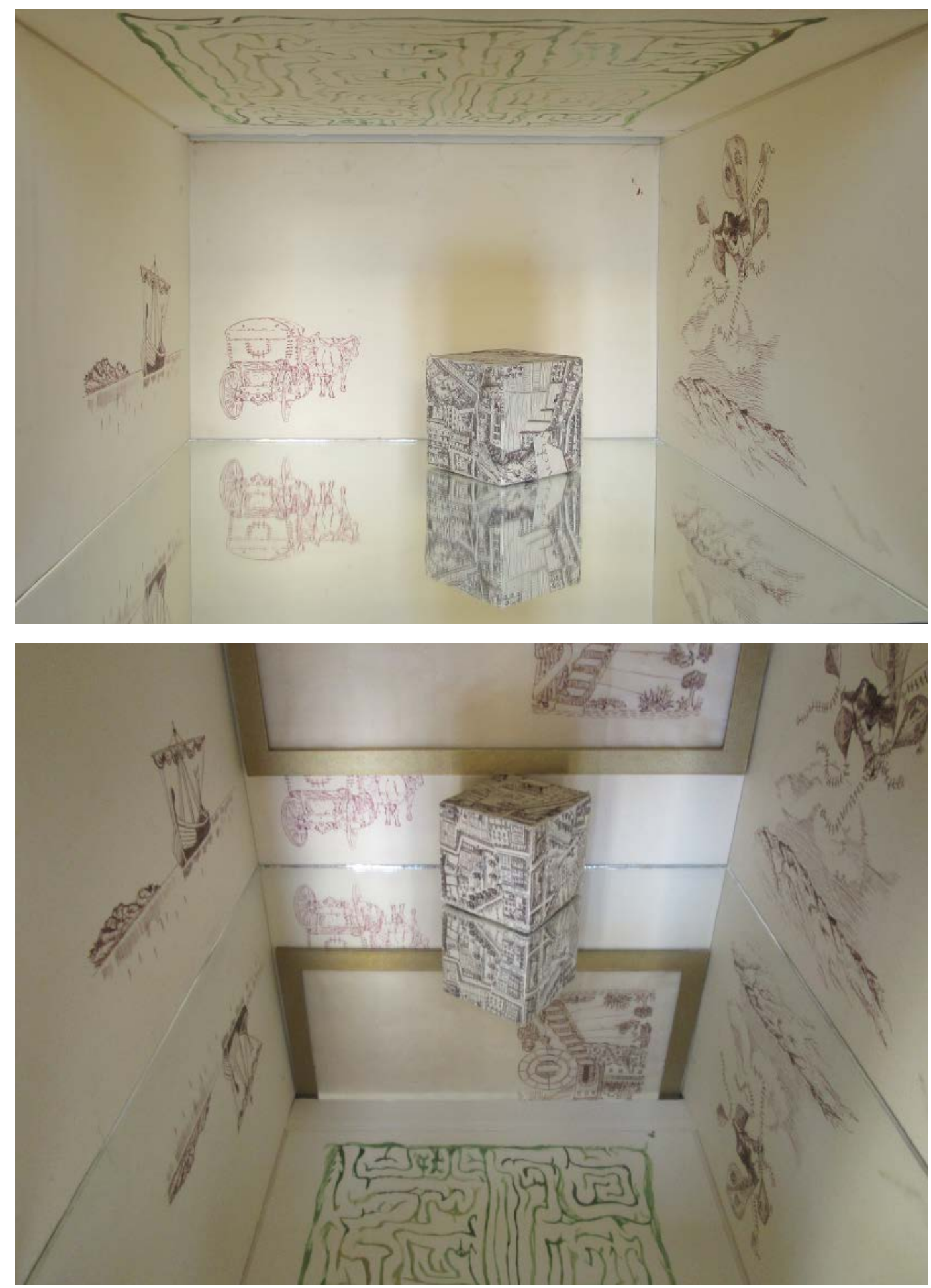
Poema Público El Espinario - En el Jardín de la Isla (1972 - septiembre).

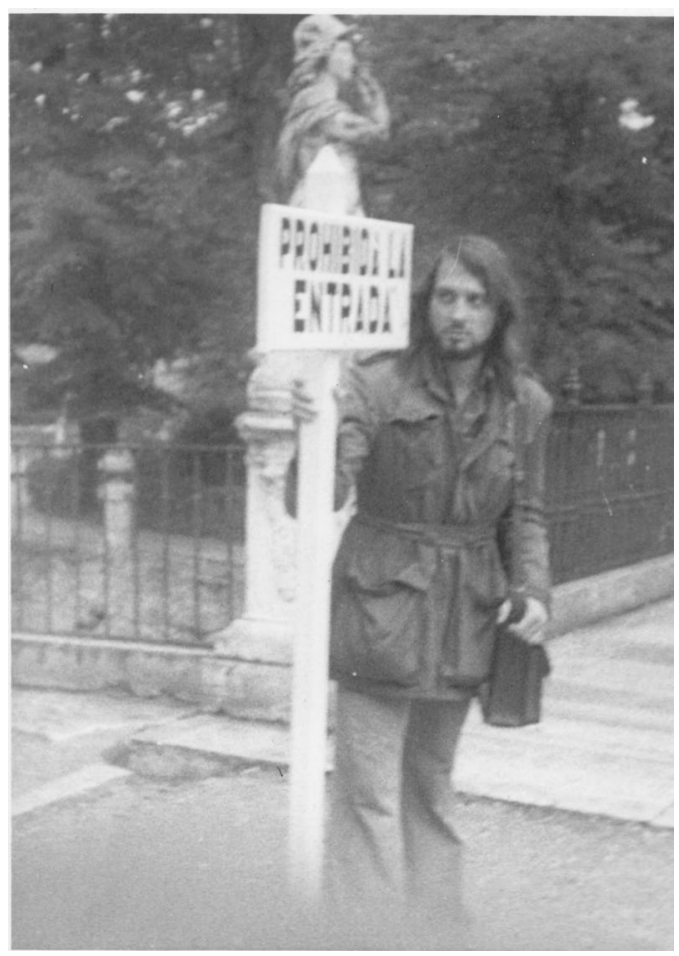


Poema Público El Espinario - En el Jardín de la Isla (1972 - septiembre).

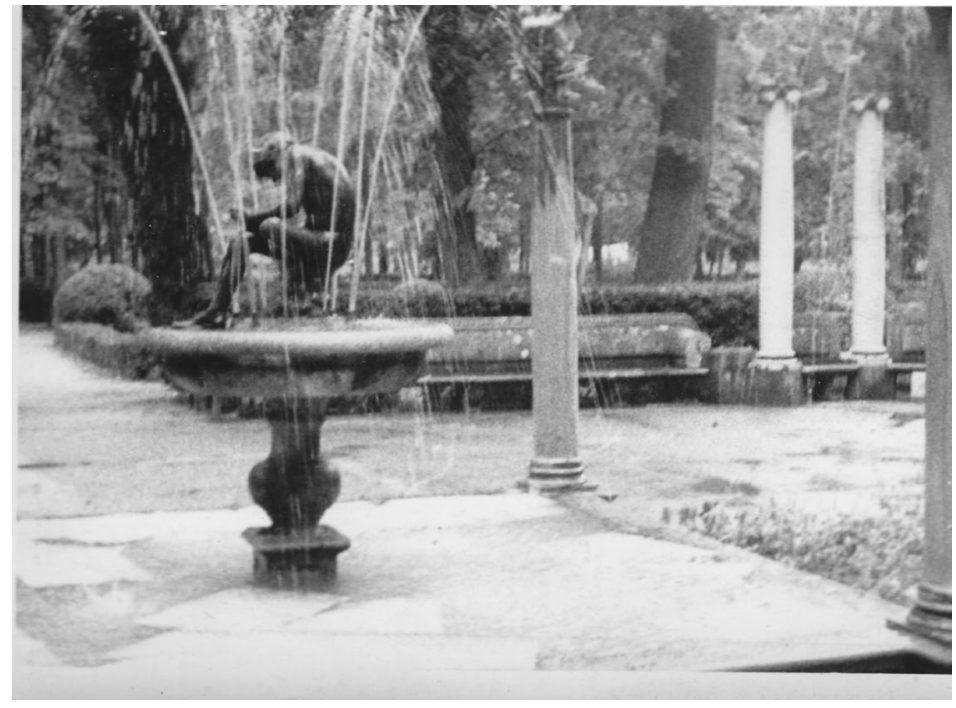


Poema Meteorológico (1972 - octubre).

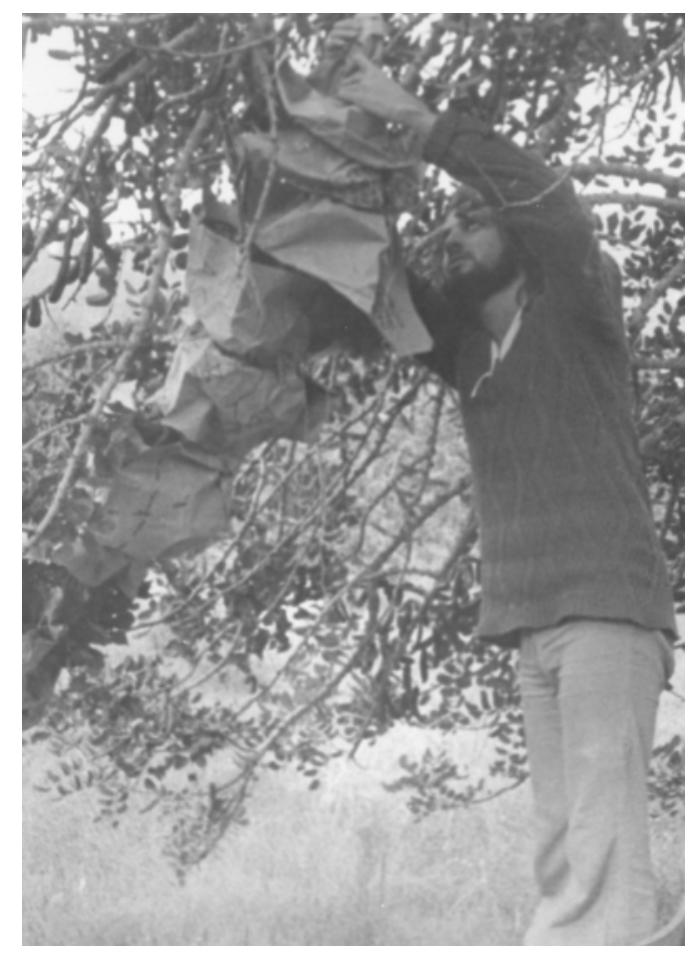


El Jardin Gramatical (1972 - octubre).

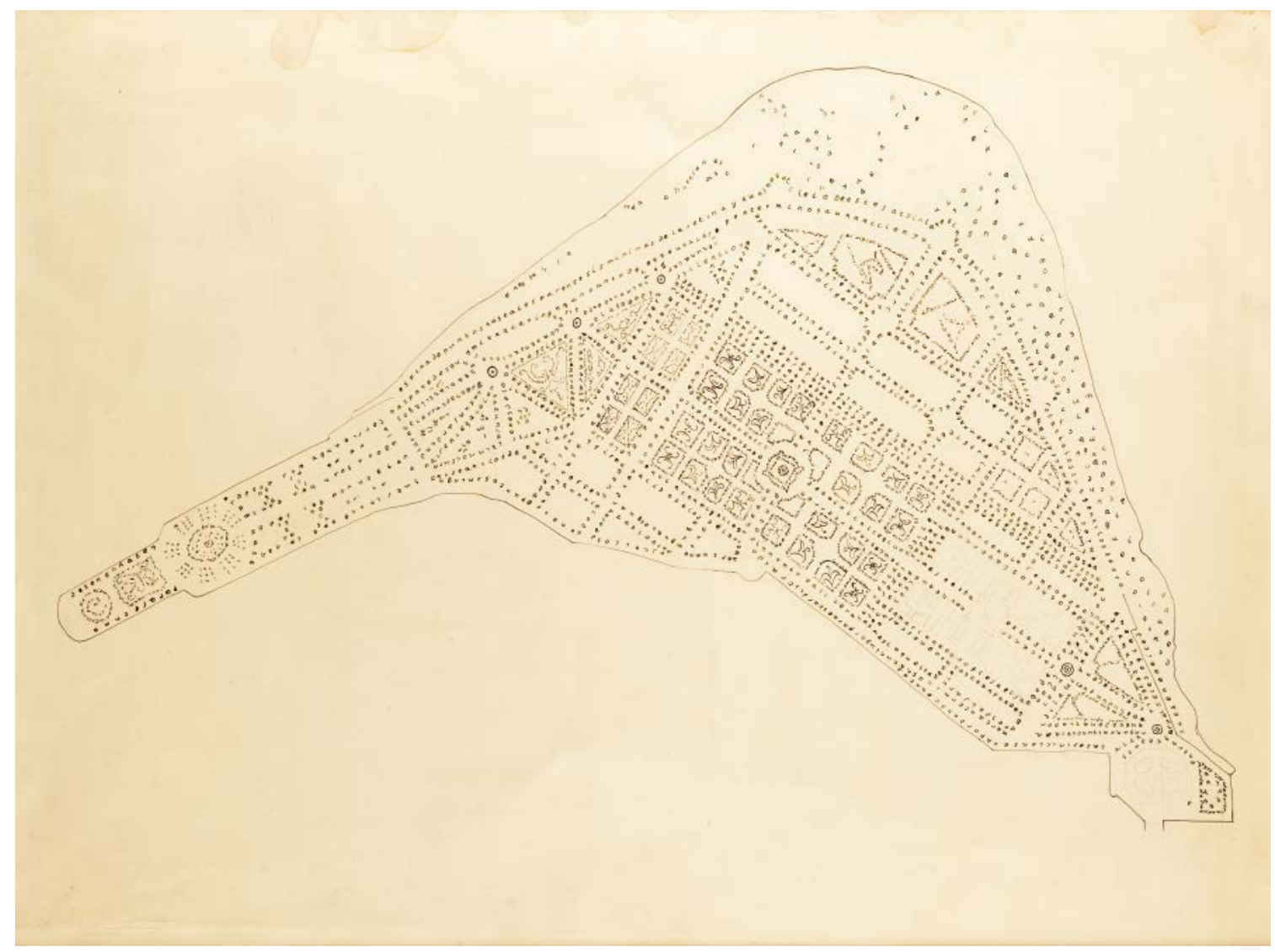


Inficción Radial (1973 - abril).

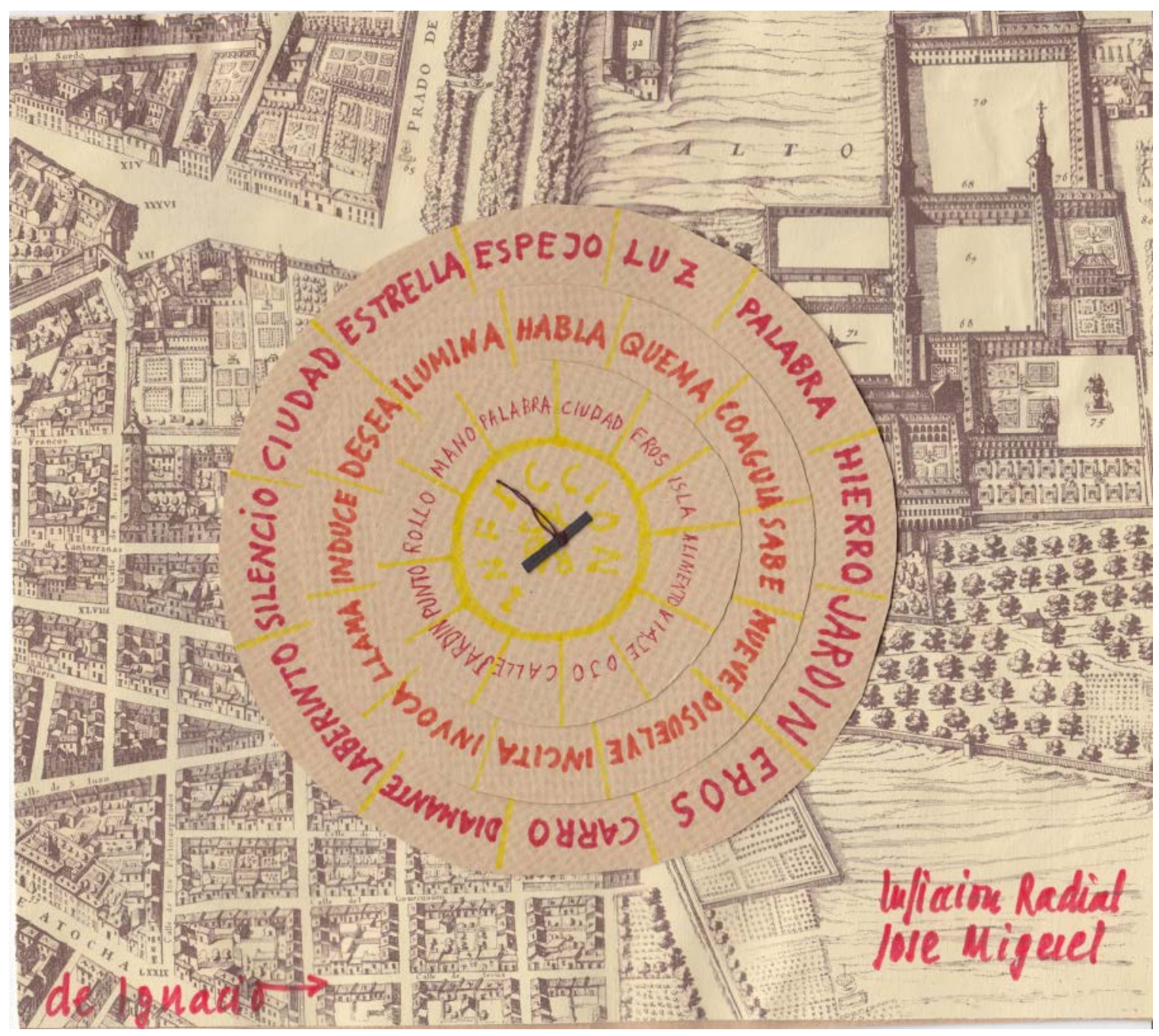


Escribiendo en Madrid - Los Fósforos (1973 - abril).

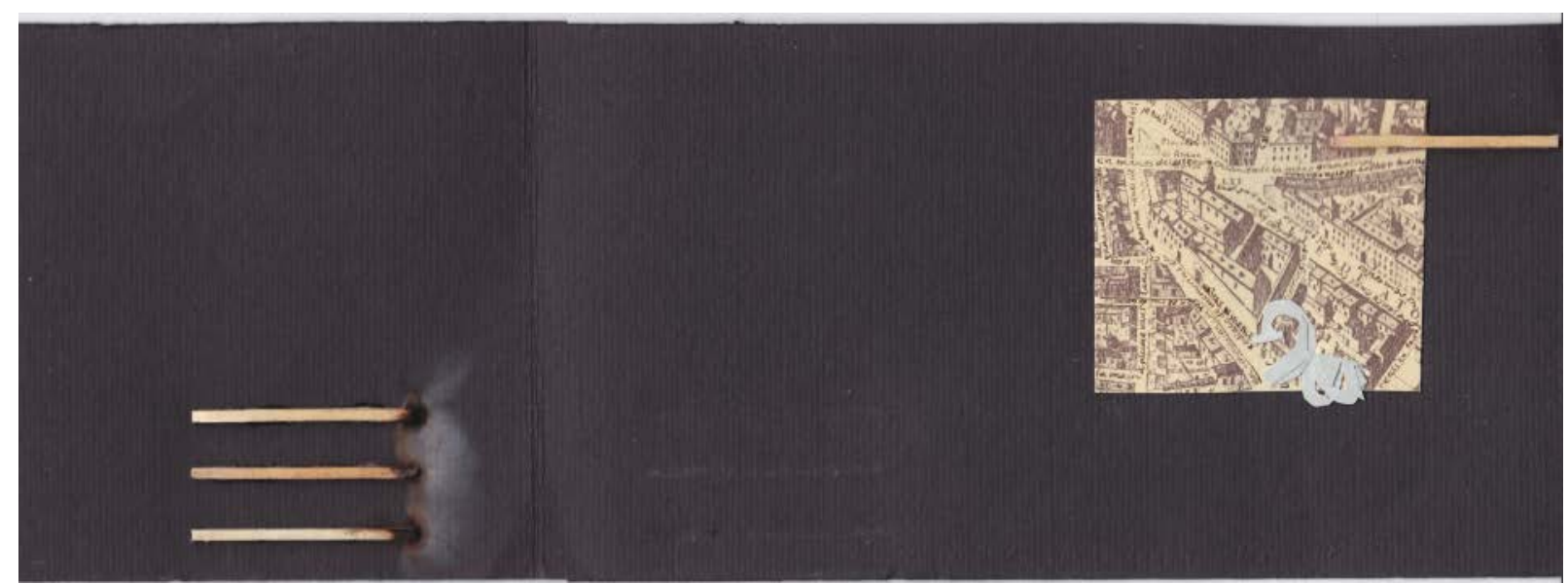


Lluvia verbal (1973 - junio).

quiero evadirme y la varkado es que No-Puedo - La verial, la verstad....

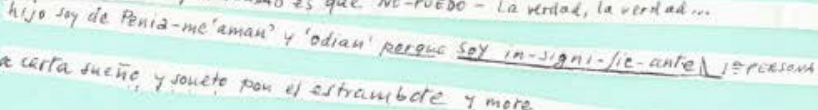

aqui troduciao el unico soneto nolano que puledo - biombo descorrido

Huvia de laz, puente de tierra ejpejo; palabra de lejanes crocotos - iroros:

pasper convertido en aura, did tie the sueño

Horid palabras, y todos cayerou en un accidente gramatical-iun tica?

rinde culte a la diosa Trivia apui Huang-Tse

en suspenso colgado mequede de A Palabra- abra

1/a y thand: a la letra le falta la musica - $h$ ? Cambiar la araña en la red extendida

Cambiar la araña enta red extendida en el agua-ila que!

Leo en el sueño 'qué bello dreño' - isucio? -

estar en la distraccion come 12 red tendida en el agua agua

en elagua la red ¿qué se eu reda? eneta sala diina ukria y dinind

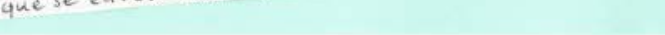

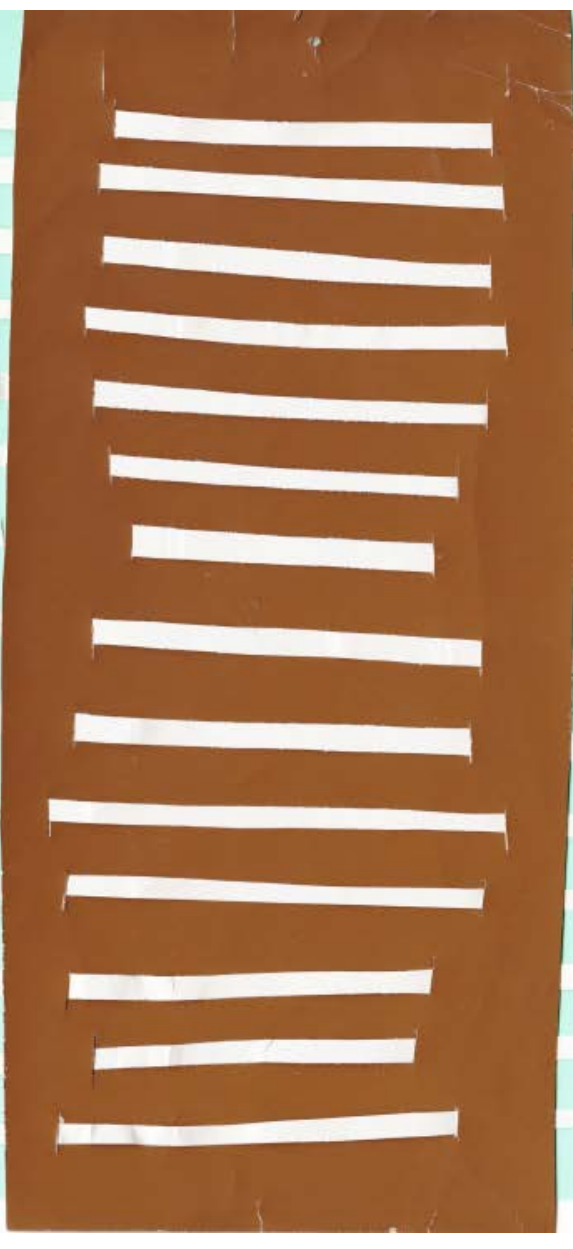


Horizonte (1973 - septiembre).

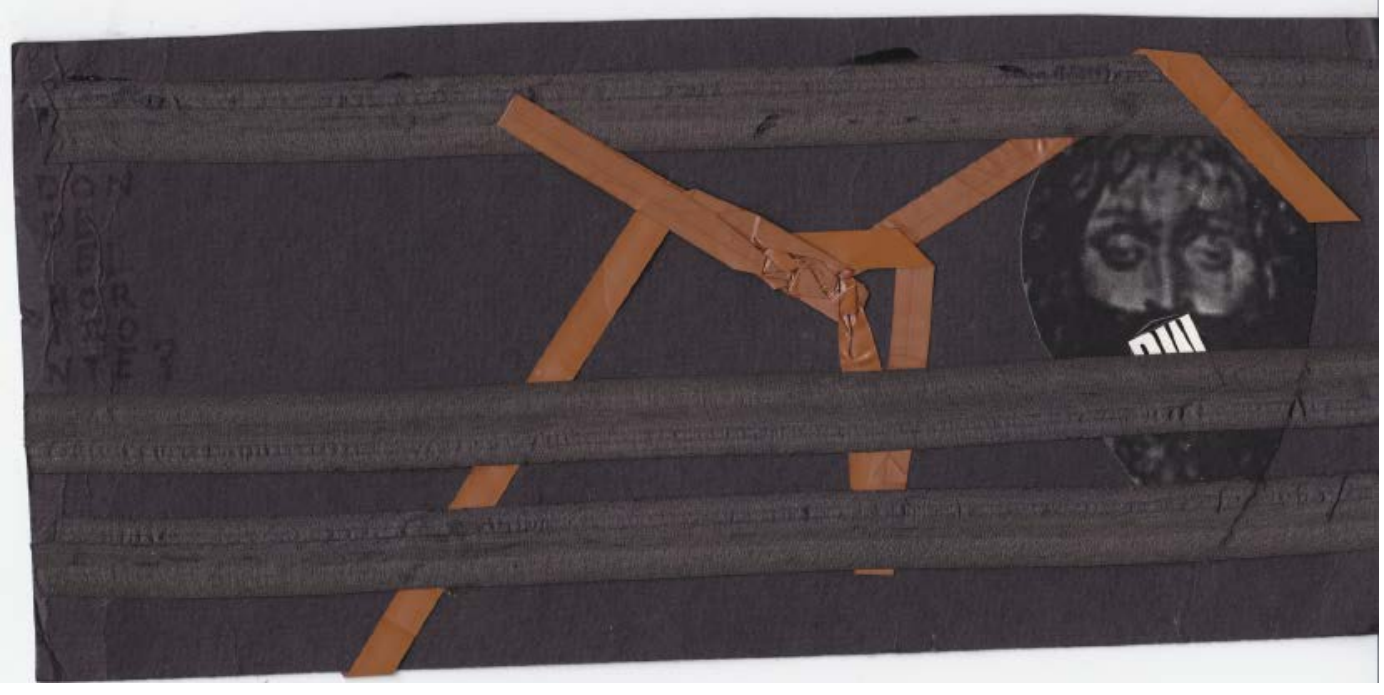


Poema de acción FRAGIL (1973 - diciembre).

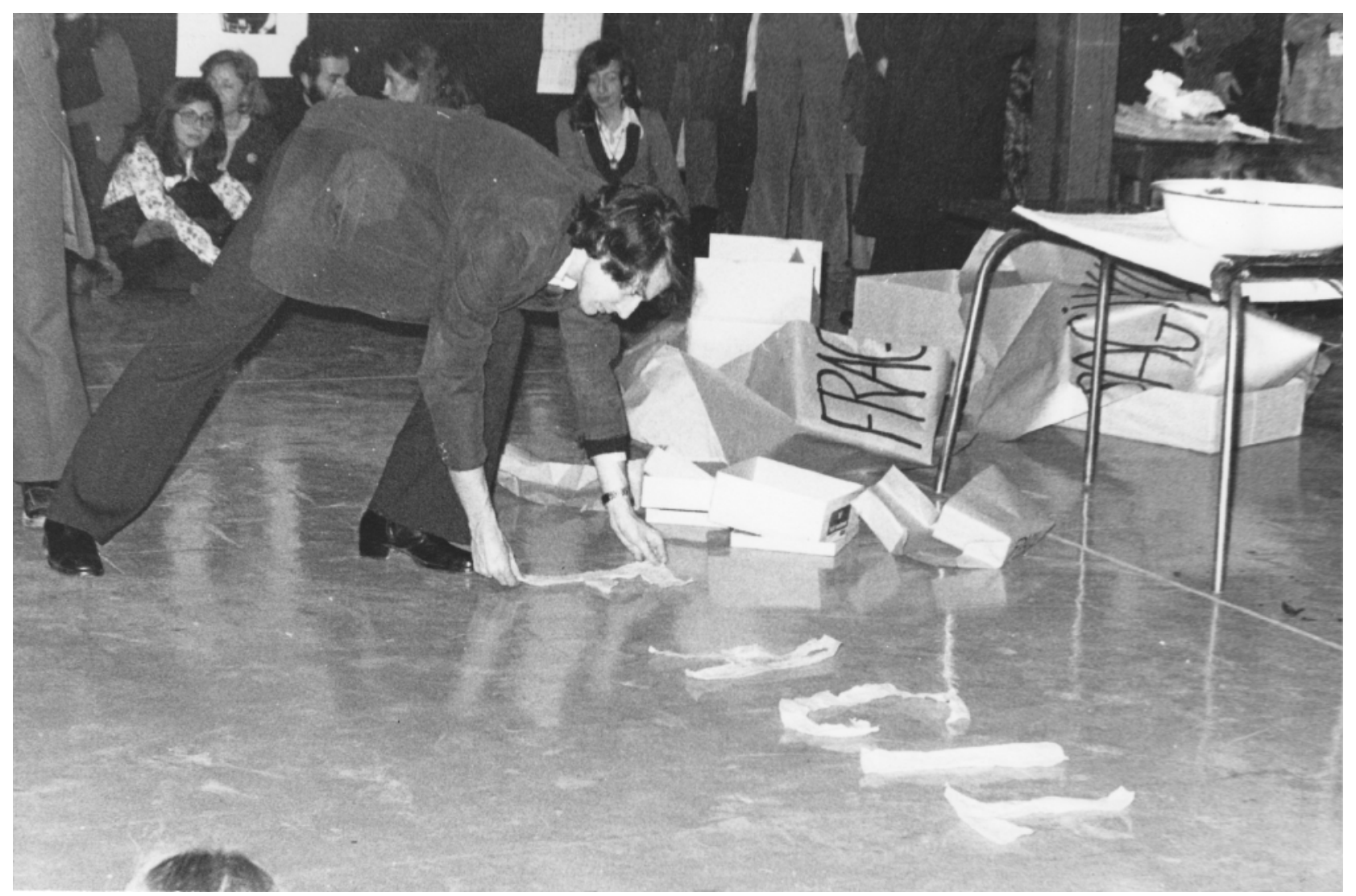


Poema de acción ASURBANIPAL... (1973 - diciembre)-

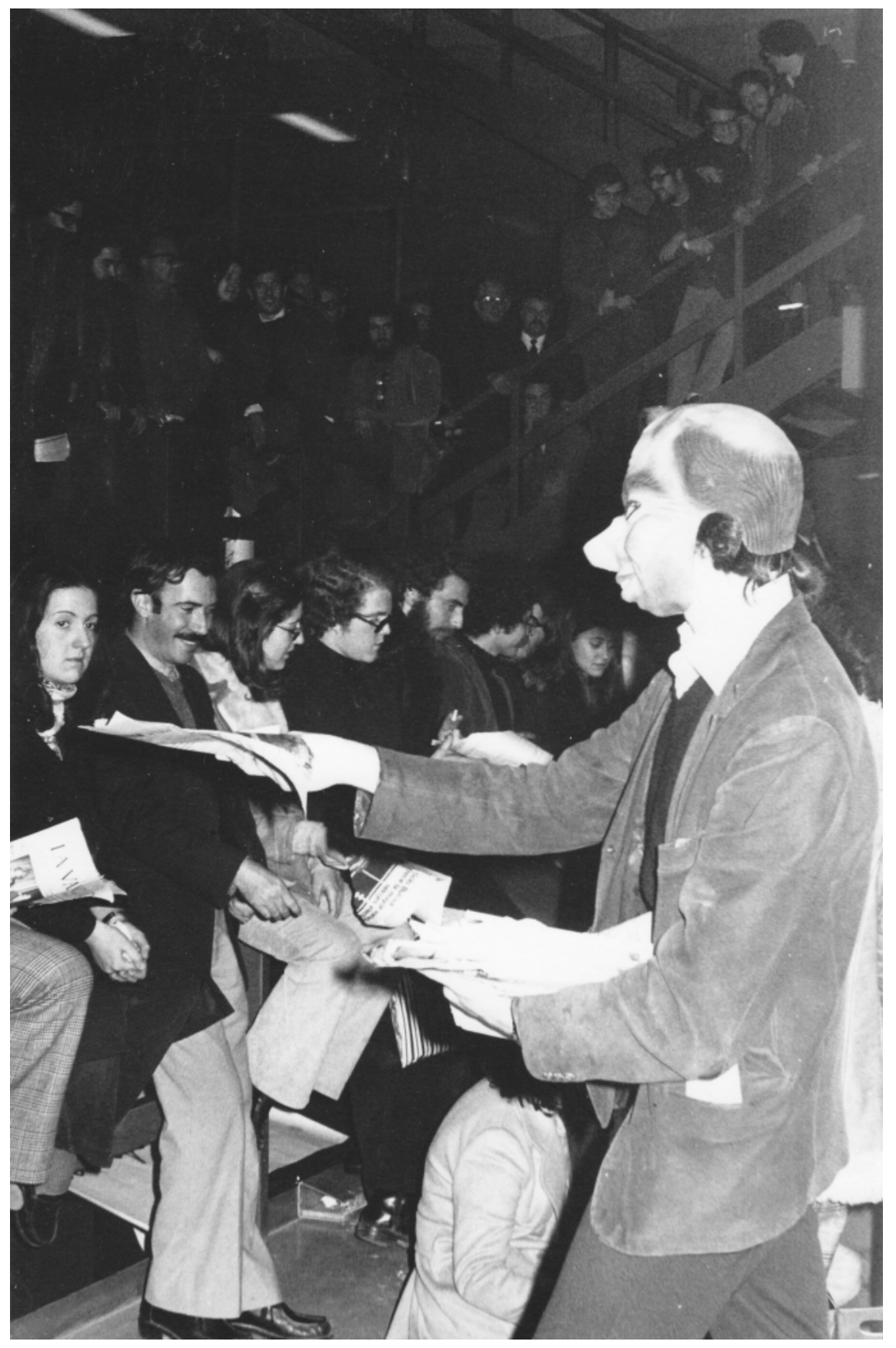


Manos mías (1974 - marzo).

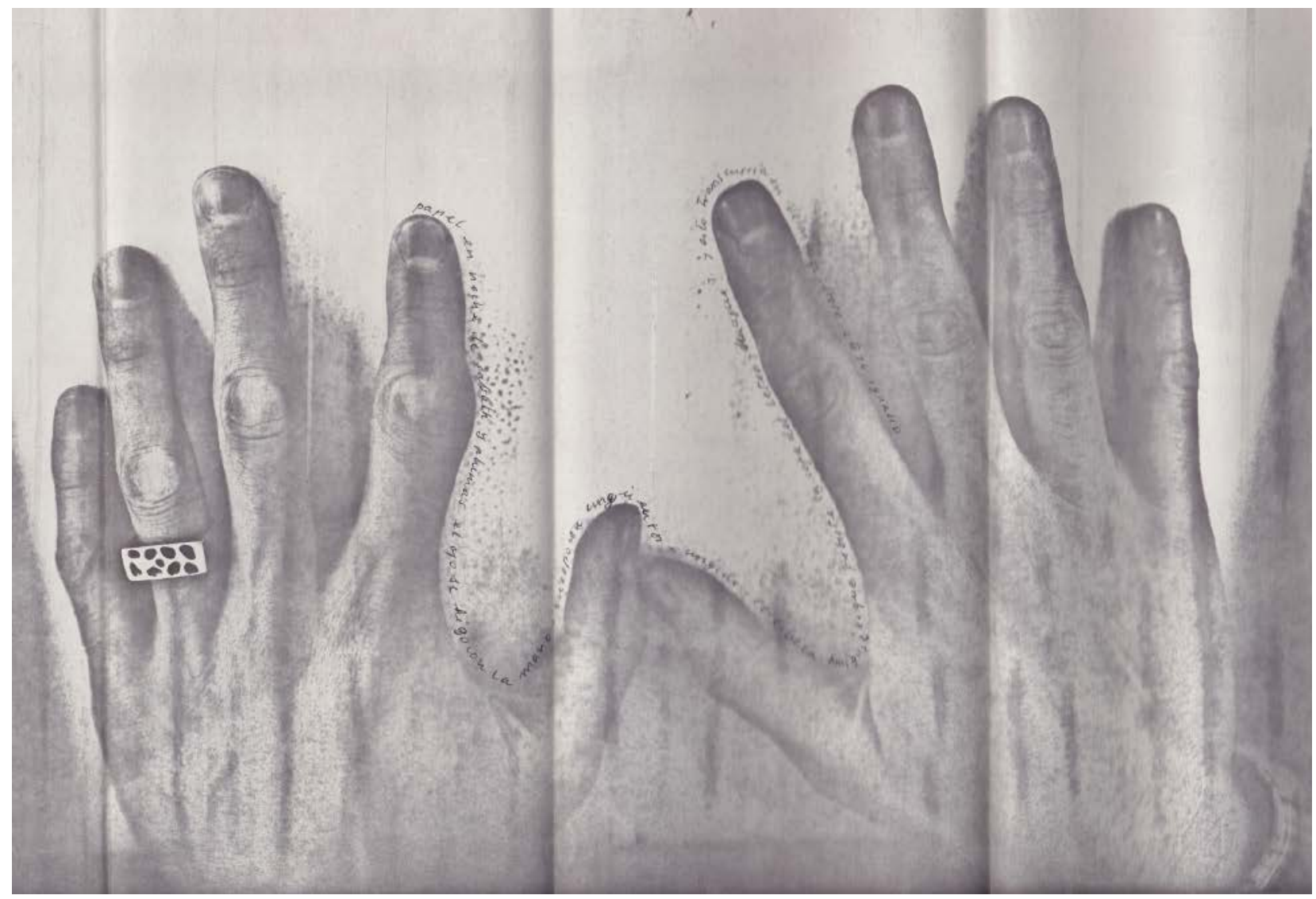


Los flecos de la escritura, o el Capirote (1974 - mayo).
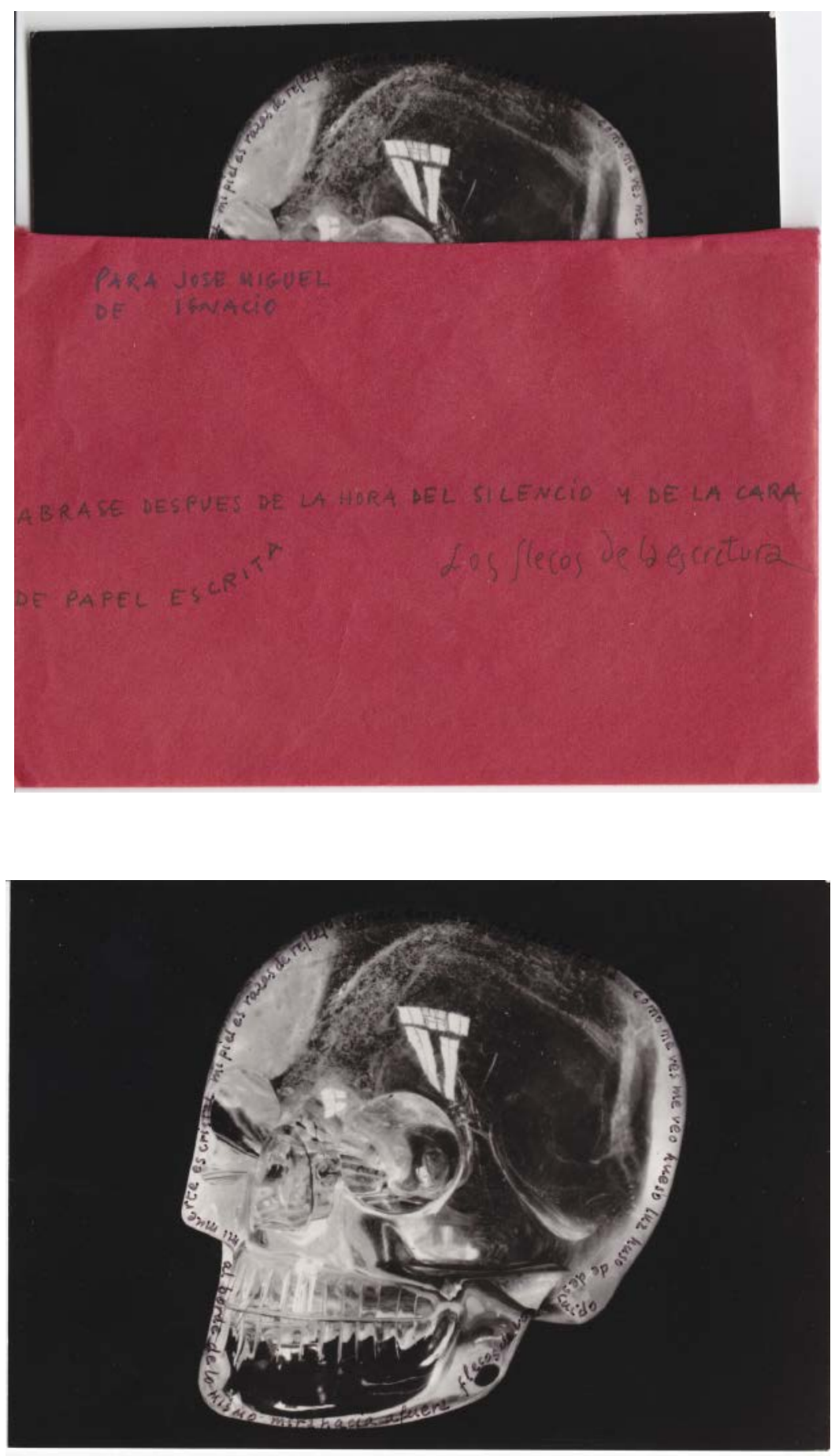
Poema-arabesco (1974).

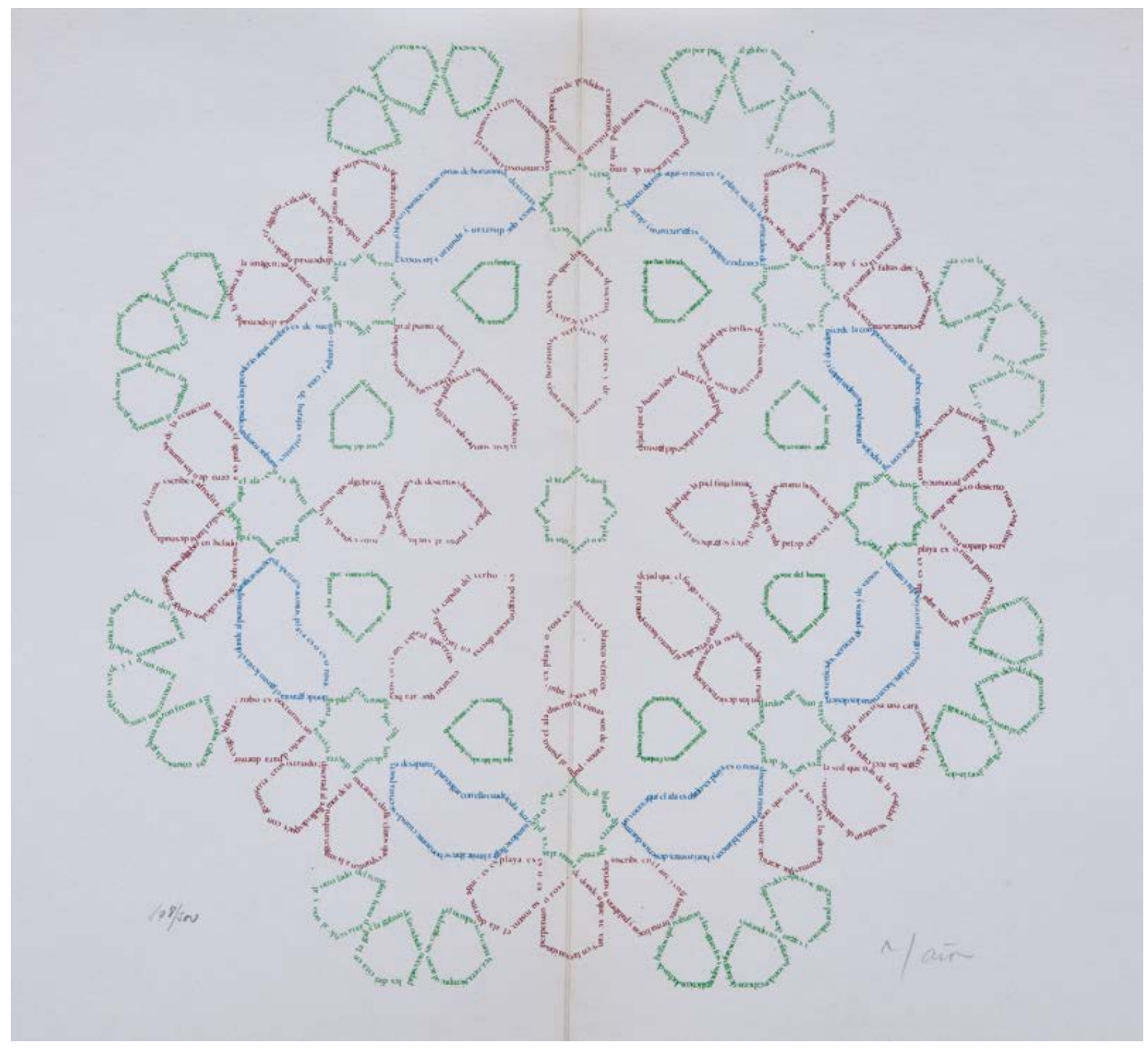


Columpio utopiano (1975 - julio).

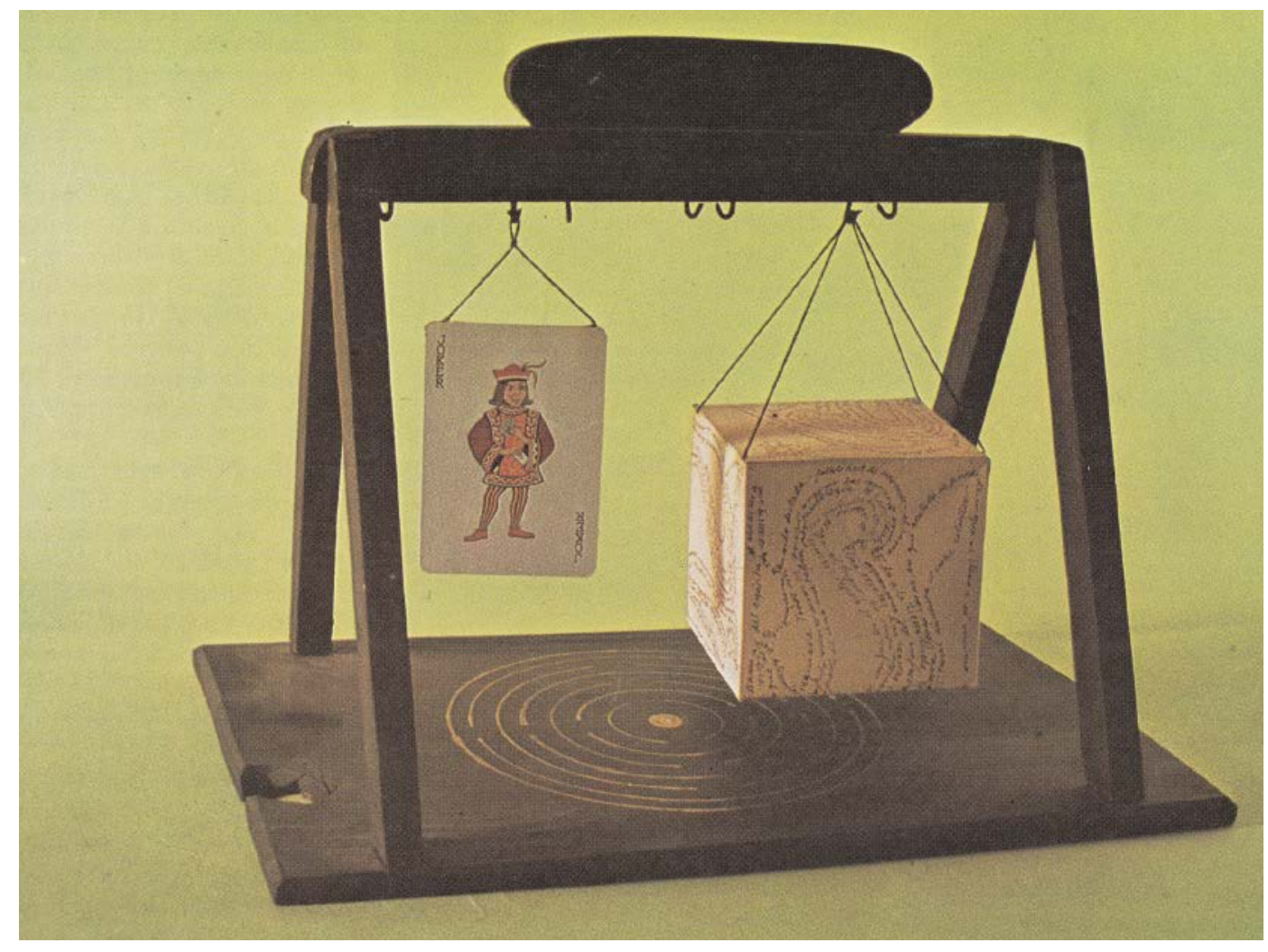


Poema Público Manifestación de pancartas en blanco (1972-2015).

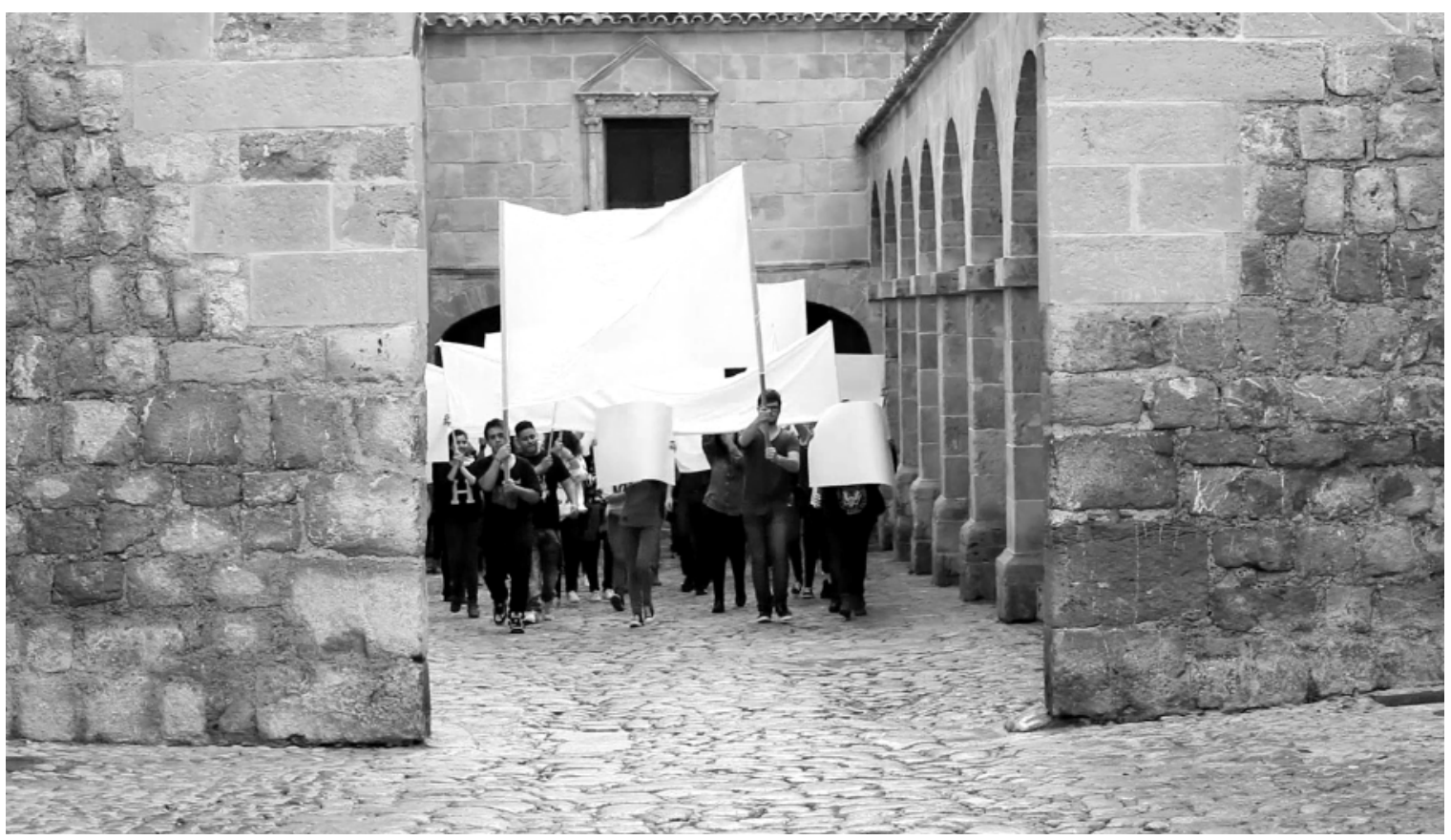


Poema de acción ESTO ES PALABRA (1972-2015).

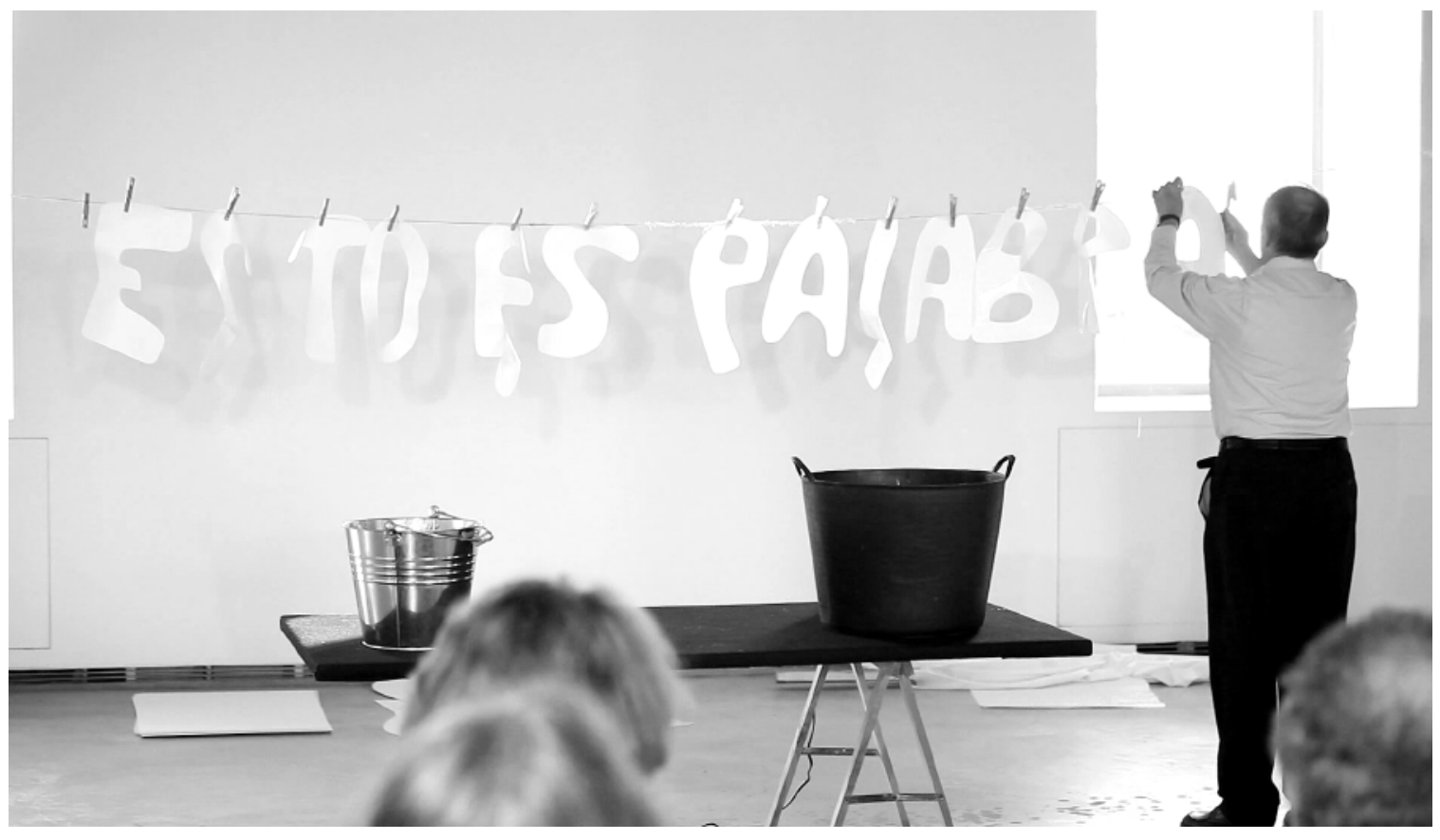


Poema Público OLA ISLA (2015).

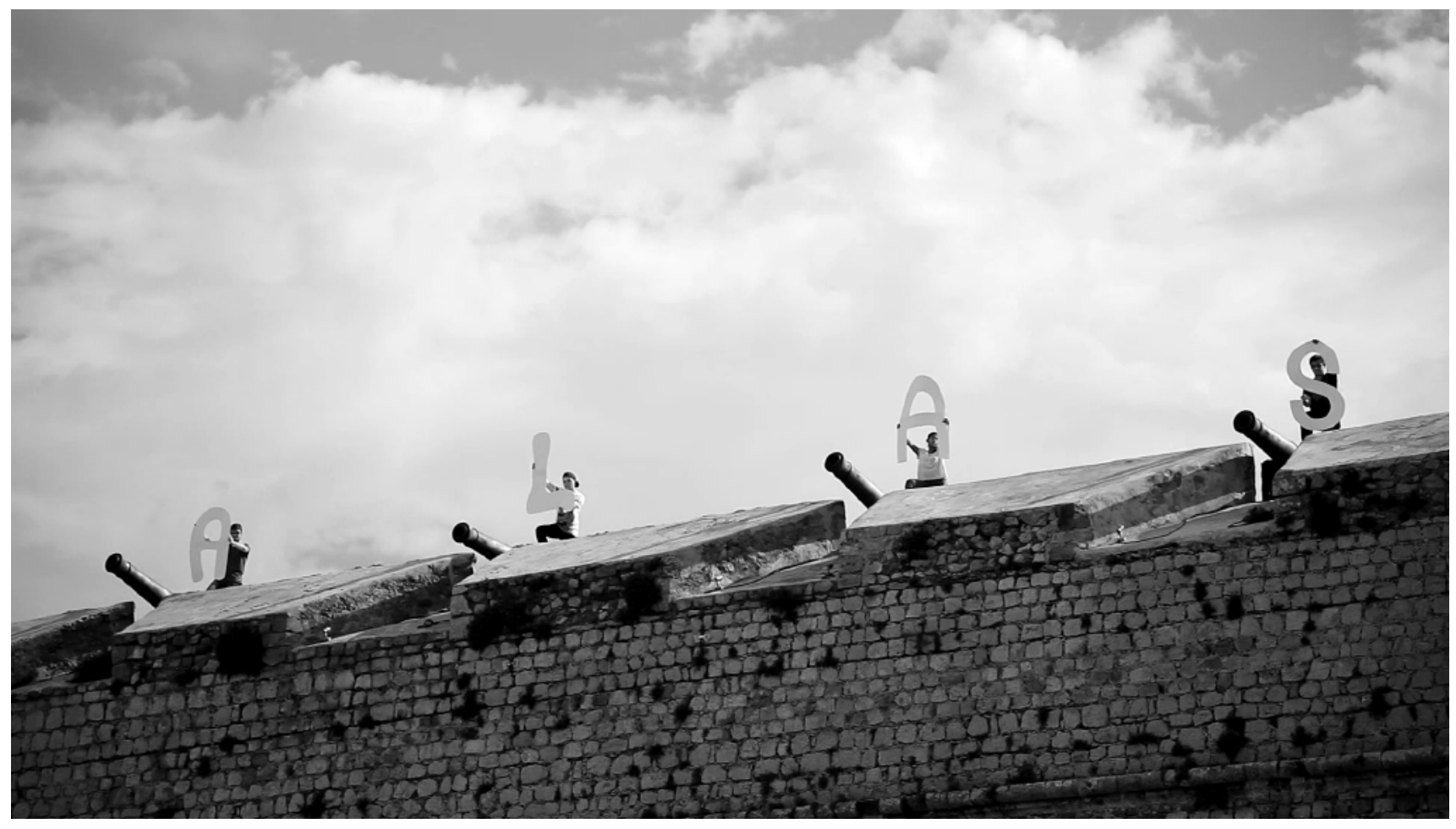




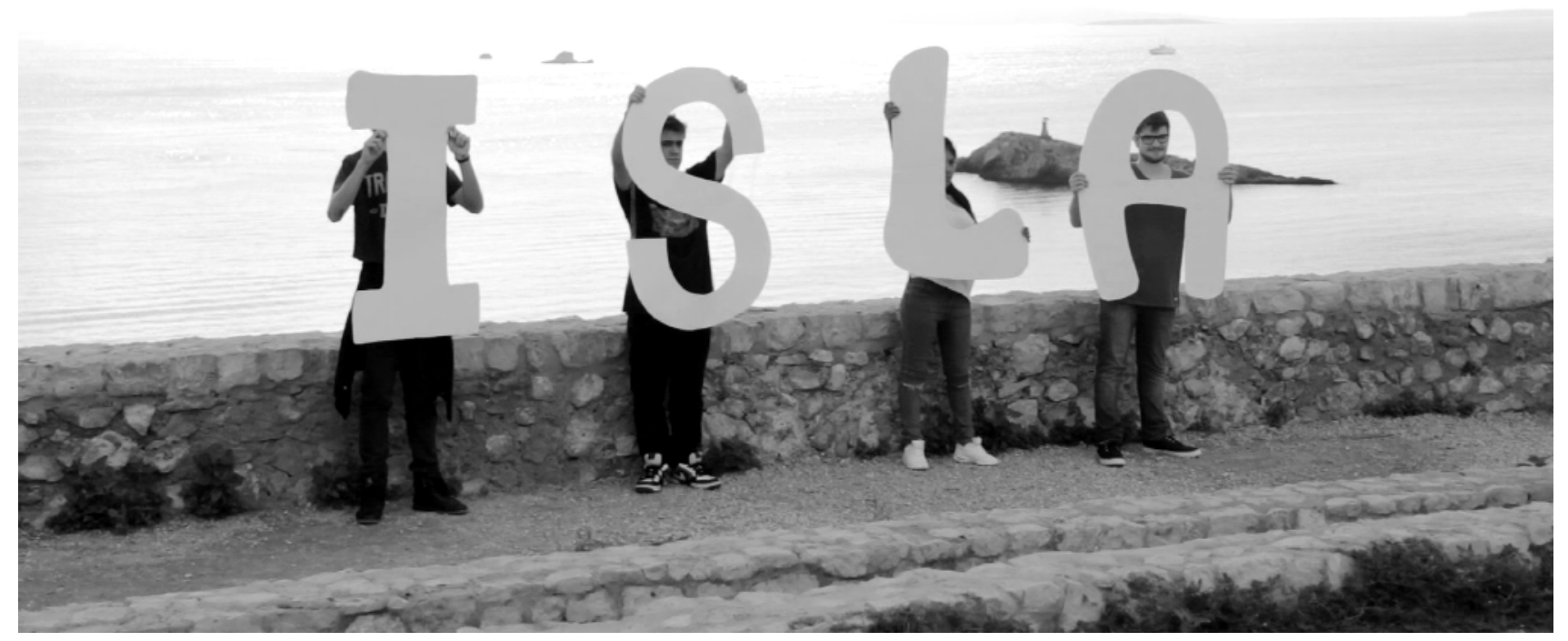


El Juego de las Salas de Salas (2016).

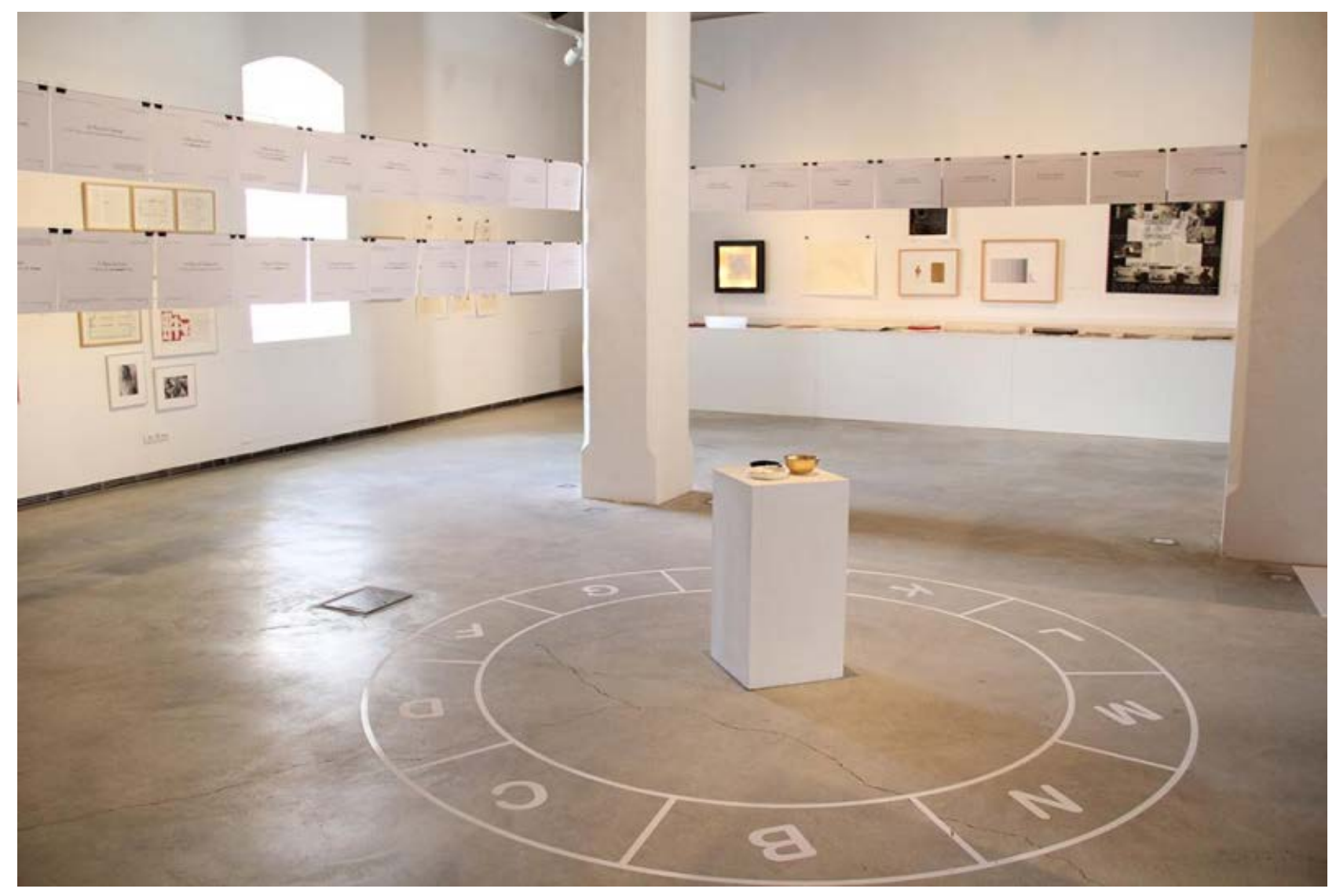


Pintura y perceptrónica - El Apostolado (1969-1973).
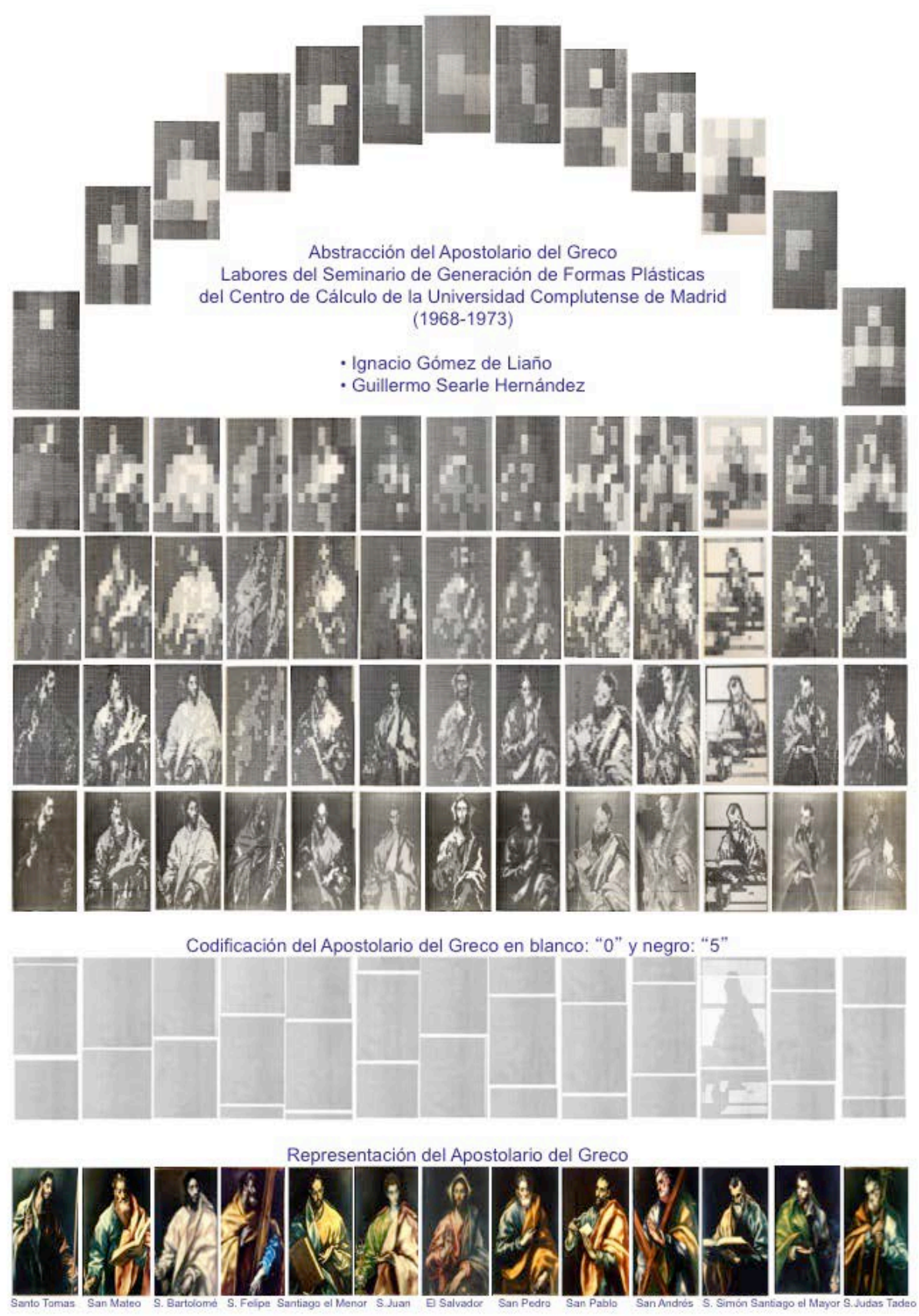
Imágenes Laocoonte n. 6 Isadora Gonzaga*

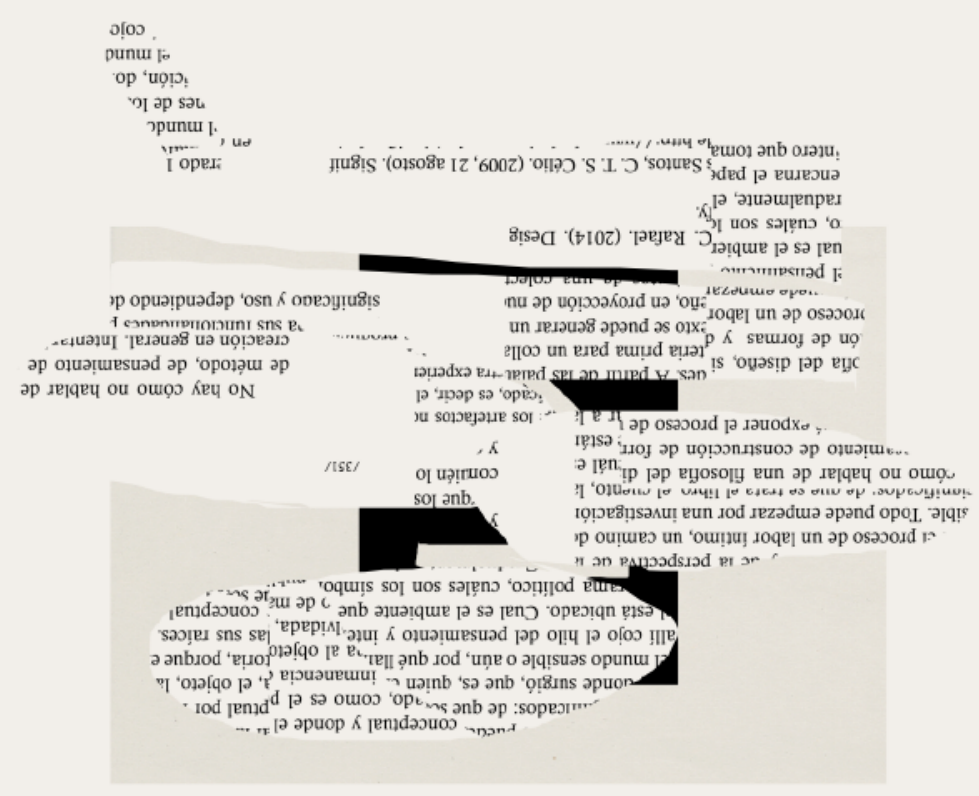

*(Río de Janeiro, 1993) Artista visual y diseñadora con grado en Design por la Universidad Federal de Río de Janeiro. En 2015 obtuvo una beca del programa Ciencia sin Fronteras y realizó una movilidad de un año en la Universidad de Sevilla, donde estudió Ingeniería en Diseño Industrial y Desarollo del Producto. También hizo prácticas en el estudio de diseño gráfico, comunicación visual y creatividad publicitaria El golpe Cultura del entorno. Fue estudiante de cursos de profundización artístico en la Escuela de Artes Visuales del Parque Lage y comisaría por la Casa França-Brasil en Río de Janeiro. Coautora del colectivo y organizadora del evento y publicación Pão na Chapa, iniciativa de comisaría de artistas del suburbio de Río de Janeiro. Participó de la residencia artística Pictopoetica de la Petrobrás en el Teatro Poeira. Desde entonces, ha trabajado con diseño aplicado en contextos culturales, como festivales, obras de teatro, museos, fiestas, branding, expografía para museos, diseño editorial, dirección de arte, producción de arte y producción cultural.

$\mathrm{Su}$ investigación se identifica con la temática del afecto, de la producción de cultura por el cuerpo, de la convivencia, del vivir en comunidad, de los saberes populares, donde las periferias territoriales construyen sus prácticas a partir de sus vivencias y transmiten de manera única entre los moradores. Los temas se traducen en registros de los signos de afecto y de la materialidad del sistema que construimos, por narrativas interdisciplinares, a través de soportes multimedia. Actualmente vive en Sevilla, se dedica a proyectos artísticos en España y Brasil, y estudia el Máster en Artes: Idea y Producción en la Universidad de Sevilla. 


\section{Sobre las imágenes para Laocoonte n. 6}

No puedo hablar de una filosofía del diseño si no hablo de proceso, de método, de pensamiento de construcción de formas y de la perspectiva de la creación en general. Intentaré exponer el proceso de una labor íntima, un camino de realización de la forma para el mundo sensible. Todo puede empezar por una investigación conceptual desde los orígenes de los significados: de qué trata el libro, el cuento, la novela, el objeto, la exposición; donde surgió, qué es, quién creó y por qué, cuál es su historia, por qué existe en el mundo sensible, o, incluso, por qué se llama así; donde están afincadas sus raíces. Desde allí, cojo el hilo del pensamiento e intento llegar al origen conceptual, allí donde está ubicado. Cuál es el ambiente que cerca el objeto a ser diseñado, cómo es el panorama político, cuáles son los símbolos que están sobrevolando la inmanencia del concepto. Gradualmente, el contenido contextual hace surgir la forma del objeto y el diseñador encarna el papel de un traductor que descifra una lengua olvidada, o el de un carpintero que toma la forma de una mesa y se la aplica a un trozo de madera amorfo.

Así, Cardoso en la publicación brasileña Design para un mundo complexo, comienza a dar ejemplos de la importancia de los bienes producidos por el hombre y cuestiona sus funcionalidades porque los factores subjetivos también influyen en su significado y uso, dependiendo de quién lo use:

Las formas de los artefactos no tienen un significado fijo, sino que expresan un proceso de significado, es decir, el intercambio entre lo que está incrustado en su materialidad y lo que nuestra experiencia puede inferir de él. Por un lado, las formas encarnan los conceptos detrás de su creación (Cardoso 2014). ${ }^{1}$

Hablo también de una construcción paralela y gradual, donde la idea gana cuerpo en conjunto con la forma, en una especie de un danza en la que ambos elementos se entrelazan en un compás armonioso.

Pensar para conocer el diseño y hacer diseño, es antes de todo cuestionar infinitamente el origen de nuestro mundo sensible. Diseñar puede ser hallar la manera propia de construir el mundo, las ideas, las relaciones; hacer consciente y comunicar el proceso propio y la creación de las formas del mundo. Según mi método de diseño, me planteé la cuestión: ¿Qué hago con lo que tengo entre manos? ¿Qué materia prima eso me ofrece? Ejemplificando y haciéndose presente el método que verbalizo en este texto, construyo el discurso antes de crear visualidades. A partir de las palabras con las que construí este discurso, he hecho de ellas la propia materia prima para un collage, para una reconfiguración de significados ${ }^{2}$ que, desde un texto, genera imágenes para ilustrar la presente revista. En cada ilustración, traigo formas orgánicas y abstractas que nos recuerdan a las formas de los objetos e interfaces que están presentes a nuestro alrededor.

Pensar en diseño o en una proyección de nuevas o antiguas formas es lanzar al mundo posibles comportamientos de una colectividad. La responsabilidad aquí tiene la forma de una consciencia, la de estar elaborando significados para nuestro entorno.

Cardoso, R. C. Rafael. 2014. Design para um mundo complexo. São Paulo, Brasil: Cosac Naify.

2 Teodorico dos Santos, C. T. S. Célio. 2009 (21 agosto). Significado. http://www.abcdesign.com.br/significado/ (Recuperado 1 diciembre, 2019). 


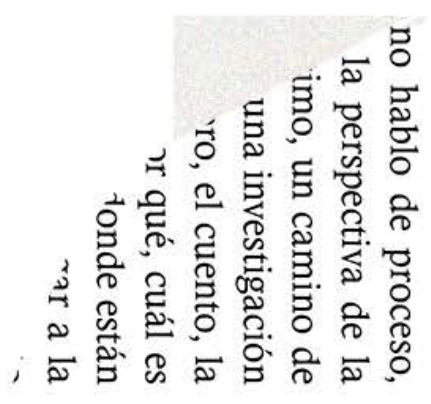

$\div$

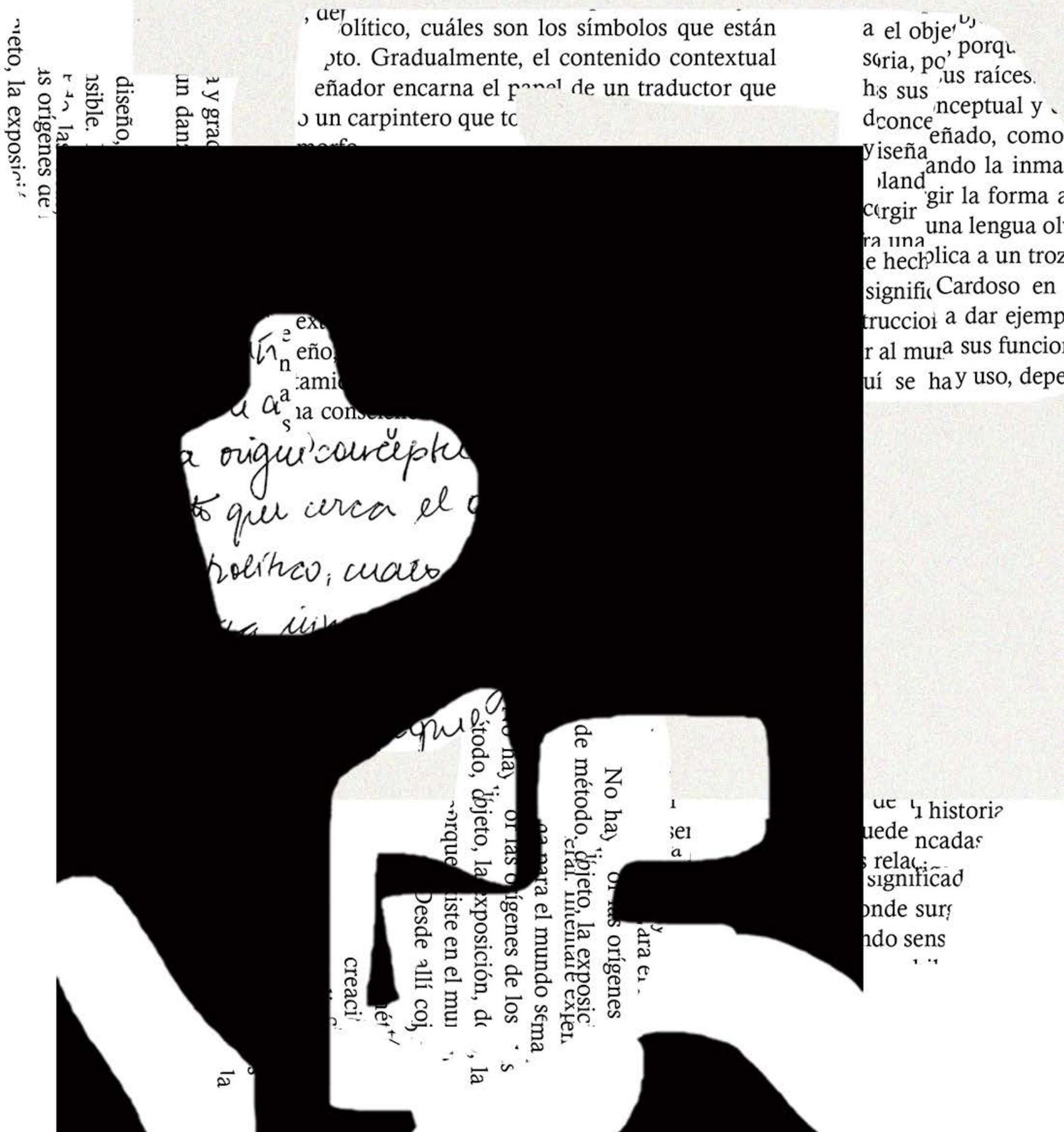

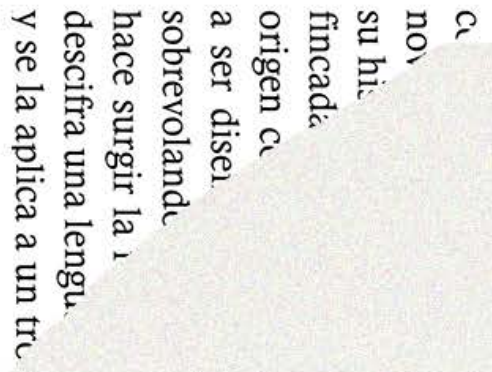

ఉ 
ner.

llobj vidada, o de ma la publica. los de la im nalidades po ndientn $\mathrm{A}$ -
, la

que e.

usdño, si nn

ज. " da yara el mu tual y d

or enc or las orígenes un tmo, fía del diseño,

rpintero que'curra la forma de

eña Desige para un mundo complexo, de los bienes producidos por el hombre :tores subjetivos también influyen en su

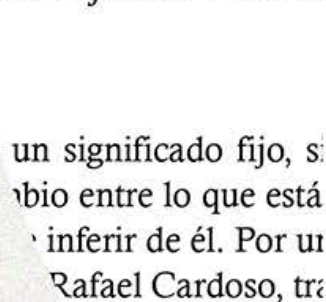

Rafael Cardoso, tri

No hay cómo no e método, de pensa 1, donde la reación en geperal. salizar la forma pa. rue amb ${ }_{\text {Snceptual por }}{ }^{1}$

$$
\text { -rola ol } n^{\prime}
$$

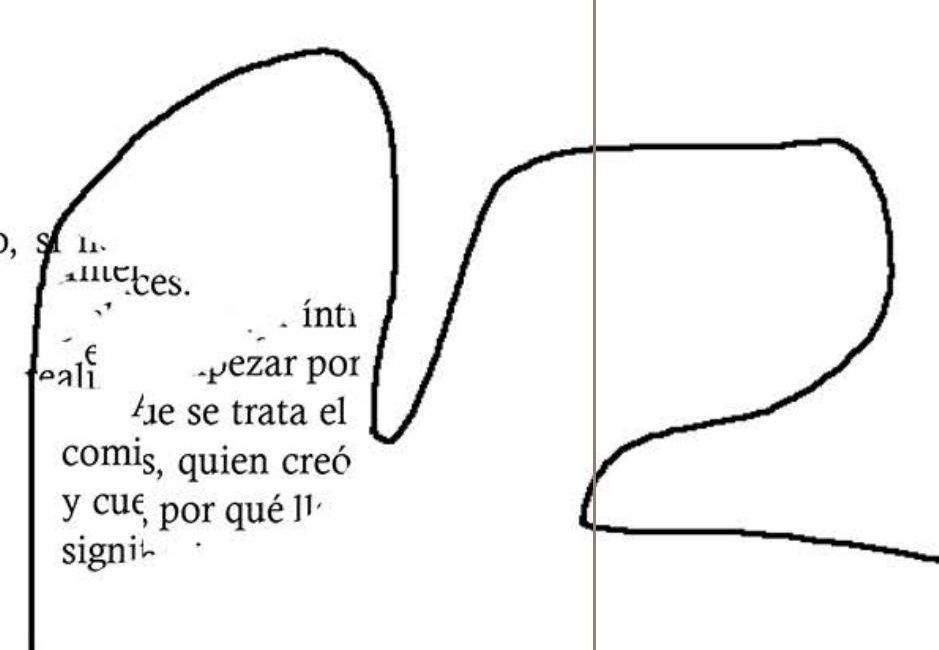

LOCOCNTE

PANORAMA: FILOSOFÍA DEL DISEÑO

Fernando Infante del Rosal y María Jesús Godoy Domínguez

(Coordinadores) 
ner.

ll obj

vidada, o de ma

la publica. los de la im nalidades po ndiendn $\mathrm{N}$ -

\section{, la \\ que e.}

ง. "f y yara el mu tual y d

or enc or las orígenes un tino,

rpintero que'curra la forma de

eña Desigh para un mundo complexo, de los bienes producidos yor el hombre :tores subjetivos también influyen en su

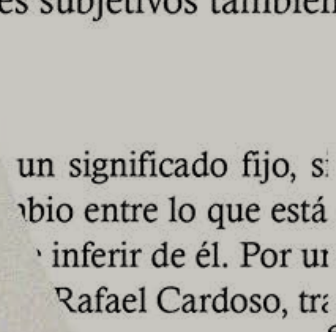

Rafael Cardoso, tri

No hay cómo no e método, de pensa

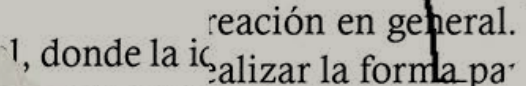
rue ambinceptual por ${ }^{1}$.

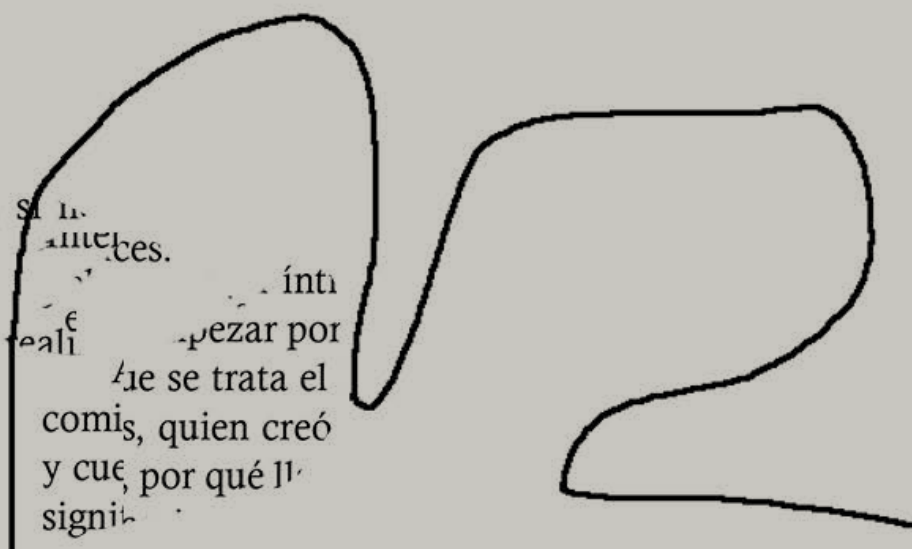




\title{
Pensar el diseño
}

\section{Thinking Design}

Fernando Infante del Rosal ${ }^{*}$ y María Jesús Godoy Domínguez ${ }^{* *}$

\author{
"Ein Zeichen sind wir, deutungslos" \\ [Somos un signo por interpretar] \\ Hölderlin, Mnemosyne
}

El diseño es una de las realidades estéticas más patentes en el abierto arco de nuestra experiencia. Interviene en la conformación de nuestro entorno y define la manera en que nos desenvolvemos en el ámbito de lo consuetudinario. Está asociado a todas las situaciones en las que requerimos la mediación de un signo, de un objeto o de un proceso. Se diseña dando forma, función y significado al espacio, a la luz, al mensaje, a los objetos, a los procedimientos; por eso hablamos de diseño en la arquitectura, la comunicación gráfica, el producto, etc. Pero esta evidencia no ha supuesto hasta ahora una auténtica conciencia del diseño, no al menos al nivel de su presencia. Esto puede deberse a que el diseño es una práctica y una profesión relativamente reciente, aún no separada simbólicamente de la artesanía y del arte a los ojos de la mayoría. Por otra parte, su usual asociación a los modos de producción industriales o tecnológicos dificulta igualmente su percepción como ámbito característico.

Si se asume el carácter extenso de esta realidad estética (entiéndase "realidad estética" como conjunto de hechos y objetos abierto a la apreciación de las cualidades sensibles, más allá de las cualidades estéticas configuradas cultural y socialmente), pensar el diseño significaría hacerse -en el pensamiento- con el modo más amplio en que la realidad y la experiencia son producidas y son dadas en nuestro tiempo. Desvelarlo como el gran mediador, aquel con el que hacemos el entorno y con el que nos hacemos al entorno. Para alcanzar al diseño en esta imagen, antes tendríamos que haber excedido la visión de las particularidades, la inminencia de lo fáctico, del oficio,

* Universidad de Sevilla, ADG-FAD, España.finfante@us.es

* * Universidad de Sevilla, España.godoydom@us.es 
de la disciplina, de los factores de producción,... al final, sorprenderíamos al diseño en una categoría, al nivel de la cultura, quizá como el principal modo de la cultura.

El pensamiento contemporáneo ha sido sensible a estos modos de conformación de la realidad y la experiencia evidenciándolos generalmente como poderosos filtros del encubrimiento. En Ser y tiempo, Heidegger dirigía su crítica a lo que él llamaba publicidad [die Öffentlichkeit] como modo de constitución de lo real:

Distancialidad, medianía y nivelación constituyen, como modos de ser del uno, lo que conocemos como 'la publicidad'. Ella regula primeramente toda interpretación del mundo y del Dasein, y tiene en todo razón. [...] La publicidad oscurece todas las cosas y presenta lo así encubierto como cosa sabida y accesible a cualquiera (Heidegger 2003, $147 \S 27$ ).

Evidentemente, Heidegger no se refiere a la publicidad como medio, a la comunicación publicitaria, sino a un modo de la impropiedad que domina y media todo y nos impide ir "al fondo de las cosas". Similar es la descripción que Hal Foster (2004) hace del diseño como esa realidad pantalla que paraliza un supuesto acceso "a las cosas". Ambas ideas muestran la disposición del pensamiento contemporáneo a la crítica de esas mediaciones generales que obstaculizan como perversiones lo que vendría a ser una experiencia auténtica de la realidad. Las ideas de publicidad en Heidegger y de diseño en Foster muestran, en primer lugar, una tremenda facilidad para transponer un ámbito efectivo -de comunicación, utillaje, hábitat, etc.- a una realidad global. En esto, el pensamiento nunca se ha mostrado apocado, si bien, cuando opera así, lo hace en la forma de la denuncia. La percepción del diseño como un modo de mediación de la realidad se ha producido numerosas veces ya en la filosofía y en la teoría del arte, pero su voluntad de acusación, al tiempo que se percata de la generalidad, niega automáticamente un pensamiento sobre aquello que se concibe como medio. El platonismo contemporáneo posee muchas formas, pero todas coinciden en una cosa: la mediación se les indigesta.

La primera dificultad para pensar el diseño la pone el propio pensamiento, los modos de pensar característicos de la filosofía de nuestro tiempo, que en el ámbito de lo próximo, de la facticidad, de lo circundante, ven todavía sombras, veladuras, pantallas. Los modos del desvelamiento y del acceso siguen rigiendo los valores del pensar, incluso cuando este pretende operar desde el análisis. Diseño sigue siendo, para este modo de pensar, aquello de lo que hay que sustraerse, aquello que hay que sortear. Para él, el diseño está demasiado pegado a los hechos y a los objetos; como dice Heidegger de la publicidad, "oscurece todas las cosas". Probablemente, a esta caracterización del pensamiento de nuestros días se le puedan poner muchas objeciones, no lo dudamos, pero es un hecho que el rechazo del diseño como régimen de inautenticidad está muy generalizado dentro de la filosofía y de la estética.

Por otra parte, podría pensarse que el encumbramiento del arte como régimen de excepcionalidad por parte de estas últimas tiene algo de reclusión y de torre de marfil. Al arte se le considera verdadero modo de acceso -al ser, a la realidad, a la verdadsolo en tanto no esté pegado a aquello a lo que supuestamente da acceso. Con el arte, el pensamiento filosófico muestra una de sus operaciones más determinantes: el pensamiento dispone, es decir, ubica e instala aquello sobre lo que piensa -el arte en este caso-, aunque lo que hace generalmente es consolidar una colocación que se ha dado 
socialmente, afianza el "reparto de lo sensible", en términos de Rancière (2000). Por eso tampoco el arte ha sido propiamente pensado -ahí vuelve de nuevo Heidegger con su conocida consigna: "Lo que más merece pensarse en nuestro tiempo problemático es el hecho de que no pensamos" (2005: 17)-, porque al arte se le concede su enorme apertura desde un espacio simbólico previamente fijado y garantizado. El pensamiento necesita repartos, requiere de la jerarquía que incluye todo espacio. No podemos pensar si no es desde y entre, y el pensar de la filosofía contemporánea -incluso aquella que pretende escapar a esa difuminada "tarea del pensar"- no puede aceptar que ese desde y ese entre estén definidos por otra tarea, la del diseño en este caso. Quizá solo lo acepte cuando un posible Hegel futuro dictamine la muerte del diseño, cuando la lechuza de Minerva se acostumbre a los rótulos de neón y vuelva a identificar el crepúsculo.

A esta tarea de pensar (el diseño) está dedicado el presente número de Laocoonte. Este pensamiento también asume su desde y su entre, tomando en consideración la reflexión que surge entre quienes se dedican profesionalmente al diseño, y desde el diseño como disciplina. La entrevista a Norberto Chaves que ha aparecido en una de las secciones precedentes es buena muestra de ello. También la conversación abierta con investigadores que se han acercado al diseño: su reflexión y su análisis se realiza en una proximidad con el diseño, a partir de la observación de las intencionalidades, los usos del lenguaje y los procedimientos de un ámbito característico (que, por extenso, podemos ver también como un modo de la realidad). Frente a la autoexigida distancia del filósofo y del esteta tradicionales, que paga muchas veces el precio del desconocimiento de los hechos con su posición de observador, estos teóricos conocen los entresijos, los debates, los problemas y los términos y se implican en ellos. De algo sin embargo sí se distancian: del normativismo estético.

Esta sección Panorama: Filosofia del diseño se abre con un texto de Pedro Medina que pretende, precisamente, abrir la comprensión del diseño más allá del discurso objetual mostrando que el propio paradigma actual excede ese ámbito, que la práctica misma del diseño se adentra en un terreno de desmaterialización, consecuencia, entre otras cosas, de la enfatización del diseño como proceso y la aparición de dinámicas colaborativas.

El segundo texto invitado pertenece al artista Dionisio González, que reflexiona habitualmente sobre la arquitectura, tanto desde su obra como desde sus escritos. En este ensayo, su incursión reflexiva busca acceder a las formas de la ciudad y el hábitat despejando los discursos arquitectónicos y urbanísticos, leyendo a través de ellos. Como en su obra visual, aquí Dionisio González atraviesa las formas y los escritos de los arquitectos para alcanzar una especie de arquitectura más allá de la arquitectura.

La sección de artículos, por su parte, cuenta con contribuciones muy diferentes que reflejan la extensión del marco teórico del diseño. La primera de ellas, "Understanding Design Aesthetics beyond functional beauty accounts", es un acercamiento de tipo analítico. En el marco de la reflexión actual de la estética del diseño y desde un punto de vista prácticamente ontológico, la investigadora Lucía Jiménez Sánchez analiza las posibilidades que brinda la teoría de la belleza funcional para la apreciación estética de los objetos de diseño. Concluye así que las consideraciones puramente funcionales defendidas por dicha teoría se quedan cortas a la hora de explicar la dimensión estética del diseño por cuanto en ella entran en juego otro tipo de consideraciones como las propiedades expresivas del objeto que van mucho más allá de las simplemente perceptuales. 
Con una perspectiva más onmiabarcante y aclaratoria, Joan M. Marín aborda críticamente algunos de los debates más interesantes que han tenido lugar en torno al diseño desde el mismo momento de su aparición, a mediados del siglo XIX, y que se prolongan hasta nuestros días con nuevos matices y particularidades. Pasa revista así a la profusa e imbricada relación entre arte y diseño, a la dimensión estética del producto industrial nacido para cumplir una función eminentemente utilitaria y al diseño como supuesto agente de estetización y, por tanto, de estimulación del consumo y sedación de las conciencias. Recalando en el diseño crítico, el diseño ecológico y el diseño para la necesidad, el autor demuestra que el ámbito del diseño es bastante más complejo que el retrato simplista que ofrecen de él estos debates y se extiende más allá de los objetos estupendos de las portadas de las revistas especializadas.

El artículo de Jorge López Lloret recoge un estudio especializado, centrado en la segunda mitad del siglo XIX, época relevante en la historia del diseño de producto, y en la que surgió el problema de la relación entre el fondo y la forma; aquí es donde según el autor se deja sentir la manera en que la sociedad y la cultura tratan a sus individuos, en especial a la mujer. López Lloret analiza las ideas opuestas sobre el diseño que coexistieron en aquella época a partir de Charles Baudelaire, por un lado, en su "Elogio del maquillaje" (1863), como defensa a ultranza del revestimiento que el poeta ve reflejado en la mujer maquillada y a la moda -por opresora que ésta fuera con el sexo femenino-, y Adolf Loos, por otro, en su señera obra "Ornamento y delito" (1908), donde se articula uno de los rechazos más radicales del revestimiento que se extiende a la moda femenina como artificio surgido únicamente, según el arquitecto, para satisfacer al macho adulto.

En un intento por diferenciar la arquitectura y el diseño como disciplinas tradicionalmente confundidas y solapadas, Saul Fischer presenta la arquitectura como un dominio independiente y soberano tanto en lo que se refiere al tipo de objeto que produce -de mayor escala y pensado para la perdurabilidad-, la actividad profesional -más compleja por el nivel de responsabilidad previo y posterior a la producción del objeto- y la carga histórica -más extensa y rica-, como también y sobre todo al pensamiento implicado en la disciplina arquitectónica donde, entre otros factores particulares a calibrar - de los que carecería el diseño-, están la estructura y organización del espacio y, en consecuencia, el impacto ambiental dentro del entorno al que va destinado el producto -el edificio, en su caso-.

Basándose en los lenguajes de patrones del arquitecto y urbanista Christopher Alexander, Antonio Hidalgo Pérez presenta una teoría del diseño como práctica orientada a establecer las condiciones de habitabilidad urbana que debe ir de la mano siempre de la ética y, por lo tanto, un diseño que se sustenta en un modelo o filosofía de la habitabilidad ecológicamente viable. El autor piensa de ese modo el diseño como práctica orientada a satisfacer las necesidades humanas pero en íntima comunión con el concepto de "integridad habitacional" por medio del cual se puede alcanzar el equilibrio a escala planetaria.

Salvador José Sanchis Gisbert, Ignacio Peris Blat y Pedro Ponce Gregorio nos acercan a la figura de Marcel Breuer, quien habiéndose formando en los ideales de la escuela de la Bauhaus, exportó al exiliarse a los Estados Unidos lo mejor de la arquitectura moderna europea, que plasmó en sus viviendas prefabricadas. Con ellas, vino a demostrar según los autores que la modernidad en la arquitectura no la aportaron los materiales o los procesos industriales de producción en serie, sino el cambio de 
actitud de los arquitectos en la manera en que incorporaron en sus proyectos esos nuevos sistemas y materiales, lo que vendría a constituir una verdadera nueva filosofía del diseño.

Por su parte, Milagros García Vázquez dedica su atención al diseño de decorado y vestuario en la obra multidisciplinar de Oskar Schlemmer, miembro destacado de la Bauhaus, tomando como ejemplo la obra escénica Das Triadische Ballett, que, aunque estrenada antes de la constitución como tal de la Bauhaus, fueron Gropius y sus alumnos los que reconocieron su valía en el mundo del teatro y el arte en general.

El artículo de Tània Costa Gomez está dedicado a prácticas artísticas y de diseño actuales -pone como ejemplo La Venecia che non si vede y La Borda- que no sólo pretenden desarrollarse desde la vía participativa, sino que se presentan como agentes de transformación social al incidir directamente en el comportamiento y las estructuras de convivencia colectiva.

Finalmente, Mara Rodríguez Venegas y Xiomara Romero Rojas llevan a cabo una reivindicación del papel de la estética en la formación académica de los estudiantes de Diseño Escénico en la Universidad de las Artes de Cuba planteando numerosos aspectos de la enseñanza artística. Como también destacan Norberto Chaves y los investigadores encuestados, el carácter de la formación en diseño es una clave fundamental.

En la sección Suplemento, que cierra este Panorama: Filosofía del diseño, se incluye un texto sobre el papel que el diseño, gráfico en este caso, puede jugar en la ciudad y en su autopercepción. Mecha Espiau, Mar G. Ranedo y Alejandro Rojas realizan una investigación conjunta que aúna sus tres dedicaciones -la historia del arte, el arte y el diseño gráfico, respectivamente-, en un ejercicio de cooperación más que de multidisciplinariedad.

Uno de los primeros teóricos del cine, el poeta húngaro Béla Balázs, afirmó que ningún arte había sido grande sin teoría. Evidentemente, Balázs no se refería a que el arte, cualquier arte, necesitara de la teoría para hacerse grande, pero sí para mostrar en otros términos su dimensión. La teoría -entendida como una práctica basada en la construcción de ideas, discursos y argumentos- no es imprescindible para que ningún arte se desarrolle, está claro; pero, históricamente, la teoría parece haber cumplido dos funciones cruciales: fomentar la percepción y la comprensión del arte como una realidad que es más que la suma de prácticas y objetos, y fortalecer su territorio endureciendo sus defensas. La teoría del diseño no ha alcanzado la magnitud suficiente como para que sus construcciones hagan más aprehensible y más endurecida la realidad del diseño. Esto puede deberse fundamentalmente a que la propia teoría no ha sido todavía tejida, a que sus hilos no han conformado aún una malla suficientemente cerrada, una urdimbre resistente. Aquí, no obstante, en este número 6 de Laocoonte, empieza a hacerse evidente una textura de referencias, términos, problemas, criterios y conceptos, una comunidad de discurso que ha decidido avanzar pensando el diseño.

\section{Bibliografía}

Foster, H. 2004. Diseño y delito. trad. Alfredo Brotons. Madrid: Verso.

Heidegger, M. 2003. Ser y tiempo. trad. Jorge Eduardo Rivera, Madrid: Trotta. Heidegger, M. 2005. ¿Qué significa pensar? trad. Raúl Gabás, Madrid: Trotta. Rancière, J. 2014. El reparto de los sensible. Estética y politica. trad. M. Padró, Buenos

Aires: Prometeo. 
¿s raír

„ue exir' e es, qui

a concrablot

i ser dica'oniunte

sol

has un us

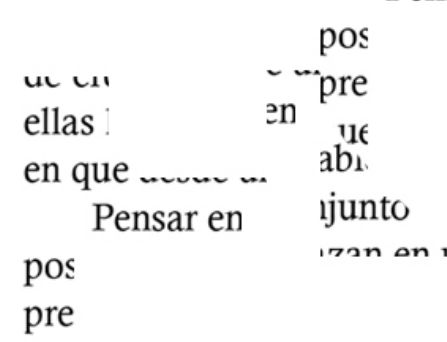

tus

art

ma
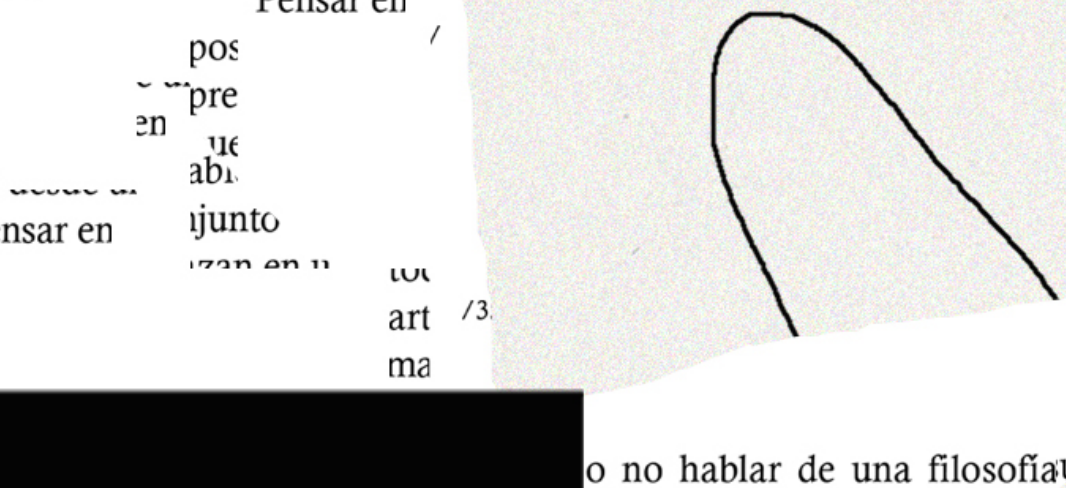

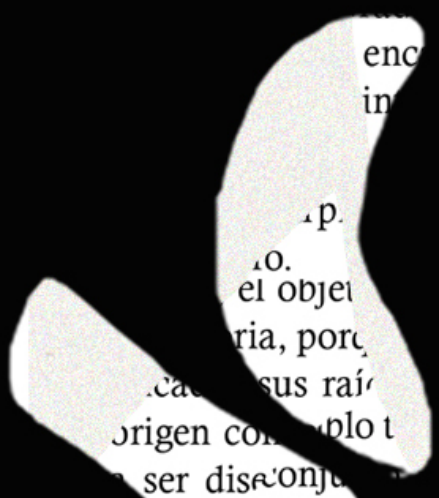

ser disfionj

seventrelazar

Pensa

nfinitame

contrar su.

hacex conscien

de las mas de

hago

?cié

lo que

presente

ralidades.

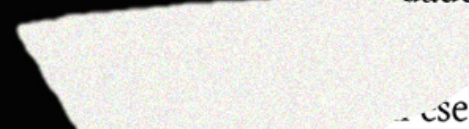

$\rightarrow$ ras que $c$

nenge, para
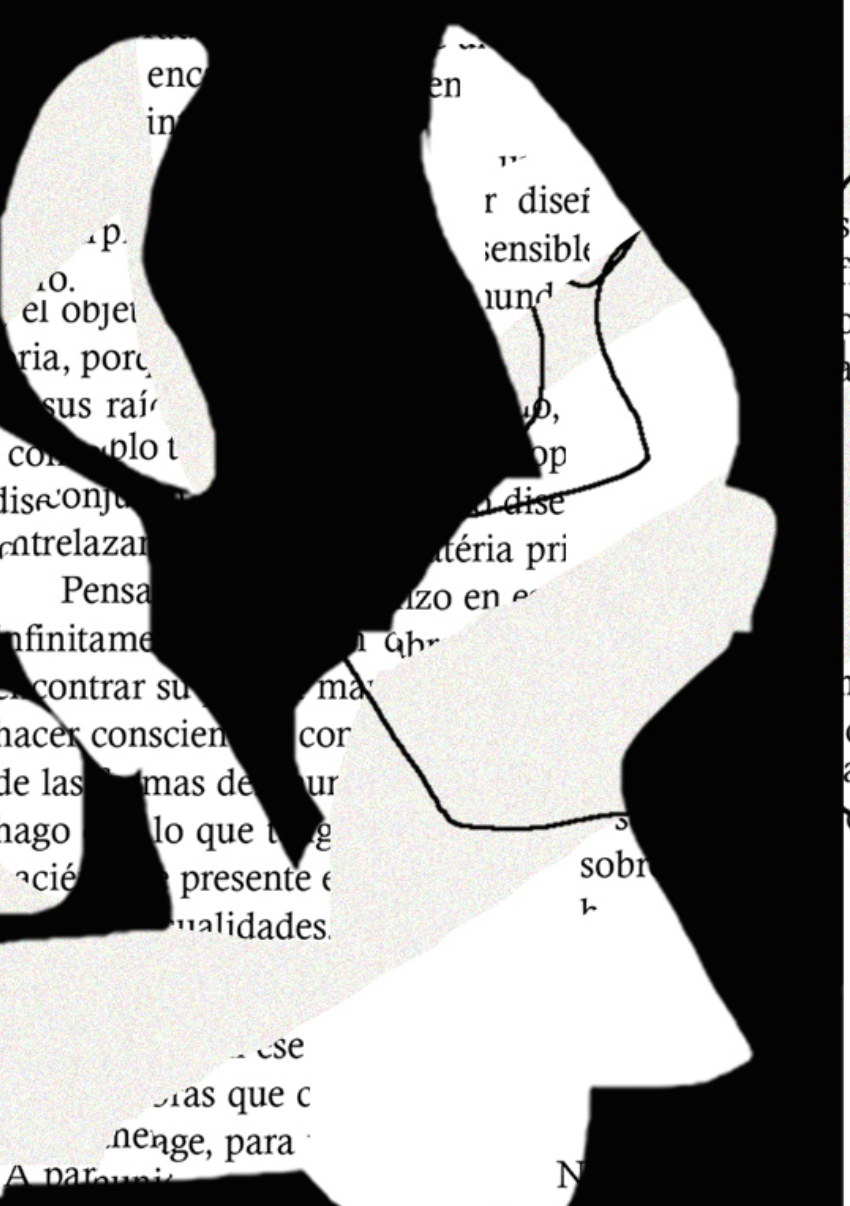

nov

o no hablar de una filosofiav

$\mathrm{Cr}$ Intentaré exponer

rea. el mundo :-

concenes

novg'

su histc.

incadas $s$ '

prigen

a.

ungiv,

do sensibleíaa

o el hilo den carp.

al y urn Curfo.

semo es el panor ma 1

intyanencia del doncep

objeto y el diseñado.

como un carplo

'sa amorfo.

$\eta$ brasileñ ${ }_{\text {no }}$ tier ${ }^{\text {to }}$,

tancia de $e_{\text {el int }}{ }^{\text {irtir de }}$.

No hay cómolos factienc .ma para $\mathrm{u}$ de método, de penso use: $c^{2}$ puede gene creación en general. 1.

en proyección realizar la forma para $\epsilon_{\text {tier }}$ conceptual por las orígs entos de una novela, el objeto, la exr su historia, porque exir.

"cadas sus raír

, en pro para um 1

ientos fincadas sus

origen 
-.iuso.

er el diseño y ?

.tgen de nuestro $\mathrm{m}$

spia manera de constr

nte y comunicar el pro

/351/

lel diseño, si no hablr

in formon. of 1

nror en dir.. o.

hace s

descifra ᄂ.

vos is snli,

351/

'To hay cómo

'n de ne
UOCOCNTE

PANORAMA: FILOSOFÍA DEL DISEÑO

TEXTOS INVITADOS

\section{in}

rar 1

de

col

hech ae metuuu, -

creación en ger

realizar la form

conceptual por

novela, el objet

su historia, por

fincadas sus ra

origen concept

a ser diseñado.

sobrevolando 1

hace surgir la $\mathrm{f}$

descifra una ler

y se la aplica a 
¿s raír

$$
\text { yue exirs a es, qui }
$$

a concrablot . Sor dica'oniunte

sol

has un us

un un

ellas

en que

Pensar en pos

ellas: $\quad$ en pre

en que

Pensar en

pos

pre

il tus

art

ma

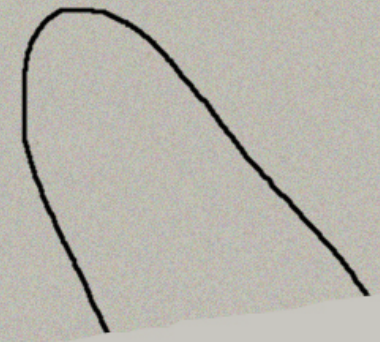

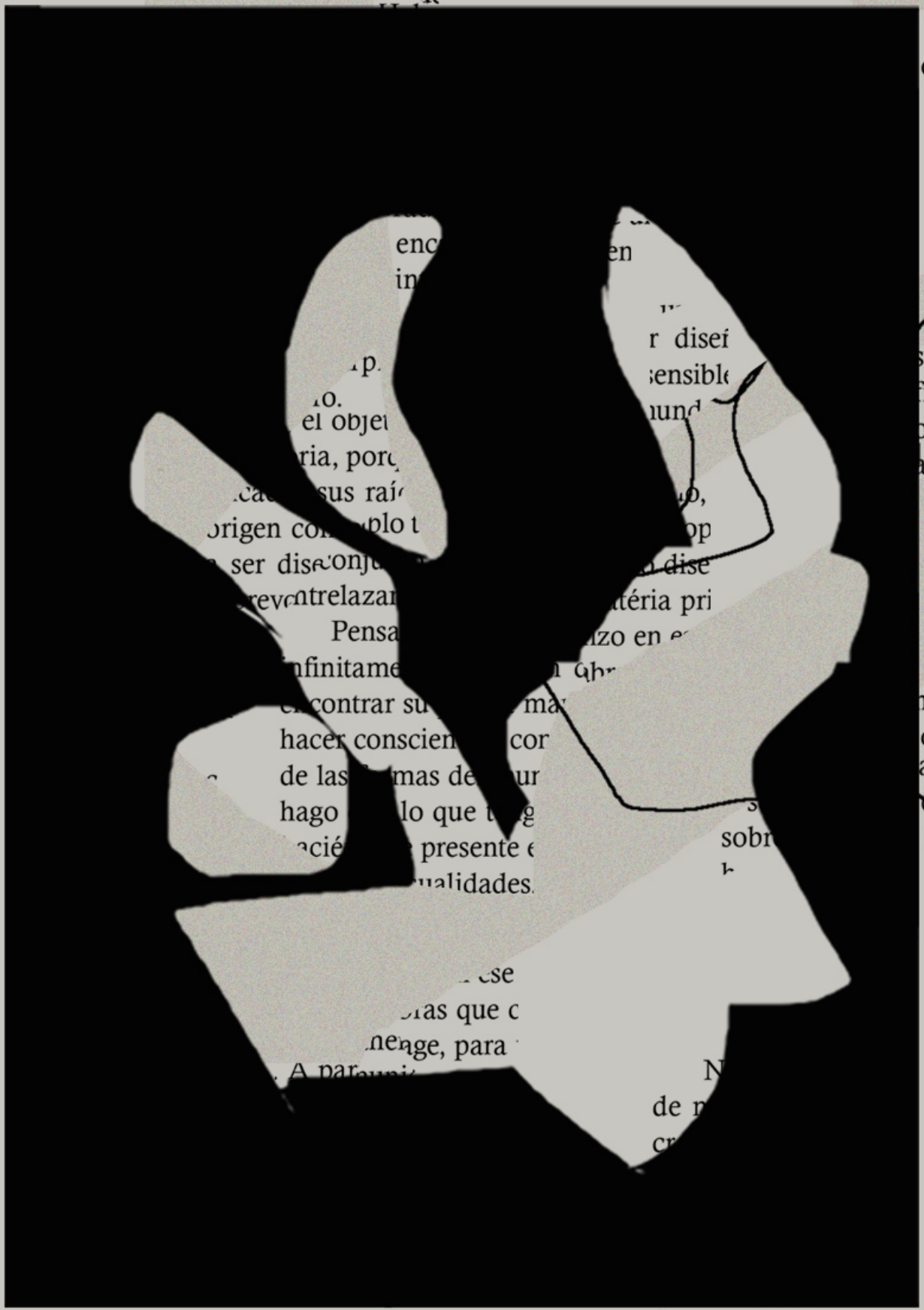

, en pro para um 1

ientos fincadas sus

origen

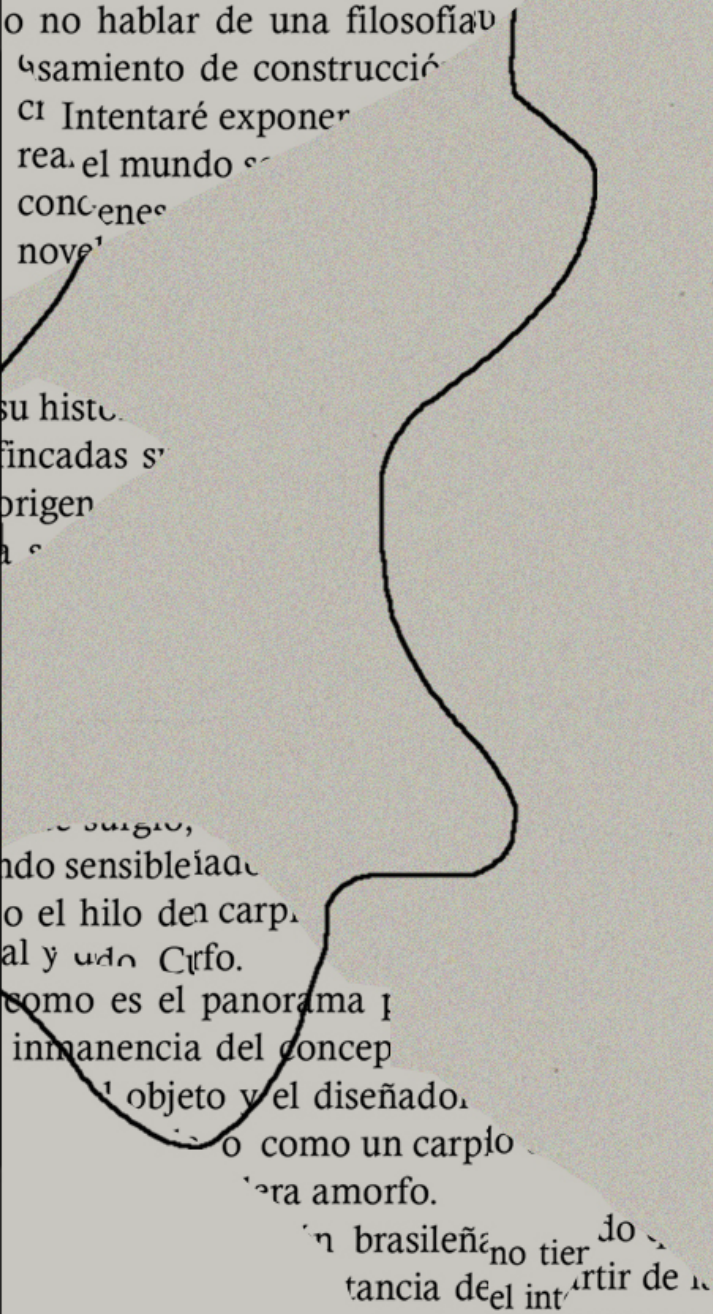

No hay cómolos factienc -ma para $u$ de método, de penso use: $\mathrm{c}^{2}$ puede gene creación en general. 1. en proyección realizar la forma para $\epsilon_{\text {tier }}$ conceptual por las oríg $\epsilon^{-}$ novela, el objeto, la exr $\mathrm{F}_{\mathrm{e}}$, su historia, porque exir

" ncadas sus raír

v concrablo también de fael. (2014). a'onjunto con la for

1azan en un comná 


\title{
Estatus y estado del diseño más allá del objeto ${ }^{1}$
}

\section{Status and state of design beyond the object}

\author{
Pedro Medina Reinón ${ }^{*}$
}

\begin{abstract}
Resumen
Históricamente el diseño no ha construido un discurso autónomo, definiéndose en relación con otras disciplinas como las artes visuales. Así, se ha caracterizado por un valor de uso, por ser un producto industrial y por su pertenencia a una cultura del proyecto. Establecer el debate en estos términos reduce la complejidad del mundo del diseño y lo remite a un discurso objetual que no corresponde al paradigma actual, marcado por la desmaterialización producida como consecuencia de la enfatización del diseño como proceso, la aparición de dinámicas colaborativas, su transformación en método y la generalización de prácticas determinadas por las nuevas tecnologías.
\end{abstract}

Palabras clave: Diseño, arte, cultura del proyecto, design thinking, colaboración.

\begin{abstract}
The design has not built an autonomous history, defining itself in relation to other disciplines such as the visual arts. Thus, it has been characterized by a use value, because it is an industrial product and its belonging to a project culture. Establishing the debate in these terms reduces the complexity of the design world and refers it to an object discourse that does not correspond to the current paradigm, defined by the dematerialization produced as a consequence of the emphasis on design as a process, the emergence of collaborative dynamics, the consideration of design as a method and the generalization of practices determined by new technologies.
\end{abstract}

Keywords: Design, art, project culture, design thinking, collaboration.

\section{Arte y diseño}

\section{En torno a discursos objetuales}

"El diseño nunca ha tenido una historia autónoma. Ha sido siempre considerado como parte de la cultura industrial, como ornamento social o como un aspecto curioso de la historia de las costumbres". ${ }^{2}$ Estas palabras se hallan al inicio del número de los Cuadernos de Diseño dedicado a la relación entre arte y diseño, y señalan un hecho

1 Tengo una deuda excepcionalmente grande con los integrantes de las numeras audiencias que oyeron versiones anteriores de este artículo, algunos de los cuales ya no lo reconocerán debido a los cambios radicales que sus observaciones inspiraron. Estoy particularmente agradecido a Paloma Atencia Linares, Jiri Benofsky, Diarmuid Costello, and Martin Steenhagen, quienes me proporcionaron comentarios por escrito; y a Alfred Archer, Al Baker, Cat Saint Croix, David Davies, Daan Evers, Dominic Gregory, Margaret Iverson, Dominic Lopes, Aaron Meskin, Ludger Schwarte, Michael Stynes, Kendall Walton, Alan Wilson, and Dawn Wilson.

2 Jarauta, F. 2006, p. 11.

* Istituto Europeo di Design, Turín (Italia).pedromedinareinon@gmail.com 
que condiciona el estatus del diseño: su dependencia de disciplinas anteriores para definirlo.

A ello se podría añadir -con Gillo Dorfles- que "la ambigua relación entre artes visuales y diseño se representa una y otra vez de forma intermitente", ${ }^{3}$ lo que indica un estado de "negociación" permanente, cruces e intercambios que cada vez son más frecuentes. Siendo así, y para evitar extender la lista de referencias, de William Morris a Tomás Maldonado, pasando por tantos otros, se puede completar este acercamiento a la falta de autonomía del diseño y su especificidad con algún clásico más, como Giulio Carlo Argan, cuando en 1972 manifestó la frontera entre los dos ámbitos creativos:

Se concede al artista cualquier licencia (...) siempre que no salga del círculo cerrado de una técnica que gira sobre sí misma. No se le permite proyectar, porque el proyecto no nace del consenso o del disenso, sino del análisis crítico de la situación (...) no se limita a reflejar el estado de las cosas, sino que interviene con una metodología rigurosa (...) El proyecto, precisa estructuras y formas, es siempre un acto estético, es diseño. $^{4}$

Esta cita establece la discusión en torno a un aspecto importante: la pertenencia o no del arte a una "cultura del proyecto", a la que sí pertenece el diseño; y su reconocimiento como acto estético, es decir, de fondo Argan tiene presente cierta "muerte del arte" cuando el valor se desplaza de la obra artística al objeto de uso. A estas características se pueden asociar otras como el carácter industrial -y, por tanto, serial y reproducible- del diseño y la concepción idealizada del arte como creación pura y sin función.

Esta posición, que tiene la funcionalidad como aspecto crucial, tiene evidentemente en su base el principio del "desinterés" como característico de la creatividad artística. Una noción que parte de Shaftesbury, pero que tiene como principal referencia la Crítica del juicio de Kant, ${ }^{5}$ que sitúa el juicio estético en otra esfera bien distinta de la que concierne a la utilidad. Una de sus derivas la hallamos en Adolf Loos cuando opone arte y utilidad al pensar que cualquier cosa que tenga una finalidad concreta está excluida de la esfera del arte.

Para abordar esta supuesta frontera entre los dos ámbitos creativos, puede ser significativa la figura de Bruno Munari, hoy día reconocido tanto en el ámbito del diseño como en el de las artes visuales. ${ }^{6}$ No obstante, ya desde joven marcó distancias entre ambos universos desde un punto de vista metodológico, que enlaza con la citada cultura del proyecto y, en algunos aspectos, con posicionamientos anteriores como el de Herbert Read, para quien no se debía adaptar la producción industrial a los cánones estéticos de la artesanía o del arte, sino adquirir una identidad propia y, por tanto, crear nuevos principios estéticos para nuevos métodos productivos y nuevos esquemas proyectuales. ${ }^{7}$

Munari da su punto de vista en muchas ocasiones sobre esta especificidad del proceso creativo del diseñador, si bien la referencia principal es Artista y diseñador, que

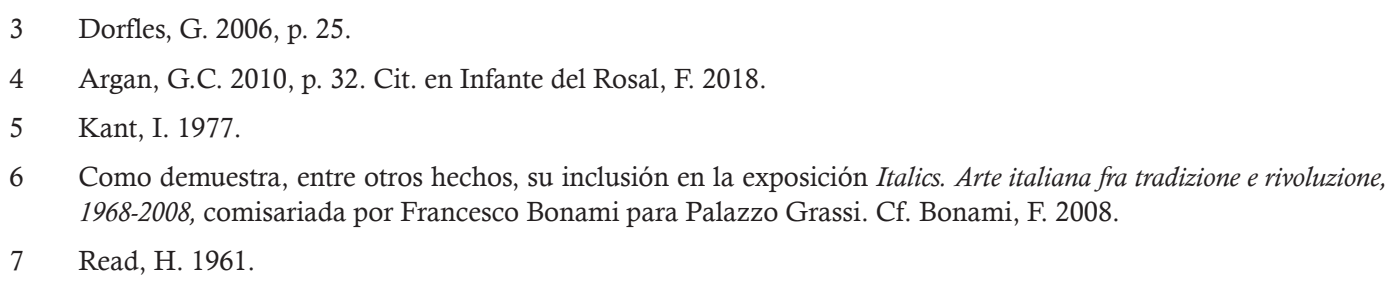


al inicio de los setenta fue un reconocido homenaje y reivindicación de la profesión de diseñador, distinta de la imagen del artista romántico. A esta figura opone el "diseñador objetivo", que viene caracterizado como "proyectista" que atiende al aspecto industrial, estético y político de aquello que crea, como perteneciente a una comunidad. En efecto, de modo muy sintético, la diferencia residiría en que el diseñador, a diferencia del artista, trabaja en grupo, no tiene estilo, resuelve problemas, inventando soluciones neutras y anónimas, y no produce obras de arte sino objetos funcionales, a través de un método específico dentro de un sistema objetivo. ${ }^{8}$

Aquí hay una definición neta de la particularidad del trabajo del diseñador, pero ni que decir tiene que esta concepción del arte está anclada en su momento histórico y político, diferenciándose de un tipo de artista que no corresponde con muchos comportamientos artísticos del último medio siglo, ligado a prácticas de corte político y procesual, ni tampoco con la realidad actual del diseño, que en buena parte está dominada por un star system donde el estilo del diseñador es reconocible y es parte del valor comercial del objeto, entendida dentro de un discurso sobre identidad y marca.

Aun así, sitúa la discusión en un punto recurrente cuando se destacan características propias del diseño, como la "funcionalidad" -y la eficacia que se deriva de la misma-, estableciendo una distancia entre valor de uso y valor estético, que se relaciona también con la activación de un proceso proyectual a partir de un cliente. Pero esta diferencia se basa en una concepción ideal del arte, que ignora buena parte de la historia del arte, repleta de comitentes, que con frecuencia encargaban las obras con el objetivo de mostrar su poder, rememorar un evento o personaje histórico o incluso educar a través de imágenes a un pueblo analfabeto.

Pero volviendo a Munari, se ha de señalar que el núcleo de su razonamiento se encuentra en el capítulo Fantasía y creatividad, siendo el artista quien trabaja con la primera y el diseñador con la segunda, una volcada a la pura ideación y la otra a un sentido práctico. Cabe preguntarse si la contraposición es tan neta y si el propio Munari trabajaba encorsetado en uno de estos ámbitos sin pasar al otro, incluso sirviéndose del mismo método. Habría que recordar las variaciones sobre los Tenedores parlantes, que son formas de diversión -un elemento esencial en Munari-que diseñó "sin ningún fin práctico, solamente para jugar con la fantasía", modificando los objetos de uso con humor, para huir de las lógicas del comportamiento cotidiano. ${ }^{9}$

En efecto, es fácil caer en contradicciones cuando se es tan drástico, por no decir que en su libro sobre el diseñador se coló un capítulo que, en el fondo, es un elogio de la fantasía. De esta forma, la síntesis de la obra del propio Munari podría ser la siguiente: "Transfiere la fantasía en la creatividad, la ordena, la organiza y la transforma en método. Es un fantasista creativo, como es evidente en otro libro, Fantasía, que corrige parcialmente Artista y diseñador".${ }^{10}$ Lo que queda entonces es la potencialidad del "hacer", que no destierra las características estéticas del objeto y permite dos tipos de aproximación a los objetos, no necesariamente inconciliables, lo que convertiría al

8 Cf. Munari, B. 1971. El método: problema - definición del problema - componentes del problema - recopilación de datos - análisis de datos - creatividad - datos sobre materiales y técnicas - experimentación - modelos/ prototipado - verificación - dibujos constructivos - solución.

9 Cerritelli. C. 2017, p. 38. Un divertissement en el que insiste Gillo Dorfles como elemento fundamental de la obra de Munari, cf. ibíd., p. 43.

10 Vitta, M. 2018. 
propio Munari en "el eslabón perdido entre Moderno y Postmoderno, en el paso del racionalismo de forma-función al decorativismo subversivo de Memphis, pero también al anti-Sottsass (...) [para quien] la emoción va antes de la función; para Munari, al contrario, la función crea la emoción". ${ }^{11}$

Ya ha aparecido una palabra muy importante para el diseño actual -incluso el más eficaz-, que es "emoción", como complemento de la funcionalidad. En efecto, la reivindicación del "buen hacer" remite a otro ámbito: el del artesano, ${ }^{12}$ que, en líneas generales, enfatiza el valor positivo del Bau-kunst (arte de construir), entendido como saber hacer que aúna conocimiento técnico y construcción fundados en la aptitud. Esta es una premisa que también debe perseguir el diseñador, pero con diferencias: el diseñador lleva a cabo el tránsito que va del utensilio a un objeto que busca también un goce estético más allá de la utilidad, lo que supone la aparición de un nuevo sector profesional que se situó entre las "bellas artes" y la artesanía tradicional.

Por tanto, aquí reside su diferencia, que se suma a su carácter industrial, que supone una "estética tecnológica" no asimilable a artes aplicadas del pasado, de ahí que una vez más se reivindique como realidad diferenciada, nueva y paralela a otras disciplinas artístico-técnicas. ${ }^{13}$ Además, desde un punto de vista ontológico, el objeto de diseño posee dos características fundamentales: es producido en serie y -así como ocurre con la arquitectura o corrientes del arte actual-experimenta una distancia entre ideación y ejecución, que afecta a aspectos cruciales como la autoría.

De hecho, el diseño rompe con la técnica constructiva tradicional en su orientación a la reproducción en la era de la industrialización y la máquina, lo que conlleva unas características prácticas y estéticas derivadas de la misma que de nuevo marcarían distancias con el arte, debido a la pérdida de "aura" en sentido benjaminiano. ${ }^{14}$

En efecto, esta es una cuestión fundamental dentro de la estética del diseño, pues está vinculada a la tecnología y ligada al principio de "montaje", que podría suponer la muerte de la creación artística -o al menos la limitación de la "autoría demiúrgica", compartida colectivamente- y su larga exclusión de la institución museo al no tratarse de obras únicas. Es lo mismo que ha ocurrido con otras artes reproducibles como el cine y la fotografía, pues - para Benjamin- la tecnología ha cambiado nuestra forma de ver y, por ende, nuestra forma de valoración estética, perdiendo el "aura" de autenticidad y unicidad espacio-temporal y, por ello, su valor cultual, sustituido por uno expositivo destinado a las masas y a cambiar la cotidianidad. Esto puede entenderse como una característica que "degrada" toda arte reproductiva, pero, por otro lado, también revela su contemporaneidad, a la luz de valoraciones sobre el arte de masas como arte de nuestro tiempo en autores como Juan A. Ramírez. ${ }^{15}$

Históricamente es la Gran Exposición del Palacio de Cristal de Londres en 1851 cuando se constata públicamente el paso de la artesanía al diseño. En este evento se mostraron las novedades industriales de la modernidad y un fenómeno fundamental: la dimensión estética del objeto de uso, con el que no estaría muy de acuerdo Loos,

11 Ibíd.

12 Sennett, R. 2009.

13 Dorfles, G. 1959.

14 Benjamin. W. 1992.

15 Ramírez, J.A. 1997 
pero que resultará fundamental para situar el debate en torno a la "forma de lo útil", el "estilo" o la "estética práctica", entre otros conceptos asociados. ${ }^{16}$

En este camino de liberación de la artesanía, el diseño ha pasado por varios períodos: uno donde el binomio forma-función era el eje; la subversión de este "calvinismo estético" por formas radicales y abiertas a lo estético; y un período donde la relación forma-función convive con una recaída en el decorativismo y la afirmación de un diseño lúdico ${ }^{17}$ y emocional. ${ }^{18}$

Por último, otro dato sobre la voluntad de escindir arte y diseño cuando se observan conceptos tan presentes en la actualidad como el de "innovación". Si acudimos al origen etimológico de la palabra (lat. innovatio, -nis), este in-novus implica un "entrar en lo nuevo". La innovación -frente a un "dar origen" de la supuesta "creación pura artística" - es definida como la "creación o modificación de un producto, y su introducción en un mercado", ${ }^{19}$ lo cual nos remite a un producto (no a una idea), no siempre creado, sino también modificado, y dentro del sistema, es decir, en referencia al mercado.

De nuevo, estas consideraciones caen en la esfera de un funcionalismo entendido como praxis, que depende de un alto conocimiento técnico, frente al privilegio de una subjetividad creadora, que aún idolatran algunos epígonos románticos. Si mantenemos una diferenciación entre un ámbito de creación y otro de innovación, se muestran dos caminos que estarían escindiendo las artes del diseño, sobre todo si lo entendemos como la mejora de algo preexistente; sin embargo, de forma similar a lo que ocurría con Munari, ¿no se trata de una reivindicación más corporativa que real a la hora de analizar la metodología y resultados de toda forma creativa dentro del sistema actual? Sobre todo en un momento como el actual donde las derivas del diseño son muy diferentes y donde conviven tendencias como la colaboración con la artesanía, la creación colectiva y la digitalización de los procesos, que nos obligan a replantear cuáles son hoy las características fundamentales del diseño.

Además, se ha de considerar que la realidad industrial en la base de las teorías nombradas - por no hablar del tipo de arte aludido, como si no existieran corrientes conceptuales y éticas dentro del mismo- remite a una condición básica: su carácter objetual. Pero reducir el diseño a diseño de objetos resulta una argumentación falaz, sobre todo desde el punto de vista del presente. Un balance de este breve recorrido en torno a la ambigua relación entre arte y diseño podría ser el siguiente:

- Bajo esta concepción aún objetual, la mayor parte de las teorías clásicas consideran el diseño como diseño de producto, lo que no abarca todas las disciplinas del ramo, como el diseño gráfico o algunas más recientes como el diseño de servicios.

- Se observa que limitar un objeto de diseño a una función específica o a puro styling no encaja en la amplitud y complejidad actual; y menos limitarlo a su relación con conceptos como creatividad o al carácter meramente funcional de la obra. Es justo con la llegada de formas más abiertas y vinculadas a un resultado emocional cuando el valor de uso y el valor estético se complementan y son relevantes para juzgar si una obra está lograda o no.

16 Mecacci, A. 2012. En efecto, Dorfles definió en varias ocasiones el horizonte táctico de la cultura del proyecto bajo una exigencia estética; cf. Dorfles, G. 2010.

17 Dorfles, G. 2006, p. 26.

18 Norman, D.A. 2005.

19 RAE. 
- Además, el carácter objetual en el que se ha establecido el debate no considera la dimensión comunicativa que tiene toda obra; algo obvio en diseño gráfico, y que puede adquirir también un valor simbólico, como ocurre con parte de la arquitectura. Pero en conjunto -como advertía Dorfles $-^{20}$ el juicio estético es necesario para discriminar si algo es verdaderamente artístico y si lo lúdico o lo espectacular no se han impuesto, cegando nuestro gusto.

- Todo ello conduce a una discusión sobre la actual "cultura del proyecto", y sobre todo a pensar si la pregunta no se ha estado formulando desde el lado equivocado. Quizás la cuestión no es si el diseño es artístico o no, sino si las artes visuales actuales pertenecen a una cultura del proyecto, incluida la metodología que esta implica. Parece difícil que no sea así, si se quiere responder a un panorama como el actual, donde la complejidad de prácticas, contextos y procesos requiere otro tipo de acercamiento al sistema creativo.

\section{Cultura del proyecto y sistema del arte}

La palabra "proyecto" ha sido vinculada a un método y una finalidad, donde el carácter estético del diseño está condicionado por estos. Además, también se han de tener en cuenta otras dimensiones del proyecto como la social (transformación efectiva del mundo) y económica (vinculada al mercado y al capitalismo), que resumiría la frase del Premio Nobel de Economía en 1978, Herbert Simon: "Diseñar es cambiar las situaciones existentes en otras más deseables". ${ }^{21}$

Si bien todas estas facetas del diseño deben contar, se ha observado una evolución histórica en la que, además de un efecto sobre la realidad, hoy se tienen en cuenta muchos aspectos a la hora de proyectar algo: se piensa en un diseño al gusto del usuario, recordando que un buen diseño debe ser fácil de utilizar, ha de ser accesible y ha de potenciar la ecoeficiencia, el uso de energías alternativas y materiales sostenibles.

En realidad, estas características podrían aplicarse a la artesanía, de la que ya se confirmó su independencia formal e industrial, y también a otras culturas del proyecto, como la ingeniería, reina del ámbito del "problem solving", aunque hay que matizar que sus soluciones están basadas en habilidades analíticas y matemáticas, frente a una parte más formal, imaginativa y estética que se le presume al diseñador.

Para acercarnos a la definición del ámbito de creación del diseño hoy, se debe enfatizar un aspecto que afecta también a las artes visuales y la ingeniería: la centralidad del proceso, por encima del resultado final, para juzgar el grado de excelencia de la obra, a la luz de problemas de corte ético en la producción y en el mantenimiento del proyecto, además de la relación central con los usuarios, desterrando todo ello la creencia en el objeto terminado como si fuera una escultura sin tiempo.

Este cambio de enfoque, que está relacionado con una transformación de la esencia del diseño y de sus prácticas, puede ser iluminado por evoluciones que el mismo mundo del arte experimentó a finales de los sesenta en torno a la entidad de la obra de arte, y que afectan al análisis de la relación entre la idea y su realización, la enfatización del rol activo del espectador o el fomento del proceso, ${ }^{22}$ entre otros aspectos.

20 Dorfles, G. 2006. Cf. ídem 1959 e ídem 1962, donde trata la dimensión comunicativa formal del objeto industrial, hablando de "consumo simbólico" no tanto del objeto como tal, sino de su imagen.

21 Simon, H.A. 1996, p. 111.

22 Cf. Medina, P. 2014. 
Así, igual que Lucy Lippard anunció en 1973 "la desmaterialización del objeto artístico" 23 en relación con la irrupción del arte conceptual, quizás podamos anunciar ahora algo similar para el diseño, desvinculado de una concepción meramente objetual. En el caso de Lippard, vinculaba este fenómeno al cuestionamiento de los ámbitos tradicionales de legitimación de la obra de arte: institución (principalmente el museo), la crítica (en revistas especializadas y por parte de la Academia) y el mercado. En nuestro caso, habrá que estudiar si es una cuestión únicamente de legitimación del diseño y preguntarnos también si este arte desmaterializado no reclama procesos y metodologías diferentes de las heredadas de una concepción objetual, desarrolladas bajo la idealización de la creación artística como algo meramente subjetivo y desinteresado.

Respecto a esta legitimación, en las dos últimas décadas han reinado diseñadores como Philippe Starck mientras las instituciones artísticas "naturalizaban" la presencia en sus salas de diseñadores como Giorgio Armani o Milton Glaser. Por otra parte, es importante recordar que esos diálogos y transferencias que son frecuentes hoy día, ya lo eran en la Bauhaus o cuando Elsa Schiaparelli unía moda y surrealismo, o Sonia Delauny llevaba la abstracción a otros terrenos. Por no hablar del gran elenco de artistas que trabajan con medios propios de la moda para reivindicar otras prácticas y formas de ver, como Louise Bourgeois o Elena del Rivero, dentro de esa gran obsesión del arte del último medio siglo que es la identidad, donde las reivindicaciones para cambiar los modos de ver -y así transformar los modos de hacer- tienen una dimensión práctica indudable.

En efecto, las transferencias del mundo del diseño al artístico y viceversa son cada vez más frecuentes, mientras se constataba el creciente interés sobre el sistema del diseño por parte de pensadores como Roland Barthes o Gilles Lipovetsky. Todo ello es consecuencia de una disolución de los límites entre disciplinas, cada vez más presente en las prácticas artísticas, pero sobre todo en el papel que lleva a cabo el diseñador como "conector" de distintas realidades y sensibilidades, de las sociales a las productivas.

Por otro lado, y para insistir en el destierro del "desinterés" como algo propio del arte actual, es evidente que en el mismo se han asentado movimientos con una praxis fuerte y una funcionalidad en nuestra sociedad, vinculado con frecuencia a la lucha por valores emergentes; por ejemplo, los defendidos por diversos multiculturalismos. Esto implica que no habría una distancia tan grande con una "utilidad" (social, política...), por no hablar del rechazo del artista como genio romántico, sobre todo cuando se trata de piezas colectivas o participativas, lo que, en su conjunto, deja como obsoleta la idea de arte como una esfera aparte de la realidad y vinculado a una concepción únicamente objetual.

Para responder a este panorama, cada vez es más frecuente hablar en términos de la obra como "proyecto", que imagina racionalmente unos resultados y está abierta a la colaboración y el cambio. Así lo ha demostrado Claire Bishop, quien ya constató la creciente importancia del concepto "proyecto" en artes visuales -ligado también al comisariado y la exposición como procesos de investigación- a partir de 1989, como demuestran casos como la Documenta de Kassel o el Proyecto Escultórico de Münster. ${ }^{24}$

Un ejemplo expreso de ello es la obra de Antoni Muntadas, quien ha teorizado

23 Lippard, L.R. 2004.

24 Bishop, C. 2016, cap. 7. 
sobre la necesidad de estructurar metodológicamente el proceso artístico para llegar a resultados plausibles, insistiendo en el carácter procesual y contextual de la obra, que no queda reducida a condición objetual:

El concepto de "proyecto" irrumpe como forma de trabajo en el lenguaje artístico contemporáneo en el momento en el que se inicia a concebir el desarrollo de una obra en estrecha relación con un contexto. La especificidad del lugar como materia (contexto como materia), la importancia de la temporalidad y de la duración de un proceso de pensamiento, y el rechazo del objeto como finalidad y producto artístico requieren necesariamente una estructura a través de la que dar forma a las cuestiones que han surgido como imperativos en el cambio sucedido al final de los años sesenta y setenta. ${ }^{25}$

Observar las fases que establece Muntadas nos remite a una metodología que, si bien es bastante diferente de otras como las del Design Thinking, entra en la misma lógica que sitúa el "proyecto" como forma de trabajo central para el desarrollo de procesos artísticos, sobre todo de aquellos más complejos, que implican fases de investigación y contemplan la intervención de diversos agentes en momentos distintos de su desarrollo.

Se observa pues que el problema quizás no sea disciplinar, sino que está ligado a una lógica objetual. Cuando nos liberamos de ella, se valoran otras dimensiones del diseño con las que tienen una mayor afinidad los denominados "nuevos comportamientos artísticos" 26 de la última mitad de siglo. Pero no todo vale, o se corre el riesgo de que cualquier imagen sea considerada artística o se relativice la función del proyecto.

Al respecto, el contexto es fundamental, pues determina estatus y valor, al margen de seguir contando con un juicio puramente estético. No obstante, la discusión podría establecerse -más allá de distinciones disciplinarias- en torno a los criterios para establecer cuándo un proyecto es logrado o no, consideración que normalmente se tiene en un ámbito estético, pero que, precisamente por su dimensión práctica, conviene matizar a través de distintos niveles de análisis, para evitar que se privilegie un único punto de vista.

Para ello, hacen falta referencias que sirvan para establecer criterios de valoración. Dentro de la larga tradición proyectual, hay varios que establecen el horizonte del buen diseño a partir de unas premisas. Probablemente el más equilibrado es el famoso Diez principios del buen diseño, elaborado por Dieter Rams en 2003:

1. El buen diseño es innovador.

2. El buen diseño hace útil a un producto.

3. El buen diseño es estético.

4. El buen diseño ayuda a entender un producto.

5. El buen diseño no molesta.

6. El buen diseño es honesto.

7. El buen diseño es duradero.

8. El buen diseño es minucioso hasta el último detalle.

9. El buen diseño se preocupa por el medio ambiente.

10. El buen diseño es tan poco diseño como sea posible. ${ }^{27}$

25 Muntadas, A. 2013, p. 3. El método: preguntas - tipologías - investigación - forma - presupuesto - calendario - desarrollo - feedback.

26 Marchán Fiz, S. 2009.

27 Cit. en Palazuelos, F. 2015. 
Este manifiesto muestra una serie de consideraciones que van más allá del privilegio de lo funcional sobre lo estético, a la luz de muchos años de experiencia y la necesidad de incluir sensibilidades sociales, como la medioambiental. Esto implica, entre otras cosas, que la creación de algo nuevo atañe a formas, usos y procesos, siendo una reflexión que, si bien podemos encontrar en más ámbitos, es cierto que ha adquirido más centralidad en las tradicionales disciplinas de la cultura del proyecto, como la arquitectura y el diseño. No obstante, se sigue hablando desde una lógica objetual.

Para ir más allá de la misma, se debería juzgar si la obra funciona en estos niveles:

- Uno de carácter práctico, que actúa sobre el mundo cotidiano, incluida su capacidad comunicativa y simbólica. En este nivel se atendería a la función social y política del proyecto, considerándose el valor moral y cognitivo del mismo. Por tanto, en este ámbito el espectador es considerado como usuario, es decir, se le supone una capacidad de acción además de percepción, actuando como ciudadano y consumidor.

- Un análisis de tipo epistémico, es decir, concebido como un fenómeno que debe ser descrito y explicado, y que afectaría a los recursos expresivos empleados, moviéndose pues en un ámbito principalmente formal, por lo que concierne al valor estético del proyecto. Aquí el usuario es espectador, pero también parte del proceso de construcción y difusión de la obra.

Se establece así la necesidad de separar el análisis en varios niveles para afirmar si se trata de un proyecto logrado en ambos aspectos. De esta manera, el valor del proyecto se juzga en cada ámbito, sin predominio de uno solo, estudiando también la correspondencia entre ambos, más allá de principios limitantes como función-forma, que hace depender la segunda de la primera. Teniendo en cuenta este análisis por niveles y la validación del proyecto de forma holista, las metodologías que vienen del mundo de la cultura del proyecto podrían aparecer como las pertinentes para responder a la experiencia actual de la realidad, estableciéndose entonces el paso contrario al punto de partida, es decir, la cultura del proyecto pasaría a ser la idónea también para los procesos artísticos contemporáneos, sobre todo aquellos que se definen por su investigación y por albergar una praxis social entre sus objetivos. Para comprobar si esto es posible, habrá que empezar por describir cuáles son las características del período actual y los desafíos que establece.

\section{Hacia nuevas realidades del diseño \\ El diseño de las sociedades postindustriales}

Se ha observado cómo el estatus del diseño (en sus diversas facetas) es definido en un primer momento por contraste con otras disciplinas, principalmente las artes visuales, al mismo tiempo que es ubicado dentro de una cultura del proyecto aún bajo una lógica objetual. ¿Se puede seguir hablando en estos términos hoy?

Bruce Mau, entre otros, ya anunció una nueva concepción de la misión del diseño: en la era de la globalización esta disciplina debería emanciparse de su producto para convertirse en sistema de pensamiento, o más bien actitud, pasando a ser el arte de organizar los recursos: hallar soluciones adecuadas y sostenibles a problemas a gran escala. ${ }^{28}$ Esto implica pensar no solo en un objetivo, sino sobre todo en los procesos que nos llevan al mismo, concibiendo unas formas de trabajo en las que la interdisci- 
plinariedad y la experiencia de grupo no son meras retóricas, sino la verdadera esencia de las dinámicas dentro de este nuevo paradigma.

En este contexto Mau llega a proclamar la necesidad del triunfo de la "clase creativa", que se atreve a imaginar íntegramente el mundo por habitar. Más allá de esta dimensión ideológica, destaca su alejamiento de una lógica objetual. Esto conduce a lo que se podría denominar la "desmaterialización del diseño" en las sociedades postindustriales, en correspondencia con el citado diagnóstico de Lippard, pero sobre todo relacionado en el ámbito específico del diseño con otro tipo de prácticas laborales y su aplicación a otros campos de acción totalmente ajenos a la "producción" en sentido clásico.

Respecto a lo que supuso para el arte a finales de los sesenta e inicios de los setenta, este paso no parece que venga acompañado por la necesidad en primer plano de escapar a los mecanismos tradicionales de legitimación o reconocimiento, pues se mueve con comodidad en espacios híbridos e indefinidos. Sin embargo, sí hay que destacar que reclama cada vez más la idea de "proyecto", como condición estructural, que llevará progresivamente a una "desmaterialización" del diseño, debido sobre todo a los siguientes factores:

- La mencionada enfatización de la importancia de su carácter procesual.

- La centralidad de la dimensión comunicativa en la sociedad.

- La aparición de ramas no objetuales como el diseño de servicios o el diseño estratégico.

- La centralidad de instrumentos y procesos digitales, que suponen un condicionamiento fundamental comparable al que ejerció la máquina para los primeros diseños.

Se insistirá en estos factores para determinar los tipos de diseño que esto genera y sus implicaciones ontológicas, pero antes se debe delimitar mejor el contexto histórico de estas sociedades postindustriales. Un pensador que lo explicó con lucidez fue Michel Serres, con su magno proyecto Le messager, iniciado en 1967. En pocas palabras, Serres constató un giro epocal, y lo manifestó a través de una imagen: estamos asistiendo al paso de la era de Prometeo a la de Hermes, es decir, del mundo de la producción y el industrialismo al de la comunicación. El filósofo francés pensó, a la vez que McLuhan, el orden complejo y móvil de la multiplicidad internacional, lo que le llevó a reconocer la importancia de la comunicación en el corazón de las transformaciones sociales.

Este predominio de Hermes no solo deja atrás a Prometeo, sino también a la estable Hestia, la diosa protectora del hogar en Roma, que estaba en el centro del ámbito doméstico, mientras Hermes regulaba los intercambios con el exterior. Hoy Hermes es el que habita el eje central de la casa y domina la situación. Por ello, este dios inestable y protector de comerciantes es elocuente para describir la transición acaecida en los últimos 50 años, un período de continua aceleración marcado también por el progresivo predominio de lo financiero sobre lo productivo. ${ }^{29}$

Hermes se convierte así en el dios protector del mundo postindustrial, donde para poder pensar la innovación (descubrimiento + aplicación) en la comunicación, hay que abordarla desde una superposición de redes, nodos de conexión en los que "solamente el sujeto errante, móvil, y no fijo, tiene alguna posibilidad de percibir la red en cuanto tal". ${ }^{30}$ 
Este diagnóstico lo completa de nuevo Bruce Mau, en este caso con el Manifiesto incompleto para el crecimiento, donde van apareciendo unos modos y lenguajes que se han normalizado en las dos últimas décadas, reconociéndose de forma generalizada que es difícil hablar de "innovación" si no la asociamos a "colaboración". ${ }^{31}$ En esta situación el diseño aparece como plataforma estratégica, un nuevo Hermes que se convierte en motor económico, fomentando el diálogo entre diferentes disciplinas y entornos creativos, sociales y empresariales.

Pero lo más importante de Manifiesto de Mau es apreciar cómo la incompletitud invita a la acción, a la creación de nuevos lenguajes, a la experimentación y a la colaboración. Y esto lleva al diseño a asumir con menos reparos que otras disciplinas la evolución en los modos de hacer y de relacionarnos que nos conducen hacia una cultura de la participación, representada por un modelo en red.

Para entender la dimensión colaborativa, una buena piedra de toque es Design, when everybody designs, ${ }^{32}$ donde Manzini afirma que nuestra situación actual requiere una nueva "cultura del diseño", pues venimos de una economía de sustitución de objetos, que no es sostenible y que no corresponde con las nuevas formas de creatividad. En efecto, las comunidades creativas y la forma de funcionar en network han sido dos de las preocupaciones de Manzini, y en este libro estudia el diseño como un fenómeno democratizado en un mundo conectado y sometido a un frenético cambio. Actualmente todos diseñan, gracias a las herramientas a disposición y la posibilidad de estar comunicados globalmente, desarrollando soluciones a problemas, que son compartidas dentro de una gran comunidad. Este "diseño difuso" debe dialogar con el "diseño profesional", siendo en el "co-diseño" donde frecuentemente se encuentran, interactuando para conseguir resultados innovadores. En suma, nos remite a pensar en qué términos se plantea una "cultura de la participación". ${ }^{33}$

\section{Aparición de nuevos tipos de diseño}

Para entender hoy qué creatividad puede surgir de esta cultura, puede ilustrar sus posibilidades una famosa exposición de 1956: This is Tomorrow, de la que ha quedado como obra más célebre ¿Qué es lo que hace los hogares de hoy tan diferentes, tan atractivos? de Richard Hamilton. Esta pieza exhibe imágenes apropiadas del universo de la comunicación de masas, anuncios que prometen una vida mejor, destinados a un sujeto reducido a su condición de consumidor y donde el interior burgués no se diferencia ya del mundo mediático. Todo es objeto de contemplación en esta realidad que ha devenido dinámica, espectacular, deseosa de bienestar, mientras se vacían identidades bajo el signo de la homogeneización global.

Esta descripción de una realidad reducida a repetición mediática está precisamente en línea con la época de Hermes recién descrita, pero lo realmente relevante para generar innovación aparece en el inicio del catálogo de la exposición: la muestra surge como fruto de la colaboración entre arquitectos, pintores y escultores para construir el programa del futuro. Se opone así a la especialización de las artes para reivindicar

32 Manzini, E. 2015.

33 Valdés Marín, I. 2014. 
la creatividad surgida de un impulso multidisciplinar y dialogante. ${ }^{34}$ Por ello, más allá de estériles debates sobre las diferencias entre arte y diseño, cabe apreciar un modo de proceder orientado a espacios de encuentro como This is Tomorrow, y que el mundo del diseño ha hecho suyos, precisamente por asumir con menos reparos el desarrollo de los modos proyectuales y la evolución hacia un modelo en red colaborativo.

Y toda red necesita un proceder. Entre todos los posibles, uno de los más importantes a la hora de profesionalizar el diseño en los últimos años y convertirlo en una plataforma estratégica de contacto e intercambio entre distintas realidades (necesidades sociales, producción empresarial, instituciones...) es el Design Thinking. ${ }^{35}$

Con la finalidad de integrar lo que es atractivo desde un punto de vista humano con lo que es tecnológicamente posible y económicamente viable, los diseñadores han sido capaces de crear los productos de los que disfrutamos hoy día. El Design Thinking es el siguiente paso, donde ponemos estas herramientas en las manos de personas que nunca pensaron en sí mismas como diseñadores y así poder aplicar estas herramientas a un abanico de problemas considerablemente más grande. ${ }^{36}$

En términos generales, el Design Thinking ha aportado metodologías -de las que se ha hecho un uso y abuso en los últimos años-que se aplican a los procesos de diseño, a través de una serie de ejercicios que atienden el punto de vista del usuario para darle un mejor servicio y que suelen desarrollarse en varias fases bajo una concepción cíclica: contexto (insights) - ideación - concepto (propuesto por empresas como Fjord) o inspiración - ideación - implementación (en casos como Soulsight), ${ }^{37}$ aunque básicamente son muy parecidos y orientados a comprender el contexto y, en función del mismo, generar ideas y soluciones que son prototipadas y probadas.

Directamente relacionado con el Design Thinking hay otro concepto esencial: el "user-centered design", ${ }^{38}$ del que derivarán otros como "experiencia de usuario" y "service design", que desplazan el foco de atención, situando al usuario y su experiencia en el centro de las diversas fases del proceso de desarrollo del proyecto.

Como se puede deducir, el usuario es también el protagonista de ese diseño difuso del que habla Manzini. Esto invita a reflexionar sobre el verdadero giro: la citada tendencia a una cultura de la participación, que, en realidad, afectará a todos los procesos cotidianos; procesos en los que el mundo del diseño se ha posicionado con meridiana centralidad, y que destierran -quizás ahora de forma decisiva- la creencia en un único autor demiúrgico.

Como resumen de todos estos cambios, se puede entender el tránsito vivido por el mundo del diseño de la siguiente forma: se ha producido una evolución de un diseño tradicional, caracterizado por dar forma (crear cosas) y ser una herramienta para solucionar problemas a partir de oficios individuales y exclusivos, a otro escenario donde el diseño es entendido de manera procesual y como forma de pensamiento, es inclusivo (con la presencia de un usuario co-creador y participativo), donde los modos de trabajo tradicionales se orientan ahora a resolver problemas generando nuevas dinámicas, y

\footnotetext{
34 Alloway, L. 1956, pp. 7-8.

35 Aparecido por primera vez en Brown, T. 2008.

36 Ídem, 2009. Cit. en Díaz Schiavon, A. 2016.

37 López, J. 2011. Medina, P. 2015, pp. 120 y 240-243.

38 Norman, D.A. y Draper, S.W. 1986.
} 
esto es llevado a cabo por medio de equipos de trabajo multidisciplinares con habilidades y actividades transversales. Por tanto, se trata de un modelo en red que potencia los procesos transversales y colaborativos.

Este panorama conlleva romper muchas convenciones afianzadas en nuestra sociedad, con frecuencia basadas en un sistema compuesto por compartimentos estancos. En este contexto se produce una "desmaterialización" del diseño, entendida de varias formas:

- Ligada a formas de diseño que no producen ya objetos sino servicios, estrategias o metodologías.

- Vinculada a la irrupción disruptiva de la tecnología digital, que propicia un trabajo puramente online o a medio camino entre el mundo virtual y el físico.

Este último caso adivina una deriva interesante: el diseñador crea únicamente una idea y su forma (un proyecto que de inicio solo existe digitalmente) y más tarde el usuario podrá personalizarlo y producirlo por medio de impresoras $3 \mathrm{D} u$ otros instrumentos propios de un fab lab, dentro de una lógica común donde se comparte el conocimiento. Se trata de esa tercera revolución industria $1^{39}$ basada en el paso a una manufactura digital y que ha generado el movimiento maker, que plantea una nueva forma de entender la distancia entre idea y realización, ya existente en el diseño industrial, pero cuya personalización por parte del usuario suscita nuevas consideraciones sobre las ideas de "autoría", "versión" y "ejecución" del diseño original.

Así, en el panorama actual se pueden establecer grosso modo 3 grandes grupos simultáneos en los que identificar tipos de diseñadores y diseño:

- Tradicional, ligado al producto físico, bien en serie o en colaboración con artesanos. Este último vive un nuevo renacimiento por sus posibilidades formales y por la valoración del producto como objeto único. En general, sus procesos son los propios del diseño objetual habitual, pero puede incorporar en algún paso procesos digitales y colaborativos, aunque son instrumentales y no estructurales.

- Desmaterializado y, por tanto, no ligado a una lógica objetual, donde la tecnología es entendida de forma instrumental y no estructural. Es el caso del diseño organizacional/relacional (diseño de servicios, management design, diseño de sistemas, diseño estratégico), o la teoría en torno al diseño y las metodologías que ofrece (Design Thinking, Design Sprint, Scrum...), que en términos generales se sirve del diseño como lenguaje y plataforma de conexión entre distintos sectores, de ahí que las dinámicas colaborativas y en red sean su ámbito habitual.

- Desmaterializado y radicalmente marcado por la tecnología. No solo abarca el uso cotidiano y básico de herramientas digitales, o trabajar en entornos digitales (animación, interacción, interfaces, realidad aumentada, realidad virtual...), sino también las actividades que se desarrollan en relación con procesos de big data y su visualización, inteligencia artificial, machine learning, robótica, blockchain... ${ }^{40}$

En su conjunto, se apunta a un cambio de paradigma, incluso en los casos más tradicionales, puesto que el valor del producto no depende tanto de su concepción como objeto terminado y autónomo, sino de todo el proceso que le concierne, tanto de producción como de vida. Además, el diseño -igual que ocurre en otros muchos ámbitos

39 AA.VV. 2012

40 Esta clasificación surge en diálogo con Javier Maseda, Director del Digital Design Lab del IED Madrid. 
creativos- cada vez se relaciona y proyecta en ámbitos más desmaterializados, fruto tanto de sus derivas teóricas y conceptuales como de su dependencia de la tecnología y de la creación de nuevas formas de comunicación y comercio derivadas de ella.

De esta manera, se va imponiendo la visión del diseño como agente transformador del mundo, cuya eficacia y capacidad de respuesta a los cambios tecnológicos y sociales se extiende a otros ámbitos creativos. Todos ellos se orientan, en suma, a crear realidad, conscientes de los incesantes cambios que vuelven rápidamente obsoletos muchos discursos implantados durante décadas.

\section{Hacia un nuevo paradigma}

Como es evidente, los parámetros para valorar un proyecto están cambiando y también el alcance de productos y proyectos. En gran parte, porque hoy se realiza el sueño de Paul Valéry de "conquistar la ubicuidad", ${ }^{41}$ mientras se adivinan numerosas derivas procedentes del mundo digital, que supondrán consecuencias en la producción, distribución, autoría y comercialización de cualquier proyecto. En definitiva, igual que la época de la máquina condicionó una estética y unos procesos en diseño, la época digital marca el trabajo del diseñador actual para que pueda generar servicios y nuevas soluciones prácticas y de comunicación.

Como en toda revolución, siempre habrá apocalípticos e integrados a favor de las nuevas tecnologías, pero es patente la actual influencia de la tecnología y las posibilidades que abre, sobre todo si es considerada como medio y se amplía la reflexión al marco de problemas en los que deberá intervenir.

Entre los nuevos fenómenos que esto está generando -y posibles procedimientos pertinentes para este nuevo paradigma-, se halla lo que Pierre Lévy denominó "inteligencia colectiva" 42 y que hoy estudian investigadores como Thomas Malone. De una forma muy general, se entiende por "inteligencia colectiva" la capacidad de pensar juntos gracias a una colaboración ordenada y respetuosa de los individuos, resultando básico que estos aporten experiencias diferentes y complementarias, que permitan un enriquecimiento cognitivo. En estos matices reside la diferencia frente a su origen en la biología, que ha observado este tipo de inteligencia en comportamientos de animales como abejas u hormigas. Esta dimensión ha dado ahora un salto cualitativo gracias a Internet y las posibilidades de comunicación y organización que facilita.

En esta línea, se identifican algunas de las características que debería cumplir esta cultura participativa para una producción más eficaz de innovación: debería ser abierta, peering (intercambio transversal de competencias), compartida y de acción global. ${ }^{43}$ Hay muchos ejemplos que demuestran su validez en diferentes ámbitos y escalas, como las citizen sciences; por ejemplo, cuando aficionados colaboran para identificar galaxias, o programas para construir escenarios plausibles de la evolución del planeta, como el Millennium Project.

Pero la ciencia exige garantías. ¿Un procedimiento como este es suficientemente fiable y avanza en el conocimiento? Hay un dato significativo para el desarrollo de metodologías en este sentido: los distintos participantes deben ser complementarios,

41 Valéry, P. 1928.

42 Lévy, P. 2004

43 De Biase, L. 2016. 
llegando a conclusiones argumentadas y fundadas, y no ser únicamente la suma de opiniones y gustos. Este espacio común de distintos agentes se puede hallar estructurado en plataformas, cuyas reglas de juego pueden cambiar radicalmente el resultado, pasando de un sistema cuantitativo de mayorías a uno "consensuado". Es decir, los participantes se corrigen entre sí en un proceso no cuantitativo, o de voto, sino en la búsqueda de consenso dentro de la comunidad. Sin duda, esto abre otras posibilidades nada despreciables, aunque aplicadas, por ejemplo, a grupos de investigación, plantean otras consideraciones como la escala en la que es más eficaz, lo que probablemente limita su implantación.

Solamente con apuntar uno de los fenómenos que puede propiciar la deriva digital, se adivinan las posibilidades de este cambio de paradigma y las experiencias a las que habrá que dar respuesta y forma. Es precisamente el mundo del diseño uno de los que parece más cercano y permeable a este panorama, por su flexibilidad y transversalidad, además de haber asumido varios de las consecuencias ya citadas y que son fundamentales en este paradigma: la enfatización de procesos colectivos y del rol activo del usuario dentro de los mismos; de ahí la dificultad para hablar de un único autor y la asunción de la condición desmaterializada y abierta del diseño. Por tanto, hay que reconsiderar una vez más las prácticas en torno a la creatividad y los criterios para establecer qué es un diseño logrado, como se ha planteado al final del primer capítulo; y, por supuesto, ir más allá de un concepto unívoco de funcionalidad y de categorías como la belleza o la validez universal de una eficacia emocional.

Necesitamos pues nuevos lenguajes para nuevas experiencias que permitan considerar ética, política y comunicativamente el nuevo contexto global, reescribiendo así las constelaciones de intereses de los sistemas consolidados. La asunción radical del diseño como proceso va en esta línea, habiendo propiciado en las dos últimas décadas un territorio híbrido y multidisciplinar donde surge buena parte de la innovación. Se trata pues de destacar la idea de "proyecto", lo que significa "imaginar" -en el sentido de Hilary Putnam- otro mundo, es decir, realizar una proyección racional para calcular la manera más adecuada para alcanzar el resultado deseado. ${ }^{44}$

Esto implica la necesidad de establecer estrategias y análisis de sistema para determinar la viabilidad y el valor de un proyecto y, sobre todo, para fomentar modos de pensamiento más allá de los necesarios conocimientos técnicos, anclados en muchos casos aún en un mundo objetual. Y todo ello sin olvidar -como explicó Francisco Jarauta en el I Encuentro de Innovación Académica- que "toda reflexión sobre el diseño termina siendo una reflexión sobre las tendencias de la cultura y sus proyectos". ${ }^{45} \mathrm{Se}$ abre entonces un interesante campo de experimentación donde realidades locales y globales se encuentran en intersecciones abiertas, un novum donde el diseño tendrá un papel central.

\section{Bibliografía}

Alloway, L. 1956. "Design as a Human Activity". Crosby, Theo (ed.). This is Tomorrow. Londres: The Whitechapel Art Gallery. Argan, G.C. 2010. Lo artístico y lo estético. Madrid: Casimiro, (1973).

44 Putnam, H. 1990, p. 129

45 Francisco Jarauta, Presentación del I Encuentro de Innovación Académica: El futuro de la enseñanza del diseño, Madrid, Istituto Europeo di Design, 27/05/2014. 
Benjamin, W. 1992. "La obra de arte en la era de su reproductibilidad técnica". Pp. 17-59 en ídem. Discursos interrumpidos I. Madrid: Taurus, (1935).

Bishop, C. 2016. Infiernos artificiales. Arte participativo y politicas de la espectaduría. Taller de Ediciones Económicas, (2012).

Bonami, F. (ed.) 2008. Italics. Arte italiana fra tradizione e rivoluzione 1968-2008. Milán: Mondadori Electa.

Brown, T. 2008. "Design Thinking”. Harvard Business Review, junio 2008. https://hbr. org/2008/06/design-thinking [accedido el 25/05/2019].

—, 2009. Change by Design, How Design Thinking Transforms Organizations and Inspires Innovation, Nueva York: Harper Collins.

Cerritelli, C. (ed.) 2017. Bruno Munari. Artista totale. Turín: Fondazione Ettore Fico.

Chomsky, N. 2017. Réquiem por el sueño americano. Los diez principios de la concentración de la riqueza y el poder. Ciudad de México: Sexto Piso.

De Biase, L. (ed.) 2016. L'intelligenza colletiva. Come funzionano le reti di informazioni e che cosa ci possiamo fare. Colección nòva-edu, Lezioni di futuro, Il Sole 24 ore, $25 / 02 / 2016$.

Díaz Schiavon, A. 2016. "El nuevo perfil del diseñador", en Jarauta, F. y Medina, P. (eds.). Cuadernos de Diseño 5: Pedagogías. Madrid: Editorial IED. https://iededitorial.com/editorial/cuadernos-de-diseno-5/

Dorfles, G. 1959. Il divenire delle arti. Turín: Einaudi.

, 1962. Simbolo, comunicazione, consumo. Turín: Einaudi.

, 2006. "La ambigua relación entre arte y diseño". Pp. 23-29 en Jarauta, F. (ed.): Cuadernos de Diseño 2: Arte y Diseño. Madrid: Editorial IED.

- 2010. Design. Percorsi e trascorsi. Cinquant'anni di riflessioni sul progetto contemporaneo. Milán: Lupetti.

Infante del Rosal, F. 2018. La autonomía del diseño. Diseño como categoría estética. Valencia: Universitat de València.

Jarauta, F. 2006. "Presentación". Pp. 11-19 en ídem (ed.): Cuadernos de Diseño 2: Arte y Diseño. Madrid: Editorial IED.

Kant, I. 1977. Crítica del juicio. Madrid: Espasa Calpe, (1790).

Lévy, P. 2004. Inteligencia colectiva. Por una antropología del ciberespacio. Washington D.C.: Organización Panamericana de la Salud. http://inteligenciacolectiva. bvsalud.org/public/documents/pdf/es/inteligenciaColectiva.pdf [accedido el 01/05/2019].

Lippard, L.R. 2004. Seis años: la desmaterialización del objeto artístico. De 1966 a 1972. Madrid: Akal, (1973).

López, J. 2011. "Design thinking: metodología para la innovación”. EOI, 15/03/2011. http://www.eoi.es/blogs/fdi/2011/03/15/design-thinking-metodologia-para-la-innovacion/\#sthash.FllPenEt.dpuf [accedido el 13/05/2019].

Manzini, E. 2015. Design, When Everybody Designs. An Introduction to Design for Social Innovation. Cambridge (Massachusetts) - Londres: MIT Press.

Marchán Fiz, S. 2009. Del arte objetual al arte de concepto. Madrid: Akal, (1972).

Mau, B. 1998. An Incomplete Manifesto for Growth. 1998. http://www.manifestoproject. it/bruce-mau/ [accedido el 11/05/2019].

, 2004. Massive Changes. Londres: Phaidon.

Mecacci, A. 2012. Estetica e design. Bolonia: il Mulino.

Medina, P. 2014. "Introducción", en Jarauta, F. y Medina, P. (ed.). Cuadernos de Diseños 
4: Diseño de procesos. Madrid: Editorial IED. https://iededitorial.com/editorial/ cuadernos-de-diseno-4/

— 2015. Nueva economía 20+20. Economía del Diseño. Madrid: Fundación EOI.

Millennium Project. http://www.millennium-project.org [accedido el 09/05/2019].

Munari, B. 1971. Artista e designer. Bari: Laterza.

, 1977. Fantasia. Invenzione, creatività e immaginazione nelle comunicazioni visive. Bari: Laterza.

Muntadas, A. 2013. Riflessioni per una metodologia del progetto. For A Project Methodology. Venecia: Monos.

Norman, D.A. y Draper, S.W. 1986. User Centered System Design. Nueva York: Hillsdale.

Norman, D.A. 2005. El diseño emocional. Por qué nos gustan (o no) los objetos cotidianos. Barcelona: Paidós.

Palazuelos, F. 2015. Los principios del "buen diseño" de Dieter Rams. https://hipertextual.com/2015/01/los-principios-del-buen-diseno-dieter-rams [accedido el 05/05/2019].

Putnam, H. 1990. "The Craving for Objectivity". Realism with a Human Face. Cambridge, MA: Harvard University Press.

Ramírez, J.A. 1997. Medios de masas e historia del arte. Madrid: Cátedra.

Read, H. 1961. Arte e industria: principios del diseño industrial. Barcelona: Infinito.

Sennett, R. 2009. El artesano. Barcelona: Anagrama, (2008).

Serres. M. 2014. Il messaggero. Pp. $42-54$ en Polizzi, G. y Porro, M. (ed.): "Michele Serres". Riga, núm. 35, (1967).

Simon, H.A. 1996. The Sciences of the Artificial. Cambridge, MA: MIT Press.

Valdés Marín, I. 2014. "Consumir diseño en la era digital", en Jarauta, F. y Medina, P. (ed.). Cuadernos de Diseño 4: Diseño de procesos. Madrid: Editorial IED. https:// iededitorial.com/editorial/cuadernos-de-diseno-4/

Valéry, P. 1928. La conquista de la ubicuidad. https://docgo.net/doc-detail.html?utm_ source $=95748793$-la-conquista-de-la-ubicuidad-paul-valery-pdf $\quad$ accedido el 19/05/2019].

Vitta, M. 2018. "Dall'oggetto all'oggetto. Le radici profonde dell'estetica". Aisthesis. Pratiche, linguaggi e saperi dell'estetico, núm. 11. http://www.fupress.net/index.php/ aisthesis/article/view/14613/13654 [accedido el 19/05/2019].

VV.AA. 2012. "Manufacturing and innovation". Pp. 1-14 en The Economist, 21 de abril de 2012. https://dc.mit.edu/sites/default/files/pdf/Econ\%20Special\%20 Rpt\%20Manufactur.pdf [accedido el 25/05/2019]. 


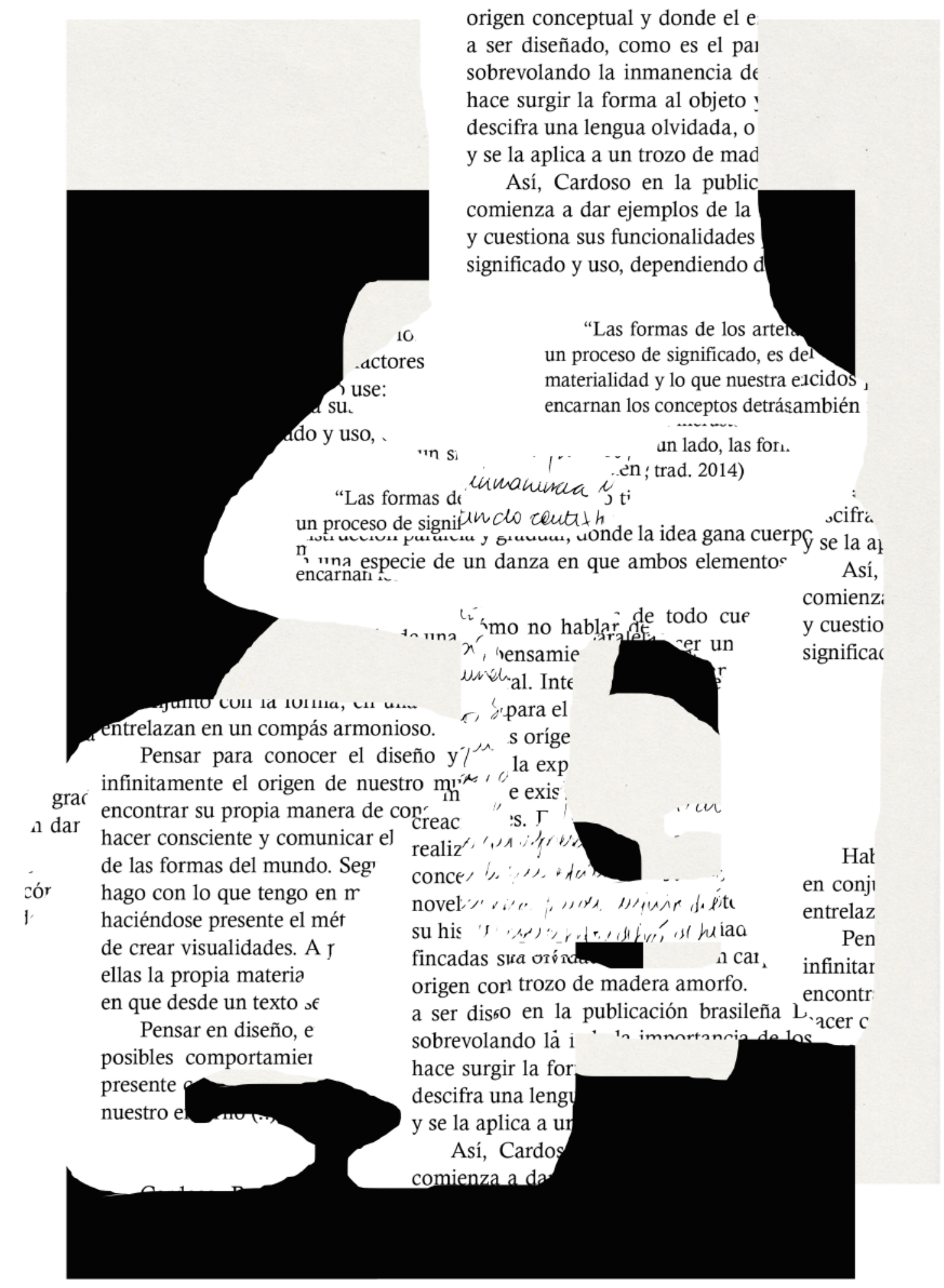

realizar la forma para $\iota_{\text {. }}$

conceptual por las orígenes ،

novela, el objeto, la exposiciór.

su historia, porque existe en el 1

fincadas sus raíces. Desde allí

origen conceptual y donde el e a ser diseñado, como es el pa sobrevolando la inmanencia d hace surgir la forma al objeto descifra una lengua olvidada, 0

Así, Cardoso en la public comienza a dar ejemplos de la y cuestiona sus funcionalidades significado y uso, dependiendo

"Las formas de los arter un proceso de significado, es de materialidad y lo que nuestra eicidos enceptos detrásambién un lado, las for. en; trad. 2014)

\section{"Las formas di}

mona sis "Las foutith , uonde la idea gana cuerp $y$ se la a ina especie de un danza en que ambos elementor Así,

¿' $m o$ no hablar de todo cue $x$, hensamie wén. Inte relazan en un compás armonioso.

conocer el diseño y y cuestio significa en conji ntrelaz

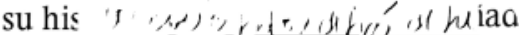
fincadas sura oróncen $n$ cat infinitar ellas la propia materia que desde un texto of encontr: Pensar en diseño, posibles comportamie presente nuestro sobrevolando lả hace surgir la for descifra una lengy y se la aplica a ur

Así, Cardos comienza a d 


\title{
Mar de Nubes. Cuerpo de Cristal
}

\author{
Sea of Clouds. Body of Glass
}

\author{
Dionisio González*
}

\section{Resumen}

E1 movimiento moderno en arquitectura descubre, desde los primeros estudios en la Bauhaus, la membrana de cristal como un logro del diseño que interpela al exterior. La vivienda así tiene la virtud del abrigo y el espesor climatérico; es decir, la integración del mundo como interventor del espacio. En esa carrera hacia la transparencia el modelo miesiano de la abstracción, el equilibrio y la reducción de las formas se multiplicó, se replicó sin la sensibilidad de éste hacia los materiales. Pero ese ser replicante que se viraliza como modelo de éxito fue generando una amorfia constructiva mimetizada por soluciones complotadas con los órganos de poder y la revolución digital. El mundo es ya pura membrana, pantalla, ventana e interfaz desde donde penetrar a espacios que, pese a su insubsistencia y su trasparencia, bien podrían "concret/ar" una bunkerización del cristal dada la pasividad y la aquiescencia del sujeto ante la pérdida definitiva de espesor.

Palabras clave: Bauhaus, expresionismo, diseño, utopía, cristal, arquitectura, ventana de Overton.

Entre un mar de nubes, destacan pilares y arcos de cristal verde esmeralda por encima de la cumbre nevada de una alta montaña. Arquitectura del armazón, del espacio abierto al universo. Arquitectura y casa no son conceptos inseparables.

\section{Bruno Taut, Arquitectura Alpina (1997: 1)}

Por lo general, vivimos en espacios cerrados. Éstos forman el medio en el cual se desarrolla nuestra cultura. Nuestra cultura es, en gran medida, el producto de nuestra arquitectura. Si queremos elevar nuestra cultura a un nivel superior, para bien o para mal, estaremos obligados a transformar nuestra arquitectura, y esto sólo nos será posible si a los espacios que habitamos les sustraemos su carácter cerrado. Esto podemos lograrlo con la introducción de la arquitectura de cristal, que deja que la luz del sol, la luz de la luna y de las estrellas no se filtre sólo a través de un par de ventanas, sino que entre directamente a través del mayor número posible de paredes que sean por entero de cristal, de cristal policromado. El nuevo entorno que habremos creado de esta forma nos tiene que traer una nueva cultura.

Paul Scheerbart, La arquitectura de cristal (1998: 2)

Paul Scheerbart escribió La arquitectura de cristal en 1914, libro dedicado a Bruno Taut. En esa suma de aforismos, que pergeña una sociedad atravesada por la luz que

* www.dionisiogonzalez.es dionisiogz@gmail.com 
permiten las grandes estructuras paredañas de cristal, se encerraba el deseo inaplazable del pacifismo. Un entramado soteriológico de efectos continuados de iluminación como único emplazamiento para la salvación. De hecho, para Scheerbart, la arquitectura de cristal convertiría las habitaciones humanas en catedrales y, por tanto, sus efectos se esparcirían como el silencio sobre las estancias y sus dueños. Bruno Taut, por su parte, construyó en 1914, en Colonia, con motivo de la exposición del Werkbund, el "Pabellón para la Industria del Vidrio y del Cristal" y algunos de los versos de Scheerbart fueron inscriptos sobre las paredes del poliedro de base (1998: 67).

Lo paradójico es que el escritor utópico, pese a sus críticas a la objetivad, anticipará la nueva construcción edilicia de integumentos de cristal envolvente y permeable del objetivismo europeo de los años 30 en arquitectura. Mientras el expresionista Taut, por su lado, con su manifiesto de "Arquitectura Alpina" publicado en 1919 aspiraría a cristalizar la montaña como un efecto tamizador del orden natural para la evitación de la guerra. Guerra que para Taut tiene su origen en la desocupación y el aburrimiento, como así expresara en la carta destinada a Guillermo II, Emperador de Alemania y Rey de Prusia. Lo cierto es que, al igual que Paul Scheerbart, Taut parece significarse en décadas posteriores como un defensor de una arquitectura de fruncimientos urbanos y paisajísticos que, a su vez, proclama una construcción de estructuras públicas no indispensables.

En esa actuación utópica sobre los Alpes, Taut predeterminaba la arquitectura como acción cósmica. La naturaleza como construcción, como fuerza e idea, como pura formalidad y curvidad que se trastoca mundo edificado. Por entonces, ya había una cierta tendencia a encapsular el jardín con bellas cúpulas de cristal para su cumplimiento botánico y Ebenezer Howard había publicado, en 1902, su manifiesto sobre "Las Ciudades Jardín del Mañana" donde sociedad humana y belleza natural debían disfrutarse conjuntamente, es decir; frente a la dicotomía campo-ciudad aparece una nueva sociedad que habita un territorio de mediaciones cuyos habitantes son íncolas de un espacio intermedio, no marginal, ni tangente sino plenamente conclusivo.

Se sabe que las teorías de Scheerbart estuvieron presentes en la construcción de los primeros manifiestos de la Bauhaus, pese a que la concepción expresionista de la arquitectura ideada por el poeta presentaba formas orgánicas cristalográficas, y "la modernidad triunfante se manifestaría en todo su esplendor a través de la planeidad, obtenida por el procesado industrial de la sílice (el flotado) y su geometría rectangular bidimensional" (Taut, 1997: 15). Aun así, la Bauhaus buscaba igualmente una nueva arquitectura que excediera el campo de la construcción. Walter Gropius indicaba, en 1935, que "como consecuencia directa de la creciente predominancia de los vacíos sobre las superficies opacas, el cristal adquiere una importancia estructural desconocida hasta hoy. Su brillo etéreo y el hecho de que parezca flotar entre pared y pared, ingrávido como el aire, da una nota alegre a las viviendas modernas" (Gropius 1966: 28).

Aunque a finales de 1923 Gropius había iniciado su alejamiento del expresionismo (incluso antes de la llegada de Moholy-Nagy principal valedor docente de los ideales constructivistas), hay algo más que lo vincula a Scheerbart y Taut: la conciencia del punto elevado y la impresión de que las ciudades ya nunca más serán penetrales, oscuras, ciegas, discontinuas. Por el contrario, serán luminosas, esclarecedoras, ya que desde el cielo el descifre de su exterioridad, de su revestimiento, dará una nueva comprensión a la totalidad del tejido urbano. La vista aérea, para Taut, modificará radicalmente la arquitectura, ésta tendrá una función redentora, anagógica. Para Gropius, la 
vista en alza mostrará la arquitectura como un sistema de émbolos donde las cubiertas se interpolan como una masa verde y especiosa. "Desde el cielo los tejados verdes de las ciudades del futuro parecerán una sarta interminable de jardines colgantes" (Gropius, 1966: 31).

En realidad, este es el sueño largamente explorado en el que los jardines domestican la naturaleza para un uso recreativo al igual que los parques introducen la naturaleza en las grandes ciudades. Es el sueño de intervenir lo natural como masa practicable donde hitar límites a un territorio ilimitado. El acotamiento del espacio variable y natural desde la arquitectura es como la encuadernación de un manifiesto de contenidos de contigüidad. Racionalizar el acontecimiento y lo contingente es, por otra parte, una audacia sin precedentes. Este reto de acristalar la práctica de lo concurrido y lo eventual forma parte de la experiencia del mundo tras la membrana. Es el efecto que transfiere el hábito de la visión sin el accidente de lo atmosférico.

Henri Lefebvre nos indica cómo Frank LLoyd Wright en la primera década del siglo XX "comenzó a suprimir el muro que sellaba un espacio y separaba el dentro del afuera, el interior del exterior. El muro se redujo a una superficie y ésta, a su vez, a una membrana transparente. La luz entraba a raudales en la casa; y en cada "pieza" de la misma podía contemplarse la naturaleza. Desde ese momento, la materialidad del volumen y del peso del muro dejó de jugar un rol primordial en la arquitectura. La materia ya no sería sino una envoltura del espacio, cediendo el predominio a la luz que poblaba ese espacio. Siguiendo la tendencia de la filosofía, del arte y de la literatura, de la sociedad entera hacia la abstracción, la visualización y la espacialidad formal, la arquitectura trató de alcanzar la inmaterialidad" (Lefebvre 2013: 339).

Sigfried Ebeling había escrito, en 1926, "Der Raum als Membram". El espacio como membrana y dos años antes, en el periódico Junge Menschen de la Bauhaus en Weimar, publicó el artículo "Células Espaciales Cosmológicas". Se sabe que Mies Van der Rohe tenía dicho libro lleno de anotaciones. Había una corriente de interpretación que, apoyada en el perfeccionamiento técnico del acero y el hormigón que reducía el área de ocupación de los elementos de carga, buscaba la suspensión etérea apoyada por cristaleras continuas divididas por finos montantes de acero. La arquitectura como cosmovisión, lo que Sloterdijk define como espumidificación del mundo que en realidad, pese a los sueños monoesféricos de la modernidad que perseguían un hiperglobo integrador, termina siendo en nuestra contemporaneidad una membrana de membranas que desde su centro, que ocupa todos los centros, manda mensajes que el remitente acusa en un laberinto de misivas (Sloterdijk 2003: 73).

Si rescatamos este deseo de inmaterialidad de la arquitectura es fácil entender como nuestras grandes urbes se han ido conformando esbeltas y acristaladas, de tal forma que el cielo quede contenido en altos prismas simplificados y neutros, que cuando irrumpe la noche brillan en intervalos como infinitas luciérnagas. En cierto modo, la Bauhaus, que promovía una fórmula de vivir conforme a un equilibrio entre el utilitarismo, la estética y la psicología, percibía como una nueva era maquinista arrollaba aquella comunidad antigua caracterizada por las artesanías, de tal manera que observaba una limitación del crecimiento democrático en aquellas grandes ciudades cuyas administraciones se fueron despersonalizando.

Gropius advertía, en 1956, cómo "arte ciencia y religión constituyen islas sin conexión entre sí; una nueva síntesis debe volver a hacer una totalidad de lo que ahora está, desgraciadamente, desintegrado" (Gropius 1959: 151). En efecto, parece que el 
trayecto temporal, ya siendo profesor en Harvard, hace a Walter Gropius plantearse cómo el sujeto de la gran ciudad está obligado a someterse a un poder distante. De algún modo, advierte cómo aquellos valores de transparencia que perseguía se vuelven indóciles; se vuelven, en definitiva, autónomos en su mímesis y expansión haciendo que aquello que fue hipotético y crítico se manifieste rizomático y literal. Gropius, que siempre alentó una arquitectura integral, una composición elemental de códigos de escala, espacio, forma y color -que vinculasen a los hombres más fuertemente que las palabras-, trataba de encontrar una terminología precisa a las ilusiones ópticas y su influencia psicológica.

Entre los efectos que buscaba discernir se encuentran el vértigo provocado por la altura y la transparencia y la agorafobia provocada por los espacios amplios, vacíos o abiertos. A este respecto, escribía, que las personas en el momento de cruzar un gran parque "se sienten perdidas en un espacio cuyo tamaño no está de acuerdo con la escala humana. Pero si se levantaran en ese espacio abierto algunos planos verticales tales como arbustos, cercos o paredes, dispuestos a la manera de las bambalinas de un teatro, la ilusión de seguridad se restablecería y desaparecería el temor, pues los ojos a tientas en ese espacio hallan ahora un sistema de referencia que les brinda apoyo; cuando encuentran un sólido en el campo visual, registran su contorno tal como lo hace el radar" (Gropius 1959: 45).

Aunque no le falta base científica, este pensamiento sorprende en la medida que alegoriza con cercos y paredes. Sin duda, existe el fundamento fuertemente arraigado en la arquitectura moderna de estilo Bauhaus, de estilo Internacional y de estilo Funcional de operar siempre sobre el vacío, de intervenir el espacio no mediado, de racionalizar la exuberancia o la explanación, sean éstos selva o desierto. La efemeralización que define desde el desarrollo tecnológico el hacer lo máximo con lo mínimo y que acuñara Buckminster Fuller llega a su máxima referencialidad con la cúpula geodésica de la Union Tank Car Company que éste construyera en Baton Rouge en Luisiana, en 1958, derruida en 2007, y que encerraba una superficie de más de 10.000 metros cuadrados. O sin duda la cúpula ballardiana propuesta como envoltorio sobre Manhattan. Estas estructuras ya se presagiaban en los jardines y parques de Joseph Paxton, en sus cármenes, invernaderos y pabellones de exposición. El gran Conservatorio de Chansworth construido en madera y vidrio en 1841 y demolido en 1920, fue entonces el mayor y más espectacular invernadero de Europa. Como lo fue más adelante el fascinante edificio, con su gran cúpula, Horticultural Building de Chicago diseñado por William Le Baron Jenney para la Exposición Universal de 1893.

Kevin Lynch cuando nos habla de obsolescencia planificada en edificios nos indica cómo la vida de éstos puede ser programada para una decadencia administrada. Lo ideal es que la previsión de vida de un edificio iguale su probabilidad de uso, pero esto casi nunca se produce. Podemos, dice, "planificar los usos intermedios y los accesos para sacar partido a los espacios vacíos temporalmente que facilitan los derribos" (Lynch 2005: 182). Es decir, que podemos especular con el vacío, con lo disfuncional, aplicándoles nuevos usos que aplazan o eliminan su declividad. Porque, finalmente, lo vacío es espacio para la libertad, más cuando es tangente con un régimen edilicio que contempla lo pleno o lo lleno como articulación urbana.

La arquitectura no formó parte del plan de estudios de la Bauhaus hasta 1927, aunque desde sus inicios en Weimar, en 1919, Gropius había hecho del edificio en su completud (der Bau) el propósito docente final. Mies Van der Rohe asumió la dirección 
de la Bauhaus en septiembre de 1930. Parece ser que Gropius ya se lo había ofrecido en 1928, casi al mismo tiempo del nombramiento de Hans Meyer que trajo, entre otros profesores, a Ludwig Hilberseimer para supervisar los proyectos de vivienda colectiva y urbanismo. Pero, la accidentada vida en Dessau, su traslado a Berlín, la célebre carta de la Gestapo que consiguió Mies, tras tres meses de negociaciones, y el final de esta escuela en 1934 provocarán un viaje diaspórico de sus profesores que seguirán impartiendo el espíritu de la Bauhaus desde el exilio. Mies y Hilberseimer continuaron su labor docente en Chicago, donde también lo hicieron Lászlo Moholy-Nagy, Hin Briedendieck, Walter Peterhans y Gyorgy Kepes.

Ludwig Hilberseimer, más proyectista que emprendedor, a diferencia de Mies, estaba gestando su proyecto The New City destinada a transformar integralmente vidas y territorios, pensando un sistema escalar que partía de la unidad mínima de la casa y se extendía hasta la inmensidad del paisaje en un ejercicio de absoluta coherencia y racionalidad (González Martínez 2015: 29). Es decir, seguía, de forma inercial, entablando diálogos teóricos entre el mundo natural y la actividad residencial. Este proyecto, que para algunos hubiera cerrado el movimiento moderno que Jürgen Habermas entendía inacabado, no era un postulado utópico, sencillamente su modestia no casaba con el optimismo constructivo de Estados Unidos, ni encajaba su idea de colonizar el territorio desde una especie de zonificación familiar en un momento de creciente verticalización concentracional y euforia por un modelo estratificado y erguido de edificación. Más interesantes parecían para ese momento, 1944, de renovación urbana, sus anteriores ideas sobre la ciudad-rascacielos de reificación pedestre, con pasarelas aéreas, calles bajas de tráfico rodado y túneles de metro superpuestos para la ciudad congestionada de Chicago. Lo cierto es que Hilberseimer, para la larga ideación de su proyecto que se prolongó durante 17 años, se apoyó en la obra de Bruno Taut y, concretamente, en su Die Stadtkrone (La corona de la ciudad).

Hilberseimer requería ciudades en curso de renovación urbana, un planeamiento desacotado. Una realidad descercada que se extendiera como una continuación del paseo y recurriese a la naturaleza en cuanto a posibilidad de expansión. Es decir, su New City se alejaría del centro para ubicarse en la inconclusión del paisaje y la periferia. Necesitaba el espacio franco donde elegir una estructura de recorrido unitario.

Pero el curso de los acontecimientos, en una sociedad de capital incremental, polarizaciones sociales y una creciente complejidad cultural, estaba más cerca de interpelar y fungir en el territorio urbano con los primeros bloques de apartamentos construidos con armazón de acero en el mundo en los números 860-880 de Lake Shore Drive (1948-1951) en Chicago. Diseñados por Mies van der Rohe junto al ingeniero Frank Kornacker. Se levantaron las 26 plantas ignorando cuánto se balancearían las estructuras. En esa misma época, Mies comenzaría a proyectar la Casa Farnsworth (1945-50), en Plano Illinois. Una segunda vivienda residencial, de una planta, sobre la llanura aluvial del río Fox. Abierta y cristalina sobre unos menudos zancos, inauguraba el efecto de transparencia. Efecto que, en 1951, le llevó a una demanda interpuesta contra Edith Farnsworth y una posterior contrademanda de ésta. Las memorias de Edith Farnsworth ofrecen un relato casi literario de las fases iniciales del proyecto:

Empezamos a vernos de tanto en tanto y a hacer frecuentes excursiones dominicales a Plano. (...) Cuando llegó el tiempo cálido, tuvimos que abrir senderos entre la maleza y la hierba de la pradera para llegar a la ribera. (...) Desde la orilla estudiamos varios 
emplazamientos para la casa y clavamos unas cuantas estacas provisionales. "Mies, ¿qué materiales de construcción estás considerando para la casa?" "Yo no plantearía el problema de ese modo. No pensaría "Vamos a construir una casa de ladrillo o de hormigón armado". Pensaría que aquí, donde todo es hermoso y la intimidad no es un problema sería una pena levantar un muro opaco entre el exterior y el interior. Así que creo que deberíamos construir una casa de acero y vidrio; de ese modo permitiremos que el exterior entre adentro. Por otro lado, si estuviésemos construyendo en la ciudad o en la periferia, la haría opaca hacia afuera y dejaría entrar la luz por un patio jardín situado en medio (Farnsworth 2016: 303-304).

Si tenemos en cuenta que tras este pabellón de vidrio, con un núcleo central que escondía el cuarto de baño y su estrecha cocina alineada, Mies diseñó el pináculo de la construcción moderna en altura -el edificio Seagram (1954-1958), edificación vidriada con marco de bronce en la avenida Park, en Nueva York-, entendemos porqué a partir de entonces las grandes urbes del planeta levantaron prismas miessianos replicantes hasta la extenuación de la mirada. Entendemos cómo los edificios de vidrio y acero definieron el paisaje urbano a finales del siglo XX. Entendemos porqué Mies se distingue por sus cajas prismáticas, su impresionada abstracción, una pureza estructural, uniones ocultas, simplicidad de manifiestos minimalistas y la utilización de materiales nobles de manera estratégica.

Es más difícil, sin embargo entender, cómo el espacio desfigurado de la abstracción y la transparencia terminan enfrentándonos a la violencia del proyecto heroico. Es difícil entender cómo la falta de velos, nos introduce en la sociedad de la transparencia de Rosseau como un órgano censor del control y la vigilancia totales. El hombre es, según Ernst Bloch, "per se impsum, un ser reflectante y anticipador" (Bloch 2017: 81). Por tanto, aunque esté programado para la acción social, ésta puede comprender la acción pasiva o aquiescente. Todo orden racional tiene una racionalidad propia, en suma, difícilmente puede ser programado como base de entendimiento colectivo, es decir, que un sistema formalizado puede ser independiente de los individuos. Toda utopía está en conflicto con un orden existente pero lo está en nombre de una idea, o sea, que el conflicto nace en la entelequia de visualizar alternativas. Toda acción rizomática, extensiva, invadiente, por más que nazca de valores "ideales", se vuelve autoritaria y totalizante. Theodore Dreiser, escribía en 1923 sobre Nueva York: "E1 gran Mundo sigue su curso. Nuestra parcela no es ésta ya que no somos los que aguardan en la oscuridad" (Dreiser 2018: 335). Finalmente, somos producto de una rendición por persuasión. También por proyección que es la forma en que lo evidente se convierte en catalizador de lo ordinario. Porque en el deseo de elevación también está el encuentro con el órgano que proyecte ese sueño constructivo o habitacional. Para Byung-Chul Han, "exposición es explotación. El imperativo de la exposición aniquila el habitar mismo. Si el mundo se convierte en un espacio de exposición, el habitar no es posible (Han 2013: 30).

Para Heidegger el habitar es construir, pero, en cierto modo, determina que sólo podemos habitar bajo la extorsión del desarraigo. Somos, finalmente, sujetos desarraigados habituados a habitar en lo que los estoicos definían como oikesis, estar siempre en tránsito hacia el hogar, o permanecer en él. Pero en suma, establecidos siempre en una superstición de fijeza que por el contrario nos devuelve la incertidumbre. Ya no habitamos ciudades sino territorios, según Massimo Cacciari, por tanto, somos hijos 
de una Exopolis expuestos a fuerzas exógenas y al crecimiento exterior de nuestras ciudades (Soja 2008: 355).

La membrana transparente conformada por las reglas técnicas de la eficiencia debe ir acompañada por la conservación identitaria de un grupo a través del tiempo. Pero dicha conservación parece seriamente bloqueada. Hay un paréntesis de conformación política que debiera vincular el pasado con un anticipo del futuro. Cualquier órgano de poder debiera ser un arbitraje entre las aspiraciones de diferentes generaciones. La cuestión técnica, sin embargo, sólo opera en el presente por más que se asocie a la precedencia. Pero los símbolos de los requisitos e imperativos que quedan reprimidos dentro de la sociedad del presente se manifiestan como patologías de incomunicación. Deformaciones de un sistema que crece asentado en la anomalía. De este modo, la transparencia carece de trascendencia porque se desarrolla desde la ilusión y la apariencia. "La sociedad de la transparencia es sociedad de la información. En este sentido, la información es, como tal, un fenómeno de la transparencia, porque le falta toda negatividad. Es un lenguaje positivizado operacionalizado" (Byung-Chul Han, 2013: 77).

La Ventana de Overton es una teoría política que detalla con puntual rigor y precisión el modo en que se puede modificar la percepción de la opinión pública para que las ideas que antes se consideraban insensatas e imprudentes sean aceptadas a lo largo del tiempo. De tal forma, que ninguna prohibición, perversión o aberración escapen a la eficacia de esta técnica. En definitiva, y a través de diferentes pasos, se podría franquear desde lo impensable y radical a lo popular y político. Cambiar, en suma, de modo drástico y extremado la valoración del individuo. Es sorprendente cómo la ventana que es sinónimo de luz y transparencia ha ido conformándose alegóricamente y operacionalmente como teoría política, sistema operativo de ordenador o pantallización total. Este es el mundo heredado de cristal, como diría Ballard:

De la misma manera que una solución supersaturada se descarga en una masa cristalina, la supersaturación de materia en nuestro continuum lleva a la aparición de masas cristalinas en una matriz espacial paralela (Ballard 1991: 92).

\section{Bibliografía citada}

Ballard, J. G. 1991. El mundo de cristal. Buenos Aires: Minotauro.

Bloch, Ernst. 2017. Despedida de la utopía. Madrid: A. Machado Libros.

Dreiser, Theodore. 2018. Nueva York. El color de una gran ciudad. Madrid: Abada Editores SL. Farnsworth, Edith. 2016. Ludwig Mies van der Rohe. Barcelona: Reverté.

González Martínez, Plácido. 2015. A la luz de Hilberseimer. Sevilla: Vibok Works.

Gropius, Walter. 1966. La nueva arquitectura y la bauhaus. Barcelona: Lumen. , 1959. Alcances de la arquitectura integral. Buenos Aires: Ediciones La isla.

Han, Byung-Chul. 2013. La sociedad de la transparencia. Barcelona: Herder.

Lefebvre, Henri. 2013. La producción del espacio. Madrid: Capitán Swing Libros SL.

Lynch, Kevin. 2005. Echar a perder. Un análisis del deterioro. Barcelona: Gustavo Gili.

Scheerbart, Paul. 1998. La arquitectura de cristal. Murcia: Colegio oficial de aparejadores

y arquitectos técnicos de Murcia.

Sloterdijk, Peter. 2003. Esferas I. Madrid: Siruela.

Soja, Edward W. 2008. Posmetrópolis, Madrid: Traficantes de sueños.

Taut, Bruno. 1997. Escritos expresionistas. Madrid: El Croquis Editorial. 
No hay cómo no hablar de una filosofía del diseño, si no de izar la forma para el mundo sensible. Tción de formas y de la

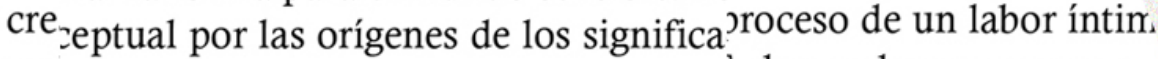

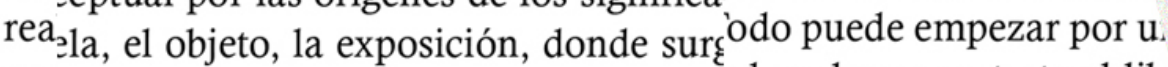

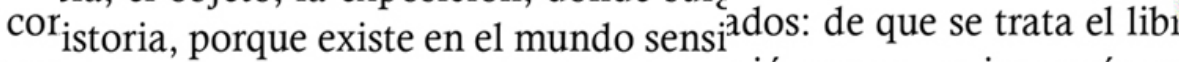
noładas sus raíces. Desde allí cojo el hilo gió, que es, quien creó y p su len conceptual y donde el está ubicado.ible o aún, por qué llama as

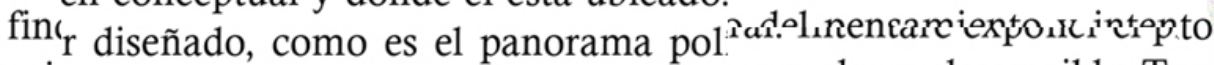
ori $_{\text {evolando la inmanencia del concepto. }}$ para el mundo sensible. Tc ce a s a forma al objeto y el diseñad ${ }^{\text {as }}$ orígenes de los significa)olo sob lengua olvidada, o como un cr la exposición, donde surg̨ido - nrocesr a un trozn de madera amnrfo le existe en el mundo sensin trai lengua olvidada,adas sus raíces. Desde allí cojo el hilona de ablo de procesc a un trozo de men conceptual y donde el está ubicado. perspectiva de lidoso en la publr diseñado, como es el panorama polndo ho, un camino diar ejemplos de levolando la inmanencia del concepto.: por una investigacióus funcionalidadı a forma al objeto y el diseñadı infl ro, el cuento, luso, dependiendı lengua olvidada, o como un $\mathrm{C} i^{\prime}$

qué, cuál e s nrecese a un trozo de madera amorfo

ata el 1

،en creó y pu.

or qué llama así, d

miento y intento a lles
- puede inferir de él. Por un in -reación ". (Rafael Cardoso, trad. 26 el ambiente que cerca el ol, especie de un danza en que ambos eleme iles son los símbolos que estso.

lmente, el contenido contextrño y hacer diseño, es antes de todo cue rna el papel de un tra o que toma la forma $\mathrm{d}^{\text {g }}$ gradual, donde la idea $\mathrm{do}_{\text {, las ideas, los relacioname }}$ danza en que ambos ropio proceso y también de r

'esign para un mundo liseñar, me planteé la cuesti' s bienes producidos por seño, es antes de tod prima eso me dá? Ejemp' es subjetivos también inf ble. Diseñar puede se ese texto, construyo el d

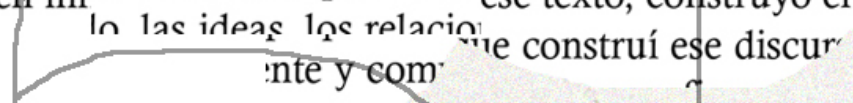

1 un significado fijo, sino que expresajue ${ }^{\dagger}$ mbio entre lo que está incrustado en Sre ¿de inferir de él. Por un lado, las form ". (Rafael Cardoso, trad. 2014)

rradual, donde la i’ 
- ormas y de rapo.

eso de un labor íntimo, un udo puede empezar por una inves 'dos: de que se trata el libro, el cu jió, que es, quien creó y por qué, ble o aún, por qué llama así, donı del pensamiento y intento a lle: Cual es el ambiente que cerca e ico. cuáles son los símholos aı

de una filosofía del diseño, si r e construcción de formas y de exponer el proceso de un labor í o sensible. Todo puede empezar los significados: de que se trata h, donde surgió, que es, quien creó y po mundo sensible o aún, por qué llama as cojo el hilo del pensamiento y intentc está ubicado. Cual es el ambiente que $\mathrm{g}$ anorama político, cuáles son los símb el concepto. Gradualmente, el conten y el diseñador encarna el papel de ur como un carpintero que toma la forr
LAU1 L11 glilla1. 111 n un sigizar la forma para e] ede inferifeptual por las orígt “. (Rafabla, el objeto, la exp istoria, porque exist y gradua adas sus raíces. De: en conceptual y do sible. $D$ : $r$ diseñado, como do, las icevolando la inman propio pri diseñar, a forma al prima e lengua olvi ese textos nrncesr a un trnzo ue construí ese discurso, he hecho de ara un reconfiguración de significado en para ilustrar... (en construccion) antiguas formas, es lanzar al mundo 1. La responsabilidad aquí se hace tamos elaborando, significados para

am mundo complexo. São Paulo,

1 agosto). Significado. Recuperado 1 br/significado/

\section{ИつCつCN7E}

PANORAMA: FILOSOFÍA DEL DISEÑO ARTÍCULOS 
- ormas y de rapon

aso de un labor íntimo, un udo puede empezar por una inves 'dos: de que se trata el libro, el cu rió, que es, quien creó y por qué, ble o aún, por qué llama así, donı del pensamiento $\mathrm{y}$ intento a lle Cual es el ambiente que cerca e ticn. cuáles son los símbolos a

de una filosofía del diseño, si r e construcción de formas y d $\epsilon$ exponer el proceso de un labor í o sensible. Todo puede empezar. los significados: de que se trata 1, donde surgió, que es, quien creó y po mundo sensible o aún, por qué llama as cojo el hilo del pensamiento y intento está ubicado. Cual es el ambiente que $q$ anorama político, cuáles son los símb lel concepto. Gradualmente, el conten y el diseñador encarna el papel de u somo un carpintero que toma la forr

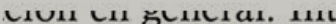
un signizar la forma para e] ambio eni ede inferieptual por las oríge n ". (Rafaəla, el objeto, la exp y gradua istoria, porque exist n danza adas sus raíces. De: en conceptual y do] sible. Dis $r$ diseñado, como do, las icevolando la inmanı ropio pri diseñar, $r$ ¥ forma al prima e lengua olvi

ese textos nrncesr a un trnzo ue construí ese discurso, he hecho de ara un reconfiguración de significado en para ilustrar... (en construccion) antiguas formas, es lanzar al mundo 1. La responsabilidad aquí se hace stamos elaborando, significados para

um mundo complexo. São Paulo,

1 agosto). Significado. Recuperado 1 $\mathrm{br} /$ significado/ 


\title{
Understanding Design Aesthetics beyond Functional Beauty Accounts
}

\section{Comprender la estética del diseño más allá de los enfoques de belleza funcional}

\author{
Lucía Jiménez Sánchez
}

\begin{abstract}
Design is presented as an apt object of aesthetic appreciation. The nature of its aesthetic dimension will be developed in terms of the relationship between form and function. Specially, by looking at the role that knowledge about function plays in our design aesthetic judgements. Then, I will present the dominant view about the aesthetic value of design coming from functional beauty accounts. Finally, in the last section, I will focus upon some problems derived from the aforementioned integral model form-function in design aesthetics. By means of practical cases, I will point to the narrowness of functional beauty accounts and its inability to include a broader range of actual design objects and their relevant design aesthetic properties.
\end{abstract}

Keywords: design aesthetic value, form-function relationship, proper function, functional or dependent beauty, design beauty.

\begin{abstract}
Resumen
El diseño se presenta como un objeto competente para la apreciación estética. La naturaleza de su dimensión estética será desarrollada en términos de la relación entre la forma y la función, prestando especial atención al rol que el conocimiento sobre la función juega en nuestros juicios estéticos de diseño. De modo que expondré la visión dominante sobre el valor estético del diseño proveniente de los enfoques de belleza funcional. En última instancia, me centraré en algunos problemas derivados del citado modelo integral forma-función en la estética del diseño. Mediante el uso de casos prácticos, apuntaré hacia la limitación de los enfoques de belleza funcional en vista a su incapacidad para acoger un rango mayor de objetos de diseño actuales y de sus propiedades estéticas más relevantes.
\end{abstract}

Palabras clave: valor estético del diseño, relación forma-función, función apropiada, belleza funcional o dependiente, belleza de diseño.

\section{Introduction}

As an object of philosophical study, design presents a seemingly puzzling nature. We are all surrounded by design objects: chairs, coffee-pots, Zara heels, cars, Wikipedia, satellites. However, despite its mundane condition, we rarely speak about them as being valuable aesthetic objects. As noticeable beautiful treasures. This extraordinary omission is paradoxical regarding design ordinariness. Fortunately, some philosophers

* Universidad de Murcia, España.jimenezsanchez.lucia@gmail.com Artículo recibido: 1 de junio de 2019; aceptado: 15 de octubre de 2019 
have recently echoed this fact by pushing the boundaries of philosophical aesthetics and claiming for design's importance (Folkman (2013), Forsey (2013), Parsons (2016)). But, why has design gone so theoretically unnoticed when it was supposedly before our eyes? As Jane Forsey points out, although this omnipresence of design does not justify a lack of aesthetic interest, it seems that this same mundane condition explains why design has been so neglected by traditional aesthetics. Thus, there is no reason to disregard that we do actually have valuable aesthetic experiences with design objects. In fact, there are several current aesthetic accounts that are primarily focused on what is peculiar about the aesthetic appreciation of broadly non-artistic objects -design objects included. Hence, following these approaches, I will defend the view that design objects are proper objects of aesthetic appreciation. That means design has a particular kind of aesthetic value as design.

\section{The Object of Design}

Design objects are intentional artefacts, products of human intentions that have been designed with the aim of fulfilling some purpose or function. ${ }^{1}$ They are mainly quotidian objects that give shape to our material cultures and whose production is generally linked to the satisfaction of a particular (set of) function(s). A good example could be Little Sun Diamond, a solar lamp created by the artist Olafur Eliasson and the engineer Frederik Ottesen. It is the third member of the Little Sun Family: a basic solar lamp especially designed to foster sustainable and clean access to electric light in those parts of the world in which this is still a privilege. This design responds to Olafur's commitment with the idea of making something that is "so shared" -as the sunlight is - a thing that everybody can benefit from.

So, they came up with a portable solar lamp able to be placed in almost any surface. Its easiness and simplicity of use derives from its double-sided division. From one side, there is a solar panel that can be effortlessly oriented to the source of the sun. On the other, there is a bulb integrated within the design of a sunflower or a diamond (it depends on the model). Thus, the idea about how valuable is the sunlight cleverly instantiated in the appearance of the lamp as a diamond. As remarked by Riis Ebessen regarding Olafur's statement: "Little Sun is a work of art that works in life". It puts the power of sun in the palm of your hand. ${ }^{2}$ This really makes Little Sun Family stand apart from other conventional or functional solar lamps. ${ }^{3}$

Design objects are, thus, quotidian and functional objects that can provide us with familiar aesthetic experiences in our daily lives. Objects belonging to the categories of product design, interior design, graphic design, fashion design, web design, will be the objects we will be focusing upon. I mean, designs that designers bring into a material form. ${ }^{4}$ Nevertheless, design objects do not have to be quotidian to be design.

1 For a strong essentialist approach to function see Parsons, G. 2016. The Philosophy of Design. Cambridge: Polity Press.

2 About communicative complexities both in the material properties of its design and its discursive mediations, see Riis Ebbesen, T. 2017. "Little Sun: An Indicative Framework for the Analysis of Art and Design Objects". Design Issues, vol. 33, num. 1: 48-60.

3 What I further underline with this example is that objects with practical functions are good candidates for aesthetic appreciation when they are not unfairly conceived as mere everyday objects that "say nothing".

4 Although there are other design practices mostly from Design Thinking that focus on developing inmaterial designs -such as interactive design, service design or system design- here, I will engage with what I consider to be the 
There are lots of design objects that are not part of our daily lives, but that are still designed, such as particles accelerators or conceptual design cases. The key point for our approach is that the object of design needs to have a functional dimension as well as a material form. This is important because what is under dispute is how this material form and function interrelate in order to constitute the aesthetic dimension of design. Then, in what way a design object can be said to be beautiful? What is to aesthetically appreciate a design object?

\section{The Aesthetic Dimension of Design: A Form-Function Relationship}

We can distinguish at least two main approaches about the aesthetic value of design: Aestheticism and Functional Beauty Accounts. The first one is a traditional formalist account that can be called Aestheticism in design. This view focuses on the appreciation of the design object's form as treated in isolation from its function. The central claim of this approach is that form is understood as independent from function because it is considered as a matter of luck or of the designer's random choice. ${ }^{5}$ Following this view, the aesthetic value of design objects is bound to the formal properties of the object considered independently from any functional consideration. Therefore, this view promotes the idea that the aesthetic appreciation of design is only concerned with the external properties of objects understood as ornament or decoration. Further, another idea that can be derived from this aestheticist approach is that it turns the practice of design into a matter of appearances and, consequently, it makes design an added value of the object; that is, something that can be seen as superfluous or inessential for the object's true identity.

The Aestheticist approach also supports its scepticism concerning the pertinence of the relationship between form and function for design appreciation in the alleged indeterminacy of function. Thus, their neglect of function as relevant to design aesthetic judgements is based upon the controversy of the notion of function in itself: it seems problematic to clarify what exactly is that that the function of an object refers to. As some philosophers like Roger Scruton (1980) have suggested, function remains an "obscure notion" for objects that present us with practical aims. Similarly, according to David Pye (1978), function is a kind of "fantasy" -inasmuch as design objects cannot be ultimately determined by their successfulness about their deliberate o idealistic functions. These objections to the notion of function of the design object are often endorsed by those who defend design aestheticism.

Nevertheless, the problem of ignoring function is that design as a distinctive object of appreciation seems to "fade away" and not to be properly understood qua design. In fact, as Forsey notices, if form is understood as independent from other values -like function- there is no specific aesthetic value we can claim for design: not any special design beauty. This can be translated into the fact that we can find the same aesthetic value on a flower, a sonnet or a coffee-pot (as Stecker's maintains). Then, a problem for Aestheticism is that, if the aesthetic value of design objects is separable from its purpose, there is no way to characterize the aesthetic appreciation of design as

basic design case. That is, the one resulted from the practice of design as oriented to the production of an object to be appreciated as design.

5 See Pye, D. 1978. The Nature and Aesthetics of Design. New York: Van Nostrand Reinhold. 
involving a particular kind of beauty. ${ }^{6}$ Following this critical remark about Aestheticism, I will argue that design objects have a distinct kind of aesthetic value that is somewhat related to function, but that is not exclusively limited or determined by it.

Still, when we speak about function in the context of design objects' appreciation, which function are we talking about? Normally, we are referring to the proper or purposive function of the object. That is, the function that the object $\mathrm{O}$ must meet in order to belong to a particular kind, C. $^{7}$ For example, the proper function of a lamp is to shed light. That does not mean that we cannot ascribe other functions to the lamp -as when we use it as a coat hanger-but, in that case, these functions are called accidental functions. Thus, the main question is in which sense is our consideration of the design object's (practical) function relevant for its aesthetic dimension?

Looking now to the second predominant approach, the Functionalist Account, it seems unquestionable that function plays a much more relevant role in the aesthetic appreciation of design objects. For the Functionalist, the considerations about the function of a design object can shed some light to our aesthetic appreciation of design objects. According to this view, design beauty especially arises from a binomial relationship between form and function as a distinct kind of Functional Beauty. Functional Beauty approaches try to account for the knowledge that the purported function satisfied by design objects plays in our aesthetic appreciation of them. They notice that: "even if everyday objects in themselves are not, as are works of art, highly charged with meaning, a cognitively rich theory of our everyday aesthetic encounters can help to explain how it is that such experiences are nonetheless highly meaningful". 8 For that reason, they argue that knowledge about an object's function can enrich our aesthetic judgements and make us able to grasp aesthetic properties that design objects possess as design. One further purpose of this view is to offer a substantive judgement of the aesthetic achievement. That is, an aesthetic judgement based upon our knowledge concerning the functional success of the object. Aesthetically appreciating the object under the thought of the function it is meant to perform enriches in some way the aesthetic judgement and makes it less uncertain. Moreover, this seems to be coherent with design theoretical needs. Thus, in order to correctly appreciate a design object, we need to consider the relationship between its form and its intended function. Aesthetic value (design beauty) will emerge once we grasp a particular fitting relationship between these two elements that constitute the aesthetic appreciation of design.

Following this approach, and after having explained how our design aesthetic judgements can be partly determined by the particular relationship between form and function, we can conclude that function can be relevant to our design aesthetic judgement insofar as it makes us recognize some significant aesthetic properties of design objects. This means to acknowledge that intended function is part of the content handled by design aesthetic judgements. In what follows, we will focus upon the especial aesthetic attention that functional accounts grant to (practical) function and upon their account of beauty in design.

6 See Forsey, J. 2013. The Aesthetics of Design. Oxford: Oxford University Press.

7 "The most basic idea behind the notion of a proper function is the idea that it is the function that belongs to the object itself". Cited in Carlson, A. and Parsons, G. 2008. Functional Beauty. New York: Oxford University Press. pp. 66 . 


\section{The Functional Approach: Functional Beauty Accounts}

As I said before, Functional Beauty accounts hold that appreciating certain aesthetic properties requires appreciating the design object as designed for a particular function. Parsons \& Carlson (2008) and Stephen Davies (2010) agree that it is "a kind of beauty that objects exhibit by virtue of the kind of function they have and whose appreciation requires knowledge about its function". ${ }^{9}$ For P\&C, our aesthetic judgements must be based on a perceptual experience of the object's appearance as seeing under the corresponding 'functional category' we apply to the object. In these sense, they adapt Kendall Walton's 'art categories' view (1964) for functional objects. Thus, following this view, we can perceive the relationship between a particular form and the function for which the object has been designed. For example, we can perceive that the form of a lamp is appropriate for the kind of thing it is if it seems to be able to give light. That means that form is eloquent with respect to the function that it serves. And the lamp, let's say, seems to be apt or "looks fit" for its purpose.

But, then we can pose the following question: how can function shape our aesthetic appreciation of form? Following some authors (Externalist), function can do this in an indirect manner, following others (Internalist), function shape our perception of form in a direct manner. Among the former, we can locate Externalists, such as Paul Guyer (2002), who defend that function can only "negatively" shape the form in which an object can be considered beautiful. That means that, function is peripheral and is not intimately connected to what makes an object beautiful. So, knowing the object's proper function can only enable us to discard those forms that are inappropriate for a given purpose; however, this knowledge cannot by itself determine whether an object of design is to be judged as beautiful. On the other hand, Internalists maintain that function is integral to the object's correct appreciation. Actually, they claim that form and function are the same thing. That means that knowledge about the function of an object affects our aesthetic perception and judgement of it. For Internalists, function plays an active role: it changes the properties we can perceive in the object-its appearance- making us see it beautiful. This is the integral relationship defended for design aesthetic judgements.

Following this approach, functional beauty judgements are based on the perception of the connection between non-aesthetic properties and the function of an object. That is, a theory of the kind "X functions beautifully". We can say that certain features of an object are attractive given a particular function. Then, the object displays its functionality by means of those indicative features. And, consequently, beauty arises from our consideration of the function in itself related to form. ${ }^{10}$ The key point for functional beauty judgements is the way in which function is to be understood. As Parsons \& Carlson explain: "an understanding of function can affect perceptual appearance, but

9 In De Clercq, R. 2013. "Reflections on a Sofa Bed: Functional Beauty and Looking Fit". Journal of Aesthetic Education, vol. 47, num. 2: 35-48. However, what P\&C stress is the need for knowledge about the object's functional fulfillment. That is a stronger condition for design beauty since that knowledge about the design object is much more specific: we must recognize how it is for the object to successfully work as the kind of thing it is.

10 "Recall again the truism that aesthetic pleasure is pleasure taken in the perceptual experience of an object per se. If we do not know what we are saying when we say ' $\mathrm{X}$ is functionally beautiful', perhaps what we are actually describing is pleasure taken, not in X's perceptual appearance per se, but in some gratification of our needs and desires that X's appearance indicates for us". In Carlson, A. and Parsons, G. 2008. Functional Beauty. New York: Oxford University Press. 
only when it includes understanding of how function is carried out, rather than merely what it is". ${ }^{11}$ That means that it is just not enough to identify the function of a particular object, but rather to recognize the role the object is supposed to perform (a knowledge that we can gain, for instance, with the practical use of the object). So, functional knowledge can directly contribute to a positive aesthetic judgement in that way. ${ }^{12}$ After all, what functionalism holds is a relationship between practical and aesthetic value out of which beauty arises naturally.

\section{A Kind of Dependent Beauty for Design}

Taking into consideration this integral binomial model, Jane Forsey has defended a special kind of functional beauty for design: what she calls Dependent Beauty. On Forsey's view, instead of stressing the fact that the object successfully fulfils its function, it is more relevant for design appreciation to stress the way in which the form actually performs it. That means that dependent beauty arises partly from the contingency of the object's form in relation to its function. Accordingly, our aesthetic judgement will be about this indeterminacy of form with regard to an object's functional kind. In other words, it will be about judging a particular formal solution among all the possible ways in which this form can be solved for a proper function. How is this so? According to Forsey, the aesthetic judgement of design objects is to be reflexive upon the object's "teleological style"; that is, it must result from the reflection upon the way in which the object fulfils its purposive function. As a distinct kind of functional beauty, dependent beauty emphasizes the idea that what makes an object of design beautiful is the economy or frugality of the solution regarding form, rather than its functional role. Consequently, when we perceive the proper beauty of design, form should be as simple as possible. And, that, furthermore, is the reason why the object looks fit. For instance, think about "the sexiest chair of the world", the Panton Chair by Verner Panton (figure 1).

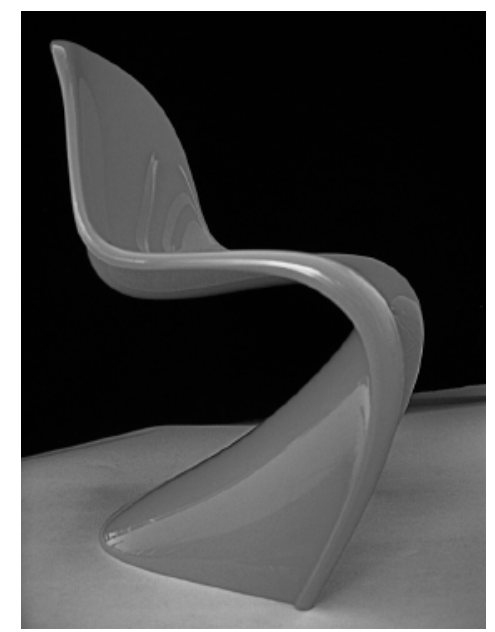

Panton Chair, Verner Panton (1960)

11 Ibid., p.94.

12 Nevertheless, to know how an object functions is not the same as to "attest" that it functions. Knowledge about function helps us to perceive features related to functionality. But we do not have to test the object's functionality in a practical sense. This is another question about what makes a design a good one, but not necessarily an aesthetic question. 
However, Parsons (2016) has criticized this view by arguing that it will be a narrow way of understanding design aesthetics. He claims that, following Forsey's approach, we would only positively appreciate cases of design in which properties of the object are standard for the kind of thing the design object is (that is, those properties that would be standard for the functional category in which the object under appreciation is included). In this sense, we would just consider the features of the object that seem to fit for a particular function; that is, the ones that apparently would be more appropriate for its functional kind. However, this only leaves room for the aesthetic properties related to the object's 'looking fit' aspect, since what we perceive is the object's formal 'correctness'. But what about those features that seem to be unfit or variable for a proper function? As Parsons explains, there are cases in which properties are perceived as contra-standard or variable for a certain functional category. That means that features of the object seem to look unfit or inapt for the functional kind to which the object supposedly belongs. In those cases of (formal) unfitness we can perceive a different aesthetic property called "looking unfit". ${ }^{13}$

The point then turns to what is to be an "appropriate" formal solution for a design object. On Forsey's less restrictive view, since form is contingent regarding an object's proper function, there is no constraint upon which properties can be considered as the focus of aesthetic attention. In fact, after her view, all features might look fit for a function as long as the object works. As described before, beautiful design objects will be those that stand out as simple or sophisticated formal solutions. Following a different line, Parsons focused upon cases where, despite the object being apparently "inappropriate" for its function, the object's form is actually functionally appropriate. Thus, judgments about an object's functionality can be more trustful when we are to judge design from an aesthetic point of view. This knowledge determines a higher range of qualities that can count as standard, contra-standard and variable to a given functional category and can help us locate the object's form in the right functional framework. However the differences between Parsons and Forsey, both share the idea that an object's function determines the aesthetic properties the object possesses qua design and, furthermore, that whatever form that seems to properly satisfy a purposive function, will result in the object's possession of the aesthetic property of looking fit/ unfit. That means, eventually, that this property is necessary for design beauty. ${ }^{14}$

To sum up, why does this binomial model (form-function) fits well with design? Because, insofar as it takes into account design's essential practical function, it can appropriately ground the aesthetic judgement of design objects qua design and, furthermore, it can explain the normative character of the aesthetics judgements of design objects by attending to the kind of thing design is. At least, the approach does not contemplate the aesthetic appreciation of design as a matter of (formal) beauty alone. Instead, it is a question about how form conveys something else, such as a function (design) or a meaning (in the case of art) and how it does this by fitting within

13 P\&C mention the Schreckgost's chair as a case of unfitness, though is not a different perception from the first time the Panton Chair was made public.

14 As Rafael De Clercq remarks, "looking fit" entails a strong condition (for design) since an object has to appear to have certain features which are indicate of functionality. But this is problematic once he shows that perceptual properties are not reliable 'indicatives' of functionality. Against the necessity of looking fit for Functional Beauty see De Clercq, R. 2013. "Reflections on a Sofa Bed: Functional Beauty and Looking Fit". Journal of Aesthetic Education, vol. 47, num. 2: 35-48. 
a particular kind of artefact. Ultimately, working well means it has to be that way. ${ }^{15}$

\section{Main Problems for Any Functional Beauty Account}

As far as it goes, Functional Beauty accounts seem to catch what is specific for design beauty judgements. However, we believe this model presents some problems when compared to our actual design appreciative practice:

\section{i) Practical function is not essential to design beauty}

The first main problem can be stated as follows: How shall we deal with cases that are apparently beautiful -attractive, appealing, etc.- as design but that are clearly nonfunctional or that fail to accomplish its proper function as presumably practical? Can in that case a design object be functionally beautiful? Let's look at Katerina Kamprani's Uncomfortable Chair 3. One from The Uncomfortable Collection (2012) that is composed by deliberately inconvenient everyday objects such as glasses, forks, umbrellas, doors or pots. This uncomfortable chair made in rough textured plastic has been designed with a concaved form seat so that it seems to be impossible to sit down without falling into the ground. In that sense, what this chair tries to attempt to is against the 'proper' function of a chair conventionally conceived as a (comfortable) place to sit down. Hence, there is no practical function for this chair. What would the functionalist say about this design object? Following the form/function binomial model, this object, considered as a chair, couldn't be, properly speaking, judged as beautiful. At most they may say that this chair might be a beautiful case considered as a different kind of thing -an artwork for instance- but not qua design. The reason behind this claim is that it is not a functional object in a practical sense. On one hand, some of its most relevant chair's features are contra-standard and variable for a chair's functional kind so accordingly the chair does not appear to be functional. On the other, there is no way we can sit down in it without risking our back. So, on both Parsons's and Forsey's criteria, this case would have to be judged as aesthetically unpleasant.

However, there is no problem on claiming that this chair might be a beautiful design object -and maybe its beauty is not unconnected to its 'inaptness'- while, at the same time, recognizing the role that knowledge about function plays in our design aesthetic judgements -that it integrally affects our perception of the object. This knowledge concerning the functionality of the object is related to our perception the form of the chair to the extent that the chair does not only apparently seem to be inapt for its conventional or practical function but also, we know that it cannot work for that task. Since it does not practically function as a chair, it cannot be a case of the object's merely looking unfit. It is a non-functional design object that nonetheless can be beautiful as design by being quite "dysfunctional". Although this claim disputes with the idea that design objects are only the ones that have practical functions. Beautifully said, the point is that functional accounts are not consistent with design cases in which aesthetic judgments are not entirely supported by the object's practical or functional success.

Yet, we can go further with another chair case. One in which we can sit down but which is not to sit down either. Consider This is a Lamp by Tobias Wong. In this case, Wong transforms the iconic Bubble Club chair -originally designed by Phillippe Starck-

15 Let's keep in mind that this integral model is not exclusive of functional beauty accounts. A similar form-content model also can work for art as Peter Lamarque suggests for poetry (2018). 
into a lamp. What he aims is to question the notion of authorship by denying the proper function of the original design. Actually, his work can be understood as being guided by an intention closer to the kind of intention issuing in conceptual art. Here the point is that we have no problem in perceiving the aesthetic property of looking fit for the object. Insofar as it is an instance of the Bubble Club model it is both functional as a chair and as a lamp -it serves the function of sitting down and it shines. However, as the kind of thing it is -a Wong's lamp-its proper function is a different -and more complex- one: that is, challenging authorship in design by turning a recognizable chair into a lamp. Then, the problem arises from the fact that if This is a Lamp somehow questions the notion of function in design and, what is more, it does so without being a dysfunctional object. One can sit down on it. Moreover, it gives light too (though function is not technically, but theoretically, denied). So, This is Lamp functions at the same time - and is appreciable-as a chair, as lamp and as an idea. In fact, it is difficult to come with a single functional beauty judgement resulting from the consideration of the object's form and its intended function. Following the Functional Beauty Account, this judgement is to be based on some correspondence between certain perceptual features and a particular function, how shall we judge whether this object is it "functionally appropriate" as design in this case? There are some interferences in the judgement of perceptual correspondence. In this sense, complex cases in which the object's functions (not all practical functions) are so intermingled cannot be well accommodated within the model of functional beauty judgements.

Nevertheless, to deny that judgments about the successful functionality of an object are necessary for a design object to be properly appreciated as beautiful does not involve giving up on the idea that essential or original functions are relevant to design beauty. Despite Forsey's and Parsons's commitment with the idea that practical function provides the key aspect that distinguishes design objects from other kinds of artifacts -like artworks or craft objects-, the aforementioned cases problematize the way in which they conceive the impact of judgements about functionality upon aesthetic judgements of design objects. Albeit function must be certainly taken into account when aesthetically appreciating design objects, it does not determine by itself alone whether a particular design object deserves aesthetic praise or dismissal.

As we have seen, deciding which is the proper function of an object leads to the problem of indeterminacy for functional beauty accounts. Briefly, this problem challenges the idea that an object's proper function can be fully determined. Thus, there are some counter-examples coming from the consideration of some multifunctional artefacts mostly from architecture- that introduce a serious problem to the Functional Accounts. This problem revolves on the idea that design objects are identified by a single functional purpose. ${ }^{16}$ This is an open critical line from where this integral relationship between form and function can also be discussed. For instance, it introduces that not only proper function is responsible of design beauty but accidental functions too.

Taking into consideration what the aforementioned cases show, I want to underlie that even when the Functional Beauty Accounts cannot welcome our first case because

16 For a cogent approach to interlaced functions in multifunctional artifacts where 'shortal' concepts relative to essential or original functions are defended as determinant to aesthetic appreciation see De Clercq, R. 2013. "Reflections on a Sofa Bed: Functional Beauty and Looking Fit". Journal of Aesthetic Education, vol. 47, num. 2: $35-48$. 
it is not functional as design, we could argue for a positive aesthetic appreciation of this object as design. The same concern is identified in the second case. In that case, in spite of being a functional design object, it seems that what is primarily appreciable is the idea with which the designer has produced the object. Actually, our judgement about its beauty is to be attached to the reflection it triggers, rather than on its successfully giving light or on being so comfortable. On my view, in those cases the binomial model form-function is problematic for our design aesthetic judgements. In fact, if we stick to the Functional Beauty Account, the range of design objects that could be welcome as aesthetically good design would be very narrow, partly because the scope of relevant features is limited to functional ones. But, as the examples analysed above show, we need a broader understanding of design aesthetic appreciation if we are to explain our positive aesthetic evaluation of design objects whose aesthetic value cannot be merely cashed out in terms of form/function

\section{ii) Expressive properties are relevant to design aesthetic judgements}

On the other hand, there is another idea that shapes the functional view that I find especially problematic. This view takes as obvious the fact that people mainly find pleasurable objects that look "highly fitting" for its function. And, furthermore, they consider this pleasure is an aesthetic pleasure. However, two things could be said in relation to this claim. First, it seems we need an argument that shows that a judgement based on the perceived functional fittingness is an aesthetic judgement. And, second, we need an argument to show that only judgments concerning the functionality of an object are to be relevant for the aesthetic appreciation of design objects.

As we have seen, both $P \& C$ and Forsey tend to collapse judgments of functionality with judgments of beauty. Nevertheless, as we have tried to show, taking into consideration that the object's functional success does not fully govern our design aesthetic judgments, there is room to argue for a broader notion of design beauty. Second, there is no reason why this pleasure has to be understood exclusively in terms of fittingness. There are other kind of properties -which are not strictly speaking based on functional considerations, such as expressive properties- that may be part of the aesthetic appreciation of design objects. The Functional Beauty Account is wrong in thinking that aesthetic judgements which are partly based on functional considerations are to be exclusively based on those kinds of considerations. ${ }^{17}$ Let us call this the problem of exclusivity of functional beauty accounts.

This problem arises from the idea that only functional considerations are legitimate to our design aesthetic judgments and, consequently, that any other consideration beyond the satisfaction of a function by a particular form only blurs what is really important to our aesthetic appreciation of design objects. So, this narrow appreciative focus excludes all expressive design properties that do not seem to directly bear in favor of the functional success of the object. But if we think, for example, on the variety of ornaments that can be appreciated in everyday objects (in forks, chairs, cars, buildings...) and that cannot be properly perceived in relation to the satisfaction of a

17 At the end, this exclusive character of functional accounts is based upon the guarantee that some apparent features of the object are indicative of functionality (that there is a kind of translation between functional features into formal features). This way relevant aesthetic properties will always reveal the object's functional condition. Although this idea has been recently challenged in De Clercq, R. 2013. "Reflections on a Sofa Bed: Functional Beauty and Looking Fit". Journal of Aesthetic Education, vol. 47, num. 2: 35-48. 
particular 'functional' form, we soon realize that the Functional Account falls sort of giving these aspects their due role in our aesthetic appreciation. Why should not they be considered as part of the aesthetic pleasure provided by the object? How can an object work poorly for that matter? In this regard, it seems unfair to disregard properties that do not appear to contribute to the functional fulfilment of an object and to deprive them of their role in our aesthetic appreciation of design beauty. ${ }^{18}$

This idea can be nicely supported by Hella Jongerious designs. Among her huge collection of design objects, we find Nymphenburg Sketches (2004), a series of unexpected Animal Bowls. They are common bowls that contains sculpted animals from the Nymphenburg's Animal Archive and which are narratively decorated with original patterns from the company's cups and saucers. The peculiarity of this design is that the sculpted animals have a huge size and they almost occupy the entirely useful surface of the bowl. That is seemingly a difficult design object to be integrated in our everyday crockery. But, nevertheless, these bowls' expressive properties seem to make them specially aesthetically appreciable. As Jongerious declares about her designs, here what we have is an usable object that seem to tell their own story. She adds further that this is possible because useful objects are highly saturated with references so it is possible to communicate new stories about them -and through them- by making explicit reference to their specific moments of production in history and their contexts of use. In this sense, functionality isn't really that important because you could think of a different function for a bowl or a cup. ${ }^{19}$ So, following these suggestions, we would endorse a view of design aesthetic appreciation where there is room for expressive design attempts beyond design functional interests.

Therefore, under our proposal, if we appreciate the object of design qua design, those expressive properties can be considered aesthetic properties while still playing their expressive role. That is, they do not necessarily feature in our aesthetic appreciation of design in a detrimental way. ${ }^{20}$ The fact that they are not explained in functional terms does not mean they are not central aspects of the appreciation of design qua design. After all, it seems that the pleasure of beauty in design does not always come with the fact of perceiving the aesthetic property of "looking fit". ${ }^{21}$ That means that our aesthetic judgement still maintains a certain autonomy with regard to function (that the link is not so intimate in all cases).

At the same time, this question connects with a peculiar trait that I think to be crucial for modernist design approaches. As a rule, functionalist approaches maximize simplicity and minimalism as the most relevant design aesthetic features. ${ }^{22}$ And they

18 As Stephen Davies claims: "the aesthetic interest of a given kind of item depends mainly on its variable properties, especially as regards its representational content and expressive character". In Davies, S. 2010. "Functional Beauty Examined". Canadian Journal of Philosophy, vol. 40, num. 2: 315-332.

19 (Italics are mine). In Coles, A. 2007. "Louise Schouwenberg: A conversation with Hella Jongerious that might have taken place (2003)" in DesignArt, London: Whitechapel Gallery and The MIT Press, pp. 89.

20 Towards the idea of design as an art practice that can be 'expressive' see Shiner, L. 2015. "Art Scents: Perfume, Design and Olfactory Art”. British Journal of Aesthetics, vol. 55, num. 3: 375-392.

21 However, this does not mean that fitness is one thing and somehow beauty an additional virtue of the useful object.

22 As if "designers are bound to realize that is their task to explain the nature of the object by its appearance, that is, to create a pattern of visual forces correspondent to the physical pattern which is characteristic for the functioning of the object". In Arnheim, R. 1964. "From Function to Expression". Journal of Aesthetics and Art Criticism, vol. 23, num. 1: 29-41. 
succeed in so doing by downplaying the importance of other traditional aesthetic design values, such as artistic elements and the traces of the designer's self-expression (think for example in the Arts\&Crafts movement). Thus, to adopt simplicity as the major value of design practice disables design to convey certain valuable content as, for example, the one related to expression. In fact, if we consider again Little Sun Diamond, we realize that its form and its proper appreciation requires more than mere functional consideration. Why to complicate its form by making it metaphorical if not for saying something more than "the whole point is to give light"? ${ }^{23}$ What should we say about these expressive properties and their role in the aesthetic appreciation of design objects? The main idea is that to take function as the only reason for design beauty ignores the possibility of accounting for certain expressive properties that surely lie beyond considerations about an object's proper function. As a consequence, all functional approaches relegate design to a mute condition. That is so because -as functional objects- design objects do not need to express more than their 'practical' function (or anything that does not contribute to it), which in turn eventually means that they cannot be beautiful qua design for other reasons than functional ones.

My point is that we can go further than the Functional Beauty account allows once we see the limitations of this model and the objection against the exclusivity of its cognitive commitment with respect to functional beauty. As I have tried to show, the model is too narrow because for it, eventually, the correctness of functional beauty judgements rests upon the object's functionality as a necessary and sufficient condition. However, as I have tried to show with the aforementioned cases, there is also a relevant content to our aesthetic judgement beyond the practical function of the object of design: a content which can be characterized in terms of its expressive, historical and social properties.

\section{Conclusions}

To summarize, the functional view focuses upon the understanding of how function can affect our perception of an object's form and, thus, can determine its aesthetic value. For the aesthetic theory of design, the idea that form's appreciation can be determined by functional considerations is welcome. However, I find problematic and disputable that the aesthetic judgement of design becomes exhausted in the appreciation of form as fit or unfit.

For that matter, the proper aesthetic framework we need for design appreciation goes beyond its functional dimension. Hence, I argue that design beauty is not only grounded upon perceptual properties of the object, that is, on a kind of formalism supported by function, but also upon a broader scope of appreciative properties for design -such as expressive properties. That means that the aesthetic dimension of design is so rich that it overflows the functional view.

\section{References}

Arnheim, R. 1964. "From Function to Expression". Journal of Aesthetics and Art Criticism, vol. 23, num. 1: 29-41.

Carlson, A. and Parsons, G. 2008. Functional Beauty. New York: Oxford University Press.

23 That is what I understood from Olafur's declarations as: light is power and the power (of changing the world) is in your hand. So, the form of a "rough diamond" metaphorically embodies this idea. 
Coles, A. 2007. DesignArt. London: Whitechapel Gallery and The MIT Press.

Davies, S. 2010. "Functional Beauty Examined". Canadian Journal of Philosophy, vol. 40, num. 2: 315-332.

De Clercq, R. 2013. "Reflections on a Sofa Bed: Functional Beauty and Looking Fit". Journal of Aesthetic Education, vol. 47, num. 2: 35-48.

Folkmann, M.N. 2013. The Aesthetics of Imagination in Design. Cambridge: The MIT Press.

Forsey, J. 2013. The Aesthetics of Design. Oxford: Oxford University Press.

Parsons, G. 2016. The Philosophy of Design. Cambridge: Polity Press.

Pye, D. 1978. The Nature and Aesthetics of Design. New York: Van Nostrand Reinhold.

Riis Ebbesen, T. 2017. "Little Sun: An Indicative Framework for the Analysis of Art and Design Objects". Design Issues, vol. 33, num. 1: 48-60.

Sauchelli, A. 2013. "Functional Beauty, Perception, and Aesthetic Judgements". British Journal of Aesthetics, vol. 53, num. 1: 41-53.

Scruton, R. 1980. The Aesthetics of Architecture. Princeton, NJ: Princeton University Press.

Shiner, L. 2015. "Art Scents: Perfume, Design and Olfactory Art". British Journal of Aesthetics, vol. 55, num. 3: 375-392.

Stecker, R. 2019. Intersections of Value: Art, Nature, and the Everyday. Oxford: Oxford University Press. 


\title{
Estética y diseño industrial: debates y controversias Aesthetics and Industrial Design: debates and controversies
}

\author{
Joan M. Marín*
}

\begin{abstract}
Resumen
En el presente texto se argumenta la importancia de la dimensión estética en el ámbito del diseño industrial, al tiempo que se abordan desde la perspectiva de la reflexión estética algunos de los principales debates que han tenido lugar en la cultura del diseño. Estos debates se han articulado en torno a la idiosincrasia propia del diseñador y su actividad; la relación entre arte y diseño; la controversia en torno a la forma y la función; la importancia de las dimensiones simbólica y emotiva del producto; y la encrucijada del diseño entre los proyectos de emancipación social o a la difusión de una estética banal.
\end{abstract}

Palabras clave: Diseño industrial, estética, arte, forma, función, simbolismo y marca.

\begin{abstract}
This text argues the importance of the aesthetic dimension in the field of industrial design, while addressing some of the main debates that have taken place in design culture, from the viewpoint of aesthetic reflection. These debates have been articulated around the idiosyncrasy of the designer and his or her activity; the relationship between art and design; the controversy surrounding form and function; the relevance of the symbolic and emotional dimensions of the product; and the crossroads of design between social emancipation projects or the dissemination of banal aesthetics.
\end{abstract}

Keywords: Industrial design, aesthetics, art, form, function, symbolism and brand.

El diseño industrial -y con mayor propiedad, si nos referimos al conjunto de las profesiones del diseño- es una de las actividades más determinantes a la hora de conformar el mundo que habitamos. Por ello, como se viene denunciando desde su propio ámbito, ${ }^{1}$ resulta llamativa -y en cierto modo peligrosa- la escasa atención que la estética ha prestado a esta actividad, pues, la mezcla de desconocimiento y de ideas preconcebidas con la que, ocasionalmente, se abordan sus estudios conlleva a una infravaloración de la actividad proyectual.

Las profesiones del diseño pertenecen a la esfera de los conocimientos prácticos encaminados al saber hacer; tienen sus antecedentes históricos en los oficios artesanales del medievo y, más directamente, se encuentran vinculadas con las artes aplicadas o decorativas que, a partir del siglo XVIII, se escindieron (o tal vez sería más

1 En esta línea, Fernando Infante del Rosal afirma: "Con todo, el conocimiento que los estetas suelen tener de la realidad profesional del diseño y las artes aplicadas y de consumo es muy escaso (...) tal desconocimiento del mundo efectivo de las artes heterónomas no constituiría causa de reproche a los que piensan y escriben sobre arte si no fuera porque para estos va unido frecuentemente a una constante y manifiesta discriminación" (Infante del Rosal 2018: 90-91).

* Universitat Jaume I de Castelló, España.marin@uji.es

Articulo recibido: 29 de mayo de 2019; aceptado: 29 de septiembre de 2019 
preciso decir fueron expulsadas) de las Bellas artes. Ahora bien, la aparición de diseño industrial, como su nombre indica, sólo será posible a partir de la revolución industrial, pues esta actividad proyectual está motivada por la implantación de los procesos de producción en serie de productos estandarizados. A diferencia del artesano que construye manualmente sus objetos para un individuo particular, el diseñador concibe y desarrolla los productos que fabricará la industria para el mercado.

La conformación del diseño industrial como una disciplina con una personalidad propia ha sido un proceso complejo -y quizás esté todavía abierto. Aunque en el último tercio del siglo XVIII ya encontramos claros ejemplos de diseño de productos industriales - como es el caso de los objetos de metal producidos por Matthew Boulton y de las cerámicas de Josiah Wedgwood-, a lo largo de todo el siglo XIX el diseño industrial se consideraba una actividad indistinta de la artesanía y de las artes aplicadas. Todavía a finales de este siglo

Los admiradores de la máquina comparten con los defensores del artesanado la idea de que el arte verdadero es el que se califica de "aplicado" o "decorativo", el que se adapta a la vida y expresa la vida. [...] este nuevo arte decorativo tiene su lugar privilegiado no en las muestras de arte, aunque sea aplicado, sino en las exposiciones universales de la industria. Contra el prejuicio ruskiniano acerca de la civilización de las máquinas, los nuevos campeones del arte decorativo quieren reconciliar el arte y la industria en una única y misma energía al servicio de las necesidades de la vida y las libertades de su expresión (Rancière 2014: 169 y 171).

Sin duda, entre la multitud de actores que a partir del siglo XX intervinieron en la consolidación del diseño industrial como una disciplina diferenciada, resultaron determinantes los esfuerzos metodológicos que realizó el racionalismo productivo que arranca con Muthesius, la Werkbund y la AEG de Peter Behrens, una tradición que continua con la Bauhaus y que comparten, con los matices propios de su diversidad, los componentes del Movimiento Moderno. Pero no fue menos importante la temprana profesionalización de las consultorías de diseño norteamericanas, que reunieron en la figura del industrial designer una serie de competencias que se extendían desde el ámbito del diseño de producto al del marketing y la publicidad. El encuentro de estas dos tradiciones, la europea, dotada de una vocación metodológica y de una concepción del producto más funcional, y la norteamericana, orientada de un modo pragmático hacia las exigencias del mercado, configurará a grandes rasgos los perfiles de la nueva disciplina.

La tarea del diseñador industrial va más allá de la creación de artefactos. En cierto sentido, es un mediador entre las personas y los objetos, que trabaja para que estos nos resulten más eficaces, comprensibles y significativos. Uno de sus cometidos más importantes, como señala el diseñador Eric Chan ${ }^{2}$ es hacer la tecnología transparente y facilitarnos el acceso a las experiencias que ella pone a nuestro alcance. En cierto modo, su formación ideal coincidiría con una actualización de la meta propuesta por Schiller en su obra La educación estética del hombre, en la cual proponía una cultura integral que permitiese el desarrollo equilibrado de las distintas facultades -técnicas, artísticas y filosóficas- del ser humano. En esta misma línea, el diseño industrial requiere de los conocimientos tecnológicos que están a la base de los procesos productivos de 
la industria y de los saberes humanísticos que posibilitan e incrementan el potencial comunicativo de sus productos. "Por consiguiente, hoy en día diseño significa, más o menos, aquel lugar en el que el arte y la técnica (y por ello el pensamiento valorativo y el científico) se solapan continuamente, con el fin de allanarle el camino a una nueva cultura" (Flusser 2002: 25). La tarea del diseño industrial aúna proyecto tecnológico, creatividad artística y sabiduría humanística. El buen diseño no es desde luego una obra de arte total -como anhelaban algunos teóricos del art nouveau-pero sí el resultado de una cultura integral.

Precisamente, la relación entre el arte y el diseño surgió como tema de debate en el mismo momento en el que el diseño empezó a perfilarse como una disciplina distinta de las artes decorativas. De hecho, como nos recuerda Raymond Guidot (2003: 17), en la exposición universal de Londres, en 1851, ya estaba abierto el debate entre "arte e industria". Como es sabido, durante la primera etapa de la Bauhaus, en Weimar, se continuó apostando por una relación colaborativa -y hasta cierto punto simbióticaentre los diferentes campos creativos. Así lo escribía Walter Gropius en el "Manifiesto y programa de la Bauhaus" de 1919:

La Bauhaus tiene como objetivo la reunión de todo el quehacer artístico (escultura, pintura, artes aplicadas y artesanía) en una nueva arquitectura, de modo, que sean elementos indisociables. El fin último, aunque remoto, de la Bauhaus es la obra de arte unitaria (el gran edificio), en el que no hay límite entre el arte monumental y el decorativo (en Medina 2018: 167). ${ }^{3}$

Sin embargo, en el seno de la propia escuela no tardaron en aparecer discrepancias entre los defensores de una formación de orientación más artesanal, artística y autoexpresiva, y los partidarios de una concepción racionalista que trataba de orientar los estudios hacia los procesos productivos de la industria -y que prevaleció a partir de 1923. ${ }^{4}$ En el texto "Máquinas de habitar", escrito por Gropius en 1922, se puede apreciar con claridad cómo el autor ha modificado los referentes que elije para la tarea proyectual. Así, después de preguntarse "¿Qué podemos hacer hoy para procurarnos viviendas dignas?" (en Medina 2018: 189) lamenta que, mientras la vida moderna impone la misma vestimenta funcional ya sea en América, Europa o Japón, los estilos historicistas y decorativos locales continúen prevaleciendo en la arquitectura y en el equipamiento para el hogar:

Las intenciones estéticas impidieron el desarrollo normal y orgánico de nuestros objetos domésticos. No conocemos ninguna silla ni ninguna mesa que se corresponda con nosotros como lo hace nuestra vestimenta. Sólo los artefactos creados por el ingeniero (cañerías de agua, calefacción, luz eléctrica, etcétera) responden a las exigencias espirituales de nuestros días. La oficina de una fábrica moderna tiene la forma orgánica de su mobiliario; nuestras viviendas no. Sólo cuando se haya eliminado lo sentimental, lo estético, la voluntad de hacer arte -y con esto a los responsables de esas cosas: el arquitecto, el artesano, el delineante de adorno-, y cuando aparezcan en su lugar el obrero, el trabajador industrial y el ingeniero, será cuando tendremos

3 Los textos de Gropius citados en este artículo están extraídos de la edición de Joaquín Medina Warmburg, Walter Gropius, proclamas de modernidad. Escritos y conferencias, 1908-1934, recogido en la bibliografía. La traducción es de María Santolo y el mismo editor. 
a nuestro alrededor las carcasas, con sus partes, que correspondan a nuestra vida y a nuestra época (en Medina 2018: 190).

Como vemos, la concepción industrial y productivista se impone. Si en el Manifiesto de 1919, Gropius instaba a los arquitectos, escultores, pintores a fusionarse con un nuevo artesanado, ahora son el obrero, el trabajador industrial y el ingeniero a quienes encomienda la construcción de las máquinas de habitar Gropius se muestra en este texto implícitamente convencido de que la primacía de los nuevos procesos de producción fabriles es irreversible, por lo que resultaría contraproducente y, a la postre imposible, mantener una metodología artesanal. Pero, además, manifiesta abiertamente que "las exigencias espirituales de nuestros días", los nuevos "modos de vida" de la sociedad moderna surgida de la revolución industrial, requieren nuevas formas para nuestros hábitats. Las formas abstractas de las máquinas ("los artefactos creados por el ingeniero") sustituirán a la ornamentación figurativa de los "delineantes de adornos" (Fig. 1). En el fondo, la idea fundamental que subyace en todo el texto es que la belleza de los objetos industriales -que en términos baudelairianos recogería "lo transitorio, lo fugitivo, lo contingente" de los tiempos modernos ${ }^{5}$ tiene unas características diferentes a la belleza artística propia de las anteriores artes decorativas.

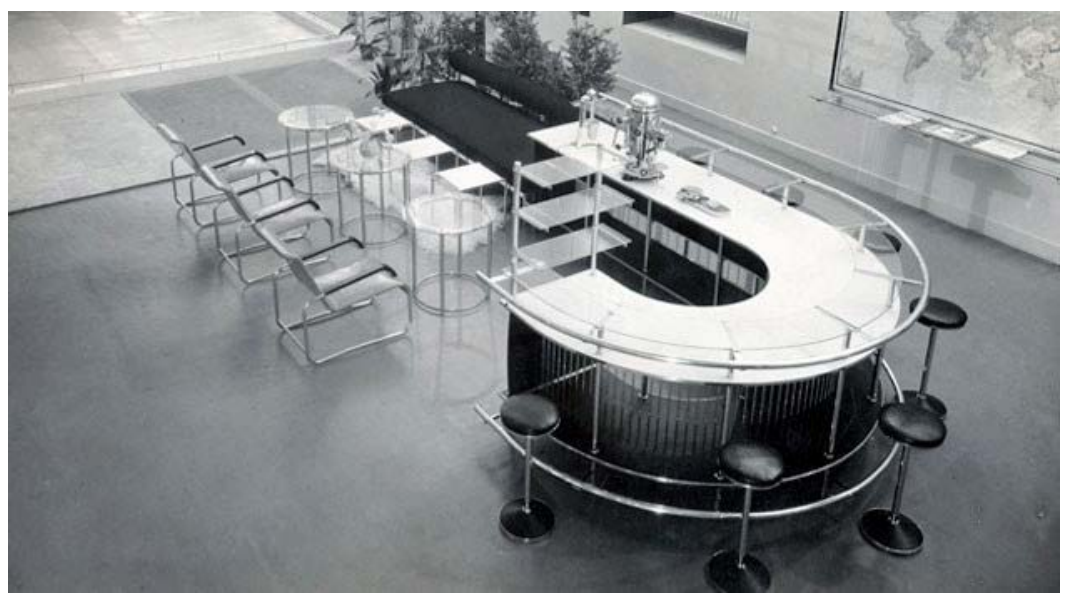

Fig. 1. Bauatelier Gropius con Marcel Breuer: prototipo de club social de una torre de viviendas. Exposición de la Deutscher Werkbund en París, 1930

Posteriormente, el ideario de la Escuela Superior de Diseño de Ulm, en gran medida heredera del espíritu de la Bauhaus, recorrería un itinerario similar. Los planes de estudio perfilados por su primer director, Max Bill, desde la perspectiva del artistadiseñador que él mismo era, adquirieron -tras las reformas impulsadas por Otl Aicher, Hans Gugelot y Tomás Maldonado- una orientación industrial situada al margen de la esfera artística. La concepción funcional racionalista del diseño desarrollada por la escuela de Ulm se distinguirá por anteponer las propiedades objetivas del producto (ergonomía, usabilidad, legibilidad, simplicidad, seguridad y accesibilidad) a cualquier otro tipo de consideración semántica o simbólica del mismo.

Las relaciones entre arte y diseño han sido materia de recurrentes controversias.

5 "La modernidad es lo transitorio, lo fugitivo, lo contingente, la mitad del arte, cuya otra mitad es lo fugitivo e inmutable" (Baudelaire 1974: 91-92). 
Bruno Munari, en su texto Artista y designer trató de delimitar los términos artista / diseñador y los de obra de arte / producto industrial con una serie de diferencias específicas de cada ámbito. El listado que se puede establecer a partir de la lectura de su obra resulta clarificador en términos teóricos y generales; sin embargo, en el ejercicio efectivo de ambas disciplinas se pueden encontrar multitud de excepciones para cada una de las diferencias que menciona. ${ }^{6}$ De hecho, contradiciendo sus indicaciones, no pocos diseñadores contemporáneos tienen un estilo propio, hacen ediciones limitadas de sus productos y, también, piezas únicas. Exponen sus objetos en museos, ferias y galerías de arte; e incluso algunos venden sus piezas en prestigiosas casas de subastas. Evidentemente, se trata de hechos puntuales dentro del extenso territorio del diseño industrial y, en la mayoría de los casos, pertenecen al ámbito de lo que se ha venido a denominar design-art, pero no dejan de ser significativos. Por no faltar, también existe una incipiente crítica del diseño profesionalizada que aborda los objetos de su especialidad y que se relaciona con su propio star system con unos modos de proceder bastante similares a los de la crítica de arte. Por lo demás, aunque en la actualidad muchos diseñadores se niegan a "jugar a ser artistas", otros se resisten a tener que decidirse entre ambos términos como Ron Arad, o Marc Newson (Fig. 2); y los hay que afirman que no son ni lo uno ni lo otro, como Nynke Tynagel o el “exdiseñador” Martí Guixé.

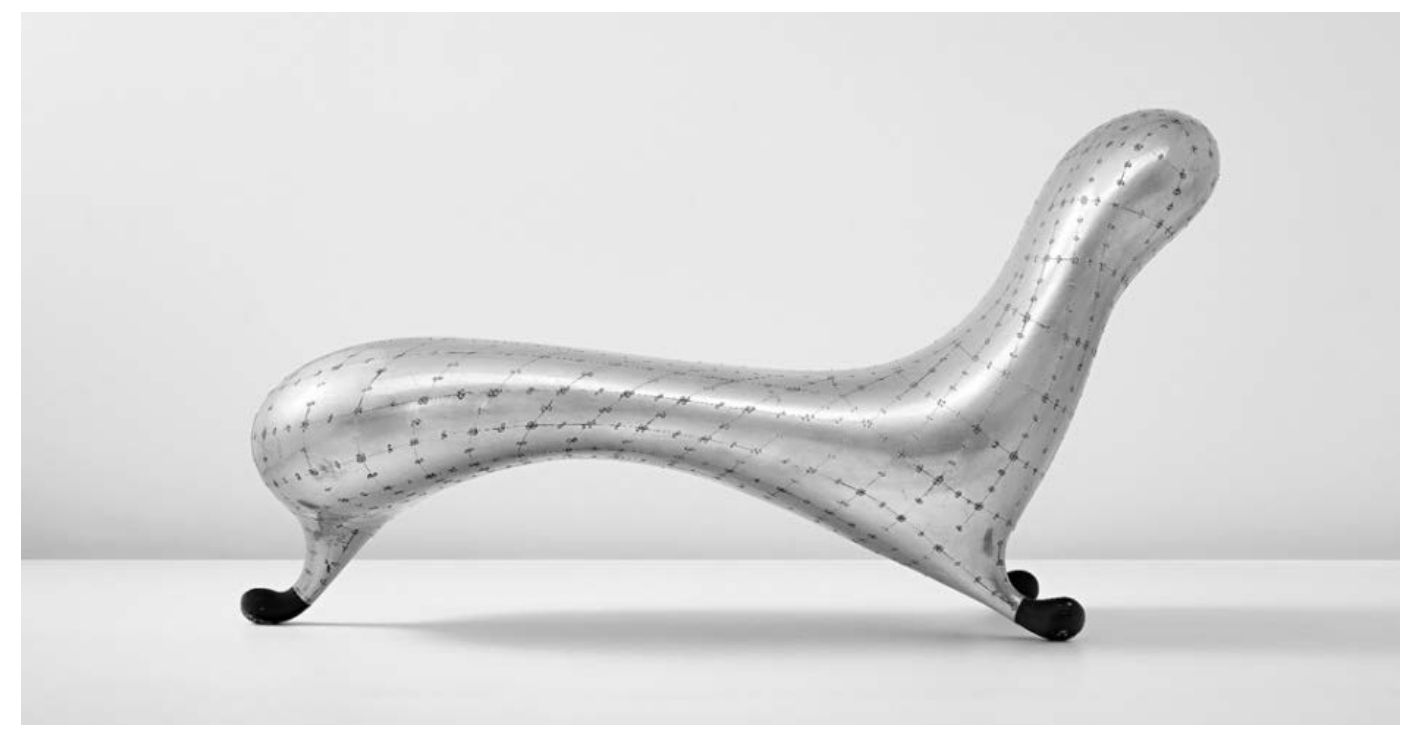

Fig. 2. Marc Newson: Lockheed Lounge, 1988

Las relaciones entre arte y diseño han sido, desde el principio, profusas e imbricadas; y, a menudo, como señala Camille Morineau, se han convertido en "un terreno minado que es preciso cruzar, pero tomando algunas precauciones". ${ }^{7}$ La separación de ambas disciplinas fue uno de los objetivos del Movimiento Moderno -del que la Bauhaus fue uno de los pilares fundamentales-, pero resulta un hecho significativo que la silla Wassily de Marcel Breuer formara parte de la exposición Machine Art que organizó el MoMA de Nueva York en 1932; y también es relevante que cuatro años más tarde

6 En Marín y Torrent 2016: 16ss, se abordan con más detalle estas cuestiones.

7 Cit en Pok, Marie (2010) "Design et art : un mariage arrangé", en Busine y Gielen 2010: 205. La traducción es del autor del articulo. 
este mismo museo de arte moderno le dedicara a la Bauhaus una excelente muestra antológica.

Por otro lado, la historia del diseño industrial ha documentado suficientemente cómo los cauces creativos del arte y del diseño industrial han confluido y se han retroalimentado desde hace más de un siglo. Sin duda, la técnica de los ready made de Marcel Duchamp inspira numerosas creaciones industriales - desde el asiento Mezzadro (Fig. 3) de los hermanos Castiglioni a la lámpara Gun (Fig. 4) de Philippe Stark- pero no es menor la influencia que el objeto industrial ejerció en los artistas del pop en los años sesenta. Por no hablar de la década de los ochenta, en la que las fronteras entre arte y diseño se difuminaron para muchos creadores de ambas disciplinas. Ciertamente, una vez pasada la ola postmoderna, las aguas volvieron a sus respectivos cauces, pero resulta evidente la permeabilidad de sus respectivos territorios en los que nunca han dejado de aflorar productos híbridos.

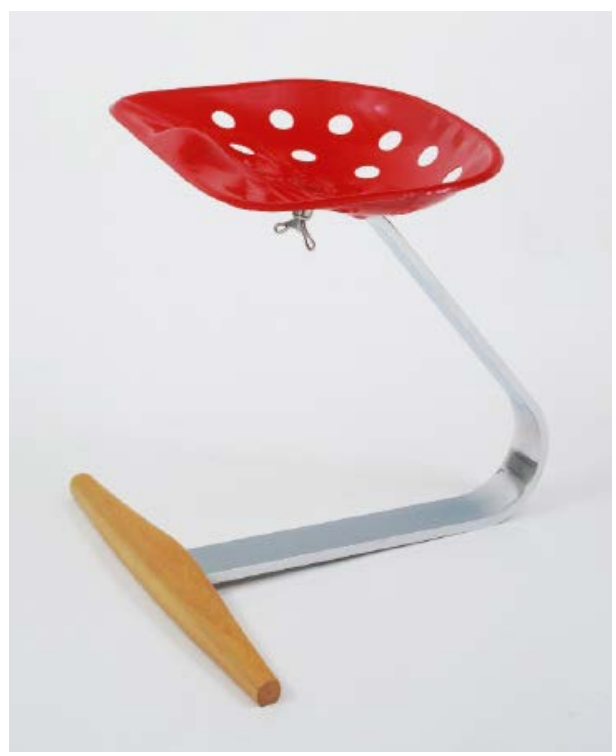

Fig. 3. Achille y Pier Giacomo Castiglioni: asiento Mezzadro, 1953

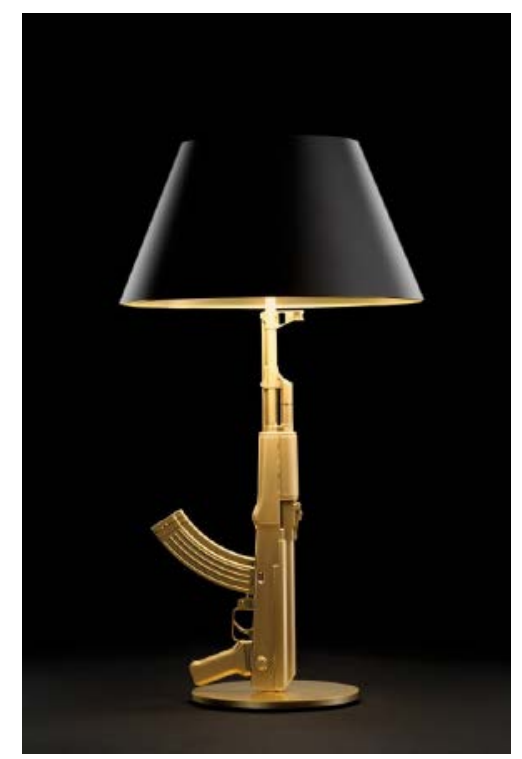

Fig. 4. Philippe Starck: lámpara sobremesa Gun, 2005

La reminiscencia de un pasado común y la permanencia en la actualidad de ciertos territorios creativos compartidos -como el design-art- han mantenido viva la polémica en torno a la supuesta naturaleza artística del diseño industrial. Por otro lado, la confluencia de dos factores distintos, como son la innegable dimensión estética de los objetos de diseño y la propensión general a subsumir lo estético dentro de lo artístico, han contribuido -tal vez de modo inconsciente, pero poderoso- a aumentar la confusión en esta controversia. ${ }^{8}$ No obstante, y pese a todo, un objeto industrial no es per se una obra de arte; pues, por lo general, presenta una función utilitaria distinta al conjunto de predicados que se le han atribuido a la actividad artística. A la tradicional condición contemplativa de las obras de arte, que se hace patente en la prohibición "no tocar", puede contraponerse la funcionalidad del objeto industrial que

8 Como afirmó con clarividencia Anna Calvera: "Otra consecuencia de la confusión entre dimensión estética y artisticidad del diseño es esa idea que entiende el diseño como una nueva forma de arte" (Calvera 2003: 18). 
se anuncia en el "listo para usar". Y, si preferimos creaciones artísticas que requieran la participación activa del público y destaquen por un cuestionamiento crítico de la realidad, la vocación reflexiva que presentan estas obras no deja de contrastar con la legibilidad inmediata del producto industrial, que suele facilitar-aunque no siempresus prestaciones objetivas sin detenerse en divagaciones semánticas.

De este modo, si queremos conservar ciertas balizas conceptuales que nos preserven del naufragio en el mar de la confusión y de lo indistinto, hemos de admitir que el diseño -al menos, el diseño industrial- no es arte, pero con la misma contundencia debemos convenir que el diseño es una actividad tan creativa como la artística. En la actualidad, si atendemos a la incidencia del diseño en nuestras vidas, su dimensión cultural no es menos importante que la del arte; ni tampoco menos trascendente, porque -al igual que ha sucedido tradicionalmente con los símbolos religiosos y con las obras de artehoy en día los objetos cotidianos también significan más de lo que son.

No tendría excesivo sentido tratar de minusvalorar la creatividad del diseño, respecto a la del arte, argumentando un menor grado de reflexión crítica y de libertad en el ejercicio de la actividad proyectual. Resulta obvio que el objetivo prioritario del diseño no ha sido potenciar la conciencia crítica de la gente-como tampoco lo ha sido en el arte religioso o la pintura histórica-, e igual de cierto resulta que el diseño industrial se ha dedicado por lo habitual a llenar con sus productos los centros comerciales -incluso, si se quiere, con mayor eficacia que la mostrada por los artistas a la hora de abastecer el mercado del arte-, pero en la historia del diseño industrial también podemos encontrar muchos momentos -Movimiento Moderno, el Diseño radical italiano, el diseño crítico y el ecodiseño- en los que la reflexión sobre las relaciones del diseño con su entorno social y el análisis de las contradicciones de la propia disciplina han pasado a primer plano.

Por otra parte, el contraste entre la necesidad que guía el ejercicio de la actividad proyectual del diseño frente a la autonomía de la obra de arte y la libertad del artista, ha sido aducido de modo recurrente como prueba de la superioridad de la creatividad artística. Sin embargo, al observar la cuestión con mayor detenimiento, se aprecia que la disparidad no radica tanto en que uno sea libre y el otro no, sino en la diferente forma en que ambos experimentan su libertad particular. El diseñador, como argumenta convincentemente Infante del Rosal, en lugar de situar su actividad más allá de las necesidades y de las leyes -ya sean físicas o de mercado- trata de conciliarlas orientando su proyecto hacia el punto en el que las distintas reglas confluyen en la dirección deseada:

Como hemos visto, el diseño puede trabajar en beneficio de la libertad, no tanto ejerciéndola, como comprendiendo y gobernando las determinaciones del mundo. No operando como libre juego sino haciéndose con el control de las leyes de todo el juego. No detectando las ranuras de la excepción sino domesticando la regla (Infante 2018: 136).

De este modo, la libertad del diseñador reside en su capacidad de encauzar las necesidades y las normas. Y si bien, en cuanto a la posibilidad de abandonarse a un "libre juego" creativo más allá de toda necesidad, no goza de un horizonte tan despejado como el artista, esto no significa que no pueda encontrar con habilidad sus espacios de libertad: 
Los diseñadores, como los pintores o los músicos de corte, precisamente porque trabajamos en un contexto adverso para el discernimiento y la contemplación del objeto, hemos desarrollado una capacidad para decir más cosas de las que nos reclama el cliente, o para la experimentación o la búsqueda formal más a allá de la presentación del mensaje, e, incluso para hacer que la pieza de diseño hable sobre el diseño, el arte y la estética, de manera similar a como los escritores o cineastas acechados por la censura han gestado modos adicionales -y furtivos- de decir y mostrar (Infante 2018: 36-37).

Aunque el diseño industrial -tal como entendemos hoy día esta actividad- no sea arte, la dimensión estética del producto industrial sigue siendo muy importante. La insistencia de la teoría estética a la hora de resaltar la autonomía de la obra de arte, alejándola de toda finalidad e interés utilitario, ha tenido el efecto colateral e indeseado de enmascarar los valores estéticos de los objetos funcionales. Frecuentemente, el menosprecio de la dimensión estética del diseño, así como el errado debate entre la forma y la función, han sido propiciados por un uso impreciso de la terminología por parte de los propios especialistas en la materia. Así lo podemos observar, por ejemplo, en el texto de Gropius, anteriormente citado, en el que se mezclan confusamente "lo estético y la voluntad de hacer arte". Una ambigüedad que refleja la tendencia generalizada a fundir y a confundir lo estético y lo artístico; ${ }^{9}$ y que, a la postre, lleva a la mayoría de la gente (incluidos no pocos especialistas) a creer que cuando nos referimos a la dimensión estética de un producto estamos hablando -siempre y exclusivamentede cualidades artísticas o decorativas.

En contra de lo que suele repetirse a la ligera, la importancia de la dimensión estética del diseño industrial no depende en lo sustancial de si somos partidarios de una concepción racionalista del diseño - que anteponga la clara legibilidad del producto, su rendimiento y su usabilidad-, o de un tipo de diseño con un alto contenido narrativo o simbólico, o bien prefiramos un diseño que emocione. Independientemente del tipo de diseño que prefiramos, el hecho incontrovertible es que todo producto indica sus funciones de uso, trasmite sus contenidos simbólicos y llega a emocionarnos a través de su forma. Esto es, el potencial comunicativo de un objeto de diseño se articula a través de su forma; y, de un modo u otro, las cuestiones formales siempre están relacionadas con su dimensión estética.

A la hora de abordar la dimensión estética del objeto industrial esta perspectiva resulta mucho más provechosa que reducirla a la cuestión de si un producto está más o menos adornado, o recuerda a este o aquel estilo artístico. En este sentido, como ya se ha señalado en otro lugar (Marín y Torrent 2016: 80ss), el debate entre funcionalistas y formalistas se ha abordado en ocasiones -y por ambas partes-desde posicionamientos reduccionistas y con conceptos imprecisos que han dado lugar a ideas equívocas. La reiterada calificación de formalista o de esteticista a productos de apariencia barroca, sofisticada, grandilocuente, o provocadora, sugiere la creencia errónea de que los productos que tienen estas características tienen un mayor cuidado de la forma y un mayor interés estético que otros productos simples, discretos, e incluso elegantes. Pero, ¿quién sería capaz de afirmar que las funcionales vinagreras de Rafael Marquina (Fig. 5) o las lámparas de Miguel Milà están más descuidadas formalmente y tienen un menor

9 Fernando Infante del Rosal, en su libro La autonomía del diseño. Diseño como categoría estética (2018), ha analizado con detalle la confusión entre "esteticidad" y "artisticidad". 
interés estético que los muebles formalistas de la productora Memphis? (Fig. 6) ¿O que los mejores representantes de la tradición racionalista y sus herederos contemporáneos -pongamos, por ejemplo, las creaciones de Dieter Rams para la Braun y de Jonathan Ive para Apple (Fig. 7)- desatienden la presentación formal de sus diseños y relegan su dimensión estética a un lugar secundario? La visceralidad con la que, en épocas pasadas, se abordó la polémica entre la forma y la función derivó en groseras simplificaciones que hoy día parecen superadas. Afirmar que el diseño formalista concede una mayor importancia a la forma, o que el goce estético únicamente puede asociarse a productos que incorporaran ciertos valores artísticos, constituyen tópicos tan errados como creer que la adecuación a la función convierte por sí sola a un producto en bello.

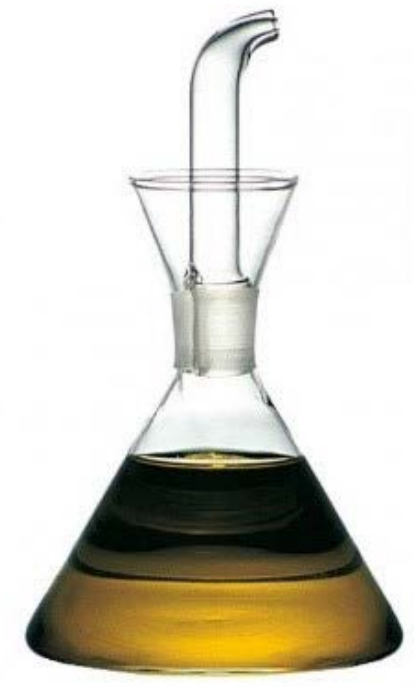

Fig. 5. Rafael Marquina: aceitera-vinagrera, 1961

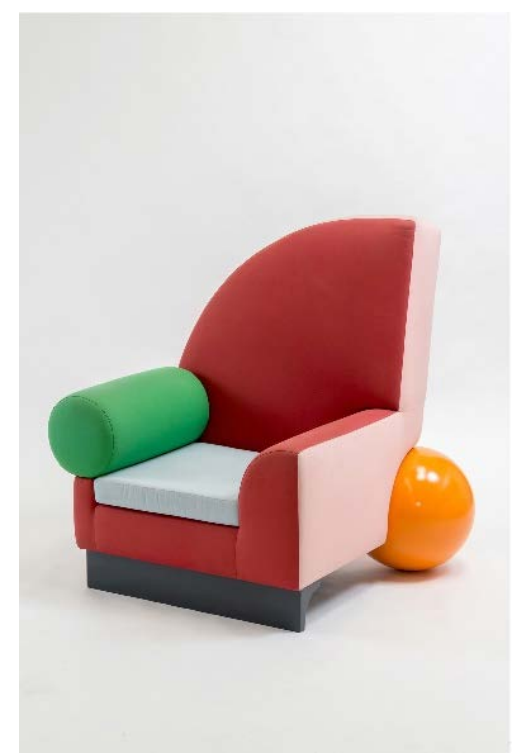

Fig. 6. Peter Shire: sillón Bel Air, 1982
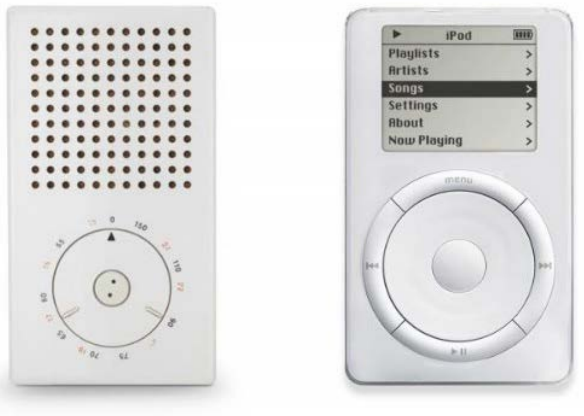

Fig. 7. Dieter Rams: radio Rams T3, 1958 / Jonathan Ive, Ipod, 2001

La dimensión estética del diseño industrial es algo más extenso y profundo que la ornamentación de los objetos. Muchos creen que ella sólo opera en la superficie, pero en realidad conforma la esencia de los productos y condiciona la percepción que tenemos de su usabilidad. Donald A. Norman ha argumentado con detalle que "los 
objetos que son agradables en términos estéticos nos habilitan para trabajar mejor" (2005: 26). Diferentes estudios han confirmado que a la hora de elegir entre objetos -por ejemplo, cajeros automáticos-con las mismas funciones y una cantidad idéntica de elementos indicativos, la gente prefiere y considera más fáciles de usar los que tienen una presentación más atractiva. En definitiva, como subrayan Lidwell, Holden y Butler: "Los diseños estéticos fomentan actitudes más positivas que los no estéticos, además de lograr que las personas se muestren más tolerantes hacia los problemas de diseño" (2011: 20).

Por otra parte, los objetos industriales, además de las funciones de uso y de su dimensión estética, tienen una trascendencia simbólica. La controversia en torno a la dimensión simbólica del producto, antes de trasladarse al mundo del diseño, se libró con especial intensidad en el campo de la arquitectura. En su libro Learning from Las Vegas. The Forgotten Symbolism of architectural form, Robert Venturi, Steven Izenour y Denise Scott, acusaron a los arquitectos del Movimiento Moderno de realizar un simbolismo encubierto que hacía en la práctica lo que negaba en la teoría; pues, en lugar de renunciar a la dimensión simbólica de los edificios, como proclaman en sus escritos, simplemente habían sustituido la simbología figurativa del eclecticismo histórico por la simbología abstracta que se deriva del cubismo y de la máquina -auténtico símbolo de la revolución industrial (Venturi, Izenour, y Scott 1978: 168-170).

Del mismo modo que los grandes rascacielos racionalistas no tardaron en convertirse en símbolo del poder económico de las grandes compañías, el diseño funcional racionalista (ya fuese alemán o japonés; o, con sus diferentes particularidades, el Good design de EEUU o el Bel design italiano), fue adoptado y auspiciado después de la Segunda Guerra mundial por las corporaciones multinacionales. La insistencia en la racionalización de los procesos de producción y la supresión de toda ornamentación superflua, propias de esta concepción del diseño, resultaron un buen motivo para su promoción.

Además, la abstracción geométrica que regía la forma de los productos del funcionalismo racionalista les proporcionaba una estética neutra al margen de cualquier tipo de simbolismo figurativo que facilitara la adscripción del producto a unos valores culturales concretos o a una determinada nacionalidad. Una estética aséptica que en un escenario de posguerra en el que se tenía que relanzar el comercio internacional -pero en el que las secuelas del conflicto bélico seguían presentes en la memoria de la gente- disminuía la posible reticencia que podían experimentar los consumidores ante los productos procedentes de otros países. ¡Qué más adecuado para afrontar las circunstancias sociales y de mercado con las que se encontraron las multinacionales de la época que impulsar un estilo internacional tanto en arquitectura como en diseño! Parafraseando lo que en su día afirmó Robert Venturi sobre la arquitectura moderna, podríamos afirmar que los mejores productos de la tradición funcional racionalista adoptaron "cierto formalismo rechazando la forma", ${ }^{10}$ alcanzaron un depurado esteticismo ignorando el ornamento; y, proscribiendo el simbolismo figurativo, se convirtieron en efectivos transmisores de los intereses económicos y de los valores culturales de sus promotores.

10 "La arquitectura moderna reciente ha logrado cierto formalismo rechazando la forma, ha promovido el expresionismo ignorando el ornamento y ha deificado el espacio rechazando los símbolos" (Venturi, Izenour, y Scott 1978: 183). 
De hecho, el interés por la vertiente comunicativa de los objetos - por su capacidad de contar historias- que de forma distinta ya había estado presente en las artes decorativas y en el styling norteamericano, no volvió a fomentarse de forma explícita hasta inicios de la década de los sesenta, cuando la situación económica -y también el estado anímico- derivados de la posguerra se habían superado. Fue entonces cuando un número creciente de consumidores pudo celebrar su acceso al consumo masivo identificándose con la figuración alegre y desenfadada del pop. La posmodernidad inmediata, que tantos aspectos comparte con el pop, continuó potenciando la dimensión simbólica del producto; por supuesto, como elemento de distinción económica y social, pero también, cada vez más, como medio de identificación personal y cultural.

Junto a la funcionalidad práctica y el atractivo estético, las connotaciones simbólicas y las experiencias emocionales que provoca un producto son factores determinantes para su elección. Desde la década de los ochenta, la importancia de la dimensión simbólica no ha dejado de incrementarse. Resulta notorio que muchos defensores de la ortodoxia funcional racionalista se han sentido incómodos con la dimensión simbólica del producto, e incluso la han considerado inconveniente. A su juicio, la atención del diseñador debería centrarse en la calidad de las propiedades objetivas del producto, sin perderse en cuestiones que, más allá de la esfera racional, tienen que ver con las aspiraciones personales y el deseo. Sin embargo, el mismo Otl Aicher, destacado representante de la concepción racionalista del diseño, no pudo sino reconocer con cierta pesadumbre: "Hemos ingresado en un mundo de signos, y muy a menudo ya no utilizamos los objetos como útiles, sino como portadores de signos. Lo que compramos está más frecuentemente determinado por la marca y su signo que por su valor de uso" (Aicher 1994: 66).

En la actualidad, las principales compañías industriales de cada sector saben perfectamente que sus productos tienen un precio similar y la misma calidad tecnológica, por lo que solo los diferencia, como señalaba Norio Ohga, ${ }^{11}$ el diseño. Pero también, cabría añadir, los distinguen los universos simbólicos creados por sus respectivas marcas. En una época en la que las claves de inclusión grupal y de distinción individual se han deslizado desde el campo de la retórica ideológica al de la imagen visual, y en la que muchas personas optan por construirse una "personalidad a la carta", ${ }^{12}$ la diversidad formal de los objetos y sus distintas connotaciones semánticas se han convertido en una herramienta para conformar nuestra identidad con cada una de nuestras elecciones.

Los objetos son con frecuencia la referencia más recurrente en el transcurrir de nuestras vidas; los usamos para que nos definan, para que emitan señales sobre quiénes somos y quiénes no somos [...] Hoy día los diseñadores, además de resolver los problemas estructurales y funcionales, son los responsables de que el diseño nos "narre", como si fuese una historia, el mensaje que el objeto nos quiere transmitir (Sudjic 2009: 24).

11 "En Sony asumimos que todos los productos de nuestros competidores tienen básicamente la misma tecnología, precio, rendimiento y características. Lo único que diferencia a un producto de otro en el mercado es el diseño" (Norio Ohga presidente jubilado de Sony. Cit. en Peters 2005: 39).

12 Para Gilles Lipovetsky (1986), la construcción de una "personalidad a la carta" es una característica que diferencia los individuos de las sociedades posmodernas respecto a los de las anteriores sociedades modernas, ideologizadas de un modo más dogmático y rigorista. 
El acrecentamiento del poder de las marcas, acaecido en la década de los noventa, impulsó la convergencia entre el ámbito de la publicidad y el del diseño, al tiempo que incrementó una progresiva interdisciplinariedad de este último (Julier 2014: 5253). De hecho, el auge del branding ha propiciado en el seno de muchas empresas y corporaciones actuales un nuevo modelo de relación entre el producto y la marca:

El antiguo paradigma era que todo el marketing consiste en la venta de productos. En el nuevo modelo, el producto es siempre secundario respecto al producto real, que es la marca, y la venta de la marca integra un nuevo componente que sólo se puede llamar espiritual (Klein 2005: 48).

La marca funciona como un poderoso símbolo que transfiere al producto el conjunto de imágenes y de sensaciones que tenemos de ella. Pero, a su vez, el producto no es sólo un objeto físico con una serie de propiedades objetivas, sino que se convierte en el vehículo (o al menos en un elemento de fundamental) de la transmisión de este conjunto de sensaciones al consumidor. Por esta razón la coherencia entre la marca, los productos y los espacios -físicos o virtuales- en los que estos se exponen y venden, se convierte en un requisito imprescindible para alcanzar el objetivo final, a saber: que la marca sea capaz de transmitir un modo de vida, una estética diferenciada e incluso una jerarquía de valores. En este nuevo contexto social y de mercado en el que el producto real va más allá de su materialidad física, comprendemos mejor el sentido de las palabras de Bruce Mau cuando afirma que "la única manera de construirse una auténtica marca propia es añadir valor: envolver el producto con inteligencia y cultura" (cit. en Foster 2004: 23).

La emoción derivada del uso o de la posesión de un producto es otro aspecto del diseño que ha ocupado el primer plano en estas últimas dos décadas, en las que las marcas han pasado de vender modos de vida y mecanismos de distinción social a ofrecer experiencias. Las dimensiones simbólica y emotiva de los objetos, aunque son diferentes, están estrechamente relacionadas. El poder simbólico de un producto no afecta sólo a la imagen que irradia hacia el exterior quien lo posee o consume, sino también al placer que le proporciona al usuario su inmersión en el universo de sensaciones y de valores que le promete el objeto y la marca elegida. La imprecisa y, en ocasiones, confusa diferencia que existe entre elegir un producto como vehículo de identificación personal, o adquirirlo por la satisfacción particular que nos produce la experiencia de su consumo, delimita el transitar entre las vertientes simbólica y emocional del producto. Ambas vertientes resultan contiguas y su acción sinérgica multiplica las opciones de elección de un producto. En estos últimos años, tanto las marcas en particular como la industria del diseño en general, han reorientado su discurso de modo significativo, pues si bien continúan siendo un mecanismo de distinción social que vende modos de vida y -ificticias?- identidades personales, han buscado potenciar su capacidad de proporcionar experiencias y despertar emociones. A propósito de su visita a la empresa Swatch (Fig. 8), Donald Norman escribió:

Aprendí que los productos pueden ser más que la suma de las funciones que cumplen. Su valor real estriba en satisfacer las necesidades emocionales de las personas y una de las más importantes entre todas consiste en establecer la propia autoimagen y el lugar que uno ocupa en el mundo (Norman 2005: 108). 


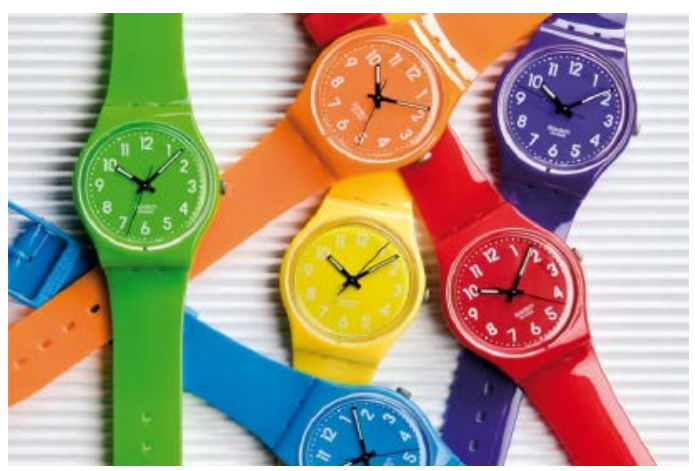

Fig. 8. Relojes Swatch, desde 1983

La importancia que ha adquirido la dimensión simbólica del producto en los últimos tiempos es uno de los factores que ha contribuido a alimentar el debate sobre si el diseño industrial es -o no- un agente activo de estetización difusa; un proceso que, mediante el aderezo estético de la realidad, tendría como objetivo la estimulación del consumo y la sedación de las conciencias.

De lo que se trata es de una estética de consumo y de diversión: no ya de artes destinadas a comunicar con potencias invisibles o a elevar el alma mediante la experiencia extasiante de lo Absoluto, sino de "experiencias" consumistas, lúdicas y emocionales, aptas para divertir, para procurar placeres efímeros, para aumentar las ventas. Cuanto más se infiltra el arte en la cotidianidad y en la economía, menos cargado está de altos valores espirituales, cuanto más se generaliza la dimensión estética, más aparece como una simple ocupación de la vida, un accesorio sin más finalidad que animar, decorar, sensualizar la vida corriente: el triunfo de lo inútil y de lo superfluo (Lipovetsky y Serroy 2014: 26).

La estetización de la vida cotidiana es un hecho objetivo en las sociedades hiperdesarrolladas que ha recibido diferentes valoraciones según la perspectiva filosófica desde la que haya sido analizado. Por un lado, los posicionamientos más críticos, en cierto modo herederos de la corriente situacionista de finales de los sesenta, ${ }^{13}$ sólo ven en ésta los efectos negativos de un nuevo mecanismo de alienación cuyo finalidad última es el control social. En cambio, otros planteamientos, como los Gilles Lipovetsky y Jean Serroy, combinan la crítica y la complacencia al considerar que la estetización del mundo es una consecuencia de la forma de producción y de organización del "capitalismo artístico" que, si bien presenta aspectos mejorables como los que dejan entrever en su anterior cita-, también tiene resultados positivos. En concreto, la sustitución de los métodos autoritarios de control social utilizados en el pasado por estrategias de seducción hedonistas; e incluso el propio proceso de estetización global al que, a pesar de sus imperfecciones y fracasos, ${ }^{14}$ no dejan de considerar un logro:

13 Las reflexiones que realiza de Guy Debord en su obra La sociedad del espectáculo son un claro antecedente de las objeciones críticas que encierra la noción de estética difusa: "La vida entera de las sociedades en las que imperan las condiciones de producción modernas se anuncia como una inmensa acumulación de espectáculos. Todo lo directamente experimentado se ha convertido en una representación" (Debord, 2007: 37).

14 "Consumimos cada día más belleza, pero nuestra vida no es más bella: ahí radican el éxito y el fracaso profundo del capitalismo artístico" (Lipovetsky y Serroy 2014: 26). 
[...] En este sentido, es forzoso reconocer que son más las lógicas industriales y comerciales las que han posibilitado el proceso de estetización en masa que la esfera del arte propiamente dicha [...] En realidad, el universo industrial y comercial ha sido el principal artesano de la estilización del mundo moderno y de su expansión democrática (Lipovetsky y Serroy 2014: 20).

Sin duda, se trata de una controversia que, por las precisiones que requiere, merece un análisis más extenso y detallado que excede los límites de este artículo. ${ }^{15}$ No obstante, sería un error pretender reducir la tarea del diseño industrial a una estetización de los objetos cuya función primordial es estimular el consumo -tal y como sugiere Hal Foster en su diatriba, Diseño y delito. ${ }^{16}$ Ciertamente, encontramos una concepción del diseño como ejercicio cosmético que sólo opera en la superficie del producto en muchas de las intervenciones estilísticas realizadas entre los años treinta y cincuenta del pasado siglo -aunque no en todas. También podemos hallarla en bastantes experimentos posmodernos, si bien en estos -como sucede en el Banal design impulsado por Alessandro Medini en la década ochenta- ya no se trata tanto de un medio para aumentar las ventas como de un recurso crítico e irónico. E incluso podemos reconocer que el poder actual de las marcas propicia una creciente superficialidad en la que, como bien dice Foster, "el envoltorio reemplaza al producto" (Foster 2004: 20). Ahora bien, considerar al conjunto del diseño industrial una actividad superficial al servicio del capitalismo que cumple la misión de estimular el deseo consumista de la masa, al tiempo que adormece la conciencia crítica, constituye una generalización inadecuada -y una recurrente metonimia- que se fija en unos momentos particulares de la historia del diseño (el Styling, la posmodernidad) y en unos sectores muy concretos de su actividad (el diseño-espectáculo, los objetos divinos, el branding) para descalificar al conjunto de la disciplina. Una consideración semejante adolecería del simplismo propio de todo reduccionismo y resultaría moralmente injusta para el conjunto de sus profesionales. El diseño industrial es mucho más que los objetos divinos de las portadas de las revistas especializadas y extiende su ámbito de acción más allá de los santuarios del consumo, como lo atestigua el diseño crítico, el diseño para todos, el diseño ecológico y el diseño para la necesidad, entre otros. Ciertamente, el diseño industrial -como su nombre indica- no se desarrolla al margen de los imperativos de la producción industrial y de las lógicas de los mercados; pero los conceptos de honestidad, utilidad, durabilidad, sostenibilidad y accesibilidad, forman parte del bagaje ideológico de la mejor tradición de esta disciplina, al menos con la misma legitimidad e intensidad que las estrategias de seducción forman parte del marketing.

\section{Bibliografía citada}

Aicher, O. 1994. El mundo como proyecto. México: Gustavo Gili, 1994.

Busine, L. \& Gielen, D. ed. 2010. Le fabuleux destin du quotidien. Hornu: Musée des Arts Contemporains \& Grand-Hornu Images.

Calvera, A. 2003. Arte ¿? Diseño. Barcelona: Gustavo Gili.

15 Ernesto. L. Francalanci ha dedicado la primera parte de su libro La estética de los objetos (Francalanci, 2010) al análisis del fenómeno que englobamos bajo el término estética difusa.

16 "El diseño es cómplice de un circuito casi perfecto de producción consumo, sin mucho 'margen de maniobra' para nada más" (Foster 2004: 18). 
Debord, G. 2007. La sociedad del espectáculo. Valencia: Pretextos.

Flusser, V. 2002. Filosofía del diseño. Madrid: Síntesis.

Foster, H. 2004. Diseño y delito (y otras diatribas). Madrid: Akal.

Francalanci, E. L. 2010 La estética de los objetos. Madrid: Antonio Machado libros.

Guidot, R. ed. 2003. Design, carrefour des arts. Paris: Flammarion.

Infante del Rosal, F. 2018. La autonomía del diseño. Diseño como categoría estética. Valencia: Universitat de València.

Julier, G.2014. La cultura del diseño, Barcelona: Gustavo Gili.

Lindwell, W., Holden, K. y Butler, J. 2011. Principios universales de diseño. Barcelona: Blume.

Lipovetsky, G. 1986. La era del vacío. Barcelona: Anagrama.

Lipovetsky, G. y Serroy, J. 2014. La estetización del mundo. Vivir en la época del capitalismo artístico. Barcelona: Anagrama.

Medina Warmburg, J. comp. 2018. Walter Gropius, proclamas de modernidad. Escritos y conferencias, 1908-1934. Barcelona: editorial Reverté.

Marín, J. M. y Torrent, R. 2016. Breviario de diseño industrial. Función, estética y gusto. Madrid: Cátedra.

Munari, B. 2003. "Artista y designer"; en Calvera, A. comp. 2003. Arte ¿? Diseño. Barcelona: Gustavo Gili.

Norman, D. 2005. El diseño emocional. Por qué nos gustan (o no) los objetos cotidianos. Barcelona: Paidós.

Peters, T. 2005. La esencia. Diseño. Madrid: Pearson.

Press, M. y Copper, R. 2009. El diseño como experiencia: el papel del diseño y los diseñadores del siglo XXI. Barcelona: Gustavo Gili.

Rancière, J. 2014. Aisthesis. Escenas del régimen estético del arte. Santander: Shangrila.

Sudjic, D. 2009. El lenguaje de las cosas. Madrid: Turner Noema.

Torrent, R. y Marín J. M. 2005. Historia del diseño industrial, Madrid: Cátedra.

Venturi, R., Izenour, S., Scott Brown, D. 1978. Aprendiendo de Las Vegas. El simbolismo olvidado de la forma arquitectónica. Barcelona: Gustavo Gili. 


\section{Del ornamento al delito. El diseño y la sociedad en Charles Baudelaire y Adolf Loos}

\section{From ornament to crime. Design and society in Charles Baudelaire and Adolf Loos}

Jorge López Lloret*

\section{Resumen}

La segunda mitad del siglo XIX fue decisiva para el desarrollo de la cultura del diseño de producto. Tuvo especial importancia el debate en torno al principio del revestimiento, aunque no se trataba sólo de aclarar las relaciones entre forma y función, sino de establecer la importancia antropológica y cultural de la disciplina. Se desarrolló la idea de que había claras conexiones entre la manera en la que tratábamos los objetos de uso y el cuerpo humano, en esa época especialmente el femenino. Se estudiará esto analizando la transformación conceptual de las relaciones de la cultura con la naturaleza entre el "Elogio del maquillaje" de Charles Baudelaire y "Ornamento y delito" de Adolf Loos.

Palabras clave: Ornamento, Revestimiento, Baudelaire, Darwin, Loos.

\begin{abstract}
The second half of nineteenth century was decisive in the development of product design culture. It was especially important the debate about the clothing principle, although it was not only about clearing up the relations between form and function but setting up the discipline anthropologic and cultural relevance. It was developed the belief that there were clear connections between how we behave towards the objects of use and the human body, at that time women's primarily. This will be studied analysing the conceptual transformation of the relations between nature and culture from Charles Baudelaire's "In Praise of Makeup" to Adolf Loos' "Ornament and Crime".
\end{abstract}

Keywords: Ornament, Clothing, Baudelaire, Darwin, Loos.

\section{Introducción}

La segunda mitad del siglo XIX fue una época relevante para la historia del diseño de producto. La inauguró la Great Exhibition de Londres (1851), el signo más claro de que la industrialización se había asentado en Gran Bretaña y se estaba internacionalizando. Cuando finalizó resultó evidente a muchos críticos, artistas, artesanos y productores que el valor estético de lo exhibido era, cuanto menos, discutible, lo que dio lugar a una serie de reacciones de las que, pasado medio siglo, surgió la Deutscher Werkbund, en cuyo seno se gestó la Bauhaus. Un elemento fundamental en este proceso fue la formulación del principio del revestimiento por parte de Gottfried Semper en 1851 (Semper 1851: 57-60), surgiendo con ello el problema de la relación entre la

* Universidad de Sevilla, España.lopezlloret@us.es

Artículo recibido: 2 de abril de 2019; aceptado: 11 de septiembre de 2019 
superficie emergente y la estructura oculta de la arquitectura y el producto (Fanelli y Gargiani 1999: 6-16).

La historiografía tradicional, a partir de la tesis clásica de Nikolaus Pevsner (Pevsner 2003: 19-39), interpretó este proceso como un problema referente a la posición del ornamento en el establecimiento de las relaciones entre la forma y la función, pero es necesario que no nos limitemos a esto. Los diseñadores (y con ellos los historiadores del diseño) se centran en los objetos y sus partes y no suelen reparar en la profundidad cultural de su trabajo. Por su parte, los filósofos (y con ellos los historiadores de las ideas) piensan en su tarea como un proceso conceptual que se encarna en la palabra y se distribuye en forma de libro. No obstante, una silla, por ejemplo, es un texto, conceptualmente no muy diferente de un libro, con el que hacemos afirmaciones sobre el comportamiento de la materia, la estructura topológica de las fuerzas y el espacio, la manera en la que vemos y tratamos nuestro propio cuerpo, el tipo de relación que impera en una sociedad y los valores culturales que se consideran más importantes en el momento de su diseño y fabricación. En este caso la técnica genera identificación personal privada y corporativa, es decir, el diseñador gestiona valores y define la relación de la cultura con las personas.

Gracias al impacto masivo que la Exposición de 1851 tuvo en el mundo occidental, así como a los debates críticos que suscitó el evento (desde John Ruskin al Deutscher Werkbund, pasando por los grupos de Arts and Crafts), la reflexión sobre el papel del diseño en la cultura fue muy intensa en la segunda mitad del siglo XIX. Entre otros temas, se suscitaron cuestiones sobre su relación con la estética, la ética y la antropología, definiéndose el diseño como un medio que ayudaba a la construcción de la sociedad y a la distribución de los distintos papeles dentro de ella, permitiendo su reconocimiento visual y gestual. A la sociedad victoriana le interesaba especialmente diferenciar lo masculino de lo femenino, concediendo un papel dominante a lo primero y un papel subordinado a lo segundo. Ilustraremos esto comparando algunas ideas de Charles Baudelaire con otras de Adolf Loos, curiosamente parecidas, pero con consecuencias culturales y sociales radicalmente diferentes.

Procederemos de la siguiente manera. En primer lugar, presentaremos y contextualizaremos brevemente la idea básica de Friedrich Schiller de que los objetos de uso que producimos asumen y expresan valores sociales éticos y estéticos, en su caso en continuidad con la naturaleza. Tras ello, nos centraremos en un capítulo de El pintor de la vida moderna (1863) de Baudelaire, el "Elogio del maquillaje", donde mantuvo dicha idea, aunque la desvinculó de la naturaleza. Tras un interludio dedicado al significado estético de las teorías de Charles Darwin, que hacían insostenibles los argumentos de Baudelaire, acabaremos con el extraordinario texto de Loos "Ornamento y delito" (1908), en el que la síntesis de estos argumentos con los presupuestos darwinianos condujo a una idea opuesta del diseño en la cultura que era, en cierto modo, una actualización de la propuesta de Schiller. Aunque esto se puede leer como un cambio en la moda que se conecta con la valoración formal del principio del revestimiento en el diseño, es, como argumentaremos en la conclusión, algo humanamente más profundo, pues el elemento fundamental en el proceso, tal y como lo vieron, aunque de diferente manera, Baudelaire y Loos, fue la transformación de la relación de la cultura occidental con los sujetos que forman parte de ella. 


\section{Dejar que las cosas sean: la heautonomía del objeto}

En la Theaterplatz de Weimar hay una conocida escultura en bronce, realizada por Ernst Rietschel en 1857, que representa a Schiller y Goethe unidos a través de una corona de laurel que los dos cogen con su mano derecha. Ambos representaban un clasicismo equilibrado y, en el caso de Schiller, socialmente comprometido. Años después, en 1929, dos de los profesores de la Bauhaus, Paul Klee y Wassily Kandinsky, se fotografiaron en Dessau imitando dicha escultura, Kandinsky como Goethe y Klee como Schiller. La Bauhaus, al igual que la República alemana que surgió de la Primera Guerra Mundial, se quería identificar con este legado equilibrado, fundándose en Weimar, en un edificio de Henry van de Velde que se halla en la Geschwister-Scho11-Straße, a unos seiscientos metros de la Theaterplatz. La conexión de Schiller con el Estilo Internacional del Movimiento Moderno es más sólida de lo que podríamos pensar, sobre todo a través de su teoría sobre el diseño de objetos de uso, pues anticipó parte de lo que sucedió a comienzos del siglo XX.

La idea de que la manera en la que tratamos los objetos puede reflejar la consideración que guardamos hacia nuestros propios cuerpos, es decir, de que el diseño de producto es un buen indicativo de cómo la sociedad y la cultura tratan a los individuos que las conforman, fue formulada por Schiller en su obra Kallias, o sobre la belleza (1793). Su planteamiento giraba en torno a la definición de la belleza de los objetos como "libertad en la apariencia" (Schiller 1990: 42-87), para lo que recurrió al análisis comparativo de la línea ondulada con la quebrada (Schiller 1990: 80-83). Aunque las líneas serpentina y ondulada provenían del Manierismo, Schiller se basó en el Análisis de la belleza (1753) de William Hogarth, conocido pintor, grabador y fundador en 1735 de la academia de diseño de St. Martin's Lane, uno de los centros de la mejor ebanistería británica.

Los motivos que llevaron a Hogarth a preferir la línea ondulada a otras fueron bastante formales y tradicionales, a saber, que en ella se daba la mejor articulación posible de la unidad con la diversidad (Hogarth 1997: 66-7), pero Schiller, sin abandonar la conexión con el diseño de producto, desde la cerámica hasta la jardinería paisajística, introdujo matices con un contenido social y antropológico más potente. Recurrió para ello al concepto de "heautonomía", procedente de la Crítica del discernimiento de Kant (Kant 2012: 222). Según Schiller, en la línea ondulada "la forma está determinada por su esencia interna" (Schiller 1990: 69), que en términos de producto se podría interpretar como el programa funcional del que fluye la forma. Creemos que Kallias se puede leer así si se atiende a los ejemplos a los que Schiller recurrió, como el siguiente:

Un recipiente es bello cuando, sin contradecir a su concepto, se asemeja a un juego libre de la naturaleza. El asa [...] existe solo a causa del uso, es decir, a través de un concepto; para que el recipiente sea bello, el asa habrá de surgir tan natural y espontáneamente de él, que haga olvidar su determinación. Pero si el asa acabara en un ángulo recto, si la amplia base del recipiente se estrechara de pronto, convirtiéndose en un cuello estrecho, y otras cosas por el estilo, esa abrupta variación de su curso destruiría toda apariencia de espontaneidad, y desaparecería la autonomía en la apariencia (Schiller 1990: 73).

Esto no era un planteamiento genérico y abstracto, pues su referente fue el trabajo con la cerámica que Josiah Wedgwood estaba haciendo en el último tercio del siglo XVIII, después de haber fundado en 1769 su fábrica de Etruria, que alcanzaría su mayor prestigio neoclásico con la réplica del vaso Barberini (o Portland) en 1790 (Brooks 
2005: 134-156). Wedgwood, de hecho, fue un referente para la cultura alemana de finales del siglo XVIII, como deja constancia un interesante fragmento de Novalis, de en torno a 1797-1798:

Goethe es un poeta totalmente práctico. Es en sus obras, como los ingleses son con sus productos, muy simple, nítido, fluido y consistente. Ha hecho en la literatura alemana lo mismo que Wedgwood en el mundo artístico inglés. Como el inglés, le ha proporcionado, a través del entendimiento, un noble gusto naturalmente económico. (Novalis 2001: 409). ${ }^{1}$

Schiller extendió estos planteamientos, surgidos directamente del diseño de producto, a la totalidad de la cultura, lo que tuvo sorprendentes implicaciones sociales y políticas, como queda claro en esta conclusión:

En el mundo estético, todo ser natural es un ciudadano libre con los mismos derechos que el más noble de los ciudadanos, y no puede ser coaccionado en absoluto, ni siquiera por causa de la totalidad, sino que él mismo ha de consentir decididamente en todo. En este mundo estético [...] incluso el chaquetón que llevo puesto me exige respeto por su libertad y requiere de mí, como un pudoroso servidor, que no haga notar a nadie que me está sirviendo (Schiller 1990: 75).

No cabe duda de que lo que se dice del chaquetón se diría también de la persona que lo viste, que no es heautónoma sino autónoma y que no es libre solo en la apariencia sino también en la esencia. Lo más perverso de todo sería que esta tuviera que subordinarse al chaquetón que viste, algo que ya trataron previamente autores conocidos por Schiller, como Hume y, sobre todo, Rousseau (López Lloret 2010: 235-70). A finales del siglo XVIII y comienzos del XIX esto definió las transformaciones de la moda femenina, llegando la mujer, según James Laver, a vestir menos ropa que nunca en la historia de Occidente (Laver 2006: 155). Desapareció el tontillo o miriñaque y se dejó de usar el corsé, recurriéndose a telas ligeras y relativamente simples e implantándose un corte recto que no reformulaba artificialmente la silueta femenina. Este respeto a la libertad del cuerpo de la mujer, que se extendió entre las modas Consulado e Imperio, provenía de afirmación de la bondad de la naturaleza, de la que la cultura debía ser una prolongación mayéutica al servicio de su manifestación y desarrollo, como plasmaron, por ejemplo, Jacques-Louis David (1800) y François Gérard (1805) en sus retratos de Madame Récamier. Pero todo esto cambió con la restauración posterior al Congreso de Viena, abriéndose una fase de decorativismo en el diseño, y nueva subordinación del cuerpo femenino en la moda, que se extendió hasta finales del siglo XIX, una de cuyas principales justificaciones teóricas fue el "Elogio del maquillaje" de Baudelaire.

\section{Maquillaje y decoración: el principio del revestimiento y el paraíso artificial}

En El pintor de la vida moderna (1863) Baudelaire analizó los apuntes gráficos de Constantin Guys, que reflejan los usos y costumbres de la sociedad europea de mediados del siglo XIX, especialmente la moda femenina. Baudelaire reconoció esto cuando

1 "Goethe ist ganz praktischer Dichter. Er ist in seinen Werken was der Engländer in seinen Waren ist -höchst einfach, nett, bequem und dauerhaft. Er hat in der deutschen Literatur das getan, was Wedgwood in der englischen Kunstwelt getan hat -er hat, wie die Engländer, einem natürlich ökonimischen und einen durch Verstand erworbenen edeln Geschmack" (Novalis 2001: 409). Traducción nuestra. 
hizo pivotar su escrito en torno al Capítulo XI, el "Elogio del maquillaje", una defensa radical de la cultura como revestimiento que, naturalmente, se extiende al diseño de producto. Sus planteamientos fueron contrarios a los de Schiller, como también lo fue su idea de la naturaleza, radicalmente opuesta a la de Rousseau:

[La naturaleza] empuja al hombre a matar a su semejante, a comérselo, a secuestrarlo, a torturarlo; pues, tan pronto como salimos del orden de las necesidades y de las obligaciones para entrar en el del lujo y de los placeres, advertimos que la naturaleza solamente puede aconsejar el crimen. Es esta infalible naturaleza la que ha creado el parricidio y la antropofagia, y otras mil abominaciones que el pudor y la delicadeza impiden mencionar. Es la filosofía (hablo de la buena), es la religión quien nos ordena alimentar a los padres pobres e inválidos. La naturaleza (que no es otra cosa que la voz de nuestro interés) nos ordena matarlos. Pasen revista, analicen todo lo que es natural, todas las acciones y deseos del hombre natural puro, no encontrarán más que horror [...] El crimen, al que el animal humano ha tomado el gusto en el vientre de su madre, es originalmente natural. La virtud, por el contrario, es artificial, sobrenatural [...] El mal se hace sin esfuerzo, naturalmente, por fatalidad; el bien es siempre el producto de un arte (Baudelaire 2005: 383-4).

En una primera aproximación, la visión que Baudelaire poseía de la naturaleza parece provenir de la prensa sensacionalista, como él mismo dejó claro cuando en la entrada XLIV de Mi corazón al desnudo se refirió a las gacetas como surtidoras de ejemplos de la perversidad humana más espantosa (Baudelaire 2009: 141). Sin embargo, si profundizamos nos topamos con la teología y con la política. Con respecto a la teología, nuestro autor afirmó sin sorna al comienzo del "Elogio del maquillaje" que uno de los errores fundamentales de su época fue "la negación del pecado original" (Baudelaire 2005: 383), lo que lo condujo al rechazo explícito de las ideas de Rousseau en su "Cohete XV", según el cual el hombre era "naturalmente depravado" (Baudelaire 2009: 57). Baudelaire fue un lector de San Agustín (Campaña 2011: 76), uno de los grandes teólogos del pecado original, quien lo analizó en su obra más relevante, La ciudad de Dios, en el marco de la contraposición entre la vida "según la carne", propia de la ciudad del hombre, y la vida "según el espíritu", propia de la ciudad de Dios (San Agustín 1965: 57-66). Baudelaire aceptó este dualismo, como muestra la entrada XI de Mi corazón al desnudo (Baudelaire 2009: 83), desarrollándolo en el "Elogio del maquillaje" como contraposición entre la naturaleza (mujer natural) y la cultura (mujer maquillada).

La visión de la naturaleza de Baudelaire remite, con todo, a otra fuente más política y antropológica, a saber, la teoría del estado de naturaleza de Thomas Hobbes. Para comprobarlo tenemos que dar un pequeño rodeo por la teoría de Baudelaire sobre la risa, según la cual "la risa viene de la idea de la propia superioridad" y "encontraremos en el fondo del pensamiento del que ríe cierto orgullo inconsciente" que se relaciona con el propio "yo" (Baudelaire 2001: 89-90). Esta es la teoría de la risa como "gloria repentina" de Hobbes, según la cual la risa es causada "por la percepción de alguna deformidad en los demás que, por comparación, hace que los que se ríen experimenten una repentina autocomplacencia" (Hobbes 2011: 58-9). Esta teoría es muy característica de Hobbes, de manera que la similitud remite a él como fuente. La risa muestra una humanidad muy poco humana y, de hecho, en el Leviatán el deseo de gloria es una de las tres causas principales de disensión que hacen que la vida natural sea una "condición llamada guerra, guerra de cada hombre contra cada hombre" (Hobbes 2011: 115), 
el conocido estado expuesto en De Cive como "bellum omnium contra omnes", en el que "todos los hombres tienen el deseo y la voluntad de hacer daño" (Hobbes 2000: 58).

No hay contradicción alguna entre el estado de pecado original propio de la ciudad del hombre y el estado de naturaleza previo al pacto social descrito por Hobbes. De la unión de ambos sale reforzado el concepto de la maldad natural, que es el punto de partida de Baudelaire. La novedad radical reside, en su caso, en la salida que propone, que no es la sociedad civil ni el estado de gracia en la ciudad de Dios, sino la implantación cultural del principio del revestimiento, cuyo paradigma es el maquillaje, el peculiar paraíso artificial que el ser humano se crea en la imagen de la mujer, que deja con ello de ser "natural, es decir, abominable" (Baudelaire 2009: 71). El maquillaje, al igual que la gracia o el pacto social, produce una cesura inmediata y un cambio de dimensión instantáneo, aboliendo u ocultando la naturaleza. Es decir, el uso de los polvos de arroz era algo de gran trascendencia:

[...] la utilización de los polvos de arroz, tan neciamente anatemizados por los filósofos cándidos, tiene como finalidad y resultado hacer desaparecer de la tez todas las manchas que la naturaleza ha sembrado de forma ultrajante, y crear una unidad abstracta en el tono y el color de la piel, unidad que, como la producida por la envoltura, aproxima de inmediato al ser humano a la estatua, es decir, a un ser divino y superior (Baudelaire 2005: 385).

En el "Elogio del maquillaje" la mujer se convierte, en cierto modo, en un "paraíso artificial". Los paraísos artificiales es una conocida obra de Baudelaire que trata del del consumo de hachís y opio para experimentar realidades alternativas. Sin embargo, hay otras formas de acceder a paraísos que conducen más allá de la inaceptable realidad, como la mujer que, maquillada y a la moda, niega explícitamente su dimensión natural. Esto legitimaba, por otra parte, la cultura del diseño basada en el principio del revestimiento, que Baudelaire identificaba, sin más, con la civilización.

Podremos comprobar eso con un par de ejemplos conectados entre sí. Comencemos con la obra de uno de los retratistas oficiales de las mujeres de clase alta en Francia durante la época de Baudelaire, Franz Xaver Winterhalter, quien hizo en 1843 (dos años antes del primer "Salón" de Baudelaire) el retrato de Leonilla Bariatinskaya, princesa de Sayn-Wittgenstein-Sayn, reclinada sobre una otomana ante un escenario opulento y tropical y rodeada de cortinas, tapices y plantas, que se halla en el museo J. Paul Getty de Los Ángeles (Aurisch et alii 2015: 124-5). Sobre la superficie impecable de su rostro se abren unos ojos cuyo negro resalta como el centro a partir del cual se extienden el rostro y el cuerpo vestido de Leonilla y, más allá, los muebles, las cortinas, las alfombras, la arquitectura y el paisaje que la rodean. La mitad superior del rostro de la retratada actuaba como una suerte de lienzo que se teñía con el reflejo del rojo de su entorno, creando una gama cromática muy del gusto de Baudelaire, quien afirmaba:

El cuanto al negro artificial que contornea el ojo y al rojo que marca la parte superior de la mejilla, aunque la costumbre proceda del mismo principio, de la necesidad de sobrepasar a la naturaleza, el resultado tiene por fin satisfacer una necesidad [...] opuesta. El rojo y el negro representan la vida, una vida sobrenatural y excesiva; ese marco negro hace la mirada más profunda y más singular, da al ojo una apariencia más decidida de ventana abierta hacia el infinito; el rojo, que inflama el pómulo, aumenta más la claridad de la pupila y añade a un bello rostro femenino la pasión misteriosa de la sacerdotisa (Baudelaire 2005: 385). 
Esto conduce al segundo ejemplo, pues tiempo después Charles Garnier tapizó de rojo las butacas de su parisino teatro de la ópera, argumentando que esto realzaba la piel de las mujeres que se sentaban en ellas: "solo el rojo puede dar lugar a esto; el brillo rosáceo que concede al rostro y los hombros de las mujeres realza su juventud y resplandor" (Garnier 1871: 177). ${ }^{2}$ Este edificio es un buen caso de paraíso artificial arquitectónico, basado en un uso obsesivo del principio del revestimiento. Cuando la Ópera Garnier, que se comenzó a construir en 1861, fue inaugurada en 1875, asombró con el dispendio de espacio dedicado al público, un mundo aparte centrado en torno a una escalera monumental que ocupaba el mismo espacio que la sala de espectáculos. Todo se cubrió con una variedad inverosímil de revestimientos: pinturas sobre lienzo, frescos, mosaicos, metales y todo tipo de piedras que instauran un espacio policromático alucinante, formado sobre la base de placas de veinticuatro tipos diferentes de granitos, brechas y mármoles, cada una con su colorido característico, desde el blanco ónix de Argelia hasta el profundo negro de Dinant, pasando por el brocatel violeta, el rojo griota, el verde de Suecia, el amarillo de Verona... (el catálogo de colores de la obra se halla en Fontaine 2018: 265-77). Si el "Elogio del maquillaje" se plasmara en arquitectura sería seguramente aquí.

Esta cultura del diseño característica del Segundo Imperio, basada en el predominio del principio del revestimiento, se extendió a todos los productos de uso que podían asumir un determinado grado de identificación personal por parte de sus propietarios: los muebles, las cristalerías, las vajillas, las lámparas, los sanitarios y cualquier otro objeto pensado para la casa de las clases medias y altas, ese trozo de paraíso que se trataba de insertar dentro de la ingrata vida de la ciudad. Para que esto resultara viable en el marco de la producción masiva de la era industrial, se compilaron catálogos de motivos decorativos extraídos de todas las civilizaciones conocidas del pasado, pudiéndose disponer libremente de ellos. Dichos motivos se aplicaban a unos objetos de uso cuya función operacional carecía de una relación lógica con su función exhibitoria, es decir, con el revestimiento que se les sobreponía. Entre estos catálogos se hallaban algunos de los libros más hermosos y técnicamente avanzados del siglo XIX, como la Gramática del ornamento (1856) de Owen Jones y El ornamento polícromo (1869-1873) de Auguste Racinet. Pese a la belleza de sus cromolitografías, estos libros servían a una cultura que estaba en el espectro opuesto de la república schilleriana, pues no dejaba que la forma de los objetos fluyera libremente a partir de su "esencia" o, si se quiere, su programa funcional. Esto se comprueba muy bien en The Art Journal Illustrated Catalogue de la Gran Exposición de Londres de 1851, que acabó con el artículo "The Exhibition as a Lesson of Taste", en el que Ralph Nicholson Wornum mostraba su insatisfacción con el resultado, dando lugar a una serie de reacciones que condujeron a la cultura alemana del diseño de producto del primer tercio del siglo XX (Wornum 1851: I $^{* *}$-XXII***).

Para comprender bien este proceso no podemos limitarnos a la historia específica de las relaciones de la estructura interna y la superficie externa del producto. Dada la conexión de la moda femenina con una visión de la naturaleza como algo brutal que ha de ser negado, hemos de centrarnos brevemente en las transformaciones sufridas

2 "Le rouge seul peut amenerà ce résultat; le reflet rosé répandu sur le visage et les épaules des femmes, contribute à leur donner plus de jeunesse et d'éclat" (Garnier 1871: 177). También, adicionalmente, escribía: "Dites-vous bien ceci, mesdames: c'est que j'ai pensé à vous en donnant à la salle du nouvel Opéra la tonalité qu'elle possède" (Garnier 2001: 127). 
por la teoría de la naturaleza en un contexto, el evolucionista, que invertía los planteamientos de Baudelaire y, con ello, ponía en duda el valor social del principio del revestimiento.

\section{Decoración, sexualidad y artificio. Interludio darwiniano}

Cuando en 1863 Baudelaire publicó El pintor de la vida moderna ya hacía cuatro años que Charles Darwin había publicado El origen de las especies (1859) y estaba trabajando en su siguiente gran obra, La variación de los animales y las plantas bajo domesticación (1868). Según Ernst Mayr (Mayr 1997: 277-298), Darwin hizo inviable cualquier visión idealista de la naturaleza. Basándose en un conjunto amplio de argumentos y temas, entre los que se hallaban las teorías sobre el desarrollo embriológico de Karl Ernst von Baer y sobre la competencia económica de Robert Malthus, desarrolló una concepción de la naturaleza en la que la lucha y el dolor tenían una importante presencia. Explicó la emergencia de las variaciones orgánicas viables como el efecto de una serie temporal abierta de ensayo y error en la que las especies se iban definiendo a través una lucha implacable y no dirigida por la posesión de los recursos alimentarios de los distintos ecosistemas. El resultado tenía matices que hacían pensar en el estado natural de lucha de todos contra todos de Hobbes y en la situación posterior a la caída en el pecado de San Agustín, aunque, obviamente, sin ningún componente político ni teológico. Pensemos en esta extraordinaria pieza retórica con la que acaba El origen de las especies:

Es interesante contemplar un enmarañado ribazo cubierto por muchas plantas de varias clases, con aves que cantan en los matorrales, con diferentes insectos que revolotean y con gusanos que se arrastran entre la tierra húmeda, y reflexionar que estas formas, primorosamente construidas, tan diferentes entre sí, y que dependen mutuamente de modos tan complejos, han sido producidas por leyes que obran a nuestro alrededor [...] la cosa más elevada que somos capaces de concebir, o sea la producción de los animales superiores, resulta directamente de la guerra de la naturaleza, el hambre y la muerte (Darwin 2003: 643).

Incluso la ribera más bucólica, pues, encierra una dura lucha a muerte sin cuartel. Darwin afirmó en su Autobiografía que uno de los motivos que le condujo a rechazar la creencia en un dios diseñador inteligente fue la observación del dolor, incluso de la crueldad en la naturaleza:

Nadie discute que haya mucho sufrimiento en el mundo. Algunos han tratado de explicarlo, con relación al hombre, imaginando que ello sirve para su perfeccionamiento moral. Pero la cantidad de seres humanos que hay en el mundo no es nada en comparación con la de los demás seres sensibles, y estos sufren a menudo muchísimo, y sin ningún perfeccionamiento moral. [Un ser tan poderoso y lleno de sabiduría como Dios, que pudo crear el universo, es para nuestras mentes finitas omnipotente y omnisciente, y nuestro entendimiento se rebela al suponer que su benevolencia no es ilimitada porque ¿qué ventaja puede haber en el sufrimiento de millones de animales inferiores durante un tiempo interminable?] (Darwin 1997: 160-1).

Uno de los ejemplos de esta brutalidad natural que más "gustaba" a Darwin era el de los icneumónidos, que, de una manera que inspiró al octavo pasajero, ponían sus huevos en las larvas de otros insectos, que así servían de alimento a sus crías. En principio, esta visión de la naturaleza podría apoyar los argumentos de Baudelaire, aunque 
Darwin derivó posteriormente el ornamento (y, sus anexos, el maquillaje y el tatuaje) a partir de esta naturaleza, no siendo su negación sino su resultado.

Darwin deseaba dar cuenta tanto del desarrollo de las formas orgánicas funcionales como del comportamiento, las costumbres, las expresiones, las formas de asociación y la cultura. Por eso atendió a las transiciones que difuminaban los límites, humanizando al animal y animalizando al humano. Se esforzó por mostrar que los animales tenían formas de asociación y valores próximos a los humanos, pero también que las formas de asociación y de evaluación humanas procedían de nuestra condición animal. Esto nos conduce a sus dos grandes obras posteriores a El origen de las especies, a saber, La variación de los animales y las plantas bajo domesticación (1868) y El origen del hombre (1871), donde dio cuenta del desarrollo de formas menos funcionales o, si se quiere, de una funcionalidad más conectada con decisiones evaluativas que remitían al capricho y al sexo, lo que tuvo consecuencias interesantes para la interpretación de la presencia pública femenina y el papel del ornamento en el contexto victoriano.

En La variación de animales y plantas bajo domesticación Darwin analizó el desarrollo de las formas de los animales a los que se había "liberado" de la guerra de la naturaleza. Las formas que surgían eran las que el ser humano, por utilidad o placer (Darwin 2008: 672), deseaba, las cuales "muestran a menudo un carácter anormal, comparado con el de las especies naturales" (Darwin 2008: 55). Es decir, la consecuencia del control humano era, en cierto sentido, la anormalidad. El caso que Darwin analizó más exhaustivamente fue el de las palomas, al que le dedicó los capítulos V y VI (Theunissen 2012: 179-212). Entre ellas se hallaban las palomas volteadoras, que según Darwin se originaron en alguna variación "semimonstruosa" (Darwin 2008: 242-243), seleccionadas por su capacidad, un tanto absurda, de dar vueltas y retroceder al volar, algo que en la naturaleza sería inviable y que solo era posible en un marco cultural y artificial. La literatura llevó esto a hipótesis extremas, como los ensayos de Des Esseintes, protagonista de $A$ contrapelo (1884) de Joris-Karl Huysmans (quien admiraba, por cierto, a Baudelaire [Huysmans 2015: 136-7]), que consideraba aburrido hacer flores artificiales que imitaran a las naturales y se complacía ante las flores naturales que, como producto de la variación bajo domesticación, imitaban a las artificiales (Huysmans 2015: 215-223), un programa que aplicó al diseño de su propia vivienda, justo cuando el Simbolismo comenzaba a dar lugar, en el ámbito del diseño de producto y de la arquitectura, al Modernismo (Torrent y Marín 2005: 122). Des Esseintes aplicó el principio del revestimiento a su tortuga, en cuyo caparazón incrustó piedras preciosas que acabaron con la vida del pobre animal (Huysmans 2015: 165-175).

Salvo insignes excepciones, que cumplían una función de imagen corporativa ciudadana en las zonas e instituciones más representativas (pensemos, por ejemplo, en las exuberantes estaciones de bombeo, como la de Crossness, construida en Londres entre 1859 y 1865, o en las impresionantes estaciones ferroviarias, cuya máxima expresión fue la londinense de Saint Pancras, que se comenzó a construir, precisamente, en 1868), la cultura del diseño más revestida se desarrolló en el ámbito doméstico, que había que diferenciar de los ingratos entornos urbanos, bautizados por Charles Dickens en Tiempos dificiles (1854) con el neologismo "coketown". La casa de las clases media y alta fue el destino del diseño más personalizado y, a la vez, el lugar que la sociedad asignó a la mujer, sobre cuyo cuerpo, por otra parte, el principio del revestimiento se desarrolló con más fuerza que sobre el hombre, para ostentar la inutilización de su cuerpo y, con ello, su condición más doméstica. Esta diferenciación funcional y exhibitoria entre la 
mujer y el hombre nunca fue tan grande como en la segunda mitad del siglo XIX, lo que tenía un contenido ostensivamente sexual, cuyo origen Darwin quiso aclarar.

Todo eso estaba en su punto álgido en 1871, cuando Darwin publicó El origen del hombre. En la segunda parte, "Selección sexual", la dimensión estética tuvo una importante presencia, derivada de los "caracteres sexuales secundarios" en el caso de los animales que se reproducían bisexualmente (Darwin 2009: 275). Uno de los casos más espectaculares era el de la diferenciación del color del macho y de la hembra en las aves, desarrollando Darwin en este caso su prosa más sugestiva y sensible, como en su minuciosa descripción de los ocelos del faisán argus macho. Afirmó que los machos exhibían su plumaje para poder aparearse, que las hembras elegían el color que más las complacía y que, con ello, iban fijando diferencialmente los motivos decorativos de aquellos. En este punto, trazó una analogía asombrosa:

El que estos adornos se hayan podido formar a través de la selección de muchas variaciones sucesivas, ninguna de las cuales estaba originalmente destinada a producir el efecto de bola y cavidad, parece tan increíble como el que una de las Madonna de Raphael se pudiera haber formado mediante la selección de pintarrajos aleatorios hechos por una larga selección de jóvenes artistas, ninguno de los cuales intentara al principio pintar la figura humana (Darwin 2009: 570-1).

Darwin no afirmaba la falta de intención en Rafael, sino que afirmaba la intencionalidad en la elección por parte de las hembras del faisán argus. En ese momento la comparación de estas con un referente casi sagrado de la cultura occidental debió resultar bastante radical, no sólo por tratarse de animales inferiores sino, sobre todo, por sus connotaciones sexuales. Se negaron a aceptarlo incluso científicos e intelectuales avanzados, como Alfred Russell Wallace (codescubridor de la teoría de la evolución) o Grant Allen. Wallace rechazó el origen sexual de las diferencias de color entre el macho y la hembra, interpretando que no había que explicar la presencia del color en el macho sino su ausencia en la hembra (Wallace 1878: 193), lo que, afirmó, no se debía al sexo sino a necesidades relacionadas con la incubación y la cría. Es decir, en lugar de la hembra sexualmente activa, Wallace propuso la madre centrada en la viabilidad de su prole. Grant, por su parte, negó en su Estética fisiológica que el placer ante el color se originara en el deseo sexual, derivándolo de la tintura de la comida, especialmente de las frutas. Su origen sería, pues, gastronómico (Grant 1877: 155-6).

Darwin no se limitó a las aves y otros animales inferiores, sino que su programa de investigación lo conducía al ser humano, cuya experiencia estética, sobre todo a través del adorno, se derivaba de la bisexualidad de su reproducción. A lo largo del proceso evolutivo el cuerpo del hombre y el de la mujer se fueron determinando según una pauta selectiva que determinó su anatomía y carácter, algo que la cultura agudizó retóricamente mediante unas prolongaciones decorativas que se explicaban, por lo tanto, a partir de la experiencia sexual. Así, según Darwin los salvajes (entre quienes Baudelaire detectó claros signos de dandismo) "tienen pasión por el adorno" (Darwin 2009: 754) como parte de su imagen personal, refiriéndose explícitamente al maquillaje:

En una parte de África los párpados se pintan de negro; en otra, las uñas se colorean de amarillo o púrpura. En muchos lugares el pelo se tiñe de diversos tonos. En diferentes países los dientes se tiñen de negro, rojo, azul, etc. (Darwin 2009: 755). En muchas ocasiones el maquillaje da lugar a la intervención física sobre el rostro 
y se fija como tatuaje o deformación más brutal: "mientras que en nosotros la cara es admirada principalmente por su belleza, entre los salvajes es el sitio predilecto de las mutilaciones" (Darwin 2009: 756). Darwin se centró en las deformaciones, un tanto sádicas, de la estructura, como, por ejemplo, en el aplastamiento del cráneo "que a nosotros nos parece [el de] un idiota", en su ahusamiento o en el aplastamiento de la nariz (Darwin 2009: 767-8). No explicó esto social y ritualmente, sino como "adorno personal, vanidad y admiración de los demás" (Darwin 2009: 758), algo que iba más allá del rostro, incluso del cuerpo, extendiéndose, como baile de apareamiento, a "los hábitos casi universales de bailar, disfrazarse y realizar toscas pinturas" (Darwin 2009: 759). En fin, en este contexto afirmó lo siguiente:

En las modas de nuestra propia indumentaria vemos exactamente el mismo principio y el mismo deseo de llevar hasta un extremo cada aspecto; exhibimos, asimismo, el mismo espíritu de emulación (Darwin 2009: 768).

Cuando Darwin se refería a "nuestra propia indumentaria" pensaba, seguramente, en el vestido femenino, pues el masculino se estaba simplificando, geometrizando y acromatizando cada vez más (Laver 2005: 202-208), es decir, no era tan "extremo" ni exhibitorio. De hecho, en el caso de la (media y alta) sociedad victoriana era la mujer quien se exhibía. Esta exhibición se basaba en el principio del revestimiento, importando tanto el cuerpo, que se sometía a deformación exageradora, como lo que se le añadía, es decir, el maquillaje y la ropa a la moda. En 1871 ya había una importante industria en torno al corsé (que era incluso objeto de ingeniería), el miriñaque y el polisón. En ese momento lo que se buscaba era generar una falda vertical por delante y abultada, de manera un tanto grotesca, por detrás, consiguiéndose que la silueta de las respetables victorianas fuera muy parecida a la de las mujeres hotentote, de las que Darwin dijo que "presentan determinadas peculiaridades, más fuertemente marcadas que las que se dan en ninguna otra raza" (Darwin 2009: 226). Tanto en el caso de las mujeres hotentote como en el de aquellas a la moda en el último tercio del siglo XIX, la explicación partía para Darwin de la misma raíz, a saber, de "la lucha general por la vida" y por conseguir "las hembras más atractivas" (Darwin 2009: 783), con las deformaciones características de un animal domesticado. Darwin fue explícito al afirmar que aquí estaba presente el mismo principio que en el arte de la cría de animales (Darwin 2009: 769), que "la cantidad de sufrimiento así causado ha tenido que ser extrema" (Darwin 2009: 758) y que, en la época primitiva, la condición de esclava de la mujer hacía que deseara "conservar su buen aspecto" (Darwin 2009: 759-60) a través de todas estas deformaciones y añadidos.

Aunque todo esto recaía sobre el cuerpo de las mujeres, el planteamiento de Darwin, a través del maquillaje, el tatuaje y la deformación corporal irreversible se podía extender a la totalidad de la cultura estética tal y como se plasmaba, por ejemplo, en la arquitectura y el diseño de los productos domésticos. En cualquier caso, la mujer maquillada del Segundo Imperio (y, por lo tanto, el principio del revestimiento) ya no podía seguir viéndose como una cesura radical que separaba a la cultura de la naturaleza brutal, sino como un desarrollo sofisticado de la necesidad que esta naturaleza tenía de seguir reproduciéndose a través de la sexualidad. No era su negación sino su culminación. 


\section{La grandeza de no poder seguir decorando}

En 1894 un influyente sexólogo, Havelock Ellis, extendió los planteamientos de Darwin hasta el formato de un libro: Hombre y mujer: estudio de los caracteres sexuales secundarios humanos. En ese momento Adolf Loos estaba experimentado la vida moderna estadounidense, pero en breve iba a comenzar su vida como escritor, conferenciante y arquitecto.

Loos es reconocido sobre todo por sus obras arquitectónicas y, en menor medida, por sus diseños. No obstante, sus escritos poseen más matices y están, por lo menos, a igual altura que sus objetos, resultando tan determinantes como ellos para las transformaciones de la cultura del diseño de producto de la primera mitad del siglo XX. Entre estos el más importante es "Ornamento y delito", donde articuló uno de los rechazos más radicales del ornamento y el revestimiento en el ámbito del diseño. Es, sin embargo, mucho más que eso, pues para Loos el producto poseía una relevancia cultural innegable, lo que resultará más claro si se parte de sus similitudes y diferencias con lo que llevamos visto, comenzando con la idea de Schiller de que la manera en la que tratamos los objetos de uso es análoga a la manera en la que la cultura trata nuestros cuerpos, especialmente (y aquí se muestra la pertinencia de Baudelaire y Darwin) el cuerpo de la mujer.

Para introducir esto es deseable que nos detengamos en un escrito anterior a "Ornamento y delito", a saber, "Moda de Señora", que apareció en Dicho en el vacío (18971900). En él podemos comprobar que su estrategia como escritor era comenzar zarandeando y escandalizando a sus lectores con argumentos sorprendentes y agresivos:

¡Moda de Señora! ¡Tú, atroz capítulo de la historia de la cultura! Cuentas a la humanidad deseos secretos. Si se hojea en tus páginas, el espíritu se estremece ante aberraciones horrorosas e inauditos vicios. Se percibe el lamento de los niños maltratados, el chillido de mujeres ultrajadas, el terrible aullido de personas torturadas, la queja de quienes mueren en la hoguera. Suenan latigazos, y el aire recibe el chamuscado olor a carne humana quemada. La bête humaine... (Loos 1993, vol. I: 140).

Cuando Loos escribió estas palabras la moda femenina estaba en una de sus fases más agresivas. No solo el estrechamiento de la cintura estaba alcanzando límites inverosímiles, sino que además el corsé empujaba hacia atrás el pubis y la columna vertebral en la zona dorsal. Aunque los añadidos seguían siendo prominentes, el diseño giraba ante todo en torno a la contorsión de la silueta, especialmente en el perfil (Laver 2005: 2015-8; Willet y Cunnington 1992: 211-2). Esto realzaba el busto y las nalgas, reflejando el interés masculino por la mujer madura, pero fisiológicamente era algo muy discutido. Loos, en concreto, vio en ello un signo del sadismo del macho adulto, parangonable con la quema de brujas o el canibalismo, ejemplos de la perversidad natural del ser humano enumerados por Baudelaire (Baudelaire 2005: 383). A diferencia de este, sin embargo, pensaba que la última manifestación de esta perversidad era la moda femenina, un artificio surgido para satisfacer a "la bête humaine". La referencia explícita a la novela que Émile Zola publicó en 1890 muestra que Loos partía de la agresividad (explícita o implícita) masculina, aunque deseaba dotar a su argumento de una relevancia cultural de mayor calado. La moda femenina y sus complementos (como el maquillaje) eran una prolongación cultural de la naturaleza bestial del ser humano, aunque Loos, tomando un camino opuesto al de Baudelaire, se esforzó por 
exonerar a la naturaleza, considerando que se trataba de un caso de selección bajo domesticación, afirmando que "somos bestias a las que se encierra en establos, bestias a las que se les escatima su alimentación natural, bestias que tienen que amar por mandato. Somos animales domésticos" (Loos 1993, vol. I: 140).

Loos creía que "el cambio en la ropa de mujer viene dictado solo por el cambio de sensualidad" (Loos 1993, vol. I: 142) y que había una conexión entre lo que la cultura, a través de la moda, hacía con el cuerpo de la mujer y lo que hacía con los objetos de uso, que a la forma imposible de "s" de la silueta femenina finisecular y los muebles, apliques y lámparas de Víctor Horta, Henry van de Velde o Héctor Guimard les subyacían las mismas ideas, tendencias y deseos. Consideraba, además, que debía evitarse tanto la deformación artificial del cuerpo femenino como el exceso decorativo de los objetos de uso, aceptando, como lo hizo Schiller, que la forma del objeto la debía determinar el programa funcional, el cual, en el caso de la mujer (como representante de todo sujeto humano subordinado), debía estar al servicio de la liberación de su cuerpo. Por eso el principio del revestimiento era inaceptable y el ornamento debía desaparecer.

Este planteamiento, cuya conexión con la remisión darwiniana de la moda de señora a la sexualidad animal es plausible, es el que define, más allá de los argumentos tópicos de la ideología funcionalista, a "Ornamento y delito". Sin negar la importancia del principio fabril en el pensamiento de Loos, se trata de algo que concede al objeto de uso significados más profundos de los que le puedan conceder sus parámetros físicos, estructurales, ergonómicos o estéticos relacionados con la economía de la producción. Esto explica en parte que Loos irrumpa en "Ornamento y delito" con un espectacular zarandeo en el que se entremezclan varias líneas argumentales, como los estudios sobre la selección doméstica y sexual de Darwin, la ley biogenética de Ernst Haeckel, la visión de la naturaleza de Baudelaire (o, tal vez, Schopenhauer) e, incluso, los ensayos sobre sexualidad de su vecino Freud, junto con, evidentemente, los argumentos más específicos del funcionalismo arquitectónico que se estaban elaborando en Estados Unidos. Pero vayamos directamente a la obertura de "Ornamento y delito":

El embrión humano atraviesa en el cuerpo de la madre todas las fases de desarrollo del reino animal. Cuando la persona nace, sus impresiones conscientes son iguales a las de un perro recién nacido. Su infancia atraviesa todas las transformaciones correspondientes a la historia de la humanidad. A los dos años ve como un papúa, a los cuatro años como un germano, a los seis como Sócrates, a los ocho como Voltaire. Cuando tiene ocho años llega a reconocer el violeta, el color descubierto en el siglo Dieciocho, pues antes el violeta era azul y el púrpura rojo. El físico muestra hoy en el espectro solar colores que ya tienen nombre, pero cuyo reconocimiento está reservado a las personas del provenir (Loos 1993, vol. I: 346).

Detengámonos aquí. Loos aplicó la ley biogenética de Haeckel (Haeckel 1889: 289315) al desarrollo biológico humano y su historia social (Masheck 2013: 104). Podemos dudar, como hizo Reyner Banham (Banham 1996: 18), de la profundidad de su pensamiento y la medida en la que comprendió unos referentes que, seguramente, asimiló en superficiales y heteróclitas charlas de café, pero eso es lo de menos, pues lo relevante es por qué recurrió a la hipótesis biogenética (y al resto de sus referentes). Esta hipótesis le permitía argumentar que las formas generadas por la cultura eran la prolongación de la naturaleza, no su negación; que los objetos de uso, por lo tanto, pertenecían a los desarrollos temporales propios de los ecosistemas culturales; y, tercero, que el desfase 
de las formas diseñadas (como sucedía con las que se subordinaban al principio del revestimiento) era algo más que una mera cuestión de moda. Este es el marco en el que se debe insertar la parte más famosa de "Ornamento y delito", donde afirmaba:

El niño es amoral. El papúa también lo es, para nosotros. El papúa mata a sus enemigos y los devora. No es ningún delincuente. Pero si la persona moderna mata a alguien y lo devora, es un delincuente o un degenerado. El papúa tatúa su piel, su barca, su remo, en una palabra todo lo que está a su alcance. No es ningún criminal. La persona moderna que se tatúa es o un delincuente o un degenerado. Hay prisiones en las que un ochenta por ciento de los presos muestran tatuajes. Los tatuados que no están en presión son delincuentes latentes o aristócratas degenerados. Si un tatuado muere en libertad, habrá muerto algunos años antes de llegar a cometer un crimen.

El impulso de ornamentarse la cara y todo lo que esté al alcance de uno es el origen del arte plástico. Es el balbuceo de la pintura. Todo arte es erótico.

El primer ornamento que nació, la cruz, tenía un origen erótico. La primera obra de arte, el primer acto artístico que el primer artista, para librarse de sus excrecencias, untó en la pared. Una línea horizontal: la mujer yaciendo. Una línea vertical: el hombre penetrándola. El hombre que lo creó sintió el mismo impulso que Beethoven, estaba en el mismo cielo donde Beethoven creó la Novena (Loos 1993, vol. I: 346-7).

El discurso es nuevamente muy sincrético, apareciendo ideas de Herbert Spencer, Cesare Lombroso, Havelock Ellis y, posiblemente, Freud (Masheck 2013: 98-9; Lubbock 1989: 171-93), ${ }^{3}$ aunque todo se articula en un argumento que busca mostrar la tesis que ya hemos referido en ocasiones, a saber, que para Loos hay conexiones entre la manera en la que tratamos los objetos de uso y en la que tratamos nuestro cuerpo y que eso tiene un origen sexual. Esto se traduce en el desarrollo de dos procesos históricos diferentes, el del arte y el del diseño de producto, con valores temporales divergentes. En 1910 Loos publicó su artículo "Arquitectura", donde separaba el arte del diseño, recurriendo de nuevo al argumento de la decoración como tatuaje que, en el mundo moderno, era inaceptable (Loos 1993, vol. II: 23-35). Herbert Spencer había escrito previamente el artículo "Uso y belleza" (Spencer 1904: 370-374), donde afirmaba que la belleza surgía cuando el uso de un objeto, norma o comportamiento dejaba de estar vigente y, sin embargo, se conservaba su forma. Es decir, la belleza era lo que los anatomistas denominaban vestigios, residuos de la naturaleza que carecían de sentido operativo en el presente. En este contexto pseudo-biológico Loos introdujo los argumentos de Cesare Lombroso y Havelock Ellis sobre el hábito de tatuarse entre los criminales en las cárceles (Lombroso 1876: 43-56; Ellis 1890: 102-108), vestigios desfasados que, al conservarse en el presente, como la deformación del cuerpo femenino en la moda o la afirmación del principio del revestimiento en el diseño, no solo habían perdido su vigencia, sino que se habían desarrollado como una perversión, es decir, como un crimen.

Loos afirmaba que la grandeza de la época moderna, basada en la producción fabril masiva, no residía en esos vestigios desfasados y perversos, sino en que había desterrado el ornamento por pura incapacidad:

Ved, esto es lo que caracteriza la grandeza de nuestro tiempo: que no sea capaz

3 Habría que estudiar qué conexión tiene la referencia a la excrecencia con los Tres ensayos sobre teoría sexual, publicado en 1905, donde Freud habló de una fase "anal" del desarrollo. 
de ofrecer un nuevo ornamento. Hemos superado el ornamento, nos hemos decidido por la desornamentación [...] Pero hay espíritus negros que no quieren tolerarlo. La humanidad debiera seguir jadeando en la esclavitud del ornamento. Las personas estaban suficientemente desarrolladas como para que el ornamento ya no les produjera sensaciones de placer, suficientemente desarrolladas como para que un rostro tatuado no despertara sentimiento estético, como entre los papúas, sino que lo disminuyera. Suficientemente desarrollada como para sentir alegría por una lata de cigarrillos lisa, mientras que no compraban una adornada ni por el mismo precio. Eran felices en sus vestidos y estaban contentos de no tener que dar vueltas con pantalones de terciopelo rojo y pasamanería de oro, como los monos de feria [...] el cuarto mortuorio de Goethe es más señorial que toda la pompa renaissance (Loos 1993, vol. I: 347-8).

Se trataba de algo más que de minimizar los recursos productivos para producir y vender a mejor precio. En realidad, todo giraba en torno al rostro, la ropa y la decoración como algo a través de lo cual la sociedad nos esclaviza. A Loos no le preocupaba solo el problema productivo de la cultura del revestimiento sino la liberación del ser humano en el seno de la sociedad. El ideario funcionalista formaba parte de esta liberación y se remontaba, de hecho, a Rousseau, lo que en ocasiones ha conducido a interpretar al ingeniero como la versión moderna del salvaje roussoniano, como planteó Adolf Max Vogt con respecto a Le Corbusier (Vogt 1998: 133-159). Se trataba, en suma, de que la sociedad no considerase a nadie un medio, sino que toda persona fuera un fin en sí, lo que para Loos y, tras él, para el Estilo Internacional del Movimiento Moderno, donde se incluía la Bauhaus, se simbolizaba con la eliminación de la cultura del revestimiento.

\section{Conclusión}

El alegato de Loos por una cultura funcional desornamentada no se quedaba en el objeto de uso, sino que implicaba la transformación social. Con sus propuestas apuntaba a la necesidad de minimizar las diferencias estilísticas que marcaban lo femenino y lo masculino como ámbitos visual y conductualmente opuestos. No era solo cuestión de que deformar la silueta de las sillas, las teteras o las máquinas de coser por cuestiones puramente estéticas u ostentatorias fuera algo indeseable en el marco industrial moderno, sino de que deformar el cuerpo humano implicaba la subordinación perversa de una parte de la sociedad a otra.

Por otra parte, Loos pensaba, al igual que Baudelaire, que la naturaleza era cruel. No obstante, como perteneciente a la cultura darwiniana, que veía la diferencia entre los sexos como un resultado de la reproducción bisexual de los mamíferos, no pensaba que fuera producto del pecado. Concebía, por eso, que la cultura del revestimiento no era una forma mágica de superar un mal metafísico y atemporal, el pecado original o la guerra de todos contra todos, en un momento puntual de ilusión estética, sino un vestigio que el proceso social evolutivo había superado y que, al mantenerse de una manera artificial, daba lugar a un trato perverso y sádico hacia el propio ser humano. Loos, quien no era un feminista decidido, pensaba que, en su propia época, esto alcanzó su máxima expresión con la manipulación del cuerpo femenino, que se plegaba a los deseos masculinos de definirlo como su "paraíso", aunque podría haberse tratado de la infancia, la clase trabajadora o cualquier otro colectivo subordinado. En este contexto, la eliminación del ornamento implicaba la posibilidad de una relación social 
más igualitaria, que comenzaba a mostrarse a través de la construcción de un mundo visual menos relacionado con las relaciones de poder. La reflexión de Loos sobre el mundo victoriano muestra que, en la historia del diseño en general (y nuestra época no es una excepción), un cambio estilístico no es solo una modificación de la moda al uso. En el nivel más superficial cambia la concepción que el diseñador tiene de las jerarquías y el equilibrio entre las distintas dimensiones del producto, pero también apoya o da lugar a una transformación social, asegurando o invalidando los roles y valores que adoptan, o a los que se han de someter, los distintos actores sociales. Después de "Ornamento y delito" la moda femenina cambió radicalmente, pero Loos planteaba problemas que iban más allá del diseño o del feminismo, que se referían a la cultura occidental en general.

Dejando de lado su estilo agresivo y meticulosamente escandalizador, Loos venía a decirnos algo que ya dijo Kant en su Fundamentación para una metafisica de las costumbres, algo que podría ser un imperativo categórico válido para los diseñadores: "todo ser racional existe como un fin en sí mismo, no simplemente como un medio para ser utilizado discrecionalmente por esta o aquella voluntad" (Kant 2015: 137). Se trata de algo que a finales del siglo XVIII ya se dejaba entrever como prioritario, pues Kant podría estar respondiendo a un diagnóstico como el siguiente, de Adam Ferguson:

Es aquí, en realidad, donde el hombre se muestra a veces indiferente y solitario y donde ha encontrado un motivo de competencia con sus semejantes; trata con ellos de la misma manera que con su ganado o con su tierra, en función de los beneficios que le reportan. Este motor tan poderoso que suponemos ha conformado la sociedad solo sirve para engendrar la discordia entre los miembros o para mantener su comercio cuando los lazos del afecto se han roto (Ferguson 2010: 61).

El pensamiento de Loos era, como los exteriores de su arquitectura, acromático, cuestión de blanco y negro, algo muy poco matizado. Eso resulta muy claro en su uso de la moda femenina de la segunda mitad del siglo XIX, que en sí misma poseía muchos más matices éticos y estéticos de los que él pareció admitir, comenzando por su prenda más señalada, el corsé (Steele 2005: 35-66). Pese a su reduccionismo y el claro desfase de sus imágenes a comienzos del siglo XXI, Loos desarrolló dos argumentos que deberían ser respetados por todos los diseñadores, en tanto que estos forman uno de los colectivos más activos y determinantes de nuestra cultura. El primero, que estuvo presente a lo largo del siglo XIX en propuestas opuestas como las de Schiller y Baudelaire, afirmaba que hay una clara unidad cultural entre la manera en la que tratamos los objetos y nuestros cuerpos; el segundo, que hemos remitido a Kant y Ferguson y que matiza al primero, afirmaba que nunca deberíamos tratar a ninguna persona como un medio. Aunque solo fuera por eso su obra, sobre todo la escrita, merece que se la siga teniendo en cuenta.

\section{Bibliografía citada}

Agustín, San. 1965. Obras de San Agustín, Volumen XVII. Madrid: BAC.

Allen, G. 1877. Physiological Aesthetics. London: Henry S. King and Co.

Aurisch, H. K. et alii. 2015. Franz Xaver Winterhalten. Maler im Auftrag Ihrer Majestät. Stuttgart: Arnoldsche Art Publishers.

Banham, R. 1996. A Critic Writes. Essays by Reyner Banham. Berkeley: University of California Press. 
Baudelaire, Ch. 2001. Lo cómico y la caricatura. Madrid: A. Machado.

Baudelaire, Ch. 2005. Salones y otros escritos sobre arte. Madrid: A. Machado.

- 2009. Mi corazón al desnudo y otros papeles intimos. Madrid: Visor.

Brooks, R. 2005. The Portland Vase. New York: HarperCollins.

Campaña, M. 2011. Baudelaire. Barcelona: Penguin Random House.

Darwin, Ch. 2003. El origen de las especies. Madrid: Alianza.

— , 2008. La variación de los animales y las plantas bajo domesticación. Madrid: Catarata.

- 2009. El origen del hombre. Barcelona: Crítica.

Darwin, Ch. 1997. Autobiografia y cartas escogidas. Madrid: Alianza.

Ellis, H. 1890. The Criminal. New York: Scribner and Welford.

Fanelli, G. y Gargiani, R. 1999. El principio del revestimiento. Madrid: Akal.

Ferguson, A. 2010. Ensayo sobre la historia de la sociedad civil. Madrid: Akal.

Fontaine, G. 2018. Charles Garnier's Opéra. A Total Work of Art. Paris: Éditions du Patrimonie.

Garnier, Ch. 2001. La nouvel Opéra. Paris: Editions du Linteau.

, 1871. Le théâtre. Paris: Hachette.

Haeckel, E. 1889. Natürliche Schöpfungs-Geschichte. Berlin: Georg Reimer.

Hobbes, T. 2000. De Cive. Madrid: Alianza. , 2011. Leviatán. Madrid: Alianza.

Hogarth, W. 1997. Análisis de la belleza. Madrid: Visor.

Huysmans, J.-K. 2015. A contrapelo. Madrid: Cátedra.

Kant, I. 2012. Crítica del discernimiento. Madrid: Alianza.

, 2015. Fundamentación para una metafisica de las costumbres. Madrid: Alianza.

Laver, J. 2005. Breve historia del traje y la moda. Madrid: Cátedra.

Lombroso, C. 1876. L'uomo delinquente. Milano: Ulrico Hoepli.

Loos, A. 1993. Escritos, 2 volúmenes. Madrid: El Croquis.

López Lloret, J. "Perversa segunda piel. Ética, estética y política en el vestido según Jean-Jacques Rousseau". Cuadernos Dieciochistas, núm. 11: 235-70.

Lubbock, J. "Adolf Loos y el dandi inglés". Pp. 173-93, en A. Pizza (ed.). Adolf Loos. Barcelona: Stylos, 1989.

Masheck, J. 2013. Adolf Loos. The Art of Architecture. London: I. B. Tauris.

Mayr, E. 1991. Evolution and the Diversity of Life. Cambridge, Massachusetts: Harvard University Press.

Novalis. 2001. Novalis Werke. München: Verlag C. H. Beck.

Pevsner, N. 2003. Pioneros del diseño moderno. Buenos Aires: Infinito.

Schiller, F. 1990. Kallias. Cartas sobre la educación estética del hombre. Barcelona: Anthropos.

Semper, G. 1851. Die Vier Elemente der Baukunst. Braunschweig: Friedrich Vieweg uns Sohn.

Spencer, H. 1904. Essays. Scientific, Political and Speculative, Volumen II. New York: D. Appleton and Company.

Steele, V. 2005. The Corset. A Cultural History. New Haven: Yale University Press.

Theunissen, B. 2012. "Darwin and his pigeons. The analogy between artificial and natural selection revisited". Journal of the History of Biology, núm. 45: 179-212.

Torrent, R. y Marín, J. M. 2005. Historia del diseño industrial. Madrid: Cátedra.

Vogt, A. M. 1998. Le Corbusier. The Noble Savage. Cambridge, Massachusetts: Massa- 
chusetts Institute of Technology.

Wallace, A. S. 1878. Tropical Nature, and Other Essays. London: Macmillan and Co.

Willet, C. y Cunnington, P. 1992. The History of Underclothes. New York: Dover.

Wornum, R. N. 1851. "The Exhibition as a Lesson on Taste". Pp. I***-XXII***, en The Art Journal Illustrated catalogue: The Industry of All Nations. London: George Virtue. 


\title{
When is Architecture not Design?
}

\section{¿Cuándo no es la arquitectura diseño?}

\author{
Saul Fisher ${ }^{*}$
}

\begin{abstract}
If there is nothing more to architecture than design -and to its attendant thinking processesthan design thinking, then core dimensions of the architectural enterprise from the perspective of (a) production and (b) use have no special character, over and above their counterparts in general design. Yet that does not appear to be true by the lights of architects or design specialists or the public at large. So what is it, at the core or periphery of the discipline or its objects, that makes architecture not design? The ways in which architecture and design constitute artistic enterprises, drawing on and promoting aesthetic interest, differ such that architecture is not, or at least not only, a branch of or variation on design generally construed.
\end{abstract}

Keywords: architecture, design, "design thinking", architectural objects, cognitive norms.

\begin{abstract}
Resumen
Si no hay nada más en la arquitectura que el diseño -y sus procesos de pensamiento concomitantesque el pensamiento sobre el diseño ("design thinking"), entonces las dimensiones centrales de la práctica arquitectónica desde la perspectiva de (a) la producción y (b) del uso no tienen un carácter especial, más allá de sus contrapartes en el diseño en general. Sin embargo, eso no parece ser cierto bajo la luz de los arquitectos o especialistas en diseño y el público en general. Entonces, ¿qué es, lo que hace que la arquitectura no sea diseño ya sea en el núcleo o la periferia de la disciplina o en sus objetos? Las maneras en las que la arquitectura y el diseño son prácticas artísticas, aprovechando y promoviendo el interés estético, difieren de tal manera que la arquitectura no es, o al menos no sólo es, una rama o variación del diseño como generalmente es entendido.
\end{abstract}

Palabras clave: arquitectura, diseño, "design thinking", objetos arquitectónicos, normas cognitivas.

A common view, in the public mind and from the perspective of some design specialists, has it that architecture is a brand of design, namely, the brand dedicated to designing the built environment. So, too, architects frequently speak of their central task in addressing architectural problems as 'designing', with the produced objects of their creativity cast as 'designs'. This much suggests that, at least as popular and specialized nomenclature has it, architecture is a special case of design (and correspondingly, that architectural objects are special cases of design objects, that architectural thinking is

* Mercy College, Estados Unidos. sfisher@mercy.edu

Articulo recibido: 1 de julio de 2019; aceptado: 17 de octubre de 2019 
a special case of design thinking, and so on). This subsumption of architecture into design, however broadly held or otherwise evidenced, nevertheless leaves a puzzle. If there's nothing more to architecture than design, and to its attendant thinking processes than design thinking, then core dimensions of the enterprise from production and use angles -architectural ethos, norms, creativity, appreciation, evaluation, and judgmenthave no special character over and above their counterparts in general design. Yet that does not appear to be true by the lights of architects or design specialists or the public at large. So what is it, at the core or periphery of the discipline or its objects, that makes architecture not design? This question may be posed relative to any number of aspects of architecture and design -social, professional, economic, pedagogic, and so on- but my focus is on aesthetic and artistic dimensions of architecture and design. The ways in which architecture and design constitute artistic enterprises, drawing on and promoting aesthetic interest, differ such that architecture is not, or at least not only, a branch of or variation on design generally construed.

To begin with, consider the space of possibilities. As a first thought, we can call 'architectural autonomism' the view that architecture as a discipline is distinct from, and not dependent on, general design as a discipline. The two disciplines may be related in some ways -for example, one may generate ideas taken up in the otherbut they have no essential bond or at least none that is definitive of the respective enterprises or joins them as one, even in part. By contrast, the anti-autonomist views include at least these options: (1) that architecture (a) simply folds into general design (d) (or, as mereologically notated, $\mathrm{Pad}$ ); (2), that design generally simply folds into architecture $(P d a)$; and (3) that architectural design can range over all other artifactual design, there being some but incomplete overlap (Oad). Let's call the Pad view 'design imperialism', and the Pda view 'Loos' foil', in honor of the Adolf Loos parable in which he mocks the architect who fashioned an exhaustive and exclusive design concept, forbidding his client from adding anything to his house. Let's call the Oad view 'spoonism', in honor of the twentieth century tradition among some architects of seeing their discipline as licensing design of all manner of artifacts, 'from the spoon to the city' (discussed below). ${ }^{1}$ There may be other variations on these possibilities; the point is to illustrate multiple ways in which autonomism can be wrong, as have indeed been asserted in various quarters. Naturally, depending on various facets of architecture and design as disciplines, there are multiple ways for autonomism to be right, as well -but I am interested in one particular path to autonomism. I argue that the core of architecture and design as disciplines is their respective sets of approaches to or ways of thinking about certain sorts of problems for which architectural objects and design objects, respectively, represent putative solutions. Further, as reflected in the fundamentally distinctive nature of the kinds of objects created in each discipline, there is a crucial lack of overlap (disjointness) in the problems these disciplines address. Their sets of approaches to or ways of thinking about such problems -that is, their respective cognitive norms and modes- differ accordingly, ruling out the possibility that architecture is a subspecies of a broader design discipline.

1 Mereologically, we can take autonomism as $\neg$ Oad (or, given disjointness as a predicate, Dad), as well as a significant instance of $\mathrm{Uad}$ (underlap) if we assume that, while architecture and design are autonomous, they also both belong to a coherently defined meta-discipline. 


\section{What is design -and is what architects do just that?}

To understand what is plausibly thought to be subsumed under what, I begin with a brief definition of architecture and a slightly less brief definition of design, both in disciplinary terms. ${ }^{2}$ We can stipulate, concisely, that architecture as a discipline is the planning for constructing the built environment, with special attention to built structures as may be habitable or otherwise occupied for the conduct of living, and as informed by aesthetic, functional, social, and other concerns and preferences. By this token, we typically think of architecture as primarily concerning free-standing buildings and the plans for them -e.g., Gaudí's Sagrada Familia in Barcelona (1882-present) or the mud brick tower houses of Shibam, Yemen (16 ${ }^{\text {th }}$ century). Secondarily, if keenly, we think of architecture as including or at least informing urban planning (e.g., Baron Haussmann's Paris renovation (1853-1870)), landscape planning (e.g., Frederick Law Olmsted and Calvert Vaux's Central Park in New York City (1858-1876)), interior planning (e.g., Louis-Charles Boileau and Gustave Eiffel's interior stairways for Bon Marché in Paris (1876)), or planning for other, related elements of the built environment.

The discipline of design, far broader in remit, is in its most general sense not tied to particular environments, sorts of structures, end-uses or end-users, or necessarily as informed by the same sorts of concerns and preferences as are central to architecture. The fabulously diverse domains of design stretch from clothing to code to milk cartons. With such extensive scope, defining design requires a greater level of abstraction, which we find in recent discussion in the philosophy of design. Here I follow, en gros, the views of Glenn Parsons (2016) and Andy Hamilton (2011).

Parsons, for his part, defines design as

1. intentional solution of a problem,

2. by creation of plans for a new sort of artifact,

3. where those plans would not be immediately seen by a reasonable person as an inadequate solution.

Correspondingly, the artifacts so created (a) solve problems, (b) are intentional, (c) consist in plans, (d) describe how to make or generate 'a new sort of thing', and (e) pass a reasonable plausibility test. The hallmark of Parsons' definition is a greatly accommodating picture of what sorts of artifacts can be designed, with a focus instead on what sort of activity or pursuit is common to all designers -namely, a kind of practically-oriented problem solving ideation. As we will see, one or another variation on this theme is extremely common in the design literature and community.

This theme is also, however, insufficient to understanding how the design discipline is commonly understood, namely, as an aesthetic enterprise. To find this aspect of design as a discipline, we turn to the definition offered by Andy Hamilton, who proposes that design comprises constructions with a central role for the aesthetic, as realized in visual, sonic, or haptic qualities. ${ }^{3}$ We can profitably put together Parsons'

2 Design is a more diffuse discipline -we know this in part just in virtue of considering the possibility that architecture might be subsumed under it- and design as a discipline is also of more recent vintage, and pursued in more diverse domains, than architecture, as traditionally conceived. A briefer thought about defining architecture may suffice in ways that would not for design.

3 Parsons rejects this view as not excluding the non-design arts, and as needlessly excluding non-artistic design, as in engineering. Parsons suggests that instead that the distinguishing feature of design (as against engineering or crafts or manufacturing) consists in the normative features of designer practice relative to practicality, user interface, and plans conception (21-24). 
and Hamilton's two views, to account for specifically artistic design. Then we get:

PHDesigns are intentional plans to solve aesthetic as well as functional problems, as engage with the senses and as may be characterized as novel and plausible. lines:

A ready move to subsume architecture under design presents itself, along these

PHA Architectural designs are intentional plans to solve aesthetic as well as functional problems of housing or other habitable spaces, as engage with the senses and as may be characterized as novel and plausible.

We can imagine more refined versions of PHA that specify in greater detail the sorts of problems that architecture addresses. In the limit, these versions will draw our attention to the many similarities that hold between the architectural and design disciplines, such as characterize (for example) their respective techniques or institutionally-designated standing qua disciplines. Thus, architecture like design draws on abstract representation through mock-ups and models -whether plastic or virtualthat prototype structures to be realized through craft or manufacture or other form of assembly. Further, architecture is frequently seen through institutional lenses -in museums, scholarly literature, journalism, and university curricula- as being allied with, or even inseparable from, the aesthetic concerns of design generally and taking up a similar or same corner of the arts -to wit, the design corner.

Yet, however refined a version of PHA as we may devise, with its attendant similarities among the disciplines, it will be wrong in two ways, one reflecting contingent facts and another on a more fundamental, conceptual plane. The contingent facts concern the practices, objects, and history of ideas in architecture and in design -I briefly review how these are distinctive and in non-trivial ways. The fundamental, conceptual story is grimmer still for the anti-autonomist: the discipline of architecture, independent of histories and cultures, aims at goals that are regularly -and likely nearuniversally- distinctive from those of design generally considered. ${ }^{4}$ As a consequence, the modes and norms of architectural cognition are not identical to those of design cognition and, per Parsons' view of the centrality of design thinking to defining design, architecture cannot be folded into design.

\section{Contingent Differences: Practices, Objects, and History of Concepts}

The contingent differences between architecture and design that I have in mind are found in the ways those disciplines are pursued professionally, the sorts of artifacts for which they provide plans or designs, and the historical discussions of each discipline. While such matters are not my core focus, they help to identify what I take to be key and ineliminable distinctions between architecture and design.

Professional practice. From a professional perspective, there are any number of similarities between architecture and design. Both are, in the main, market-driven pursuits or disciplines, although design is more directly and genetically so (see 'History of concepts', below). In both disciplines, practitioners engage with classical texts of the field that address theoretical problems and raise enduring questions, to grapple with and

4 There are exceptions and in any case one should hesitate to talk about universality among the disciplines, as socially-constructed kinds. But as such kinds go, there are distinctions in this case of a compelling, enduring, and rational character such that one would expect the distinctions, mutatis mutandis, to remain more or less in place. 
bring to life their intellectual heritage. ${ }^{5}$ And, typically, practitioners in both disciplines do not directly realize their schema or plans -designers are rarely manufacturers, and architects are rarely builders.

On the other hand, while professional design features some activities associated with professional architecture, only architecture features universal and legal responsibilities as pertain to documentation, contractual tasks, or post-construction services. In these ways, architecture is a more complex profession. So, too, are architecture's complexities greater for the prescriptive or normative character of the discipline. Architects are committed to conceiving how the built environment should look, act, and feel (Leatherbarrow, 95). The design discipline, by contrast, has a far weaker commitment in these regards -another indication of the greater extent to which design is driven by consumer preference, even as design contributes to such preference-formation.

Objects of the domain. In architecture and design alike, objects of the domain comprise the realized (built, assembled, or manufactured) objects along with the plans for their realization, and -on one construal- the ideas those plans represent, too. Moreover, plans in both domains similarly constitute prospective representations of imagined, future artifacts - moreover, in both domains such representations allow the viewer access to structures and aspects that cannot be naturally seen, as in crosssections or unusual perspectives (Leatherbarrow, 2001, 89). Although basic outlines of an ontology may appear as roughly parallel across the two domains, there are differences, as well -among both plan-objects and realized objects.

As concerns plan-objects, the main differentiating aspect of architectural representations (as against design drawings), is that owing to sheer scale and multiple levels of detail, such representations are often compound entities (such as sets of multiple drawings) or collections of perspectives dynamically generated by drawing on complex data sets (as in CAD or BIM representations). Only by taking together the full set of such representations might we have access to the entire imagined structure, and even then we may only be accessing a fragment of the whole (Hill, 1999; Leatherbarrow, 2001).

As concerns the realized objects of architecture and design, one prominent similarity in the present era is that each enjoys relations to industrial production, although historically design is almost exclusively so related. As Rappoport (2009) has noted, this close, even genetic, relationship of design to industrial production has the consequence that design objects are by their nature replicable in practice. By contrast, whereas in principle built architectural objects may be replicable -conceivably as essentially so- in practice replication rarely occurs outside of public housing or suburban developments., Other, more trivial differences among objects of the two domains typically include scale or breadth of utility. Further and more significant distinctions reflect the stable, lasting, and continual value of built structures as compared with manufactured commodities or consumer goods. Thus, whereas design is often quotidian and even more often does not age well (e.g., from plastic shopping bags

5 In architecture, for example, classical texts include Alberti's De re aedificatoria (1443-1452), or Mimar Sinan's autobiographies (Adsız Risale, Risāletü'l-Mímāriyye, Tuhfetü'l-Mi'mārīn, Tezzkiretüll-Ebniye, and TežkiretüllBünyān) (c 1588); cf. Crane, Akın, and Necipoğlu, 2006. In design, for example, classical texts are of more recent vintage and include Dresser, The Art of Decorative Design (1862) or Tschichold, Die Neue Typographie (1928). 
to ocean detritus, within weeks), architecture often aspires to create structures that aesthetically transcend their particular era and are built to last (e.g., Pyramid of Khufu at Giza (c2580-2560 BCE, or Angkor Wat (12 ${ }^{\text {th }}$ century CE). In general, architecture is not oriented towards obsolescence and instead may generate value in re-use and even in ruins (Rappoport, 2009). Yet other differences consist in the tendency of architectural objects to interact with environmental conditions and to shape space (as design objects do not), and the greater degree to which architectural objects are static and grounded in the earth; these are, however, tendencies and by degree (Rappoport, 2009).

Even as tendencies or by degrees, however, these sorts of distinctions among realized objects of architecture and design give some suggestion as to how to think about differences among the disciplines. ${ }^{6}$ If architectural objects are generally conceived of and planned for relative to long timespans, as rooted in their sites, and maintaining value over the long haul, they may feature, or require, qualities that do not pertain in the case of other, more quotidian and obsolescence-prone objects, and the ways that we approach their design may vary accordingly -perhaps systematically.

History of concepts. The histories of these two domains, loosely understood as matching to their modern disciplines, intertwines from earliest times, as seen in compendia, manuals, or other recordings of different ancient or antique traditions. ${ }^{7}$ As a modern discipline dedicated to commodity and consumer goods, design has a very recent history, rendering its traditions entirely and distinctively of recent vintage in ways that cannot be attributed to architecture, with its clear ancient roots. Design was born of the mercantile and manufacturing world of mid-eighteenth century Europe, with concomitant motives of meeting manufacture, market, and consumption needs. Design as a discipline was initially intended to augment the look, feel, build, and durability of goods, in order to signal their overall quality and thereby represent added value, drive taste, and advance socially-promoted preferences. ${ }^{8}$

Despite clear differences among the domains, distinguishing architecture from design over the course of history is muddied by several considerations. First, prior to the birth of modern design, architecture was seen as executed through design in the sense that Vasari (1568), among others, indicated: the '...visual expression of the concept" of the artist or architect. This use of 'design' -shortly thereafter transformed slightly to stand for 'building schema' or 'plans for built structures', or even 'ideas for built structures'- quickly gained currency in architectural writing. ${ }^{9}$ In some such writings, there have been notable attempts to define 'design' as indicating a particular

6 Such tendencies can be categorically determinative even as tendencies. For example: Design objects appear to be more generally what we might call maniable artifacts $(M)$, as compared with architectural objects, which more closely resemble rooted, structural artifacts $(R)$, where an artifact is $M$ iff it can be held, moved, or is pliable; and an artifact is $R$ iff it is not maniable. Now, not all structures in the built environment are Rs. Notably, transient and nomadic populations build in temporary ways sometimes to be re-created after transport (e.g., teepees); others not. That some elements of the built environment are $M$ or hybrids of $M$ and $R$ does not mean, of course, that they are not architecture. But it might mean that their design framework is, at least in part, shaped by and characteristic of non-architectural design.

7 On Greek architecture and design, cf. Vitruvius (15 BCE); on Indian architecture and design, cf. Mānasāra ( मानसार ) (sixth to eighth century CE; Acharya, 1928); on Chinese architecture and design, cf. Yingzao fashi (營造法式) (eleventh century CE; Feng, 2012). The link of Aztec architecture to design is harder to discern in writings but imagery in codices is suggestive; cf. García Ocampo Rivera (2016).

8 Cf. Sir William Chambers (1759/91), 75; Forty, 140.

9 Cf. notebooks of the seventeenth century British architect Roger Pratt (1928), who refers to designs and drafts synonymously. 
sort of architectural idea, whether related to composition (Soane, 2000); the specifically unconstructed or not-yet constructed (Scott, 1914); or the intellectual and immaterial, as characterized architectural practice increasingly divorced from construction in modern times. ${ }^{10}$

Second, after the birth of modern design, architects -individually or especially in groups and movements- have occasionally taken a great interest in pursuing design as integrated, to some degree, with architecture. Indeed, the word 'design' gained increasing currency in professional architectural circles in the West over the course of the twentieth century, as emblematic of growing interests of architects beyond the built environment and buildings in particular. Among numerous such instances, Joseph Hudnut organized all architecture-related disciplines at Harvard University into the Graduate School of Design, and in the following year brought in as Chair of the Architecture Department Walter Gropius, who subscribed to the slogan "from the spoon to the city". This slogan ("dal cucchiaio alla città"), was initially formulated by the Italian architect Ernesto Nathan Rogers (1946), as based on the similar adage, "from sofa cushions to city building" ("vom Sofakissen zum Städtebau"), formulated by the German designer Hermann Muthesius some years earlier, in announcing the Deutscher Werkbund remit $(1906,1912) .{ }^{11}$ The core notion is that architects can design at all scales, from the very small to the very large, inclusive of the standard built structures which fall somewhere in the middle of the fullest scale. In Buckminster Fuller (1949), we find a similar view, promoting 'comprehensive design', the idea that all facets of life and instruments for living are subject to design, through the guidance of social science, materials engineering, and systems analysis. Such efforts range widely -from Charles Rennie Mackintosh's nearly-practical Hill House chairs (1902) to Archigram's phantasmagoric cities of the future (1960s)- and there is no principled or practical obstacle to such pursuits in a 'spoonist' key, or overlap of architecture with design at all scales. Nor, however, is there anything in those efforts or their advocates that suggests an inherent or even compelling persistent link between the disciplines.

These differences in architectural and design practices, objects, and histories, give us ample reason to suspect PHA or anti-autonomism more generally, as contingently false. The notion that architecture is a branch of design reflects neither how the two domains or disciplines have developed, nor how they relate to one another at present; moreover, objects of the two domains frequently differ in character and nature. However, there is a yet more compelling reason to see architecture as autonomous from design, rooted in the ways that each discipline is pursued, according to what might be thought of as ways of thinking, or cognitive norms, of their respective professions.

\section{Disciplinary cognitive norms: What are design thinking and architectural thinking?}

All these differences affect the nature of architecture and design as disciplines, with

10 Cf. Forty, 137-138

11 Muthesius' Werkbund conception offered a variation on earlier motivation for design of commodities and goods: industry can mass-produce culture and art to bring standardization to manufacture of goods of increasing and intentional aesthetic quality and so promote consumption of ever-greater value. In short, aesthetic qualities continued to represent added value, but also stand as an intrinsically good quality of the manufactured product. A similar notion was adopted by the Bauhaus (as advanced by Walter Gropius and others) and by the Ulm School of Design, as advanced by Max Bill (1954); cf. Kostešić (2017). 
their attendant ways of viewing the world, of collecting and analyzing information, and of applying resulting insights to planning or designing for new artifacts that contribute to aesthetic and functional betterment. Yet it seems unlikely to devise a detailed causal mapping of contingent features of architectural and design practices to the essence of architectural practice or of design practice, if only because it seems unlikely that those practices have any such essences. There are nevertheless marks of distinction among those different practices, which we can see more readily if we take their primary charges as modes of identifying problems and seeking solutions to them. This is a notion at the heart of Parsons' view of design -therefore, as well, of PH and PHA- and reflects the package of concepts, in design literature old and new, of 'design thinking'. Much, though not all, of the history of that literature is intertwined with reflections on design thinking as specific to architecture, and teasing the two apart can be difficult. Here I assume that such literature is, on the whole, primarily intended to address the nature of design thinking generally -and only secondarily, to address the nature of architectural design thinking. This turns out to be a reasonable assumption given attempts in more recent literature to identify hallmarks of design thinking specifically associated with architecture.

What, then, is design thinking supposed to be, and how did it evolve? A most general conception of design thinking is that it offers, alternatively, descriptive or normative accounts of the sorts of thinking, and norms governing such, relative to design of artifacts- where such design carefully tracks the identification and resolution of problems.

The older literature on design thinking (1960s) traces back to Herb Simon's The Sciences of the Artificial (1969) and Christopher Alexander's Notes on the Synthesis of Form (1964). For Simon, designing is a cognitive process of feedback loops in which the designer identifies problems to be addressed and potential solutions, that are next prototyped and tested, to facilitate artifactual creation and advance our understanding from performance -which ostensibly yields new problems to be solved. In his early work, Alexander also tries to identify the flow of cognition in design thinking, rendering the problem of planning a new artifact into parts: first, assessing what its required components would be; next, identifying their needed relations; and finally, developing plans for the whole new artifact as based on a fuller grasp of those constituent elements and their logical relations. In the later A Pattern Language (1977), Alexander and colleagues appear to have abandoned a cognitivist approach to design thinking, in favor of a culturally-bound repertoire of solutions to design problems -and yet, the notion persists that design consists in identification and resolution of problems. The difference, whether an advance or otherwise, is their suggestion that we can usefully generate design efficiencies by providing solutions of a standard and ready-to-use nature.

A next, more self-aware generation of design thinking theorists -Donald Schön (The Reflective Practitioner, 1983), Peter Rowe (Design Thinking, 1987), and Bryan Lawson (How Designers Think, 1990)- seeks to identify ways of thinking special to, and common across, all design processes. Some proposed elements in their conception of design thinking are still borrowed from broader cognitive strategies. Thus, framing the problem as an initial, defining stage, as coupled with a stage of relating new problems to prior catalogued experiences, resembles Minsky's notion of representing information per stereotyped situations (1974), along with other general cognitivist theories in a Kantian 
vein posing the mental structuring of experience. Other elements are more clearly attached to specifically design challenges. Notably, a central conceptual challenge in design concerns identification of solutions in scenarios where the attendant problems have themselves not been identified, at least perspicuously. This challenge has elicited a variety of responses; in Schön, we find the suggestion that designers draw on imagination and intuition to creatively identify the broadest dimensions of a problem space ('divergence'), before focusing on prospective solutions ('convergence').

A third generation of design thinking research forks into practical, managerial advocacy on one hand and empirical studies on the other. On the advocacy side, design thinking incorporates a utility calculus -typically gauged at the individual level (particularly relative to product design) but with the assumption that in the aggregate, this totals to broad social utility. ${ }^{12}$ A further step, towards social cognition of design, has it that- along with traditional product design- problems of management, policy, and other social character can be addressed through iterative cycles of ideation and execution (Brown and Wyatt (2010); Kelley (2001)). Finally, recent empirical studies assess design thinking as specialized cognitive operations and practices, as iterations of the familiar range of such operations: gathering, storing, and retrieving information; analyzing and reasoning; accumulating and representing knowledge; developing ideas and understanding; and directing actions on the basis of intentions and synthesized understanding. Specific research in this tradition centers on such dimensions of design cognition as development of design expertise (cf. overview in Cross, 2018); apportionment of cognitive tasks over time in a given design process (cf. Huysentruyt, Lespinet-Najib, and Chen, 2012; Alexiou, Zamenopoulos, Johnson, and Gilbert, 2009); roles of the visual or of drawing in design thinking (cf. Goldschmidt, 1994); analogy, nonlinearity, or divergence in design thinking (cf. Özkan and Dogan, 2013; Nguyen and Zeng, 2012; Bila-Deroussy, Bouchard, and Diakite Kaba, 2015; and Goldschmidt, 2016); and sources of creativity and individual style (cf. Chan, 2015).

Over generations of reflection on design thinking-and particularly in contemporary empirical study- the scope of design cognition seems sufficiently broad as to range over whatever might be thought of as architectural design thinking. Indeed, some prominent design thinking scholars, as architects themselves, take architecture as the base case in design. Indeed, conceptions of architecture as focused on problem-solving are much older than the mid twentieth century design thinking tradition; as Plowright notes $(2014,25-26)$, we find talk about problem-solving in Serlio $\left(16^{\text {th }}\right.$ century) and Durand (1802-1805). More to the point, design thinking and its constituent cognitive tasks are described in intentionally abstract terms, so as to capture the broadest range of design domains and tasks. But this level of abstraction carries a risk of skimming over important and distinctive features of the given domains that span all fields in which design plays some role. This, it turns out, is true of architecture: there are aspects of architectural thinking that are so distinctive as to not be captured in design thinking.

What is architectural thinking? One tack in defining architectural thinking as distinctive is to start with the generalized problem-solving conception of design disciplines and show that architecture does not fit that conception. This is Plowright's strategy; he argues that architectural projects do not have discrete or 'containable' 
character -rather, per Rittel \& Webber (1973), such projects are typically 'wicked' problems. Further, the situation or scenarios that architectural projects address are not really solutions, after all, because they do not correspond to actual problems (Plowright, 26). Instead, Plowright says, architectural projects are responses to sets of "pressures, forces, perceptions, desires, priorities, and values" (26). What he is alluding to here as forcing non-discreteness, non-containability, and non-problem status is the extraordinarily complex nature of architectural competitions, requests for bids or proposals, and other contemporary scenarios in response to which project designs are created. The responses so crafted, Plowright proposes, are far greater in complexity than design solutions focused on 'merely' aesthetics or functionality.

Plowright's alternative picture of architectural thinking features three principal modes in which architects appeal to different norms for reasoning and starting points. First, he suggests, architects appeal to patterns and rules to determine the design; Durand (1802-05) is an early proponent and Christopher Alexander et. al. (1977) are late proponents. Second, architects appeal to a norm-guided negotiation of forces, both internal and external to the project and planned structure, as may characterize systems comprising the structure and its context -and as prompt navigating opportunities and constraints that complex projects present. Pertinent historical cases include construction of the Centre Pompidou (Beaubourg) in Paris (Renzo Piano and Richard Rogers, 1971-77) and the first and second World Trade Centers in New York (One and Two World Trade Center, Minoru Yamasaki, 1968-71; and One World Trade Center, David M. Childs (SOM), 2006-13), or reconstruction of Potsdamer Platz (Renzo Piano, Hans Kollhoff, Richard Rogers, Helmut Jahn, Rafael Moneo, et. al., 1991-present). Multidimensional cases like these show how architects gauge competing interests, preferences, and needs of varied stakeholders (as well as site- or use-specific concerns), requiring not merely sensitivity, perspective, and tact -but also adherence to rules of political engagement and negotiation, such as reciprocity, trust, fairness, or objectivity. And third, architects appeal to some central, overarching concept that drives all design or other considerations, such as are associated with ideologies like Modernist formalism or, more generically and traditionally, the parti or simple guiding idea as initially identified in the design process. Each of these norms and starting points for architectural reasoning has a variety of historical and contemporary advocates, and in the architectural design process each may be used with others, non-exclusively. That said, it is the second sort of appeal, with its emphasis on normative negotiation of forces relative to a system, that Plowright poses in particular as the sort of thinking that architects pursue in response to the complexity of scenarios they address, particularly in light of the public engagement of architects.

There is much that is correct in Plowright's proposal: as an empirical matter, these are among the norms and starting points for architectural reasoning. That said, it is not clear that these are sufficiently distinctive to separate architectural reasoning from other or generic design thinking. For one, the challenge of navigating "pressures, forces, perceptions, desires, priorities, and values" is a sort of problem, albeit of possibly varying complexity by degrees, and perhaps even by kind, frequently encountered in product, commercial, or other design. Thus, movements for socially-responsible and participatory design promote design processes that are user-engaging and communitybased, culturally and ethically sensitive, and welfare-maximizing (Papanek, 1973; Margolin and Margolin, 2002; Bannon and Ehn, 2012; Clark, 2013). The products 
of such processes optimally advance quality of life and avoid costs to humanity (e.g., energy-efficient transport or low-cost prosthetic limbs). But at all events they should demand awareness of norms for negotiating diverse interest and perspectives. Accordingly, what for Plowright represents the most distinctive aspect of architectural reasoning ends up as no more distinctive than a special sort of problem-solving in the classical framework of design thinking.

For another, while architecture features a notable complexity or non-discreteness (wickedness), it's not just those features that distinguish architecture -if they distinguish it at all- from design generally. For truly distinctive features of architectural practice and reasoning, we would do well to look at the distinctive nature of architectural objects. A different tack, then, to identifying specifically architectural thinking follows a bottom-up approach. We start with distinguishing features of architecture and see what those require in architectural thinking -and as may be unavailable in design thinking generally.

As noted in section two, numerous features of architectural objects -particularly among realized, built structures- distinguish them from other sorts of artifacts. In consideration of some such features -and yet other distinctive features of architectural objects- architectural thinking also takes on a distinctive character. Such features of built architectural objects include their (1) capacity for spatial structuring and for environmental impact (traffic, flow, and other behavior); (2) persistent, diverse, fullbody engagement of people; (3) interconnectivity with other architectural objects, to jointly constitute networks of architectural objects and topographical and social context; and (4) prospectively lengthy lifespan and flux over that lifespan. All these features in turn motivate a fifth feature -but of architectural representational objectswith potential to drive distinctive sorts of reasoning in architecture. This fifth feature is the quality of architectural plans of being neutral, open, or extensible so as to accommodate future activity, behavior, choices, and change. Architects need plans to be not-fixed, to the greatest extent possible, to account for the nature of built architectural objects lasting for what may be a very long time, with the various capacities for openended engagement with users and surroundings even during the planned program for the built objects, and with re-use possibilities that are perforce unknown. Plowright is correct to highlight the non-discrete and non-containable nature of architecture; however, his focus on those features of scenario prompts (in effect: design challenges or problems) doesn't provide architectural thinking with a mark of distinction. The non-discrete and non-containable nature of the possible responses or solutions -that is, built architectural objects and their corresponding plans- however, does.

\section{Architectural Thinking as Distinctive}

In light of these special features of architectural objects, at least two aspects of architectural thinking distinguish it from design thinking generally.

For one, the open-ended, indeterminate nature of the life of a built structure means that architectural thinking should allow for recalibration of the knowledge base, of understanding, and of ideas regarding that structure. This is to accommodate new information introduced at any stage of the designing process or subsequent to it, from construction through the course of the structure's lifespan. For example, architects routinely orchestrate on-site changes as prompted by site- or construction-driven needs 
and requirements. ${ }^{13}$ A designer of pencils or wall brackets has a limited role in this regard-limited, that is, by the nature of the objects, their expectable re-use and life cycle, and their manufacture (and patent rights) as much as by anything else. Design thinking likely incorporates feedback on something like the Simon model, but does not incorporate recalibration as in architectural thinking. ${ }^{14}$ The recalibration built into architectural thinking anticipates and facilitates re-use over the long haul-namely, for the same designed artifact, at least as concerns the same version.

For another, and of greater import, design and architecture feature entirely different sorts of solution-types. General design produces schema for broadlyapplicable, complete, and fixed solutions to problems. Thus, for example, the designs for the Helvetica font (Max Miedinger and Eduard Hoffman, 1957) or the K-brick (Anna Keichline, 1927) addressed practical challenges with design solutions that were deployable across a wide variety of contexts, because mass produced and simple to distribute; were self-contained, in that execution on the design realized or produced the whole item; and non-extensible, in yielding more or less the functionality for which they were designed -and no more. Not all of general design may have all of these features yet they appear to be broadly characteristic. It is a further question as to whether such features represent constraints on aesthetic intentions or appreciation relative to general design, as much as they do on the functional character of designed objects.

By contrast, architecture produces plans that (a) while they may be broadly applicable, also may only be applied once and in a given context; (b) may be incomplete solutions; and (c) are almost never fixed solutions. As concerns (a), built structures may come in multiples but even an architectural plan specifying multiple structures may only eventuate in one instance being realized. As concerns (b), the incompleteness of architectural solutions is evidenced by the contributions of contractors in contemporary construction, who make any number of changes to build structures under development, as supplemental to highly detailed specifications drawn up by architects. ${ }^{15}$ And as concerns (c), every extension ever added to a house, castle, factory, or museum is a case of what was, in its initial plan, a non-fixed solution to the initial design challenge. All such cases point to solution-types that shape architectural thinking as approximations addressing an indefinite future, in contrast with solutiontypes that shape design thinking as viable schema for present use and experience.

13 As Leatherbarrow notes, Vitruvius himself highlights the role of architects in making adjustments to buildings under construction.

14 One regular exception here is code design, which often shares with architecture the characteristic feature of open-ended, indeterminate life-cycle -though typically in the case of code, lifecycle is far more constrained than in the architecture case, by external factors such as rapid change in programming environments, viz. platforms and languages.

15 What architects call 'design intent' illustrates the incompleteness of solutions in architectural design (Grondzik 2004). The intent is more detailed than the project programme or brief, which outlines the nature of the structure to be built and the basic goals and requirements for the building project. Further details of design intent spell out how, from the architect's perspective, the built structure would realize those goals and meet those requirements in the resulting spaces, with the forms so created, and in terms of necessary systems. All of this, however, is significantly less detailed than more granular solutions provided in further stages of defining technical specifications ('specs') and construction or contractor details. There is, in fairness, a great deal of flux historically and at present as to where the architect's job ends and the technical detailer's job begins. Yet the basic notion of design intent is that the architect's core design idea is at a level of detail that, being highly incomplete, allows for multiple -perhaps very many -modes of realization. 


\section{Conclusion}

In light of the nature of its objects, representational or built, architecture has at least these attendant cognitive norms: requiring recalibration in thinking about plans for a given built structure, and reasoning to solutions that are incomplete or non-fixed. Given the $\mathrm{PH}$ view of design, those norms appear sufficient to embracing autonomism. The problem for the anti-autonomist, in short, is that design cannot subsume architecture if design thinking cannot accommodate all of architectural thinking, and architecture's varying cognitive norms indicate that such accommodation is not possible.

On the other hand, it may be thought that, rather than taking these features of architectural objects and architectural cognitive norms, plus the $\mathrm{PH}$ view of design, as evidence for autonomism, we should sooner throw out or amend $\mathrm{PH}$ (or, in particular, Parsons' view). Thus, given the open-ended nature of architectural solution-types that drives a sort of reasoning distinctive to architecture, Parsons' plausibility test is not easily gauged in the moment, at creation of the plan or schema -and is nearly impossible to gauge for the long term- in light of the high incidence among built architectural objects of re-use, disuse, destruction, or even simpler changes. On the other hand, many built structures last over great timespans and many more still are built to do so. So the very notion of a plausibility test may be untenable, if we insist that architectural reasoning is a species of design reasoning generally.

That approach, however, requires tinkering with a view about the nature of design that appears to cover just about all standard cases, once we exempt architecture from the ranks of general design. Aside from posing a less costly solution, we have ample reason to take architectural objects, the solution-types they represent, and the corresponding cognitive norms of architecture, as distinctive enough to mark them as autonomous from design as a whole.

\section{Bibliography}

Acharya, P. K. 1928. Indian Architecture according to Mānasāra-śilpaśāstra [Mānasāra English trans.]. London: Oxford University Press.

Alexander, C. 1964. Notes on the Synthesis of Form. Cambridge, MA: Harvard University Press.

Alexander, C., Ishikawa, S., \& Silverstein, M. 1977. A Pattern Language: Towns, Buildings, Construction. Oxford and New York: Oxford University Press.

Alexiou, K., Zamenopoulos, T., Johnson, J. H., \& Gilbert, S. J. 2009. "Exploring the Neurological Basis of Design Cognition Using Brain Imaging: Some Preliminary Results", Design Studies, Volume 30, Issue 6: 623-647.

Bannon, L. J. \& Ehn, P. 2012. "Design Matters in Participatory Design", 37-63, en J. Simonsen \& T. Robertson (eds.). Routledge International Handbook of Participatory Design. London and New York: Routledge.

Bila-Deroussy, P., Bouchard, C., \& Diakite Kaba, S. 2015. "Addressing Complexity in Design: A Systemic Model of Creativity and Guidelines for Tools and Methods". International Journal of Design Creativity and Innovation, Volume 5, Issue 1-2: 60-77.

Brown T. \& Wyatt J. 2010. "Design Thinking for Social Innovation", Stanford Social Innovation Review,

https://ssir.org/articles/entry/design_thinking_for_social_innovation.

Chambers, W. 1825 [1759/91]. A Treatise on the Decorative Part of Civil Architecture. London: Priestly and Weale. 
Chan, C.-S. 2015. Style and Creativity in Design. Springer International Publishing.

Crane, H. \& Akın, E. (eds. and trans.); Necipoğlu, G. (intro.). 2006. Sinan's Autobiographies. Five Sixteenth-Century Texts. Leiden: Brill.

Clark, B. 2013. "Generating Publics through Design Activity", 199-215, en W. Gunn, T. Otto, \& R. C. Smith (eds.). Design Anthropology: Theory and Practice. London and New York: Bloomsbury Academic.

Cross, N. 2018. "Expertise in Professional Design", 372-388, en K. A. Ericsson, R. R. Hoffman, A. Kozbelt, \& A. M. Williams (eds.). Cambridge Handbook of Expertise and Expert Performance ( $2^{\text {nd }} e d$.). Cambridge, UK: Cambridge University Press.

Dresser, C. 1862. The Art of Decorative Design. London: Day and Son; 1977. Reprint edition, New York: Garland Publishing Company.

Durand, J.-N.-L. 1802-05. Précis des Leçons d'Architecture Données à l'École Royale Polytechnique. Paris: chez l'auteur.

Feng, J. 2012. Chinese Architecture and Metaphor: Song Culture in the Yingzao Fashi Building Manual. Honolulu: University of Hawai'i Press.

Forty, A. 2000. Words and Buildings: A Vocabulary of Modern Architecture. London: Thames \& Hudson.

Fuller, R. B. 1949. "The Comprehensive Designer", 243-47, en J. Krausse and C. Lichtenstein (eds.). 2001. Your Private Sky: R. Buckminster Fuller Discourse. Baden: Lars Müller Publishers.

Goldschmidt, G. 1994. "On Visual Design Thinking: The Vis Kids of Architecture", Design Studies, Volume 15, Issue 2: 158-174.

— , 2016. "Linkographic Evidence for Concurrent Divergent and Convergent Thinking in Creative Design", Creativity Research Journal, Volume 28, Issue 2: 115122.

Grondzik, W. 2004. "Design Intent", 43, en Tom Porter (ed.), Archispeak: An Illustrated Guide to Architectural Terms, London and New York: Taylor and Francis.

García Ocampo Rivera, A. M. 2016. Towards an Understanding of Aztec Architecture and Urban Planning, doctoral dissertation, The University of British Columbia.

Garud, R., Jain, S., \& Tuertscher, P. 2008. "Incomplete by Design and Designing for Incompleteness", Organization Studies, Volume 29, Issue 3: 351-371.

Gropius, W. 1955. Scope of Total Architecture. New York: Harper \& Brothers Publishers. Hamilton, A. 2011. "The Aesthetics of Design", 51-69, en J. Wolfendale \& J. Kennett (eds.), Fashion-Philosophy for Everyone: Thinking with Style. London: Blackwell.

Hill, R. 1999. Designs and Their Consequences, New Haven, CT and London: Yale University Press.

Huysentruyt, J., Lespinet-Najib, V., \& Chen, D. 2012. "A Model of Cognitive Activities in Design", 9th International Conference on Modeling, Optimization \& SIMulation, Jun 2012, Bordeaux, France.

Kelley, T. 2001. The Art of Innovation: Lessons in Creativity from IDEO, America's Leading Design Firm. New York: Currency/Doubleday.

Kostešić, I. 2017. "Sveobuhvatni Dizajn: Podrijetlo i Razvoj Ideje" (Comprehensive Design: The Concept - Its Origin and Evolution), Prostor, Vol. 25, Issue 1 (53): 128-139.

Lawson B. 2005 (1980). How Designers Think: The Design Process Demystified, Fourth edition, Amsterdam and Boston: Architectural Press (Elsevier).

Leatherbarrow, D. 2001. "Architecture Is Its Own Discipline", 83-102, en A. Piotrowski 
and J. W. Robinson (eds.), The Discipline of Architecture, Minneapolis, MN and London: University of Minnesota Press.

Loos, A. 1900. "The Story of the Poor Little Rich Man", 124-127, en Newman, J. O. \& Smith, J. H. (trans.); Rossi, A. (intro.). 1982. Adolf Loos, Spoken into the Void: Collected Essays, 1897-1900. [Translation of A. Opel (ed.) 1921. Ins Leere Gesprochen: Gesammelte Schriften, 1897-1900. Vienna: Georg Prachner.] Cambridge, MA: Opposition Books, The MIT Press.

Margolin, V. \& Margolin, S. 2002. "A 'Social Model' of Design: Issues of Practice and Research". Design Issues, Volume 18, Number 4: 24-30.

Minsky, M. 1974. "A Framework for Representing Knowledge", MIT-AI Laboratory Memo 306 (June 1974), 95-128, en J. Haugeland (ed.). 1981. Mind Design. Cambridge MA: The MIT Press.

Muthesius, H. 1912. "Wo stehen wir? Vortrag, gehalten auf der Jahreversammlung des Deutschen Werkbundes", Jahrbuch des Deutschen Werkbundes: 11-26.

Nguyen T. A. \& Zeng Y. 2012. "A Theoretical Model of Design Creativity: Nonlinear Design Dynamics and Mental Stress-Creativity Relation", Transactions of the SDPS: Journal of Integrated Design and Process Science, Volume 16, Issue 3: 65-88.

Özkan Ö. \& Dogan F. 2013. "Cognitive Strategies of Analogical Reasoning in Design: Differences Between Expert and Novice Designers". Design Studies, Volume 34, Issue 2: 161-192.

Papanek, V. J. 1973. Design for the Real World: Human Ecology and Social Change. New York: Pantheon Books.

Parsons, G. 2016. The Philosophy of Design, Cambridge, UK and Malden, MA: Polity.

Plowright, P. D. 2014. Revealing Architectural Design: Methods, Frameworks and Tools. London and New York: Routledge.

Pratt, R. 1928. The Architecture of Sir Roger Pratt, Charles II's Commissioner for the Rebuilding of London after the Great Fire: Now printed for the First Time from His NoteBooks. R. T. Gunther (ed). Oxford: Oxford University Press.

Rappoport, A. 2009. “Архитектураидизайн-конфликтилимирноесосуществование?” (Architecture and Design - Conflict or Peaceful Coexistence?), en проект байкал (Project Baikal), архитектура vs дизайн (Architecture vs Design), Issue 22: 135137. doi:10.7480/projectbaikal.22

Rittel, H. W. J. \& Webber, M. W. 1973. "Dilemmas in a General Theory of Planning”, Policy Sciences, 4, 155-169.

Rogers, E. N. 1946. "Ricostruzione: dall'Oggetto d'Uso alla Città", Domus, 215: 2-5.

Rowe, P. G. 1987. Design Thinking. Cambridge, MA: The MIT Press.

Schön, D. 1983. The Reflective Practitioner: How Professionals Think in Action, New York: Basic Books.

Scott, G. 1914/1924. The Architecture of Humanism. New York: C. Scribner's Sons, 2nd edition; 1954. Reprint edition, Garden City, NY: Doubleday.

Simon, H. A. 1969. The Sciences of the Artificial. Cambridge, MA: The MIT Press.

Soane, J. 2000. Sir John Soane: The Royal Academy Lectures, Revised \& Abridged Edition. D. Watkin (ed.). New York and London: Cambridge University Press.

Tschichold, J. 1928. Die Neue Typographie: Ein Handbuch für zeitgemäß Schaffende. Berlin: Verlag des Bildungsverbandes der Deutschen Buchdrucker; R. McLean (trans.), R. Hendel (foreword), R. Kinross (intro.). 2006. The New Typography. Berkeley: University of California Press. 
Vasari, G. 1568. Lives of the Artists. 1991. J. Conaway Bondanella \& P. Bondanella (trans.). New York and Oxford: Oxford University Press.

Vitruvius. 15 BCE. De architectura; Ten Books on Architecture, 1914, 1960. M. H. Morgan (trans.), Cambridge, MA: Harvard University Press; New York: Dover. 


\title{
Diseño y habitabilidad: una aproximación basada en los lenguajes de patrones
}

\section{Design and habitability: an approach based on pattern languages}

\author{
Antonio Hidalgo Pérez
}

\begin{abstract}
Resumen
En este texto se presenta un marco de trabajo inicial de lo que entendemos como una teoría del diseño basada en los lenguajes de patrones. Esta teoría del diseño se incluye dentro de una reflexión más amplia sobre las condiciones de habitabilidad de nuestra especie. Reflexión que denominamos "filosofía del habitar o de la habitabilidad". Con ese objetivo, recuperamos algunas de las investigaciones del arquitecto y urbanista Christopher Alexander. Argumentamos a favor de una pequeña corrección del modelo que él propone para analizar los patrones. Complementamos esta reflexión reclamando pensar el diseño dentro de una teoría de las necesidades (Max-Neef) y un enfoque basado en procesos (Reschel). Todo ello acuerdo con una perspectiva que asume rigurosamente los límites biofísicos del planeta. Se trata, por tanto, de avanzar en un programa de investigación sobre el diseño de habitabilidades ecológicamente viables.
\end{abstract}

Palabras clave: patrones, diseño, habitabilidad, necesidades, procesos.

\begin{abstract}
In this text, an initial framework of what we understand as a theory of design based on pattern languages is presented. This theory of design is included within a broader reflection on the habitability conditions of our species. A reflection that we call "Philosophy of the Inhabiting or of the livability". With that goal, we recover some of the researches of the architect and town planner Christopher Alexander. In addition, we argue in favor of a small correction of the model he proposes to analyze the patterns. We complement this reflection by claiming to think the design within a theory of needs (Max-Neef) and a process-based approach (Reschel). All this in accordance with a perspective that rigorously assumes the biophysical limits of the planet. That is, therefore, a question of advancing in a research programme on the design of ecologically viable habitats.
\end{abstract}

Keywords: patterns, design, needs, livability, processes.

\section{Introducción}

Desde la década de los sesenta, pero especialmente en los años setenta, el arquitecto y urbanista Christopher Alexander elabora una interesante reflexión sobre lo que denomina "lenguajes de patrones". Nos referimos a obras como El orden intemporal de construir (1971), El experimento de Oregon (1975) y Un lenguaje de patrones (1979). En línea con otros autores que ya han advertido sobre su interés filosófico (Broncano 2000),

* IES Juan Carlos I, Murcia, España. antonhida.p@gmail.com

Artículo recibido: 22 de julio de 2019; aceptado: 18 de octubre de 2019 
consideramos que muchas de las ideas que Alexander presenta en sus obras deben ser recuperadas y ampliadas en el sentido particular de una filosofia de la habitabilidad, en cuyo centro se encuentra el problema del diseño de patrones y, por extensión, el de la gobernanza de las ciudades. Se trataría de iniciar un programa de investigación sobre nuestros estilos habitacionales, en un momento en el que se multiplican los riesgos derivados de la crisis ecológica global, la desigualdad planetaria creciente y los desarrollos de la tecnociencia (Riechmann 2014).

Dado ese objetivo, en este artículo comenzamos presentando un modelo de interpretación de esos patrones, que nos han de servir como instrumentos de racionalidad. Proponemos, a continuación, examinar la práctica del diseño a la luz de una concepción de las necesidades humanas según el modelo de Max-Neef $(1986,1998)$, ofreciendo así un posible desarrollo de la relación entre ética y diseño. Por supuesto, la satisfacción de necesidades no es el único factor determinante del diseño de patrones: también lo son los límites biofísicos del planeta, tema que aquí, sin embargo, quedará tan sólo apuntado. No obstante, planteamos al final un marco general de la filosofía de la habitabilidad basado en cuatro dominios habitacionales básicos, que ha de permitir integrar y ordenar las cuestiones tratadas hasta el momento. Apoyándonos en el enfoque procesual de Reschel (2000), esta parte facilitará, a su vez, corregir parte de la teoría de las necesidades introduciendo lo que denominamos "procesos de orden pragmático"; es decir, los patrones de acción a los que el diseño tiene la tarea de dar una determinada infraestructura.

Consideramos que este marco de trabajo, del que aquí presentamos sólo una pequeña parte, permite a la filosofía evitar las frecuentes discusiones "semánticas" sobre la ciudad y comenzar a elaborar un orden común de discusión para dar cuenta del problema de la habitabilidad desde un punto de vista no sólo crítico, sino también constructivo.

\section{Patrones como unidades mínimas de organización de lo habitacional}

¿Por qué es importante definir un modelo al hablar de patrones? Lo primero, porque un modelo sirve como filtro para obtener información relevante y suficiente, o que se juzga como tal, sobre aquello que se desea investigar. Los criterios utilizados en su elaboración nos han de proporcionar una perspectiva, y si esta perspectiva no responde adecuadamente a la complejidad del objeto de investigación, la información que manejemos puede resultar escasa e inducir planteamientos incorrectos. Nuestro objetivo es poner en el centro de la reflexión filosófica el problema de la habitabilidad. Por tanto, si tenemos razón al afirmar que los patrones son las unidades mínimas de organización de lo habitacional, esto es, que no existe forma de habitabilidad que no se presente organizada según un determinado conjunto o lenguaje de patrones, lo primero que debemos hacer es explicar en qué consisten éstos en términos estructurales. El modelo propuesto nos permitirá entonces disponer de un primer marco para pensar lo habitacional y establecer las bases críticas del diseño. Lo que sería un diseño de habitabilidades ecológicamente viables.

Pero antes de presentar nuestra propuesta (apdo. 2.1), en la que argumentamos a favor de corregir el modelo a tres niveles de Alexander por otro de cuatro niveles o dimensiones estructurales, quisiéramos recordar algunas de las razones que justifican ordenar la reflexión sobre la arquitectura y el urbanismo desde un enfoque basado en los lenguajes de patrones. Posteriormente (apdo. 2.2), utilizaremos el modelo 
propuesto para deducir cuatro categorías básicas de la pragmática del diseño. El hilo de la argumentación nos ha de conducir, desde aquí, a la identificación de algunos principios de orden constructivo, como el principio de limitación, cuya introducción servirá de puente entre el análisis estructural de los patrones y la reflexión sobre patrones y necesidades que ocupa la segunda parte de este artículo.

Al introducir la cuestión de los patrones, Alexander no se fija en ningún estilo arquitectónico particular, sino más bien en la forma de adaptarse al medio natural que demuestran todas las sociedades humanas. Esta adaptación se concreta, siempre, mediante la configuración de un entorno que se entiende como "artificial". Un pozo, una casa, un camino. Estilos de adaptación, a los que Alexander se refiere, en términos generales, como "modos de construir" que varían de una cultura a otra, pero tienen en común, sin embargo, que se despliegan y objetivan a través de múltiples "estructuras físicas", de elementos que se entrelazan unos con otros en tanto que "componentes fundamentales de la construcción" (1981: 24). Pues bien, tales estructuras o componentes, en tanto que unidades mínimas de cualquier organización de la vida individual y colectiva, son lo que Alexander denomina patrones. En este sentido, los patrones son las condiciones de posibilidad de cualquier régimen de habitabilidad. De ahí la centralidad del diseño: es parte integral del proceso mismo de habitar. Así pues, más allá de las particularidades de cada uno, el enfoque basado en los lenguajes de patrones proporciona ese orden común de discusión al que nos referíamos antes porque nos permite elaborar un marco teórico fundando sobre aquello que comparten todos los modos de construir que conocemos.

Aunque sin profundizar en ello ni explorarlo con el rigor necesario, ${ }^{1}$ Alexander reconoce que los patrones que dan sentido y "carácter" a un lugar, no son necesariamente patrones de carácter físico o patrones relativos a la acción humana. Los patrones que Alexander denomina "de acontecimientos" hacen referencia al conjunto de eventos o sucesos de orden natural, mecánico o social, de los que depende el frágil equilibrio o identidad de este o este lugar:

El paso de los trenes, la caída del agua, el lento agrietarse de las estructuras, el crecimiento de la hierba, el derretimiento de la nieve, la oxidación del hierro, el florecimiento de las rosas, el calor de un día de verano, cocinar, hacer el amor, jugar; y no sólo los acontecimientos de nosotros mismos sino de los animales, de las plantas, incluso de los procesos inorgánicos (1981: 66).

En cierto modo, estos patrones de acción se podrían interpretar en términos de "habituaciones", según los planteamientos sociológicos de Luckmann y Berger (2001). Tampoco resultaría difícil ampliar esta noción con las importantes aportaciones de Marcel Mauss (1979), Pierre Bourdieu o, más recientemente, Ingold (2008: 1-35). Las "técnicas corporales" del primero o la noción de "habitus" del segundo explican bastante bien esa idea de los patrones como formas, antropológica e históricamente determinadas, por medio de las cuales ordenamos generativamente nuestras acciones. Como diría Bourdieu, los patrones de acción conforman "sistemas de disposiciones duraderas y transferibles",

1 Al final presentamos una versión ampliada de estas ideas de Alexander. Apoyándonos en Reschel (2000), distinguimos cuatro tipos de estructuras procesuales (de orden natural, técnico, pragmático y sistémico), y damos contenido a los terceros (es decir, a los patrones de acción) identificando cuatro modalidades: patrones de concentración, de conservación, de dispersión y de generación. 
en las que se juega tanto lo que nuestra experiencia tiene de "estructurado", puesto que son producto de las historias y los contextos a los que pertenecemos, como de capacidad "estructurante", dado que también tenemos la capacidad de autocorregirnos, modificar nuestros patrones o modos de relación, y coordinarnos bajo apreciaciones y objetivos distintos (2007: 86). En palabras de Alexander: "Ellos [los patrones] son las reglas a través de las cuales nuestra cultura se conserva y se mantiene viva, y somos seres de nuestra cultura estructurando nuestras vidas a partir de estos patrones de acontecimientos" (1981: 68). Todo ello concuerda, además, con la idea desarrollada por Lahire acerca de nuestra condición de "actores plurales", formados en "una pluralidad de mundos sociales no homogéneos" a los que debemos la pluralidad de repertorios de acción que ponemos en funcionamiento día a día:

Los repertorios de esquemas de acción (de hábitos) son conjuntos de compendios de experiencias sociales que han sido construidos-incorporados en el curso de la socialización anterior en marcos sociales limitados-delimitados; y lo que cada actor adquiere progresivamente, y de un modo más o menos completo, son tanto unos hábitos como el sentido de la pertenencia contextual (relativa) de su puesta en práctica (2004: 55).

Al hablar de patrones nos encontramos ante un repertorio pragmático de nuestra especie, esos elementos o "resortes" que encontraríamos en cualquier inventario sobre las "formas de ser que existen en el mundo", dirá Alexander. Una suerte de condensadores de las memorias, experiencias, procesos de socialización, proyectos comunes, etc., explica Lahire, que nos distinguen como individuos, miembros de una cultura y una especie, y por medio de los cuales desplegamos las secuencias o cursosde-acción propios de nuestros estilos o culturas habitacionales. "Cada persona dentro de una cultura vive su vida pasando de una situación a otra, la construye como una suerte de collar en la que se van enhebrando todas aquellas situaciones que están a su alcance" (1971: 113).

Ahora bien, como es evidente, tales patrones o formas de vida dependen necesariamente de multitud de infraestructuras, los "esquemas de espacio" a los que también se refería Lefébvre: "Esquema generador ligado a una praxis, a una realidad y a una verdad dentro de los límites de una sociedad" (1976: 38); o Goffman al hablar de los "anclajes de nuestros haceres" como parte de la dimensión logística, fundamental para entender su idea de "marcos sociales" (2006: 260). En este sentido, diríamos que las sociedades humanas, vistas desde la perspectiva de sus repertorios y secuencias de acción, recrean a través de sus lenguajes de patrones los "cuadros espaciales que sus conductas requieren", como observa Alexander. Se podría hablar, siguiendo a Lukács, de "legalidades objetivas del ser social" o "formas de objetividad del ser social que crecen en el cauce de la emergencia y del despliegue de la praxis social" (2007: 77). Todo lo cual permite pensar los lenguajes de patrones espaciales como conjuntos de "categorías culturalmente definidas en el espacio", donde "cada una de ellas define una actitud o un lugar o una cosa y sus respectivos comportamientos humanos" (1971: 96). "Por esta razón -concluye Alexander-, expreso que el planeamiento de una ciudad es el diseño de la cultura" (1971: 113). En este sentido, escribe Broncano:

La idea de cultura como conjunto de redes de posibilidades prácticas nos permitirá aproximarnos a la idea de artefacto desde la perspectiva de las posibilidades prácticas 
determinadas por (y determinantes de) las capacidades humanas. Los artefactos constituyen los portadores de los espacios de posibilidad que los humanos crean. No son meras affordances físicas, ni siquiera affordances meramente funcionales, son redes de sentido que actualizan las trayectorias que constituyen la vida humana (2009: 55).

Por tanto, si queremos disponer de una teoría del diseño de tales infraestructuras habitacionales, capaz de servir como programa a la vez crítico y constructivo, un ejercicio fundamental será determinar lo que se entiende por patrones, explicar en qué consisten las unidades mínimas de las que se componen dichas infraestructuras.

2.1. Un modelo de cuatro dimensiones: constitutiva, compositiva, morfológica y valorativa.

¿Cuál es la posición de Alexander? ¿Qué definición ofrece de los patrones? En términos generales, dice Alexander que:

Podemos definir un patrón como un principio general del diseño y del planeamiento a través del cual se formula un problema concreto que puede presentarse repetidas veces en cualquier proceso de diseño. Además, delimita el tipo de contextos en los cuales este problema puede ocurrir y muestra las características esenciales que ha de poseer cualquier edificio. En este sentido, podemos afirmar que un patrón es un imperativo empírico que formula las condiciones mínimas necesarias para conseguir la salud individual y colectiva de una comunidad (1976: 66).

Teniendo esto en cuenta, es posible formular una definición más breve y formalmente interesante afirmando, como hace Alexander, que un patrón es "una regla tripartita, que expresa la relación entre un contexto determinado, un problema y una solución" (1981: 199). Esta fórmula sintetiza perfectamente el modelo a tres niveles que él plantea: un contexto de referencia, siempre; una reconstrucción reflexiva de las "fuerzas" o "tendencias" en conflicto o dispuestas de manera injusta, perjudicial o ineficiente; $y$, en tercer lugar, una configuración orientada a ordenar las cosas de modo tal que el conflicto se reduzca o desaparezca, es decir, dirigida a ganar estabilidad, completitud. Se trata, por tanto, de instituir un orden o conjunto organizado de relaciones distinto, nuevas "leyes morfológicas", según escribe:

Cada uno de estos patrones es una ley morfológica que establece un conjunto de relaciones en el espacio [...] Y cada ley o patrón es, en sí mismo, un patrón de relaciones entre otras leyes, que en sí mismas sólo son, asimismo, patrones de relaciones (1981: 84-85).

Aunque no es el momento de exponer las conclusiones que se deducen de aquí, resulta evidente que, conforme a este modelo, el diseño basado en los lenguajes de patrones no puede ser sino un diseño de carácter situado. Lo cual es decisivo, por ejemplo, a la hora de pensar procesos de traslación y adaptación técnica, tal y como ha avanzado Vega Encabo (2004: 51-71). Pero no sólo situado, sino también, y precisamente por ello, pluralista y abierto a procesos de corrección reflexiva con el objetivo -al menos el objetivo que nosotros defendemos- de reforzar la viabilidad de nuestros sistemas habitacionales. No obstante, lo que nos interesa ahora es más bien exponer en qué sentido consideramos que este modelo de Alexander debe ser mejorado y ampliado. Según nuestra propuesta, esas tres partes que acabamos de identificar -contexto, problema y solución- se corresponden, respectivamente, con tres de las 
cuatro dimensiones estructurales de los patrones que expondremos aquí: la dimensión constitutiva, la dimensión compositiva y la dimensión morfológica. Un breve comentario acerca de cada una estas dimensiones.

1) Hablamos de dimensión constitutiva con el objetivo de subrayar la naturaleza constitutiva, y por tanto el carácter de exigencia o compromiso para el diseño de patrones, que poseen todos y cada uno de los elementos que encontramos en un contexto determinado, desde las condiciones medioambientales o la materialidad misma de los patrones hasta los conjuntos de acciones involucradas o los programas y valoraciones que rigen, de fondo, en ese contexto. El contexto no es un mero recorte en el paisaje. De hecho, Alexander se refiere a tales elementos constitutivos en términos de "orígenes funcionales de la forma" (1969: 21), si bien falta en su obra un desarrollo más profundo y sistemático de los mismos (es lo que pretendemos empezar con los denominados dominios o ámbitos habitacionales, al final de este artículo).

2) La dimensión compositiva, en cambio, sirve para dar cuenta de la reconstrucción crítica que Alexander identifica como el auténtico "cuerpo" de los patrones. Es conveniente plantear el caso en términos de composición porque, según lo apuntado antes, los problemas son el resultado de nuestra reflexión sobre los desajustes que observamos en los patrones habitacionales existentes (desajustes que se traducen, por ejemplo, en el incremento de los riesgos, y por tanto de la vulnerabilidad, de una población). Los problemas, diremos, no vienen dados, sino que debemos componerlos, y hacerlo de manera tal que, señala Alexander, logremos obtener una perspectiva exacta sobre aquello a lo que aspiramos a dar una respuesta interesante y valiosa; es decir, lo contrario a dar cuenta de ciertas fuerzas "a expensas de otras que quedan sin resolver" (1981: 221). Por supuesto, componer dicha perspectiva puede ser, según el caso (por ejemplo, dependiendo de la escala), un ejercicio difícil y complejo, pero esto no impide comprender la dimensión compositiva como aquella en la que "se describe el trasfondo empírico del patrón, las evidencias a favor de su validez” (1971: 89).

No obstante, y ciertamente en unos casos más que en otros, no se trata de una composición exclusivamente técnica, sino también social, en la medida en que estas composiciones de las que hablamos son la expresión de una toma de posición eminentemente ética y política. En la dimensión compositiva, por decirlo así, se "cocinan" nuestros proyectos éticos. Es en el momento de la composición cuando se ponen de manifiesto cuáles son, y de qué tipo, nuestros compromisos y objetivos como sociedad; cuál es nuestro sentido de lo valioso y lo deseable. Según lo diría Ortega, en la composición se juega una auténtica crítica del deseo (Ortega y Gasset 2015); el momento de seleccionar conjuntamente entre las "posibilidades pragmáticas" (Broncano 2000) del contexto. Esto es fundamental en Alexander, que apuesta muy decididamente por introducir mecanismos de mayor calidad democrática en el diseño y la planificación de las ciudades. Para Alexander, este ejercicio de composición debía ejecutarse ampliando y mejorando al máximo la colaboración con la ciudadanía: no sólo implicándola, sino reconociéndola como un agente más, y decisivo, en el proceso de diseño. Lo cual implica, entre otras cosas, realizar previamente un examen riguroso de las condiciones bajo las cuales la participación ciudadana puede ser razonablemente virtuosa, un requisito que encontraremos posteriormente al desarrollar el tema 
de las necesidades, ${ }^{2}$ y que Alexander pretende recoger al formular su "principio de participación":

Todas las decisiones acerca de qué se ha de construir y de cómo se ha de construir han de estar en manos de los usuarios. [...] El equipo de especialistas de la planificación debe entregar a los miembros de los equipos de diseño los patrones, los métodos de diagnóstico y toda la ayuda adicional necesaria que precisen para diseñar (1976: 42).

3) En cuando a las "soluciones", optamos por subrayar su carácter morfológico porque los patrones, en su momento de instalación, no son sino conjuntos organizados de relaciones, "leyes morfológicas" o "patrones de relación", según la expresión citada de Alexander. En la dimensión morfológica se especifican las instrucciones que explican cómo es el patrón propiamente dicho, cuál es su orden particular. Lo morfológico, en este sentido, nos sitúa frente al problema central del diseño: lograr que en un contexto $(\mathrm{X})$, mediante tal o cual arreglo causal ( $r$ ), se proporcione acomodo o se facilite la realización de una pauta de acción (y), cumpliendo esto (A) y esto (B) y esto (C), y así sucesivamente hasta completar la lista de factores cuya consideración permite que $(r)$ sea óptimo en ese contexto (X). Pero debemos evitar suponer que tales ordenamientos genéricos proporcionan soluciones definitivas. Aunque en la reflexión de Alexander encontramos una defensa valiente de la alta necesidad de ciertos patrones, él mismo reconoce que los patrones son "reglas empíricas", "hipótesis" continuamente a prueba.

Por otro lado, es importante tener en cuenta que los patrones, según la propuesta de Alexander, no son recetas para aplicar mecánicamente; al contrario, se trata de instrucciones con-o que deben poseer-un alto grado de realizabilidad en circunstancias diferentes, lo que Lawler y Vega Encabo denominan "realizabilidad múltiple" (2011: 167-178). Alexander se refiere concretamente a la "variación y singularidad que siempre hay en la forma en que se manifiestan los patrones" (1981: 125).

Cada solución -observa- se formula de manera que nos dé el campo esencial de relaciones necesarias para resolver el problema, pero de un modo muy abstracto y general, con lo que usted puede resolver el problema por sí mismo, a su modo, adaptándolo a sus preferencias y a las condiciones locales del lugar en que está haciéndolo (1980: 11).

4) Ahora bien, ¿bastan estos tres niveles - constitutivo, compositivo y morfológicopara dar cuenta completamente de la complejidad intrínseca de los patrones y, por tanto, de la práctica del diseño de habitabilidades? Nuestra respuesta es que no. Desde el principio hemos sostenido que los patrones expresan y objetivan tomas de posición de carácter ético, es decir, de acuerdo a valores, entendidos como "generalizaciones inmanentes en lo racional" (Luhmann, 1998) o "funciones", según reclama Javier Echevarría en su "axiología de la tecnociencia" (2003; 2017). Si esto es así, debemos aceptar la premisa de que los arreglos morfológicos no son nunca neutros, ni pueden serlo, sino que se diseñan y ejecutan conforme a una finalidad o finalidades determinadas, un propósito

2 Más que examinar las distintas metodologías que se manejan, interesa subrayar que la colaboración es una práctica fundamental del proceso de diseño según el enfoque que presentamos. Los márgenes de maniobra pueden luego variar (dependiendo de la escala, tipo de problemas, etc.), pero pensamos que ante problemas de difícil solución o cuya solución no conocemos (wicked problems), es más razonable la opción de una participación bien reglada y efectiva que su reducción o negación. 
o unos principios. Por eso nos parece razonable corregir el modelo a tres de Alexander incorporando un cuarto nivel, que llamaremos valorativo. Es un cambio importante, puesto que nos permite introducir con una mayor sistematicidad -y poner en primera línea del debate- la relación entre diseño y ética, o si se prefiere, la cuestión relativa a la axiología del diseño.

En definitiva, según el modelo presentado, sostenemos que los patrones deben ser analizados en términos constitutivos, compositivos, morfológicos y valorativos, de lo cual deducimos una posible definición: los patrones, diremos, son arreglos materiales causal y axiológicamente orientados.

\subsection{Hacia una pragmática del diseño y la habitabilidad}

A partir de estas cuatro dimensiones, con las que pretendemos formular un posible modelo de análisis de los patrones de habitabilidad, se abre un programa de investigación muy amplio sobre el diseño y la gobernanza de nuestras ciudades. Lo que presentamos ahora es una parte mínima, pero importante en cuanto a la pragmática del diseño que se sigue de lo expuesto. De acuerdo, por tanto, con la diferencia entre lo constitutivo, lo compositivo, lo morfológico y lo valorativo, entendemos que la pragmática del diseño está determinada por cuatro factores; factores que identificamos a partir de la lógica propia de cada una de esas dimensiones o áreas operatorias que hemos identificado. Pues bien, en relación con la dimensión constitutiva, sostenemos que el diseño de patrones precisa de una inteligencia para las predeterminaciones; en cuanto a la dimensión compositiva, diremos que su lógica propia tiene que ver con lo proyectivo; por su parte, la dimensión morfológica pone en primera línea la cuestión de los ajustes; mientras que lo que rige en lo valorativo es la cuestión de los fines. De ello es posible derivar cuatro principios constructivos: limitación, colaboración, adaptación y pluralidad, si bien aquí nos ocuparemos solamente del primero.

1. ¿Por qué hablamos de predeterminaciones? Si aceptamos que el contexto es algo que viene dado, es decir, que existen multitud de elementos constitutivos (clima, un entorno construido, personas con tales o tales hábitos, valores, etc.), entonces no podemos negar el hecho de que el diseño de patrones opera siempre dentro de un espacio lleno de constricciones o predeterminaciones que describen su paisaje de posibilidades. Por supuesto, esta idea de predeterminación no implica que se anule necesariamente nuestra capacidad de intervención. Lo que ocurre más bien es que se acota un cierto margen de maniobra cuya realidad habrá que descubrir una vez conozcamos la complejidad del contexto de referencia. Es de suponer que habrá determinaciones sobre las que se podrá intervenir para revertir su condición de tales, así como determinaciones sobre las que será imposible o muy difícil cualquier tipo de intervención.

2. Además de estas predeterminaciones, la pertinencia de los patrones se juega en la exactitud con que se realice el ejercicio de proyección relativo a cada uno; es decir, la composición del proyecto. Lo que componemos a partir de las limitaciones o posibilidades que impone el contexto. Se trata de ejercicio de registro e ideación por medio del cual se consigue representar crítica y colaborativamente el problema al que nos enfrentamos. Es sugerente hablar de una lógica proyectiva en relación a la dimensión compositiva porque el significado literal de "proyección" es "lanzamiento 
hacia adelante", y parece que eso es precisamente lo que explica la razón de ser de lo compositivo. En el proyecto no se copia o describe meramente lo que sucede, sino que se introduce todo aquello que estamos en condiciones de pensar, analizar, formular, expresar... incluidos los objetivos que somos capaces de fijar colectivamente en base a nuestros sistemas de valoración, lo que deseemos conservar o defender por el valor que le asignemos como sociedad; y todo ello, en definitiva, para ir más allá de los problemas que revelan nuestros sistemas habitacionales. En cierto modo, el proyecto nos conduce a hablar también de teoría, en la medida en que el proyecto es la arquitectura teórica del ejercicio del diseño.

3. En cuanto a la lógica propia o razón de ser de la dimensión morfológica, hemos propuesto hablar de operaciones adaptativas de ajuste. Entendemos que los patrones, en su formulación concreta, tienen como función primera la de ordenar lo habitacional de un modo y otro, y esto quiere decir ajustar los elementos en juego -recursos, bienes, necesidades, hábitos, etc.- bajo una regla y estructura específica. Es un problema de forma: intervenir sobre las fuerzas o tendencias en conflicto para corregirlas y orientarlas por medio de arreglos causales distintos, es decir, instituyendo un modo concreto de ajustar las cosas. Dos ejemplos ${ }^{3}$ de patrones que formula el propio Alexander para ver esto con más claridad:

[Gradiente de intimidad] Trace los espacios de un edificio de un modo que creen una secuencia que comience con la entrada y las partes más públicas, pase por áreas ligeramente más privadas y termine en los dormitorios de privacidad máxima (1980: 546).

[Los objetos de su vida] No se deje engañar por la idea de que la decoración moderna ha de ser repulida o sicodélica, 'natural' o 'arte moderno', 'plantas' o cualquier otra cosa que reclamen los hacedores de gustos del momento. Es más bello cuando nace directamente de su vida, de las cosas que a usted le importan, de las cosas que le dicen algo (1980: 253).

4. No obstante, falta por identificar la lógica propia de dimensión valorativa. En este caso, diremos que se trata de un asunto de finalidad, dado que las posiciones axiológicas o de carácter ético se traducen en el ámbito del diseño habitacional en términos teleológicos. El diseño de patrones es una práctica con arreglo a fines, y son esos fines -esa pluralidad de fines- los que conforman el núcleo axiológico de los mismos. De ahí que la relevancia otorgada a ciertos valores, en determinadas circunstancias, tenga como primera consecuencia la necesidad de corregir nuestros lenguajes de patrones bajo fines acordes a ellos. No hay relaciones de ajuste que no estén axiológicamente orientadas, es decir, ejecutadas bajo un orden de finalidades, de unos principios, porque no hay proyecto que se componga sin una problematización de los valores y deseos que forman parte de nuestras vidas y estilos habitacionales.

En definitiva, sostenemos un modelo de patrones donde se distinguen cuatro dimensiones, las que denominamos constitutiva, compositiva, morfológica y valorativa.

3 Queremos subrayar que los traemos como ejemplos de lo que venimos exponiendo, no para defender que proponen una solución correcta. Lo que nos interesa no es la solución que expresan estos patrones, sino que todos los patrones deben expresar una. 
A partir de aquí deducimos que el diseño de patrones, lo que vendría a ser la pragmática del diseño, se juega entre cuatro factores de lo que se debe dar cuenta: las predeterminaciones que definen el paisaje de posibilidades del diseño; la composición de un proyecto, en el que se obtiene una representación crítica y reflexiva sobre el problema que se debe resolver; una operación de ajuste, cuyo objetivo es reordenar de nuevo la situación; y la institución, por ende, de una constelación o mixtura de finalidades en las que se expresan los objetivos de la sociedad y sus aspiraciones habitacionales.

De las conclusiones que se pueden extraer de aquí señalaremos al menos una, que tiene que ver con las predeterminaciones. Éstas sugieren registrar la idea de límite como una de las ideas fundamentales de la teoría de lo habitacional, puesto que tales son, todas y cada una, e independientemente de su naturaleza particular, limitaciones operatorias que condicionan radicalmente la práctica del diseño y la planificación. En este sentido, como hemos apuntado, uno de los principios rectores del diseño debe ser lo que denominamos principio de limitación, que establece, según lo dicho, que el diseño de patrones debe ejercerse como una inteligencia de los límites que condicionan de manera más o menos irreversible nuestros sistemas habitacionales. Ahora bien, cabe preguntarse de qué límites hablamos. A continuación presentamos un posible desarrollo, de acuerdo con la teoría de las necesidades, que permitía pensar los "límites antropológicos" del diseño habitacional.

\section{Teoría de las necesidades e integridad habitacional}

De las cuestiones importantes que surgen cuando nos interrogamos sobre el acto de habitar, la de las necesidades es una de ellas. Resulta difícil pensar que una reflexión sobre la habitabilidad pueda tener éxito si no incluye una buena teoría de las necesidades. A nuestro parecer, es el marco desde el que se puede elaborar una racionalidad habitacional bien armada normativamente, sobre todo teniendo en cuenta el contexto actual de emergencia energética y la complejidad de revertir las fracturas metabólicas sobre las que se erigen nuestros sistemas habitacionales (Sempere 2018).

Se trata de conducir la reflexión, según la invitación de Sloterdijk, hacia una "teoría positiva de la posición íntegra" o "de la vida bien posicionada" (2006: 408); es decir, de plantear el problema de lo habitacional desde la necesidad -universal, de la especie- de conservar un cierto equilibrio relativo a nuestro bienestar, un equilibrio que bien podríamos recoger mediante la noción de integridad. Adolf Loos lo resume de manera muy atractiva: "La manta es el detalle arquitectónico más antiguo" (2003: 149). La arquitectura - o el diseño de patrones- no aparece desde esa perspectiva sino como técnica de mediación entre los recursos de que disponemos y la satisfacción, por ejemplo en este caso, de la necesidad de protegernos de las inclemencias del tiempo, de conservar un poco de calor para dormir bien. Los lenguajes de patrones deberían permitirnos pensar lo habitacional en el mismo sentido: como dispositivos o instrumentos de organización de nuestra integridad habitacional. Formas del diseño para una vida buena. Para ello nos serviremos de ciertas ideas expuestas por MaxNeef, que presentamos brevemente a continuación.

\subsection{Necesidades, satisfactores y bienes}

Según Max-Neef, las necesidades "son finitas, pocas y clasificables", y aun a riesgo de exigir ciertas modificaciones en función del momento histórico o la cultura, cabe afirmar que tienden a repetirse lo suficiente como para sostener que forman un 
repertorio relativamente cerrado. Tomémoslas, por tanto, como hipótesis de trabajo, sin entrar a discutir si sobra o falta alguna. Por otro lado, sostiene el chileno que existen dos categorías fundamentales de necesidades que se entrecruzan continuamente: las "existenciales" y las "axiológicas". Dentro de la primera se incluirían las necesidades de ser, tener, hacer y estar, dentro de la segunda, en cambio, encontraríamos las necesidades de subsistencia, protección, afecto, entendimiento, participación, ocio, creación, identidad y libertad. En cuanto a las primeras, un apunte: si la necesidad de ser "registra atributos, personales o colectivos", la de tener "registra instituciones, normas, mecanismos, herramientas (no en sentido material), leyes, etc.", mientras que las necesidades de hacer y estar registran, respectivamente, "acciones, personas o colectivas" y "espacios y ambientes" (1998: 58-59).

No obstante, y esta es una distinción fundamental de la teoría de Max-Neef, es un error no diferenciar "entre lo que son propiamente necesidades y lo que son satisfactores de esas necesidades" (1998: 41). De hecho, escribe el chileno que "lo que cambia, a través del tiempo y de las culturas, es la manera o los medios utilizados para la satisfacción de las necesidades" (1998: 42). No cambian las necesidades, sino los satisfactores, donde convergen "formas de organización, estructuras políticas, prácticas sociales, condiciones subjetivas, valores y normas, espacios, contextos, comportamientos y actitudes; todas en una tensión permanente entre consolidación y cambio" (1998: 50). De lo cual se deduce que los satisfactores son instrumentaciones en las que se expresan, a través de su propia articulación, segmentaciones sociales, asimetrías de poder, división del trabajo, acumulaciones de capital, jerarquías sistémicas... En suma, las estrategias de racionalidad que rigen lo habitacional, sea conservando un sentido fuerte de la integridad, o sea, por el contrario, instituyendo y generalizando formas de vida precarias, insostenibles, y mucho más vulnerables a los riesgos. Así, escribe Max-Neef:

Cada sistema económico, social y político adopta diferentes estilos para la satisfacción de las mismas necesidades humanas fundamentales. En cada sistema, éstas se satisfacen (o no se satisfacen) a través de la generación (o no generación) de diferentes tipos de satisfactores. [...] Lo que cambia es la elección de cantidad y calidad de los satisfactores, y/o las posibilidades de tener acceso a los satisfactores requeridos (1998: 42).

Nada de esto cuadra con la creencia de que las necesidades, como dijera Baudrillard, son "puras funciones generadas por efecto de la ideología dominante" (1974: 52-87). Que un determinado sistema de producción requiera instituir un cierto estilo $u$ orden en la satisfacción de las necesidades no implica que las necesidades sean un invento ideológico. La distinción entre necesidades y satisfactores permite salir de esta pequeña trampa y, al mismo tiempo, utilizar las necesidades como fuerza de resistencia e instancia crítica frente a las perjudiciales o indeseables modalidades de satisfacción. Unos satisfactores, por cierto, que desde nuestro punto de vista poseen una función y naturaleza equivalente a los patrones de habitabilidad, siendo así que, a partir de estas reflexiones de Max-Neef, parece razonable que en el debate sobre la relación entre necesidades y diseño, los patrones o infraestructuras habitacionales sean pensados precisamente como satisfactores.

Ahora bien, no se trata sólo distinguir entre necesidades y satisfactores, sino de 
sumar a estas dos la noción de bienes materiales ("económicos", dice Max-Neef). Como se ha señalado, las modalidades de satisfacción varían según las épocas y de acuerdo a las culturas, condiciones económicas o los recursos de los que se dispone. Según el chileno, si los satisfactores son "lo histórico de las necesidades", lo "culturalmente determinado", los bienes materiales o económicos son "su materialización" (1998: 53). Lo cual se traduce, por ejemplo, en que los bienes, como él mismo apunta, potencian los satisfactores "para vivir las necesidades de manera coherente, sana y plena". Hablamos de los "objetos y artefactos que permiten afectar la eficiencia de un satisfactor, alterando así el umbral de actualización de una necesidad, ya sea en sentido positivo o negativo" (1998: 56). Se advierte que tales bienes no pueden ocupar, en relación a las necesidades y los satisfactores, una posición menor: "Mientras un satisfactor es en sentido último el modo por el cual se expresa una necesidad, los bienes son en sentido estricto el medio por el cual el sujeto potencia los satisfactores para vivir sus necesidades" (1998: 51).

No cabe duda, por lo demás, de que al introducirlos obtenemos una perspectiva mucho más rica y compleja del diseño: se trata de pensar los lenguajes de patrones como instancias asociadas a nuestros hábitos y necesidades, pero añadiendo a esa relación los bienes que movilizan, los recursos que se consumen para ello, los impactos que producen; en términos generales, cómo afectan a las condiciones medioambientales o ecológico-energéticas que hacen posible la vida de la especie humana. "El que un satisfactor pueda tener efectos distintos en diversos contextos depende no sólo del propio contexto, sino también en buena parte de los bienes que el medio genera, de cómo los genera y de cómo organiza el consumo de los mismos" (1998: 51). La reflexión sobre nuestros sistemas habitacionales debe poner en el centro el modo en que se concreta u objetiva esa "causación recíproca" entre bienes y satisfactores que es característica de toda cultura y de sus modelos de crecimiento o desarrollo. No tener esto en cuenta es adoptar un enfoque limitado, ciego ante las fracturas metabólicas sobre las que se organizan nuestras sociedades, y peligroso. Diremos, así, que una hipotética teoría de la vida bien posicionada o de la "integridad habitacional" exige una reflexión rigurosa sobre los bienes que hacen posible una vida buena. Ahora bien, desde un punto de vista necesariamente universalizable. Nos corresponde pensar a fondo, advierte Sloterdijk, "la conexión de inmunidad y comunidad" (2006: 409). El sujeto político aquí no viene determinado por el Estado o la nación, sino por la pertenencia a la especie humana. Es seguramente el sujeto político propio de la época del Antropoceno: la humanidad en su conjunto, constituida por la amenaza de sus condiciones mismas de habitabilidad.

\subsection{Tipos de satisfactores y límites planetarios}

La pregunta que sigue es cuándo y bajo qué circunstancias el conjunto de habitabilidades característico de nuestra cultura incluye o no buenas modalidades de satisfacción. Para responder a ello, Max-Neef propone una tipología de al menos cinco satisfactores (cinco tipos de patrones habitacionales, diremos), quellama "destructores", "inhibidores", "singulares", "pseudo-satisfactores" y "satisfactores sinérgicos". Los primeros, explica el chileno, "no sólo aniquilan la posibilidad de su satisfacción en un plazo medio [al ser aplicados], sino que imposibilitan, por sus efectos colaterales, la satisfacción adecuada de otras necesidades"; los segundos son "aquellos que por el modo en que satisfacen (generalmente sobresatisfacen) una necesidad determinada, dificultan seriamente la posibilidad de satisfacer otras necesidades"; mientras que los terceros y los cuartos son, respectivamente, satisfactores "que apuntan a la satisfacción 
de una sola necesidad, siendo neutros respecto a la satisfacción de otras necesidades" y que "estimulan una falsa sensación de satisfacción de una necesidad determinada". Por último, los satisfactores sinérgicos son "aquellos que por la forma en que satisfacen una necesidad determinada, estimulan y contribuyen a la satisfacción simultánea de otras necesidades. Su principal atributo es el de ser contrahegemónicos en el sentido de que revierten racionalidades dominantes tales como las de competencia y coacción" (1998: 64-65).

Una vez presentado el cuadro, Max-Neef propone clasificar los cuatro primeros como satisfactores de carácter exógeno, y los sinérgicos como endógenos; lo que significa que los exógenos son "tradicionalmente impulsados de arriba hacia abajo... impuestos, inducidos, ritualizados o institucionalizados"; mientras que los endógenos expresan "procesos liberadores... de personas libres, capaces, potencialmente o de hecho, de diseñar sus proyectos de vida en común" (1998: 65). Sin embargo, dado que él mismo reconoce que los satisfactores sinérgicos también pueden ser impulsados por el Estado, la diferencia importante, a nuestro parecer, tiene que ver más bien con la calidad de la agencia que exigen estos últimos; esto es: con el tipo de control que se ejerce sobre las modalidades de satisfacción de las necesidades, así como sobre la producción, distribución y naturaleza de los bienes materiales de los que depende su satisfacción. De lo que se trata es de encontrar un punto de vista que unifique correctamente el diseño de habitabilidades bajo los principios de una concepción crítica de la razón práctica; y ésta no habría de explicarse ya, según Broncano, en términos de simples imperativos, sino más bien a través de "un examen cuidadoso de las condiciones bajo las cuales la agencia humana se convierte en una agencia razonablemente virtuosa, de los condicionantes de la calidad de la agencia" (2005). Esta perspectiva matiza la idea de Max-Neef y permite profundizar en la dimensión democrática del diseño, que conecta perfectamente con la defensa de la colaboración y la participación ciudadana (de calidad, por tanto) ya comentadas.

Ahora bien, si observamos los conflictos como desajustes en la satisfacción de necesidades, en la medida en que su correcta satisfacción denota un desarrollo pleno, saludable y bueno de las mismas, entonces cabe suponer que será importante no pasar por alto tampoco que la calidad de la satisfacción de las necesidades dependerá no sólo del control democrático que ejerzamos sobre dicha satisfacción, sino también de que se respete la pluralidad axiológica que nos constituye como seres humanos; es decir, De que los lenguajes de patrones organicen y conecten, de manera ecológicamente viable, secuencias o cursos-de-acción para las muchas necesidades que tenemos. Por ende, convendremos en que la satisfacción de necesidades no puede ser valiosa ni aceptable si no se hace eco de que las necesidades, como apunta Max-Neef, "deben entenderse como un sistema en el que se interrelacionan e interactúan” (1998: 41).

Sin embargo, esta reflexión sobre necesidades, satisfactores y bienes, se quedaría a medias si no se amplía con un marco apropiado en el que se ordene correctamente el problema de la crisis ecológica global. Aunque, según hemos advertido, no es una cuestión que pretendamos desarrollar aquí, se trata de una parte fundamental de la filosofía de la habitabilidad y, por ende, del diseño de patrones. Entre otras cosas, nos conduce a plantear cuál es la escala -o mejor dicho: cuáles son las escalas- del problema de la habitabilidad. Recientemente, Campillo ha realizado sugerencias muy interesantes, intentando recuperar la tríada kosmos, pólis y éthos, con el objetivo de cuadrar un mapa adecuado a los desafíos globales, donde el yo y el nosotros se piense 
junto con la naturaleza (Campillo 2018). Lo mismo encontramos en Max-Neef al subrayar que necesidades, satisfactores y bienes deben articularse normativamente teniendo en cuenta tres dominios: "uno mismo (Eigenwelt)", el "grupo social (Mitwelt)" y "la relación con el medio ambiente (Umwelt)" (1998: 43). De acuerdo con estas posiciones, y como consecuencia también de introducir la dimensión constitutiva en la definición de los patrones, reconocemos que una de las escalas de lo habitacional es el planeta, cuyos límites deben ser un factor de primer orden (por ejemplo, a la hora de dar contenido al principio de limitación) en los procesos de diseño y planificación urbana. Por supuesto, habría que contar aquí con la noción de "límites planetarios" de Rockström y su equipo (2009) como análisis de base, pero no seguiremos ahora esta pista. Interesa, más bien, un paso previo, que tiene que ver con el marco general dentro del cual ordenar e integrar lo dicho hasta aquí: la naturaleza o el planeta como escala constitutiva de lo habitacional, los diferentes tipos de bienes materiales y las dos clases de necesidades (existenciales y axiológicas). En este sentido, proponemos hablar de cuatro dominios habitacionales básicos; dominios que los patrones de habitabilidad declinan siempre bajo una articulación determinada (y están, al mismo tiempo, interpenetrados por ellos).

\section{Algunas correcciones a partir de un enfoque basado en procesos}

En base al modelo de patrones que se ha presentado, y con el objetivo de profundizar en nuestro marco de trabajo, se puede hablar de cuatro dominios habitacionales básicos: [1] de acuerdo con lo dicho sobre la naturaleza o el medioambiente como factor determinante de la habitabilidad, el de los elementos que constituyen el entorno biofisico, natural, donde se despliegan nuestros estilos habitacionales; [2] tal y como reclama Max-Neef al hablar de bienes materiales, el de los bienes e infraestructuras, es decir, las cosas o objetos que diseñamos o cultivamos para adaptarnos al mundo, darle una forma técnicamente orientada y, por tanto, organizar nuestra experiencia como especie ([1] y [2] responderían a la diferencia entre "capital natural" y "capital cultivado" de Arias Maldonado (2018)); [3] el de las acciones que realizamos, lo que vendría a ser el dominio de la praxis propiamente dicha, que se objetiva siempre movilizando o usando elementos, bienes e infraestructuras (este tercer dominio nos permitirá observar las "necesidades existenciales" desde un punto de vista renovado, más estrechamente vinculado a la cuestión de la habitabilidad); y [4] el de los sistemas de racionalidad en función de los cuales se ordenan, valoran, y articulan los anteriores tres dominios bajo programas y principios de uno u otro tipo, y cuya introducción, además, se presenta como absolutamente necesaria desde el momento en que decidimos introducir la cuestión axiológica al analizar la estructura misma de los patrones habitacionales.

Ahora bien, ¿cómo pensamos estos dominios o ámbitos? Nuestra propuesta es hacerlo en términos procesuales, siguiendo algunas ideas expuestas por Nicholas Reschel (2000). Sin embargo, una primera pregunta se impone: ¿qué es un proceso? Según Nicholas Rescher un proceso es: (1) un complejo o conjunto de acontecimientos (complex of occurrences) cuya unidad se despliega en diferentes fases o estadios; además, (2) se trata de un conjunto unitario de acontecimientos que posee una cierta "coherencia e integridad temporal"; y además, añade Reschel, un proceso (3) tiene una estructura, un patrón de organización o un modo general según el cual tales acontecimientos se organizan (a formal generic patterning of occurrence). Según esta idea de procesos, entre las conclusiones destacables se encuentra el hecho de su naturaleza radicalmente histórica: 
los procesos existen solamente a través de sus "concretas manifestaciones históricas" (2000: 25); por tanto, se entienden los procesos como espacial y temporalmente determinados. No obstante, para Rescher el núcleo del asunto tiene que ver con su "identidad estructural", lo que permite, en última instancia, hablar de acontecimientos secuencialmente ordenados según patrones característicos. En suma: una unidad de acontecimientos cuyo despliegue se realiza por fases, coherencia temporal que implica la conservación de esa unidad a través de su despliegue, y una estructura característica de esa unidad, que viene a ser la expresión mínima de su identidad.

A partir de aquí, Reschel establece una posible clasificación de los modos procesuales o los tipos de procesos teniendo en cuenta tres criterios: (1) el carácter de la estructura [structure type], (2) la naturaleza o contenido de los acontecimientos [occurrence type], y (3) el resultado final de los procesos [result type]. De acuerdo con la "estructura secuencial" de los procesos, los que según Reschel responden a la pregunta "what sort of structure?", se distinguen cuatro tipos de procesos: (a) procesos causales (la floración); (b) procesos operatorios basados en reglas (realizar una división); (c) procesos ceremoniales (lavarse las manos antes de comer); y (d) procesos performativos (tocar una pieza al piano). De acuerdo con el segundo bloque de procesos, que se recogen bajo la pregunta "what sort of occurrences?", existirían un total de cuatro: (e) políticos, (f) matemáticos, (g) mentales y (h) biológicos. Por último, tendríamos los (i) procesos de estilización social, (j) de resolución de problemas y (k) de producción de productos, en respuesta a la pregunta "what sort of result?", conformando el tercer bloque de clases de procesos.

Sin embargo, tenemos serias dudas de que este esta clasificación sea útil si lo que interesa es conformar un marco explicativo y crítico del fenómeno de la habitabilidad. Además, Reschel no explica las relaciones que existen -o si más bien no existen- entre los once procesos que identifica. Por tanto, desde nuestro punto de vista, se podrían hacer algunas correcciones que presentamos a continuación:

1. De acuerdo con el criterio de la estructura, que consideramos fundamental, nuestra posición, tal y como indicábamos al principio, resulta más pertinente distinguir entre estructuras procesuales de orden natural (los procesos característicos de un ecosistema), estructuras procesuales de orden técnico (el cultivo de alimentos, el diseño de un barrio, la decoración de una casa, etc.), estructuras procesuales de orden pragmático (descansar, ir a trabajar, cocinar, etc.) y estructuras procesuales de orden sistémico-racional (la ciencia, la economía, el derecho, la religión, etc.). Los lenguajes de patrones, las formas según las cuales respondemos al problema de la habitabilidad, se encontrarían siempre en el cruce de estos cuatro procesos (origen, los cuatro, de su profunda fragilidad).

2. Si respetáramos la clasificación de Reschel, tendríamos que explicar a continuación qué procesos de contenido es necesario considerar a partir de las diferentes estructuras procesuales señaladas. Pensemos por ejemplo en las acciones. Evidentemente, una teoría de la habitabilidad basada en los lenguajes de patrones debe dar cuenta de nuestros patrones de acción, esto es, de los procesos que ponemos en marcha a través de lo que hacemos. Parece razonable afirmar que no todas nuestras acciones son iguales: dormir, respirar, cocinar, pasear, escribir, etc. Pero, ¿cómo distinguirlas? Ha habido intentos interesantes, como el de Arendt (2009), que diferencia 
entre labor, trabajo y acción. Nosotros, en cambio, sugerimos hablar de cuatro grandes bloques de patrones de acción o procesos pragmáticos, una taxonomía cualitativa bajo la cual quizá podríamos comprender todo el repertorio de acciones humanas que son relevantes en términos habitacionales.

En primer lugar, los gestos o procesos pragmáticos que denominamos de concentración; por otro lado, los que entendemos como gestos de dispersión; en tercer lugar, los que hemos dado en llamar de conservación; y por último, los gestos o procesos pragmáticos de generación. Los primeros tienen que ver con nuestra tendencia a hacer cosas en un mismo lugar (dormir, estudiar, rezar, cuidar el huerto); los segundos más bien con la movilidad o el acto de desplazarse (ir a trabajar o a la biblioteca, pasear, transportar mercancía, etc.); los terceros tienen que ver con nuestros consumos o actos automáticos (respirar, comer, etc.); y los cuartos más bien con nuestras capacidades de generar, tunear o crear cosas distintas (un poema, una silla, un algoritmo, una teoría, etc.). Los cuatro son procesos que dan contenido, una concreción precisa, a las estructuras procesuales de orden pragmático; y los cuatro son procesos, por tanto, mediante cuya articulación, en base a conjuntos de satisfactores o patrones, según decimos, damos satisfacción a nuestras necesidades.

Para un programa de investigación del diseño centrado en lo habitacional, es importante proporcionar un cuadro riguroso de lo que al principio de este artículo hemos llamado "patrones de acción". Estos funcionan como los "sobreentendidos" de los patrones de habitabilidad, pero ocupan un lugar confuso o menor en la teoría de las necesidades de Max-Neef, y Alexander tampoco reflexiona sobre ellos convenientemente. Pues bien, gracias al enfoque basado en procesos, podemos fijar los procesos de orden pragmático como una estructura fundamental de lo habitacional, y utilizar los cuatro tipos de gestos citados -de concentración, de dispersión, de conservación y de generación-para sustituir las "necesidades existenciales" del chileno. De este modo, tendríamos cuatro necesidades pragmático-estructurales, que describen el repertorio de acciones de las que el diseño debe dar cuenta. Consideramos que una teoría crítica de nuestros sistemas habitacionales, una filosofía de la habitabilidad, no puede pasar por alto las formas en que hacemos efectivos los distintos procesos de orden pragmático que hemos descrito.

\section{Resumen final}

En este artículo, que compartimos como primer esbozo de una filosofía de la habitabilidad, se ha presentado un modelo de interpretación de los patrones, entendidos como instrumentos de racionalidad de lo habitacional, describiendo además los factores que determinan los procesos de diseño. Se ha propuesto pensar el diseño de patrones dentro de una teoría de las necesidades y la noción de "integridad habitacional". Se ha apuntado también que esta integridad debe articularse con otros equilibrios a escala planetaria. Y por último se ha propuesto profundizar en esta reflexión aplicando un enfoque basado en procesos, con el objetivo de crear un mapa teórico -del que aquí presentamos una pequeña parte- del problema de la habitabilidad. Éste debería ayudar o conducir una reflexión colectiva, y rigurosa, sobre nuestro futuro, el de nuestras ciudades, y los patrones habitacionales que debemos diseñar ante la multiplicación de los riesgos y la puesta al descubierto de nuestra vulnerabilidad. 


\section{Bibliografía}

Alexander, C. 1969. Ensayo sobre la sintesis de la forma. Buenos Aires: Infinito.

— 1971. La estructura del medio ambiente, Barcelona: Tusquets. , 1981. El modo intemporal de construir, Barcelona: GG. 1980. Un lenguaje de patrones, Barcelona: GG.

Alexander, C. et alt.. 1976. Urbanismo y participación. El caso de la Universidad de Oregón, Barcelona: GG.

Arendt, H. 2009. La condición humana, Barcelona: Paidós.

Baudrillard, J. 1974. Crítica de la economía politica del signo, México: Siglo XXI.

Berger, P., Luckmann, T. 2001. La construcción social de la realidad, Buenos Aires: Amorrortu.

Bourdieu, P. 2007. El sentido práctico, Buenos Aires: Siglo XXI.

Broncano, F. 2000. Mundos artificiales, Barcelona: Paidós. , 2009. La melancolía del ciborg, Barcelona: Herder. 2005. "La agencia técnica", en Revista CTS, n 5, vol. 2.

Campillo, A. 2018. Mundo, nosotros, yo. Ensayos cosmopoliéticos, Barcelona: Herder Echeverría, J. 2003. La revolución tecnocientifica. Madrid: FCE. , 2017. El arte de innovar. Madrid: Plaza y Valdés.

Goffman, E. 2006. Frame Analysis. Los marcos de la experiencia, Madrid: Siglo XXI.

Lahire, B. 2004. El hombre plural, Barcelona: Bellaterra.

Lawler, D., Vega Encabo, J. 2011. "Realizabilidad múltiple y clases de artefactos", Revista CTS, n ${ }^{\circ} 19$, vol. 7.

Lefébvre, H. 1976. Espacio y politica, Barcelona: Península.

Loos, A. 2003. Dicho en el vacío. 1897-1900, Murcia: Arquilectura

Luhmann, N. 1998. Sistemas sociales, México-Barcelona, Iberoamericana: Anthropos. Lukács, G. 2007. Marx, ontología del ser social. Madrid: Akal.

Maldonado, M. A. 2018. Antropoceno. La política en la era humana. Barcelona: Taurus. Mauss, M. 1979. Sociología y antropología. Madrid: Tecnos.

Max-Neef, M. 1998. Desarrollo en escala humana. Montevideo-Barcelona: Norda-Icaria Reschel, N. 2000. Process Philosohy, University of Pittsburgh Press.

Riechmann, J. 2014. Un buen encaje en los ecosistemas. Madrid: Catarata.

Rockström, J., Steffen, W., Noone, K., et al., "A safe operating space for humanity", en Nature, vol. 461, 2009.

Sánchez Criado, T. 2008. Tecnogénesis. La construcción técnica de las ecologías humanas, Madrid: AIBR.

Sempere, J. 2018. Las cenizas de Prometeo. Barcelona: Pasado y Presente.

Sloterdijk, P. 2006. Esferas, Madrid: Siruela.

Vega Encabo, J. 2004. “'Traslación' y adaptación de técnicas. Tecnologías apropiadas y procesos de transferencia", Revista CTS, n ${ }^{\circ} 3$, vol. 1 . 


\title{
Marcel Breuer: un diseñador global. Experiencias en el ámbito de la vivienda prefabricada
}

\author{
Marcel Breuer: a global designer. Research in the field of \\ prefabricated housing
}

\author{
Salvador José Sanchis Gisbert ${ }^{*}$, Ignacio Peris Blat ${ }^{* *}$ y Pedro Ponce Gregorio ${ }^{* * *}$
}

\section{Resumen}

En la nueva escuela de la Bauhaus se intentaba formar a una serie de artistas capaces de integrar los procesos creativos en un nuevo ideal de diseño. Marcel Breuer pertenece al primer grupo de arquitectos formados según estos principios, capaz de combinar la integración de los nuevos materiales, los procesos industriales y la fabricación en serie para la creación de nuevos proyectos. Este artículo pretende mostrar por una lado la gran polivalencia como diseñador de M. Breuer (mobiliario, interiores, arquitectura y urbanismo) así como recuperar sus investigaciones en el campo de la vivienda prefabricada, cuestiones ambas relacionadas con su singular formación y aprendizaje que marcaron su filosofía del diseño.

Palabras clave: Marcel Breuer; Bauhaus; arquitectura; filosofía del diseño; prefabricación.

\begin{abstract}
In the new school of the Bauhaus, an attempt was made to create a series of artists capable of integrating creative processes into a new design ideal. Marcel Breuer belongs to the first group of architects trained according to these principles, able to combine the integration of new materials, industrial processes and serial production for the creation of new projects. This article aims to show on the one hand the great versatility as a designer of M. Breuer (furniture, interiors, architecture and urban planning) as well as recovering his research in the field of prefabricated housing, issues both related to his unique training and learning that marked his philosophy of design.
\end{abstract}

Keywords: Marcel Breuer; Bauhaus; architecture; philosophy of design; prefabrication.

\section{Introducción}

Walter Gropius funda la escuela de la Bauhaus en 1919 siendo su director hasta 1928. Introduce a Marcel Breuer como profesor nada más completar sus estudios en 1924. No sólo fue uno de los primeros alumnos de una escuela tan singular sino que, además, participó activamente como profesor. Coincide con otros artistas como Kandinsky o Paul Klee, pintores, influenciados por Theo Van Doesburg, uno de los primeros responsables de la abstracción y de los desarrollos geométricos de la pintu-

* Salvador José Sanchis Gisbert, Universitat Politècnica de València, España. salsang1@pra.upv.es

** Ignacio Peris Blat, Universitat Politècnica de València, España. igpebla1@pra.upv.es

** Pedro Ponce Gregorio, Investigador libre, España.pedpongr@arq.upv.es

Artículo recibido: 30 de mayo de 2019; aceptado: 15 de octubre de 2019 
ra abordados en la Bauhaus; Laszlo Moholy Nagy, diseñador y fotógrafo; Josef A1bers, diseñador, fotógrafo, tipógrafo... constituyendo un equipo docente inmejorable. Compartían el ámbito profesional, docente y privado. Esta cercanía y el permanente contacto directo, generaba una transferencia de conocimientos entre las diferentes disciplinas muy enriquecedora. En consecuencia, M. Breuer entiende el diseño como un problema global, un ejercicio creativo multidisciplinar liberado de prejuicios y planteado desde una profunda abstracción.

M. Breuer escribe dos textos, a mediados de los años 30, en los que comienza a mostrar sus inquietudes teóricas y su particular posicionamiento en el campo del diseño. Por un lado el artículo titulado "On architectural and materials", publicado en la revista Circle en 1936, deja patente los nuevos postulados y las señas de identidad fruto de su formación en la Bauhaus. Es significativo en este sentido cuando, como corrección de un texto mecanografiado, ${ }^{1}$ en el apartado tercero, sustituye el término "modern movement in architecture" por "new architecture" "...la nueva arquitectura no consiste única y esencialmente en adquirir nuevos materiales ni en buscar nuevas formas, sino en adaptarse a una nueva mentalidad" (Breuer 1936: 1). También es especialmente relevante la conferencia titulada Where do we stand?, ${ }^{2}$ en la que expone sus ideas sobre los compromisos y relaciones de la arquitectura moderna con la arquitectura vernácula y el valor de lo tradicional.

Cuando viajamos, por ejemplo, nos interesamos intensamente por los lugares en los que la vida cotidiana de la población aún permanece imperturbada. Nada nos da mayor satisfacción que descubrir una obra artesanal heredada de padres a hijos, libre de la pompa pretenciosa y la inutilidad de la arquitectura del siglo pasado. Esto es algo de lo que aún podemos aprender, aunque naturalmente no en el sentido de la imitación, pues para nosotros sería improcedente y falso construir siguiendo una tradición nacional o un estilo antiguo... (Breuer 1938: 2).

En esa misma conferencia expone su entendimiento sobre la condición de los materiales con los que opera en el campo del diseño, “...la utilización de materiales tanto nuevos como tradicionales y la transformación de conceptos tradicionales en contemporáneos conducen a la generación de formas nuevas, lo cual no supone un retroceso sino una evolución..." (Breuer 1938:4).

Como vemos, M. Breuer está definiendo las claves de su manera de hacer. Estos textos podemos entender que culminan con la publicación de su monografía Marcel Breuer: Sun and Shadow. The Philosophy of an Architect. Este libro, el más importante de toda su carrera, se aborda como un ejercicio de diseño global, contando para su desarrollo con la colaboración de fotógrafos, pintores, diseñadores y arquitectos ${ }^{3}$ : se plantea como un proceso creativo multidisciplinar. Se organiza en cuatro partes. La primera y la cuarta, se titulan igual, Obras y proyectos, y recogen el trabajo de M. Breuer en dos etapas diferentes ordenadas cronológicamente. Las dos partes centrales del libro son escritos del propio M. Breuer. Se titulan, respectivamente, Principios y El arte del espacio. Contienen siete textos con las ideas que formulan su cuerpo teórico. En este caso no

\footnotetext{
https://www.aaa.si.edu/assets/images/collectionsonline/breumarc/fullsize/AAA_breumarc_204117.jpg

El título original es Wo stehen wir heute? Es una conferencia realizada en el Werkbund de Suiza en 1934. Fue traducida al inglés por el propio Marcel Breuer en 1938.

3 Alexis Brodovitch, Peter Blake, Ben Schnall, Robert Damora entre otros.
} 
se trata de explicar o presentar sus obras, como suele hacerse en un libro monográfico, sino que se pretende, mediante su obra construida, clarificar el pensamiento con el que se han acometido estos trabajos. Es una publicación absolutamente singular y extraordinaria, pues es extraño encontrar a un arquitecto que, más allá de exponer su obra, se esfuerce por explicar en esos años, su filosofía de diseño.

\section{De la butaca Wassily al edificio de la unESCo. Desarrollo profesional en etapas}

M. Breuer permanece en Europa hasta que en el año 1937 emigra a los Estados Unidos, donde se afincará definitivamente. Vivió y trabajó en diferentes países como Alemania, Inglaterra, Francia, Estados unidos, en un proceso de formación y crecimiento sensible en cada localización. Resulta adecuado recorrer estas etapas para terminar de comprender la dimensión del personaje. Así encontramos una primera etapa europea hasta 1937, en la que encontramos un trabajo principal centrado en el diseño de mobiliario con pequeñas incursiones en el campo de la arquitectura por falta de oportunidades, en gran parte debido a la profunda inestabilidad en la que se vive en Europa durante casi todos esos años. Destaca también su labor como docente en la Bauhaus, una cualidad muy importante para el proceso de comunicación del diseño.

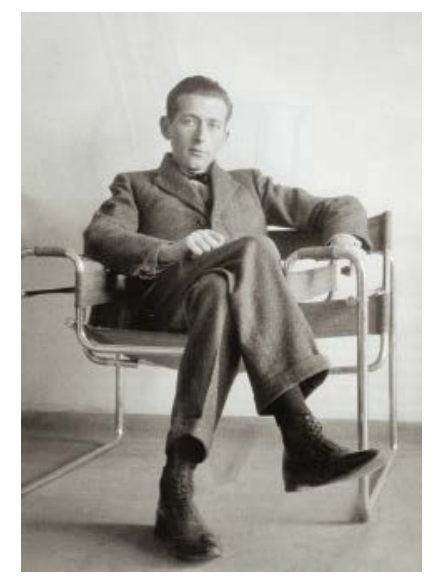

Figura 1. M. Brever sentado en la butaca B3 Wassily 1927

Con menos de treinta años es capaz de proponer dos sillas que son, hoy en día, auténticos iconos del diseño de mobiliario como la butaca B3 Wassily (Figura 1), y la silla en voladizo B32, Cesca. Ambos diseños se basan en el hábil entendimiento y manipulación de las cualidades del tubo de acero cromado. Estos primeros trabajos, propios de un diseñador industrial, le dotan de unas cualidades en su relación con el material, de gran influencia para el resto de su desarrollo profesional. En 1930 se encarga de desarrollar las propuestas de mobiliario y arquitectura para la exposición del Werkbund de París (Figura 2). Es uno de los grandes responsables en el logro de la introducción del diseño industrial en el ámbito particular del mobiliario de las viviendas. El compromiso con el usuario se evidencia a través de un estudiado confort. Muestra de ello son los mecanismos de suspensión para el diseño de sillas, así como la utilización de materiales como la madera cuando se encuentran en contacto directo con el cuerpo. 


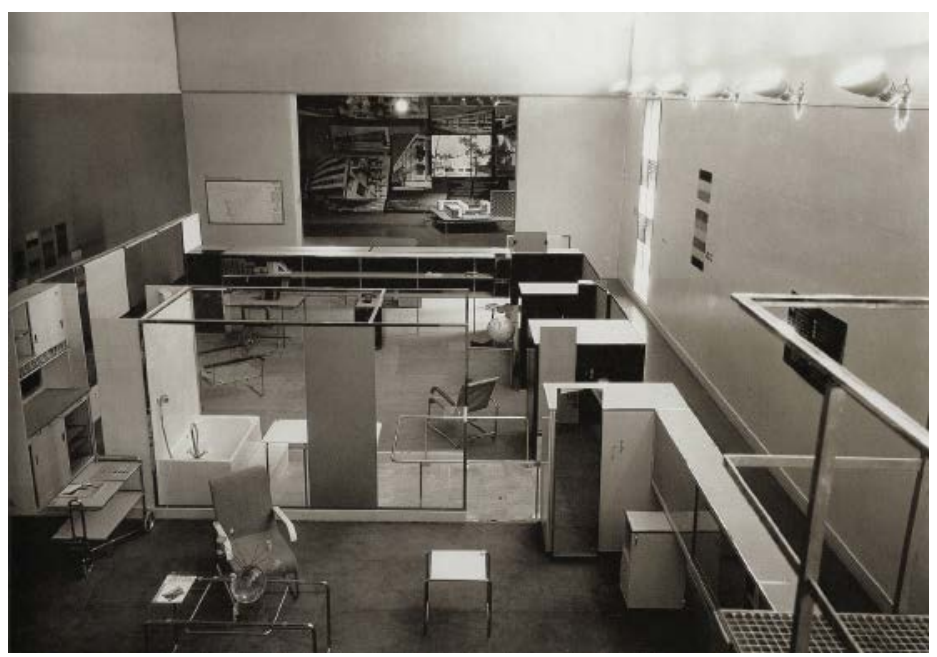

Figura 2. Exposición del Werkbund, París 1930

Sus únicas obras construidas en estos años son una vivienda unifamiliar, la casa Harnischmacher, en Wiesbaden en 1932 y los apartamentos Dordenthal, en Suiza en 1934. Son obras abordadas de un modo global donde los binomios alojamientoespacio y amueblamiento-usuario, forman un conjunto íntimamente asociado. Quedan diferentes proyectos no construidos entre los que destacamos, por su interés espacial y planteamiento estructural, los bloques de apartamentos Spandau-Haselhorst (Figura 3) y el hospital Elberfeld (Figura 4). Son ejemplos que muestran, además de su interés por los sistemas en voladizo, su gran versatilidad como proyectista, enfrentándose por primera vez a la escala urbana.

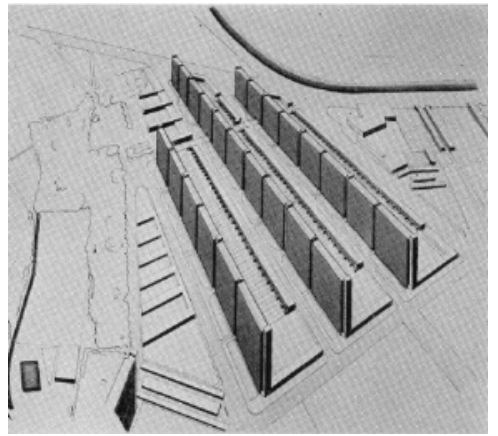

Figura 3. Spandau-Haselhorst. 1928

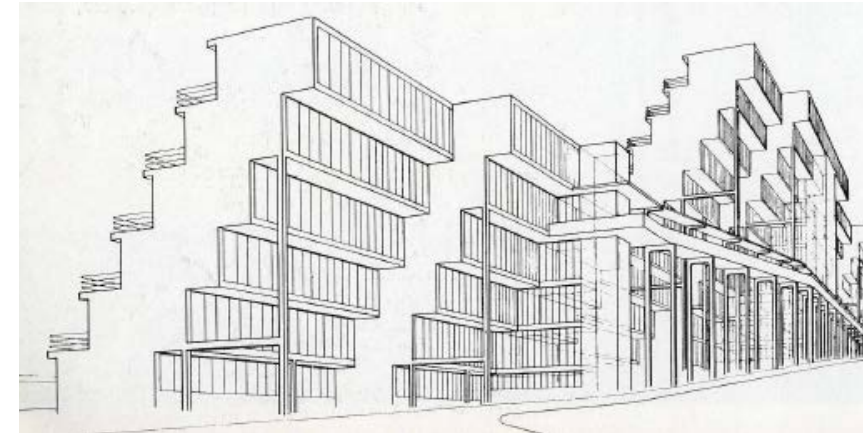

Figura 4. Hospital de Elberfeld. 1928

Siguiendo esta línea, resulta de mayor interés, por su ámbito urbano y de espacio público, la propuesta para la Unidad Vecinal del Futuro de Londres ${ }^{4}$ (Figura 5), en colaboración con F.R.S. Yorke, realizada durante su estancia en Inglaterra. La implantación de la edificación resuelve diferentes usos y genera, a través del estudio

4 El título original es "Civic Center of the Future". Si bien podemos encontrarlo traducido como Ciudad del Futuro en muchos textos, parece más adecuada la interpretación propuesta, Unidad Vecinal, puesto que realmente es, como explica M. Breuer en sus textos, una célula, un barrio, cuya repetición conformaría el tejido urbano, la ciudad. 
de su propia geometría y de su disposición, una propuesta de entendimiento sobre el espacio público. Cede todo el plano del suelo para el habitante resultando un espacio continuo. Dispone bloques de 12 alturas, siempre abiertos y transitables en planta baja. Su posición enfrentada N-S en el caso residencial, con extensión de hasta $210 \mathrm{~m}$. de largo, o más aislados y en forma de Y para el uso oficina, de unos $130 \mathrm{~m}$. de largo, favorecen la aparición de ámbitos de carácter más estático, a modo de plazas, dentro del conjunto. La idea de plaza resulta todavía más evidente en la solución para el centro comercial. Un edificio más compacto que dispone de un espacio central, con identidad propia, acotado por una edificación escalonada.

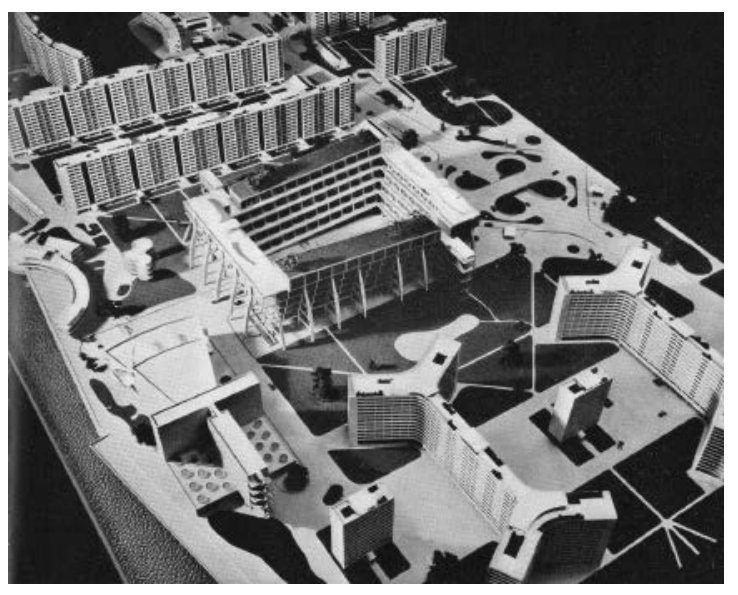

Figura 5. Civic Center of the Future. Londres. 1936

La etapa americana comienza en 1937 cuando W. Gropius le consigue un puesto como docente en la Universidad de Harvard. Su segundo período de docencia finaliza voluntariamente en 1947. Son años centrados en el campo residencial principalmente donde la vivienda es su principal campo de trabajo. Por un lado, atiende encargos de viviendas unifamiliares que compagina con el estudio e investigación de prototipos prefabricados y sus sistemas binucleares. La exposición de un prototipo suyo de bajo coste en el jardín del MoMA en 1949 le supone un gran reconocimiento y además logra en 1952 el encargo del proyecto para la sede de la Unesco en París ${ }^{5}$ (Figura 6).

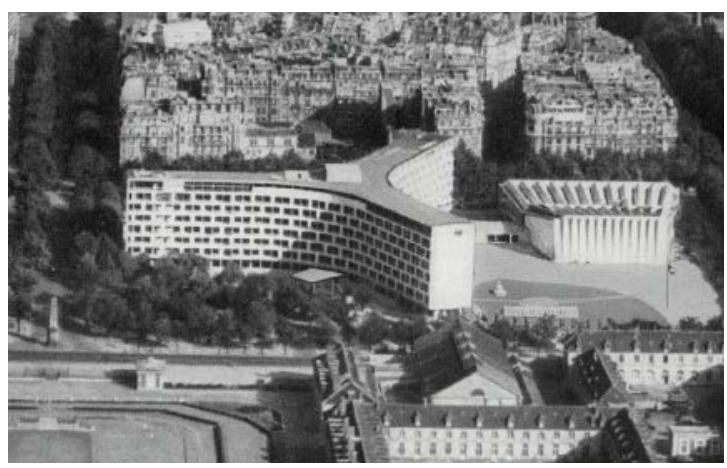

Figura 6. Vista de la sede de la Unesco desde la Torre Eiffel

5 Este encargo, realizado por una comisión de arquitectos entre los que se encuentra Le Corbusier y W. Gropius, lo realiza junto a Pier Luigi Nervi y Bernard Zehrfuss. 
Todos estos trabajos se recogen en la publicación de su monografía en 1955, comentada anteriormente, titulada "Marcel Breuer: Sun and Shadow. The Philosophy of an Architect" (Figura 7). Constituida como un auténtico manifiesto, cierran una etapa de cambio que le colocan en una nueva dimensión.
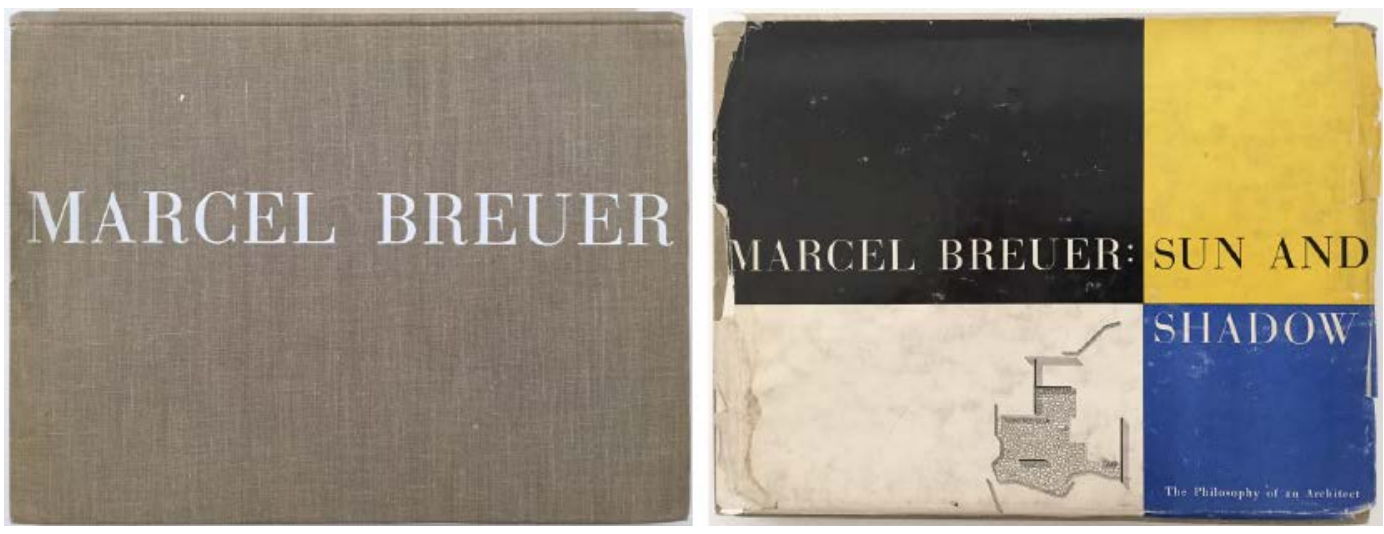

Figura 7. "Marcel Breuer: Sun and Shadow. The Philosophy of an Architect".

Portada libro entelada y sobre cubierta en papel a color diseñada por A. Brodovitch

A partir de 1955, su indudable nivel como arquitecto y diseñador, así como su alta capacidad de trabajo en equipo, le abren una nueva etapa internacional que culminará con su retiro efectivo en 1976 por problemas de salud. Este reconocimiento profesional le facilita el acceso a encargos por todo el mundo. En ellos, podrá experimentar con soluciones que lleva años elaborando en el campo de la prefabricación, la producción en serie y la estandarización. Se iniciaron en el campo del diseño del mobiliario, con la butaca Wassily, recorrieron el ámbito residencial y experimentan un nuevo cambio de escala con el edificio de la Unesco de París. De la mano de Pier Luigi Nervi descubre las enormes posibilidades de un material como el hormigón, versátil y económico que empleará principalmente para atender la nueva escala de estos proyectos. Incorpora soluciones prefabricadas en hormigón para sus Edificios institucionales, Conventos, Universidades, Edificios comerciales, Industriales, Oficinas centrales de grandes multinacionales... el número y diversificación es ingente. Si bien nunca abandona el campo de la vivienda, ahora se asocia con encargos de alto presupuesto y gran tamaño.

\section{El campo de la vivienda en M. Breuer. Estudios para la prefabricación y producción en serie \\ El estudio de las viviendas prefabricadas en M. Breuer se fundamenta en diversos motivos. Por un lado, en el libro Marcel Breuer: Sun and Shadow. The Philosophy of an Architect, su monografía-ideario más importante, los principales trabajos que se recogen están referidos a la vivienda. Es uno de los arquitectos que más esfuerzo ha dedicado a este tema. Desde que llega a los Estados Unidos se centra en el desarrollo de propuestas relacionadas con el habitar en múltiples facetas. Se le atribuyen 98 propuestas residenciales, ${ }^{6} 84$ de las cuales se plantean antes del año 1956.}

6 Atendiendo a las investigaciones realizadas por Joachim Driller con motivo de su tesis doctoral y recogido posteriormente en la publicación Breuer houses. 
En términos de producción, estudió unidades vecinales de gran tamaño, propuestas urbanas, como el "Civic Center of the future" de 1936, "New Kensington Defense Housing" de 1941 o "Stuyvesant Six" en 1943, llegando a desarrollar la primera vivienda de bajo coste expuesta en el jardín del Museo de Arte Moderno de New York en 1949. En términos de diseño, algunos de estos trabajos comparten una serie de inquietudes e intenciones como son la atención prefabricación, empleando materiales tradicionales como la madera, el control de $\operatorname{costes}^{7}$ o el estudio de la función, buscando el máximo confort para sus habitantes, que llega a materializar con los estudios de las casas binucleares.

M. Breuer, tanto por la formación recibida e impartida desde sus inicios en la escuela de la Bauhaus como por su amplio e importante trabajo desarrollado en el campo del mobiliario y los procesos industriales asociados, experimenta, con las obras de arquitectura, un cambio de escala en relación a la prefabricación, la producción en serie y el control de los procesos constructivos. Este cambio se asocia a la mejora de los procesos y la reducción de costes, cuestiones fundamentales a contemplar por un buen diseñador. Constata el fuerte sentido constructivo que se muestra en sus obras.

Para sacar todo el provecho a un principio constructivo y estructural, se necesita pasión y lógica. Existe un alma de la construcción y un instinto para la ejecución. [...] Experimentar con una construcción es divertido y transmite la sensación de estar actuando creativamente. Aunque, evidentemente, esto no debería ser una acrobacia sino una exploración de lo posible (Jones 1963: 19).

En el libro Marcel Breuer: Sun and Shadow. The Philosophy of an Architect en la parte cuarta titulada "Part Four: Works and Projects" dedica un apartado específico dentro del campo de la vivienda colectiva, a los sistemas prefabricados como herramienta capaz para desarrollar este tipo de implantaciones. La modulación, el orden, la idea del ensamblaje y la construcción en seco, son aspectos que guardan con la prefabricación una profunda relación.

Así, en el campo de la prefabricación y producción en serie de viviendas, encontramos cuatro proyectos residenciales: Kleinmetallhaus (1925), BAMBOS (1927), Yankee Portable (1942) y Plas-2-Point (1943). Los dos primeros se desarrollan en Europa ligados a su etapa en la Bauhaus, en estos el material empleado era el acero. Los otros dos proyectos los desarrolla casi 15 años después durante su primera etapa en Estados Unidos, cuando todavía es docente en Harvard, y en ellos el material utilizado es la madera. Estas dos últimas propuestas se presentaron ante la National Housing Agency en Washington, D.C., incluso como alojamientos para ex combatientes, pero no llegó a formalizarse ningún contrato. El alto grado de investigación que en su formulación tienen estos proyectos nos hacen entender que es necesario su revisión y se expone a continuación.

Kleinmetallhaus, 1925-1926.

Los primeros proyectos que desarrolla con la idea de producirse en serie se

$7 \quad$ Estas variables eran muy tenidas en cuenta por la restricción en el uso de materiales, acero principalmente, debido a los períodos de Guerra en los que se encuentra inmerso el país, y eran una herramienta clave para cualquier diseñador 
remontan a su etapa en la Bauhaus. Seguramente en el momento en el que establece sus series modulares para los sistemas de armarios "cabinet", preparados para incorporar a la vivienda un mobiliario que se produjera en serie, empezó a rondarle por la cabeza la idea de extender una producción en la fábrica al campo de la vivienda.

El primer caso, las propuestas de la Kleinmetallhaus (Figura 8), también conocidas como small metal house, consisten en una serie de viviendas adosadas de dos alturas organizadas mediante dos bandas, una el estar-estudio, con la escalera incorporada y con doble altura, y otra banda con los servicios y los dormitorios en el nivel superior. Muestran el ideal de la Bauhaus de permitir desarrollar unos modelos en los que se combinen funciones como el habitar y el trabajo, dentro de una idea de colonia. Aunque encerrado en un solo volumen y con posibilidad de acceder hasta la cubierta, de algún modo el esquema de la vivienda guarda ciertas similitudes con su vivienda construida en Lincoln años después. El sistema propuesto hablaba de realizar un sistema modular de paneles de acero con un armazón estructural también de acero. En el año 1925 realiza una primera propuesta de viviendas para ser fabricadas en serie.

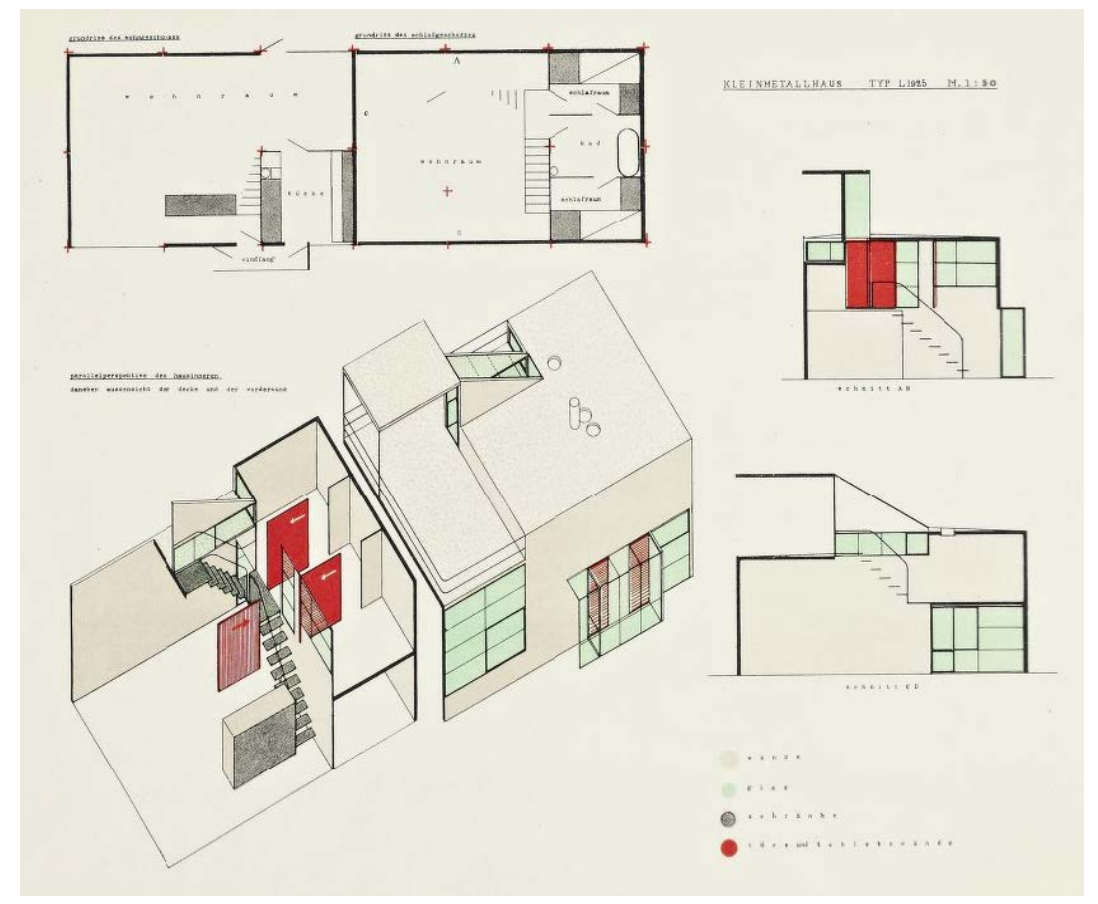

Figura 8. Kleinmetallhaus, 1926

Más adelante realiza unas modificaciones sobre el sistema que llama "small metal house" donde recoge hasta 6 posibilidades de distribución de la vivienda. A diferencia del primer dibujo general aparecido en 1925, en las axonométricas que acompañan las distintas plantas aparece una junta vertical que podría querer hacer referencia a un posible ensamblaje de los paneles de aproximadamente $3 \mathrm{~m}$. de altura. No se aprecia ninguna estructura adicional en la planta y parece que los cerramientos tienen cierto grosor, por lo que de alguna manera es de suponer que conforman a la vez cerramiento y estructura. 
Bambos, 1927.

Manteniendo y ampliando los principios que contábamos anteriormente, el programa de estas propuestas ahondaba todavía más en la idea de combinar funciones como la docencia y la convivencia. Se trata en este caso de una propuesta de viviendas para los "Jungmeister", jóvenes maestros de taller, que debía venir a completar en un escalón inferior, las viviendas que Gropius había diseñado para los maestros, las "Meisterhäuser" o villas para los maestros. Estas estaban totalmente alejadas del ideal de vivienda mínima que manejaba en esa época la Bauhaus y su construcción no estuvo exenta de polémica.

Las Bambos, viviendas cuya denominación obedecía a las iniciales de sus futuros ocupantes (Breuer, Albers, Meyer, Bayer, Meyer-Ottens y Schmidt), nunca llegaron a realizarse por problemas de financiación. La atención al programa y la función son singulares en este proyecto, agrupándolas de modo diferencial en área residencial, con luz de sureste y suroeste, área de trabajo, con luz de noreste, y las zonas de servicio como garaje, lavandería y trasteros. Existe información de 3 tipos distintos de combinaciones para la relación vivienda-taller. En las Bambos 1 el espacio del taller es independiente de la vivienda, formándose el conjunto a través de dos volúmenes adosados a distinta altura. Se encuentra elevado del plano del suelo y se accede a él mediante una escalera exterior. A ésta se accede directamente a cota de la calle. Con esta operación libera el suelo generando un espacio a cubierto lateral, a modo de patio o porche, y en planta alta recupera la cubierta como espacio de terraza. El cuerpo de la casa se organiza con un núcleo central de baños y cocina y dos dormitorios subdividibles a ambos lados. Sus dimensiones son generosas visualmente y $\mathrm{M}$. Breuer propone que se puedan compartimentar según las distintas necesidades de los usuarios mediante tabiques ligeros o mamparas textiles. Existe un pequeño lucernario inclinado para permitir que la zona central de servicios disponga de una buena iluminación y posible ventilación, demostrando la importancia que se le concede a estos espacios por M. Breuer. En las Bambos 2, la agrupación se realiza verticalmente, disponiendo la vivienda sobre el cuerpo del taller. En este caso al suroeste el espacio residencial, con el mismo programa que las Bambos 1, se termina con una terraza. En las Bambos 3 (Figura 9), la agrupación tiene un carácter extensivo y se basa en un sistema de bandas adosadas que tienen casa y estudio-taller. Este último se subdivide y se combina con la banda de vivienda que tiene anexa, formando en planta una especie de L. El esquema del espacio residencial también es distinto y se parte de una gran sala común y una banda de dormitorios-cabina de muy reducidas dimensiones. En consonancia a la planta propuesta, desarrolla una solución de huecos totalmente coherente con las necesidades de los espacios a los que sirve, y recurre al plegado de la cubierta para darle sentido mediante un sistema de lucernarios. Los dormitorios funcionan con una ventana rasgada alta continua dispuesta a noreste. La sala principal dispone de un gran hueco acristalado abierto a suroeste y a un patio. Por último, las zonas de talleres, disponen de un lucernario continuo de norte a suroeste, siendo opaco a la altura del plano de suelo, al igual que la zona de dormitorios. 


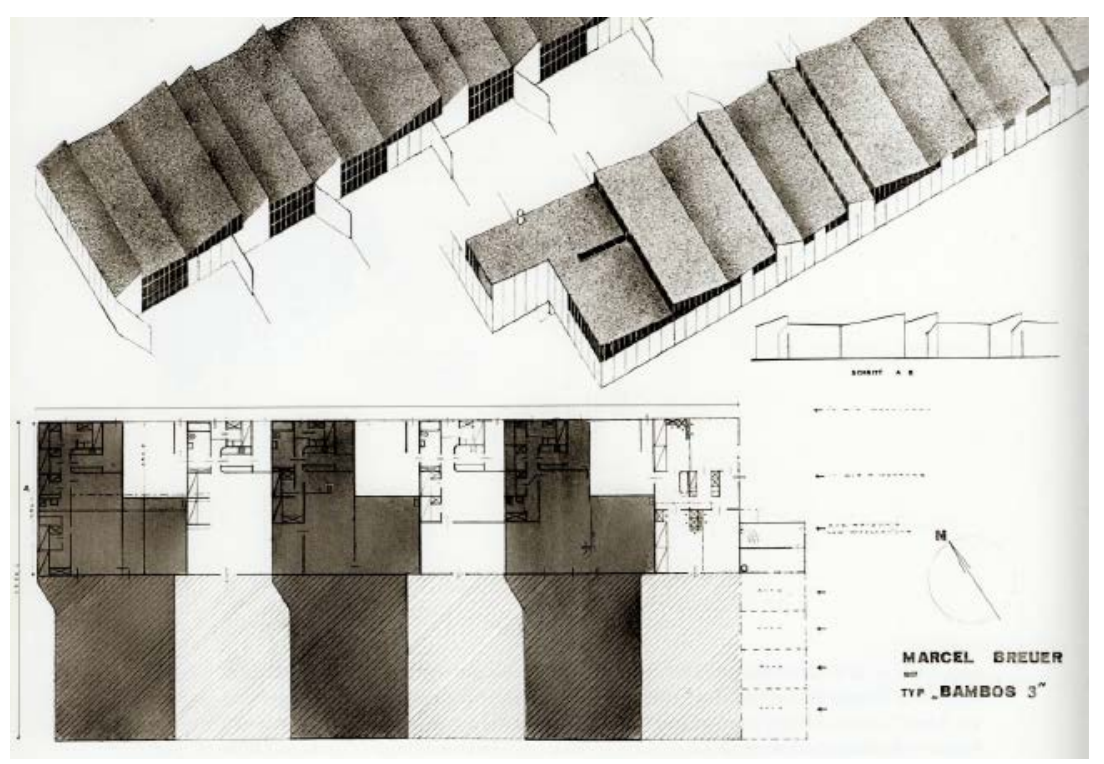

Figura 9. Bambos tipo 3. 1927

Con estas diferentes soluciones M. Breuer da una respuesta a sus ideales de lo que una casa moderna hoy debe contemplar. Por un lado, la vivienda vinculada al plano del suelo, facilita el acceso al espacio exterior desde todos sus lados y con máxima vinculación de las estancias. Por otro, la casa mirador, o casa belvedere, se eleva sobre el paisaje ofreciendo a sus habitantes mejores vistas y con una mayor sensación de libertad y de dominio de la naturaleza. Es interesante que la propuesta, a nivel constructivo y estructural, diera continuidad a los precedentes de la Kleinmetallhaus, pues parte de una comparación con el muro de piedra, que sostiene y aísla a la vez, pero necesitando importantes espesores para hacerlo adecuadamente. En contraposición, propone soportar y aislar mediante elementos independientes que forman parte de un mismo sistema. Se trata de paneles con entramado de estructura de acero que alojan en su interior los materiales aislantes y los elementos practicables como puertas o ventanas. Pretende, de este modo, transmitir una sensación de profunda ligereza condensando en una misma línea material, lo más fina posible, todas las funciones posibles en una envolvente tecnológicamente más compleja.

Los constructores medievales explotaban el arco de piedra hasta sus últimas posibilidades; un ingeniero moderno deseará también obtener el máximo de sus estructuras. Esta ambición es la raíz de los descubrimientos que, a su vez, repercuten en la economía. La estructura no es sólo un medio para resolver un problema, sino también un principio y una pasión (Breuer 1963: 19).

Es uno de los arquitectos que con más claridad ha entendido lo que ha supuesto la posibilidad de trabajar las estructuras no sólo a compresión como con la piedra, sino en flexión, con la incorporación del acero. "es un cambio tan radical que, por sí sólo, justificaría que la arquitectura se manifestase de una forma totalmente nueva" (Breuer 1963: 19).

Es probable que, la investigación previa desarrollada en Inglaterra para el fabricante de muebles en madera laminada Isokon, tenga gran influencia en las otras dos propuestas. 
Yankee Portable, 1942.

Este prototipo no construido, emplea paneles de madera en listones, a base de compuestos de madera "reciclada" o incluso con acabados plásticos (Figura 10). E1 sistema ofrecía algunas ventajas muy importantes, como era la implicación de un fabricante, Custance Brothers, que de algún modo respaldaba los diseños de M. Breuer. Esta propuesta de prefabricación se produce con un cambio de localización del arquitecto, ahora con residencia en Estados Unidos, y de material, proponiendo la madera como base de todo el proceso, como no podía ser de otro modo en Nueva Inglaterra. Los sistemas basados en el acero, que vimos anteriormente, permanecen para Europa. Sin embargo, comparten la idea de resolver el cerramiento y la estructura del mismo modo, a través de un panel auto portante de madera. El ensamblaje del propio panel, realizado sobre el suelo flotante que trabaja como una plataforma independiente formada también por paneles, junto a la cubierta, que en este caso ya presenta una ligera pendiente a ambas fachadas, arriostran y dan estabilidad a todo el sistema. La propuesta es desmontable y fácilmente transportable. El encuentro con el plano del suelo lo realiza a través de unos pequeños muros de hormigón que soportan un sistema de vigas de cimentación en madera paralelas a la fachada. Siempre aparecen ligeramente retiradas del frente, por la que logra mantener esa cierta sensación de ingravidez, apareciendo la caja flotando sobre el terreno. La cimentación es directa precisando para su instalación de una pequeña transformación y de terrenos favorables para asentarse.

La propuesta base adopta una profundidad fija de aprox. 7.20 m., 24', y propone, adoptando una agrupación en fila, establecer combinaciones posibles con viviendas de 1 a 3 dormitorios. En la práctica suponía que las viviendas podían crecer en función de su programa desde los $7.20 \mathrm{~m}$ hasta los $9.60 \mathrm{~m}$, lo que suponía en la práctica pasar de 6 a 8 paneles de aprox. $1.20 \mathrm{~m}$ de ancho. Los testeros en estos casos se trataban como medianeros y organizaba las estancias según dos bandas paralelas, agrupando el baño, siempre el mismo en todos los casos, y la cocina, que dispone de un segundo acceso e incorpora siempre un espacio para comer. Todas las estancias disponen de luz natural y ventilación directa al exterior. El centro geométrico de esta casa lo ocupa una chimenea para la calefacción. La sala principal se conecta con el exterior a través de un porche, con una solución que en planta ya ha propuesto anteriormente para la cabaña Chamberlain.

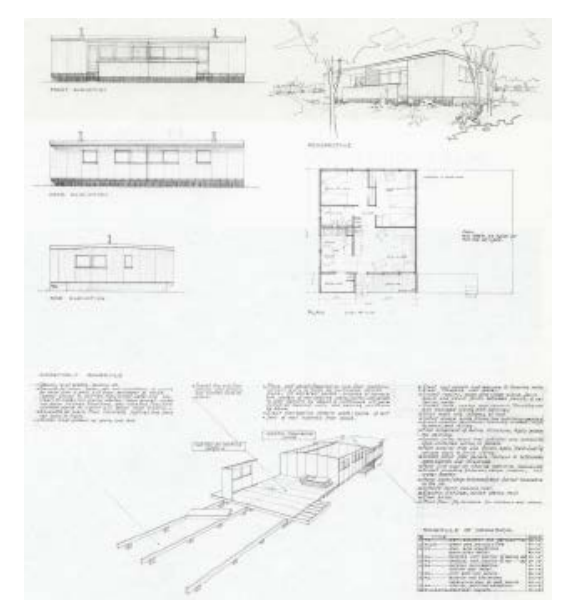

Figura 10. Yankee Portables 
Cuando la agrupación se basa en dos viviendas pareadas la profundidad aumenta hasta los $8.40 \mathrm{~m}$ y la distribución interior dispone el baño y la cocina en uno de sus testeros. Esta solución es la menos interesante de todas, puesto que parece que hace prevalecer un esquema de orden formal, reduciendo las posibilidades de la sala principal, el estar, a una relación idéntica a la que disfrutan las viviendas en hilera, beneficiándose poco de su condición aislada. En este esquema la distribución de áreas según su función es más clara, mostrándose como dos bandas que deslizan una junto a otra. En todas las soluciones la sala principal se ve obligada a soportar las circulaciones de acceso al resto de estancias, si bien en alguna de las propuestas por la posición más centrada del acceso, esta condición se evidencia menos. Las perspectivas que acompañan a los dibujos reproducen nuevamente esa búsqueda de relación con la naturaleza. Todas las viviendas, en sus agrupaciones, aparecen claramente arropadas por árboles de cierto porte. Es posible encontrar en ellos esbozos de caminos que se insinúan repeticiones en las agrupaciones, la presencia en segundos planos del vehículo como medio de transporte y, por supuesto, a sus habitantes disfrutando con una fuerte vinculación con el paisaje.

Plas-2-Point, 1943.

El sistema Plas-2-Point (Figura 11) debemos entenderlo como una evolución de las Yankee Portable compartiendo sus mismos principios, un sistema modular de paneles de madera. Aquí la cuestión más destacable es que apunta hacia una gran flexibilidad, que se puede aplicar desde el punto de vista de la vivienda y del emplazamiento, admitiendo en este último caso variaciones climáticas y geológicas. Respecto a la vivienda, el sistema estructural y constructivo propuesto, permite la modificación por parte del usuario de las distribuciones interiores, ofreciendo un alojamiento casi diáfano al poder compartimentar inicialmente sólo el baño y la cocina, generando nuevas estancias según las necesidades futuras. Respecto del emplazamiento y sus posibles variaciones climáticas, la libertad respecto a la posición y existencia de los cerramientos y particiones, le permite que pueda llegar a instalarse en lugares muy cálidos tropicales, eliminando los paneles de fachada y aumentando la superficie del porche. Por último, respecto del terreno, presenta un sistema de apoyo con el plano del suelo resuelto mediante dos únicos pies de muro de bloque de $1.20 \mathrm{x} 0.10 \mathrm{~m}$., 4'x8", que se encargan de transmitir las cargas de esta construcción al terreno. Esto resuelve, además de esa sensación de ingravidez con el terreno, el permitir desligar la construcción del tipo de terreno, siendo un sistema mucho más económico.

Para permitir esta manera de encontrarse con el plano del suelo y facilitar al usuario posibles modificaciones de su vivienda, plantea un sistema de dos grandes vigas centrales de madera, conectadas con un soporte en cada extremo, y que descansan sobre los pies de bloque. De estas vigas, tanto en el plano del suelo como en el del techo se disponen 7 vigas en voladizo conectadas a través de dos correas. El sistema precisa de dos paneles de 1.20 en cada fachada opuesta para arriostrar el conjunto, recogiendo las cerchas en su extremo final. No soportan ninguna carga y en realidad actúan atirantando tanto el plano del techo como el del suelo, que son los encargados de transmitir las tensiones a la viga central. Una de las distribuciones posibles que presenta se basan en el mismo sistema de doble banda o crujía habitable de dimensión total 24' x 24', como sucedía con la propuesta de las Yankee Portable de 1 habitación. En este caso ha girado 90 grados la posición del acceso y ofrece al frente de fachada la 
sala principal y la cocina, realizando un acceso entre ambos desde una pieza de porche como la que hemos ido viendo y que se encarga de realizar la transición con la calle. En cualquier caso realiza una desvinculación entre el porche y la sala principal o estar de la vivienda, ya que dispone de una pieza de almacenaje que fuerza al estar a una relación con el exterior a través de una ventana situada en la fachada opuesta.

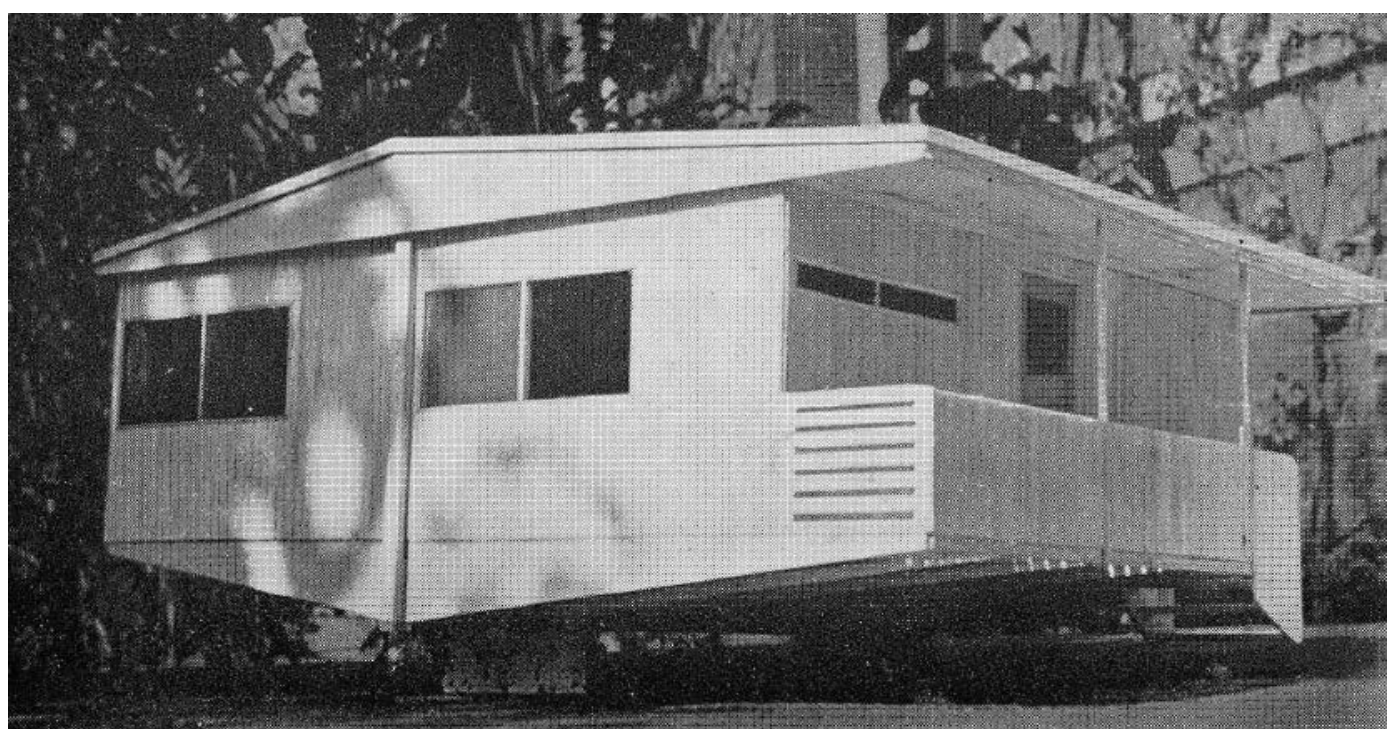

Fig. 11. Plas-2-Point

La planta tipo está pensada con tres frentes de fachada, uno vinculado a los accesos, y dos perpendiculares que resuelven la ventilación e iluminación de todas las estancias. La cuarta fachada es prácticamente ciega para permitir una agrupación de viviendas pareadas. La dotación de servicios higiénicos sigue siendo 1 estancia. La cocina incorpora de nuevo un pequeño espacio para comer. Es un tipo francamente ajustado de aprox. $52 \mathrm{~m}^{2}$ más el espacio del porche. El acabado de los paneles de madera laminada era mediante un revestimiento de resina plástica que debía aumentar la durabilidad de la madera. Permitiría un mantenimiento reducido sencillo e incluso incorporar el tema del color, particularizándolo para cada usuario. También mejoraba la impermeabilidad de la madera y su protección contra el exterior. El sistema propuesto era, en palabras de sus autores, un 30\% más ligero, un $70 \%$ más económico y ocupaba para el transporte entre un $30-40 \%$ menos que otros sistemas prefabricados del momento.

\section{Conclusiones}

M. Breuer se forma según los ideales de la Bauhaus a principios de los años 20 , en uno de los momentos más incipientes y revolucionarios de la arquitectura, y extiende aquellas ideas en el extranjero, desarrollando soluciones evolucionadas y adaptadas a los nuevos tiempos y necesidades sociales. En los Estados Unidos, con motivo de su llegada, existe la intención de presentarlo como uno de los arquitectos de sólida formación que salieron de la Bauhaus y que desarrollaron una labor completa en el mundo del diseño y la arquitectura. De este modo se respalda su capacidad para impulsar en este país su figura de arquitecto de la modernidad, capaz de hacer progresar la cultura arquitectónica en el nuevo continente. Este es uno de los aspectos 
que más interesan a Peter Blake, ${ }^{8}$ acérrimo luchador contra el término modernismo y del consecuente pensamiento reduccionista que intentaba asociar la arquitectura moderna en términos de estilo. P. Blake siempre pensó que, de algún modo, el término modernismo debería estar asociado a la idea de reforma, en los términos en los que desde la Escuela de la Bauhaus se intentaba transmitir.

$\mathrm{Su}$ indudable valor también ha sido reconocido por otros historiadores como Sigfried Giedion, para el que M. Breuer desarrolla los proyectos de los apartamentos Dolderthal en Zurich, o Henry Rusell Hitchcock. Este último aprovecha el ciclo de conferencias de Harvard del año 1938, en el cual M. Breuer presenta la traducción al inglés de su conferencia "Where do we stand?", para ahondar en esta idea de un diseñador global, un talento híbrido y casi un nuevo mesías.

Para dar el impulso decisivo a la arquitectura moderna hicieron falta dos temperamentos muy distintos; para nuestras ideas sobre la arquitectura moderna, el inflexible análisis intelectual de Gropius es un núcleo tan crucial, al menos, como la síntesis creativa de Le Corbusier, más difícil de expresar con palabras. Pero la continuación de la arquitectura moderna, sobre todo su evolución saludable en América, exige más bien la actuación de talentos híbridos, entre los que Breuer puede servir admirablemente de ejemplo (Hitchcock 1938: reel 5737).

M. Breuer es una de los diseñadores que mejor se adapta a las condiciones de los Estados Unidos. Por un lado es un fiel reflejo de la arquitectura moderna europea, con un perfil técnico desligado de ataduras formales, y demuestra la habilidad suficiente para filtrar de la arquitectura vernácula americana lo mejor de sus sistemas constructivos y de sus materiales, muy del gusto americano. Es un claro exponente formado según los ideales de la escuela de la Bauhaus. Representa la búsqueda incesante que persigue trasladar el ideal de la belleza que confía su razón de ser en los aspectos formales de apariencia y fruto de una inspiración, hacia el terreno de las relaciones constructivas y espaciales en un proceso de abstracción. Las propuestas de viviendas prefabricadas presentadas pueden constituir un hilo conductor que permite establecer las conexiones existentes entre su trabajo desarrollado en la Escuela de la Bauhaus y su etapa profesional posterior.

A lo largo de las diferentes etapas expuestas anteriormente se pueden extraer una serie de estrategias, intenciones y premisas en su tarea de diseño que podemos sintetizar en:

- Profunda relación entre material y diseño: cómo el diseño como proceso y producto (forma) está vinculado al material concreto y su adecuado conocimiento (materia).

- El diseño, proceso y producto, se hace cargo de variables como economía, transporte, dimensiones, peso... evidentes en la prefabricación.

- Su diseño muestra una relación convergente/divergente entre estructura y cerramiento, en el sentido constructivo, y también entre estructura y forma.

- Evolución en el diseño a partir soluciones anteriores o variaciones de las mismas. En las organizaciones de sus proyectos podemos detectarlo en el empleo de bandas, núcleos, sección, orientación, sustentación, agregaciones...

8 Arquitecto, crítico y editor de la revista Architectural Forum. Comisionado de Arquitectura y Diseño del Moma desde 1948. Redactó catálogo del Moma con motivo de la Exposición de la Casa en el Jardín, obra de M. Breuer. 
Demuestra con sus trabajos que la modernidad en la arquitectura nola aportaron los materiales o los procesos industriales de producción en serie, sino el cambio de actitud por parte de algunos arquitectos en la manera en que incorporaron en sus proyectos estos nuevos sistemas y materiales, una nueva filosofía del diseño.

\section{Bibliografía}

AAVV. 2003. Marcel Breuer diseño y arquitectura. Weil am Rhein: Vitra Design Museum. Bergdoll, B and Christensen, P., 2008. Home Delivery. Fabrication the modern dwelling. New York: Museum of Modern Art.

Blake, P. 1949. Marcel Breuer, architect and designer. New York: Museum of Modern Art. Breuer, M. 1936. On architectural and material, en Archives of American Arts, image id AAA_breumarc_5718_1323_001imageidAAA_breumarc_5718_1324_001,https:// breuer.syr.edu/xtf/view?docId=mets/33343.mets.xml;query=circle;brand=breuer.

— 1938. Where do we stand ?. Conferencia original de 1934 titulada Wo stehen wir heute? traducida al inglés por él mismo en 1938. https://www.aaa.si.edu/ collections/marcel-breuer-papers-5596/subseries-6-1/reel-5718-frames-936-954.

Breuer, M. and Blake, P. 1955. Marcel Breuer: Sun and Shadow, The Philosophy of an Architect, New York: Longmans, Green \& Company.

Gatje, R. F. 2006. Marcel Breuer, a memoir. New York: The Monacelli Press.

Hitchcock, H. R. 1938. "Marcel Breuer and the American Tradition in Architecture". Harvard University Archives. Marcel Breuer papers, 1920-1986. Box 34, Reel 5737, Frames 1053-1078, https://www.aaa.si.edu/collections/marcel-breuer-papers-5596/series-9/reel-5737-frames-1053-1078

Hyman, I. 2001. Marcel Breuer architect. The career and the buildings. New York: Harry N. Abrams.

Driller, J. 2000. Breuer houses. London: Phaidon Press Limited.

Jones, C. 1963. Marcel Breuer. Construcciones y proyectos 1921-1961. Barcelona: Editorial Gustavo Gili. 


\title{
Diseño y artes escénicas: el papel de Oskar Schlemmer en Das Triadische Ballett y la actualidad de la Bauhaus
}

\section{Design and performing arts: the role of Oskar Schlemmer in Das Triadische Ballett and the present of the Bauhaus}

\author{
Milagros García Vázquez
}

\begin{abstract}
Resumen
Existe una obra estrechamente vinculada al universo de la Bauhaus, Das Triadische Ballett, ballet creado en gran parte por Oskar Schlemmer, cuyo diseño, desde el escenario, el vestuario, la coreografía, e incluso la música, comenzó sin embargo a nacer antes de la aparición de la institución fundada por Walter Gropius. Cuál fue su génesis, cuál fue el papel del diseño en el proceso creativo que le dio forma, hasta qué punto llegó la implicación de Schlemmer en esta obra y cómo ha pasado a estar su nombre tan íntimamente unido a la Bauhaus, son algunos de los objetivos de este estudio. Asimismo, es esta puesta en escena una ocasión constante para ver actualizados los parámetros en los que se movería la escuela artística alemana, pues se trata de una obra de la que aún hoy, desde que la idea surgiera en 1912, pueden seguir viéndose representaciones.
\end{abstract}

Palabras clave: Bauhaus, Oskar Schlemmer,

Triadisches Ballett, diseño, escena, danza.

\begin{abstract}
There is a work closely linked to the universe of the Bauhaus, Das Triadische Ballett, a ballet created largely by Oskar Schlemmer, whose design, of the stage, costumes, choreography, and even the music, began nevertheless before the appearance of the institution, which was founded by Walter Gropius. What was its genesis, what was the role of design in the creative process that shaped it, how extent was the Schlemmer's involvement in it and because is its name so intimately joined to the Bauhaus, are some of the goals of this article. Also, this play is a constant opportunity to update the parameters of this artistic German School, because this work, since the idea was born in 1912, can still be seen performed even today.
\end{abstract}

Keywords: Bauhaus, Oskar Schlemmer, Triadisches Ballett, design, stage, dance.

\section{La actualidad de la Bauhaus a escena}

"En la pintura de Oskar Schlemmer vive una nueva energía espacial... Despierta en el espíritu del espectador la idea de una cultura venidera de la totalidad, una cultura donde todas las artes serán reunidas de nuevo" (Maur 1977: 9). ${ }^{1}$ Estas palabras, dirigidas por Walter Gropius en 1961 a la memoria del ya por entonces desaparecido Oskar

1 Texto original en alemán, traducción propia. Todas las citas extraídas de originales en alemán, inglés o francés, son traducciones propias.

* Universidad Pontificia de Comillas, España.mgvazquez@comillas.edu Artículo recibido: 31 de mayo de 2019; aceptado: 15 de octubre de 2019 
Schlemmer, podrían ser aplicadas a la propia actividad de la Bauhaus, donde el polifacético artista trabajaría desde 1921 hasta 1929. Esa "cultura venidera de la totalidad" es la fomentada desde las filas del profesorado de los Bauhäusler, tanto por el propio Gropius, cabeza y fundador, como por J. Itten, W. Kandinsky, L. Feininger, L. Moholy-Nagy, J. Albers, G. Stölzl, P. Klee, M. Breuer o H. Bayer, algunos de los docentes más destacados. Junto a la arquitectura, la pintura, la escultura, el diseño de tejidos, el dibujo, la fotografía, en el marco de la riqueza creativa de la Bauhaus estarán también presentes las artes escénicas -en las que Schlemmer tendrá un papel fundamental-, y todo lo que ellas comportan, es decir, espacio, movimiento, luz, color, música, temporalidad, y también diseño, el de los decorados y el del vestuario de los diferentes personajes. La especificidad de estas artes del escenario otorgan a sus creaciones una nota distintiva importante, la de un inmanente potencial de actualización, pues, una vez diseñado el decorado, elaborado el argumento y dispuestos los demás componentes, las obras pueden volver a representarse una y otra vez, bien en su versión original, o bien con las variantes aportadas por los diferentes directores que las pongan de nuevo en marcha. Por esta razón, toda recuperación hecha hoy de los trabajos realizados en este ámbito dentro de la Bauhaus, es una notable forma de actualización de este espacio creativo que ve cumplirse en 2019 sus cien años de historia. El análisis de esta potencial actualidad es el objeto de las páginas siguientes.

Una de las representaciones escénicas más innovadoras de los primeras décadas del siglo XX, y donde el diseño resulta un elemento esencial es, sin duda, Das Triadische Ballett (El Ballet Triádico). Un proyecto estrechamente vinculado tanto a Schlemmer, como a la Bauhaus. Al primero, por ser creador y artífice, y a la segunda, por haber obtenido dentro de ella el primer gran éxito ante el público. Bien es cierto que la gestación de la obra precede a la fundación de la escuela, lo mismo que su primera puesta en escena en 1922, pero en su diseño, contenido artístico y estético, y en su progresiva constitución, sus parámetros son equivalentes a los de la que sería catalizadora de las nuevas energías artísticas emergentes a principios de siglo en el centro de Europa, la propia Bauhaus.

Ante estas afirmaciones se podrían abrir dos cuestiones, cómo nace la vocación de Oskar Schlemmer por el mundo de la escena, y cuál fue el proceso completo por el cual Das Triadische Ballett está hoy tan estrechamente unido al mundo de la Bauhaus, a pesar de haber sido creado fuera de ella, que su estudio se ha convertido en una de las vías de acceso para mejor conocimiento de los presupuestos y directrices de los que parte y en los que incide el trabajo realizado en el seno de esta institución artística.

\section{Oskar Schlemmer y su vocación artística}

Comencemos por la trayectoria de Schlemmer. Ésta ofrece, por un lado, una panorámica condensada de las nuevas corrientes de principios del siglo XX; y por otro, justifica la integración del artista en el universo, podríamos decir, "pluriartístico" de la Bauhaus. Del mismo modo, su evolución da cuenta de cuál fue su contribución a ella, así como de su denodado interés e intensa dedicación en el Ballet Triádico. Desde niño se relaciona con las artes, su abuelo paterno, pastelero, era conocido por las artísticas imágenes y dibujos con los que adornaba sus dulces, su padre obtuvo algunos reconocimientos como comediógrafo, y su abuelo materno era orfebre. El joven Oskar destaca en las clases de arte impartidas en la escuela, obteniendo algún galardón, pero pronto ha de salir para aprender un oficio tras la muerte de su padre y la subsiguiente 
necesidad económica. Aun así, su formación profesional sigue incardinada en el mundo del arte, consiguiendo su título de artesano en dibujo para marquetería, enseñanza donde conoce todo el proceso, desde el dibujo al patronaje, el traslado del modelo, el recortado de las piezas y su montaje. Su primer trabajo se enmarcará dentro del Jugendstil, colaborando en la realización del panel El hermanamiento de Europa y América diseñado por Hans Christiansen para la Exposición Universal de St. Louis en 1904.

En 1906 obtiene una beca para estudiar en la Academia de Bellas Artes de Stuttgart, perfeccionando su talento natural para el dibujo, la pintura y la composición. Conoce a los que serían sus más cercanos amigos, al pintor y diseñador gráfico suizo Otto Meyer-Amden y a Willi Baumeister, también pintor y diseñador gráfico, además de escenógrafo, fotógrafo y tipógrafo. Con el primero realizaría su primera pintura mural, una Anunciación ${ }^{2}$ para la capilla católica de la "Ausstellung Kirchlicher Kunst Schwabens" ("Exposición de Arte Sacro de Suabia") en Stuttgart.

En 1911, durante un viaje a Berlín, se aproximará al mundo de las Vanguardias artísticas, entrando en contacto con el círculo de artistas vinculados a la revista expresionista Der Sturm, editada por el escritor, galerista y músico Herwarth Walden. Aquí conocerá además el Cubismo, mostrando especial aprecio hacia la obra de Picasso y Derain en unas primeras tentativas. A su regreso a Stuttgart en 1912, comienza su carrera como profesor en la Academia de Bellas Artes, abriendo al año siguiente una sala de exposiciones junto con su hermano Willy, el "Neuen Kunstsalon am Neckartor", donde podrán verse por primera vez en la ciudad obras de artistas de Vanguardia como Kandinsky, Klee, G. Münter, F. Marc, O, Kokoschka, Meyer-Amden, G. Braque, A. Gleizes, o J. Metzinger. La galería se ve obligada, sin embargo, a cerrar al año siguiente, debido a las duras críticas recibidas por parte de la prensa.

Su participación en la "Werkbund-Ausstellung" de Colonia en 1914, con algunos de los paneles ${ }^{3}$ destinados al pabellón principal construido por Theodor Fischer, le permitirá conocer a Ernst Ludwig Kirchner y muy probablemente será entonces cuando tenga un primer contacto con Gropius. El viaje que inicia después del evento le lleva a Londres, Amsterdam y París, hasta que con la irrupción de la Guerra es destinado a la infantería del frente occidental. Herido al año siguiente en un brazo, sigue pintando durante su convalecencia hasta su recuperación y nuevo destino en el cuartel de Gaisburg.

En las vacaciones de 1916, concedidas durante la guerra a los estudiantes, experimenta con diversas composiciones abstractas, como en Bild $K$ (Landesmuseum Münster, Depositum Schlemmer) o Komposition auf Rosa (Landesmuseum Münster, Depositum Schlemmer). En la primera, los motivos gráficos reducidos a líneas y pequeñas áreas de color grises, blancas y negras, recuerdan el mundo en que vive en esos momentos, hélices y alas de avión, un visor de tiro y, junto a ellos, la palabra Bild y la letra K. Maur (1977) ha relacionado esta letra con el siguiente contenido de una de las páginas de su diario, ${ }^{4}$ vinculándola a la palabra "Kampf", ("lucha") al evocar esta imagen la visión de un piloto ante su campo de actuación. ${ }^{5}$

\footnotetext{
2 No conservada.

3 No conservados.

$4 \quad$ Fechadas a mediados de marzo de 1916.

5 Volker Demuth vincula esta letra a las palabras "Kunst" y "Krieg", "arte" y "guerra" respectivamente en alemán (Demuth 2002: 189).
} 
¿Cómo es posible alcanzar la profundidad en el arte? ¿Cómo oponer resistencia a los impedimentos consustanciales a la habilidad? ¿Cuál de estos impedimentos es el más fuerte? ¿Cómo transformar la idea en una forma? ¿Cómo trasladar nuevas ideas a nuevas formas? Emprendo una lucha contra mi línea renacentista. ¿El campo de batalla? Austeridad, forma, superficie. Las formas de lo nuevo. Sin técnica, sin trucos artísticos. Sólo fijando lo necesario (Schlemmer 1989: 24-25). ${ }^{6}$

En Komposition auf Rosa aparece la figura humana, plana y geométrica, elaborada a partir de líneas rectas, formas circulares y superficies lisas de color sin matices. Una esencial simplicidad en la línea de uno de sus artistas más admirados, y quizá modelo para sus aspiraciones, Klee. Al final de este verano, Schlemmer escribe en su diario:

Klee es el espíritu moderno conocido más cabal. [...] El trabajo de Klee es absolutamente maravilloso. Con una línea mínima es capaz de desvelar toda su verdad. [...] Ella lo es todo, íntima, delicada, es todo lo mejor, y es, sobre todo, nueva. [...] Las obras de todos los hombres importantes tienen sus raíces en un conocimiento simple aunque ampliamente abarcante. Este hallazgo supone haberse encontrado a sí mismo, y con ello, el mundo y todas las cosas (Schlemmer 1989: 28-29). ${ }^{7}$

Al terminar la contienda, hecho que vive destinado en Berlín, regresa a su Stuttgart natal donde sigue trabajando en la Academia de Bellas Artes. Junto con otros compañeros $^{8}$ forma parte del "Üecht Gruppe", abogando por un cambio en el sistema formativo de la Academia y apoyando la venida de Klee como sustituto del anterior director, Adolf Hölzel. Gropius respaldaba la iniciativa. Para refrendar sus propósitos organizan una exposición, "Herbstschau Neuer Kunst", con sus propias obras, con algunas de las más conocidas realizadas por los artistas del grupo berlinés "Sturm" y dedicando una sala especial a Klee, invitando así al debate sobre su obra. Schlemmer expone aquí, entre otras, Plan mit Figuren (Staatgalerie Stuttgart), un lienzo donde predomina una estricta geometría y el suave modelado de los cuerpos. Semejantes a figurines de madera, tienen el aspecto de ser patrones modulares para otras obras, o ensayos para figuras terminadas, a modo de tentativas en proporciones, medidas y relaciones entre sí, con áreas de color, unas veces planas y otras tonales para dar sensación de corporeidad. Todo un juego de volúmenes que anuncia las figuras plásticas y densas que compondrán sus futuras pinturas. La exposición obtuvo un eco positivo y considerable, aunque el objetivo no se logró y Arno Waldschmidt fue elegido director en lugar de Klee.

En 1920 Schlemmer abandona la Academia, colabora con el grupo "Sturm", y sigue exponiendo sus obras, ahora en la Galerie Arnold de Dresde, junto a los trabajos de Baumeister y Kurt Schwitters. Gropius le pide entonces formar parte del profesorado de la Bauhaus, ubicada entonces en su primera sede, Weimar. Se encarga allí primeramente de los talleres de escultura en piedra, pintura mural -junto con Itten- y dibujo anatómico. En este mismo año el escritor, dramaturgo y pintor Lothar Schreyer

6 Afirma después cómo la fotografía y el cine posibilitaron un arte propio de un mundo nuevo, el arte abstracto, que "hace aquello que la fotografía no puede hacer". Aunque, precisamente en la Bauhaus, esta línea generatriz del arte moderno desde el Impresionismo, será superada gracias a los experimentos fotográficos de MoholyNagy.

$7 \quad$ Septiembre de 1916

8 Gottfried Graf, Albert Kinzinger, Albert Müller y Hans Spiegel. 
es convocado para abrir una nueva área de creación en la Bauhaus, el taller de escenografía, una iniciativa cuyo conocimiento acoge Schlemmer con gran entusiasmo, enseguida conoceremos los motivos.

Se percibe ya en aquel momento el enfrentamiento entre las diferentes posiciones de Gropius e Itten. Unas divergencias recogidas por Schlemmer en sus cartas a Meyer-Amden ${ }^{9}$ de 1922. Por un lado, la mentalidad práctica de Gropius; por el otro, el carácter místico de Itten; uno piensa en el trabajo eficaz mediado por la técnica, y el otro, en el desarrollo de las capacidades creativas de los alumnos en condiciones de silencio y mediante experiencias interiores concretas. Itten confiesa a Schlemmer su deseo de marcharse, ante lo cual Gropius prepara la venida de un nuevo profesor, Kandinsky, que se incorporará en este mismo año. Es ahora cuando las siluetas vistas en algunas de las mencionadas obras de Schlemmer encuentran su expresión acabada en Die Geste (Tanzerin, Bayerische Staatsgemäldesammlungen, Neue Pinakothek München). Imagen elocuente de su inclinación hacia el mundo de la escena, de hecho, confiesa a Meyer-Amden que cada vez son más quienes le dicen que el teatro es lo suyo (Schlemmer 1989: 82). ${ }^{10}$ En un cuadro de dos metros por uno, una inmensa figura parece haber terminado su paso de baile y estar en suspensión esperando el aplauso, estirando brazos y piernas, rodeada por un resplandor al fondo como un eco de sus propias formas.

Cuando en 1923 llega a la escuela Moholy-Nagy, la convergencia entre arte y técnica impregna la orientación pedagógica y creativa de las diferentes áreas. La fotografía y las grabaciones fílmicas adquieren un progresivo protagonismo en detrimento de la pintura. Schreyer abandona la Bauhaus en estos meses, y Schlemmer queda sólo, al frente del área dedicada a las artes escénicas.

Cuando el poder político cambia de orientación en Turingia, y gobiernan los opositores del estilo de la Bauhaus, los integrantes de la escuela se plantean el traslado, eligiendo Dessau como nuevo destino. Poco a poco la institución se transforma, y lo que era un centro para la educación y fomento de la creatividad artística, se va tornando en una empresa de producción casi industrial. Comienzan a surgir grupos que presionan para realizar una reforma en el funcionamiento interno, Gropius se ve obligado a dimitir. Le sustituye el suizo Hannes Meyer, quien pondrá el foco de atención en impulsar el trabajo y rendimiento de los talleres y en activar el departamento dedicado a la arquitectura. La función de la Bauhaus es ahora esencialmente social, más que artística, tal como declara el propio Meyer en un texto que podría considerarse su manifiesto:

Construir y crear son lo mismo, un acontecimiento social. [...] La Bauhaus de Dessau no es un fenómeno artístico, sino social. Como organismo creador, nuestra actividad está condicionada socialmente. [...] Nuestro trabajo es la búsqueda de la forma armónica esencial. No buscamos un estilo Bauhaus, ni una moda Bauhaus, ni superficies ornamentales a la moda divididas en líneas horizontales y verticales, inspiradas por el Neoplasticismo, ni imágenes geométricas o estereométricas sin vida y contrarias a la funcionalidad. [...] El objetivo final del trabajo de la Bauhaus es reunir todas las fuerzas vitales para la constitución armónica de nuestra sociedad (Meyer 1929: 2). ${ }^{11}$

9 La correspondencia mantenida entre ambos, como veremos en este estudio, es una de las fuentes más ricas a la hora de estudiar la obra y profundizar en el pensamiento estético de Schlemmer.

10 Carta a Otto Meyer-Amden, fechada en Weimar, el 13 de marzo de 1922.

11 La revista Bauhaus. Zeitschrift für Gestaltung comienza a editarse tras el traslado desde Weimar a Dessau, aparecerá 
Moholy-Nagy, Breuer y Bayer dejan la Bauhaus en 1928, Schlemmer lo hará en 1929 para comenzar una nueva etapa en la Academia de Artes y Oficios de Breslau. ${ }^{12}$

\section{E1 origen de Das Triadische Ballett}

La iniciativa de contar en la Bauhaus con un área dedicada a la escenografía es acogida, decíamos, con gran alegría por parte de Schlemmer, y es que prácticamente había consagrado su vida al mundo de los escenarios ya desde el año 1912. En aquellos momentos, cuando acababa de regresar a Stuttgart, ésta se había convertido en un centro vivo para el arte moderno, punto de encuentro no sólo para sus amigos Baumeister y Meyer-Amden, sino también para el pintor H. Stenner, los arquitectos G. Schleicher -más tarde colaborador de Adolf Loos-, R. Herre o R. Döcker, creadores pertenecientes al círculo de Hölzer. En este ambiente se movería el primer bailarín del Ballet Real de Stuttgart, Albert Burger y su esposa Elsa Hötzel. Baumeister hará las presentaciones entre Schlemmer y los Burger, iniciándose una estrecha amistad, que les llevaría a idear juntos el Ballet Triádico.

El matrimonio había pasado ese verano unos días en Hellerau, barrio al norte de Dresde, toda una referencia para el arte escénico moderno gracias a la escuela rítmico-musical abierta allí por Emile Jacques-Dalcroze ${ }^{13}$ en 1911. Todos aquellos que deseaban estar al día de las últimas novedades en música y danza acudían a la escuela o a sus actividades.

Un importante colaborador de Dalcroze fue el escenógrafo Adolphe Appia, quien encontró aquí un lugar donde la importancia concedida a las relaciones entre el cuerpo, el espacio escénico y la música, le permitirían poner en práctica sus novedosas ideas sobre la puesta en escena. Planteamientos que tenían en cuenta la integración entre dichos tres elementos y sus condiciones temporales y dinámicas, junto con los juegos de luces, sombras y colores.

Appia había conocido la didáctica de Dalcroze ya en Génova en 1906, escribiendo poco después:

Mis impresiones fueron complejas y sorprendentes, en un primer momento me sentí conmovido hasta las lágrimas, recordando durante cuánto tiempo lo había estado esperando. Pero pronto sentí el despertar de una nueva fuerza completamente desconocida para mí. Ya no me encontraba entre el público, estaba en el escenario junto con los actores (Appia 1924: 383). ${ }^{14}$

A partir de aquí, le queda claro el modo de encaminar sus inquietudes sobre la expresión musical del cuerpo y sus posibilidades relacionales con el entorno y, por

periódicamente desde 1926 hasta 1931.

12 Se aproximaba la disolución de la Bauhaus. En 1930 Meyer es sustituido por Mies van der Rohe, continuador de la línea iniciada por su predecesor cada vez más orientada hacia la arquitectura. Tras la derrota socialdemócrata en Dessau en las elecciones de 1932, la Bauhaus se traslada a Berlín. Cuando los nacionalsocialistas 1legan al poder en 1933, el gobierno cierra sus puertas.

13 Dalcroze desarrolló un método musical (eurítmica) cuya pedagogía contempla la relación entre música, movimiento y coordinación, combinando el solfeo con la expresión corporal rítmica y su relación con el espacio y la improvisación. "La educación por y para el ritmo es capaz de despertar el sentido artístico de todos los que se sometan a ella" (Dalcroze 1920: 115).

14 Citado en Beachman 1985: 155. Las principales teorías escenográficas de Appia pueden encontrarse en su libro Musik und die Inszinierung (1899). 
ende, con el espectador: "El método me fue revelado por Dalcroze en 1906, sin cambiar mi orientación, su eurítmica me liberó de una tradición demasiado inflexible, y, particularmente, del decorativismo romántico de Wagner. [...] La eurítmica determinó mi evolución futura" (Appia 1924: 378). ${ }^{15} \mathrm{El}$ sistema lo resume el propio Appia en una carta dirigida al mismo Dalcroze: "La externalización de la música (es decir, su rehabilitación) es una idea que he estado deseando durante muchos años. Nada puede salvar a la música de su suntuosa decadencia excepto la externalización" (Beachman 1994: 74).

Esta experiencia vivida por Appia, será compartida por Burger cuando conoce el mundo creado en torno a las ideas de Dalcroze en Hellerau. Esa misma posibilidad abierta de expresión, mediante el dinamismo del cuerpo humano, comprendido en su libertad de movimientos, involucrado con el color y las formas plásticas, desplegando sus gestos al son de una pieza musical desarrollada en el tiempo y en el espacio del escenario, no sólo entusiasma Burger, sino que se correspondería con las inquietudes expresivas de propio Schlemmer. Muestra de ello será cómo ambos trabajan dichas cuestiones y sus soluciones durante la gestación y proceso creativo del Ballet Triádico.

Burger se siente igualmente liberado al encontrar este nuevo ámbito de acción, tan parejo a su deseo de romper con el mundo del ballet clásico en el que había sido formado y al que había dedicado su carrera. Al regresar a Stuttgart, comienza ya a planear un proyecto con una puesta en escena nueva, revolucionaria. Paralelamente, la ciudad cuenta ya con iniciativas, en principio, propiciatorias, para ver nacer otra propuesta audaz y novedosa. Nos referimos a las actuaciones de la bailarina letona Sent M'ahesa, o a las de la alemana Clotilde von Derp. Representantes señeras de la "Danza expresionista" (Ausdruckstanz) de la que fueran pioneras Isadora Duncan o Loïe Fuller. Su peculiar forma de moverse en el escenario rompía con las reglas clásicas del ballet, al proponer como alternativa la expresión individual, creativa, espontánea del cuerpo en movimiento, haciendo partícipes de él al color, los tejidos y las luces. Igualmente, se habían visto allí las especiales puestas en escena de Rita Sacchetto, quien dotaba movimiento con su danza a diferentes pinturas y obras de arte. Eran las llamadas Tanzbildern. Ejecutadas como ecos de los Tableau Vivant del siglo XIX, se diferencian de ellos por el hecho de no ser el principal objetivo reproducir e manera estática una pintura, ${ }^{16}$ sustituyendo a las figuras por personas, sino el emplear la obra para, combinando artes visuales, movimiento y música, crear representaciones dinámicas de esas obras. Su propósito era el de expresar, de forma personal, todo lo que el artista utilizando únicamente la pintura, el plano en dos dimensiones, no pudo mostrar. La misma intención ponía en sus representaciones coreográficas de los poemas Ibsen o Whitman, aspirando a dar forma y vida en el escenario a las palabras escritas sobre el papel.

Es importante tener en cuenta este ambiente creado en torno al mundo de la danza a principios del siglo XX, pues aquí surgirán, se alimentarán y desarrollarán las ideas de Schlemmer, sobre escenografía y movimiento en particular, y sobre el arte en general. Como se desprende de estas experiencias del ballet moderno, las novedades provienen en su mayor parte de la interacción de esta disciplina artística, la danza, con las artes plásticas, en definitiva con el diseño de formas, y la aplicación, cargada de

15 Citado en Beachman 1985: 155.

16 Saccheto tomaba como referencia obras de los pintores Thomas Gainsborough, Joshua Reynolds, Sandro Botticelli o incluso Velázquez (véase Simonson 2013). 
significado, de los colores en esos mismos diseños, cuyo uso supera ahora una función meramente decorativa. Formas a las que se suman el diálogo entre ellas, el conjunto de sus movimientos, la música que los anima, las variaciones de luces y sombras y su contextualización espacial en el escenario.

No hay que olvidar en este punto, por otra parte, el papel jugado al respecto por las novedades musicales. En estos años, la segunda década del siglo XX, la población de la ciudad de Stuttgart tuvo la ocasión de poder escuchar el Pierrot Lunaire de A. Schönberg, concretamente el 11 de noviembre de 1912, bajo la dirección de Hermann Scherchen. La obra original es un conjunto de cincuenta poemas en forma de rondel publicados por el belga Albert Guiraud en 1884. En ellos se cuenta la historia de algunos de los personajes de la Commedia dell'Arte, Colombina, Arlequín, el viejo Doctor y el sol del ocaso y la luna. Otto Erich Hartleben traduce los poemas al alemán en 1893, trasladando a los personajes a un contexto moderno, y sin conservar las rimas y longitud originales de los versos. La cantante Albertine Zehme pide a Schönberg escribir la música para cantar ella misma una selección de dichos poemas. El músico suma al ritmo sincopado de la versión de Hartleben la ruptura del relato al dividir la selección de los poemas en episodios melodramáticos breves y al utilizar la atonalidad en la composición. La prensa local describe la incomprensión del auditorio ante la obra por parte, y es que gran parte del público se marchó de la sala antes del final. Sin embargo, algunos espectadores se sintieron verdaderamente entusiasmados ante la nueva música, entre ellos los mismos Schlemmer y Burger. El bailarín creyó encontrar en el compositor austríaco a la persona ideal para crear el acompañamiento musical más apropiado a su ballet, sobre todo por las analogías reconocidas con la pieza de Schönberg en la historia, los personajes, y la búsqueda de la novedad en el ritmo y desarrollo. Burger escribe una carta al músico, explicándole la naturaleza del proyecto.

Como bailarín principal del Teatro Real me dedico de forma independiente a la danza moderna, apoyándome principalmente en las ideas de Dalcroze. Busco mostrar la novedad de mis pensamientos en forma de pantomima. Aspiro a encontrar una unidad entre danza, escenario y música, y trabajo con algunos pintores en el diseño de la escena y del vestuario. Su música, que acabo de conocer en el concierto que ha tenido aquí lugar, se me presenta como la única apropiada para mis ideas (Günther 1963: 65).

Unas semanas más tarde, el bailarín recibe la respuesta de Schönberg.

Respecto a su pregunta he de decirle lo siguiente. Si conoce usted mi música y ha tenido en cuenta su casi total alejamiento respecto al mundo de la danza, y aun así la considera apropiada para sus ideas, entonces yo también la tomo como tal. Puesto que en este sentido yo mismo tengo mis ideas sobre el teatro, sería muy interesante conocer las suyas. Sin embargo, me encuentro ahora ocupado con otros trabajos, pero esto no ha de constituir un obstáculo, estoy en todo caso dispuesto a darle nombres de jóvenes músicos que buscan lo mismo que yo (Günther 1963: 65).

Ante esta situación, y el deseo de tener listo el ballet para la inauguración del Pabellón de las Artes en Stuttgart en marzo del año siguiente, Burger acude a Appia y a Dalcroze para dar con la música que necesitaba. El primero se encontraba enfermo y, a pesar de entusiasmarle las ideas de Burger, se ve obligado a declinar su colaboración. Lo mismo sucedería con Dalcroze, quien, sobrecargado de trabajos, no puede hacerse 
con otro más. El francés le recomienda a Albert Jeanneret, hermano de Le Corbusier. Aun habiendo encontrado músico, no hubo tiempo más que de presentar un pequeño esbozo para la inauguración del pabellón, una suerte de "ejercicio obligatorio con artistas soñadores, unos bailarines guerreros y unas floristas" (Günther 1963: 65).

Uno de los trabajos en los que había estado centrado Dalcroze, con la colaboración de Appia, era en la puesta en escena de la ópera Orfeo y Eurídice, de Gluck, estrenada en este mismo año en el festival de Hellerau. Escenarios simples, geométricos, vestuario sencillo y una coreografía donde los alumnos de Dalcroze ponían en práctica las ideas del maestro, supusieron de nuevo un hito en la danza moderna durante aquellos años. Años en los que podían ir viéndose también los trabajos de los coreógrafos Rudolf von Laban, ${ }^{17}$ su alumna Mary Wigman ${ }^{18}$ o Nijinsky. Este es el contexto para nuestro ballet en el mundo de la danza de principios de siglo.

En 1914 la guerra interrumpe la finalización definitiva del ballet. Schlemmer mantiene correspondencia con Burger durante sus años de soldado, y así, de forma epistolar en la distancia, continúan compartiendo las ideas a poner en práctica en el desarrollo del proyecto. Cuando el 7 de diciembre de 1916 Schlemmer recibe aquel permiso para pasar un día en Stuttgart, los Burger presentan una danza en tres piezas, a modo de pieza "piloto" de lo que sería el Ballet Triádico, acompañadas de la música de Marco Enrico Bosi, con el vestuario diseñado hasta aquel momento para la obra definitiva. Algunos entusiastas, como Hans Hildebrandt, deseaban que volviera a repetirse. Oswald Kühn, crítico del Schäbischen Merkur, supo valorar la línea de actuación del ballet y sus presupuestos estéticos. Incluso Leutnant Stotz, oficial de cultura del regimiento, organizó en otoño de 1917 un segundo festival para que hubiera una nueva representación, en la que Schlemmer pudo incluir una nueva pieza, Die Serenade mit langen Gitarre (Günther 1977: 51). A pesar de este reconocimiento, el pintor, recordándolo, cuenta decepcionado a Meyer-Amden haber experimentado el rechazo por parte del auditorio (Schlemmer 1989: 34). ${ }^{19}$ Este anticipo parecía anunciar un final próximo para los trabajos en la obra, pero su estreno definitivo no llegaría todavía, aún habría que esperar hasta 1922.

En otoño de 1919, Schlemmer se traslada al distrito Canstatt (Stuttgart), donde contará con una gran sala y un escenario real para continuar con sus trabajos. Una vez terminada la Guerra, éstos se llevan ahora a cabo con mayor intensidad, aunque no exentos de las dificultades derivadas del conflicto. Así lo contaba la que sería dentro de unos años la esposa de Schlemmer, Tut Schlemmer:

Era un trabajo en equipo, Oskar Schlemmer diseñaba los trajes y hacía los patrones, aun no teniendo idea de costura. La señora Burger cosía ella misma gran parte. Carl Schlemmer realizaba las partes plásticas de la decoración del escenario y se ocupaba de la ejecución técnica. El aprendizaje costó caro y hubo que superar grandes dificultades. En ese tiempo de posguerra se carecía de muchos materiales

17 Su notación aplicada a la danza, "cinetografía" o "notación Laban", propone la integración del espacio circundante del bailarín con sus gestos, cuyas direcciones se traducen sobre el papel en símbolos colocados en tres líneas, como notas en una partitura musical. Deseaba así ampliar la gama de movimientos de los bailarines respecto a las normas clásicas del ballet, para hacerlo más expresivo y creativo.

18 Sus coreografías aspiraban a ser la expresión del interior del bailarín. Un cuadro de Kichner, Totentanz der Mary Wigman (1926), la recuerda en una de ellas. El pintor escribió en su diario "la creación de un nuevo concepto de belleza está presente tanto en sus trabajos como en mis pinturas” (Henze 2016). 
y los que había eran muy caros. Se trataba de nuevos materiales para la época, alambres de níquel, objetos metálicos, que a Schlemmer le fascinaban. No había cristal flexible, ni celofán, ni aluminio, tampoco cremalleras, por lo que todos los trajes se abrochaban con mucha dificultad. Unos eran unidos con soldaduras, otros remachados o claveteados. Las formas hechas a base de papel maché eran pegadas con interminables tiras de papel de periódico (Scheper 1988: 26).

A lo largo de estos meses, Schlemmer llega a sentir ganas de abandonar el proyecto, tal como le cuenta a Meyer-Amden en sus cartas. Tiene claras sus ideas, su deseo es ponerlas en movimiento, y esto no le resulta difícil en sí mismo, pero considera cada vez más complejo el hacer que otros bailarines compartan y exterioricen sus mismas emociones. Llega a decir a su amigo si "no habrá cosas mejores que hacer que cortar faldas para ballet" (Scheper 1988: 26).

Los elementos más claros desde el principio, habían sido la historia, el argumento, $\mathrm{y}$, sobre todo, los personajes y sus figuras. El Ballet Triádico contaría la historia de una pareja, en los personajes interpretados por Burger y Hötzel, quienes, seducidos por un daimon, el propio Schlemmer, ${ }^{20}$ caen en la confusión perdiendo su inocencia primigenia. En distintos estadios la recuperarán, pero ahora de una forma, podría decirse, más elevada y enriquecida, pues lo que antes era una ingenuidad inconsciente, es ganada como una inocencia consciente de sí. A pesar de contar con una historia perfectamente trazada desde el comienzo, la puesta en escena, el diseño del escenario, los colores y formas del vestuario, la iluminación, serían objetos de numerosos cambios desde aquel 1912 hasta el estreno el 30 de septiembre de 1922. Estos cambios revelan cuál es el centro de las reflexiones de Schlemmer en la gestación y creación del ballet. No se trataba tanto del argumento, como del diseño visual de las formas, de la aplicación de los colores y su significado y, por ende, de la construcción de una atmósfera adecuada para sumergir al espectador en el acontecimiento puesto en movimiento sobre el escenario.

Se conservan diversos documentos en los cuales puede seguirse el trabajo de Schlemmer sobre el ballet, y reconocer, a partir de los cambios e incorporaciones respecto a la primera idea, esta evolución de sus preocupaciones al respecto y sus implicaciones en la obra final. En una carta a Meyer-Amden con fecha del 30 de noviembre de 1912, escribe un primer esbozo del plan para el ballet:

Preludio:

I. Gris, atmósfera polvorienta, antiguo vestuario de ballet, música convencional.

El rojo Revolucionario sale en un intenso y luminoso rojo, irradiando una luz brillante en forma de cuña.

II. Una figura vieja y nueva (blanca y roja), ensamblada en una forma cuadrada de color azul, y ésta a su vez en un triángulo azul.

El camino:

I. Una pared azul oscuro, figuras rojas y naranjas, un delirio dionisíaco, barbarie salvaje como fuente de fuerza (danza al modo de los pueblos exóticos).

II. Agotamiento. Una pared verde, figuras violetas y verdosas.

III. Locura: Avivamiento, éxtasis loco y sobreexcitado hasta los límites de lo posible. Vestuario alado, máscaras con sonrisas medievales y trascendentales. Pared amarillo limón, figuras grisáceas, azuladas. 
IV. Enajenación mental. Un ataúd... como decorado "y mientras no lo tienes, si la semilla no muere", tumba para la resurrección, una pared marrón, figuras grises y negras.

V. Resurrección. Dicha, atmósfera: una pared blanca, figuras azul claro y rosa claro. Nueva música.

Nueva danza.

Nuevo color (Scheper 1988: 18-19).

Al mes siguiente, Schlemmer ha pensado ya en modificar estas primeras ideas, los anota en su diario a finales de año, bajo el título "Evolución desde el antiguo al nuevo ballet". El planteamiento esquemático anterior cobra un carácter más narrativo, lo cual supone un mayor espacio para la historia, junto al ya contemplado para los colores y las figuras:

Telón: terciopelo oscuro; el derredor de madera natural color claro.

Lo gris: decoración convencional, quizá con luna, ¡como en una atmósfera vespertina! En la danza y la música: Finalización, como apoyo según las convenciones, corriente, ligeramente aceptable, estilo de los ballets rusos, a causa de su éxito. Los bailarines muestran el arte con el que podrían haber tenido éxito, seguramente sea del gusto del público.

Un daimon se desliza rápidamente sobre el escenario (corporeización de lo dionisíaco), un excitante color amarillo anaranjado, máscara, se pone a jurar, gesticulando delante del telón; los bailarines (interrumpidos en su danza) retroceden, se asombran. El telón se divide (o cae desde arriba una tela como un velo de color marrón oscuro, que envuelve a los bailarines y se va volviendo, poco a poco, más amarilla y roja). El daimon se esconde de nuevo. El ambiente tiene algo de oscuro, de búsqueda, de transformación; confusa y sorda, la melodía, la música y el tempo suben y bajan de nuevo, igual que sucede con los bailarines. La música, en los últimos registros, suena paralelamente color marrón. El daimon aparece de nuevo y con su aparición levanta el velo marrón. La atmósfera crece en adelante de roja a naranja oscuro. Música y danza provocan apasionadamente - éxtasis erótico, el daimon baila, triunfa. La atmósfera se intensifica cambiando desde el naranja hasta el amarillo limón como símbolo de lo enfermizo, irritante, extático, el movimiento de los bailarines y también la música son estridentes, con tonos altos.

Entonces: paralelamente cae la noche profunda - un fondo oscuro, los bailarines se cubren de gris. La música, profunda, en un tono menor, tristeza.

En medio del fondo aparece un punto violeta que se va convirtiendo en un círculo. El círculo se transforma en un cuadrado azul. La música se vuelve más clara - hasta el azul, un profundo y puro azul que lo domina todo. La música: mayestática, festiva, la danza lenta, delicada. Aparece el querubín (un ángel vestido de plata, muy vaporoso, tenue, delicado, con una silueta imprecisa). La atmósfera pasa del azul oscuro al azul claro, cada vez más clara hasta el blanco puro (o plateado) - los bailarines se reúnen, guiados por el querubín. Una estrella blanca brilla al fondo. La música suena suave (Schlemmer 1989: 6-7). ${ }^{21}$

Burger en una carta pone al corriente a Jeanneret acerca del tema del ballet, a la que sucedería otra misiva de Schlemmer sobre los detalles respecto al simbolismo de los tonos y colores. En esta relación se pone de manifiesto la importancia esencial de los colores en

21 Diciembre de 1912. 
el ballet hasta en los detalles a simple vista banales, como podrían ser el cromatismo de los telones que dividen las escenas:

Telón: blanco (como símbolo del comienzo, del devenir)

I. Una cortina violeta como símbolo de la confusión, de la apatía: Música y danza confusas, buscando (comienza un poco de melodía y se pierde de nuevo, lo mismo el tempo de la danza, amaga y desaparece de nuevo).

II. Telón rojo: como símbolo de la actividad, de la pasión despertada, de la sensualidad, algunas trompetas en la música (siempre que no esté limitada al piano).

III. Telón amarillo: símbolo de la trascendencia, atmósfera alocada y extática en la música y la danza.

IV. Tránsito al azul (telón azul): símbolo de la espiritualización, de la rememoración.

V. El telón azul: símbolo de la pureza, de la claridad, el color del cielo (Günther 1963: 65).

Esta evolución del plan cromático y su correspondiente ejecución material en el Ballet Triádico, en el que Jeanneret en respuesta a Burger afirma encontrar un tono demasiado filosófico al final de la pieza, cuenta con significativos precedentes. En primer lugar, enlaza con una idea ya trazada por el propio Kandinsky en 1909 y publicada en el Almanaque del Blaue Reiter en 1912 y conocida por Schlemmer. Nos referimos a Der gelbe Klang-ideada junto con otras tres piezas, Der grüne Klang, Schwarz und Weiss y Violet-, cuya descripción, perfectamente detallada por Kandinsky en el Almanaque, ${ }^{22}$ contiene grandes similitudes con las anteriores indicaciones dadas por Schlemmer para su ballet. Los colores y las luces, sus cambios y progresiones, son puestos igualmente en estrecho paralelo con el desarrollo musical ${ }^{23}$ a lo largo de los seis cuadros que componen la pieza. El propósito de Kandinsky es aquí mostrar un ejemplo de cómo, a pesar de que cada una de las artes se sirve de un medio externo diferente -el sonido, el color, o la palabra-, todas convergen en un punto común que las identifica: ser reconocidas como vibraciones, o experiencias interiores, en el alma del espectador y contribuir a lo que él llama "Verfeinerung der Seele", la mejora o sensibilización de su espíritu. Así, de la ópera toma la música como fuente del sonido interior; del ballet, la danza como movimiento abstracto; del sonido, su significado independiente y el potencial de su carácter autónomo. Además, esta interacción sinestésica entre las artes encontrará entre los profesores de la Bauhaus, no sólo a Kandinsky, sino también a otros adalides, como serían Itten o Gertrud Grunow. Por otro lado, Schlemmer conocía bien del mismo modo las experiencias sinestésicas de Skriabin, ${ }^{24}$ y sus asociaciones de tonos musicales a colores y efectos lumínicos.

Hasta ahora hemos hablado principalmente acerca del escenario y del diseño de la puesta en escena, pero, como decíamos, y nos indicaba Tut Schlemmer, la elabora-

22 La reproducción íntegra del Almanaque puede encontrarse en el alemán original en: Kandinsky, W., Marc, F. (eds.). 2016. Primera edición 1965. Der Blaue Reiter. Munich/Berlín: Piper, y también traducida al castellano en: Kandinsky, W., Marc, F. (eds.) 2010. El jinete azul: Der Blaue Reiter. Barcelona: Paidós.

23 Se había previsto que la música fuera compuesta por Thomas von Hartmann y que las piezas fueran estrenadas en 1914, el estallido de la guerra lo impidió.

24 Para su Prométhée. Le Poeme du feu introdujo un parte para un piano al tocarse que pudiera combinar música y luz. Fue creado por Alexander Moser. De uso privado, se ignora si funcionó, hoy existe un modelo en el Museo Skrjabin. Esta parte de la obra se interpretó en 1915 con la "cromola" de Preston S. Millar, sin el éxito esperado. Desde entonces se ejecuta sin los efectos lumínicos pensados por el compositor. 
ción del vestuario resultó esencial. Al igual que sucede con el resto de los elementos espaciales y ambientales del ballet, no resulta en absoluto accesorio, sino crucial en el desarrollo integral del conjunto y en su significación visual. De hecho, las ideas sobre las atmósferas formuladas hasta ahora, encuentran su origen en la configuración de las formas para los figurines del vestuario. Así se lo explica Schlemmer en carta a Hildebrandt: "Primero fue el vestuario, los figurines. Después se buscó la música. [...] A partir de la música y los diseños del vestuario se desarrolló la coreografía" (Schlemmer 1989: 98). ${ }^{25}$

En otra de sus cartas refiere igualmente esta relevancia capital del vestuario, aquí como diferencia sustancial entre su forma de entender la danza y la del Dalcroze. En tanto que la de éste, a los ojos de Schlemmer, es un ejercicio de escuela, "una danza ética", con significaciones "básicas y bellas", su voluntad es en cambio "estética, mejor dicho, artística. [...] Dalcroze no tiene vestuario, o depende de los diseños de Hodler. Para mí el vestuario lo es todo" (Scheper 1988: 27). Y es que el vestuario para Schlemmer constituye un compromiso con la expresión de un ideal de belleza artística autónomo, sin otra finalidad que el arte en sí mismo (Schlemmer 1927b).

Tanto el color como la geometría, son los elementos a partir de los cuales Schlemmer elabora toda una gramática aplicada al diseño de los diferentes trajes para los bailarines. Ésta cobrará su sentido en la combinación entre los movimientos de la danza y las formas geométricas con las que están vestidos quienes los ejecutan, quedando así convertidas en formas vivas y dinámicas. Ello sin descuidar, al mismo tiempo, la contextualización de sus gestos en la atmósfera lograda gracias al cuidado diseño del resto de la escena. El predominio de los valores geométricos en los modelos para el vestuario, queda ya reflejado en una de las notas de su diario en octubre de 1915:

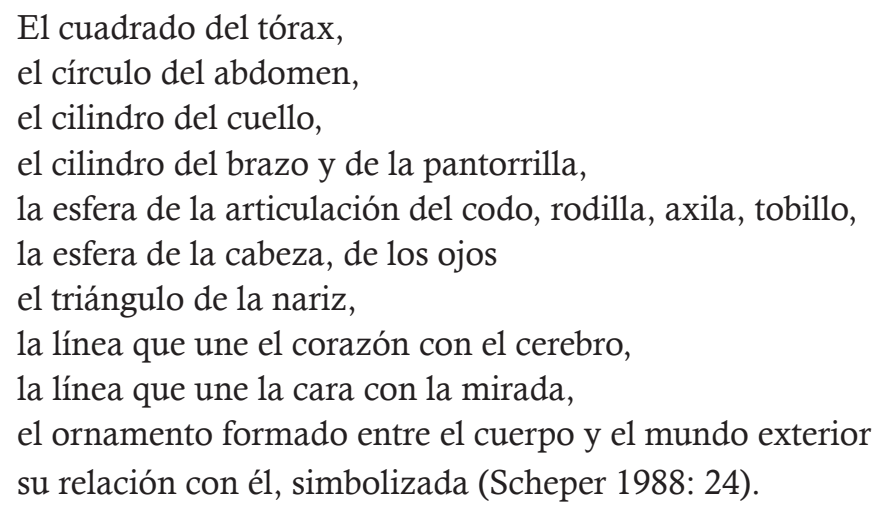

La interacción de estas formas dotadas de vida a través de la danza, articuladas únicamente mediante su movimiento específico y el sonido de la música, sin intervención de las palabras, no es sino lo propio de la pantomima, género en el cual Schlemmer -igual que Burger- ve el despliegue de infinitas, y deseadas, alternativas para la renovación del panorama escénico de la época. De un modo quizá similar a cómo venían haciendo ya las Ausdruckstänzerinen arriba mencionadas, pero incorporando la estética del arte coetáneo, del Expresionismo, del Futurismo y del Cubismo fundamentalmente. Las razones se las da Schlemmer a su amigo Meyer-Amden: "Veo grandes posibilidades en el ámbito del ballet gracias a la pantomima por su independencia 
respecto a lo histórico, lo que la diferencia del teatro y la ópera, por eso creo que de este pequeño pero libre ámbito de la escena surgirán novedades decisivas" (Scheper 1988: 25).

En aquella misma carta desvela el origen de su entregado trabajo a la creación de este ballet, incluso viviendo inmerso y de forma activa en un conflicto bélico. Desde aquel 1912 descubría, gracias a este proyecto, cuál es para él el medio más inmediato de expresión artística y, podríamos decir, el más completo: el cuerpo humano, y éste en su interacción con el espacio tridimensional. El acontecimiento estético limitado al plano en un lienzo, o al estatismo de una escultura, eclosiona y cobra vida si las formas pictóricas y plásticas se ponen en movimiento "encarnadas" en la figura humana sobre un escenario, y si se ofrecen, no únicamente a la experiencia del ojo, sino también a la del oído gracias al acompañamiento musical.

De esta manera, un diseño global de la escena bajo dichos parámetros no sólo pone en juego los elementos artísticos esenciales, como la línea o el color, sino que además hace desaparecer la ficción de la tridimensionalidad propia de la pintura tradicional, y ya no con los recursos propios del arte abstracto, es decir, prescindiendo de los tonos de color y de la perspectiva, sino incorporando la auténtica tercera dimensión a las imágenes al colocarlas sobre el escenario. Elimina a su vez otro efectismo ilusorio, el de la luz y los tonos de color, incorporando ambos como elementos reales. Al mismo tiempo, suma a la presencia de las formas en el espacio, común tanto a la pintura como a la escultura, su desarrollo en el tiempo gracias a la música y al movimiento de la danza. Schlemmer describe estos fenómenos a Meyer-Amden, hablando de la existencia de una "geometría en el suelo sobre el que se danza" como "parte y proyección de la estereometría espacial", a lo que añade cómo él mismo práctica al piano incluso "una geometría similar de los dedos y el teclado", esforzándose por encontrar "una identidad y unidad entre el movimiento, la forma de los cuerpos y la música" (Schlemmer 1989: 62). ${ }^{26}$

Podríamos ver aquí la aspiración hacia la Gesamtkunstwerk, a la "obra de arte total", idea gestada ya durante el Romanticismo, donde las figuras del filósofo, el poeta y el artista se confunden, y que llega a su culminación con Wagner. Para él, la danza, la música y la poesía eran tres artes inseparables, porque el hombre es cuerpo -que se mueve y se ve-, sonido - que se escucha en su voz-y palabras - de las que se sirve para expresarse (Wagner 2007). Entiende el arte como la actividad más elevada del hombre, y el arte escénico, la unión más íntima, excelsa y perfecta de todas las artes (Wagner 2013: 36). En el caso de Schlemmer, éste no busca satisfacer el deseo por alcanzar esa "obra de arte total" reuniendo las artes en un único golpe de expresión, sino involucrando la propia vida del artista en la obra hasta un punto tal, que llega a integrarse en ella, y ella en él. La experiencia vital del artista se convierte en el corazón de la verdadera obra de arte total, en palabras de Schlemmer, en el "símbolo de la unidad entre la naturaleza y el espíritu" (Scheper 1988: 34).

\section{Das Triadische Ballett y la Bauhaus}

Esta concepción interdisciplinar y complementaria de las artes es la que quizá le lleva a visitar y a conocer más de cerca, en 1920, lo que se venía haciendo en la recién inaugurada Bauhaus. Al regresar de aquel viaje a Dresde, donde exponía con Baumeis- 
ter en la Galería Arnold, decide pasar por Weimar y conocer la escuela a la que seguía con interés desde que Gropius publicara aquel manifiesto fundacional en 1919. A la primera invitación del arquitecto a formar parte del profesorado, Schlemmer contesta con una negativa, argumentando trabajos pendientes por terminar, es decir, el Ballet Triádico era aún su prioridad. Finalmente, ante la insistente llamada de Gropius, quien volvería a invitar a Schlemmer en octubre, llegan a un acuerdo. Firmará su contrato en diciembre, y comenzará su trabajo en 1921, permitiéndosele vivir entre Weimar y Stuttgart para terminar el ballet.

Esta unidad entre las artes, existente en el sistema pedagógico y estructura vital de la Bauhaus que admiró a Schlemmer, se ajustaba perfectamente a su idea acerca del hombre, del arte, del artista y de la relación entre ellos, concentrada de forma representativa y simbólica sobre el escenario y en la reunión de la superabundancia de los recursos escénicos, como venimos viendo. Así lo deja de manifiesto, ya como profesor integrado en la institución, en sus reflexiones antropológicas y estéticas:

La historia del teatro es la historia de la transformación de la figura del hombre: el hombre como representante de acontecimientos corporales y espirituales en proceso de cambio desde la ingenuidad a la reflexión, de la naturalidad a la ficción. Forma y color son los medios de este cambio, los medios del pintor y del escultor. El escenario de dicha transformación es la estructura formal del espacio y de la arquitectura, el trabajo del arquitecto. Por ello, el papel del artista, quien sintetiza estos elementos, se confirma en el ámbito de la escena (Schlemmer 1925b: 7). ${ }^{27}$

Esta nueva ocupación en la Bauhaus, junto con nuevos trabajos como escenógrafo, concretamente en el acondicionamiento del teatro de Württemberg para el estreno de las obras de Paul Hindemith, con textos de Kokoschka, Mörder, Hoffnung der Frauen y Nuschi-Nuschi, demorarían un par de años más el estreno definitivo de Triadisches Ballett, que no tendría lugar hasta aquel 30 de septiembre de 1922 en el Württembergischen Landestheater.

Los espectadores que tuvieron ocasión de acudir al estreno se encontrarían, en primer lugar, con un título cuanto menos insólito. El prefijo "tria-", se refiere a la tríada de notas que forman un acorde. Schlemmer llegaría a describir el ballet como una "apoteosis de la ternalidad" (Scheper 1988: 34), "una tríada en figuras, formas y colores. [...] Una obra colectiva a partir de la pintura y la plástica, la danza y la música" (Schlemmer 1925a: 191). Y es que para nuestro artista "el tres es una figura dominante y eminentemente importante en la cual el yo monomaníaco y la oposición dualista son superados y comienza la colectividad" (Scheper 1988: 34). Según este planteamiento, la obra pretende la superación del yo individual y de su enfrentamiento al otro en la dualidad, mediante la combinación de elementos reunidos en tríadas a través de la creación artística, conectando todos sus puntos creador, bailarines, coreografía, escena, música y público, y aspirando así alcanzar esa realidad colectiva. Un deseo para cuyo cumplimento se precisa la implicación más plena posible por parte del espectador, otra razón por la cual la obra invita a la participación simultánea de la vista y el oído. Este anhelo de cómplice plenitud es el origen, por tanto, de la presencia constante del número tres. Tres son las series en que se divide el ballet: la serie amarilla, alegre,

27 Los Bauhausbücher, editados por Gropius y Moholy-Nagy se publicaron desde 1925 hasta 1930, con un total de 14 números. 
burlesca y cómica; la serie rosa, festiva y semi-seria; la serie negra, mística, fantástica y seria. Asimismo, el ballet se apoya en tres elementos, la combinación entre vestuario, coreografía y música; al igual que la puesta en escena se articula a partir del espacio, la forma y el color. A ello se suman las tres dimensiones del escenario y las tres formas básicas de la geometría, en las que se basan tanto los trajes como las diferentes partes del decorado: el triángulo, el círculo y el cuadrado. Formas estrechamente vinculadas aquí, por otra parte, a los tres colores también básicos, el rojo, el azul y el amarillo, presentes en todo el diseño.

En segundo lugar, la música, estímulo para el movimiento de estas formas y colores, que escuchó aquel auditorio, no fue finalmente compuesta por Jeanneret, tampoco por los demás músicos con los que Burger contactó buscando al compositor ideal, como August Halm, o Waldemar Schmidt, quien llegó a proponerse por propia iniciativa (Günther 1977). También Paul Hindemith se ofrecería en julio de 1920 a comprometerse con la musicalización. Realizó tres composiciones diferentes, que Schlemmer descartaría, pues hubieran ofrecido dificultades a los bailarines en la coreografía. ${ }^{28}$ Finalmente se utilizaron piezas tanto de compositores contemporáneos, como Mario Tarenghi, Bossi, Debussy, así como de otros clásicos, Haydn, Mozart, Pietro Domenico Paradies, Baldassare Galuppi o Händel. ${ }^{29}$ Esta inseparable imbricación entre el sonido y las formas dinamizadas sobre el escenario en los gestos y movimientos de los bailarines, quedaba descrita por el propio Schlemmer como una de las cualidades especiales del Ballet Triádico: "El valor de este ballet reside en la musicalidad de la organización de las formas [...] surgidas del deseo de jugar con ellas, con los colores y el material. ¿No son esfera, semiesfera, cilindro, disco, espiral, elipse, etc., las formas espaciales de la danza, los elementos de movimiento y rotación por excelencia?" (Schlemmer 1927a: 523). La música adquiere así su forma y dinamismo plenos en el acontecimiento sobre el escenario.

Este público había contado con la introducción escrita por el propio Schlemmer al especial ballet que iban a contemplar, o mejor dicho, vivir, "un trabajo común de entusiastas solícitos que han querido contribuir a dar forma a una idea". Y esta idea no es otra que la de lograr algo, dice, "poco común: unidad y compenetración entre todos los elementos de la danza, los movimientos del cuerpo, espacio, vestuario, forma y color" (Scheper 1988: 33) ${ }^{30}$ El medio para ello era la introducción del arte moderno, al que atribuye la tarea de "indicar el camino a la danza y darle la fuerza elemental", "casi todas las orientaciones de la pintura moderna, Cubismo, Futurismo, Expresionismo, Suprematismo, Surrealismo, Constructivismo, experimentan su reflejo, a veces incluso su plenitud, en el ámbito escénico" (Schlemmer 1927a: 521). El resultado, "una fiesta del color y de la forma" (Scheper 1988: 33).

Sin embargo, todo el esfuerzo puesto en este proyecto durante 10 años, no fue

28 Hindemith llegó a componer la música para la puesta en escena del Ballet Triádico que tuvo lugar en el Festival de Música de Cámara Donaueschingen en 1926, representado allí a invitación del compositor. Realizada para ser ejecutada en un órgano mecánico.

29 Según Vinzenz (2018: 198), la representación comenzaría con la obertura del Titus de Mozart. Para las cinco danzas de la serie amarilla se utilizaron una pieza de Tarenghi, tres de Bossi y una de Debussy. Haydn acompañaría la primera danza de la serie rosa y Mozart la segunda y tercera danza de esta serie. Para las danzas de la serie negra se interpretaría a Haydn, Paradies, Galuppi y Händel, en este orden. Con orquesta sonaron únicamente la segunda danza de la serie rosa de Mozart y la primera de la serie negra de Haydn, el resto de las piezas escogidas -de las que no constan los títulos-se interpretaron al piano (Scheper 1988: 298). 
tomado en serio por la crítica tras el estreno, sino como una mera chanza, fruto de la imaginación desorbitada de un artista. Así, por ejemplo, en el Württembergischen Zeitung del 2 de octubre de 1922, se lee: "Las máscaras de baile de Schlemmer son, sin excepción, producto de una fantasía de artista fecunda y llena de humor. Estos títeres de madera, personajes inquietos y agitados, borlas, bolas doradas, discos de colores, ejercen inmediatamente su efecto sobre los músculos de la risa" (Günter 1978: 97).

La obra pasa prácticamente desapercibida, como un evento local, excepto para un grupo especial del auditorio. Como Schlemmer ya trabaja por entonces en la Bauhaus, un grupo de alumnos asisten junto con Gropius al estreno. Entusiasmados por el resultado, los alumnos piden a Schlemmer una puesta en escena en Weimar, en la semana del ballet de la Bauhaus. Dicha representación tiene lugar el 16 de agosto de 1923, obteniendo un éxito considerable.

Esta es la razón por la que la relación entre Schlemmer y Burger iría rompiéndose paulatinamente, pues el Ballet Triádico comienza así a considerarse obra únicamente de Schlemmer, y creación nacida en el seno de la Bauhaus. El pintor buscaba siempre dejar claro que la obra pertenecía a ambos, pero la realización de los carteles donde aparecían sus nombres, y se describía su participación en el ballet, no siempre dependía de él. Burger decide distanciarse definitivamente del proyecto a partir de las representaciones sucesivas que tendrían lugar en Dresde en ese mismo 1923 y a partir de 1924 hasta 1932 en Hannover, Frankfurt, Bremen, Donaueschingen, Dessau o Berlín y finalmente en París.

De manera que, aun siendo el Ballet Triádico una creación anterior a la Bauhaus, son Gropius y sus alumnos los que ven sus posibilidades, los que reconocen su novedad y las aportaciones de sus conceptos, no sólo al mundo de la escena, sino también al de las artes en general, en la gramática de la forma, del color, del movimiento y en la integración en ellos de la figura humana y de la música. Igualmente, saben confirmar las fuentes de inspiración artística para el ballet, las nuevas corrientes artísticas modernas que ellos mismos conocían y desarrollaban. Y es también gracias al impulso concedido desde Bauhaus para sucesivas representaciones, como esta obra encuentra el eco esperado entre el público y la crítica. Todo ello sin pasar por alto que Schlemmer se hace cargo, como dijimos, del teatro de la institución, siendo bajo su dirección una de las secciones más activas de la casa. Por estas razones, no es de extrañar que el nombre de este ballet esté siempre vinculado, de un modo u otro, a la Bauhaus, además de porque las audacias formales y estéticas en él planteadas se encuentran como ante un espejo frente a la propuesta pedagógica y creativa del proyecto de Gropius.

\section{El ballet de Schlemmer y el siglo XXI}

Desde aquel 1932, cuando tiene lugar en París la última representación antes de la desaparición de la Bauhaus, la primera vez que se realiza una nueva puesta en escena del Ballet Triádico es en 1977, ${ }^{31}$ en la "Berliner Festwoche", de la mano del bailarín y coreógrafo Gerhard Bohner. Un trabajo nada fácil, pues de los 18 trajes originales,

31 En 1970 Margarete Hastings realizó una reconstrucción grabada para la televisión alemana basándose en documentación, textos, e imágenes originales. Margarete Hastings, Franz Schömbs, Georg Verden (coreografía según Oskar Schlemmer), John Halas (dir.), Edith Demharter, Raphl Smolik, Hannes Winkler (bailarines), Erich Ferstl (música, según P. Hindemith). 1970. Das Triadische Ballett: Ein Film in drei Teilen. Stuttgart: Bavaria Atelier GMBH/Stuttgart Ballett. 
se conservan únicamente $6 ;^{32}$ y respecto a las coreografías, no existen más que dos referencias precisas de las doce danzas -cinco, tres y cuatro respectivamente para cada una de las tres partes- que componen el ballet, junto con los documentos y artículos redactados por Schlemmer conteniendo sus ideas genéricas respecto al movimiento y la danza. Estas dos fuentes principales son: una breve descripción recogida en una carta dirigida por Schlemmer al pintor y compositor Alexander Rath en 1926, ${ }^{33}$ y otra descripción fechada en 1927, ${ }^{34}$ enviada al director de orquesta Hermann Scherchen, quien estuvo interesado en la posibilidad de dirigir una representación del ballet. Con dichas dificultades se enfrentaba Bohner, quien, no buscando reproducir literalmente la representación original conforme a las fuentes, supo, según la crítica, conservar el espíritu global del ballet, tanto en el diseño del vestuario, a cargo de Urlike Dietrich, como en los movimientos de los bailarines. Sin embargo, la música continuaría siendo el caballo de batalla principal. La compuesta esta vez por Hans-Joachim Hespos, no lograba fundirse en un todo con lo sucedido en el escenario, como fue siempre la aspiración de Schlemmer, parecía más bien conservar su carácter independiente y de acompañamiento, según nos dice la crónica de la época de Hartmut Regnitz (Regnitz 1977: 29).

Una de las últimas coreografías ha sido elaborada en el "Theater der Klange" en 2015 y ha corrido a cargo de Jacqueline Fischer, bajo la dirección de Jörg Udo Lensing, autor también de la escenografía y parte del vestuario, con música de Thomas Wansing. En 2017 se renovó el vestuario para ponerla de nuevo en escena, y celebrar así el 30 aniversario de la especial preferencia de esta compañía por la Bauhaus como fuente de inspiración. Ya en sus orígenes, en 1987, reconstruyeron la pieza Das mechanische Ballett, ideada por los alumnos de la Bauhaus Kurt Schmidt y Georg Teltscher en 1923, año en que, recordemos, comenzaba la labor de Schlemmer como director del teatro de la Bauhaus. Esta obra ha estado en el repertorio del "Theater der Klange" durante treinta años, con más de 200 representaciones en giras por todo el mundo. Trias, nombre que dieron a su particular reconstrucción del Ballet Triádico, no hacía sino continuar la huella dejada por la Bauhaus sobre el diseño en el mundo de la escena y la danza.

Los últimos testigos de esta actualidad de la Bauhaus son los bailarines del "Bayerischen Junior Ballett München", quienes, desde 2014, han realizado ya diversas representaciones, y aún en 2019, pueden seguir viéndose en el Theaterhaus de Stuttgart, la ciudad que lo vio por primera vez.

Así pues, el papel de Schlemmer en la actualidad de la Bauhaus no parece cesar. Las puestas en escena de su Ballet, ya inseparable de la realidad de esta institución nacida ahora hace 100 años, le darán vida en cada ocasión, de forma siempre renovada, pues una puesta en escena es siempre, como decíamos al comienzo, un acontecimiento revivificado con cada representación. Por otro lado, el hecho de que siga siendo objeto

32 Tras la ruptura, Burger y Schlemmer se repartieron el vestuario. Schlemmer se quedaría con los seis que llevara en la representación de Stuttgart, el resto pasarían a ser propiedad de Burger. Desaparecieron en el incendio que tuvo lugar en el Kunstgebäude de Stuttgart durante la Segunda Guerra Mundial, en 1943, donde Burger tenía su escuela de danza.

33 Bauhaus-Archiv, Berlín. Alexander Rath fue alumno de la Bauhaus desde 1920, escribió a Schlemmer interesándose por la cuestión de no haber sido finalmente compuesta una música específica para el ballet.

34 Bauhaus-Archiv, Berlín. En este caso, la misiva incluye dibujos y acuarelas con los figurines y diversos esquemas, así como anotaciones e indicaciones escritas a mano por Schlemmer. 
de interés, que sea estudiado y trabajado reiteradamente en el mundo de la danza y del teatro, es sintomático de su carácter universal y atemporal, no adscrito con fecha de caducidad a una época y lugar concretos. Sorprendente en todas sus dimensiones, continúa desplegándose como potencial material de trabajo para presentes y futuros artistas, y objeto de gozo estético para los espectadores que deseen, aunque solo sea, aspirar a cumplir las esperanzas de Schlemmer.

El Ballet Triádico, en su forma actual, no es más que el comienzo, una etapa (para mí). ${ }^{35}$ Las ideas para un ballet cómico, y al mismo tiempo trascendental, están dispuestas. Más y mejores bailarines, medios para la creación de los figurines, una música más perfecta; estas son mis esperanzas (Schlemmer 1989: 98).

Esperanzas por lograr poner sobre el escenario con formas, colores, luces, gestos, música, movimiento, su idea del "hombre como acontecimiento, como el ser capaz de lo inmediato, el mediador, el transmisor del lenguaje, de la palabra, de la música", en un espacio que hace posible ver "su transformación, sus cambios, su disfraz a través del vestuario y de la máscara, su reflejo en muñecos sin vida, en las figuras mecánicas, en las marionetas, y con ello la superación de la forma" (Schlemmer 1927a: 524). Una concentración de fenómenos que pueden parecer irrealizables, él mismo se lo llega a preguntar retóricamente "¿Utopía? [...] La escena comienza con la transformación interior del espectador, el hombre como el alfa y la omega de toda condición del hecho artístico. [...] Seguirá siendo una utopía, en tanto que no encuentre una disposición espiritual" (Schlemmer 1925b: 20). El Ballet Triádico parece que seguirá entonces vivo mientras haya espíritus inquietos, como sus bailarines, que deseen corresponder a esta disposición interior y profunda para con el hecho artístico.

\section{Bibliografía citada}

Appia, A. 1924. "Theatrical Experiences and Personal Investigations", (ensayo inédito

(1924?) Yale: Appia Collection, Beinecke Library, Yale University, p. 383, citado

en: Beachman, R. 1985. "Appia, Jacques Dalcroze and Hellerau. Part One: 'Music

Made Visible"” en: New Theater Quarterly, vol. 1, núm. 02, mayo 1985, pp. 154-164.

Beachman, R. 1985. "Appia, Jacques Dalcroze and Hellerau. Part One: 'Music Made

Visible"” en: New Theater Quarterly, vol. 1, núm. 02, mayo 1985.

- 1994. Adolphe Appia: Artist and Visionary of the Modern Theatre. Oxon/Nueva

York: Routledge.

Dalcroze, E-J. 1920. Le Rythme, la musique et l'education. París: Libraire Fischbacher

Demuth. V. 2002. Topische Ästhetik: Körperwelten, Kunsträume, Cyberspace. Würzburg:

Königshausen \& Neumann Verlag.

Günther, H. 1978. "Die Triadische Legende", en: Stuttgarter Zeitung, 14 de enero de 1978, p. 97.

— 1977 . "Die Stuttgarter Landsleut' des Oskar Schlemmer", en: Stuttgarter Zeitung, 9 de julio, 1977, p. 51.

— 1963. "Von dämonischen zum Triadischen Ballett", en: Sonntagsbeilage zur

Stuttgarter Zeitung, 6 de julio de 1963, p. 65.

Henze, W. 2016. Ausstellung: Totentanz. Werke Ernst Ludwig Kirchners zu Mary Wigman.

35 Entre paréntesis en el original. 
Kleines-Katalog. Wichtrach/Bern: Galerie Henze \& Ketterer, disponible en: http:// www.henze-ketterer.ch/de/ausstellungen/aktuell/wichtrachbern/a114-totentanz/ [consultado el 26 de mayo de 2019].

Kandinsky, W., Marc, F. (eds.). 2016. Primera edición 1965. Der Blaue Reiter. Munich/ Berlín: Piper.

Maur, K. v. 1977. Oskar Schlemmer. Der Maler, der Wandgestalter, der Plastiker, der Zeichner, der Graphiker, der Bühnengestalter, der Lehrer. Stuttgart: Württembergischer Kunstverein. Catálogo correspondiente a la exposición en torno a Oskar Schlemmer en la Staatsgalerie de Stuttgart (11.08-18.09.1977).

Meyer, H. 1928. "Bauhaus und Gesellschaft", en Bauhaus. Zeitschrift für Gestaltung, año 3, núm. 1, enero de 1929.

Regnitz, H. 1977. "Getanzte Raumphysik. 'Triadisches Ballett' in Berlin wiederaufgeführt", en: Stuttgarter Zeitung, 8 de septiembre, 1977, p. 29.

Scheper, D. 1988. Oskar Schlemmer. Das Triadische Ballett und die Bauhausbühne. Berlín: Akademie der Künste.

Schlemmer, O. 1989. Oskar Schlemmer. Idealist der Form. Briefe. Tagebücher. Schriften. Leipzig: Reclam Verlag.

— 1927a. "Ausblicke aus Bühne und Tanz", en: Melos, núm. 12, diciembre, 1927, pp. 520-524.

—, 1927b. "Mechanisches Ballett", en: Gentges I. 1927. Tanz und Reigen. Berlín: Bühnenwolksbundverlag, pp. 80-83.

—, 1925a. "Der theatralische Kostümtanz", en: Einstein, C., Westheim, P. (eds.) (1925/reimpresión 1984). Europa Almanach 1925. Leipzig: Kiepenheuer Verlag, pp. 189-191.

—, 1925b. "Mensch und Kunstfigur", en: Gropius, W., Moholy-Nagy, L. (eds.) 1925. Die Bühne im Bauhaus. Munich: Albert Langen Verlag, pp. 7-43.

Simonson, M. 2013. Body Knowledge: Performance, Intermediality, and American Entertainment at the Turn of the Twentieth Century. Nueva York: Oxford University Press.

Vinzenz, A. 2018. Vision "Gesamtkunstwerk": Performative Interaktion als künstlerische Form. Bielefeld: Transcript Verlag.

Wagner, R. 2007. La obra de arte del futuro. Valencia: Universidad de Valencia. , 2013. Arte y Revolución. Madrid: Casimiro Libros. 


\title{
Lo performativo en prácticas de arte y diseño actuales vinculadas a procesos de innovación social. El caso de La Venezia che non si vede y de La Borda
}

\author{
The performative in current art and design practices linked to \\ social innovation processes. The case of La Venezia che non \\ si vede and La Borda
}

Tània Costa Gomez*

\begin{abstract}
Resumen
En este artículo se propone abordar la capacidad performativa de ciertas prácticas artísticas y de diseño actuales que inciden en contextos sociales con la voluntad de afectar e influir en los estilos de vida y hábitos de lo cotidiano. En el caso del arte podría decirse que son iniciativas que cuentan con antecedentes como la tradición contemporánea de la estética relacional y el arte contextual, mientras que en diseño provienen de una visión avanzada del diseño de sistemas y servicios. En ambos casos, en esta investigación nos interesan los proyectos implicados en procesos de cambio social y que tengan como objetivo procurar vías posibles de transición hacia modos de vida sostenibles. Por lo mismo, se trata de producciones que abarcan la visión social, ética, política y estética.
\end{abstract}

Palabras clave: Arte, diseño, innovación social, performatividad, wicked problems.

\begin{abstract}
This article proposes to address the performative capacity of certain current artistic and design practices that have an impact on social contexts with the aim of affecting and influencing the lifestyles and habits of everyday life. In the case of art, it could be said that these initiatives have antecedents such as the contemporary tradition of relational aesthetics and contextual art, while in design they come from an advanced vision of the design of systems and services. In both cases, in this research we are interested in the projects involved in processes of social change that aim to provide possible ways of transition to sustainable lifestyles. For the same reason, they are productions that encompass social vision, ethics, politics and aesthetics.
\end{abstract}

Keywords: Art, design, social innovation, performativity, wicked problems.

\section{Introducción}

Observamos la dimensión performativa del arte y el diseño en aquellas prácticas que impulsan a un contexto o colectivo a la acción organizada en pos de un objetivo común, más allá de la propia dinámica artística y de diseño. Se trata, pues, de una dimensión que se realiza ya fuera de escena, por lo tanto "obscena", y que ayuda a tomar/dar forma a nuevas maneras de vivir, comportamientos alternativos y subjetividades no normativizadas.

* EINA, centro Universitario de diseño y arte adscrito a la Universidad Autónoma de Barcelona, España. 
Nuestro objeto de estudio se enfoca, pues, hacia la capacidad performativa que demuestran ciertas prácticas artísticas y de diseño actuales que no sólo pretenden desarrollarse desde la vía participativa sino que, además, se presentan como agentes de transformación en contextos de innovación social. El objetivo de tales producciones es impulsar estilos de vida y hábitos de lo cotidiano, que pudieran estar latentes o con una existencia de baja intensidad, para que activen procesos de cambio social. En este sentido, en este desarrollo entendemos la capacidad performativa del arte y el diseño como aquella que provoca modificaciones substanciales o estructurales en el contexto donde actúa, de manera que genera un movimiento que implica la creación de nuevos mundos. Por lo mismo, las prácticas aludidas proponen ir más allá de la dinámica participativa, relacional o contextual para incidir directamente en el comportamiento, formas sociales, estructuras convivenciales y consideraciones estéticas. Inevitablemente todo ello implica un posicionamiento político y ético en cuanto se sobrepasan estrategias de escenificación e, incluso, estéticas del acontecimiento (Peran 2002) con el objetivo de abordar procesos de transformación. Concretamente en esta investigación nos interesa la versión de transformación en el sentido social, o de innovación social, dejando para otros foros su interpretación relativa a transformaciones individuales, rituales o espirituales.

En el caso del arte podría decirse que son iniciativas que cuentan con antecedentes como la tradición contemporánea de la estética relacional (Bourriaud 1998) y el arte contextual (Ardenne 2002), mientras que en diseño provienen de una visión avanzada del diseño de sistemas y servicios (Polaine 2013). En ambos casos, aquí nos atañen las visiones implicadas en procesos de cambio social que tengan como objetivo procurar vías posibles de transición hacia modos de vida sostenibles. Cabe decir que en esta investigación entendemos como sostenibles tanto una concepción macro, que apunta a preocupaciones globales principalmente relacionadas con la cultura ecológica y material, como un enfoque micro, que atienda a las actividades de la vida cotidiana, las creencias y subjetividades (Rolnik y Deleuze 2006).

\section{Una perspectiva sistémica de la práctica artística y de diseño}

Las prácticas artísticas y de diseño que se enmarcan en el territorio que pretendemos trazar coinciden, también, en trabajar desde una perspectiva sistémica, incluso dentro de lo que se denominan wicked problems. Es decir, consideran el objeto de estudio o producción como una pieza más dentro de un sistema complejo, donde los componentes están interrelacionados en forma de redes distributivas y cuya resolución solo puede ser temporal y parcial ya que, tal como apunta Rittel, "el problema muta y evoluciona constantemente" (Rittel 1973). Se refiere a problemáticas globales, como la pobreza, la inmigración, la marginación, la escasez de recursos naturales, las dificultades energéticas, etc. Rittel, y más tarde Buchanan y Margolin, son los iniciadores de una perspectiva sistémica del diseño que considera cualquier asunto a trabajar dentro de una densa red de relaciones que lo condiciona y que, por lo tanto, de alguna forma ha de ser igualmente intervenida. Nos encontramos con un posicionamiento similar al elaborado a finales de los 70 por Rosalind Krauss en cuanto al campo expandido de la obra de arte, que incluye el contexto como parte significativa de la propuesta artística y que confirma su condición de obra abierta promulgada por Umberto Eco.

Esta perspectiva da pie a que ciertas prácticas artísticas y de diseño amplíen su campo de trabajo a las realidades colindantes y las influyan y modifiquen, provocando 
cambios sustanciales en su morfología, estructura y dinámica relacional. Es a partir de aquí que puede darse la posibilidad de lo performativo en el arte y el diseño, en tanto que generadores de otras narrativas de mundo o en cuanto cultivo de estilos de vida alternativos. Es en este sentido que Terry Irwin propone el diseño en transición (Transition Design) como perspectiva desde donde abordar los wicked problems y como metodología a través de la cual trabajar la transformación entendida como transición hacia un cambio de paradigma. El diseñador ha de afrontar cualquier problema de diseño desde una visión de su encaje en uno o más wicked problems y ha de iniciar el estudio del caso mapeando las relaciones a partir de la relación triádica básica entre el sujeto, los objetos hechos por el sujeto y el contexto ambiental. A partir de aquí, el desarrollo del proyecto y propuesta iterativa de diseño se dará desde la acción, en colaboración participativa, con perspectivas a largo plazo, desde la empatía y siempre como solución temporal, transicional (Irwin 2012).

Esta aportación del diseño a la comprensión de realidades complejas se apoya en la interpretación de las tesis sobre la "autopoiesis" de la organización de lo vivo de Varela, Maturana y Uribe. Concretamente en su versión de apertura a la posibilidad de aplicación a sistemas de organización social. Esto sería ya de la mano de la teoría general de los sistemas sociales desarrollada por Niklas Luhmann y por la visión sistémica de la vida de Fritjof Capra, en las que se atribuye la capacidad de autopoiesis a las estructuras sociales a partir de la premisa según la cual "The entire material world, ultimately, is a network of inseparable patterns of relationships. We have also discovered that the planet as a whole is a living, self-regulating system" (Capra 2015: 242).

III. La Venezia che non si vede, de Antoni Abad, y La Borda, cooperativa de viviendas en cesión de uso. Creación de escenarios de futuro para la transformación de estilos de vida

Para centrar esta propuesta teórica se propone un estudio de caso, a través de la comparativa entre dos proyectos de 2017: La Venezia che non si vede, del artista Antoni Abad, y La Borda, cooperativa de viviendas en cesión de uso en Barcelona. Se trata de una práctica de diseño y una artística que comparten como hilo conductor una visión ética de la problemática actual de acceso a la vivienda y gentrificación turística, en nuestro entorno urbano inmediato.

La Venezia che non si vede fue presentado en la Bienal de Venecia 2017 y, entre otras acciones, crea una aplicación de móvil (Blind.wiki) para recoger y compartir en código abierto descripciones de lugares de la ciudad de Venecia relatados por personas invidentes. Además de aportar una interpretación del lugar a través de otros sentidos, se enfatiza la importancia de la memoria colectiva y de los modos de vida de un pasado reciente en el cual la ciudad estaba habitada por los venecianos y no por los turistas.

La propuesta contaba con diversas instalaciones en el pabellón catalán de la Bienal y con otra actividad, también participativa, dirigida a la experiencia directa del espectador. El visitante tenía la oportunidad de realizar un recorrido en una embarcación tradicional veneciana, junto con una persona invidente que iba relatando su experiencia de vida como habitante de ese mismo barrio.

Por su parte, el primer edificio construido por la cooperativa de viviendas en cesión de uso La Borda ha sido diseñado por el estudio de arquitectura colaborativa La Col con la participación de las actuales usuarias. El proyecto promueve un sistema de vivienda desmarcado del mercado especulativo convencional y demuestra que es 
posible la transición hacia nuevas formas de vivir, más sostenibles social y materialmente, que comporten, finalmente, un cambio de paradigma. En efecto, el sistema de vivienda en cesión de uso comporta la no propiedad individual de la vivienda de los usuarios promotores, pero la posibilidad de continuidad del uso por sus descendientes. Cabe apuntar que la construcción abarata costes ya que el ayuntamiento cede el uso del suelo sin necesidad de compra y porque diversas fundaciones, como La Dinamo, financian estas cooperativas con recursos no públicos.

Este tipo de arquitectura colectiva se concibe en colaboración con las usuarias, se priorizan los espacios comunes que fomentan las relaciones personales, se utilizan estrategias de arquitectura ecológica para minimizar el impacto ambiental y para evitar la pobreza energética de sus habitantes.

Tanto la propuesta de Antoni Abad como la de La Borda inciden en el wicked problem que representa el acceso a la vivienda, la precarización y las desigualdades que genera la gentrificación turística. Los intentos de solución emitidos desde un paradigma convencional resultan fallidos porque no se ubican en el escenario de futuro sino en el del pasado y, por lo mismo, no tienen capacidad para atender más que aspectos parciales del conflicto. En cambio, la visión sistémica aborda la problemática en conjunto y, en lugar de plantear intervenir con/en un objeto, comunicación o espacio, piensa en diseñar un sistema que reconfigure la relación entre el usuario y la vivienda a través de la arquitectura o mediante un multiproyecto artístico. En ambos casos se pone el acento en dar paso a un nuevo paradigma, en este caso de innovación social, y en los dos proyectos se confía en la emergencia autopoiética del sistema, las relaciones que lo sustentan y sus agentes.

Para hablar/pensar en la creación/existencia de mundos futuros y llevarlos a cabo, dice Ezzio Manzini que previamente hemos de proyectar los escenarios dónde puedan realmente llevarse a cabo. El diseñador propone el SLOC scenario, es decir, un contexto pequeño, local, abierto y conectado (Small, Local, Open, Connected) como paisaje ideal para la transformación social. Y se centra en lo que llama comunidades creativas, es decir, grupos de personas que superan sus problemáticas comunes aportando soluciones creativas a través de la autogestión y que, superando el rol de usuario, se implican en la consecución de sus expectativas. El empoderamiento deviene de la combinación de los elementos adecuados al escenario requerido y de la facultad auto-otorgada de generación de conocimiento desde el mismo sistema que lo demanda, no desde una actitud de espera pasiva de recepción de gestos asistencialistas por parte del poder establecido.

También Goodman, en su teoría de la creación de mundos, plantea la premisa según la cual para crear mundos hay que partir de otros ya existentes y, para ello, expone una serie de variables posibles a través de la combinación de las cuales concebirlos. En un contexto distinto a Manzini, pero con líneas de pensamiento confluyentes, Goodman vincula la creación de mundos al conocimiento y al trabajo. Por una parte, porque si “(...) los mundos se hacen en igual medida que se encuentran, el conocimiento podrá entenderse también como un rehacer y no solo como un referir. [...] Comprensión y creación van de la mano". Y, por otra parte, porque "si es cierto que la disposición para aceptar mundos alternativos puede ser liberadora (...) también lo es que la mera aceptación complaciente de todo mundo posible no acaba por construir tampoco mundo alguno. [...] Un espíritu amplio no sustituye el trabajo" (Goodman 1990: 42, 43).

Precisamente, los proyectos de Abad y La Borda crean mundos a partir de otros 
existentes y a través de la producción creativa entendida como dispositivo de transformación de sus propios contextos. Igualmente, tales dispositivos actúan como generación de conocimiento y, por lo tanto, como investigación artística y en diseño. Dicho de otro modo, ambas propuestas desarrollan lo que Borgdorff expone como "investigación a través de la práctica del diseño y del arte" (Borgdorff 2006: 27). Es decir, un tipo de práctica artística y de diseño que es, en sí misma, investigación enfocada a la generación de conocimiento; en lugar de ser investigación que forma parte del propio proceso de producción o de utilizarse como caso de estudio para el argumentario de otras disciplinas. Asimismo, Borgdorff señala que la práctica de las artes no existe nunca aislada de su contexto y, por ello, tanto afecta como es afectada por el mismo. De esta manera, podemos añadir que los dos casos aludidos de investigación a través de la práctica de las artes y el diseño muestran su capacidad performativa en tanto crean intersticios de contenidos alternativos, en un sentido similar a los anteriormente citados Bourriaud y Hakim Bey.

\section{Lo performativo en el arte y el diseño enfocado a procesos de innovación social}

En los dos casos de estudio expuestos no se plantea una pieza de arte o un producto de diseño, sino que se genera un conjunto de acciones o actuaciones que contribuyen a convertir a los agentes implicados en agentes de cambio/para el cambio. De esta manera, nos alejamos de la idea del diseño "solo" instrumental o del arte "solo" removedor de conciencias y avanzamos hacia una concepción conjunta de incidencia sobre un estadio micro de la subjetividad y formas de vida de la cotidianidad que, a su vez, son capaces de ser replicadas y escaladas de forma que alcancen a afectar a un estadio macro para la sostenibilidad.

Es en este sentido que proponemos la consideración y, por lo tanto, denominación de este tipo de prácticas como performativas. No sólo porque se realizan desde la acción, porque ponen los cuerpos en movimiento, porque podemos tomar registro de las mismas como coreografía política. También porque tales acciones promueven cambios de vida, generan estructuras sostenibles para la comunidad y, por lo mismo, crean mundos posibles y reales. Vaya por delante que ello, además, contribuye a producir modificaciones en las subjetividades, consciencias y sistema de valores. Por esta razón el modelo es ético y político al mismo tiempo, pues afecta a esferas micro y macro en una dimensión multiescala. Y, en consecuencia, en procesos de innovación social como los estudiados, el modelo se desplaza en dirección desde lo micro a lo macro, no a la inversa. En efecto, la aspiración de La Borda es consolidar una unidad eficaz que pueda ser escalada y replicada, con las variantes necesarias para cada caso, con el objetivo de crear una red suficientemente influyente para cambiar el sistema. En el caso de la propuesta de Antoni Abad se parte de la descripción personal desde una condición particular con el objetivo de generar una red abierta de mayor alcance y, finalmente, se libera a merced de las interacciones de los participantes y se su emergencia temporal.

Inicia esta perspectiva de lo performativo el estudio comparativo entre los enunciados constatativos y los performativos desarrollado por John L. Austin en la primera conferencia de How to do Things with Words. Allí se plantea que hay enunciados que dan información (registran, describen, afirman...) y otros que, utilizando el neologismo empleado por el autor, tienen una función "realizativa". Es decir, la oración "Indica que emitir la expresión es realizar una acción y que ésta no se concibe normalmente 
como el mero decir algo", como "Cuando, con la mano sobre los Evangelios y en presencia del funcionario apropiado, digo "¡Sí, juro!”, no estoy informando acerca de un juramento; lo estoy prestando" (Austin 1955: 47).

Así pues, este uso del lenguaje no se circunscribe al objetivo de comunicar sino, también, al de actuar, hacer u operar, con lo cual se podría definir como "operativo" o "performativo". De acuerdo con el posicionamiento de Austin, en esta investigación nos hemos decantado por utilizar el término "performativo" ya que "operativo" nos remite a una interpretación demasiado connotada en cuestiones de eficiencia, viabilidad, ejecución, etc. Podríamos decir que lo performativo nos permite abrir un intersticio más allá del lenguaje con capacidad de iniciar una historia, activar un proceso, incidir en una vida. Nos vemos, pues, en condiciones de rescatar este punto in(d)icial y añadir que Austin apunta a esa zona en la que el lenguaje contiene "proyecto", de manera que representa una apertura hacia una futura acción que, en el caso del diseño y el arte, será coordinada, programada e impulsada siempre en relación con un contexto específico. En la teoría del enunciado performativo se centra esta capacidad de resorte activador en una palabra, pero, sin duda, para alcanzar un estadio performativo se necesita lo que el autor llama contexto situacional. Y éste es el que marca la diferencia de lo performativo desde una perspectiva sistémica y su oportunidad para iniciar modificaciones relacionales en un contexto.

Otra versión de lo performativo se deriva directamente de la naturaleza inestable y cambiante de la acción impulsada y así es como lo describe Allan Findeli. Según el autor, en el proceso convencional de diseño se identifica un problema A y se imagina una solución $\mathrm{B}$, resultando el proyecto de diseño como el trayecto entre A y B o el cambio de una situación a otra. En cambio, la nueva lógica de la estructura del proceso de diseño no acaba en el punto B ya que A y B no son situaciones sino partes de un sistema en el que están incluidos los usuarios y los diseñadores. Así, pues, según el autor “(...) state B is only a transitory, more or less stable, state within a dynamic process, never a solution; the production of a material object is not the only way to transform state A into state B (...)" (Findeli 2001:10).

En efecto, la transformación de un sistema no es nunca definitiva sino que se va conformando, reformando y deformando en la medida que los elementos que lo constituyen van interactuando. Es relevante el factor que señala Findeli cuando destaca que en el sistema se incluyen diseñador y usuario como agentes activos. Se observa la misma circunstancia en las prácticas artísticas como la comentada, dónde Abad emite una propuesta que se realizará de una u otra manera dependiendo de los usuarios y espectadores participantes que la construyan y del tipo de interacciones que generen con otros agentes involucrados. De hecho, la wiki.blind sigue actualmente su curso autogestionada por sus usuarios y empoderada gracias a su condición digital en código abierto alojada en una forma de red social de conocimiento. Se deduce de ello, pues, que la creación de mundos desde una perspectiva sistémica de las artes identifica esos nuevos mundos con la capacidad performativa del arte y del diseño. Apunta al respecto Findeli: "In existentialist terms, this could sound as follows: design responsibility means that designers always should be conscious of the fact that, each time they engage themselves in a design project, they somehow recreate the world" (Findeli 2001: 14). 


\section{Conclusión. Lo performativo como reencantamiento del mundo}

Cuando, por su parte, Erika Fischer-Lichte desarrolla la idea de una estética performativa pone sobre el tablero de juego una pieza principal para la presente investigación. Se trata de su vinculación a un proceso de transformación: “...los procesos de reencantamiento del mundo y la transformación de los participantes en la realización escénica" (Fischer-Lichte 2011: 361).

Cierto que otros aspectos coinciden con visiones en las que los agentes ya han modificado su identidad convencional: el artista facilitador, la autoría compartida, el espectador participante, la obra situacional. Pero el signo distintivo principal reside en su capacidad de producir transformación en el contexto en el que se desarrolle. Esta es la clave que aloja a proyectos como el de Antoni Abad o la cooperativa La Borda en un mismo territorio, que no se mide por su pertenencia a una u otra disciplina sino por su firme determinación a intervenir (ya no sólo a incidir) en entornos homogéneos para crear intersticios donde desarrollar formas de vida no normativas, alternativas.

Seguramente, esos espacios alternativos circunscritos a breves áreas delimitadas por la superficie convencional, no existirán durante mucho tiempo sin ser de nuevo engullidas por lo general. Por ello el comportamiento de las TAZ (Temporary Autonomous Zone) descritas por Hakim Bey era el de guerrilla, basado en la generación de cedulas independientes de rápida aparición y desaparición territorializando y desterritorializando el tablero de juego del poder. En cualquier caso, son situaciones emergentes que operan desde aspiraciones de invisibilidad pero con la intención de creación de autoorganizaciones sociales temporales. En el caso de la propuesta de Abad, la participación de agentes autónomos en la wiki.blind parece totalmente afín a esta premisa y, de hecho, ya había realizado anteriormente otras obras con la misma metodología participativa.

Respecto a La Borda, ciertamente no nace con vocación de provisionalidad, sino más bien de permanencia y con intención expansiva. Seguramente su naturaleza responde mejor a la perspectiva de intersticio social que Nicolas Bourriaud rescata del argumentario de Marx y que re-define de la siguiente manera: "E1 intersticio es un espacio de relaciones humanas que, insertándose más o menos armoniosa o abiertamente en el sistema global, sugiere otras posibilidades de intercambio, diferentes a las hegemónicas en dicho sistema" (Bourriaud 1997: 117).

Tanto en La Venezia che non si vede de Antoni Abad como en La Borda, lo performativo surge después de que se despliegue la acción programada, es decir, cuando empieza a emerger la fase de transformación ya emancipada. Por lo tanto, una de las conclusiones principales que se derivan de la aproximación realizada en este texto es que reconocemos el hecho performativo sólo en aquellos procesos de innovación social que se desarrollan más allá de la intervención del artista o diseñador. Desde este punto de vista, la capacidad de las propuestas artísticas y de diseño para producir una transformación social no se entendería como performativa si no ha producido una modificación estructural, que a su vez dé paso a ulteriores procesos de cambio que ya se generen y desarrollen de manera autónoma respecto a la obra o producción. Por lo mismo, una vez finalizada la fase de implementación de la obra o producción, la responsabilidad e impulso de cambio vuelve a recaer y es absorbida por los propios agentes afectados que, entonces, abandonan el rol de usuarios o espectadores para pasar a ejercer su capacidad de agencia de manera emancipada. 


\section{Bibliografía citada}

Ardenne, Paul. 2002. Un arte contextual. Creación artística en el medio urbano, en situación, de intervención, de participación Murcia: CENDEAC, 2006.

Austin, John L. 1955. How to do Things with Words. Cambridge: Harvard University Press.

Borgdorff, Henk. 2006. "El debate sobre la investigación en las artes". Cairon: revista de ciencias de la danza, ISSN 1135-9137, Nº 13, 2010.

Bourriaud, Nicolas. 1998. Esthétique relationnelle. Paris: Les presses du réel.

Capra, Fritjof. 2015. The systems view of life a unifying conception of mind, matter, and life. Cosmos and History: The Journal of Natural and Social Philosophy, vol. 11, no. $2,2015$.

Fischer-Lichte, Erika. 2011. Estética de lo performativo. Madrid: Abada. Ed. org. 2004.

Findeli, Alain. 2001. "Rethinking Design Education for the 21st Century: Theoretical, Methodological, and Ethical Discussion". Design Issues: Vol 17, N 1, pp. 10-14.

Goodman, Nelson. 1990. Maneras de hacer mundos. Madrid: Visor.

Irwin, Terry. 2012. "Wicked Problems and the Relationship Triad". Grow Small, Think Beautiful: Ideas for a Sustainable World from Schumacher College. Floris Books, 2012.

Luhmann, Niklas R. 1997. Organización y decisión, autopoiesis y entendimiento comunicativo. Barcelona: Anthropos.

Maier-Aichen, Hansjerg. 2004. "Idea Factory: un repte global en un marc de recessió mundial". Barcelona: EINA, Escola de Disseny i Art, col. PlecsEsparsos, 2004. En: Julier, Guy. La cultura del diseño. Bcn: Gustavo Gili, 2010.

Polaine, Andy y Lovlie. 2013. From Insight to Implementation Service Design. NY: Rosenfeld Media.

Rolnik, Suely y Guattari. 2006. Micropolitica. Cartografias del deseo. Madrid: Traficantes de Sueños.

Peran, Martí. 2002. Arquitecturas para el acontecimiento. Valencia: Generalitat Valenciana.

Varela, Francisco J. y Maturana. 1974. "Autopoiesis: the organization of living systems, its characterization and a model". Biosystems Volume 5, Issue 4, May 1974. 


\title{
Articulaciones de la estética y el diseño. El caso de la evaluación a partir de la investigación dirigida en la carrera de Diseño Escénico de la Universidad de las Artes de Cuba
}

\author{
Aesthetic and design joints. The case of the evaluation based \\ on the research conducted in the Scenic Design career of the \\ University of the Arts of Cuba
}

\author{
Mara Rodríguez Venegas ${ }^{*}$ Xiomara Romero Rojas ${ }^{* *}$
}

\section{Resumen}

En este texto analizamos el papel de la evaluación a partir de la investigación dirigida (ID) en la enseñanza-aprendizaje de la Estética en la carrera de Diseño Escénico. Para ello ubicamos algunas notas como antecedentes de la ID, indagamos en el concepto de formación estética como claves de esta propuesta, y por último, valoramos la aplicación de esta metodología a través de trabajos de jóvenes de dicha carrera. Concluimos con que la implementación de la evaluación como ID permite la fundamentación de los trabajos de los estudiantes acorde al entorno cultural y social que los rodea.

Palabras claves: Formación estética, valores estéticos, investigación dirigida, enseñanza, diseño escénico

\begin{abstract}
In this text we analyze the role of evaluation based on directed research (ID) in the teaching-learning of Aesthetics in the career of Scenic Design. For this we place some notes as background of the ID, we inquire into the concept of aesthetic training as keys to this proposal, and finally, we value the application of this methodology through the work of young people of said career. We conclude that the implementation of the evaluation as an ID allows the foundation of student work according to the cultural and social environment that surrounds them.
\end{abstract}

Key words: Aesthetic training, aesthetic values, directed research, teaching, stage design

La única manera de prepararse para la vida social es participar en la vida social.

John Dewey

\section{Introducción}

El aprendizaje y una enseñanza de la Estética a través de la Investigación Dirigida (ID en adelante), debe impulsar estrategias del trabajo científico entre los estudiantes.

* CIESAS Occidente. Guadalajara, Jalisco, México. mararv84@gmail.com

** Universidad de las Artes, La Habana, Cuba.xromerorojas@gmail.com Artículo recibido: 8 de julio de 2019; aceptado: 19 de octubre de 2019 
Resulta pertinente distanciarse del proceso educativo de manera vertical para entenderlo de forma horizontal, desde una perspectiva dinámica y relacional donde ambas partes aprenden. Esto resignifica el papel de ambos sujetos (estudiante y profesor) para desarrollar estrategias pedagógicas en la que la investigación no está separada de la enseñanza, sino que es parte de ella.

La evaluación a partir de la ID constituye nuestra propuesta pedagógica para la enseñanza de la Estética a los estudiantes de Diseño Escénico de la Universidad de las Artes $^{1}$ de Cuba. Ella muestra una cercana relación con las metodologías de Aprendizaje Basado en la Investigación (ABI en adelante) desarrolladas por algunos autores entre los que destaca Ernest Boyer (1990). También se relacionan de manera cercana con la corriente del constructivismo pedagógico en la cual se provee a los estudiantes de las herramientas pertinentes para dar soluciones problemas de investigación. Si bien han existido diferentes formas de aplicar el ABI, en este texto hacemos referencia a la ID que desde nuestra visión mantiene cercanía con la investigación guiada del ABI considerando algunos cambios. A pesar de que esta última metodología ha tenido detractores, para la enseñanza de la Estética resulta positiva para el proceso pedagógico porque propicia un acercamiento más íntimo entre la reflexión estética y la praxis del diseño. Esto se debe a que según nuestro criterio la evaluación a partir de la ID, guarda una carga 'formativa' en tanto dota de valores teóricos y humanos a los estudiantes y procura una reflexión crítica en sus trabajos de investigación.

Esta práctica se ha validado en la mayoría todas las carreras y perfiles que existen en el recinto educativo cubano. Vale destacar que mediante ella ha acontecido un distanciamiento de la enseñanza de la Estética enfocada en su historicidad y en una visión tradicional de las artes visuales, para centrarse en procesos culturales y artísticos que convergen en el presente y viabilizan la vinculación de diferentes disciplinas como la psicología, la pedagogía, la sociología, la etnografía y la antropología (Véase a Cabrera 2007). Desde este sentido transdisciplinario, nos inclinamos por esta propuesta pedagógica que exige al educador nutrirse de la práctica simbólica que caracteriza a los procesos artísticos y visuales en la actualidad. En virtud de ello, propone una evaluación enfocada en que los conocimientos adquiridos en el curso se apliquen a la fundamentación teórica de un trabajo de diseño escénico. Así esta actividad final alcanza otro significado alejado de la reproducción de conocimiento, enfocándose en la reflexión y la crítica del mismo mediante su aplicación a los trabajo de los estudiantes de diseño.

La ID ha incentivado a los estudiantes a fundamentar teóricamente sus propuestas de tesis para la culminación de estudios de pregrado. También ha propiciado la presentación de ponencias relevantes en eventos y la mayoría de los trabajos se convierte en material de consulta por otros estudiantes.

Por tanto, en este texto analizamos el papel de la evaluación a partir de la ID, en la enseñanza-aprendizaje de la Estética. Para ello valora el papel de esta metodología y su pertinencia. Pese a que ha sido aplicada desde los años setenta del pasado siglo en otros ámbitos disciplinares, en las materias teóricas que conforman el currículo de Diseño Escénico esta metodología se adecua e implementa a través de un diálogo

1 La Universidad de las Artes, es la única de su tipo en Cuba, y a la vez que acoge a estudiantes de todas las provincias del país, también lo hace con jóvenes de diferentes latitudes del mundo que reciben una formación artística en dicho recinto académico. 
transdisciplinar (Véase Moraes, 2007). ${ }^{2}$ El texto se divide en tres partes: la primera resalta algunas notas que podrían tomarse como antecedentes de la ID, más tarde se analiza el concepto de formación y la incidencia de los valores estéticos como claves de esta propuesta, y por último, se valora la aplicación de esta metodología exponiendo algunos trabajos de jóvenes de la carrera de Diseño Escénico.

\section{La investigación dirigida, algunas notas para su contextualización}

La ID a la que hacemos referencia es también conocida como investigación orientada o guiada. Constituye un modelo de aprendizaje que hunde sus raíces en la vertiente constructivista del aprendizaje, del que sus principales exponentes son Jean Piaget y Lev Vygotsky. El primer autor centra su interés en la construcción del conocimiento mediante la interacción del medio, mientras que el segundo sustenta que el medio social viabiliza la reconstrucción interna del mismo en el proceso enseñanza-aprendizaje. Estas iniciativas apuntaron al desarrollo de metodologías de aprendizaje como la ABI que propone Ernest Boyer (1990). El autor retoma el aprendizaje por descubrimiento donde se indaga el estatus de la pregunta de investigación según su pertinencia para el trabajo que realiza el estudiante, que responde a la exposición reveladora del problema. Esto supone un análisis teórico-metodológico de los argumentos presentados en los textos, delimitando los antecedentes y actualidad del tema que supone una explicación informada de teorías. Además de la aplicación de ellas a problemas prácticos que finaliza con la escritura y defensa de un trabajo de investigación.

De esta manera se concibe una forma activa de aprender en la media que se entiende la construcción del conocimiento en su sentido gradual. En una descripción más certera del ABI, Mónica Peñaherrera (2014) sostiene que

El modelo de aprendizaje basado en la investigación es un modelo coherente con la didáctica actual, que se basa en la idea de que los estudiantes se apropien y construyan conocimientos cimentados en la experiencia práctica, el trabajo autónomo, el aprendizaje colaborativo y por descubrimiento, rubros fundamentales para alcanzar dominios en los aprendizajes, desarrollar conocimientos y actitudes para la innovación científica, tecnológica, humanística y social (Peñaherrera 2014: 207).

Autores como Heather Banchi y Randy Bell (2008) sostienen que la ABI suele expresarse en varios niveles, la indagación de confirmación, la estructurada, la guiada y la abierta. Se suele decir que la investigación abierta es la más exitosa, pero en ocasiones es rechazada por los profesores, debido a que los estudiantes son quienes formulan sus problemas y soluciones y en ocasiones el profesor podría invisibilizarse. Esta postura reformula el papel del profesor dentro del proceso, pero también supone mirar con otros ojos al estudiante como también portador de conocimiento.

Nuestra experiencia profundiza en la indagación guiada que entendemos como ID, debido a que según las experiencias obtenidas hemos introducido algunos cambios que involucran el papel de profesor, el estudiante y el programa. Ello demuestra la aceptación de esta estrategia de enseñanza en detrimento de otras. En ella el educador

2 Cuando hacemos referencia a este concepto coincidimos con M. C. Moraes quien dice que "la Transdisciplinariedad procura trascender las disciplinas en la tentativa de resolver lo que se queda más allá de las disciplinas. Así el conocimiento transdisciplinar ha de complementar los conocimientos disciplinarios, multidisciplinarios o interdisciplinarios" (Moraes, 2007: 37). 
va guiando el proceso de enseñanza formulando problemas de investigación asociados con el programa de Estética, del que los estudiantes van generando preguntas, acordes al interés de su trabajo de investigación. Esto indica que el profesor de esta materia teórica debe conocer los procesos creativos actuales para entablar un diálogo transdisciplinar con los estudiantes y con el contexto cultural. Por tanto

el educador ha de estar inmerso en esa realidad simbólica y no quedar al margen de ella, puesto que él ha de educar en el entramado sensible del porvenir [lo que le permitiría concebir las disciplinas teóricas y prácticas, de verlas en una interacción y una actualización estéticas enriquecedoras (Cabrera 2007:18-19).

Ello se observa en tres esferas importantes, el papel del profesor, del programa y del estudiante. Según las experiencias de la aplicación de esta propuesta el papel del educador en este proceso despertó posiciones discordantes que mostraban un apego a la enseñanza del programa de Estética vinculado a una perspectiva histórica. Esta condiciona la historia de la asignatura como eje central y desde una perspectiva tradicional. De modo que no considera la vinculación de la disciplina con expresiones, prácticas y discursos creativos actuales, así como su sentido transgresor que éste tiende a manifestar en la concepción misma de los procesos educativos. Si bien el sentido histórico ha de estar presente, éste no debe convertirse en el centro de atención porque según las experiencias anteriores establecen un divorcio entre la realidad simbólica actual que rodea al estudiante y las temáticas abordadas por la Estética desde una perspectiva tradicional, marcada por el sesgo histórico. Esto supone lo que señala Ramón Cabrera (2007) que "las disciplinas teóricas dejan un escaso espacio a las nuevas disciplinas y franjas de confluencias donde se presentan hibridados entre otras" (2007:17).

La principal demanda de los profesores de las carreras creativas a los de las disciplinas teóricas, entre las que ubicamos a la Estética, ha sido concebir un programa con una metodología que nutra al estudiante de herramientas para fundamentar su trabajo de diseño y enriquecerlo desde el punto de vista teórico. Bajo este reclamo se ha elaborado la propuesta de investigación dirigida o guiada como metodología que pretende satisfacer tal exigencia, a través de la forma de impartir el programa de la asignatura.

Esta práctica demanda un cambio si bien del programa, también de la forma de aplicarlo. El sesgo histórico no se abandona, más bien tiende a ocupar el eje de antecedente, mientras que el rector sería la problematización de fenómenos y temáticas vinculadas a los procesos creativos de interés para los estudiantes. Esto supone la construcción de una metodología que permita salirse del programa, modificarlo según las necesidades de los estudiantes y de la especialidad. El reto sería construir un programa adaptado a dichos reclamos que permita el diálogo transdisciplinar sin abandonar la formación estética de los estudiantes.

En esta propuesta el estudiante no juega un rol pasivo, más bien desarrolla la reflexión y la crítica teórica vinculada a su trabajo. Por ello se insiste en desarrollar la autogestión del estudiante, en el trabajo individual y en la formulación de preguntas relevantes como resultado de su experiencia. Si se piensa en un programa modificado y adaptado a los intereses de la carrera se está dando paso a un diálogo más cercano estudiante-profesor que se vale de la implementación de herramientas teóricas y de la solución de problemas a través de ellas.

Han existido casos en lo que los estudiantes no ha recibido con beneplácito dichos 
cambios y mayormente se debe al escaso interés e inutilidad que le dan a la investigación teórica. Estos son obstáculos generalmente vencidos mediante el interés que el profesor exprese por el trabajo de su discípulo demostrando otras formas en las que podría llevarse a cabo la investigación.

Si bien nuestra experiencia se ha enfocado en función de la enseñanza de la Estética, delimitamos el importante papel que en la ID cumple el concepto de formación estética. Partiendo de ello resulta imprescindible entender que la educación por el arte como la educación artística, aspira a la formación general del estudiante (Véase Cabrera 2007), por lo que resulta apremiante comprender el papel de la formación estética. Esta podría entenderse como una herramienta que permita articular la ID con las necesidades teóricas del Diseño Escénico.

\section{La formación estética como componente de la Investigación Dirigida}

La ID no podría pensarse al margen del concepto de "formación" por el carácter amplio y dinámico de su significado. Sus aspectos constitutivos han variado históricamente y continúan haciéndolo actualmente, ya que se asocia directamente a las necesidades sociales, económicas, políticas, culturales y de empleo. El concepto es asumido en el ámbito profesional, como una actividad educativa orientada a proporcionar conocimientos, habilidades, destrezas, desarrollar aptitudes y actitudes necesarias para un correcto desempeño profesional y laboral de los estudiantes. El pedagogo e investigador cubano Pedro Horruitiner Silva (2006) plantea:

El término formación, en la educación superior cubana, se emplea para caracterizar el proceso sustantivo desarrollado en las universidades con el objetivo de preparar integralmente al estudiante en una determinada carrera universitaria... (Horruitiner Silva 2006: 17).

Los antecedentes de esta formación están en el interés que la práctica humana le ha conferido a la premura de formar individuos sensibles a las necesidades de su época y de su contexto. Puede entenderse como un proceso donde intervienen aspectos esenciales marcados por necesidades del desarrollo social, cultural, de la época y de creación. Sin embargo, la debilidad de las estrategias formativas en general, y de las Estéticas en particular se hallan en que se desconectaron del hombre real, al fijar su atención en la finalidad y no en el proceso.

La propuesta de ID de la Estética en la Universidad de las Artes, mostró la ineficacia de las maneras de enseñar anteriormente y evidenció la necesidad de que se tuviera en cuenta la enseñanza mediante la investigación. Ella articulará las experiencias creativas de los estudiantes con la Teoría Estética y también proyectará el estado real de la formación estética, las vivencias y necesidades reales de los estudiantes. Este aspecto en particular, resulta esencial dado el carácter vivencial, individual y contextual de la experiencia estética. ${ }^{3}$ En concordancia con ello José Antonio Portuondo dijo que "[el] juego dialéctico entre el hombre y sus circunstancias, en virtud del cual aquel transforma a las circunstancias y, al hacerlo, se transforma a sí mismo" (Portuondo 1986: 20). Lo que significa que la formación estética debe entenderse a la luz de las problemáticas

3 Según Nicola Abbagnano, "la experiencia estética consistiría en proyectar en el objeto estético emociones propiamente humanas, o sea en 'dar a las cosas insensibles sentido y pasión', y como dijo Vico" (Abbagnano 1967: 396-397). 
actuales. En ella se le otorga un lugar significativo a las contradicciones que acontecen en la vida donde interviene no solo lo social, lo económico, lo político, lo cultural, sino las vivencias, preferencias y necesidades individuales de estos creadores en formación. Estos aspectos tienden a expresarse en las múltiples y variadas manifestaciones que se proyectan en el medio académico cubano. A estos aspectos tienden a dirigirse las investigaciones propuestas en el programa de estudios de la disciplina en el recinto universitario cubano.

Cuando hablamos de formación estética valoramos no solo lo que anhela la sociedad y la universidad, sino también el universo que rodea al estudiante. Entre sus ámbitos referidos destacan el contexto familiar, social, económico, tecnológico, así como también las relaciones que establecen con otras culturas, pueblo o naciones, de las cuales asumen también, muchos de sus paradigmas culturales y estéticos (visibles en formas de vestir, gesticular, hablar, comer, interrelacionarse, etc.). Tal y como sostiene Mayra Sánchez,

Los problemas estéticos están presentes en los más diversos imaginarios, en los más variados campos del conocimiento, en la propia realidad cotidiana en que se mueve el hombre, en las producciones y en el mercado, y no solo en el arte. Esto abre a la estética nuevas perspectivas. Tras el concepto de espíritu de la época se plantea hoy a la Estética un nuevo y extenso campo de influencia, lo cual por sí solo justifica el papel que le corresponde desempeñar en la universidad. La Estética se ha convertido en instrumento para salir airoso en una contienda donde no bastan razones. Son apremiantes los retos de un saber que profundice en la genealogía de los conceptos y nociones (Sánchez 2009: s/p).

En este sentido la evaluación debe solventar el estudio de temáticas estéticas que favorezcan el despliegue creativo, crítico y cuestionador de los estudiantes en las diferentes especialidades. También debe atender los intereses y perspectivas de los estudiantes. Esto supone entender la ID como un ejercicio en el que los estudiantes logren:

- Analizar el carácter procesual de esta disciplina manteniendo distante el sesgo hermético e inútil para su formación.

- Asumir el riesgo de distinguir sus trabajos de otros, pero también de entender sus perspectivas e intereses.

- Buscar lo igual en lo desigual, lo armónico en lo discrepante, lo conocido en lo que se sospecha, a partir de la comprensión de la formación estética, como aquello que no puede ser concebido de forma homogénea, ni hegemónica y se asuma con todas las gamas de contradicciones que le son propias a la existencia individual humana, aquí y ahora.

- Desarrollar capacidades para interrelacionarse y proyectarse hacia y desde la cultura, la política, la ideología, la economía, los problemas medioambientales y otros como necesidad incuestionable.

- Desarrollar capacidades de comunicación, de interrelaciones y empáticas con "el otro diferente", sin perder su identidad propia ni mucho menos desorientarse en un "relativismo" absolutizado donde "vale todo"; todo ello esencial para el desarrollo de sus proyectos creativos y de vida.

- Asumir la diversidad y multiplicidad de acciones diferentes.

- Desplegar aptitudes ético-estéticas ante la vida toda (capacidades, competitividad, idoneidad, disposición, etc.) y actitudes para enfrentar los problemas 
que se presentan (cualidades, maneras, formas, modos, etc.) que lo faculten para "vivir".

- Asuman no la formación estética con unos criterios de Estética que la supongan, no sólo en lo que se divulga y consume de bello, positivo, constructivo, seguro, etc., sino también en aspectos que se referencian como negativos, escatológicos o feos, reconstructivos, etc., pues es en esta complejidad donde lo que consideramos formación estética podría ser realmente útil por realista.

Estos aspectos se conectan sobremanera con la trascendencia de los valores éticos y estéticos como componentes de la formación estética.

\section{Los valores éticos en la formación estética}

En la ID es necesario considerar los entrecruzamientos teóricos para distinguir los valores estéticos de los éticos y lograr la factibilidad de la evaluación que se propone. Como antes se mencionó, con la ID los docentes deben pensar de manera abierta, flexible y dinámica, lo que les permitirá ampliar su visión de la realidad social en la cual se desenvuelven los estudios universitarios. Esta lógica demuestra la trascendencia de códigos y de valores estéticos. Estos últimos fueron asumidos en consonancia con las relaciones estéticas de cada contexto y temporalidad. Son estos valores estéticos los que los estudiantes asumen en el contexto cultural en el que les ha tocado vivir en la actualidad.

Como señala el destacado filósofo y esteta español Isidoro Reguera (1994):

Hoy en la actualidad e incluso [se suele] identificar o confundir la ética y la estética. Tanto una cosa como la otra se hacen la mayoría de las veces por motivos periféricos, como ya nadie tiene principios morales por los menos que valgan los estéticos, se dice, como ya no hay conciencia por los menos que haya buena educación... lo que sea, con tal de que el orden y la armonía -las 'maneras', características de estas disciplinas valorativas- se mantengan en cualquier lugar y aspecto (Reguera 1994: 13).

Sabiendo la importancia del concepto valor estético en esta investigación, partimos de los criterios del estudioso Stefan Morawski, quien propone entenderlo como

(...) un conjunto de cualidades tipificadoras de un objeto, acontecimiento..., manifiesto en y desde la experiencia apreciativa o estimativa sensible del sujeto y, por lo mismo, determinado social, histórica y culturalmente (Morawski 1977: 23).

Asumimos coincidiendo con José Ramón Fabelo (2001) que el valor es un conocimiento por significación, lo cual incluye la subjetividad en el propio contenido de lo que se evalúa. Ellos se ven afectados o no, por la incidencia de los más diversos mecanismos y estructuras sociales y culturales (a veces imperceptibles a simple vista). En este escenario, el profesor tiene la compleja tarea de asumirse como agente y portavoz crítico en la relación que, supone el mundo de los valores estéticos con el mundo social-cultural. Los valores estéticos están presentes en los más diversos espacios imaginarios e ideologías sociales. Por ello las conceptualizaciones del valor estético trascienden al interior de la enseñanza académica y se encuentran en ámbitos disímiles, así como en los proyectos culturales. 
No por casualidad Reguera en su libro El feliz absurdo de la ética (1994), ${ }^{4}$ hace referencia al papel que la sociedad y dentro de ella, el papel que la educación debe asignarle a los valores estéticos dentro de sus proyectos sociales y culturales. A partir de lo cual Jesús Martín-Barbero, en su artículo Nuevas visibilidades de lo cultural y nuevos regímenes de lo estético (2008) se refiera a que estas nuevas condiciones están:

[...] exigiéndonos una nueva noción de tiempo, correlato de una memoria activa y activadora del pasado, que nos permita desplegar los tiempos amarrados, obturados, por la memoria oficial y nos posibilite hacer estallar el historicismo que sutura al pasado como único depositario de los valores y esencias de la identidad nacional (Reguera 1994:35).

Lo esencial de los valores estéticos, es que pasen por el prisma individual de cada sujeto y que sean incorporados como parte de su accionar, donde realmente se gana o se pierde la batalla de la apropiación legítima o distorsionada de ellos. De modo que la universidad no puede enajenarse a estas condicionantes de las que beben estos valores. Por lo que, tener en cuenta la participación activa de los estudiantes, no solo como portadores de paradigmas culturales y estéticos, sino como sus consumidores, divulgadores, reproductores.

La formación y los valores estéticos son componentes y viabilizan la efectividad de la ID. La naturaleza axiológica de la Estética no debe entenderse solamente como atributo que tiene un objeto en sí mismo, ni tampoco como condición razonable, juiciosa o demostrativa del sujeto. Debe exaltarse el significado que adquieren para él las relaciones que establece con estos procesos, objetos o fenómenos existentes en la sociedad. Por lo que es ésta una relación de significación, donde la valoración estética conforma el imaginario y mapa socio-cultural del hombre contemporáneo.

Con la propuesta de evaluación a partir de la ID del programa de Estética de la Universidad de las Artes, los profesores-investigadores encargados de esta enseñanza, han comprobado resultados y experiencias novedosas con relación a la evaluación final de los trabajos de estudiantes. Las experiencias de la ID pasan a ser la razón principal o motivo en que se afianzan, y aseguran los contenidos de la Estética.

A partir de estas ideas se fomenta la indagación sobre temáticas que desde el ámbito de la Estética pudiera arrojar luz tanto a la impartición de la asignatura como a la investigación. En virtud de demostrar cómo se ha hecho visible la aproximación de la disciplina teórica en cuestión a la enseñanza de las artes en Cuba, nos permitimos tomar las experiencias de la investigación en el proceso de enseñanza-aprendizaje de la Estética en la especialidad de Diseño Escénico, como ejemplo palpable del objetivo principal de este trabajo.

\section{Estética y Diseño de frente. La investigación dirigida de la Estética y su im- pacto en la carrera de Diseño Escénico}

La enseñanza del Diseño Escénico en Cuba incluye la labor tanto de los maestros de la especialidad como de aquellos que imparten asignaturas teóricas que integran el

$4 \quad$ Una de las ideas que defiende el autor es que sólo desde la estética o desde la religión puede plantearse la ética. Considera que la ética es la práctica de la felicidad y no del bien, del deber o de la justicia como siempre ha sido concebida esta. Argumenta que la ética es la vida feliz: la realización de la felicidad o de la felicidad misma donde señala que la lógica señala el camino mientras que la estética lo cumple. En tanto que la ética intenta elevar al individuo la vida feliz, la religión intenta bajar a Dios a ella. 
currículo académico de la carrera. Al ser una práctica que requiere de aptitudes artísticas, también demanda de la conceptualización e investigación de algunos presupuestos que explican su devenir.

El programa de la carrera de Diseño Escénico en la Universidad de las Artes, está orientado en primera instancia a la práctica teatral y acoge Diseño de Vestuario, Maquillaje, Escenografía y Luces. Este currículo está integrando por asignaturas que complementan la visión de los procesos culturales, artísticos y teatrales básicos en la formación académica. Entre ellas destacan Historia del teatro, Historia del teatro latinoamericano, Historia del Arte, Estética, entre otras que acompañan el desarrollo de del estudiante. Todas son indispensables para su formación y la manera significativa en que se articulan con los intereses curriculares de la carrera.

La Estética como disciplina integrante de la carrera más allá de cumplir con un programa que toca diferentes problemáticas de la cultura, se ha readecuado a partir de los intereses de los estudiantes. Ello es posible debido a la exploración de la zona teórica que resulta vital para el diseñador en formación. Para este cometido se realizan algunos ejercicios que suponen un entrenamiento introspectivo de la obra en ejecución. Por tanto, se toman en cuenta presupuestos teóricos que acompañan al pensamiento estético contemporáneo.

La asignatura de Diseño Escénico, en la mayoría de los casos, se auxilia de un texto teatral a partir del cual el estudiante deberá trabajar para una escena o una obra. En el ejercicio se suele recrear la época, o idear otra en dependencia de su capacidad y de las posibilidades que le brinde el texto para transgredir espacios temporales. De esta forma la libertad creativa acompaña también el proceso de enseñanza-aprendizaje.

Otro de los aspectos que tributan al trabajo en cuestión es el empleo de materiales alternativos para concebir el vestuario, accesorios y la propia escenografía, contribuyendo a crear la atmósfera adecuada. De esta forma son visibles el empleo de piedras, cartón, nylon, cintas de video, madera, palmiche, rayos de bicicleta, metal entre otras, muchas veces acudiendo a diferentes técnicas entre las que destacan las del papier maché. En ocasiones esta técnica, da volumen visual a determinadas texturas, pero también, con ayuda del color imita disímiles materiales como el metal o la madera.

En este sentido se observan dos momentos importantes dentro de la creación. E1 primero de introspección, traducido en cómo la escena de una obra puede ubicarse en otro contexto dependiendo de las posibilidades creativas que brinda; y el segundo momento que aborda los elementos que validarían la obra en cuestión a partir de materiales con los que se trabajan tanto el diseño de vestuario como la escenografía.

Aunque las características del ejercicio se apoyan más en las potencialidades creativas del estudiante, la realización del mismo demanda de una fundamentación teórico-conceptual y es aquí donde la Estética entra a jugar un rol significativo con su propuesta de ID. Por lo que inspirándonos en el ABI de Ernest Boyer (1990) e introduciendo algunas adecuaciones que parten de la docencia del programa de Estética a partir del que formulamos un problema de investigación relacionado de manera general con la disciplina de Diseño Escénico. Estos últimos seleccionan una pregunta de investigación que supone la revisión de literatura y teorías buscando la relación estudiante-autores-textos. Después retomamos la aplicación de teorías a la praxis del diseño como fundamentación del mismo, para finalmente que el estudiante sea capaz de escribir un manuscrito crítico y reflexivo que expondrá como evaluación final de la asignatura.

Resulta imprescindible el acercamiento de estos dos saberes (Estética y Diseño) a 
partir de la necesidad de un diálogo transdisciplinar. Hoy es un hecho que la difusión de fronteras entre los ámbitos de la praxis artística, del diseño, la teoría estética y la filosofía se percibe como un síntoma cultural, artístico o académico que cuenta ya con antecedentes desde el pasado siglo. Esto hizo que las relaciones entre el arte, la vida y la cultura se hicieran cada vez más sólidas al tiempo que parecían confundirse, mezclarse e invisibilizar sus límites. Como ya señalaba Danto en su texto El final del arte (1995) las fronteras entre la pintura y el resto de las artes (la poesía y la interpretación, la música y la danza) se han hecho radicalmente inestables (Danto 1995: 3), y desde estos espacios de diálogo, es posible entonces pensar la Estética en su relación con el Diseño Escénico, salvando las diferencias pero insistiendo en una suerte de readecuación que responda a los intereses de la carrera y de los estudiantes.

Los exámenes finales de la asignatura suponen una reflexión teórica sobre una obra realizada para Diseño Escénico. Dicha creación artística mayoritariamente se relaciona con una temática abordada por la Estética entre las que pueden destacar: el arte y las nuevas tecnologías, la estetización, la espectacularidad, el kitsch, los imaginarios escénicos, relaciones arte-diseño, entre otros. Sin duda, éstas suelen ser las más representativas en el orden de evaluar su desarrollo teórico y aproximación a los conceptos que maneja el diseño escénico y que responden a los intereses de los estudiantes y de su asignatura rectora.

La selección de los casos paradigmáticos en la aplicación de la ID se fundamenta a partir de varios aspectos que competen la praxis (la complejidad de sus diseños mediante su producción) y la teoría (las formas en las que fundamentan su trabajo leyendo su entorno social y cultural y vinculándolo con estudios recientes correspondientes a la temática de interés. También en el interés que expresan por la investigación que genera en ellos la autogestión ya sea mediante la localización textos y en la relación de sus trabajos con problemáticas tratadas por la Estética. En ese proceso se resignifican los nexos entre las dos disciplinas mediante una crítica contextualizada en su trabajo y fundamentada el sentido del mismo. De manera que su argumento asume el valor conceptual de su propuesta que incluye vestuario, maquillaje, luces, escenografía y performance.

El primer caso que seleccionamos es el de Adrián Rodríguez que demuestra interés por la influencia de las nuevas tecnologías en la escena teatral. Su trabajo insiste en los modos en que los sujetos perciben, conciben y producen una puesta en escena donde conectan espacio-tiempo, cuerpo, objetos (Véase a Cotaimich 2004:5). Su pregunta de investigación ¿Cómo las nuevas tecnologías resignifican el sentido de la obra teatral? lo invita a dialogar con el texto La era postmedia de José Luis Brea. En su diálogo asume la implementación de las nuevas tecnologías en los procesos creativos como un componente de la puesta en escena contemporánea posibilitándole transgredir épocas y contextos, al tiempo que resignifica el mundo que vive el hombre actual. Bajo este cuestionamiento Adrián hace la escenografía de la pieza teatral Farsa y licencia de la Reina Castiza (Figura 1). Según las posibilidades que le brindaba la obra, Adrián emplea íconos y símbolos de los medios de comunicación como marcas de bebidas, firmas patrocinadoras de películas, fotografías de dibujos animados de Walt Disney, entre otros. La escenografía y las luces otorgan un ambiente sugerente que articula una vida íntima llevada a la espectacularidad donde lo público, lo privado y lo íntimo se trastocan incentivado por la publicidad y las tecnologías que hicieron de la vida del hombre un espectáculo cotidiano. Estas imágenes muestran la manera en que la tecnología 
influye en la percepción de la obra teatral proponiendo otra lectura sobre la obra que trae al contexto de la cultura actual.

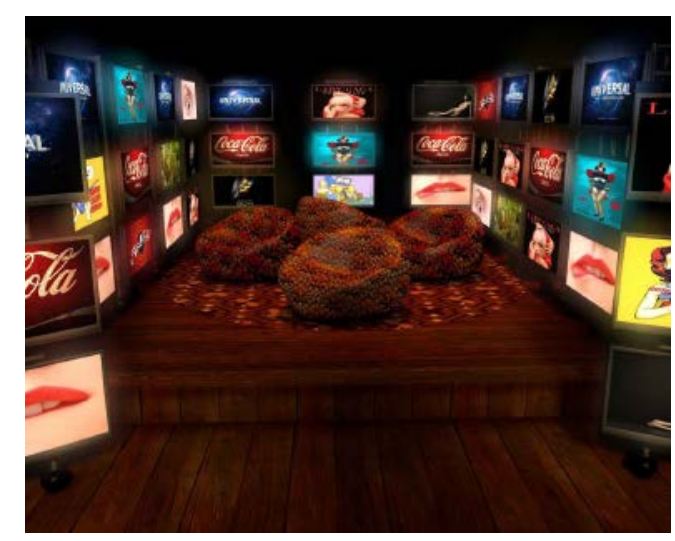

Figura 1. Diseño escenográfico para una escena de la obra Farsa y licencia de la Reina Castiza realizado por el estudiante de diseño Adrián Rodríguez

El fenómeno de lo intertextual también acompaña la reflexión de otros trabajos, como es el caso de la estudiante Alicia González, quien se inclinó por pensar su obra a partir de evidencias de lo intertextual en sus diseños. El discurso intertextual y performativo de "Realizando sueños" en la confluencia cada vez más cercana entre Arte y Diseño es la propuesta de la joven que dialoga con el texto de Linda Hutcheon, $\mathrm{La}$ política de la parodia postmoderna. A partir de él la joven cuestiona ¿cómo el collage y la intertextualidad ejercen un papel preponderante en los estilos de vestir que adopta el hombre en la sociedad actual? Su trabajo juega con la yuxtaposición de prendas supuestamente descontextualizadas que recrean una forma de vestir transgresora que podría ser aceptada o no para el público. Para ello la diseñadora organizó una pasarela que dialogaba constantemente con el público al trastocar su lugar y colocarlo en la posición de creador (Figura 2). En la acción, el público debía vestir maniquíes con determinadas objetos, accesorios o prendas que encontraban en el suelo que más tarde serían exhibidos en una pasarela. Esto supone una suerte de deconstrucción donde las prendas conformadas cobraban un nuevo significado a través de los materiales que las componían.

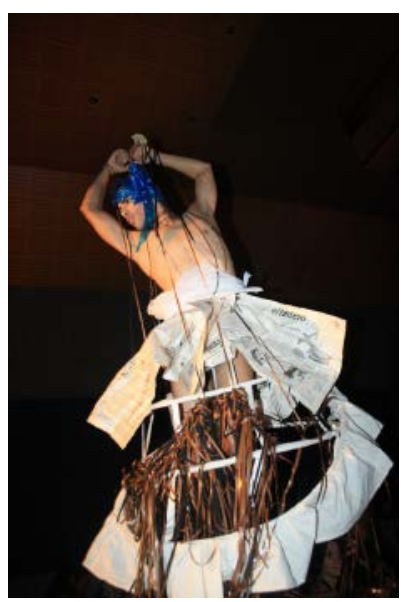

Figura 2. Diseño correspondiente al trabajo

Realizando sueño de Alicia González

Por su parte, Hugo A. Ruíz realiza un vestuario con materiales residuales como cintas de video, nylons, cartón, hojas de yagrumas, alambre, entre otros (Figura 3). E1 
mismo es expuesto en la pasarela Cuban's Trashions ocurrida en el marco del Festival Elsinor nombre que adopta el Festival de las Artes del recinto educativo en la facultad de Arte Teatral. Más allá de la factura con materiales alternativos la pregunta que guio el trabajo de Hugo fue ¿En qué media la sociedad condiciona la implementación de cánones estéticos que hacen de la vida un performance? Para ello Hugo tomó como eje central la significación del performance cotidiano al que está expuesto el sujeto actual. Esto suponía un diálogo con el texto Estética de lo performativo. A nivel teórico el joven reflexiona sobre la complejidad de su trabajo a partir de la escenificación. Con ella llama la atención hacia la difícil movilidad que trae consigo el cartón, que es el material básico de este diseño. Pero también alude a cómo los cánones sociales y de moda inmovilizan al ser humano en contra de su naturaleza. De ahí que el material básico que utiliza Hugo, proponga una reflexión teórica, social y práctica. Como antes se mencionó este diseño se realizó para la pasarela Cuban's Trashions, de ahí que los argumentos que use su creador denoten como un indicador sugerente lo performativo.

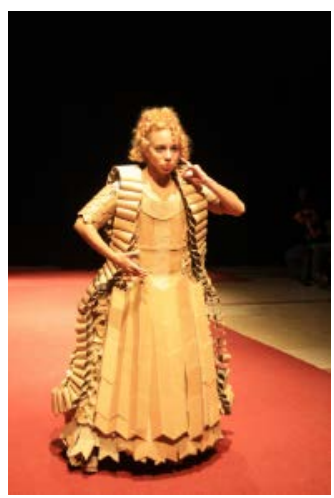

Figura 3. Diseño realizado por el estudiante de diseño Hugo A. Ruíz cuyo material primario es el cartón

Para algunos diseñadores el trabajo con estos materiales alternativos constituye una práctica revolucionaria que se ha ido reivindicando. Su uso en la confección de prendas de vestuario ha tenido varios seguidores al descubrir las innumerables posibilidades creativas que ofrecen estos materiales al descontextualizarlos de su finalidad común.

En Cuba dada la carencia de tejidos, los diseñadores han empleado como alternativa otros soportes y texturas siendo muy recurrente desde las últimas décadas del pasado siglo en el teatro cubano. Podría darse el caso que sin proponérselo el diseño escénico cubano haya explorado la creación a partir este tipo de materiales por la carencia de tejidos $\mathrm{u}$ otras texturas y no para promover una nueva forma de creación, aunque la segunda necesariamente quede implícita. Lo cierto es que este fenómeno se hace necesario seguirlo de cerca pues su desarrollo en dicho ámbito influye también en la enseñanza del diseño en Cuba.

Rolando Suárez fue otro de los estudiantes que ideó dos diseños para la pasarela Cuban's Trashions. La particularidad de su trabajo es su acercamiento con el metal. Aunque el diseño tiene la finalidad de exhibirse en pasarela y no como un trabajo para la asignatura de su carrera, Rolando decide fundamentar su obra partiendo de lo intertextual. Su pregunta de investigación para los dos casos seria ¿cómo lo intertextual y lo performativo le dan sentido a la puesta en escena de la vida misma? Para ello retoma el diálogo con el texto Estética de lo performativo de Erika Fischer-Lichte, donde este elemento completa la pieza como componente primordial. Si bien el intertextual se encuentra en la articulación de varios materiales y también de tendencias pasadas 


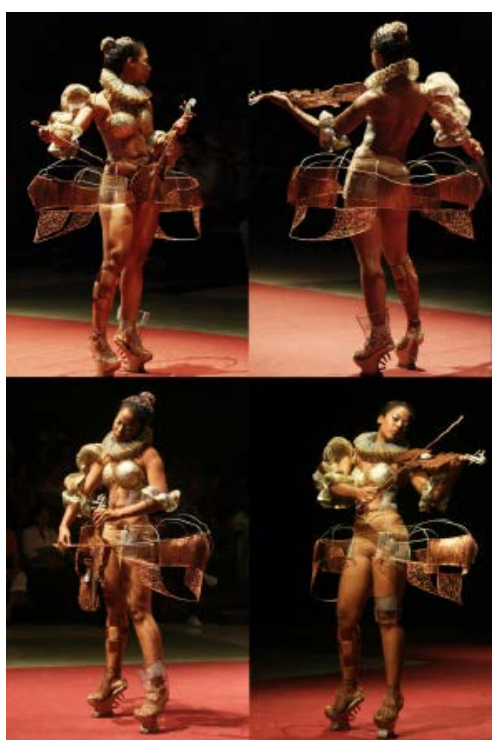

Figura 4. Diseño realizado por Rolando Rodríguez, quien toma como materiales básicos para su trabajo el hijo de alambre, rayos de bicicletas y otros materiales alternativos

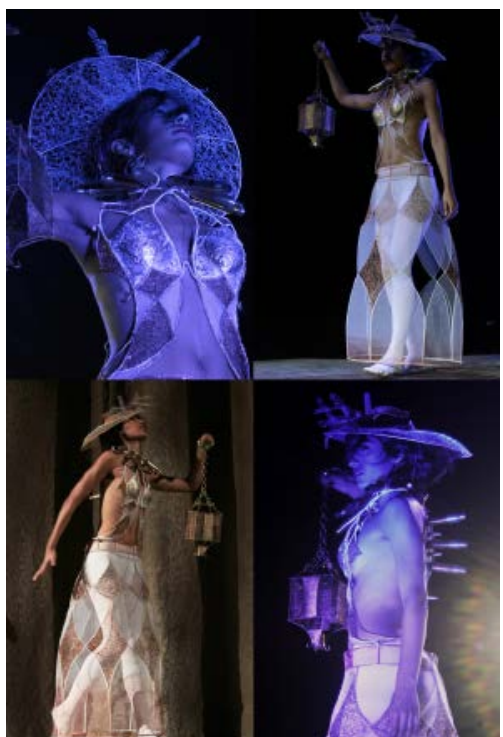

Figura 5. Diseño de Rolando Suarez realizados con metal, tejido de alambre y otros materiales que recrean la silueta del vestuario de la primera década del pasado siglo

y actuales de la moda, ella no cobraría sentido sin el acto de escenificación. A ello le añade valor el juego de luces al crear un ambiente particular que completa el diseño de vestuario, su representación o performance con la escenificación o el ambiente que se logra. Siendo así estos componentes argumentados desde la teoría estética y cultural fundamentan el trabajo de Rolando.

También analiza la mezcla de texturas como un elemento importante en la misma que está inspirada en un personaje ficticio que alude a un violín. Aunque la pieza se propone contar la historia del violín, el uso de materiales que invocan a dicho instrumento supone el realce de lo intertextual (Figura 4).

Su segundo trabajo se apropia de la silueta del vestido femenino de las dos primeras décadas del siglo XX. La misma se trabaja con diferentes materiales como el metal y el alambre, al que le incorpora como accesorios objetos que simulan un farol y algunos casquillos de balas que rodean el cuello y el dorso del maniquí (Figura 5). Este accesorio según el creador sugiere una conexión con los primeros veinte años del siglo pasado, donde estalla la Primera Guerra Mundial y la preocupación por la existencia humana, por el destino del hombre y de la humanidad, temas que se vuelve una constante. ${ }^{5}$

Estos son algunos ejemplos sobre los que puede trabajarse el diálogo disciplinar. No se trata que la asignatura se convierta en un eslabón más de la carrera, sino que contribuya a la formación del estudiante de diseño y le muestre distintas zonas de análisis que podrían visibilizarse en sus obras así como en eventos investigativos. El rol de la ID es fomentar si bien el interés por la indagación, también una formación estética para saber leer el medio y expresarlo en cada diseño para a su vez fundamentarlo teóricamente. 
Los trabajos seleccionados y analizados en este texto no se quedaron en clase sino que también se presentaron en una edición del Evento de Reflexión ${ }^{6}$ y de ALBUR. ${ }^{7}$ En estos espacios se presentan trabajos de corte filosófico y estético con la particularidad que permiten la articulación con saberes a su práctica visual como es el Diseño Escénico. Dichos eventos han contado con una buena acogida por parte del estudiantado al constituir un espacio donde mostrar y fundamentar su obra a partir de un trabajo investigativo previo. Son una buena oportunidad para socializar ideas y reflexionar acerca de los derroteros de la praxis del diseño. Aunque el evento cuenta con pocas ediciones constituye un referente para la investigación en artes desde los inicios de la carrera.

Estas pueden contarse también, como experiencias donde el diseño y el saber estético se articulan en virtud de fomentar la investigación académica entre los estudiantes. La ID permite este diálogo que constituye un elemento importante en la formación del estudiante de esa especialidad. Si bien esta se basa en la práctica más que en la teoría, la segunda resulta importante a la hora de encontrar y explotar otras zonas sobre las cuales se podría crear. Por ello es imprescindible que el estudiante conozca y sociabilice sus resultados investigativos no solo en el aula, sino también en eventos mediante la presentación de sus trabajos. También es imperiosa la necesidad de que el profesor se informe de las formas de creación, de las discusiones que en materia de diseño se llevan a cabo. Solo así el proceso de enseñanza-aprendizaje que propone la ID sería horizontal y dinámico.

\section{Conclusiones}

La evaluación a partir de la ID constituye una modalidad acertada para la enseñanza y aprendizaje de la Estética a la luz de sus problemas actuales. En ella la formación estética del estudiante universitario porque permite abordar los problemas de la cultura actual de una manera crítica y reflexiva. En este sentido el propósito de la disciplina Estética en la Universidad de las Artes ha sido acompañar los procesos creativos proporcionándoles a los estudiantes herramientas teóricas a través de la ID y algunos de los métodos aplicables en el aula.

Si bien la evaluación a partir de la ID manifiesta cercanías con la ABI que propone Boyer (1990), en nuestra experiencia fomenta en el estudiante la introspección de temáticas pertinentes para sus ámbitos y también para la cultura contemporánea. Además, le otorga la oportunidad de proponer temáticas relacionadas con sus intereses creativos a través de la revisión de fuentes bibliográficas como antecedentes del tema de interés. Así mismo se incentiva en el estudiante el sentido de la autogestión y del trabajo individual como elementos básicos de la propuesta de Boyer (1990). A ello se le suma la perspectiva constructivista dentro de la pedagogía en particular la vygotskiana que valida la propuesta de la concepción del conocimiento como objeto en construcción y no como dado, y que también apunta a la cualidad de investigar la realidad en la que se desarrolla el proceso de enseñanza-aprendizaje. Esto le otorga un rol activo y responsable al estudiante. Además, permite al profesor-investigador de Estética incli-

6 Evento de investigación estético-filosófica organizado por los profesores-investigadores del Departamento de Filosofía de la Universidad de las Artes. En él los estudiantes presentan avances de sus trabajos creativos articulándolos con una teoría que fundamente sus trabajos.

7 Evento teórico organizado por los jefes de departamento de cada facultad cuyo objetivo es dar a conocer y reflexionar sobre la praxis artística contemporánea. 
narse hacia otras zonas antes invisibilizadas por esta disciplina lo cual demanda de su información y conocimiento acerca de la realidad simbólica que nutre al estudiante, así como de las discusiones y temas de la especialidad de Diseño Escénico.

De manera que la aplicación de la evaluación a partir de la ID no solo demanda del esfuerzo del estudiante, sino también del profesor, quien debe de ser muy cuidadoso de los contenidos y temáticas que propone y desarrolla en clases. Más bien en este proceso no solo se observa el aprendizaje por parte del alumno, sino también del profesor. De modo que pese a algunos obstáculos expuestos en la primera parte de este texto, este tipo de evaluación visibiliza la capacidad de la asignatura de actualizarse y trascender.

\section{Bibliografía}

Abbagnano, N. 1967. Diccionario filosófico. La Habana: Editorial Instituto del Libro.

Banchi, H. \& Bell, R. 2008. The Many Levels of Inquiry. Science and Children, 46(2), 26-29, October 2008.

Boyer, E. 1990. Scholarship Reconsidered: Priorities of the Prefessoriate. Pircenton:Carnegie Fundation for Avancement of Teaching.

Brea, J. L. 2004 La Era Postmedia. Acción comunicativa, prácticas (post)artísticas y dispositivos neomediales. Consultado en http://www.laeraposmedia.net. y http://www. joseluisbrea.net (30-9-2010).

— 2004: El tercer Umbral. Estatuto de las prácticas artísticas en la era del capitalismo cultural. CendeaC. Consultado de http:// www.joseluisbrea.net (30-9-2010).

Cabrera, R. 1998. Escuela, imagen y medio total. Nuevo León: Universidad Autónoma de Nuevo León. Facultad de artes Visuales.

— , 2007. "La formación del educador artístico". Una vocación humana permanente". Artes, La Revista. N¹4, V.7. Julio-Diciembre.

Cotaimich, V. 2004. "El impacto de las nuevas tecnologías en la puesta en escena. La Estética Dialógica como desafío estético, poético y político. Generalidades acerca de la integración de nuevas tecnologías en la escena teatral". En línea: <.ar/jornadas04/ponencias/cotaimich.pdf>. Consultado el 11 de abril de 2009.

Danto, A. 1995. "El final del Arte". El Pasante (formato digital), 22-23.

Fabelo, J. 2001. Los valores y los desafios actuales. Universidad Autónoma de Puebla. México. I. Filosofía. Habana.

Fischer-Lichte, E. 2011. Estética de lo performativo. Abada Editores, S.L., Madrid.

Horruitiner Silva, P. 2006. La Universidad Cubana: el modelo de formación. La Habana: Félix Varela.

Hutcheon, L. 1993. "La política de la parodia postmoderna". Criterios, La Habana.

Martín-Barbero, J. 2008. Nuevas visibilidades de lo cultural y nuevos regímenes de lo estético. La Puerta FBA; (3) Gedisa.

Moraes, M.C.: Interdisciplinariedad y transdisciplinariedad en la educación. Fundamentos ontológicos y epistemológicos, problemas y prácticas. En Torre, S., Pujol, M. A., Sanz. G. (Coords) (2007): Transdisciplinariedad y Ecoformación. Madrid: Universitas. p. 27-44.

Morawski, S. 1979. Fundamentos de estética. La Habana: Arte y Literatura

Peñaherrera, M., Chiluiza, K. y Ortiz, A. 2014. "Inclusión del Aprendizaje Basado en Investigación (ABI) como práctica pedagógica en el diseño de programas de postgrados en Ecuador. Elaboración de una propuesta". Journal for Educators, Teachers 
and Trainers, Vol. 5(2), pp. $204-220$.

Portuondo, J. A. 1986. Ensayos de Estética y de Teoría Literaria. La Habana: Letras Cubanas.

Reguera, I. 1994. El feliz absurdo de la ética. (El Wittgenstein místico) Madrid: Tecno, S.A. Juan Ignacio Luca de Tena, 15 -28027//. Reedición (2004).

Sánchez, M. 2009. "Repensar la estética". Paper presented at the Jornada XXV Aniversario del Instituto de Filosofia, Instituto de Filosofia. Sin publicar.

Vygotsky, L.S. 1962. Thought and Language, Cambridge, MA: MIT Press. 


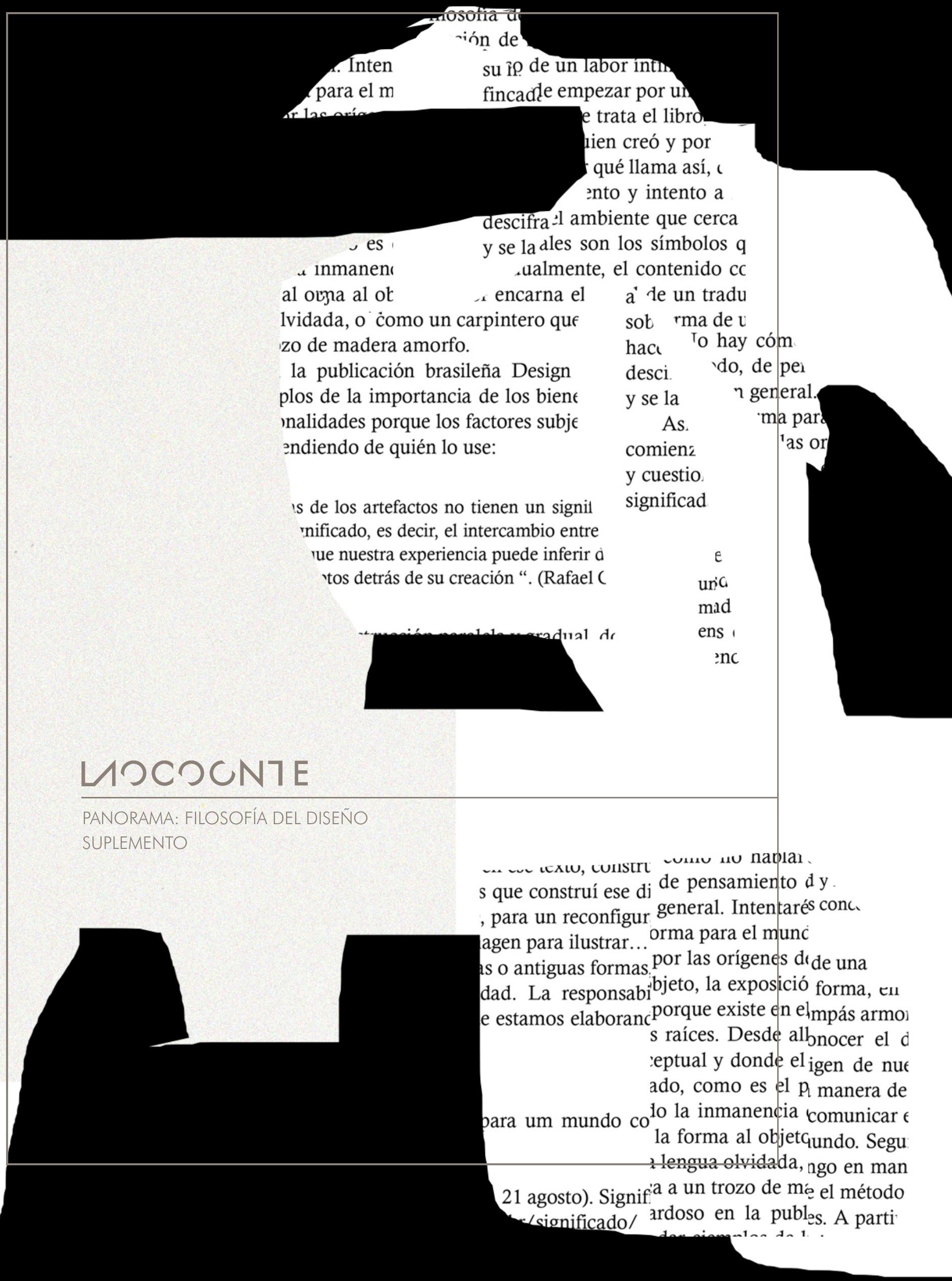




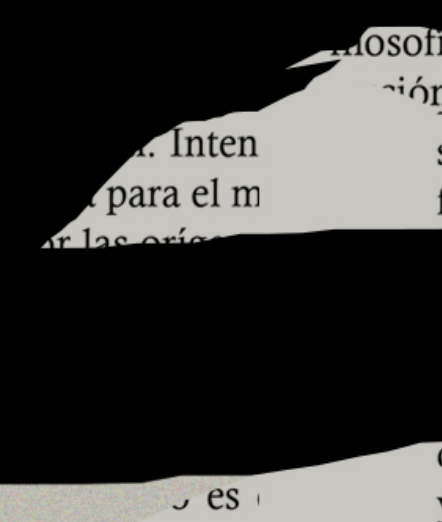

^ inmanen su î de un labor inth.

fincade empezar por un al orna al ot lvidada, o ċomo un carpintero quє zo de madera amorfo.

la publicación brasileña Design plos de la importancia de los bient inalidades porque los factores subje əndiendo de quién lo use:

is de los artefactos no tienen un signil rnificado, es decir, el intercambio entre rue nuestra experiencia puede inferir d tos detrás de su creación “. (Rafael C

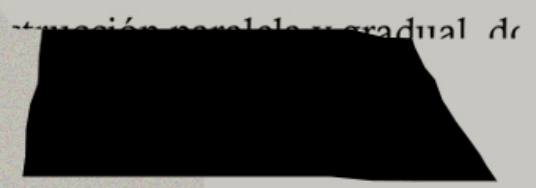
trata el libro iien creó y por qué llama así, c snto y intento a descifra $ı$ l ambiente que cerca y se ladles son los símbolos q .ualmente, el contenido cc . encarna el à de un tradu sob rma de $\mathrm{v}$ hace 'o hay cóm desci. do, de pei y se la As. comienz y cuestio. significad $\eta$ general

\author{
As
} . 


\section{El diseño, la ciudad y un lápiz de labios}

\section{Design, the city and a lipstick}

Mercedes Espiau Eizaguirre*, Mar García Ranedo ${ }^{* *}$ y Alejandro Rojas Bermejo ${ }^{* * *}$

Diseñar en Sevilla antes de los 80 era una actividad adscrita casi prácticamente al mundo de las agencias de publicidad. Agencias de origen local algunas, y delegaciones nacionales otras, copaban los encargos del desarrollismo tardofranquista andaluz desde la capital. Las agencias locales eran en su mayoría pequeñas empresas que gestionaban medios publicitarios, funcionaban como centrales de medios.

A finales de los 70 operaban en Sevilla las agencias Alas, que en aquella época era una delegación de su central en Madrid; Cid y Expansa, y la comercializadora Movierecord, especializada en la venta de publicidad para salas de cine cuya creatividad se desarrollaba en Sevi1la. Todas tenían su propio departamento creativo con equipos de directores de arte, grafistas e ilustradores. El término diseñador comienza a emplearse más tarde, ya en los 80 .
Las agencias funcionaban como auténticas escuelas de diseño para los alumnos en prácticas, aprendices en aquella época. Las agencias eran centros únicos de información sobre el estado del diseño fuera de España, a través de suscripciones a magacines y anuarios internacionales especializados y al inventariado de trabajos extranjeros, sus empleados podían conocer las corrientes del estilo moderno en Europa, como el NeueGraphik suizo o el estilo milanés, y las tendencias visuales de los Estados Unidos, agitadas por la resaca lisérgica de la psicodelia hippy y los movimientos contraculturales. En ese sentido también tuvo relevancia la relación de la provincia con los militares de la base de Morón de la Frontera. Unas relaciones que con el aperturismo franquista se relajaron y permitieron el trasvase de información visual clandestina, a través de discos de rock y revistas de todo tipo. 


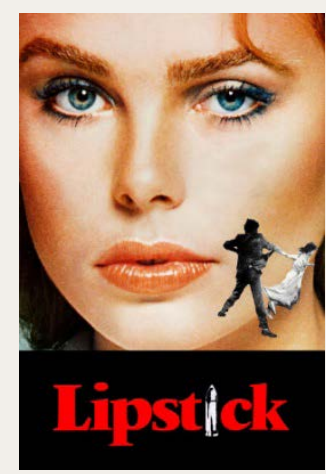

Lamont Johnson, Lipstick, 1976

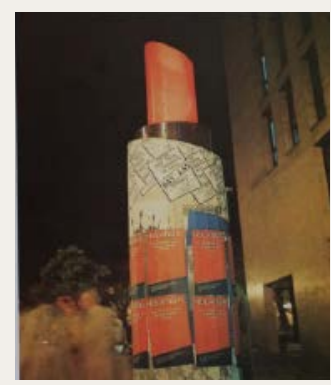

Juan Miguel Salado, Columna publicitaria Margaux, 1985

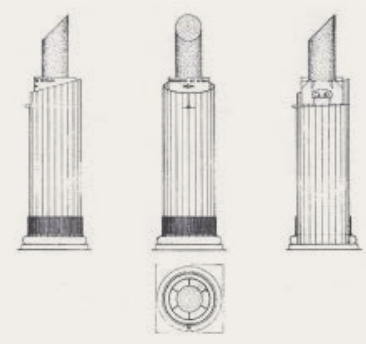

Juan Miguel Salado, Planta y alzado de Margaux, 1985
La cultura visual de la sociedad sevillana en los años 70 era en general escasa y limitada a la tradición popular. La formación sobre gráfica publicitaria se impartía en la Escuela de Arte y estaba muy centrada en la tradición visual del franquismo y en el imaginario de lo popular. En este contexto de precariedad cultural, la aparición de Margaux supone, más allá de su función como hito publicitario, un punto de conexión entre la sociedad y lo moderno. Para los más jóvenes del momento una manera de visibilizar lo que se intuía que estaba ocurriendo fuera de nuestro país.

El siguiente artículo plantea una reflexión en torno a un soporte publicitario diseñado para la ciudad de Sevilla en la década de los 80. Reflexión que forma parte de un trabajo mayor (que ocupa a los tres autores desde hace dos años) en torno a la recuperación de la memoria de los diseñadores y el diseño en el contexto de dicha ciudad. Una labor investigativa que busca relacionar cómo el diseño ha logrado desarrollar complejos cambios en la relación entre los ciudadanos y el paisaje urbano. En esta ocasión será a través de Margaux, un soporte publicitario que por su peculiaridad formal marcó un hito en la mirada moderna del sevillano.

\section{Glamur y competencia en el diseño sevillano de los 80 . Una mirada fugaz}

Probablemente recuerden una película de 1976 que se llamaba Lipstick y que supuso el debut cinematográfico de la supermodelo Margaux Hemingway.

Se trata de una película con un tema más que escabroso, pensada para una protagonista cargada de morbo no solo por el glamur de su profesión y su fama, sino por ser la nieta del escritor americano; algo, esto último, que le garantizaba el favor de los intelectuales, por muy frívola que pareciera la nieta o ante la cuestionable calidad de la película.

Pues bien, diez años después surgió otra Margaux, pero esta vez en Sevilla y en forma de barra de labios gigante colocada en medio de la calle. Margaux es el nombre que recibe la columna anunciadora creada por el arquitecto Juan Miguel Salado en 1985 con la función de hacer de soporte a la publicidad gráfica, es decir, como una de aquellas columnas publicitarias decimonónicas, concebida ahora como un icono de modernidad. Su función como hito comunicativo en el espacio, estipula un cilindro truncado que, como si de una funda se tratara, alberga en su interior un segundo cilindro negro asomando por la parte superior y del que surge un tercer y último cilindro rojo cortado a bisel. Apoyado en una basa simple de caucho negro, el conjunto se ilumina por dentro diferenciando la superficie pulida de los cilindros interiores, y el brillo texturado que impregna la placa perforada del envoltorio.

Es inmediatamente percibida como un enorme lápiz de labios. Ahí, en medio -por ejemplo- del andén del Colegio de Arquitectos. Su tamaño y plasticidad sobresalen en el entorno, acentuando nuestra extrañeza al contemplar un objeto que, por cotidiano, no debería estar ahí, así, sin más. Sin embargo, en ese contexto, el objeto multiplica su elocuencia como emblema del "encanto sofisticado" de lo glamuroso, 
y acapara toda nuestra atención.

Es evidente que el pop está presente. Monumentalizar lo vulgar y descontextualizarlo es el mantra de artistas como Oldenburg, Rosenquist o Wesselmann, que han instalado, recortado o pintado barras de labios como representación de la erótica de lo femenino desde su dimensión de estímulo publicitario.

La inclusión de lo cotidiano en el entorno, su alusión a convenciones estereotipadas por la publicidad y su apariencia hiperrealista y sobredimensionada, consiguen hacer insólito lo común haciendo aparecer, en medio del casco histórico de Sevilla, una suerte de objet trouvé. Es decir, una rareza que, en la ciudad, funcionó como un hito plástico de indudable sensibilidad pop.

La ironía es que Margaux había sido concebida como soporte publicitario, como columna anunciadora e informativa y no como objeto plástico. Es decir, estaba dentro de lo que entendemos como mobiliario urbano, por cierto, en gran parte renovado -y por el mismo autordurante esos años.

Pero, consciente de su poder simbólico, fue promocionada por el Ayuntamiento de Sevilla en la Feria de la Construcción de 1987, donde se expuso colocada en una posición inusual como barra de labios pero compatible con el impulso de un cohete. Otro juego más de similitudes con la ironía del pop: el lápiz de labios como arma (femenina, eso sí).

No obstante, su nombre, Margaux, haciendo una clara alusión a su referencia cinematográfica inmediata (Lipstick), propone una asociación directa entre ambas (película y barra de labios) y lo hace, además, por la vía emocional, por su capacidad de evocar el atractivo y la sensualidad de lo femenino: es el lápiz de labios en sí y no su función como hito de comunicación lo que le da valor ante el espectador. Su función queda más que amortiguada.

En cualquier caso, esa forma de aludir indirectamente a la película (y su protagonista) a través del nombre, nos sitúa a Margaux como un producto, sí, derivado del pop pero plenamente inserto en la estética (y la ética) posmoderna y sus "anotaciones" eruditas: la posmodernidad y sus referencias eclécticas a diversas expresiones y contextos culturales. Por ejemplo, el hecho de utilizar materiales como el caucho o la placa metálica perforada, nos remite sutilmente a la ciudad y a la arquitectura. Es un objeto urbano. $\mathrm{Y}$ en su conjunto responde a esa nueva instancia cultural de lo posmoderno: formas geométricas que introducen la dinámica de la diagonal; yuxtaposiciones de formas y volúmenes de brillante cromatismo, y un uso promiscuo de materiales y referencias que mezclan lo culto y lo popular, lo barato y lo caro, el arte y la industria.

De hecho, frente a la distante racionalidad del diseño moderno, aquí se prioriza la espectacularidad de la puesta en escena. La instalación de un objeto con suficientes ingredientes como para funcionar como un potente acento visual y con un uso "relativamente" funcional, lo consagran como una auténtica pieza de antidiseño al estilo Memphis y, por tanto, cuestionando las tradicionales categorías de forma, función y técnica.

La ambigüedad de su mensaje,

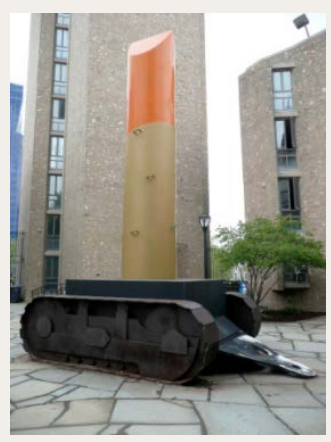

Claes Oldenburg, Lipstick (Ascending) on Cartterpillar Tracks, Morse College, Yale University, Estados Unidos, 1969

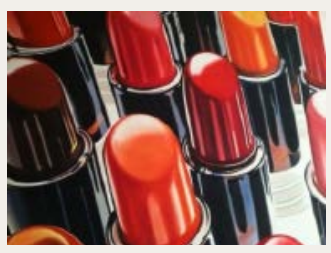

James Rosenquist, Lipstick, 1977

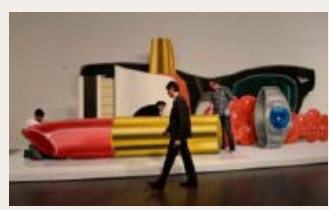

Tom Wesselmann, Still Life\#60, 1973

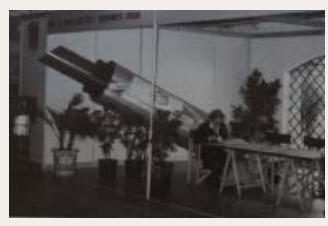

Margaux en la Feria de la Construcción de Sevilla, 1987

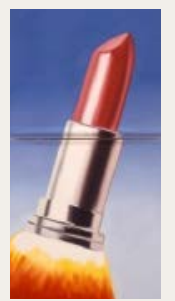

James Rosenquist, Through a GlassCeling, 2004 


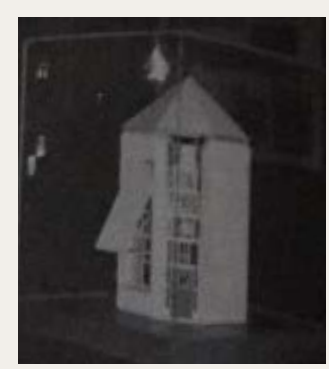

Juan. Miguel Salado, maqueta de kiosco bar, 1985

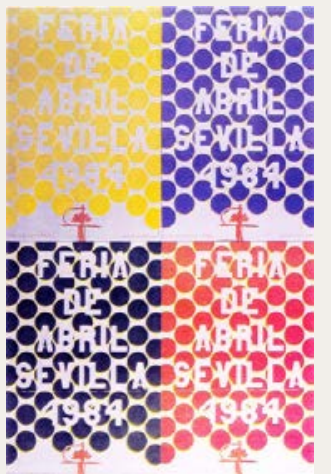

José Ramón Sierra, Cartel para la Feria de Abril de Sevilla, 1984 desprejuiciadamente difuso entre el reclamo glamuroso de lo erótico y su intención de ofrecer una información concreta al viandante (regado, quizás, con unas gotas de cine eruditas), lo aproxima a lo que entendemos como un objeto espectáculo. Un objeto que no deja a nadie indiferente, que llama la atención por su singularidad y no por su supuesta función (el medio es el mensaje). Porque la pieza, que debía funcionar como soporte, lo hizo también como reclamo visual en sí mismo: el soporte se convirtió en signo (el medio es el mensaje). $\mathrm{Su}$ autosuficiencia como producto plástico conseguiría velar su funcionalidad (el medio es el mensaje). Lo atractivo, lo sugerente, es su apariencia, no la publicidad que contiene (el medio es el mensaje). Lo importante es el anuncio, no lo que se anuncia (el medio es el mensaje).

Con ese contexto de fondo, en la década de los 80 la modernidad llegó a Sevilla. Y escribo modernidad en cursiva porque es un término lo suficientemente ambiguo como para darnos mucho juego. Porque no es lo mismo modernidad que posmodernidad, pero en Sevilla y en ese momento, estaban muy cerca. Porque los 80 son, sin duda, el momentazo posmoderno sevillano pero a él se yuxtapone también, un vago espíritu de modernidad. Ese que traían puesto los nuevos agentes políticos y culturales que ocupaban los puestos de poder por esos años: gente joven, culta, universitaria y progresista que se encuentra, casi de repente, con un país libre en el que poder actuar creando una nueva sociedad. Una nueva sociedad, crítica y urbana, que se abre por fin a los estándares internacionales de ocio y consumo a la par que articula una nueva estructura de estado que ha de proyectarse, formal y simbólicamente, a través de una nueva imagen. $Y$ esa imagen tiene que ser, necesariamente, distinta, singular, moderna.

Esa corriente de modernidad sevillana, carente de precedentes históricos hasta el momento, dominó el panorama cultural de la ciudad durante esa década. Y justo en su mitad llega Margaux para proclamar esa nueva actitud públicamente al situarse en plena calle, es decir, en el espacio común de la ciudad, destacando una de sus ubicaciones, la ya mencionada del andén del Colegio de Arquitectos, precisamente por relacionarse muy directamente con este edificio y su entorno.

Para empezar, su autor es un arquitecto que, desde el Área de Infraestructura del Ayuntamiento de Sevilla, investiga y promueve la renovación del paisaje urbano de la ciudad a través de su mobiliario. Sus diseños para quioscos y/o fuentes, nos hablan de microarquitecturas que interpretan las formas del movimiento moderno pasadas por el filtro de Aldo Rossi y sus arquitecturas estilizadas: la verticalidad es su nota dominante.

En ese sentido, la pieza es una muestra clara de la profunda y fructífera relación entre arquitectura y diseño, que en Sevilla tuvo una especial intensidad por estas fechas. De hecho, solo un año antes, en 1984, otro arquitecto, José Ramón Sierra Delgado, firma el cartel de la feria de abril.

Un cartel no poco polémico que, de entrada, plantea el mismo juego óptico del equívoco gracias al 
uso de una trama de lunares semejante, como patrón, a la placa perforada de Margaux. La referencia al op art es más que directa, pero la paradoja está en cómo un cartel ortodoxo a la moderna (rigor, geometría, equilibrio, simplificación...) juega a tener una apariencia ambigua y crear una imagen clara y confusa a la vez al más puro estilo optical.

Pero su imagen no solo vibra, sino que insinúa varias cosas a la vez: lunares y farolillos; claveles, estoques y cruces; alamares, mantones, flecos, palios ... motivos todos ellos que perfilan, frente a Margaux, un mundo castizo, popular y localista. Es evidente que, sugerido a través de una figuración esquematizada aunque muy ilustrativa, el pop sigue presente. Como también sigue presente en su edición que, basada en la idea de repetición de un mismo motivo en distintos colores (rojo, negro, amarillo y azul), cita al mismísimo Warhol.

Al final, el cartel, como Margaux, es equívoco y, por tanto, el juego está servido. $\mathrm{Y}$ al igual que Margaux, su espectacularidad formal, en las antípodas de la estética tradicional sevillana, se impone ante cualquier otra lectura inmediata.

La posmoderna cultura de la imagen, con todo su mundo de citas eruditas y alusiones a lo vernáculo, se estaba poniendo en marcha. Y de ella también participa la sede del Colegio de Arquitectos (junto al que se sitúa Margaux) que, retomando elementos del pasado para percibirlos con una nueva mirada, se define antes como una "arquitectura de la elocuencia" que como esa "arquitectura del espacio" tan característica del Movimiento Moderno.
Terminado en 1983 el edificio es muy Memphis en sus diferentes alturas, en sus perfiles angulosos y en la irregularidad geométrica de sus volúmenes. En sus muros lisos se abren huecos asimétricos para organizar un patio sevillano hacia la Plaza del Cristo de Burgos que, situado tras una falsa fachada $y$ ante un muro cortina, rivaliza con el soportal minimalista del frente que da a Calle Imagen.

Las relaciones empiezan a fluir: una fábrica de ladrillo para mimetizarse con la vecina Iglesia de San Pedro; un muro cortina y un mini soportal traduciendo el carácter de la calle Imagen, y dos notas de decoración y funcionalidad vernácula: un jarrón de cerámica en el ángulo de la azotea y un toldo triangular que sombrea el hueco del patio.

El carácter posmoderno vuelve a hacer acto de presencia. Los espacios "residuales", con más fuerza plástica que articuladora o funcional, hacen de la sede un edificio exótico pero lleno de guiños reconocibles que estimulan la curiosidad del espectador.

Igualmente criticado en su momento, la sede viene a redondear una nueva lectura iconográfica del lugar. Literalmente enfrentado a la arquitectura de la tradición (la Iglesia de S. Pedro y la Pza. Cristo de Burgos) por un lado, y al único ejemplo contundente del Movimiento Moderno con que cuenta la ciudad (la calle Imagen) por el otro, actúa más como cómplice e incluso como bisagra o enlace que como un elemento extraño. El entorno no le es ajeno. Y Margaux viene a confirmarlo.

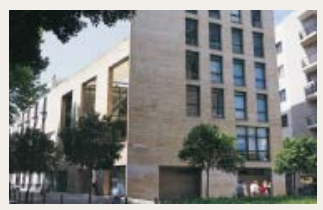

Perea Caveda, E.; Ruíz Cabrero, G. Sede del Colegio de Arquitectos de Sevilla, (1977-83)

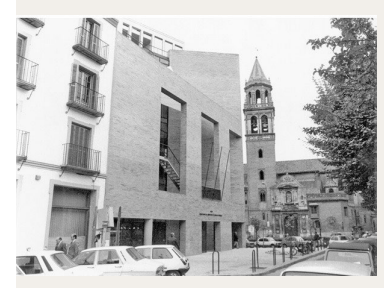

Vista desde Plaza Cristo de Burgos 


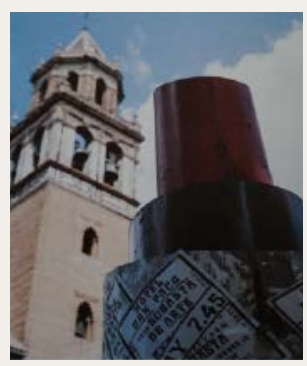

Vista con la Torre de San Pedro
El papel de Margaux a partir de este momento es el de un nudo de conexiones. Su condición de hito publicitario y su ubicación específica la ponen en contacto con el espacio religioso de la iglesia, con el lúdico de la plaza, con el cultural del Colegio de Arquitectos y con el espacio lineal de la calle Imagen. Impregnada de la textura comercial de esta última (luces, colores, rótulos, grafismos...), asume su papel de punto final de la misma destacándose como señal, como símbolo de persuasión comercial. Y aunque exenta de cualquier edificio, se erige como expresión de lo que Venturi llamó "lo vernáculo comercial" y su desprejuiciada forma lúdica (Venturi, 2016).

Pero Margaux tiene también connotaciones culturales e institucionales. De hecho está en medio de la calle, en el espacio público, el espacio más político que hay (al menos en este momento). Situada junto al Colegio de Arquitectos, se alinea con él en su labor de colaboración -junto a otras entidades, colectivos o particulares- con una administración empeñada en la promoción pública de la cultura y necesitada, además, de una nueva imagen.

Porque Margaux nace dentro de ese espíritu global de renovación de la imagen política que impregna la recién estrenada democracia, protagonizada por gentes de muy diversos planteamientos y actitudes que, sin embargo, coinciden en la necesidad de alinearse con la cultura más progresista favoreciendo a aquellas tendencias estéticas de vanguardia capaces de divulgar, de una forma moderna, la labor de las instituciones y sus competencias.
De ahí la aparición de Margaux como parte de la renovación del paisaje de la ciudad a través del mobiliario urbano, en medio de la efervescencia cultural de Sevilla - convertida ahora en una referencia internacional-, donde "el arte comenzó a marcar la agenda de la ciudad como si fuera un trampantojo, ocultando sus limitaciones y maquillando su realidad" (Abbad 2018).

Porque, si bien se había tejido una importante red cultural en la ciudad desde los años 70, los protagonistas de esta suerte de "revolución cultural" ochentera participaban del espíritu Memphis una vez más, para coincidir con su fundador, Ettore Sottsass, en que "Hoy todo lo que uno hace se consume. (Memphis) se dedica a la vida, no a la eternidad". Y esos protagonistas desarrollan toda una producción claramente orientada hacia el mercado de consumo (fundamentalmente de la industria cultural y en su mayoría de promoción pública). Artistas, diseñadores, arquitectos manejan y se expresan en los más diversos medios sin prejuicio alguno, dando primacía a la imagen como vehículo de conocimiento y sugestión simultáneamente.

Porque la creatividad se entendía desde el concepto del consumo como paradigma. El consumo es lo moderno, lo que define a la nueva sociedad que, como dice Debord, hace del acto comercial un espectáculo, algo camuflado tras el atractivo visual de las imágenes y sus connotaciones (Debord 2010). Y en ese contexto, el diseño fue tomando posiciones hasta casi institucionalizarse: "¿estudias o diseñas?" Esta era la frase estrella del momento. 
Frase con la que se bromeaba y que se convirtió, con mucha ironía, en la muletilla de cualquier encuentro cultural o lúdico que se preciara.

En cualquier caso, se trata del valor de la apariencia por encima de todo. La imagen sugerente, la imagen de la persuasión, del glamur, antes que la imagen eficiente e inequívoca. La competencia casi no importa. Lo que importa es anunciar la modernidad, hablar de ella. Por eso Margaux está casi bien, porque, como decía Venturi, "los anuncios están casi bien" (Venturi $2016: 26$ ).

\section{Experienciar la ciudad desde el objeto}

"Los profetas llamaban "paganos" a aquellos que estaban cautivados y atados al mundo de los objetos, y denominaban "ídolos" a aquellos objetos de uso que, en tanto objetos, podían cautivar y atar".

Vilém Flusser (2002)

En la ciudad contemporánea estamos habituados aconvivir con el mobiliario urbano que sirve como soporte para la publicidad. Desde mupis, columnas, opis, marquesinas, letreros luminosos, videopantallas, lonas para fachadas o para transporte públicos (todos ellos elementos empleados en el interior de la ciudad) pasando por las vallas representativas de la publicidad exterior. Los mupis (siglas de: mobiliario urbano como punto de información) o las columnas son diseñados bajo la máxima de la operatividad para ser "encontrados" en el deambular callejero y consumidos de un solo vistazo. Estos contenedores -colocados en lugares cén- tricos y concurridos de la ciudad, al servicio de la inevitable fuerza del consumo-, pueden adoptar formas ocurrentes que buscan causar sorpresa y extrañeza. Su función como objetos, a veces desvinculados de su contenido significativo, adquiere un valor subjetivo en tanto que experimenta el callejeo desde lo sorpresivo, lo chocante o lo empático. Se ha comprobado que el marketing experiencial, también llamado emocional -aquel que busca interactuar con el ciudadano a nivel personal mediante un evento o intervención experimental-,es más efectivo que otras técnicas tradicionales de marketing, y en este integrar la publicidad como experiencia, ciertos objetos de consumo representan algo más que los objetos comunes que aparentan ser. E1 bombardeo constante de mensajes y anuncios, con el que las personas se encuentran a diario, hace que cada vez sea más difícil atraer la atención, y aunque se busquen fórmulas o técnicas de marketing novedosas, a veces las ideas más simples son las más eficaces para captar la atención del ciudadano. De entrada, parece que tal elaboración pudiera ser una metodología tan solo orientada a atrapar al ciudadano-cliente de una forma menos intrusiva. Si bien, no debemos desdeñar el hecho de que el diseño, articulado como marketing experiencial, sirva también para promover causas solidarias, concienciar la defensa del medio ambiente o crear ideología de cooperación social. Aunque despojado de la sumisión del producto, su valor de mercancía no se ve afectado, y se regula, igualmente, con los imperativos de la producción y el rendimiento. Su potencial didáctico y su 


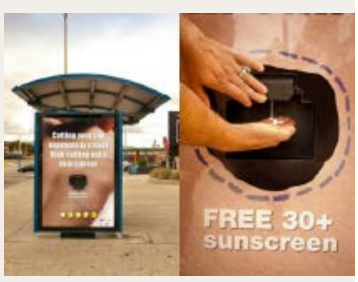

Campaña publicitaria de SunSmart Austalia

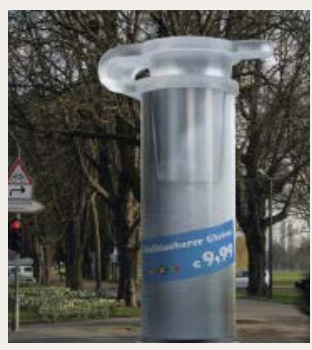

Campaña publicitaria Toys "R" Us

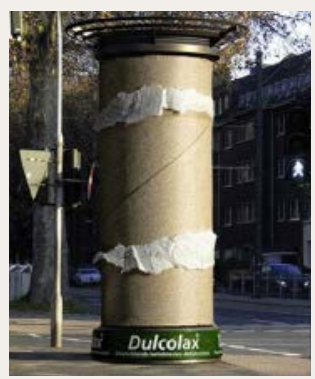

Campaña publicitaria Dulcolax

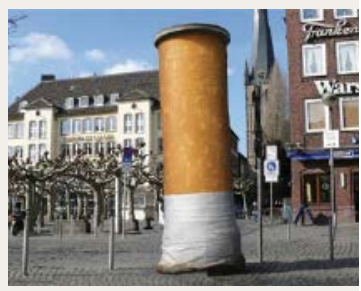

Campaña publicitaria contra el tabaquismo formulación empática introduce al espectador consciente en una experiencia interactiva. En suma, se da un efecto boomerang, un ida y vuelta de respuestas ante un espacio de signos cuya finalidad se procesa por el espesor de su filantropía o de su asesoría y mensaje.

Es el caso de la campaña publicitaria llevada a cabo por SunSmart Australia para promover la práctica de medidas preventivas para evitar el cáncer de piel, impulsada por el Consejo de Cáncer de Australia Occidental. El soporte publicitario se ideó como un objeto-dispensador de crema protectora para la piel, ofreciendo dosis gratis al ciudadano que reparaba en el anuncio. Es decir, que es asimilado como alerta precautoria y no como incitación al consumo de una determinada marca de crema. Hay algo reconocible en estas formas de operar con moblaje dispensador que recuerda a algunas estructuras habilitadas conformas elocuentes como columnas receptoras de publicidad gráfica. Cuando hablamos de elocuencia nos referimos a formas precisas de rápida identificación que conformadas desde la sobredimensión semejan o reproducen objetos de uso común (por ejemplo, la jeringa gigante diseñada para una campaña de concienciación social, Greenpeace, con la frase: "No hay mejor medicina para el medio ambiente que tu contribución"; las columnas convertidas en gigantescos rollos de papel higiénico, colocadas en las calles de Dusseldorf, como anuncio de un laxante;las colillas enormes para sensibilizarcontra el tabaquismo, en Berlín, o la columna transformada en tapón de juguete inflable de playa para promover una campaña de Toys " $R$ " Us, y la recogida de este tipo de juguetes). Está claro que esta tautología derivada de las prácticas del dibujo hardedge, de contornos nítidos y presencia impersonal del pop art, buscaban una imaginería dinámica y formas reproducibles o múltiples.

Sin duda, este "gigantismo" de formas eficientes sujetas a la sociedad de consumo recuerda a las barras de labios o lispticks, diseñados -a gran escala- por los arquitectos municipales, y que, en la década de los ochenta, del siglo pasado, ocuparon el espacio urbano de la ciudad de Sevilla.

Lo curioso es que en dichas barras de labios la conceptualización de la idea no se proyectaba en el diseño del soporte, y viceversa; tampoco eran, precisamente, objetos de fabricación industrial ultra-tecnológica, sostenibles y duraderos, como se le presupone al diseño de última generación, sino que, más bien, fueron manufacturados, con tratamiento de prototipos, -debido a la incipiente, y aún precaria, tecnología local empleada en la elaboración de nuevos materiales constructivos y en las técnicas de diseño-. Nada que ver con el mycoform o bioplástico, resistente al agua, ideal para el diseño del mobiliario urbano para la intemperie -muy empleado por los arquitectos en los noventa para sus macro estructuras- o el microcemento, material también impermeable, y reciclable, utilizado en la fabricación de muebles así como en la construcción, o el acero adaptable a condiciones climáticas extremas, además de todos esos materiales ecológicos que en la actualidad buscan un compromiso ético de sostenibilidad y respeto con el me- 
dio ambiente sin comprometer la funcionalidad y resistencia, como, por ejemplo,el caucho reciclado de neumáticos ya en desuso o la madera cuya certificación garantice su procedencia de bosques de tala controlada. Hoy lo preponderante en el diseño del mobiliario urbano es el acuerdo o la reconciliación con el entorno, por encima de cualquier otra circunstancia que pueda generar deslumbramiento o asombro; porque, lo fascinante es la posibilidad de entender nuestro contexto urbano de manera confortable, habitable y sostenible. Aquellos lipcktics o barras de labios de factura pop, resueltos con planchas y remallados de hierro lacados en colores, fueron tan efímeros como el propio hierro permitió; cumpliendo, paradójicamente, con los fundamentosde renovación e innovación propios de la fabricación en serie basados en la obsolescencia programada y la caducidad sistemática. Fueron, sin embargo, una experiencia, una vivencia que dejó huella y recuerdo afectivo.

\section{Un rouge muy urbano}

Si echamos la vista atrás, e imaginando la experiencia visual que para el ciudadano supusieron las barras de labios, entenderemos que esta forma de ornamentar el espacio urbano buscara generar cierta disyuntiva entre la ciudad tradicional y la cultura moderna. Dicho soporte publicitario/objeto puso en tela de juicio las convenciones del lenguaje empleado en el diseño de mobiliario urbano de la época, incitando al ciudadano a experimentar la ciudad desde un caudal más perceptivo; el mobiliario urbano evadió su pasividad e indiferencia para volverse agente activo, desde el desconcierto, en una ciudad en plena transformación. ¿Qué impulso, y de qué índole, motivó a los arquitectos/diseñadores municipales a generar un mobiliario urbano a partir de un objeto de consumo cosmético... -con clara referencia a una forma fálica-? ¿Se trató de simbolizar la erótica genuina que alude a lo femenino desde el lápiz de labios? ¿O fue un tributo erótico al hombre, revestido de cosmética publicitaria, para fantasear con la paradoja?

Lo cierto es que estos lápices o barras de labios -no pretendían promover ideas o conceptos envueltos en estrategia publicitaria desde su iconicidad; tampoco aseguramos que representaran una militancia consumista de la cosmética femenina (higiene, productos de belleza y "perfectibilidad"), sin embargo, si podemos afirmar que fueron parte de una existencia caracterizada por cierta condición acrítica y desideologizada propia de la sensibilidad moderna del momento y su relación con el consumo, traducida como indiferencia por lo trascendente y un interés centrado en el dominio de lo cósico. Un "cambio de sensibilidad que ha inducido a las masas a desear la proximidad de las cosas, a adueñarse de ellas, como señala Beatriz Colomina (2010: 69). Si bien, las barras de labios carecían de funcionalidad y compromiso sostenible, no podemos desdeñar su valor al analizar el enorme esfuerzo que representa promover desde formas ocurrentes, imaginativas y poco ortodoxas el diseño de mobiliario para la calle,en una ciudad cuyo paisaje urbano era condicionado por su peso histórico,

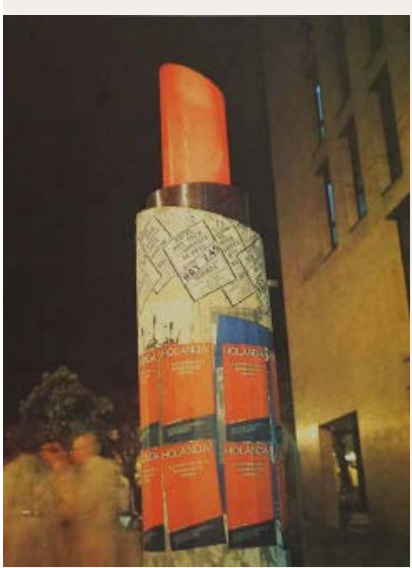

Juan Miguel Salado, Columna publicitaria Margaux, 1985 
de urbe antigua, en un modelo de polis conservadora. Este acceso al diseño desinhibido, llamativo, singular y espontáneo revela sin más el deseo de acercamiento de la ciudad al modelo de cultura moderna, "consumiendo", perceptivamente, al propio objeto, ofrecido para ser"devorado" y transformado en objeto productivo. Es el objeto absoluto, tan egoico y literario como afuncional y seductor. "El objeto absoluto es aquel cuyo valor es nulo, y cuya calidad es indiferente, pero que escapa a la alienación objetiva en cuanto se hace más objeto que el objeto, lo que le proporciona una cualidad fatal" (Baudrillard 1991: 126).

La década de los ochenta -la primera etapa de la democracia en el estado español- supuso un momento clave en la transformación social, económica y política del país, que en lo cultural se caracterizó por el dominio de cierto conservadurismo(medios de comunicación en general ligados al poder) bastante lógico dado el perfil político que caracterizó la transición hacia la democracia. Tanto, en el ámbito editorial como en el sistema del arte -en pleno desarrollo de modelos críticos que sustentaran ciertas estructuras legítimas-, lo ecléctico y lo nuevo se interpretaron como fundamentos de vanguardia. Las primeras galerías de arte contemporáneo habían comenzado su andadura pocos años atrás, y los museos se incorporaban al tejido del sistema del arte con programaciones incipientes de carácter internacional. En este contexto, el espacio urbano inició también su renovación. Todo, incluso, la manera de enseñar la cultura o el modo de convivir con la nueva ciudad tuvo que ser reemplazado. La apuesta política consistió en construir a toda costa y a toda velocidad, una modernidad cultural que nos identificase como parte del modelo internacional reflejado desde los escenarios europeos y norteamericanos, para lo que fue imprescindible mirar hacia delante con optimismo y entusiasmo. Recordemos la exposición comisariada, en 1989, por el teórico y profesor de estética José Luis Brea, titulada Antes y después del entusiasmo, en la que el autor enunció un cambio de sensibilidad para los inmediatos noventa, con el abandono de los lenguajes conservadores y con el sentido de retorno a esas economías de la representación fáciles y entusiastas. En esta especie de convocatoria imaginaria, en la que se encontraba inmerso el sistema cultural del momento, convivirían generaciones y tendencias de lo más dispar, todas ellas fundamentadas desde una revitalización del panorama cultural español. Como parte de esta actividad exacerbada, en la ciudad de Sevilla surgió un foco de interés que alcanzó proyección nacional e internacional, caracterizado como ambiente artístico paradigmático y protagonizado por una serie de artistas -vinculados a la revista Figura- que promovían la novedad como principio estético y el descaro como actitud clave de consigna vanguardista.

En este entorno, la barra de labios/soporte publicitario se asemejaba más a una escultura. Contrasentidos que simbolizaron el diseño de la década de los setenta y de los ochenta en torno a la fascinación por los modelos intrascendentes y el deslumbramiento por la manufac- 
tura industrial que ya adelantasen los dadaístas. El objeto fútil convertido en útil para cautivar la mirada y reforzar la idea de lo extravagante y divertido del diseño con función. El gadget, como señala Lipovetsky, será el símbolo de la economía frívola y posible modelo o paradigma del objeto de consumo: "desde el cuchillo eléctrico para ostras, limpia cristales eléctrico, máquina de afeitar eléctrica de tres posiciones o el tostador eléctrico de nueve posiciones..." (Lipovetsky 1991: 181). En este sentido, podríamos preguntarnos si detrás de este desarrollo, de forma estrambótica y excéntrica, del diseño del mobiliario urbano, no se escondía una crítica a lo artificioso e inauténtico del objeto de consumo o bien se pretendía generar una percepción de la ciudad renovada desde la lógica de la seducción del objeto de consumo.

Hoy el imperativo tecnológico y sostenible y la seriación globalizada del diseño hacen de esta forma de ocupar el espacio urbano -guiño que desprograma lo programadoun asunto que sensibiliza de forma nostálgica la irracional cortedad de la vida de los objetos con su mecánica ciega y su forma estratégica de movilizar el consumo. Baudrillard apunta que los seres y los objetos están ligados, y estos cobran, cómplices, una densidad y un valor afectivo. La barra de labios representó el prototipado, lo afuncional, con ese hechizo más próximo a lo decorativo o al atractivo del propio objeto cosmético en sí mismo; simbólico y anunciador de una erótica urbana contenida durante décadas. Su factura, más próxima al artefacto artístico que a la tecnología compleja y depurada que aventura el diseño, lo domestica, lo humaniza como el discreto encanto de la economía de medios. En este sentido, podríamos hablar de un anti-diseño, por su alejamiento de la ortodoxia teórica marcada desde el modernismo austero dela Bauhaus, según el cual el diseño debe abandonar toda estética cargante, accesoria y decorativa para centrarse en su función: "el diseño no tiene como tarea concebir objetos agradables a la vista, sino encontrar soluciones racionales y funcionales. No arte decorativo, sino diseño informacional orientado a crear formas adaptadas tanto a las necesidades y a las funciones, como a las condiciones de la producción industrial moderna (Lipovestky 1990: 188).

Pero, ¿es posible anular, barrer, lo kitsch de la concepción del diseño? El propio Lipovestky rebate esta argumentación paradójica. No es más que una mera teoría: la estética en el diseño es inseparable a su función; es parte constitutiva y consustancial en su operatividad como proyecto, incluso en los diseños más recientes que buscan la depuración en las formas y la sofisticación tecnológica. No hay más que mirar cómo el diseño ha sido influido por el arte de vanguardia para entender que hay aspectos de éste imposibles de reducción a meros principios de síntesis y funcionalidad. "Con la tendencia poetizada y posfuncionalista, el diseño, realizando un giro espectacular, no hace sino pregonar más abiertamente su esencia de moda. La fantasía, el juego, el humor, principios constitutivos de la moda, tienen ahora carta de ciudadanía en el entorno modernista; han conseguido inmiscuirse en el diseño mismo. De este modo, esta-

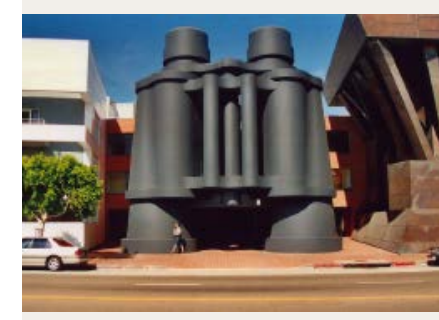

Frank Gehry, Binacular's Building, Santa Mónica, 1991 


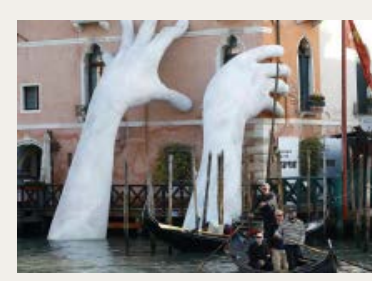

Lorenzo Quinn, Support, Venecia, 2017 mos condenados a la yuxtaposición de contrarios estilísticos: formas lúdicas/formas funcionales. Por un lado, cada vez más fantasía e ironía; por otro, cada vez más funcionalidad minimalista. El proceso no ha hecho más que empezar; la uniformidad no está en el horizonte del mundo de los objetos" (Lipovestsky1991: 191).

\section{La paradoja del objeto}

Hemos concluido, en esta deconstrucción temática de la barra de labios como valla publicitaria, que el enfoque basado en una posición que analiza los hábitos del individuo mediático y los rituales como prácticas sociales y económicas de la década de los ochenta fueron claves en la iconoclasia de la época, tanto en el ámbito del diseño, como en el arte. La barra de labios como mobiliario urbano no idealizaba cuestiones relacionadas con la mujer, con sus hábitos y formas de comportamiento, sino más bien buscaba la identificación a través de un objeto, que la historia ha devengado como de uso femenino, de todo un contenido de carácter sociológico, es decir; la barra de labios entendida como instrumento para reconocer los síntomas colectivos de una sociedad. De hecho, el empleo de esta imagen "popera" del lipstick en la ciudad de Sevilla parece más inserto en la seducción del objeto como imagen de expresión y representación que tenían artistas como Andy Warhol o Claes Oldenburg por mucho que la teoría estética se resista a reconocer, como señala Fernando Infante en su libro La autonomía del diseño (2018: 37): "Una parte de la teoría estética se resiste a reconocer que los diseña- dores puedan tener las mismas intenciones, al menos parcialmente, que los aristas. Aunque tal teoría se afana en dar con las claves de la definición del arte o del objeto artístico, parece contar ya de entrada, con la solución, con el preconcepto que demarca a los objetos artísticos". Ese prototipado del moblaje urbano no está muy alejado de la premisa naif del Binacular's Building que diseñó Frank Gehry, en Santa Mónica, en 1991, para la agencia de publicidad Chiat Day Mojo Advertising. En cierto modo, la seducción se acentúa en el momento en que un objeto de uso cotidiano se escala a tamaños y dimensiones imposibles. El gigantismo ha sido y sigue siendo una fórmula fácil de impresionar al espectador. El lipstick no es sino esa pareja de manos (Support) que saliendo del agua se posan sobre el hotel Ca'Sagredo en el Gran Canal de Venecia, pensadas por Lorenzo Quinn más como una trampa visual y superchería disneyana que como ese mensaje, supuestamente conceptual, de la destructividad humana.

Las décadas de los ochenta y noventa se caracterizaron principalmente por un consumismo exarcebado, reflejo de una economía ascendente. Los diseñadores y los logos se convirtieron en verdaderos símbolos del estatus económico. La prosperidad de los ochenta se manifestó como una ostentación del glamur, era la época del bienestar y esto se formalizó en un estilo cuya principal característica era la exageración, que en los noventa perdió vigor. Muchos de los gestos aprehendidos y característicos de lo social se manifestaron desde el objeto de deseo y la fantasía reconocible, 
por ejemplo, una barra de labios. Gestos que escenifican un tipo de vida social enmarcados dentro de un orden económico de sociedad de consumo o de capitalismo multifuncional, como diría Fredric Jameson, que configuran un modelo de comportamiento mediáticamente contaminado por la novedad y el espectáculo y socialmente regulado por lo efímero (Jameson 1991). E1 diseño, como el arte, como la literatura, como la arquitectura, se apropia de una iconografía propia de la cultura de masas. Esta atención a lo popular - postulado de la cultura posmoderna- reconfigura nuestra manera de entender la vanguardia que parece contaminarse con lo cotidiano: la saturación de la representación icónica es un aspecto inherente a la visión posmoderna. Por todo esto, a los objetos de consumo y su representación debemos analizarlos como dinamizadores y vitalizadores de la realidad, además de -como señala Naomi Klein- "provocadores castrantes y omnímodos que vehiculizan todos los discursos, todas las conductas socializadoras" (Klein 2001).

Una de las características más importantes del ayuntamiento entre individuo -actor/ciudadano- y el objeto de consumo -barra de labios/mobiliario urbano- es la configuración como método de análisis y reflexión sobre el que establecer los mecanismos de comunicación que convierten a dicho objeto en icono de la cultura popular.

La barra de labios en la ciudad de Sevilla no fue si no el espejismo de una modernidad más prefigurada que instaurada. Su simbolicidad, la erótica velada, la feminización de la ciudad, siempre estatuida desde la erectibilidad falocrática, todas las economías del sueño polifuncional de la boca, no fueron sino añadidos involuntarios a un régimen superficial de la forma. Lo más profundo es la piel decía Valery.

Recordemos la obsesión de Le Corbusier con los objetos, fundamentalmente, con los tecnológicos. Solía establecer curiosas analogías entre éstos, la producción en serie y la arquitectura -como recoge la revista publicada junto al pintor francés Amédée Ozenfant, bajo el nombre de L'Espirit Nouveau-. De manera que cuando incluye imágenes de aviones y barcos, procedentes de catálogos de revistas de publicidad, lo que le interesa es señalar cómo esos mismos medios de producción seriada empleados para la tecnología puntera son aplicables a la arquitectura. Preconizó la creación de viviendas en serie -emulando al sector del automóvil o el navalcomo ese "lugar" donde el diseño encuentra sinergias con la producción industrial. Parafraseando a Le Corbusier: "En todo momento o por medio de periódicos y revistas, se nos presentan objetos de una novedad impresionante. Todos estos objetos de la vida moderna acaban por crear un estado de ánimo moderno" (Colomina 2010: 109).

\section{Bibliografía}

Abbad, P., 2018. "Como una ola. Movidas artísticas en la Sevilla de la transición". La Muy, en:https://lamuy.es

Baudrillard, J., 1991. Las estrategias fatales. Barcelona: Anagrama.

Brea, J.L., Before and after the enthusiasm/Antes y después del entusiasmo. Amsterdam: Editorial SDU with contemporary Art 
Foundation.

Colomina, B., 2010. Privacidad y publicidad. La arquitectura moderna como medio de comunicación de masas. Murcia: Cendeac, Colegio oficial de arquitectos de Murcia y Observatorio del diseño y la arquitectura de la región de Murcia.

Debord, G., 2010. La sociedad del espectáculo. Valencia: Pre-Textos.

Flusser, V., 2002. Filosofía del diseño. Madrid: Editorial Síntesis.

Infante del Rosal, F., 2018. La autonomía del diseño. España: Creatividad \& Recerca.

Jameson, F., 1991. El posmodernismo o la lógica cultural del capitalismo avanzado. Barcelona: Paidós.

Klein, N., 2001. No logo. Barcelona: Paidós.

Lipovetsky, G., 1998. El imperio de lo efimero. Barcelona: Anagrama.

Rancière, J., 2011. Aisthesis. Santander: Shangrilla.

Realizaciones para Sevilla. 1983-1987. 1987. Sevilla: Área de Infraestructura y Equipamiento Urbano del Ayuntamiento de Sevilla.

Salado González, J.M. 1985. Puestos de agua en Sevilla. Sevilla: Área de Infraestructura y Equipamiento Urbano del Ayuntamiento de Sevilla y Consejería de Obras Públicas y Transportes de la Junta de Andalucía.

Venturi, R., 1978. Complejidad y contradicción en la arquitectura. Barcelona: Gustavo Gili.

Venturi, R., 2016. Aprendiendo de Las Vegas: El simbolismo olvidado de la forma arquitectónica, Barcelona: Gustavo Gili. 


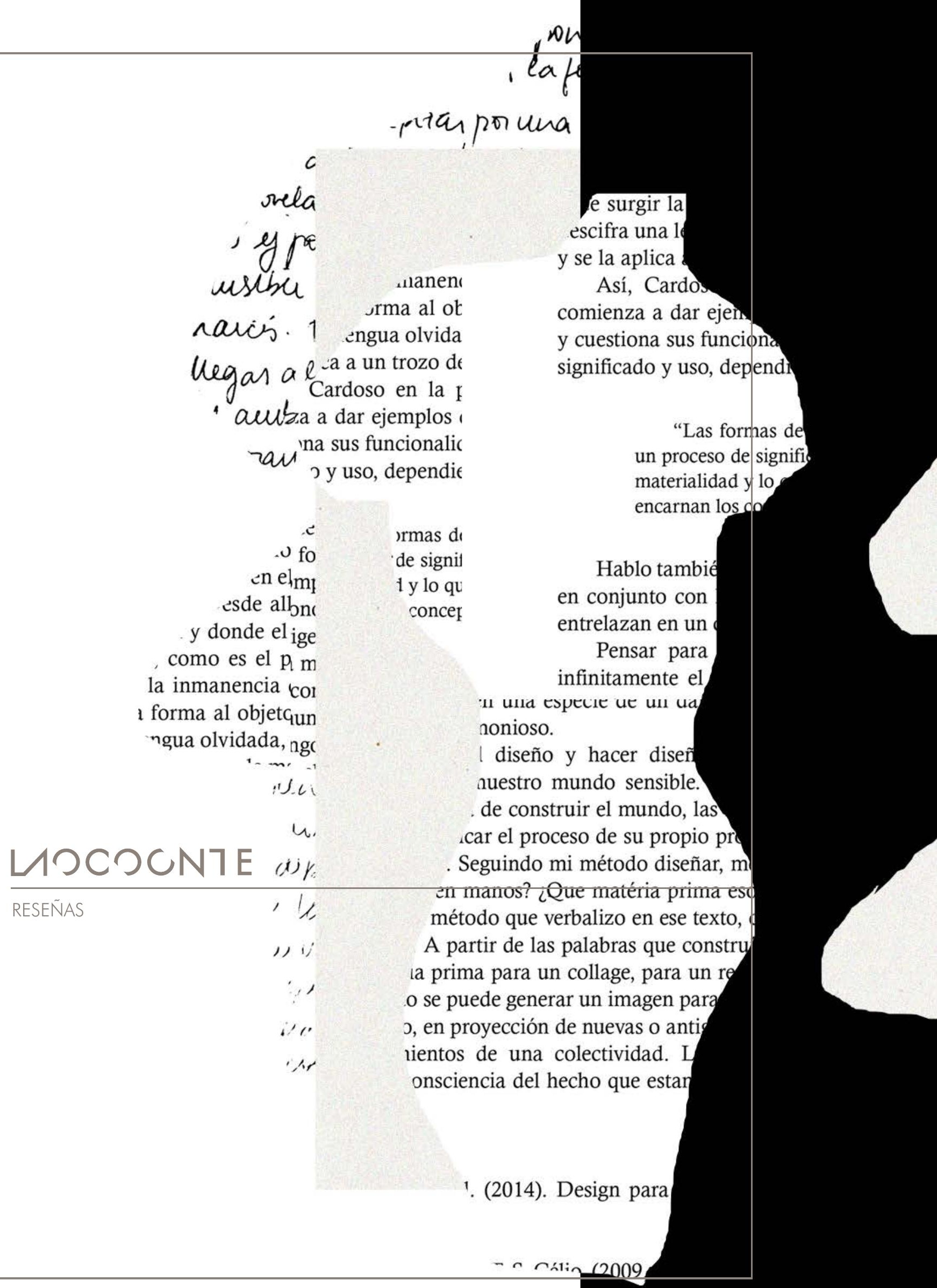




\title{
Walter Gropius. La vida del fundador de la Bauhaus
}

\author{
Jorge Martínez Alcaide
}

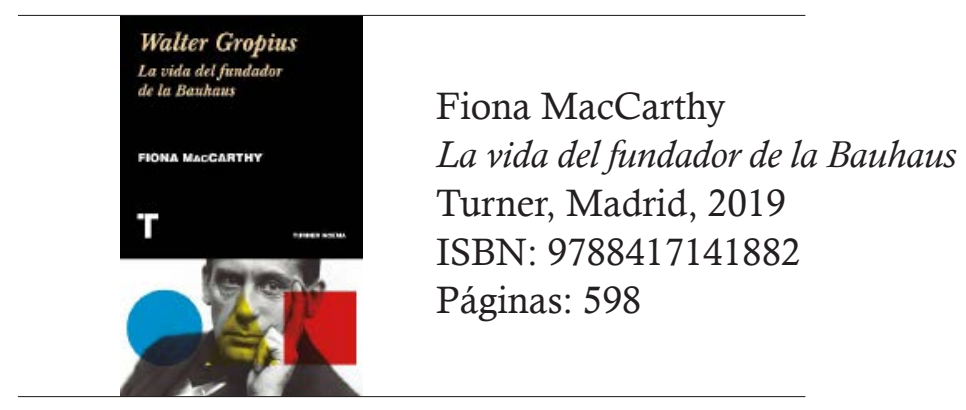

En el año del centenario de la Bauhaus, la prestigiosa y reconocida autora Fiona MacCarthy nos trae esta obra sobre la vida de su creador, Walter Gropius. MacCarthy es experta en el arte y el diseño de los siglos XIX y XX, y ha tenido una prolífica carrera escribiendo en medios tales como The Guardian, The Times Literary Supplement o The New York Review of Books. Su labor como biógrafa ha sido premiada con diversos galardones, destacando el Wolfson History Prize (1994), concedido por su obra William Morris: A Life For Our Time, y el James Tait Black Prize for Biography (2012), concedido por su obra The Last Pre-Raphaelite: Edward Burne-Jones and the Victorian Imagination. Estas credenciales de la autora avalan un estudio pormenorizado, riguroso y exhaustivo del que fuera fundador de la Bauhaus: Walter Gropius (1883-1969).

La obra se divide en tres apartados, al igual que la propia vida de Gropius se desarrolló en tres países diferentes: una primera parte dedicada a Alemania, una segunda a Inglaterra y una tercera a Estados Unidos. Además, se incluye un prefacio y un conjunto de láminas, así como un extenso listado de fuentes y referencias consultadas por la autora. Por todo esto, la presente obra es más que recomendable para todos aquellos amantes de la Bauhaus que quieran profundizar en sus conocimientos sobre ella o sobre su fundador, pero también para aquellos neófitos que quieran adentrarse en el estudio de uno de los principales protagonistas de la arquitectura, el diseño y el arte en el siglo XX.

El estilo de la autora es atrayente, pues va trazando la línea vital de Gropius mientras alterna escenas y episodios de su vida laboral y personal, y de esa manera va describiendo o descubriendo al lector la figura del arquitecto. Y lo interesante de Walter Gropius es que tanto su vida laboral como personal incluían o concernían a personas que o bien ya eran o acabarían siendo verdaderas personalidades del arte y de la escena social a nivel mundial, lo que otorga un plus de misterio a su figura, ya de por sí atrayente.

El libro arranca con la infancia de Gropius en el seno de una familia acomoda-

* Universitat de València, España.jorgemartinezalcaide5@gmail.com 
da de Berlín, pero será a partir de su mayoría de edad cuando comiencen a aparecer los datos interesantes acerca de su persona, pues será cuando por primera vez tome contacto con la arquitectura, realizando una pasantía en un despacho, y será también cuando se matricule en la escuela de arquitectura, pues tenía vocación de arquitecto ya desde su juventud. En esta primera etapa de su vida vivirá sucesos que serán determinantes para su futuro, como por ejemplo el coincidir en uno de los primeros despachos en los que trabajará con un futuro colega como será Mies van der Rohe o enrolarse en el ejército en una Europa pre-bélica, en el $15^{\circ}$ regimiento de húsares.

MacCarthy también destaca los primeros trabajos que acometió Gropius, consistentes en unas viviendas sociales para los trabajadores de la finca rural de un familiar suyo, un encargo que despertará en él esa conciencia de compromiso social que irá siempre ligada a su figura, y reforzará su idea, que nunca abandonaría, de que el ser humano necesita vivir rodeado de zonas verdes.

Pero si hubo un acontecimiento vital para Gropius, fue, según la autora, el hecho de trabajar para Peter Behrens, de quien le asombró su versatilidad, ya que se encargaba no sólo del diseño de sus edificios, sino también de todos sus espacios interiores, así como de los elementos accesorios, tales como cubertería, vajilla o cristalería. Sin duda esto influiría en una de las principales ideas que años después desarrollaría en la Bauhaus, la Gesamtkunstwerk, u "obra de arte total".

Las vicisitudes de la guerra harían de Gropius un héroe de guerra, y propiciaron que éste tuviera una epifanía y se convenciera de que aquello que realmente quería era crear una escuela de arte. A partir de ahí la autora cuenta de manera minuciosa todos los problemas que asediaron al arquitecto hasta que fue designado director de las escuelas de arte y de arquitectura por parte del gobierno de la República de Weimar. La fusión de esas dos escuelas sería el germen de la Bauhaus, para la que Gropius tuvo que buscar profesores que combinaran en sus personas dos aspectos difíciles de aunar: el respeto por la artesanía y la tradición y una nueva y moderna sensibilidad artística.

Será precisamente esta mezcla de seguidores de la tradición de William Morris con esa moderna sensibilidad lo que conforme la identidad de la Bauhaus. El profesorado que contrató Gropius será excepcional, y muchos de sus miembros se convertirán en verdaderas figuras del arte mundial. Algunos de los nombres que, en algún momento, conformarán la plantilla de la Bauhaus serán los siguientes: Gerhard Marcks, Lyonel Feininger, Johannes Itten, Paul Klee, Vassily Kandinsky, Oskar Schlemmer, Gunta Stölzl, Josef Albers, Marcel Breuer, Laszlo Moholy-Nagy o Mies van der Rohe, entre otros.

En cuanto a la Bauhaus, se explica de manera pormenorizada y acertada su proceso de creación, así como su plan de estudios, en el que, a grandes rasgos, Gropius propuso una serie de talleres que tenían al frente a un maestro, y animaba a sus alumnos a que pasaran por varios de ellos para que así pudieran dominar diversas disciplinas: escultura en piedra y madera, cerámica, muebles, oro y otros metales, impresión gráfica, encuadernación y tejido. También se mencionan las paradojas en las que recayó la escuela, como por ejemplo el hecho de que en esta primera etapa de Gropius no incluyó en el plan de estudios la arquitectura. Esto, siendo él mismo arquitecto, le acarreó fuertes críticas, si bien es cierto que él tenía su estudio de arquitectura en la escuela y algunos alumnos trabajaban con él, y que en la segunda fase de la escuela sí que se otorgó mayor importancia a esta disciplina.

Y mientras realizaba estos logros, en el terreno personal su vida también era frené- 
tica, pues tenía una relación amorosa con la que años después sería su primera mujer y madre de su hija Manon, Alma Mahler. Y es que, según los documentos aportados por la autora, Gropius resultaba muy atractivo para las mujeres, lo que le llevó a tener varias amantes y dos esposas. Con la mayoría de sus amantes mantuvo relación epistolar durante su vida, y gracias a ello puede verse cómo Gropius quedó en buenas relaciones con la mayoría de ellas, salvo una excepción: Alma Mahler. Con la viuda del célebre compositor mantendrá una tensa relación durante toda su vida, dominada por fuertes discusiones causadas por la tutela de la hija que tenían en común. Todas estas relaciones aparecen retratadas pormenorizadamente en la presente obra, descubriendo una faceta del arquitecto que el público desconocía.

La autora también menciona el hecho de que en la Bauhaus comenzaron a producirse objetos antes nunca vistos, como por ejemplo la lámpara de mesa MT 8 (algunos de los cuales se pueden observar en las láminas que incluye el libro), y que su director, ayudado por su segunda mujer, Ise, exploraría las opciones de convertir la Bauhaus en una marca comercial y explotar así las posibilidades económicas que ofrecía la escuela, algo que se acabó logrando a medias. Y como no podía ser de otra manera en una biografía de Gropius, la autora escribe acerca de las convicciones sociales y arquitectónicas más profundas del arquitecto, aquellas que le llevaron a crear la Bauhaus y a defenderla durante toda su vida. Pero esto no lo hace en un capítulo dedicado únicamente a su filosofía, algo que el lector agradecería, sino que lo hace a lo largo de toda la obra en breves notas, lo que puede confundir al lector.

Así, el objetivo que tenía Gropius cuando creó la Bauhaus era, siguiendo la estela de sus predecesores William Morris con su movimiento Arts and Crafts y la Deutscher Werkbund, de Muthesius, crear una comunidad de librepensadores en la que reinara la armonía y en la que el arte formara parte de ella; que fuera autosuficiente y que, por encima de todo, estuviese centrada en la búsqueda de la belleza. Como puede verse, es una utopía visionaria como las de Morris y Muthesius, pero con una característica diferente, y es que la Bauhaus, en vez de mirar hacia el pasado, tenía la vista puesta en su futuro, como se vería en las numerosas actividades que llevaría a cabo, desde la fabricación de artículos novedosos hasta la edición de libros (destacando los Bauhausbücher o los libros de la Bauhaus), pasando por acciones verdaderamente revolucionarias como la creación de una nueva tipografía universal desarrollada por Bayer y que prescindía de la mayúscula, en pro de la racionalidad y la eficiencia modernas.

Pero todos estos logros que ayudaron a conformar el panorama del arte y del diseño modernos a escala nacional e internacional, se vieron en parte ensombrecidos cuando Gropius, debido a los ataques políticos hacia su persona, dimitió de su puesto de director de la escuela en favor del profesor Hannes Meyer, de tendencia socialista en una Europa de entreguerras, lo que supondría para la escuela un cambio de rumbo. No obstante, eso no impediría que los nazis pusieran la escuela en su punto de mira y acabaran cerrándola (mientas estaba al frente Mies Van der Rohe), acusándola de producir arte anti alemán, esto es, que fuera funcional y purista, en clara oposición al arte tradicional y rústico, que era el que estaba en consonancia con las ideas de nación de los nazis.

Tras su destitución y el cierre de su querida escuela, Gropius, que veía con tristeza el desmoronamiento de su Alemania natal, lograría un visado de residencia en Inglaterra, pero sin renunciar a su nacionalidad alemana, algo que le habría causado un gran pesar. En Inglaterra el matrimonio Gropius llevará vida de refugiados políticos, 
y si salió adelante fue por el buen hacer del matrimonio formado por Jack y Molly Pritchard, verdaderos mecenas que habían promovido la construcción de Lawn Road Flats, un moderno bloque de apartamentos en Hampstead que destaca por ser el primer edificio doméstico de Reino Unido en el que se usó hormigón armado. Además, eran viviendas de un claro carácter social, dominadas por un ambiente progresista que atrajo a muchos artistas de la época, creándose un clima que a Gropius le recordaba al de la Bauhaus.

A pesar del clima artístico en el que tan a gusto se sentía, faltaban encargos, por eso celebró los pocos que recibió en este país, como la remodelación de sendos recintos del zoo de Londres, o algunas obras para la empresa de desarrollo arquitectónico de su mecenas, Isokon. En cualquier caso, Gropius tendrá que abandonar su interés por las viviendas sociales y dedicarse a realizar encargos burgueses con el mero fin de sobrevivir. Esta situación de precariedad será la que haga que el matrimonio Gropius se mude a EEUU, donde él se pondrá al frente del departamento de arquitectura de Harvard.

Confirmando el tópico, la autora explica cómo EEUU sería para Gropius la tierra de las oportunidades, pues allí pudo llevar a cabo una gran cantidad de proyectos que, de haber seguido en Europa, nunca habrían visto la luz. En esta época la Bauhaus ya estaba consagrándose como un hito del diseño mundial, algo a lo que contribuyó la exposición que se le dedicó en el MoMA. Gropius será el adalid de la modernidad en suelo americano, y con él entrarán con fuerza en el continente los nuevos materiales y las nuevas fórmulas arquitectónicas, a pesar de que había figuras patrias como Frank Lloyd Wright que ya estaban experimentando con ellos y que no veían con buenos ojos la llegada de un competidor de la talla de Gropius. Entre otros proyectos, ahora Gropius se dedicará por fin a la experimentación con casas prefabricadas y al diseño de viviendas en altura, destacando su rascacielos: el Pan Am (1958). Por otra parte, instaurará en este país el trabajo colaborativo que tanto defendía, creando un estudio (el TAC) que recibirá encargos de todo el mundo. Por último, en la última etapa de su vida, recibirá toda una serie de galardones que reconocerán su labor en el campo de la arquitectura y del diseño, y se dedicará a viajar y a organizar el archivo de la Bauhaus.

En definitiva, estamos ante un libro especial, muy recomendable para el lector curioso en general y sobre todo para los interesados en conocer y entender mejor la Bauhaus, pues se ahonda en la figura de su fundador hasta un nivel al que no se había llegado hasta la fecha, aportando datos minuciosos acerca de su turbulenta vida personal y académica que contribuyen a entender mejor el nacimiento de esta escuela. Con esa mezcla de lo personal y lo académico la autora consigue que la lectura sea más ágil, y aunque en ocasiones la balanza se inclina excesivamente hacia lo personal, mantiene siempre una perspectiva que nos ayuda a integrar ambas facetas de su vida. Por otra parte, dado que los capítulos están estructurados por lugares geográficos y etapas, se agradecería algún sub-apartado dentro de los capítulos que ayudara a estructurar mejor los contenidos, puesto que el lector puede abrumarse ante la ingente cantidad de información que aporta la autora y llegar a perder el hilo de la narración.

En cualquier caso, estamos ante una obra que nos acerca más a la figura de un autor que contribuyó a cambiar el panorama artístico y arquitectónico a nivel mundial, y a quien se recuerda, por encima de todo, por ser uno de los grandes filósofos de la arquitectura del siglo XX y por llevar a la práctica una utopía, encarnada en forma de escuela, que cambiaría la forma de producir y entender el arte hasta nuestros días. 


\title{
LつCつCN7E
}

RESEÑAS

\section{¿Qué significa pensar la politica desde la estética?}

\author{
Àger Pérez Casanovas*
}

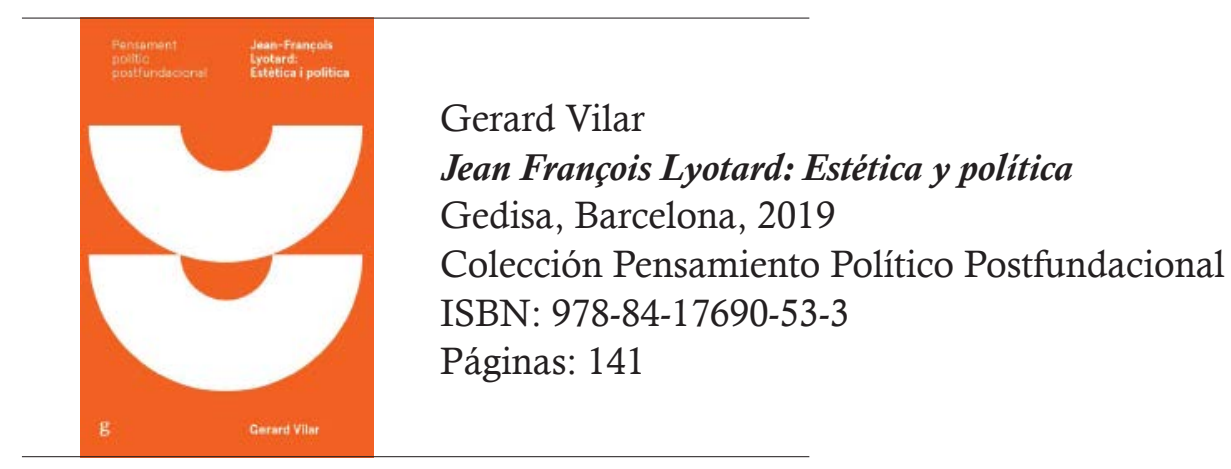

¿Qué significa pensar la política desde la estética? Este es el reto que nos presenta el pensamiento político de Lyotard en su rechazo de las fórmulas universales y el consenso de los discursos. Frente a la universalidad, Lyotard entiende el campo político como un terreno de disputa, de un disenso al que denomina el différend (diferendo), esto es, una diferencia que no llega nunca a la resolución redentora y absoluta. En este campo, el pensamiento estético aparece como modelo de una reflexión continua que permite estar atentos al particular y que hace frente a la falta de fórmulas inamovibles a través de la invención y la creatividad, de la formulación constante de principios que, como señala Kant en la Crítica de la facultad de juzgar, no se pueden reducir a reglas.

Es este territorio de invención compartido por la política y la estética el que explora Gerard Vilar en su texto Jean François Lyotard: Estética y política, publicado por Gedisa en la colección de Pensamiento Político Postfundacional. A través de cinco conceptos clave, Vilar traza un relato del pensamiento político de Lyotard que intenta dar cuenta de éste a tres niveles: la diferencia como matriz generadora de su pensamiento, el campo de fuerzas políticas (y filosóficas) en juego en su momento y la relevancia del pensamiento lyotardiano hoy. Consciente de los riesgos de elaborar una exposición sistemática de un autor que defiende que no existe un relato verdadero, Vilar explicita cómo el texto constituye uno de los relatos posibles del pensamiento político de Lyotard, en este caso regulado por una finalidad instructiva que pretende dar al lector las herramientas necesarias para adentrarse en un autor que puede resultar arduo sin el acompañamiento adecuado. Así, el texto no pretende agotar el pensamiento político lyotardiano, nada más lejos, sino que muestra el potencial crítico de éste para los problemas políticos de nuestro presente. Y, a través de este mostrar, se alza como una invitación a explorar por cuenta propia la obra de Lyotard.

¿Y por qué Lyotard? Vilar propone siete razones para recuperar a Lyotard, a modo de epílogo, que dan cuenta de cómo el pensamiento político de Lyotard es capaz de interpelarnos de un modo directo y de ofrecer una 'lección de vida' al lector situado

* Universitat Autònoma de Barcelona, España.ager.perez@uab.cat 
en la convulsión del ahora. Estas razones se pueden condensar en dos ejes: por qué Lyotard en el discurso político actual, y por qué para el discurso filosófico.

Por un lado, señala su relevancia en el contexto de una crisis de la democracia, del apogeo de las políticas de la identidad, y de las consecuencias de \#MeToo. Lyotard revive aquí como una voz de toma de conciencia de los mecanismos de poder que se esconden tras los universales asumidos en el lenguaje cotidiano -contra el uso acrítico de estos conceptos, la tarea filosófica reclama una anamnesis de las luchas colectivas que residen tras el lenguaje. El uso crítico de los universales es un ejercicio de revisión sin fin, pues no hay una meta redentora donde se puedan superar, a la hegeliana, los diferendos políticos y éticos fundamentales que impiden subsumir los particulares bajo un universal. La política se sitúa en el campo de la discusión deliberada, del disenso entre partes que surge en el tuerto, y justamente por este motivo la política toma una dimensión estética, pues la discusión requiere una creatividad constante para encontrar nuevas vías, y que a menudo pasa por re-crear el lenguaje.

Por otro lado, enfatiza su relevancia para aquellos que nos comprometemos con la tarea filosófica. Si bien ya hemos mencionado cómo la tarea filosófica de Lyotard debe necesariamente perder toda pretensión de universalidad (ya que el propio autor defiende la tesis de que no existe un relato verdadero), cabe destacar como esta tarea es eminentemente una práctica creativa. Como otros autores contemporáneos formados en la escuela francesa de Deleuze y Foucault, Lyotard entiende la práctica filosófica como una tarea fundamentalmente de escritura, en virtud de la cual se amplia y se revisa el vocabulario filosófico. Además, se trata de una tarea sin fin: debido a la constante tensión agonística que caracteriza lo político, nunca se llega a fundamentos últimos, y una filosofía que pretenda dar cuenta de esta realidad debe abrazar este antifundamentalismo. Vilar define esta filosofía como una "precariedad del pensamiento", siempre fragmentaria y sin fin.

El texto de Gerard Vilar se vertebra en cinco conceptos clave del pensamiento político de Lyotard, que constituyen los capítulos centrales de la obra: 'Argelia', 'Postmarxismo', 'Postmodernidad', 'Diferendos', y 'Lo inhumano'. Si bien el orden de los capítulos corresponde de modo aproximado al desarrollo cronológico de estos pilares del pensamiento lyotardiano, el movimiento del ensayo desplaza progresivamente el peso hacia el diferendo (différend) como concepto matriz de sus escritos políticos. Así, se desvía el foco de la popularizada noción de 'posmodernidad', cuya paradójica ambigüedad y a la vez especificidad histórica le han valido al pensador una especie de extravío de la tradición filosófica y un cierto olvido en el presente. Centrar su pensamiento político en el concepto de diferendo, en cambio, sitúa a Lyotard en una historia de familia con unos problemas compartidos que permite mostrar su relevancia para nosotros. El diferendo, desarrollado en el ensayo Le différend (1983), es presentado por Gerard Vilar como el concepto matriz de todo su pensamiento, a pesar de su acuñamiento tardío. El diferendo plantea el problema de la diferencia y la no-identidad que no se deja subsumir a un principio totalizante, y es precisamente este problema de la indeterminación que se resiste a un absoluto el problema que Lyotard comparte con la tercera crítica kantiana y con las Investigaciones filosóficas de Wittgenstein.

Situando el diferendo como foco central, el texto traza el recorrido político-filosófico de Lyotard a través del problema de la diferencia como inquietud de fondo. Inicialmente, ésta se manifestará como la preocupación por la representación del pueblo 
argelino durante la guerra de 1954-1962. La reticencia del filósofo a hablar en nombre de "los argelinos" como un todo, ya que "ninguna conciencia puede llegar a abrazar la sociedad entera" lo conducirán a rechazar el marxismo tradicional para desarrollar un postmarxismo no-fundamentalista y crítico con la Razón. El problema de la diferencia y el disenso en la política se trasladan luego al ámbito del saber y los discursos en 'Postmodernidad', a través del análisis de los "juegos del lenguaje".

En 1986, entrevistado por Teresa Oñate, Lyotard decía: "no puedo ser analítico porque he leído demasiado a Wittgenstein". Traducido a términos políticos, ha leído demasiado a Wittgenstein para pretender una teoría totalizadora del consenso y el acuerdo - lo que hay son juegos del lenguaje en constante disputa, el campo político es un campo agonístico cuyo principio a la vez regulador y perturbador es el diferendo. Finalmente, en 'Lo inhumano' el problema de la diferencia central se desplaza en el último Lyotard hacia el terreno de lo presentable, lo representable y lo irrepresentable. Ya anunciados proféticamente en sus escritos de la guerra de Argelia, resurgen aquí las categorías del olvido y el testimonio, vinculados ahora a la Shoah. La tensión entre la búsqueda de una razón precaria pero capaz de hacer justicia al testimonio, por un lado, y la ausencia de principios fundamentales, por otro, llega aquí a sus puntos más extremos, mostrando las dificultades éticas causadas por el carácter fragmentario e inacabado del pensamiento lyotardiano.

El trabajo de Vilar, lector de Lyotard meticuloso y en ocasiones crítico, constituye un camino de entrada al pensamiento político de éste que consigue interpelar al lector a través de problemáticas candentes en el contexto contemporáneo, tanto filosófico como civil. La elección del diferendo como concepto matriz que articula una política desde la diferencia pone de relieve el vínculo con la estética que, Vilar insiste, permea toda la obra. En suma, ¿no es la atención al diferendo en las disputas políticas y jurídicas análoga a la atención al detalle en las 'disputas del gusto'? El trazo, el tono y la figura concreta de una obra no se dejan subsumir a una regla o principio absoluto, y encarnan de este modo una resistencia a la totalización que repite a su manera la imposibilidad de universalización del diferendo. Es esta resistencia de facto la que solicita la invención y la creatividad atendiendo las particularidades - sea en el campo de la estética, la política o la ética. Frente a las "políticas de la redención" de los discursos totalizantes, Lyotard nos invita a habitar en la tensión del desacuerdo, en la pluralidad de discursos en disputa. Asimismo, frente a un meta-relato de progreso, nos permite pensar las luchas sociales a partir de sus particularidades y sus objetivos concretos contextuales, acercándose así al pensamiento de las micro-revoluciones de Rancière.

Finalmente, para los que tratamos de dedicarnos a las prácticas filosóficas, la obra de Lyotard se presenta como una lección de humildad. Sobre ésta dice Vilar: "La filosofía constituye una tentativa de pensar condenada por adelantado al fracaso". Un adagio con el potencial, quizás, de manifestar la obstinación de las prácticas filosóficas a las dinámicas de producción científica y académica con pretensión totalizante y disciplinar; la vindicación lyotardiana del fracaso como revelación del diferendo es a un tiempo el elogio de lo inacabado como muestra de la precariedad de la Razón, una mostración que es posible en la escritura filosófica y que la instala plenamente en lo político. 


\title{
Ideologías estéticas en los orígenes de la pintura moderna
}

\author{
José Luis Plaza Chillón*
}

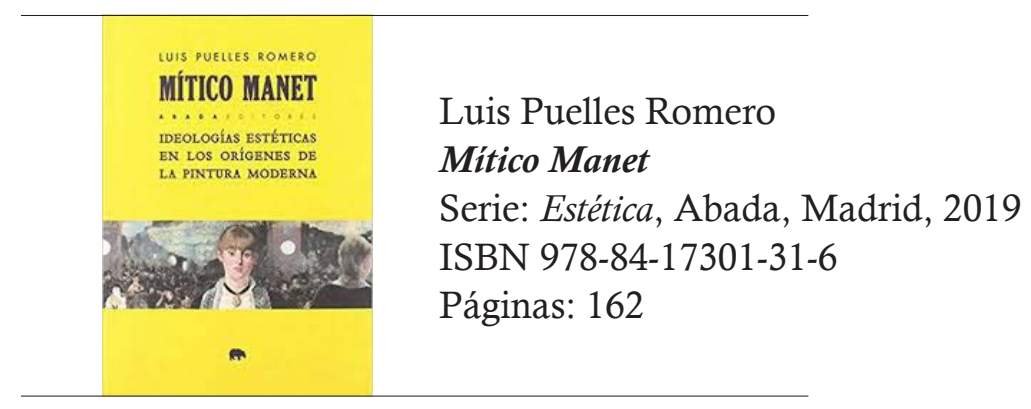

No debe extrañar al lector que el punto de partida escogido por Luis Puelles Romero (profesor de Estética y Teoría de las Artes en la Universidad de Málaga, y autor del libro que ahora reseñamos) para abordar teóricamente lo que ha supuesto la mitificación estética de una figura tan relevante en el arte contemporáneo como Edouard Manet, sea precisamente la observación personal del pintor francés a través de su poco frecuentado Autoportrait à la palette (1879), por lo que supone de canto al individualismo y de liberación del artista sumergido "ya" en la plenitud de la "vida moderna". La definitiva huida del academicismo de tradición setecentista, predominante todavía en estos años de convulsión plástica y poética y la imposición de un examen subjetivo y transgresor contra el gusto normativo configurarán en Manet un nuevo arte intrínseco y de apartamiento que configurará, sin duda, lo que hoy denominamos como arte moderno. Pero en la conformación de este innovador relato lo acompañaron las decisivas aportaciones críticas y biográficas, en orden cronológico, de Baudelaire, Zola y Mallarmé; dichos autores fueron concluyentes para entender cómo se han armonizado las audacias estéticas que han concedido a Manet la consideración de adalid de la nueva pintura.

Esta crónica de la modernidad tendrá continuación en el siglo XX en nombres tan decisivos como Bataille, Foucault, Greenberg, Clark o Bourdieu, que han dedicado al artista una serie de sobresalientes páginas, abundando sobre todo en su "soberanía visual", a la vez que han ayudado a elaborar una "ideología de valores estéticos" a través de la cual los lienzos de Manet se presentan como ejemplos incuestionables de la contemporaneidad. La ruptura radical, las extravagancias, el escándalo, la herejía, la vulgaridad, los desvaríos, la desestructuración, la parodia, la exclusión, la profanación, los extravíos e incluso la blasfemia fueron algunos de los epítetos vertidos sobre las obras de nuestro artista; son precisamente estos apelativos los que servirán de abordaje para legitimar por parte de estos intelectuales citados y otros más, una obra que tiene en su haber razones fundacionales de la modernidad, contribuyendo, de esta manera, al decisivo encumbramiento de Manet. El correlato del libro se articula a través de las 
siguientes ideas: "modernidad, originalidad y visualidad", que tienen su correspondencia ideológica y poética en Baudelaire, Zola y Mallarmé, a través de los cuales trazará un provechoso plano que compondrán cada uno de los tres capítulos del mismo.

En el primer capítulo ("secuencia", titula el autor) aborda el concepto de "belleza moderna" propugnado por Baudelaire; para ello parte del académico francés del siglo XVII, Charles Perrault y su primigenio distanciamiento de las poéticas que exaltaban la tradición clasicista antigua y su continuación en el Renacimiento y el Barroco, que desembocará en el Romanticismo con distintas exploraciones de la sensibilidad y el gusto, donde lo "grotesco" o lo vulgar adquirirán una especial categoría que será expuesta por autores como Víctor Hugo o Stendhal. La subjetividad contemporánea se rodeará de componentes sacados de la pura cotidianeidad encarnados en esa modernidad fugaz e incierta que representan Baudelaire y Manet, interrogándose no solo por el modelo mimético del clasicismo, sino y sobre todo, por la analogía final de la belleza. Desde el primer envío de un cuadro de Manet al Salón oficial en 1859 (Le Buveur d'absinthe) y su consiguiente rechazo académico, la trayectoria del pintor parisino estará marcada por un itinerario repleto de quebrantamientos e insubordinaciones, auspiciado por ese particular individualismo burgués fraguado en la "tranquilidad" de saberse libre de cualquier dependencia económica, entregado, por tanto, de lleno a la consecución de una revolución estética. A diferencia de los críticos, serán precisamente algunos pintores los primeros en darse cuenta lo que supone de diferente e innovador el arte de Manet, sustentado en unas imágenes que huyen de la propia representación y crean perplejidad.

Si bien el pintor había adquirido una personalidad propia antes de conocer a Baudelaire no le fue indiferente el trascendental ensayo El pintor de la vida moderna (1863), y aunque fue posterior a su pintura Musique aux Tuileries (1862) (panegírico plástico de la teoría baudeleriana), parece proyectar las ideas de su amigo en el citado lienzo. Si bien es verdad, como mantenía el periodista Antonin Proust, que fue Manet quien influyó en el poeta, no es menos cierto que fue el crítico parisino el primero en captar que las imágenes que habitan en su pintura solo existen en ella, rechazando cualquier atisbo susceptible de sometimiento a lo existente, a la pura copia; son, por tanto, como proclamaría Deleuze, "imágenes-fantasmas", esencia misma de alteridad. No en vano Baudelaire proclamará "la imaginación" como impulsora esencial de la creación artística, eximiéndola de cualquier intercambio con la realidad. La libertad, heterodoxia o transgresión con la que el pintor empapaba sus lienzos provocaban reacciones encontradas que no solo lo llevaban a la condena, sino también a la mofa o incluso el odio; dicha incomprensión se convirtió en una característica que distinguía al artista moderno: una suerte de "mártir" o dandi proclamado por Baudelaire, y que encontró perfecto acomodo en su amigo Manet. El arte inquieto ofrecido por el pintor detiene el tiempo para prender lo efímero; su mirada perseverante hacia el pasado (Tiziano, Velázquez, Goya) muta para afirmarse en la transitoriedad representada por la vida urbana, desplazando todo lo que pueda contener de ceremonia para situarse siempre en los márgenes. No ha de sorprender que la conocida como Escuela de Batignolles, compuesta por poetas y pintores adictos a la rabiosa modernidad (Fantin-Latour, Renoir, Degas, Bazille, Monet...), consideraran al creador de Olympia (1863) como ejemplo de resistencia ante los embates sufridos por la política artística institucional; aquí germinará la esencia de lo que un poco después fue denominado como "impresionismo".

El escritor Émile Zola protagoniza la segunda "secuencia" del libro, y es erigido 
como el verdadero "inventor" de Manet, porque desde el principio de su amistad se volcará sobre su quehacer artístico alentando al público del esfuerzo intelectual que supone enfrentarse a su pintura; no serán válidos los métodos tradicionales de aquellos años para afrontar una obra tan compleja, repleta de "extravíos y desorientaciones", alejada, por tanto, de cualquier atisbo de perfección. La lealtad a sí mismo será acaso la mayor virtud de nuestro pintor, aunque ello suponga distanciarse del gusto de la mayoría de sus contemporáneos. Esa fidelidad "a sí mismo" había sido destacada precisamente por Baudelaire en su Salón de 1859. A pesar de la incomodidad que suponía para el gran público la contemplación de su obra, que había dejado ya atrás cualquier resquicio de valor académico; su objetivo en última instancia será sin duda el reconocimiento, sin que ello suponga contravenir el elogio de la "subjetividad del artista", defendido encarecidamente por el novelista. Manet conseguirá hacerse con una "mirada personal": única e inimitable. Más allá de aprender a "ver por sí mismo", el arte del parisino sabrá adjudicarse excelencias identificadas por Kant en la "genialidad", a saber: "originalidad, ejemplaridad, temperamento natural y anomia". Es por ello que cada lienzo pintado se convierte en un episodio inimitable, en el que la autonomía como sinónimo de "pureza" cobra protagonismo, a la vez que se sigue considerando el análisis formal como elemento esencial de la composición.

Zola parte de Lessing y su influyente Laocoonte (1766) para crear una línea a la que acudirán también acreditados teóricos del siglo XX como Sedlmayr o Greenberg, incidiendo en que lo que distingue y fundamenta el "arte moderno" es la integridad de un medio concreto, acompañado siempre con principios de autonomía, o lo que es lo mismo: "la libertad formal". Manet supondrá por tanto el arranque de la pintura de vanguardia cuya culminación cruzará la frontera de la II Guerra Mundial para recalar en el Nueva York de Jackson Pollock. Ya se había encargado de hacer callar al "signo" en favor de la observación, de esta manera dicha pintura se desligará de toda carga retórica. La fealdad, la ironía o la parodia son caracteres que se instalan en sus lienzos para atraer con fuerza la mirada; "llamar la atención a cualquier precio", decía Thèophile Gautier. En un alarde visionario, Zola no duda en colocar a Manet (y acierta) en uno de los "maestros del mañana", reivindicando para él un sitio en el Museo del Louvre. Las acometidas críticas del escritor francés se insertan en un contexto nuevo donde el "juicio estético" se democratiza ante un público cada vez más receptivo y libre, alejado de cualquier convencionalismo académico; sin que ello suponga, como advierte Zola, que dicha concurrencia esté preparada estéticamente para apreciar la singular obra de Manet.

Stéphane Mallarmé será el protagonista de la tercera y última "secuencia" del ensayo; de los tres acompañantes, quizás el más afín al pintor; no sólo por el hecho de que la obra de ambos (literaria y plástica) se inserte en los límites de la creación artística (de ahí su dificultad interpretativa), sino porque sus formas de vida y posturas estéticas caminarán paralelas; los dos sufrieron el rechazo institucional y la incomprensión del público. Esa amistad confluirá de forma primorosa en la realización del retrato que el pintor hizo de Mallarmé (1876), que a decir de Bataille se trataría de su mejor obra. El análisis que el poeta simbolista hizo de la obra de Manet radicará en la consecución de algo que considera revolucionario, como fue la "obtención de la visualidad"; este requisito demanda llevar hasta el límite la contingencia misma de la pintura, y para ello tendrá que soltar todo el lastre que supone una formación clásica. El resultado será la consecuencia de la metamorfosis de la pintura en representación para la mira- 
da. Los asuntos sobre los que reflexionará el escritor a propósito de la obra plástica de su amigo tienen que ver, en primer lugar, con la percepción del público y su derecho a opinar sin contar con un tercero, para abundar a continuación sobre el concepto de "simplificación" como cualidad primordial de la pintura moderna, y que en el caso de Manet redunda sobre lo "inacabado" (el non-finito renacentista), una categoría estética poetizada por Mallarmé donde cobra valor "lo sugerente", convirtiendo el producto en una "obra abierta" para que el espectador pueda introducirse en ella, adelantándose de esta manera a los postulados semiológicos de Barthes y Eco; y finalizar con el concepto de plein air (al aire libre) que acabará por ser la característica que defina a la pintura impresionista: "luz, aire, espacio, atmósfera", son algunas de las palabras que el poeta usa para precisar las últimas obras del pintor.

El epílogo abre un debate sobre el destino de la "imagen-fantasma" teorizada por Deleuze a través de la interpretación que hace del diálogo El sofista de Platón, y cuestionar de esta manera la "asimilación" realista (naturalista) del pintor: "la imagen como copia y como fantasma". El autor establece una comparativa que parte de Manet, y puede concluir en el Pop Art, las maquetas escultóricas de Thomas Durand o, especialmente, en las fotografías conceptuales del canadiense Jeff Wall, todo atravesado por esa "imagen-fantasma" en la que se ha convertido el arte contemporáneo. E1 autor concluye reflexionando sobre el concepto de "simulacro" y su proyección en la obra de Wall, partiendo de algunas pinturas del francés; ambos participan de la misma idea de disimulo y exquisitez en el diseño de la imagen elaborada con la ambigüedad que supone el reflejo silente de un espejo. 


\section{LつCつCN7E}

RESEÑAS

\section{Sobre a estética}

Luis Carlos Pereira*

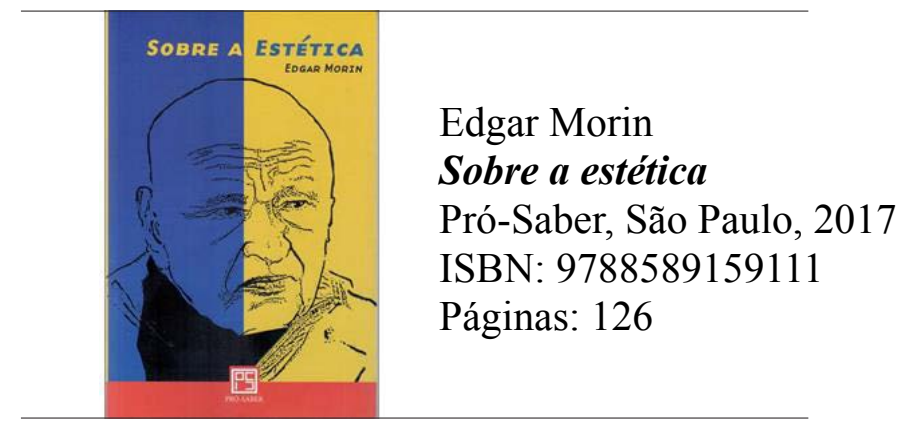

A Editora Pró-Saber lançou no Brasil, em 2017, a obra mais recente de Edgar Morin: Sobre a estética. Pesquisador emérito do CNRS (Centre National de la Recherche Scientifique), formado em Direito, História e Geografia. Além disso, realiza estudos em Filosofia, Sociologia e Epistemologia. É autor de mais de 30 livros, entre eles, $O$ método (6 volumes), Maio de 68: a brecha, Introdução ao pensamento complexo, Ciência com consciência e Os sete saberes necessários para a educação do futuro.

Com 125 páginas que abrangem oito capítulos, além do prefácio, da introdução e da conclusão, o livro tem origem nas conferências proferidas pelo autor na Maison de L'Homme, durante o primeiro semestre de 2016, em Paris, e é assim introduzida:

(...) há trinta anos, venho acumulando notas sobre a estética, mas havia desistido de escrever 'minha' estética, que poderia ter sido o volume final de O Método. Essas conferências foram a ocasião propícia para apresentar o essencial do que eu tinha a dizer [...]. Jamais cessei de ler ou reler romances, poemas, de frequentar cinemas (11).

A Estética, do grego aisthetiké, que por sua vez vem de aisthésis, percepção, sensação, remonta a Platão, Aristóteles e Baumgarten (1750), que a concebe como ramo da filosofia, arte da percepção, sensação, beleza e sensibilidade. Sob essa perspectiva, Morin desenvolve arte e estética, no livro, como poetização da vida, em oposição ao prosaico.

Na introdução, "Estética generalizada", Morin contextualiza a estética como o efeito da arte e dos parâmetros de beleza na vida dos seres humanos, partindo do princípio de que ela se constitui da sensibilidade humana pelo prazer e pela admiração, "fortalece-se e se desenvolve em certas condições pessoais, culturais, históricas ou sociais" (11). Nesse sentido, a obra se aproxima das meditações filosóficas de Baumgarten (1750), para quem "estética" é a ciência que trata do conhecimento sensorial que chega à apreensão do belo e se expressa nas imagens da arte, em contraposição à

* Universidade do Estado do Rio de Janeiro, Brasil.luiscarloscaue@hotmail.com 
lógica como saber cognitivo. Por conseguinte, a estética é um elemento integrador da parte poética da vida.

No primeiro capítulo, "Sentimento estético", Morin trata a emoção estética como universal, mostrando, todavia, que, assim como a cultura, a linguagem, a música, a natureza, ela se manifesta de forma singular: "nem Pablo Picasso, nem Wassily Kandinsky teriam sido apreciados antes do século XX" (15). Ou seja, os países, as culturas locais e regionais ditam a denominação de beleza dentro de seus próprios conceitos. Para o autor, não se pode esquecer também que, no processo de evolução, há simultaneamente continuidade e descontinuidade.

No segundo capítulo, "A natureza do sentimento estético", o autor vai do questionamento interrogativo da estética da natureza à natureza da estética. O pensador contemporâneo vê emergir a essência de tudo que há de belo na estética. Propõe, para isso, que devemos sair do nosso estado fixo e estável para o euforizante. Dessa forma, transformando nossa percepção, seremos transportados ao estado poético, dando oportunidade à compreensão daquilo que nos parecia banal.

No terceiro capítulo, "Individualização, mercantilização, industrialização", o autor nos leva a refletir sobre o lucro: "a obra converteu-se numa mercadoria". A obra de arte, assim como uma obra literária, depende do mercado ou de um editor, e muitos artistas não conseguem o sucesso pela falta de reconhecimento. Segue expondo o que ocorre com os filmes, e afirma que essa mesma lógica se aplica às músicas, às minisséries televisivas, ao rock.

No quarto capítulo, "A criatividade", Morin mostra que a criatividade não nasceu com a humanidade, que ela se efetiva a partir do pensamento e das ações ("relação cérebro/mão). Numa tessitura interessante, vai nos revelando que a criação do artista se dá de forma semelhante à do parto, misturando sofrimento e alegria, e a força propulsora dessa criação é a inspiração. A inspiração, por sua vez, surge de um "estado de transe", que o autor descreve através do xamanismo. Segue explanando como outros artistas usaram certas substâncias, como a cafeína, por exemplo, para buscar a inspiração através do "estado de transe", e relata sua experiência pessoal ao escrever "O método", dizendo que obteve inspiração com seu estado estético alterado.

No quinto capítulo, "Transes de vida e tramas da vida", o autor nos conduz a uma grande viagem para que tenhamos a compreensão das nuances do retrato, da leitura, do romance, da poesia, da oratória, do teatro, do cinema, da música e, finalmente, da ópera. Vale destacar duas reflexões importantes: a fotografia e a poesia. A primeira ele chama de "a magia do desdobramento pelo charme da imagem carregada de sentimentos"; sobre a segunda diz que remete à afetividade e à estética, que expressam a realidade humana, e ela o faz de maneira quase musical. E finaliza nos convidando para as virtudes estéticas da ópera, a qual une a tragédia e a música.

No sexto capítulo, "Artes novas e estéticas ampliadas", mostra que a fotografia, a história em quadrinhos, as séries de televisão e o rap também são formas de arte que demoraram algum tempo para ser reconhecidas como tal. Descreve as séries de TV que, ao longo do tempo, foram ganhando espaço. Cita algumas mais antigas, como Dallas, Star Trek -inclusive uma brasileira, Dona Beija-, e as mais contemporâneas, como Família Soprano e Game of Thrones, que fazem parte do cotidiano das pessoas e têm valor estético. Termina o capítulo tecendo sobre a força do rap, que nasceu nas periferias e ganhou seu espaço, conquistou seu valor. Também cita o clipe e a publicidade, além de discorrer sobre a sedução estética do consumo. 
No sétimo capítulo, "Interferências: estética, poética, mística, lúdica", o autor discute os estados alterados de consciência e as manifestações de prazer, uma vez que a criatividade artística contempla os estímulos exteriores transportado o artista do estado fixo e estável para o estado sensível, provocando sua inspiração. É preciso que o artista tenha a sensibilidade mais elevada no desempenho de sua missão, e é nesse sentido que Morin exemplifica como "pós-xamânica" essa alteração. Do mesmo modo, a compreensão da estética requer a alteração de estado: do fixo para o sensível.

No oitavo e último capítulo, "Estética e cultura", a palavra cultura é tratada como camaleão, devido a seus significados, pois há cultura no sentido etnográfico, antropológico, entre outros. Vale ressaltar aqui a sobriedade do autor, porque não é incomum depararmo-nos com autores que criticam a singularidade da palavra, preferindo suas pluralidades, perdendo seu caráter erudito e restrito. Quanto à estética, nós a encontramos amplamente nas culturas, contribuindo para a renovação do fortalecimento "de uma cultura das humanidades, inseparável de uma cultura humanista" (102).

Pelas discussões que apresenta, essa obra é de grande relevância para a contribuição que pode trazer a estudantes de pós-graduação que desenvolvem pesquisa sobre filosofia, educação, artes, e a qualquer cidadão que tenha interesse ou queira entender melhor o mundo da percepção e da sensibilidade pelas diferentes artes, inclusive o cinema e o teatro, mesmo que como autoformação. Por outro lado, a obra contribui para o rigor da pesquisa em estética como ramo da filosofia que estuda a natureza, a beleza e os fundamentos da arte, trazendo à luz suas pluralidades de manifestação. 


\title{
LつCつCN7E
}

RESEÑAS

\section{Músicas populares. Sociedad y territorio: Sinergias entre investigación y docencia}

\author{
Mar Aleixandre Badenes*
}

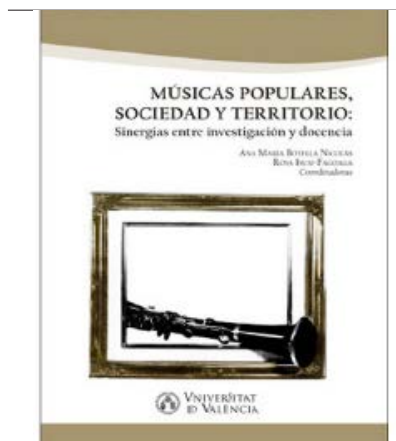

Ana María Botella Nicolás y Rosa Isusi-Fagoaga (coords.)

Músicas populares. Sociedad y territorio: Sinergias entre investigación y docencia

Valencia: Vicerrectorado de Participación y Proyección Territorial, 2018

ISBN: 978-84-9133-126-1

Páginas: 255

Músicas populares es el tema principal sobre el que se construyen los contenidos del presente libro, contribuyendo al fomento de la investigación de este género musical en tierras valencianas. Se trata de un compendio que aúna el rigor de la investigación científica ya que consigue concentrar los diversos estudios que se llevan a cabo en la actualidad y con una voluntad de difusión social ofreciendo una panorámica viva y latente del tema. En él participan desde los etnomusicólogos más expertos en la materia con un consolidado y afianzado recorrido, hasta los nuevos investigadores interesados en el estudio y en llevar a cabo ensayos experimentales y prácticos de música popular. Evidencia una clara congregación de trabajos significativos y de gran interés, enmarcados por las I Jornadas para el Estudio de la Música Popular, que tuvieron lugar en Valencia entre el 5 y 7 de abril de 2018.

Sus coordinadoras, Ana María Botella Nicolás y Rosa Isusi-Fagoaga cuentan con una dilatada trayectoria académica y formativa. La doctora Botella, además de ser licenciada en Geografía e Historia, especialidad musicología, y diplomada en Magisterio, con especialidad en el ámbito musical, es supervisora en revistas científicas y participa con asiduidad como comité erudito en congresos y jornadas investigativas y divulgativas. Cuenta con la publicación de más de sesenta artículos y treinta capítulos de libro. Cabe destacar que entre sus principales líneas de investigación se encuentran el folklore y las TACs e innovación educativa a través de la interdisciplinariedad. La doctora Isusi-Fagoaga es musicóloga y titulada superior de conservatorio. Posee una amplia experiencia investigadora y docente. Cuenta con más de cuarenta publicaciones, entre sus líneas de investigación se encuentran la recuperación y difusión del patrimonio musical hispánico y la innovación educativa. La formación específica y orientada al patrimonio y al folklore musical de las coordinadoras, así como sus señaladas trayectorias didácticas, nos adelantan una minuciosa y genuina revisión de

* Universitat de València, España.maraba6@alumni.uv.es 
las propuestas con especial atención al contenido, estructura, organización y alcance de los escritos.

El libro se estructura en 22 capítulos además del prólogo que antecede a éstos, escrito por el anterior Rector de la Universitat de València, Esteban Morcillo Sánchez, y el Vicerrector de Proyección Territorial y Sociedad, Jorge Hermosilla Pla. El primer capítulo presenta al lector la información que se encontrará a lo largo de la publicación objeto de reseña. Con una redacción clara, concisa, precisa y una estructura completa, integra una breve introducción, en la que se explicita el propósito de dar voz a una extensa compilación de estudios recientes para que su divulgación favorezca el conocimiento de nuevos paradigmas y procedimientos metodológicos de los procesos de investigación en el campo de la música popular. Y, como consecuencia posibilita el enriquecimiento cultural, investigativo y científico de este campo de la música en los investigadores noveles. Continúa con un preciso y extenso estado de la cuestión basado en multitud de estudios, trabajos, cancioneros y corrientes musicales más relevantes, así como de personalidades destacadas en el mundo etnomusicológico, musicológico, sociológico y antropológico. Después de este extraordinario punto de partida, se presenta el corpus completo del volumen de forma ordenada y con una progresión lógica para la comprensión eficaz. En este apartado se resumen los siguientes epígrafes redactados por los distintos investigadores de una forma clara y estructurada que avanzan destellos de la considerable y significativa obra. Finalmente, se anuncian una serie de consideraciones con las que se establecen varias ideas fundamentales a modo de conclusión.

Con respecto al resto de capítulos, se inician con una breve pero clarificadora introducción que facilita la comprensión del lector. Posteriormente, se expone y se ahonda en profundidad en cuestiones de gran relevancia para la música popular, donde cada investigador e investigadora aborda libremente y de manera adecuada un seguido de aspectos interesantes bajo atrayentes exposiciones y argumentos bien definidos, razonados y explicados, con un óptimo proceder y fundamento bibliográfico que aporta consistencia al texto y, en algunos casos, incluso se presentan tablas, figuras, imágenes y gráficas que esclarecen, sintetizan e ilustran los temas planteados y que otorgan mayor consistencia y riqueza a las investigaciones.

Por todo ello, se podría decir que los proyectos que se plantean son amplios, siempre dentro del marco temático enunciado, es decir, se abordan aspectos del folklore y de la tradición oral, de su convivencia con la música clásica, de conceptos y categorías, de instrumentación particular, de la música urbana actual y se reflexiona sobre la medida en que el arte musical afecta a los sujetos de la sociedad y a las relaciones entre los mismos. También se habla sobre la proyección y repercusión del género en los estilos, de reflexiones y de competencias sociales, de producciones discográficas y publicitarias, así como se matizan dichos aspectos a través del estudio concreto de casos de ciertas localidades de la geografía valenciana y de fuera de ella. Asimismo se integran diseños y aplicaciones de propuestas didácticas a través de las nuevas tecnologías digitales, los medios de comunicación audiovisual y de metodologías activas, motivacionales y participativas, en las que el alumno es la clave del engranaje educativo y en la confección de nuevo material, que contribuye al fomento de la innovación docente atendiendo a los aspectos curriculares y al desarrollo cognitivo del alumnado.

Sin duda, el lector encuentra entre las páginas del volumen disertaciones inéditas y de suma importancia que abarcan cuestiones musicales desde la vertiente más folcló- 
rica hasta la más urbana, integrando de esta manera una gran diversidad que le otorga un gran valor divulgativo, al tratar lo popular desde todas las vertientes y fundamentado en conocimientos de gran relevancia. Con la motivación de visibilizar y poner en valor dicha excelencia, por su parte, el Departamento de la Expresión Musical, Plástica y Corporal de la Universitat de València promovió el escenario idóneo para que, con un carácter riguroso, científico y académico, pudieran ponerse en común los saberes y las competencias que atañen a la música popular, contando con la colaboración del antiguo Vicerrectorado de Proyección Territorial y Sociedad, el Aula de Música de la Universitat de València, el Museo Etnológico del Ayuntamiento de Valencia y el Instituto Superior de Enseñanzas Artísticas de la Comunidad Valenciana.

La difusión y el conocimiento de lo popular en relación con la música es, probablemente, una de las principales carencias de la sociedad a lo largo del tiempo y que se intenta paliar con la publicación del presente ejemplar. Como ya ha sido señalado con anterioridad, esta publicación no solo permite presentar una base teórica y metodológica fundamentada y de gran rigor sobre la cual continuar futuras investigaciones en la materia, sino que, a su vez, brinda la oportunidad a expertos en la misma de continuar el camino iniciado y presentado en ésta. Así queda patente un legado vivo, dinámico y visible con el que construir los cimientos sólidos de las voces latentes que permitan preservar el patrimonio cultural y dar a conocer los estilos actuales a toda la sociedad educativa e investigadora. Efectivamente encontramos entre nuestras manos una muestra de aire fresco y renovador que pretende sentar las bases, allanar el camino y poner la primera piedra para que florezcan futuros análisis, ensayos y memorias de gran calidad y confrontación, que deberán pasar, cuando menos, por la reunión, la cooperación y la sinergia de los estudiosos en la materia, y la propagación y difusión de los trabajos y cometidos llevados a cabo. 


\title{
La necesidad de la mirada antropológica sobre la literatura
}

\author{
Pablo de Benito David*
}

\begin{tabular}{|c|c|}
\hline 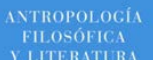 & Joan B. Llinares (ed.) \\
\hline YLITERATLRA & Antropología filosófica y literatura \\
\hline & PRE-TEXTOS, Valencia, 2019 \\
\hline & ISBN: 978-84-178307-3-1 \\
\hline & Páginas: 424 \\
\hline
\end{tabular}

Nos parece obligatorio empezar diciendo lo que este libro representa: un homenaje. Con su genuina y activa personalidad y su más que demostrada sabiduría, el profesor Joan B. Llinares edita un nuevo libro configurado desde un prisma completamente heterogéneo de saberes que cristalizan en su pasión y su disciplina. Este proyecto no podía haber llegado a realizarse sin la Unidad Docente de Metafísica y Teoría del Conocimiento integrada en el Departamento de Filosofía de la Universitat de València, que celebra así la jubilación de un compañero irrepetible.

De la mano de nada menos que trece antiguos alumnos, Antropología filosófica y literatura es un libro consagrado a revisar las líneas del pensamiento cultural histórico desde las ópticas modernas hasta las más contemporáneas. Marco Polo, Goethe, F. Dostoievski, Walter Benjamin, Cormac McCarthy, Jorge Semprún o G. Deleuze son algunos de los autores que aparecen para ser reflexionados, pensados y estudiados desde una nueva mirada comparativa. En su haber, el logro de una edición cuidada al milímetro, revisada y acondicionada para el lector que sabe apreciar el gusto por la decisión, la resolución y el trabajo bien hecho. Como todo buen homenaje, y esto se nota en los artículos que conforman el libro, se ha construido desde el apego, la admiración y, con una fuerte dosis de respeto, desde la influencia de un mirar característico, antropológico, literario: filosófico, en definitiva. Las huellas de ese estilo filosófico aprendido se ven, se leen y, lo más importante, se sienten.

El apoyo material que tiene la filosofía en la literatura nunca fue sutil, sino que más bien para muchos ha sido evidente, intuitivo y elemental. La literatura guarda en su simiente el transmitir del mensaje filosófico, manifiesto para el ojo estudioso y la mente exegética. La antropología, por su parte, representa esa nueva mirada que se fija en los detalles que se pasaron por alto, que importaban sólo por su aportación descriptiva o argumental. La antropología encuentra en la literatura una fotografía nítida de un tiempo pretérito, un campo fértil donde entrever los pensamientos de los antiguos y los modernos; encuentra las formas de discernir de los hombres y mujeres que nos precedieron. Por ello, antropología, filosofía y literatura van, si no unidas, entrelazadas como galaxias cercanas por la fuerza y la determinación de la constelación de la

* Universitat de València, España. pablo.beda@gmail.com 
creación humana.

La obra consta de catorce artículos que tratan unas temáticas muy diversas que hacen imposible una síntesis comunitaria. Sin embargo, el rasgo característico de todas ellas es su punto de partida y su destino: la literatura y la antropología filosófica. Todos los textos excavan en la tradición literaria para conformar un discurso histórico y antropológico que sintetiza, examina e interpreta su marco cultural y su preocupación filosófica.

El primero de ellos, elaborado por Bernat Martí Oroval nos introduce en la fascinante visión del Occidente tardo-medieval y renacentista sobre Oriente, concretamente Japón. "Del Cipango de Marco Polo al Japón de Francisco Javier" es una muestra evidente de que las ideas mueven a los hombres a explorar los lugares más allá de la imaginación. Para los europeos, aquellas tierras eran el lugar del éxito y del fracaso absoluto: "[...] se hablaba de la existencia de seres fantásticos, monstruos, [e] inmensas minas de oro [...]" (p.31). De la aventura a la "antropología misional" de Francisco Javier podría pensarse que esta idea se transformó, pero Bernat Martí Oroval muestra cómo lo mítico, inscrito en la propia narración de las experiencias de "los otros", de alguna forma, jamás abandonó los relatos.

El análisis de Kilian Lavernia narra el significado de la derrota bélica en dos obras -consideradas menores- del gran poeta alemán Goethe. Muestra cómo Goethe articula una "comprensión de la historia a partir de la naturaleza, y no una comprensión del mundo a partir de la historia" (56) con dimensiones antropológicas fundamentales para la interpretación epistémica del "yo" como una permanente lucha contra sí mismo. Kilian Lavernia en, "Por ejemplo, Goethe en la guerra. Antropología de la existencia", evidencia el trasfondo del estilo goethiano: no hay que maquillar la realidad, sino lo contrario: la narración de la guerra debe ser igual de dura en términos estéticos.

Luca Giancristofaro estudia en su ensayo dedicado a la imaginación poética diltheyana la poderosa influencia que ejerció el poeta Goethe en la producción del filósofo alemán. Nuestro autor comenta y expone el carácter positivista de Dilthey en su intento por crear una teoría psicológica de la poesía basada en la constitución psico-fisiológica del artista, evidenciando la poderosa y estrecha relación que une la literatura a la antropología filosófica. Dilthey enmarca como elemento fundacional para el análisis estético la fantasía creadora y la hermenéutica, analizando "[...] la relación entre la fantasía poética y la realidad vivida por el poeta, la experiencia vital” (88).

Lorena Rivera nos ofrece una lectura propia del conflicto que vertebra la obra de Dostoievski -razón contra fe- en la obra Los demonios. La interpretación, apoyada en obras fundamentales como Apuntes del subsuelo y El sueño de un hombre ridículo, construye un relato antropológico que encuentra, expone y analiza la fuerza y la reverberación de los cismas internos más fundamentales del carácter humano en la literatura, mostrando, además, su enorme repercusión y eco en la propia antropología filosófica. De este modo, ofrece una visión altamente especializada centrándose en el estudio sistemático de los personajes clave de las diferentes obras del clásico ruso y sus coetáneos.

Pedro Piedras nos expone la innegable contemporaneidad de la sensibilidad de Hugo von Hofmannsthal por el dolor animal -como sufrimiento provocado por el arbitrio del comportamiento humano- que se muestra en sus relatos. La ingenuidad, su perfección moral y su fidelidad -entre otros elementos- otorgan a los animales, según Pedro Piedras, una dignidad sobrehumana que serviría a Hofmannsthal para mostrar "[...] lo despiadado del ser humano de un modo diferido pero igualmente 
salvaje" (163) y que, por supuesto, quedaba exento de la ley y de su castigo. Su carácter antropológico es esencial: nuestra violencia sobre ellos no nos habla de ellos, sino de nosotros. Por otra parte, Pedro Piedras analiza la obra del director Michael Haneke que, de forma cinematográfica, se vale de "utilizar la imagen del sufrimiento animal como reflejo y heraldo del sufrimiento humano" (172). El maltrato animal, termina afirmando el autor, "se convierte en horrible preludio del otro" (Ídem).

Partiendo de la tesis de que los filósofos de habla española y portuguesa son invisibles, Pablo Drews elabora un mapa de los porqués y propone una "terapia argumentativa" (180) apostando por la filosofía fermentaria del gran filósofo uruguayo Carlos Vaz Ferreira. Estos porqués son estudiados y clasificados en tres grandes vicios que actuarían como freno para la visibilidad misma de la filosofía latinoamericana, a saber, "el fervor sucursalero" (181), el "afán de novedades" (182) y el "entusiasmo nacionalista” (183). A través de la filosofía de Carlos Vaz Ferreira, que aunó su esfuerzo en combatir los malos hábitos mentales y lingüísticos de estos vicios en perpetuo diálogo con la filosofía vitalista, la pragmatista y las filosofías latinoamericanas, afirma que los problemas sociales y políticos de las democracias podrían ser resueltos y tratados de una forma concreta para conseguir así un verdadero crecimiento epistémico y ontológico, tanto como una verdadera visibilidad.

Vanessa Vidal, en una apuesta novedosa derivada de su intrincado y permanente estudio de la obra de Walter Benjamin y Theodor W. Adorno, nos introduce en una de las ideas más complejas de la Modernidad: la de imagen dialéctica. Sin embargo, si bien este concepto es atribuido a Benjamin, la ensayista evidencia a través de un estudio exegético que la primera formulación publicada de esta idea pertenece a Adorno, concretamente, está elaborada en su obra Kierkegaard. Konstruktion des Ästhetischen. Vanessa Vidal lleva a cabo una exposición de las imágenes dialécticas mostrando la profunda relación entre el mito, la imagen y la dialéctica en los textos platónicos entendida por Adorno desde Kierkegaard: "El mito cambia, desarrolla una historia interna al entrar en una nueva configuración con lo conceptual y se convierte en imagen en el interior del discurso filosófico" (215). Desde este momento, mostrará la importancia de esta reflexión de Adorno sobre las imágenes dialécticas, proponiendo la necesidad de utilizarlas como el verdadero instrumento de la filosofía contemporánea.

El breve ensayo "Walter Benjamin hacia el surrealismo" de Salvador Cuenca Almenar focaliza su atención en el viraje benjaminiano del interés por la obra barroca y romántica alemana hacia la Vanguardia artística y política surrealista. Las tesis transformadoras y liberadoras del surrealismo - el goce corporal, la experiencia viva, entre otras- apoyaron su crítica al concepto de experiencia kantiano, a saber: el empobrecimiento moderno de la experiencia. De forma amena y perspicaz, Salvador Cuenca profundiza en estas tesis y cartografía el sentir intelectual del berlinés y sus influencias filosóficas y políticas. Como final abierto, el ensayista plantea una actividad teórico-práctica: mirar nuestra sociedad con los ojos críticos en momentos concretos de nuestra actualidad.

Desde la antropología política, Miquel Ángel Martínez y Josep Artés, en "Relatos salvajes, bárbaros y civilizados. La importancia de la antropología en el análisis de Deleuze y Guattari", presentan y estudian las constituciones de las diferentes formaciones del poder y el respectivo control y dominio por parte de éstas de la población en su implementación histórica. Apoyándose en el Anti-Edipo de G. Deleuze y F. Guattari, proponen una relectura de las categorías tradicionales básicas de la antropología oc- 
cidental. De este modo, el "salvaje" -o máquina territorial de las sociedades contra el Estado-, el "bárbaro" - o máquina despótica de las sociedades imperialistas- y el "civilizado" -o máquina capitalista- son presentados para comprender y entrever desde la antropología las consecuencias, dimensiones y repercusiones de las políticas ejercidas por el poder contemporáneo del sistema neoliberal.

Analizando una de las obras fundamentales de Cormac McCarthy, Meridiano de sangre, Juan David Mateu realiza una lectura antropológica extremadamente concisa y muy atenta de los personajes principales de la novela para evidenciar las figuras de la alteridad que aparecen en el "occidente salvaje". De este modo, identifica al salvaje -los indios-, al bárbaro -los mercenarios-y a los civilizados -el juez- para, desde los ojos y el relato de un niño sin nombre, hacer comprensible que la línea que diferencia a estas categorías conceptuales antropológicas no sólo no es clara, sino que es inexistente. Juan David Mateu argumenta y demuestra, siempre desde una lectura profunda del texto, cómo todos los personajes entrecruzan esas definiciones, mostrando así que todos tienen una naturaleza humana inexorablemente unida a la violencia y la destrucción. Elementos, por otra parte, que le llevan a plantear y a elaborar una enjundiosa discusión filosófica sobre la propia naturaleza humana y su carácter violento.

En "Epistemologías y política de la psiquiatría. Apuntes sobre psiquiatría crítica" Carlos García-García hace una presentación rigurosa de la creación y la historia de la psiquiatría crítica y, basándose en reflexiones aportadas por sus padres fundadores Ronald Laing, Michel Foucault, Thomas Szasz y Erving Goffman- despierta al lector la necesidad epistémica de preguntarse por la inexacta vinculación de la psiquiatría con el saber científico o -la petición de esta corriente- a las humanidades. Desde la psiquiatría crítica, defiende Carlos García-García, hay un ataque directo a la concepción mecanicista-cientificista del ser humano y una apuesta por entender al paciente como una subjetividad compleja y dinámica, apostando así por un cambio político e institucional en la disciplina de la psiquiatría.

Paolo Stellino evidencia en "Orientalismo, perspectivismo y representaciones cinematográficas de la guerra de Irak" cómo la hegemonía cultural americana es transmisora en sus producciones fílmicas de una perspectiva reduccionista sobre Oriente. ${ }^{1}$ En la línea de E. Said, Paolo Stellino desvela esta problemática a través de un análisis fílmico certero, tanto de las escenas de diversas películas como de sus diálogos. La crítica se realiza inmanentemente contra los prejuicios, la falta de reflexión que el film mismo prohíbe por su estructura cinematográfica, el reduccionismo y la flagrante eliminación de las diferentes perspectivas que no sean las "adecuadas" para los intereses culturales hegemónicos, transmitiendo así una "óptica deforme y reductiva" (371) de la realidad.

Jordi Valor, en "Retos que la verdad plantea al relativismo", sugiere un debate epistémico que afecta de lleno a la antropología cultural. El ensayo nos sitúa ante las problemáticas fundacionales del relativismo, mostrándonos cómo en función de la necesidad, valor, fuerza, exigencia o ambivalencia que se le dé al concepto de verdad, las prácticas, sobre todo en la antropología, pueden verse seriamente afectadas. Su propuesta es hacer entender que, si bien el relativista "no puede renunciar a la verdad

1 Paolo Stellino comenta que, ya en la primera imagen del film American Sniper, se deja constancia de esta relación conflictiva entre Occidente y Oriente como un "choque de civilizaciones". Paolo Stellino, "Orientalismo, perspectivismo y representaciones cinematográficas de la guerra de Irak”, en: Ibíd., pp. 366-367. 
de forma categórica", el relativista debe "desarrollar sus ideas sobre la coexistencia de una pluralidad de marcos normativos igual de valiosos" (413).

Por último, Joan B. Llinares presenta en "Notas de filosofía y antropología filosófica en las memorias de Buchenwald de Jorge Semprún" no sólo un breve y riguroso relato vital sobre el intelectual español, sino un discurso intrínseco que elabora toda la trayectoria literaria y humanista desde sus primeros años como estudiante de filosofía hasta la presentación de los temas trascendentales de los que Semprún habló, trató, investigó y sintió a lo largo de toda su vida: el mal, la libertad, la muerte y Dios. Joan B. Llinares se introduce en las problemáticas filosóficas a través de las discusiones de Semprún no sólo con la tradición más antigua, sino con la contemporánea: Kant, Schelling, Heidegger o Wittgenstein son los interlocutores de un hombre que, como el mismo Joan B. Llinares afirma en la primera página de su ensayo, no merece ser desconocido.

Antropología filosófica y literatura, por tanto, tiene, dentro de sí, no sólo un excelente ejemplo de una mirada antropológico-filosófica sobre la literatura, sino la demostración tácita e inmanente de que es en la lectura lenta y sosegada de los textos donde una persona puede encontrar el amor por un oficio crítico y una disciplina vital, personal e íntima: la reflexión sobre el "yo", el "otro" y el "nosotros". 


\title{
A propósito de Chandler, o la novela policíaca como tratado filosófico
}

\author{
Juan Evaristo Valls Boix*
}

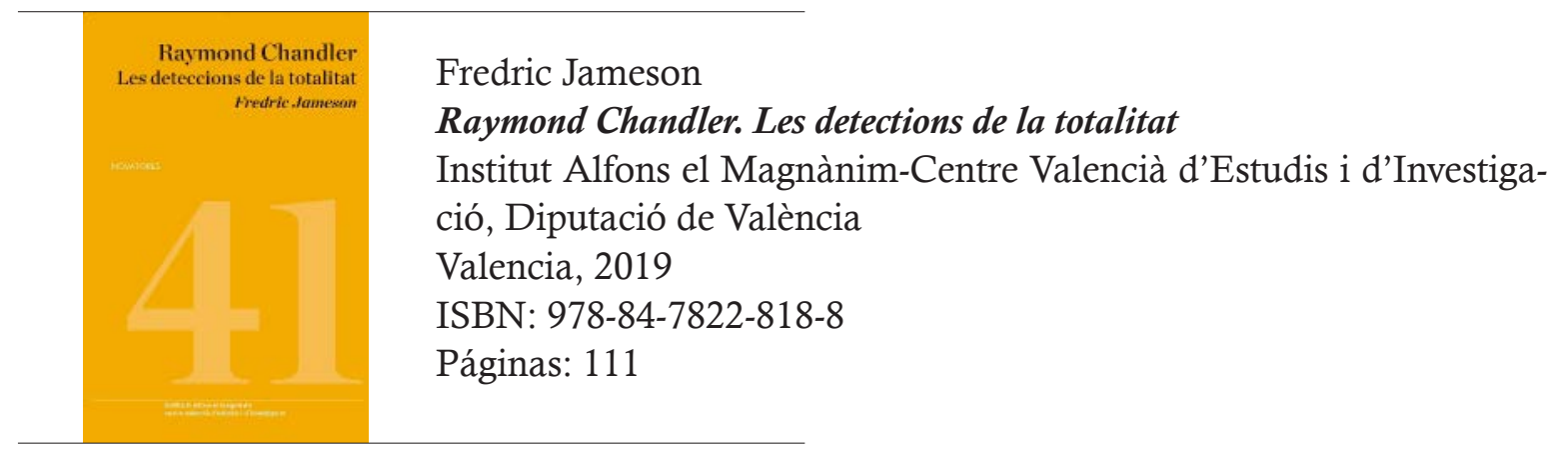

El Instiut Alfons el Magnànim acaba de publicar en su colección Novatores uno de los últimos libros de Fredric Jameson: Raymond Chandler. Les detections de la totalitat, un delicioso, agudo y breve estudio sobre la poética del escritor de Los Ángeles que recorre estratégicamente toda su narrativa para estudiar su forma de pensar el espacio y las ciudades contemporáneas. Se trata de una edición cuidada que llama a la lectura lenta, y cuya traducción al valenciano, rigurosa y fluida, firma Núria Molines.

La primera estampa que nos brinda Jameson es la de Raymond Chandler como un pintor de la vida estadounidense, que afrontó la tarea de escribir novelas compuestas por miríadas de fragmentos que describían los espacios y los modos de vida norteamericanos. Si estos habían resultado hasta el momento esquivos a la literatura "seria", solo la novela policíaca, sin temor al desprestigio, podía abordar con solvencia la tarea de escribir la vida fragmentada y la ciudad de las distancias para pensarlos desde toda la complejidad que encierra lo cotidiano. Chandler pudo hacer esto y, de paso, reinventó la novela policiaca, donde ya no se trataba de un misterio cuyas intrigas solo la mente despierta del detective podía reducir al cálculo de la lógica racional, sino antes bien de pensar el espacio urbano, y pensarlo como un lugar estructuralmente desordenado. Lo que con Chandler uno aprende de Los Ángeles, para expandirlo después a cualquier ciudad contemporánea, es que la auténtica esencia de las cosas es artificial e inesencial; que es la banalidad y el asfalto lo más profundo, y el anonimato, el sustrato de toda presunción de originalidad.

Al pensar las calles y su basura, el poder del dinero, la soledad, los celos y la mezquindad como ordenación espacial, y todo lo desajustado que conforma el movimiento de la ciudad, Raymond Chandler acometió lo más difícil: pensar la insignificancia, leer aquello que no se deja leer, escuchar una ciudad gobernada y ordenada por el capitalismo tardío. De ahí que Marlowe no sea un policía ni busque el orden: tan solo es un detective, un Private Eye que escudriña la ruina y los restos, los márgenes de las

* *Universitat de Barcelona, España. juanevaristovallsboix@gmail.com 
calles. Mientras que el detective contempla, la policía ordena. Si el detective salva la ciudad al comprenderla en su desajuste, el policía la condena: la ciudad siempre es culpable, siempre criminal y siempre esquiva ante el orden. Vigilar y contemplar, por ende, nunca fueron tan distintos. Con Chandler se tornan tan diferentes como dominar y redimir. El tránsito de un verbo al otro llevó a Chandler a cultivar un género pulp con el afán y la obcecación del modernismo europeo. Su mayor propósito fue el de pensar el espacio.

La vida estadounidense, nos explica Jameson en su lectura de Chandler, no tiene forma fija ni trascendencia, y no está sometida al peso simbólico que carga la vieja Europa. De ahí que las formas de vida americanas hayan de reinventarse a cada punto, y la noción de experiencia haya de cuestionarse y revisarse continuamente desde sus mismas condiciones de posibilidad. Mientras que la literatura europea es metafísica y da por sentado como punto de partida una cierta naturaleza de la sociedad que impone una ordenación del espacio, la literatura americana, sostiene Jameson, nunca va más allá de ese punto de partida: toda imagen de Estados Unidos, todo proyecto de ciudad, ha de confrontarse con su misma imagen y levantarse sin modelo. Así, si el símbolo de la coherencia social lo encarnaban en el s. XIX los apartamentos parisinos, que componían un mapa social con sus dos entradas, sus intérieurs burgueses y sus chambres de bonne para el servicio, son Los Ángeles la capital del s. XX: es esta ciudad la que testimonia que la coherencia social parisina se ha tornado imposible, y que no caben ya mapas sociales definitivos: Los Ángeles despliega una horizontalidad sin término, un amalgama de elementos dispersos e inarmónicos que conforman, sin vertebrarla, la sociedad. No hay estructura privilegiada que nos permita comprender la sociedad in toto, sino que solo queda presentar, y este es el minucioso ejercicio de Chandler, el conjunto aglomerado y mestizo de todos los elementos que componen, sin ordenarla, la vida de las calles.

Chandler muestra cómo la sociedad americana, a diferencia de la europea, articulada como una sustancia social cohesionada, se caracteriza por una separación inicial de unos con otros, una separación que se proyecta como forma espacial para hacer, de la ciudad, una topografía de la soledad, una topografía que impugna o dificulta la experiencia colectiva y sitúa en su centro la distancia: el aparcamiento del motel, la movilidad del tráfico como centro de lo que en algún momento fue estable. Desde las atalayas de los coches o el aislamiento en la oficina que tan acertadamente pintara Hopper, solo cabe mirar, asomarse al abismo que separa unas soledades de otras, escudriñar qué hay al otro lado de la distancia. De ahí que solo una novela de detectives, escritura de la mirada solitaria, pueda dar cuenta de esta vida estadounidense contemporánea. Pensar la vida del s. XX, y anticipar la del XXI, no es sino recorrer, si acaso se pudiera, las calles de Los Ángeles.

Por todo ello, la escritura de Chandler tiene un componente profundamente desmitificador, tanto de la imagen idealizada de la ciudad como del crimen como trama narrativa. Para desenmascarar la primera, observa Jameson, Chandler presta suma atención a las condiciones materiales de la sociedad que evoca: sea por la recurrente descripción de mercancías y marcas para pensar relaciones sociales, sea por la diversidad de registros y formas de oralidad con las que caracteriza, a través del lenguaje, todos los estratos sociales, sea por el modo en que el reparto de la riqueza y las condiciones de vida tienen un impacto directo en la organización espacial, que estructura la novela a través de una tipología de espacios que retorna una y otra vez al despacho: 
soledad y distancia. En cuanto a la desmitificación del crimen, las novelas de Chandler nunca han sido un ejercicio de ingenio ni un enigma matemático: nunca tuvieron interés alguno por la resolución del crimen ni por la inteligencia del detective: desmitificar supone aquí también impugnar el recurso al ideal y a la forma cerrada y unitaria.

Los crímenes no conforman la novela sino que son una excusa para su desarrollo. El crimen es antes un punto abstracto en cada novela concebido para hacer converger todas las líneas narrativas hacia él, pero nada más. Lo que habitualmente quedaba como el fondo o el paisaje del crimen pasa aquí a primer plano: es la realidad material de las calles la que toma como excusa el relato ideal de la novela para desplegarse. En Chandler, la violencia aleatoria del argumento secundario interviene para contaminar el crimen central, y se trata de una violencia tan físicamente abrupta como moralmente banal e insignificante. Puede el lector esperar la resolución de un rompecabezas intelectual, el triunfo del sentido, la racionalización de la real, la última palabra del orden, el restablecimiento de la justicia. De pronto, no obstante, se revelan todas estas expectativas como una distracción, como el propio velo ideológico y espectacular con que la ciudad oculta su basura, cubre su roña y normaliza sus mil violencias cotidianas. Frente a la tradición inglesa de la figura del detective, a Chandler no le interesa la resolución del misterio, sino perseverar en la radical carencia de significado de la calle. Pensar la realidad, con Chandler, consiste pues no en desear el misterio, sino en asumir la banalidad, pasar del sentido oculto a la insignificancia patente. Toda la trama acaba siendo una distracción, o una excusa, para el despliegue de descripciones del espacio, de detalles, muecas y gestos de la gente, la observación del movimiento de las mercancías, el malestar generalizado y la sofisticación de sus formas, el rostro que el trabajo imprime a la sociedad y cómo el espacio urbano se constituye por esa huella.

Concluye Jameson su ensayo con una pertinente observación. Durante todo el estudio, trata de leer la obra de Chandler desde una estética estructuralista, que combina la sistematicidad estructural y el valor estético, y que entiende a este último como un efecto de la interacción de los elementos de tal sistematicidad. De ahí que Jameson analice la tipología chandleriana de espacios y piense el desarrollo de las novelas a partir de su combinación y sucesión, un ejercicio que resulta muy satisfactorio en las primeras novelas de Chandler y que permite construir un mapa cognitivo chandleriano. Sin embargo, en las posteriores novelas, desde The High Window, Chandler invoca estos mapas cognitivos al mismo tiempo que desconfía profundamente de ellos, y evita la atribución definitiva y apriorística de valores o posiciones fijas a los espacios. Mantiene Chandler, señalará Jameson evocando a Heidegger, una falla o una grieta entre la dimensión espacial y la hermenéutica, para señalar un hiato constitutivo de la interpretación, una enésima distancia que esta no puede salvar. La ciudad, así, se lee en la forma de lo ilegible; la realidad de la ciudad está quebrada y resiste a su pleno ordenamiento, a la totalidad de la mirada y al reajuste policial. La mirada del detective es aquella que sospecha, no que vigila: sospechar, mirar por debajo, no es aquí sino advertir la grieta y la falta de sentido, y evitar que pase desapercibida.

El propósito de la filosofía, la estética y la política, concluye Jameson, habría de consistir no en cubrir esta distancia, sino en mantener la inconmensurabilidad del espacio y el sentido, las calles y los mapas. Cultivar esa tensión es el mayor logro de Chandler, su mayor acierto estético, su ingenio filosófico y, en fin, su principal clamor de justicia. Es esta apertura al margen, a la alteridad, a las calles fuera del mapa, el secreto final de la narrativa chandleriana, lo que alienta y encalla al tiempo la lectura. 
Es esa exuberancia de materia insignificante, toda la basura, los parias, criminales y donnadies que habitan las calles, la que excita la búsqueda del detective. En definitiva, tras la lectura de Jameson, uno puede encontrar en Chandler aquello que con tanto esmero delineó Siegfried Kracauer: la novela policíaca como tratado filosófico. 


\section{Videre aude!}

Anacleto Ferrer*

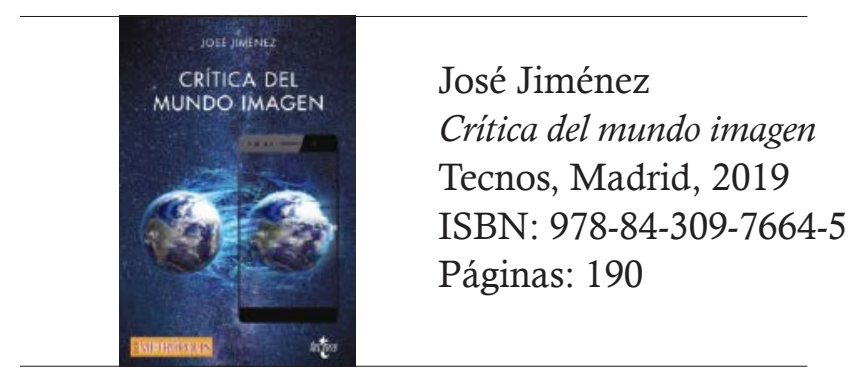

José Jiménez, Catedrático de Estética y Teoría de las Artes de la Universidad Autónoma de Madrid y ensayista con una larga y brillante trayectoria, ha publicado recientemente una nueva obra en la que indaga sobre el papel diferenciador de la imagen artística en el momento histórico, caracterizado por la uniformización de la galaxia de la imagen hipermediática, en que nos hallamos ínsitos.

Se trata de un libro ambicioso en su propósito, complejo en sus planteamientos y, no obstante, diáfano en su estilo, una trinidad difícil de conseguir en la escritura filosófica. Pues de eso se trata, de un libro de filosofia: "Que pretende elaborar, transmitir, una estela de pensamiento crítico para cuestionar en qué mundo vivimos. De dónde venimos. Adónde vamos. Cuáles son los rasgos, factores, determinantes del proceso de nuestro mundo: el mundo moderno, desde sus inicios hasta hoy, en estos años en que el mundo se ha configurado plenamente como el mundo imagen" (9-10).

Las preguntas que orientan la investigación de Jiménez, que combinan lo antropológico con lo estético confiriéndoles sintonía con el reto de su ya extensa producción, la sitúan deliberadamente en la estela del pensamiento crítico de Immanuel Kant, y su caracterización del juicio estético como desinteresado, y el concepto de genealogía en la línea de los planteamientos de Friedrich Nietzsche, es decir, no historicista, sino de reconstrucción procesual de las experiencias humanas en relación con el tema abordado.

El texto se abre con la constatación de que "[la] uniformización a través de la imagen conlleva la pérdida, la dispersión, la fragmentación, del sentido de la humanidad. De ahí que siga siendo referencial el término modernidad para seguir definiendo nuestra época. Aunque, eso sí: en una nueva fase" (10) en la que ante nuestra mirada se superpone una auténtica cortina icónica. El suyo se presenta, pues, como un trabajo de desvelamiento que vuelve a poner el foco en la alegoría platónica de la caverna, y lo lleva a cabo en siete pasos, los capítulos del libro.

En el primero, el autor, siguiendo la estela de su libro La vida como azar. Complejidad de lo moderno (1989), se pregunta “¿En qué mundo vivimos?”. Es pues un capítulo de diagnóstico. Hemos vivido y vivimos todavía, explica Jiménez, la complejidad de lo

* Universitat de València, España. anacleto.ferrer@uv.es 
moderno, no el relevo epocal de la tan debatida postmodernidad. Una modernidad que lleva inscrito en su núcleo "una referencia central a la experiencia del tiempo" (22), íntimamente ligada al desarrollo de la técnica y a la expansividad de la estética. Así pues, aceleración temporal, implementación técnica y estetización de la experiencia son, a su juicio, los rasgos específicos de la idea de modernidad aún vigente.

El segundo capítulo explora el binomio "Técnica y modernidad" partiendo de la formación de las grandes ciudades y la transición del sujeto social que las habita, en el período de entreguerras del siglo XX, de la multitud (indiferenciada) a la masa (un sector unificado). Un paso que se sitúa "en paralelo con el despliegue de medios masivos de producción y de comunicación cultural" (35).

El tercer capítulo es el dedicado a "La expansión técnica de la imagen", sobre todo desde que la fotografía, en lo que tiene de acto icónico de carácter pragmático, emergiese como primer desencadenante específico del mundo imagen. "Lo que Platón, en su alegoría, denominó caverna, hoy lo podemos llamar cortina icónica, que encierra y aprisiona nuestra mirada" (52), concluye Jiménez.

El capítulo central está consagrado a "La configuración mediático-estética de la experiencia", para lo que se realiza un destilado recorrido por el influjo del diseño, la publicidad y los medios de comunicación de masas, así como un examen de la aparición de las vanguardias, gracias a la expansión de la imagen a partir de la segunda mitad del siglo XIX, y su crisis, ya en el XX, debido "a un distanciamiento de las prácticas artísticas respecto de la sociedad" (63). La estetización de la cultura, de la sociedad y del poder por los grandes dictadores del primer tercio del que Eric J. Hobsbawm -presente en estos análisis junto a las ya clásicas observaciones de Walter Benjaminha llamado el siglo corto, "alcanza su realización más plena en los soportes multi-media" (73) que, por efecto de las innovaciones técnicas, no ha hecho más que intensificarse hasta hoy, en que se ha consumado el experimento de la estetización creciente bajo la forma de la "estetización difusa, omnipresente, en la que vivimos" (74).

Llegados a este punto, se impone una tarea de "rescate de la singularidad, que establece diferencia, heterogeneidad, en el ámbito del continuo global de la imagen" (87), y este es el cometido asignado a las imágenes artísticas, de las que, entre otros asuntos, se habla en el apartado titulado "Despliegues y escenarios de la imagen global": introducir discontinuidades, problematizar, singularizar la imagen ya dada. "Lo decisivo en el proceso artístico de la imagen es "el corte", el extrañamiento, la desvinculación que se introduce respecto del continuo global de la imagen" (97), propone Jiménez.

Los dos capítulos que cierran el libro son "¿Qué es una imagen?” y "Crítica del mundo imagen". En el primero de ellos, tras un documentado seguimiento del concepto filosófico de imagen -por el que desfilan Platón, Aristóteles, Cicerón, Ficino, Blake, Beckett o Pessoa-, el autor reclama una concepción de "las imágenes como formas simbólicas de conocimiento e identidad que se forjan en las distintas culturas humanas para estructurar espacios de sentido, y que circulan a través de distintas vías expresivas o "lenguajes" (149). En el segundo, que funciona como conclusión del conjunto, José Jiménez apuesta por una concepción de la Estética como teoría filosófica en diálogo con las diferentes artes que actúe "como crítica general de la imagen" (148), estableciendo criterios de distinción entre las múltiples clases de imágenes de la hiperpoblada iconosfera contemporánea.

Si la propuesta emancipatoria de la Ilustración era formulada por Kant, en 1784, 
por medio del horaciano sapere aude! (jatrévete a saber!), la invitación del autor de la sugerente obra objeto de esta reseña, en 2019, es a "pasar de mirar a ver: abrir la vía del conocimiento a través de la representación sensible" (163). Videre aude!: jatreve a ver!, a desocultar y diferenciar las formas veladas por la cortina icónica del mundo imagen. 


\title{
La inaplazable memoria del dolor y el sufrimiento
}

\author{
Antonio Notario Ruiz*
}

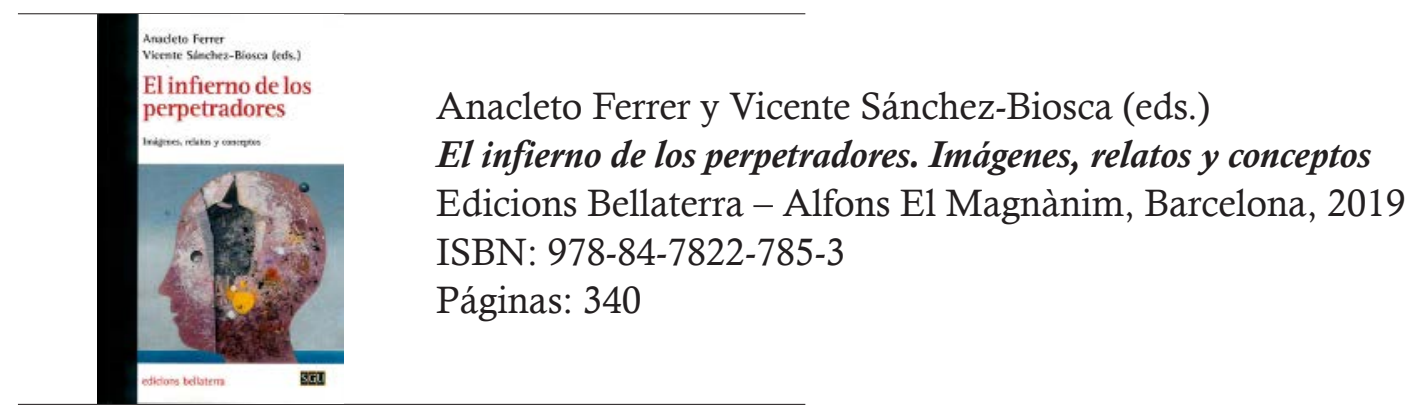

En los compases finales de la Segunda Guerra Mundial, antes de que se conociera por completo la magnitud alcanzada por la voluntad criminal del nazismo, los filósofos Adorno y Horkheimer, entre otros, habían comenzado a llamar la atención sobre las víctimas. Lo hacían desde la filosofía y desde ese paradigma naciente entonces, la Teoría Crítica. Otras voces encontraban expresión para sus experiencias o las de amistades, familiares y vecinos a través de la literatura, como en el caso de Anna Seghers (La séptima cruz, 1939 y La excursión de las muchas muertas, 1943). Aunque había precedentes en los textos de la Escuela de Salamanca-Francisco de Vitoria, Bartolomé de las Casas, Domingo de Soto, Fray Juan Ramírez de Arellano y otros muchos autores-, se configura en los textos de los filósofos francfortianos una categorización de las víctimas como protagonistas de la etapa de terror desatada por los totalitarismos pero también de cara al futuro, encarnándose en los supervivientes. Las presentan como un nuevo sujeto de la historia y no como mera consecuencia de conflictos y guerras. En el momento inicial de la posguerra, tras la liberación de los campos de concentración y de exterminio, surgió la otra ocupación y preocupación: la de buscar a los verdugos y juzgarlos, aunque con escaso éxito penal. Víctimas, supervivientes y verdugos marcan la mayor parte de las teorizaciones y de los relatos hasta el célebre juicio de Eichmann en 1961. Es a partir de ese momento, gracias sobre todo a la cobertura de Hannah Arendt y a sus propuestas teóricas a partir de las declaraciones del nazi, cuando se contempla de frente uno de los problemas subyacentes al asesinato masivo fríamente organizado: el problema del mal en una doble vertiente: como tema central y global, por una parte, y en su individuación en cada uno de los actores que ejecutaron los planes asesinos, por otra. Fueron emergiendo entonces otras preguntas: ¿quiénes asesinaron, torturaron o vejaron a las víctimas? ¿Cómo actuaron? ¿Por qué? Y la gran pregunta, ya indicada también por Adorno sobre la transformación en asesinos, torturadores y violadores de personas que vivían vidas anodinas, normales: ganz normale Männer. Esa

* Universidad de Salamanca, España.anotaz@usal.es 
cuestión es clave para abordar el intento de no repetir esa barbarie.

En esa problemática se inserta esta publicación que solo puede calificarse como acertada, muy bien documentada y recomendable para quienes investiguen en un amplio abanico de disciplinas, desde la historia a la filosofía, la psicología a la teoría de la comunicación, la sociología a la estética, la fotografía al cine y, sin duda, a las personas que investigan en la historia contemporánea de España. La categoría de perpetrador se había tenido en cuenta en el ámbito de la psicología pero aplicada de forma preferente a los casos de violencia doméstica, escolar o de espacios sociales reducidos y en el campo de la criminología. Pero desde los años ochenta del siglo XX ha comenzado su uso en las investigaciones sobre los asesinatos masivos cometidos tanto por diferentes regímenes totalitarios como en conflictos recientes -la guerra en los países balcánicos que formaban la República Federal Popular de Yugoslavia o los conflictos étnicos de Ruanda-. Y desde comienzos de este siglo ha ido emergiendo el uso de esta categoría vinculada con las responsabilidades individuales en los crímenes colectivos: la del perpetrador y como extensión inevitable, los actos de la perpetración. Los investigadores que colaboran en este libro desarrollan diferentes perspectivas, incorporando el ámbito castellanoparlante así a un campo de estudio novedoso pero que ya tiene un cierto recorrido en otras tradiciones como la alemana y la anglosajona.

Han sido Anacleto Ferrer y Vicente Sánchez-Biosca quienes han reunido y editado en este libro doce ensayos, precedidos por una Introducción, alcanzando una densidad asfixiante y angustiosa tanto por el contenido estético y ético como por la profundidad con que se afronta en cada uno de ellos la tarea adorniana de intentar conocer el cómo y el porqué de los comportamientos de diferentes perpetradores de la historia reciente. Desde puntos de vista diversos, utilizando diferente documentación de los campos nazis de exterminio, los asesinatos en Camboya o el sadismo de miembros de las tropas estadounidenses en Irak, un denominador común parece perfilarse en diferentes actividades, en diferentes contextos, sin distinción de sexos o de cualquier otro tipo: la del placer de la mirada que se recrea en la propia obra y tarea de aniquilamiento del otro, obra y tarea que no es fácil dudar que también proporcionaba placer a los perpetradores en algún nivel. Ferrer y Sánchez-Biosca han asumido la propuesta adorniana, planteada en los años sesenta y se han unido con esta publicación a la que podemos denominar como tradición investigadora abierta por Raul Hilberg en 1961, solo que ampliando el campo de estudio a diferentes procesos de destrucción sistematizada del otro.

Entre las muchas fortalezas de este libro no es la menor la incorporación al panorama español de la investigación en un ámbito de problemas que, lejos de estar circunscrito al pasado, sigue vigente. Perpetradores y perpetradoras actúan con facilidad hoy como ayer sin que las sociedades actuales acierten a encontrar la forma de evitarlo. Fuera del foco de esta publicación se puede pensar en los muy recientes casos de la persecución de la minoría rohinyá en Myanmar o en las peligrosas derivas que se perciben en algunos países africanos y asiáticos. También cabría una continuidad de la investigación dirigida a la esfera cotidiana, no por más cercana y reducida menos preocupante que las grandes matanzas burocratizadas o no del siglo XX, en la que se va produciendo día a día esa tragedia que nadie parece ser capaz de detener: los asesinatos de mujeres a manos de sus parejas o exparejas.

El libro que reseño es una obra coral vinculada a un proyecto de investigación que recoge las voces de doce personas, todas ellas relevantes en este campo de investigación 
por trabajos anteriores. El libro está estructurado en una introducción a cargo de los editores y tres partes. La primera recoge los trabajos de Gabriel Gatti (Universidad del País Vasco) que reflexiona sobre las víctimas; el ensayo de Cristina García Pascual (Universidad de Valencia) sobre los perpetradores; y el de Benno Herzog (Universidad de Valencia), ocupado en los mecanismos de silenciamiento e invisibilización. La segunda parte recoge los ensayos de Jesús Casquete (Universidad del País Vasco) sobre las vinculaciones de una parte de la iglesia protestante con la violencia nazi; el de Arturo Lorenzo Aguilar (ULL) sobre algunos aspectos de la película Shoah de Claude Lanzmann; el de Jaume Peris Blanes (Universidad de Valencia) sobre algunas experiencias de la violencia en la dictadura chilena y sus consecuencias; el de Daniela Jara (Universidad de Valparaíso) sobre las representaciones de los perpetradores en la posdictadura chilena. La Tercera Parte reúne el ensayo de Anacleto Ferrer (Universidad de Valencia) que se ocupa de cuatro testimonio fotográficos del Holocausto; el de Rafael R. Tranche (Universidad Complutense) que recupera testimonios y reflexiones en torno a la liberación del campo de Bergen-Belsen; el de Alberto Sucasas (Universidad de A Coruña) que se centra en el victimario; el de Susanne C. Knittel (Universidad de Utrecht) que profundiza en los mecanismo de repetición, reenactment y representación en casos diferentes; y, cerrando el libro, el ensayo de Vicente Sánchez-Biosca (Universidad de Valencia) sobre diferentes vivencias asociadas a los actos de perpetración y sus implicaciones éticas y psicológicas. Cada uno de los ensayos, muy bien documentados en general, aporta elementos para la reflexión, en especial sobre el asesinato masivo organizado por el nazismo, aunque haya también dos ensayos centrados en la violencia asesina desatada en el Chile de la dictadura y en otros se mencionen las matanzas de los jémeres rojos en Camboya o los comportamientos sádicos de personal militar estadounidense en Irak. En muchos de los ensayos se presentan conclusiones pero también preguntas y problemas que quedan abiertos, facilitando el ejercicio crítico para los potenciales lectores.

Sería prolijo reseñar cada uno de los textos por extenso o incluso brevemente, por lo que propongo una selección que, dirigidos hacia objetivos diferentes, sirvan como visión panorámica del libro. Comenzando con Arturo Lozano Aguilar (135-153), se ocupa de uno de los protagonistas de la película de Claude Lanzmann Shoah: uno de los verdugos de Treblinka que ya había sido entrevistado en 1974 por Gitta Sereny. Esta duplicidad de fuentes permite a Lozano Aguilar contrastar la evolución de enfoques históricos entre los años setenta y ochenta. Pero le permite, sobre todo, mostrar la pericia de Lanzmann en su intento por encontrar al verdugo más allá del personaje creado a lo largo de los años y que había conseguido convencer a Gitta Sereny sobre la fiabilidad de su testimonio.

Jaume Peris Blanes afronta en su ensayo (155-175), uno de los más relevantes del libro en mi opinión, varios testimonios de protagonistas de la violencia asesina ejercida por la dictadura chilena. Una parte de esos testimonios se encuentran recogidos en documentales y textos más o menos novelados, aparte de entrevistas de diferente tipo. A diferencia de otros casos estudiados en este libro, en Chile se dio la circunstancia de que algunas personas pasaran de víctimas a verdugos. El que más ocupa a Peris Blanes es el de Alejandra Merino, militante del MIR que acaba colaborando con la DINA tras ser torturada salvajemente por ésta. Lo narra ella misma en el documental dirigido por la compañera de uno de los militantes asesinados por la DINA, Carmen Castillo. Aparece un problema ético y psicológico peculiar puesto que el paso de la 
protagonista del documental -y no solo de ella- de víctima a perpetradora fue el precio de su supervivencia.

Anacleto Ferrer (191-223) ha elegido cuatro ejemplos fotográficos para su reflexión, lo que permite cierta continuidad en la lectura de su ensayo con el de Rafael R. Tranche. Aunque sean cuatro los conjuntos fotográficos elegidos, Ferrer los relaciona con otras fotografías y con algunos documentales y películas. Pero es preciso subrayar el marco teórico que explicita Ferrer antes de analizar las imágenes. Un marco sustentado por Benjamin y Kracauer que le lleva a afirmar que

[1]as imágenes y los conceptos, la representación visual y lingüística, la aprehensión y la comprensión desde la estética y la historia son el haz y el envés de una misma voluntad de apropiación de lo acontecido y de enunciación del acontecimiento no siempre exenta de desajustes (192).

El texto de Rafael R. Tranche se centra en las imágenes del descubrimiento y liberación de Bergen-Belsen, que han acabado dando lugar a un proyecto cinematográfico que no se ha podido ver en su integridad y en el montaje previsto por su inspirador, Sidney Bernstein, hasta el año 2014. La gran variedad de registros tanto fotográficos como filmados y sonoros, la variedad de 'voces' visuales permitieron que se acumulara un archivo que no ha existido en otros casos. Y ese archivo precipita en el documental que no consiguió ver Bernstein pero que ahora puede producir en quienes lo vean la conmoción que Sontag contó que le habían producido las fotografías de la liberación del campo de Bergen-Belsen. Pero el autor plantea una cuestión central que atañe a estas y a todas las imágenes que se comentan en este libro: ¿Cuál es la utilidad de las mismas más allá de "horrorizarnos una vez pasado su momento genésico"? Y él mismo contesta que el visionado de todas estas imágenes convierten al espectador en testigo, "depositario de su transmisión, pero al tiempo le condenan, como a la mujer de Lot, a quedar atrapado en la escena sospechoso de su inacción” (250).

El capítulo que cierra el libro es el escrito por Vicente Sánchez-Biosca (297-337). Se centra en el análisis de imágenes de perpetradores que, a la vez que documentos de barbarie, y tal vez en tanto que tales, se convierten en perpetradoras. Combina análisis de dato de la Segunda Guerra Mundial, de imágenes filmadas del gueto de Varsovia, fotografías de la Camboya aterrorizada por Pol Pot y de los abusos contra los presos por parte de personal militar estadounidense en la segunda guerra del Golfo. Unas y otras le llevan a concluir la dualidad de las imágenes de perpetradores: "constituyen un enigma y un velo" (335), "nacen de una pasión enfermiza, un goce, infligen sufrimiento y lo prolongan en su condición de archivo documental (334).

Memoria y aviso, por lo tanto, más que en cualquier otro texto sobre los diferentes desbordamientos asesinos desde Auschwitz. La filosofía, en la mayoría de sus ramificaciones posibles, no debería contribuir a la desmemoria que se procura desde diferentes centros de poder en la actualidad. Por eso esta publicación ha de servir en debates filosóficos, en la docencia de estética, de ética, de filosofía política tanto como en debates de antropología, de comunicación audiovisual o de sociología. Y sin perder de vista que la documentación audiovisual puede seguir creciendo en relación con esas u otras atrocidades pasadas, presentes o futuras. A la vez, este trabajo contribuye de forma excepcional a avisar sobre las condiciones todavía presentes de construcción de personas dispuestas a perpetrar, da igual si una violación grupal de mujeres a manos de lo que se ha dado en denominar como "manadas", un asesinato de una mujer sin techo en un cajero automático, o palizas mortales a los seguidores rivales de un equipo de fútbol. 
La herencia del dolor y el sufrimiento que nos deja la historia no ha cesado de crecer. Las figuras de la maldad, sus diferentes encarnaciones adquieren una doble presencia gracias a la potencia de la visualidad mecánica o digital. Adquieren también una nueva violencia que no es solo representación de los actos de perpetración. Y no son solo pasado. Lo que Claussen ${ }^{1}$ ha denominado como el imperativo categórico adorniano sigue vigente: organizar el pensamiento y la acción de modo que Auschwitz no se repita de ninguna forma y en ningún nivel. 


\title{
LつCつCNTE
}

RESEÑAS

\section{La alargada sombra de la pintura}

\author{
Raquel Baixauli*
}

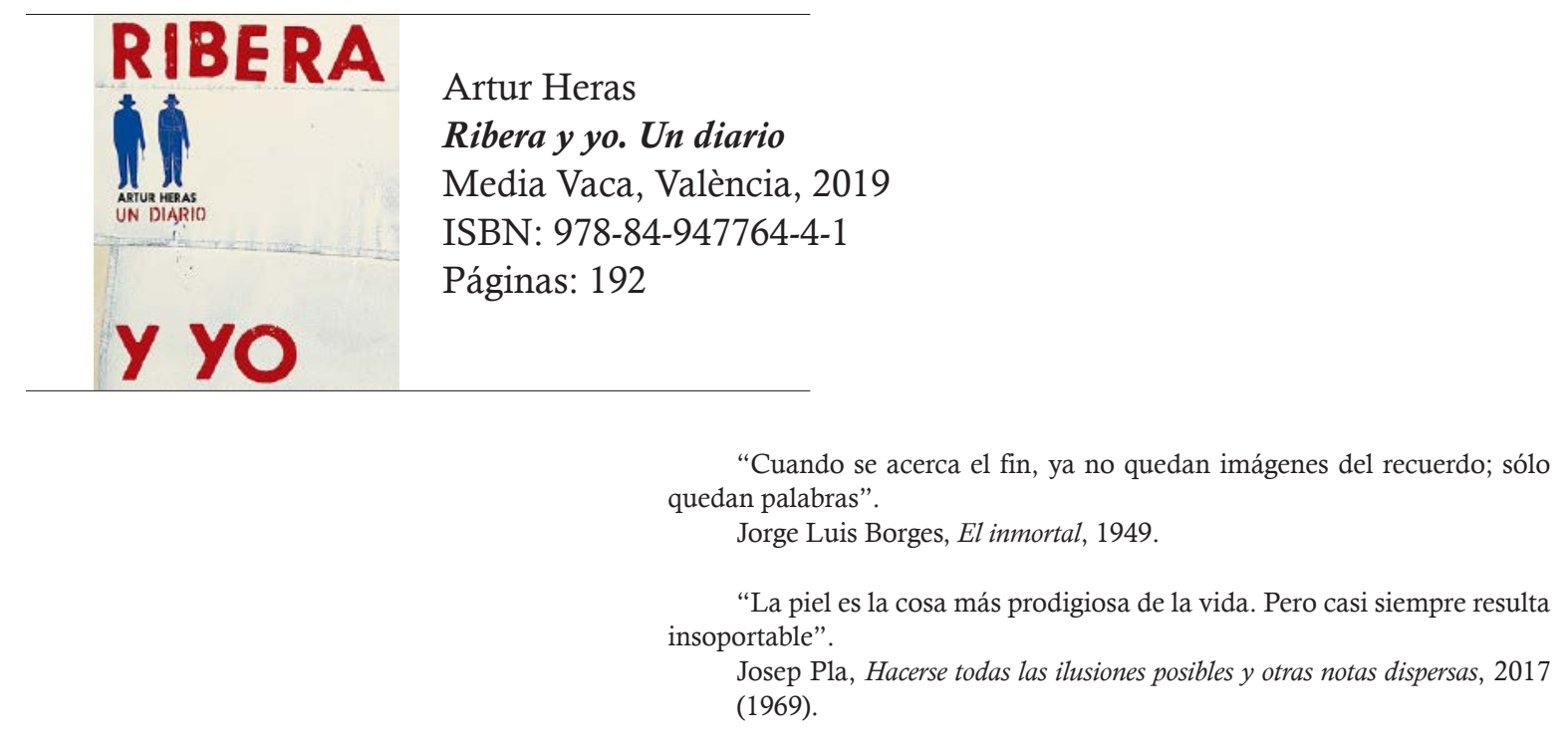

Ribera y yo es, en palabras de su autor, un libro de historias de pintores escrito y dibujado a la sombra de un pintor barroco. Siguiendo la estructura propia de los dietarios, esta obra reúne distintas notas personales de Artur Heras (1945), en las que se intercalan multitud de referencias y datos históricos sobre la vida y obra de José de Ribera (15911652), así como páginas ilustradas que remiten a los clásicos cuadernos de dibujo.

Entre Heras y Ribera existen siglos de distancia. Sin embargo, las vidas de ambos están protagonizadas por similitudes distantes que permiten la identificación del uno con el otro. Al igual que Ribera, el artista y gestor cultural Artur Heras nace en Xàtiva, pero pronto sale de sus calles para formarse en el ambiente cultural valenciano. Ninguno de los dos regresará a su pueblo natal de forma decisiva.

Un simple vistazo a las páginas de este diario ya nos hace entrever que, más allá de su partida de nacimiento, constatada en febrero de 1591 por la Colegiata de Xàtiva, la biografía de Ribera se encuentra plagada de incertidumbres y vacíos. De él sabemos que pronto viajó a Italia, donde se formó definitivamente como pintor, bebiendo del influjo estético de autores como Caravaggio. Tras pasar por ciudades como Roma, Bolonia y Parma, se establecerá en Nápoles hasta su muerte.

En el relato personal de Heras, Ribera aparece y desaparece a la luz de truenos y relámpagos, navegando en el vaivén del tiempo, saltando de 1591, pasando por el año 1955, hasta llegar a 2018. El artista se imagina a José de Ribera embarcando en un galeón, migrando a Génova, y se pregunta si alguna vez habría visto pintada una tempestad. También imagina la infancia que debió de tener, cómo debió de ser su casa en Xàtiva, en la que seguro sacrificaban animales para comer, y observa cómo años 
después pintaría lienzos de santos martirizados con la misma potencia tenebrista. En un intento por (re)conocerse, Heras se pregunta si debió vivir cerca de su calle, y qué música escucharía Ribera. A lo largo del diario, el autor señala cómo pudo influirle el descubrimiento, en 1506, del grupo escultórico Laocoonte y sus hijos. También, durante su estancia en Roma hasta 1616, piensa cómo hechos importantes, como la muerte de Caravaggio o la violación de Artemisia Gentileschi, debieron conmoverle.

A pesar de estos apuntes, las páginas de esta suerte de dietario no tienen intención de construir una biografía del pintor barroco -o al menos, no una biografía al uso-. Por ello, la impronta de Artur Heras impregna el original relato, al introducir referencias culturales de forma dispersa. Citas de lecturas que forman parte de la particular biblioteca de Heras -desde las Novelas ejemplares de Cervantes hasta las palabras insertas en los escritos de Josep Pla, Marguerite Yourcenar, Albert Camús o John Berguer, pasando por Goethe o Stendhal- se cuelan en las páginas del cuaderno avivando el relato, sumadas a menciones a canciones de Raimon, y curiosidades y datos de otros pintores más allá de Ribera como Ignacio Pinazo, Francis Bacon, Pablo Picasso, Antoni Tàpies o Manolo Miralles. Además, entre líneas se atisban vivencias personales y recuerdos de amigos que ya no están, regalándonos un autorretrato único previo a todo un ejercicio de investigación de las emociones.

En esta fusión de voces, Heras reta al lector a través de un complejo juego de percepciones. Gracias a su capacidad magistral de imaginar el pasado y a las vívidas descripciones que realiza a lo largo del texto, el relato se convierte en algo sensorial a la vez que premonitorio. En este juego de espejismos del tiempo, el autor del diario rememora escenas del cine de Buñuel, secuencias sacadas de un film de Kurosawa o personajes distraídos que parecen salidos de las cintas de Pasolini. Y, siguiendo estas recreaciones, el autor parece querer trazar una línea imaginaria entre Valencia y Nápoles, entre él y el propio Ribera.

Las palabras escritas a propósito de Ribera comparten espacio a partes iguales con una gran cantidad de dibujos de Artur Heras. Algunos de ellos son dibujos realizados durante sus años de formación, y remiten a momentos triviales y a instantes de esparcimiento de la vida del artista; otros son, cronológicamente, más recientes y, aunque puedan incorporar nuevas técnicas, presentan la esencia, inicial a la par que única, propia de la firma $\mathrm{AH}$.

Del poder de las imágenes también habla el autor del diario cuando, tras enfrentarse a solas a los cuadros del propio Ribera, decide emular a los gigantes de la mitología griega Ticio e Ixión. Como resultado, estas obras de Artur Heras fueron destacadas protagonistas de la muestra antológica Sura com el desig i el destí en la memòria (2019), exposición celebrada en Xàtiva que conmemoraba sus 55 años como pintor, tras las que se editó, además del respectivo catálogo, el presente diario, Ribera y yo.

Para finalizar, tal como relata Belting en su Antropología de la imagen, es necesario recordar que, para los antiguos griegos -según cuenta Plinio el Viejo- el origen de la pintura respondía a un mito en el que, ante la partida de un hombre, su amada, en su intención de preservarlo de manera eterna, dibujó el contorno de su sombra proyectada en la pared. De Ribera no se conoce ningún autorretrato firmado, pero Artur Heras se imagina cómo debió de ser y contribuye a esbozar su sombra en la pared. A la par, nos ofrece una especie de autorretrato existencial no ya en imágenes, sino en palabras, que habla sobre la muerte a través del nacimiento. En definitiva, este libro habla, aunque incomode, sobre la piel. 


\section{LつCつCNTE}

\section{Sondear la maravilla}

Juan Evaristo Valls Boix*

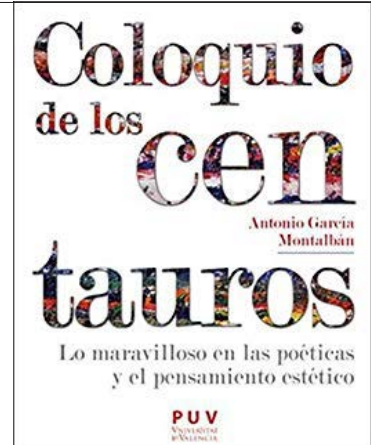

Antonio García Montalbán

Coloquio de los centauros. Lo maravilloso en las poéticas y el pensamiento estético

Publicacions de la Universitat de València (PUV)

Valencia, 2019

ISBN: 978-84-9134-369-1

Páginas: 218

Tan difícil como tentador es tratar de conocer lo que se desea, y más cuando aquello que deseamos es, al mismo tiempo, aquello que tememos, que duele o espanta. Quizá esta mínima nota dé cuenta de por qué lo maravilloso, aquello admirable, sorprendente o extraño, insólito incluso, haya recibido solo tímidamente la atención de la filosofía y la estética, que se han ocupado de categorías más ilustres como lo sublime, el éxtasis y el entusiasmo, lo perfecto, lo grande o lo elevado. Y sin embargo, constante es la tentación ante la dificultad de lo mirífico, irreprimible el deseo por lo extraño y lo insólito, y así lo prueban las diferentes artes a lo largo de los siglos. A esta desatención de los estudiosos, que contrasta con el afán de los artistas y lo que muchos callan, se ha enfrentado Antonio García Montalbán en su Coloquio de los centauros. Lo maravilloso en las poéticas y el pensamiento estético. Su tarea es ardua y pertinente: rescatar la línea teórico-conceptual que ha valorado lo maravilloso en el pensamiento estético de la Modernidad para devolverle a esta categoría la relevancia que nuestros sentimientos y ocultos deseos le confieren, y para satisfacer una carencia en los estudios eruditos de los siglos XVII, XVIII y XIX. Le acompaña en este propósito el profesor Romà de la Calle, que firma el prólogo y apadrina el proyecto con su vasto saber de la época moderna.

No es la primera vez que García Montalbán emprende la labor de sondear la maravilla. Primer fruto de sus esfuerzos fue su tesis doctoral Septentrionalidad y medievalidad en el paradigma arteaguiano de lo maravilloso. Una lectura de las reflexiones de Esteban de Arteaga en Le Rivolucioni del Teatro Musicale Italiano, defendida en 2015 en la Universidad de Valencia y dirigida por el citado Romà de la Calle. García Montalbán se ocupaba en este trabajo de la figura de Esteban de Arteaga, una figura de la teoría estética tan olvidada como la categoría de lo maravilloso. Prosiguió García Montalbán sus estudios con otros dos títulos, publicados en el mismo año: El paradigma arteaguiano de lo maravilloso y el Discurso de lo maravilloso. Esteban de Arteaga y los fundamentos de la ficción historicista romántica. Tras la insistencia en la investigación y divulgación del legado de este autor, García Montalbán expande ahora sus miras a un estudio más general de 
filosofía comparada donde lo maravilloso se define por su contraste con las poéticas y las propuestas de diversos autores. El libro, así, es una historia teórica de lo maravilloso, que no persigue tanto una cronología estricta como los modelos narrativos o tendencias que lo han ido conformando durante los siglos. Sin embargo, no por azar se dedica el enjundioso segundo capítulo del estudio a Arteaga, para glosar la importancia de quien, con sus "Riflessioni sul maraviglioso", comprendido en Le Rivoluzioni del Teatro Musicale Italiano, ofreciera el primer esfuerzo por abordar con detenimiento el difícil concepto de lo maravilloso. Arteaga elabora una historia filosófica del teatro musical, y selecciona los elementos recurrentes que componen lo maravilloso, basando su teoría en la historia de la medievalidad europea y en la fusión del ciclo carolingio con el bretón, para evolucionar después hacia el universo literario del Innamorato de Boiardo, la Gerusalemme Liberata de Tasso o el Furioso de Ariosto.

El libro de García Montalbán destaca por su estilo claro y pausado, que permite desplegar una notable erudición que hace, de la lectura, un viaje por el pensamiento estético de los últimos siglos, de Arteaga a Baudrillard, pasando por Kant, Goethe o Nietzsche. Cita textos originales y casi siempre rescata voces de estudiosos o teóricos perdidas para hacerlas resonar en todo su vigor. Cuida García Montalbán también los títulos, los epígrafes y las partes, y ofrece un conjunto bien pergeñado y muy ordenado de todo el saber que analiza. Comienza, con este estilo, con un capítulo en que trata de ofrecer una aproximación a los precedentes de lo maravilloso, para recorrer las propuestas de Tasso, Francisco de Cascales, Luis Alfonso Carvallo o Jean-François Marmontel. Dedica unas páginas a Kant y a la Crítica del Juicio para revisar el papel central que la imaginación despliega en la experiencia estética, y comparar esta facultad tan habitualmente desatendida con lo maravilloso, igualmente abandonado. Todos estos precedentes sirven para comprender mejor, en el capítulo segundo, el alcance, el interés y la vigencia crítica del pionero trabajo de Esteban de Arteaga, donde la maravilla es sondeada con rigor y detenimiento inusitados.

El capítulo que sucede a los análisis arteaguianos sigue rastreando la categoría de lo maravilloso, y trata de dilucidar su dinámica al ponerla en relación con otros conceptos estéticos que le son muy próximos. Entendiendo que es el descrédito de la imaginación como facultad cognoscitiva lo que ha traído consigo una pobre conceptualización de lo maravilloso, García Montalbán se detiene a describir con notable detalle categorías como lo sublime, el éxtasis, el entusiasmo, lo perfecto y lo grande, buscando encontrar entre todas ellas lo que distingue a lo maravilloso propiamente dicho. Esta categoría cuenta con algo de todas las anteriores, sin reducirse por ello a ninguna. Según concluye García Montalbán, en lo maravilloso es el elemento de lo insólito lo que resulta fundamental y característico. En lo maravilloso, pues, lo raro, extraño y desacostumbrado, es lo más propio y característico. El interés que suscita este rasgo siniestro de lo maravilloso es la potencia subversiva de que está cargado lo insólito, según García Montalbán, lo que torna lo maravilloso en un espacio para la insubordinación, para desatar lo reprimido e imaginar otras formas de lo real. De ahí el vínculo de lo maravilloso con la imaginación, y de ahí la pertinencia de prestar atención a esta categoría, que puede ser la puerta para todo aquello que en un orden permanecía impensado, contenido y desprestigiado.

Concluye la obra de García Montalbán con dos vibrantes capítulos que experimentan con la categoría de lo maravilloso una vez esta se ha hermanado y distinguido de otros conceptos estéticos y se ha relacionado con lo insólito y su potencial subver- 
sivo. El penúltimo capítulo ensaya una lectura dionisíaca de lo maravilloso, que se entiende como la energía de lo demoníaco en Goethe y como la experiencia existencial por antonomasia en Nietzsche, como una "transfiguración" y un desorden. De todo ello, García Montalbán deduce que es en la música donde lo maravilloso dionisíaco se manifiesta plenamente. En el último capítulo, por fin, se ofrece una tentativa de pensar lo maravilloso en relación con las propuestas de algunos autores del pensamiento contemporáneo como Freud, Adorno, Baudrillard o Derrida, entre otros. El rigor y la solidez de los primeros capítulos se ve complementado por la intrepidez y afán de originalidad de las partes finales.

En suma, el Coloquio de los centauros al que García Montalbán nos convida resulta un ejercicio de erudición e inventiva, así como una apuesta por adentrarse en la extrañeza, insólita y subversiva, de lo maravilloso. García Montalbán nos ofrece una cartografía de esta desatendida categoría desde sus antecedentes hasta sus exploraciones contemporáneas, pasando por una enjundiosa teorización de su momento esplendoroso, la Edad Moderna. Con ello nos invita a sondear la maravilla, pese al riesgo de lo extraño y la dificultad de lo desatendido. Pese a todo, cabe dirigir la mirada a lo extraño, y pensar lo maravilloso como un lugar para lo nuevo, para lo inaudito y, en suma, para la expresión de todo aquello que secretamente anhelamos. 


\section{LつCつCNTE}

RESEÑAS

...Y lo sabes

Marc Hernández Montoro*

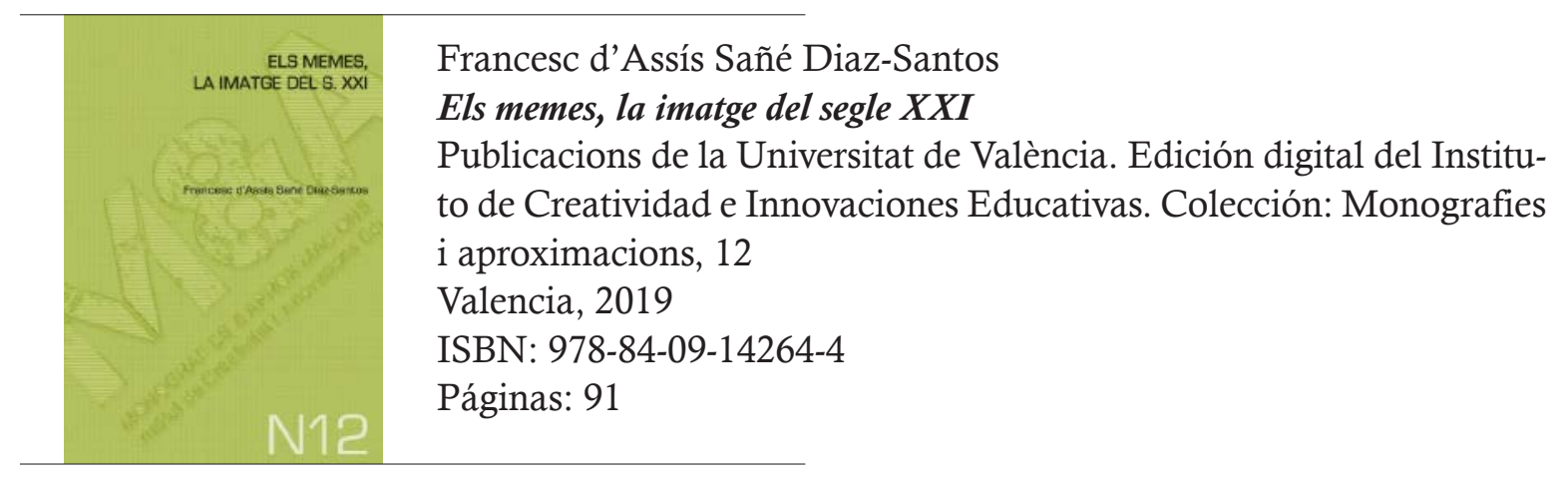

Esta reseña debería comenzar con la frase: "Este es un buen libro... y lo sabes", estampada sobre un retrato de Julio Iglesias. El cantante, fotografiado en vista frontal de tres cuartos, exhibiría una amplia sonrisa y los vestigios de operaciones estéticas sobre su rostro, al tiempo que señalaría con el dedo índice al objetivo de la cámara. Esta imagen ha sido enviada y reenviada millones de veces por las redes sociales, con ligeras modificaciones de la parte inicial del texto. Se trata de uno de los "memes" más populares. Quizás dentro de algunas décadas los memes hayan sido sustituidos por otro producto digital, que ahora no podemos ni imaginar, pero, al escribir estas líneas, se postulan para constituir la "imagen" de lo que ha transcurrido de siglo XXI. Una especie de grafiti del ciberespacio, pero con una peculiar interacción entre la imagen y el texto, y con una pretensión cómica o reflexiva. A este asunto se enfrenta Francisco de Asís Sañé Diaz-Santos en su libro, publicado en catalán, titulado precisamente: Los memes, la imagen del siglo XXI. A pesar de la novedad de esta combinación de textos e imágenes, el autor presenta un conocimiento riguroso del campo y se enfrenta a tres cuestiones fundamentales: 1) cuál, o cuáles son las cualidades que tiene el meme como imagen; 2) cuál es su relación con el individuo (bajo la noción de cuerpo receptor y cuerpo performador de imágenes, como medio, etc.); y 3) cuál es su puesta en escena dentro de una sociedad mediada por imágenes. Para dar respuesta a estas cuestiones, Francisco Sañé organiza una exposición sistemática (aunque también sigue una cierta ilustración histórica), que va adoptando diversos esquemas analíticos e introduciendo paulatinamente al lector en las nociones básicas que han sido formuladas en este ámbito: "memeverse", "dank memes", "memeplex", "referencias", "inside-joke" "starter-packs", etc., y otras del ciberespacio, como "normie", "templates" o "clickbaits", todo un repertorio de neologismos que, como sucede en cualquier innovación, resultan imprescindibles para el análisis del "argumento mémico". Sin duda uno de los con-

* Universitat Autònoma de Barcelona, España.marchernandezmontoro@gmail.com 
ceptos más interesantes que introduce Sañé es el de la "comunidad mémica", una actualización de la comunidad lingüística adaptada a esta peculiar forma comunicativa.

La obra tiene, al menos, dos méritos incuestionables, ya apuntados por el profesor David Casacuberta (UAB) en el prólogo de la obra. En primer lugar, demuestra que la mirada filosófica puede enfrentarse a fenómenos culturales muy actuales donde se combinan elementos heterogéneos como la brevedad, su índole divertida y su amplia y acelerada divulgación (lo que llamamos ahora un fenómeno "viral"), que además no se concreta en soportes clásicos (libro, cuadro, etc.), sino que se fundamenta en las capacidades expresivas de las tecnologías de la era digital. Pero, en definitiva, no otra cosa hicieron en algún momento Siegfried Kracauer, Walter Benjamin o Theodor W. Adorno, por citar ejemplos notables de filósofos del siglo XX, que se enfrentaron a la fotografía, al cine o a la radio, cuando estos medios comenzaron a popularizarse. $Y$ precisamente como los autores mencionados, Sañé también realiza un análisis crítico en el que subraya la capacidad del meme para generar una comunidad y las consecuencias políticas del nuevo fenómeno, que el libro analiza con algunos ejemplos relacionados con el extremismo de derechas o la xenofobia, y ello ya nos conduce a la otra vertiente del análisis.

En segundo lugar, el meme es un mecanismo de elaboración y desarrollo de información, un dispositivo expresivo que tiene efectos sobre la conciencia, y que, por eso mismo, debe interesar a la filosofía y a la estética. El libro explora bien los niveles del meme y su interacción y elementos. No solo la, digamos, filosofía teórica, sino también la práctica, porque, como bien indica Casacuberta, "el meme explora los procesos de remix, de apropiacionismo, del háztelo-tú-mismo del punk; crea metaniveles de ironía, de nuevas lecturas, dinamita los contextos desde dentro, y plantea así una forma nueva de discutir, de analizar de pensar, de filosofar". Por ello, las referencias al análisis del discurso de Foucault resultan más que justificadas. En la creación o recreación de memes, en su envío o reenvío, también están entretejidos los hilos plateados del poder.

Se atribuye al poeta latino Silio Itálico la sentencia "verba volant, scripta manent", es decir: "las palabras vuelan, los escritos permanecen". Dos milenios después bien podríamos decir que verba manent, las palabras se mantienen. Usamos los mismos términos que hace siglos. Aparecen algunos nuevos (como los neologismos mencionados a propósito de los memes), pero los viejos se resisten a morir y buscan su último acomodo entre las hojas de los diccionarios. Pero, gracias a la revolución digital, estamos más bien ante el caso contrario: scripta volant, los escritos vuelan por la Red, los textos dan la vuelta al mundo en fracciones de segundo y bibliotecas enteras pueden ir de un lado a otro con la velocidad del rayo. El meme añade una importante novedad: es un texto más una imagen, o viceversa, que se relacionan de una manera peculiar. Más bien deberíamos decir: scripta et imagines volant, aunque, como bien señala Sañé, la experiencia de ver una imagen de meme o leer su texto difiere de la experiencia de contemplar cualquier otra imagen o leer cualquier otro texto, por las mediaciones que están presentes.

El libro, en definitiva, presenta un análisis riguroso del fenómeno del meme, aunque concluya con un cierto eco wittgensteniano: "El meme no se explica, se muestra", y se cierre en su parte argumental con una frase paradójica "Todo en la vida es meme excepto los memes. Los memes son poder". Pero, en definitiva, la paradoja o la ironía propia de los memes son viejos conocidos de la filosofía desde los tiempos en los que Sócrates deambulaba con sus discípulos por las calles de Atenas.

La obra incluye como anexo una ilustrativa "memeteca", que sin duda se podría 
ampliar en sucesivas ediciones del libro, según la comunidad digital vaya elaborando nuevos memes o alumbrando nuevas formas expresivas.

El libro de Francisco Sañé ha sido publicado por la Universidad de Valencia y se puede descargar libremente de la web de su Instituto de Creatividad e Innovaciones Educativas (www.uv.es/icie), en el espacio dedicado a la colección "Monografies i aproximacions". También se puede conseguir directamente en la dirección: https:// www.uv.es/mia1/memes.pdf. 


\title{
Arqueologías de la modernidad en las artes. Ensayo estético
}

\author{
Carlota Fernández-Jáuregui Rojas*
}

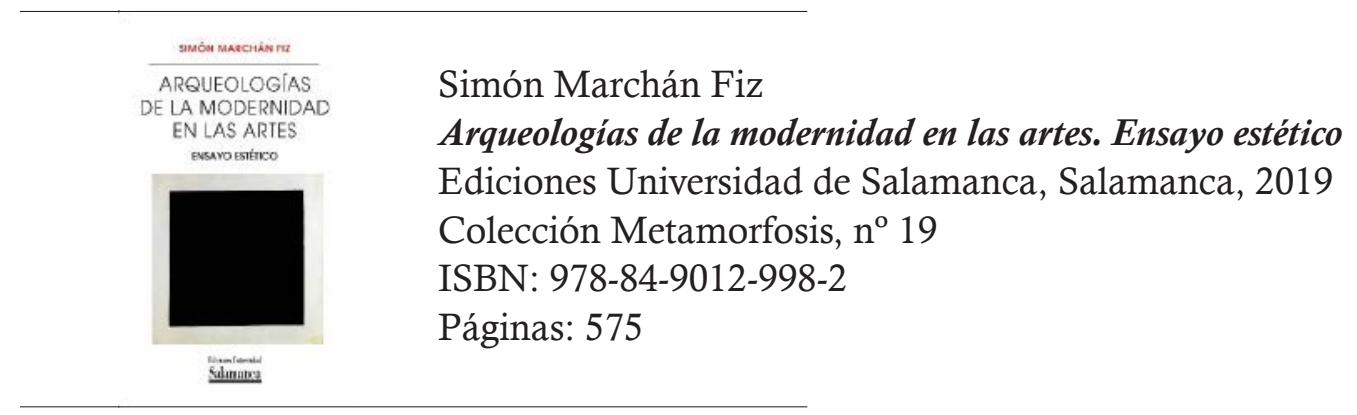

Llegará el día, decía Virgilio en sus Geórgicas, en que el labrador halle, al trabajar la tierra con el arado, las ruinas sepultadas de otra época y contemple entonces admirado "sobre las abiertas tumbas gigantescas osamentas". Son muy pocos los autores capaces de sobrevolar con una visión sinóptica las ruinas de la modernidad en las artes y llevar a cabo una labor arqueológica y retrospectiva con tal conocimiento que permita descubrir y ordenar desde el presente los fragmentos y los estratos históricos, teóricos y simbólicos sobre los que éstas se alzan. Pero más difícil todavía es encontrar quien, lejos de contemplar la modernidad como un paisaje detenido en sus relaciones y en sus momentos, sepa filtrarse e implicarse con generosidad por los desplazamientos internos de sus formas y describir la composición rítmica y dinámica de sus sedimentos. A tan valioso empeño podía sólo acceder un reconocido maestro como Simón Marchán Fiz, construyendo una obra de indudable referencia en la poética topológica de la modernidad y sus ruinas.

La monumental labor arqueológica que el profesor Marchán Fiz emprende en este Ensayo estético está compuesta por textos que, publicados entre 1974 y 2019, son ahora cuidadosamente reunidos y reelaborados. A lo largo de sus páginas, el autor no se detiene únicamente en el hallazgo de los yacimientos de la modernidad artística anclados al momento auroral de su instancia enunciativa sino, más bien, en descubrir los movimientos que trazan esas urnas y tegumentos bajo los estratos de la historia a través de sus "horizontes de posibilidad" y en el desbordamiento y extensión de sus propias figuras, pues natural es de la ruina el no ser nunca primera, sino siempre alzada -ruinas renacentistas, barrocas, románticas, modernas, etc.- sobre el/lo original inalcanzable. Este principio, que a nuestro parecer sostiene estructural y argumentalmente el libro, está en conexión con las paradojas mismas de lo nuevo, expuestas por Hans Robert Jauss en "Tradición literaria y conciencia actual de la modernidad", a saber, el dilema deícticamente insorteable de que ahora ya no es ahora y, por tanto, que lo nuevo es sólo aquello que se separa constantemente de sí mismo. Si con Baudelaire descubrimos que sólo la Nada es nueva -“Au fond de linconnu pour trouver du nouveau!"-, este 
proceso puede quizá encontrarse reflejado en el arco temporal y conceptual que Marchán Fiz dibuja entre la disolución de la forma artística romántica en la modernidad y la disolución que experimenta en la abstracción y en el caos de las vanguardias: "La modernidad acaba confrontándose consigo misma en cuanto recluye cada actualidad en el propio referente y la empuja a una imparable antigüedad" (p. 30). Lo nuevo, podríamos decir, sintetizando la vieja Querelle aquí rememorada, es la desaparición del futuro haciéndose pasado.

En sintonía con la idea anterior, destacaremos en lo que sigue dos hilos que, como tramas principales del libro, entretejen su estructura y su sentido: acontecimiento y desplazamiento. El primero remite a la accidentalidad de lo moderno, en el doble sentido que el autor encuentra tanto en las Lecciones sobre estética de Hegel, donde lo sustancial se contrapone a lo accidental, como en El pintor de la vida moderna de Baudelaire con su oposición de lo fugaz (relativo-circunstancial) a lo ideal (eterno-invariable) y, el segundo, atiende a la "historia efectual" (Wirkungsgeschichte) e "historia conceptual" (Begriffsgeschichte) del arte, es decir, "como una elección reflexiva a partir de las condiciones de posibilidades artísticas que ofrece la historia moderna, supeditada a las condiciones y a los intereses de cada presente" (15). Con ello, Marchán Fiz trasciende, desestabiliza y remueve el detenido acontecimiento con la idea del desplazamiento, una "dinámica de las transformaciones" que se abre hermenéuticamente en lo que denomina los tres "horizontes de posibilidad" de las prácticas artísticas en la modernidad que, a su vez, se corresponden con las tres grandes secciones en que se divide el libro: "El estallido de los referenciales y la quiebra de la representación", "La sublimación en la abstracción" y los "Nuevos pensamientos para los objetos y las imágenes". Si en el primero aborda la pérdida de identificación referencial que sucede entre la imagen artística, su ideal y la realidad (desde la disolución del Clasicismo hasta el Cubismo), en el último examinará el desquiciamiento semiótico y semántico entre el objeto o el hecho artístico y la "situación", dinámica e intercambiable, en la que éste se encuentra (Duchamp y el ready-made, la estética del desperdicio, el Dadaísmo, etc.).

Podemos así afirmar que la idea del efecto -tómese aquí el término en su jerga billarística- es causante de la transformación de un accidente estático (la historia conclusa de los acontecimientos en cuanto hechos artísticos que caen, literalmente, delante de nuestros ojos) en un desplazamiento temporal y formal de las genealogías y discontinuidades, y que ello provocará "una expansión de las artes" en "direcciones imprevisibles" cuyo correlato será la correspondiente extensión en la definición misma del arte (253). Así, por un lado, si la belleza fugitiva y relativa que clama la modernité realiza un primer desplazamiento en lo que el autor denomina el "desbordamiento de lo bello" -planteado en el capítulo "La fealdad reta a la belleza en la pintura y la escultura" (67-99)-, por otro lado, la experiencia moderna sobre la pérdida de lo que llamábamos un aurático el/lo original, desembocaría en un segundo desplazamiento hacia la búsqueda de unos orígenes antropológicos, aquí representados en la querencia primitivista del arte según autores como Gauguin, Einstein o Picasso en su retorno hacia formas míticas y rituales -"Las nostalgias de lo primitivo" (181-197)-, por un lado, y en su vuelta, por otro, a los fenómenos naturales y las sensaciones que claman autores como Cézanne o Matisse en una especie de "protovisión" que pone en suspenso la percepción y la sensación - "El retorno a los fenómenos en la pintura moderna" (101-130)-, mediante la oscilación fenomenológica entre lo que el autor denomina la tendencia "autocéntrica" de la percepción hacia las formas y la tendencia "alocén- 
trica" hacia la luz y el color (121-122). Esta oscilación constituiría el efecto activador por el cual un acontecimiento artístico y cultural concreto (la vuelta a los fenómenos) se manifiesta en un desarrollo histórico a partir de una serie de relaciones existentes "entre la figura y el fondo en el Impresionismo, de la luz y del color o del color en el Postimpresionismo o los modos de aparición del objeto en Cézanne" (122). Por ello, el autor propone la existencia de dos caras en la modernidad, que reúnen en su formulación componentes estáticos (accidentales) y dinámicos (deslizamientos): una "accidentalidad exterior" (vuelta a los fenómenos) y una "accidentalidad interior" (de los simbolismos y surrealismos en su retorno antropológico al "otro", a lo interior animal, a lo primitivo ritual, etc.). De este modo, asoman a lo largo del libro términos que implican no sólo el hallazgo de un "yacimiento", una "ruina" o una "quiebra" sino, más bien, la "cartografía" o "arqueología" de los "deslizamientos" y transferencias de aquello que se desborda, que rebasa y que rebosa, que se ramifica y metamorfosea. Quizá porque una de las lecciones que se desprenden de la historia de la Estética es que los hombres estamos destinados a tener que hacer algo con lo bello, aquello que sólo podemos soportar, en términos rilkeanos, transformándolo en otra cosa, emplazándolo a otra época, o desplazándolo hacia otro lugar. ¿Será ese mismo desplazamiento el que motive la "belleza de la indiferencia", compañera de la angustia que causa todo lo que no parece reversible, que trazaría la línea desde el fragmento barroco, la alegoría y las naturalezas muertas (477) hasta Duchamp (466)?

No sólo las rupturas, los desgastes y excedentes motivan nuevos desarrollos -del mismo modo que, en términos freudianos, lo reprimido aflora en su repetición-; también las carencias crean -a manera de contrapaso- la emulación por el arte de aquello mismo que lo destruye y disuelve en cada momento. Así, "el artista moderno", sentado en la roca de su ahora vacío, "a pesar de y precisamente por esta carencia", desarrolla una dependencia de su época, escribe Marchán Fiz, mayor que en los historicismos "pues su modo radical de ser histórico, prendado de cada actualidad, auspicia una hipóstasis del presente" (31). Si con Baudelaire se instauraba en la conciencia poética el Tiempo destructor del Ideal, y con Bergson el Instante anegaba el interior de la percepción en el Sujeto, cabría encontrar un mismo gesto destructor en la poética de la velocidad y la estética de las máquinas (ferrocarriles, aviones, automóviles) y en las prácticas artísticas del tiempo moderno (fotografía, danza y, después, cine) que localizara la fuente de su placer en el displacer de no poder detener el instante, ese que un día fue tan bello. A este proceso dedica el autor el capítulo "La percepción artística dinámica en la pintura, la escultura y la fotografía" (131-180) donde estudia el modo en el que la "percepción estática tradicional es complementada o sustituida", en un nuevo desplazamiento o deslizamiento, "por una percepción dinámica, cinemática", cuyo acontecimiento-efecto habría de encontrarse en "los ritmos que imprimen en nuestras vidas las máquinas y la ciudad, promovida por los objetos móviles que invaden los nuevos paisajes industriales y urbanos" (133). Esta nueva percepción de la realidad y de la naturaleza hará del arte un medio para ver (con los desarrollos artificiales y fantasmales de la fotografía y la cinematografía) aquello incluso que el ojo no ve; es decir, que una agudísima sensibilidad y percepción, agitada y excitada cada día con una suerte de estímulos nuevos, nos lleva sin embargo, en nuevo contrapaso, a querer ver más allá de lo que vemos en la Naturaleza gracias al Arte, adentrándonos en aquella búsqueda al fondo de lo desconocido, nuevo ahora para nuestros ojos y nuestros sentidos, que desembocará en la sustitución de la visión por la concepción en Apollinaire 
en su deriva hacia el cubismo y al arte conceptual (243 y ss.). Este mismo nuevo clima de la modernidad será el que conducirá, según el autor, a las prácticas futuristas, constructivistas y, a través de combinaciones sinestésicas de luz, velocidad y rugido de motores, a la abstracción: "En estas pinturas [se refiere a la serie de 1912 sobre $L a$ velocidad del automóvil de Giacomo Balla] los elementos del vehículo, en particular las ruedas en cuanto condensaciones retóricas, se desintegran en fragmentos", intentando una imposible "representación simultánea de estadios sucesivos del movimiento" que, gracias a múltiples efectos lumínicos y de líneas oblicuas que parecen emular la velocidad del objeto móvil, provocan su desmaterialización "hasta bordear los umbrales de la abstracción" (147). La misma ansiedad que provoca en Monet, Renoir o Pisarro el cambio atmosférico a lo largo de una misma jornada, o el causado por la sucesión de las estaciones, se traslada en el intento de "captar espacialmente la simulación del movimiento" mediante la expresividad del cuerpo humano, sea en acciones suspendidas (Degas o Muybridge) o dinámicas (cronofotografías de Marey o en las danzas de Fuller) y ese intento gestual crearía en torno a la obra de arte tanto la abstracción (nuevamente, por la desmaterialización que provoca el movimiento a través de superposiciones, transparencias y ritmos en las obras de van Gogh, Russolo o Balla) como el Cubismo, entendido como un dar vueltas a un mismo objeto para reconstruir las sucesivas apariencias en la duración de la visión - "Meditaciones estéticas' sobre el cubismo y el futurismo con sus fugas" (199-254)-. El Cubismo, con su serpentina danza alrededor del objeto, sería también efecto de otro deslizamiento, caracterizado como "rehabilitación de lo sensible", es decir, "una sensibilización hacia la materia y hacia una nueva "cultura de los materiales"”, que llevará al "ready-made de Marcel Duchamp y del object trouvé dadaísta surrealista” (252-253).

Desplazamiento y accidentalidad se estrechan especialmente en las mencionadas "nostalgias de lo primitivo", donde "los artefactos y los objetos rituales de los "pueblos primitivos' se inscriben en una estética del acontecimiento que se gesta en el transcurso de una temporalidad; en ella los cambios de funciones y significados impulsan nuevos puntos de vista, nuevos pensamientos, aquel 'extrañamiento' duchampiano, espacio-temporal y semántico, tal vez irrecuperable, de lo que ha sido desterritorializado" (196). De igual modo, Picasso es representado en su "voluntad agresora, disgregadora, impertinente, resistente” ('297) estrechándose su figura a la del Nietzsche de la II Intempestiva, capaces ambos de subirse a las ruinas y de mirar por encima de ellas: contra la historia, por encima de la historia, más allá de ella. El pintor es, en efecto, retratado en este capítulo - "Un artista moderno intempestivo: P. Picasso" (255-297)- en relación al ademán nietzscheano en continua transgresión, soledad y resistencia hacia sus contemporáneos; en su fortaleza; en la creación de discontinuidades a través de la intertextualidad y diálogo con el arte antiguo y clásico y en su proteica pluralidad de estilos.

Si, tal como planteábamos, el artista moderno era capaz de perseguir aquello mismo que destruía su arte (gesto de radical, bellísima y congruente destrucción, por otra parte, también muy nietzscheano), la sección central del libro, dedicada a la abstracción, demuestra cómo un mismo impulso antirrealista y antinaturalista desemboca abstraído en las formas y, a fuerza de introducirse enajenadamente en ellas, abre el espacio abstracto, como un gesto de retorno hacia la Idea, vuelta quizá a aquel Ideal que en Baudelaire impidiera el Spleen, alcanzado ahora mediante los procedimientos de idealización y estetización que acompañan el trabajo de abstracción: si lo nuevo, 
proponíamos, era aquello que se escinde continuamente de sí mismo, lo abstracto podría igualmente definirse como lo que se separa o aísla de todas sus determinaciones accidentales. Vuelta entonces al binomio de Hegel, ahora desde el fin del arte, para encontrar en lo abstracto-abstraído (lo sustancial disuelto) el principio de todo arte. De ahí, según el recorrido por el que nos lleva Marchán Fiz - "El 'principio abstracción' en sus poéticas aurorales" (301-342)-, que Kandisnky reclamara una "nueva época", Malévich "el grado cero" y Mondrian "la nueva imagen", algo en realidad no ajeno a la nueva dispositio que parecían exigir Duchamp o el arte Merz, y que haría de la colocación una nueva manera de ver las cosas, en sintonía con la idea de procedimiento, según la terminología de Shklovsky (384): se trata entonces de una "abstracción instauradora" capaz de simbolizar y realizar nuevos mundos. El "giro espiritual" del arte abstracto en Kandinsky tiene que ver con el "giro verbal" del pensamiento en Mallarmé, Saussure y Shklovski, que Marchán Fiz encontrará en la vuelta de la arquitectura sobre sí misma: el arte abstracto tiende al poder del lenguaje para invocar -en su sentido primero de incipit- la palabra en la mente del oyente como si se tratara de un impulso corporal, un signo gráfico y un sonido (306ss.). Porque, podemos afirmar, la música es el efecto de la poesía que hace devenir el acontecimiento del cuadro en el desplazamiento de la abstracción. Porque entrar en el cuadro es entrar en el poema, y entrar en el poema es entrar en la mente, donde se halla la Idea, lo más parecido a la Nada. Y, de nuevo, es la Nada el único verdadero principio.

El shock que Benjamin encontrara en la experiencia poética moderna de Baudelaire nos parece similar al momento de revelación que ante la Nada abstracta experimentó Kandinsky, según el relato del propio pintor sobre el que lúcidamente reflexionará Marchán Fiz (313): "Y de repente vi por primera vez un cuadro [El almiar de heno de Monet]. Que esto era un almiar de heno, me lo aseguraba el catálogo. No lo podía reconocer. Este no reconocer me era penoso [...] Sentí claramente que el objeto faltaba en este cuadro. Pero inconscientemente se desacreditaba también el objeto como elemento imprescindible del cuadro". Este "amor a última vista", por utilizar la expresión benjaminiana, que sucede aquí entre el pintor y el objeto, se transformará en el adiós a primera vista, podríamos decir, que caracterizaría la experiencia artística de la inobjetividad y del ready-made con respecto a la disolución del objeto y al extrañamiento de su "situación" mediante una nueva "inscripción" o, respectivamente, con la "objetividad potenciada" y la "descontextualización de las citas" en la nueva arquitectura -aspectos tratados en los capítulos "La "inobjetividad" como grado cero de las formas (343-384); "La transfiguración artística de los objetos en la estela de una intuición kantiana" (445-482), y "La arquitectura como crítica de su lenguaje y la abstracción potenciada" (403-442)-.

La liberación del objeto -cuya forma "no modal" referiría Roland Barthes en El grado cero de la escritura, obra invocada por Marchán Fiz en su correlato con la pintura y la arquitectura (374 y 405-406) y desde la que, creemos, podría definirse un nuevo modus, no marcado, para lo modernus - llevará a Duchamp a la "anestética" o "indiferencia visual" (466-471) y a Malévich a encontrar "la construcción de las formas a partir de la nada" rompiendo con la forma en cuanto dialéctica cerrada o clausurada -de nuevo resulta pertinente (y seductor) apuntar la existencia de un paralelo con la deconstrucción que se efectúa sobre el estructuralismo lingüístico-: "Pero yo me he transformado en el cero de las formas y he ido más allá del 0-1" (Malévich apud Marchán 322). Y, siguiendo la teoría de los desplazamientos, lo que podríamos llamar el 
contrapaso de la abstracción será -por efecto de la "función poética" que después definiera Jakobson-, la construcción o, posteriormente, el arte concreto.

Así como la ruina entrega su cuerpo a la naturaleza, que con sus fuerzas la invade y con sus raíces la abraza, dándole un nuevo lugar y sentido, así la obra de Marchán Fiz evita el "pensamiento binario" sobre el arte y la clasificación estática y absoluta de las vanguardias, para conducirnos a un espacio abierto de significación, dominado por los "entrecruzamientos", las "líneas de fuerza", las tensiones y "confrontaciones irresueltas" (542) que mueven con sus "horizontes de posibilidad" estas admirables Arqueologías sin fin.

Las arqueologías aquí trazadas son la huella de una modernidad viva y en movimiento, mudada entre los capítulos que la sostienen, como si se tratara de las fases de metamorfosis que componen la imagen de una siempre sucesiva mariposa. El Ensayo estético de Marchán Fiz, fruto de una labor realizada a lo largo de una vida dedicada a la docencia, a la escritura y al pensamiento es, a su vez, imago de otras "Metamorfosis": las de la excelente colección dirigida durante más de dos décadas por José Luis Molinuevo en el área de Estética y Teoría de las Artes de la Universidad de Salamanca quien, con este último título, pasa el testigo a Domingo Hernández Sánchez como director de la colección. 


\title{
Estética de la Instalación
}

\author{
Luis Cemillán Casis*
}

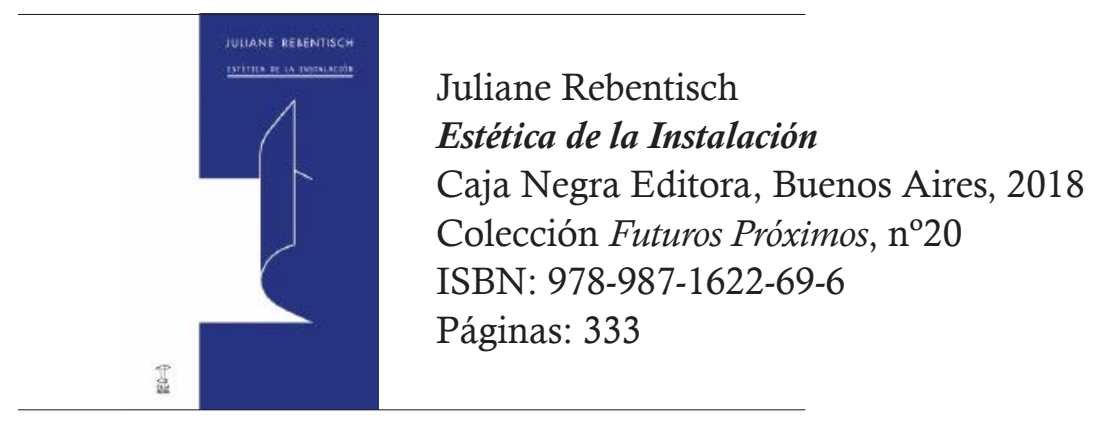

La editorial Caja Negra es la primera que se ha aventurado a publicar en español una de las obras imprescindibles de Juliane Rebentisch, profesora de Filosofía y Estética en la HfG Offenbach y presidenta de la Deutsche Gesellschaft für Ästhetik. Si bien numerosas y heterogéneas han sido las aproximaciones hacia la instalación artística desde que la crítica de arte de los 60 en adelante conceptualizara la posibilidad de un(as) arte(s) expandido(as), este volumen supone, en sí mismo, una expansión desde el propio acercamiento teórico a estas prácticas, al partir la autora desde el ámbito de la estética filosófica. Y es que Estética de la Instalación advierte de que hay que superar la literatura de confrontación que se ha practicado hasta el momento entre el academicismo y el plano de la crítica y prácticas artísticas, ya que se han dedicado a trazar un camino cada vez más irreconciliable entre ambas. Frente a esta disputa, la novedad que se propone con el presente volumen, y pese a que, como advierte la propia autora, el título pueda llevar a confusión, no pasa por tratar de demarcar las peculiaridades de una posible instalación como género artístico, ni tampoco por elaborar una especie de clasificación en base a ejemplos y prototipos concretos. Más bien, bajo un acercamiento desde la metodología de la estética filosófica, Rebentisch se propone defender la capacidad con la que la instalación ha permitido cuestionar y repensar alguno de los problemas esenciales para la teoría del arte (hasta entonces leídos sólo desde la crítica modernista y no tanto desde la filosofía), como son la autonomía de la obra, las posiciones y relación entre sujeto y objeto, lo orgánico e inorgánico... En este sentido, si bien asegura que desde la crítica defensora del modernismo se rechazó en un principio el arte instalativo por su falta (aparente) de autonomía, y que la crítica posmoderna, afín a la instalación, rechazaba de por sí el concepto de autonomía estética, la tesis fundamental de Rebentisch es que al "actualizar, reunir y agudizar problemas centrales del discurso estético moderno” (p.18), una posible defensa de la autonomía por parte del arte instalativo ya no tendría cabida en los estándares o debates del modernismo estético. Así, no se trataría entonces de pensar que la instalación se opone a la autonomía artística, sino que las prácticas instalativas establecen y reformulan un 
"nuevo encuadre" o una nueva forma de pensar su autonomía estética, más allá de la defendida por el discurso objetivista moderno. Y este nuevo encuadre es el que trata de dibujar a través de un complejo volumen (dividido en tres capítulos encabezados por tres problemas propios de la estética), en el que obliga a conversar a múltiples autores tan dispares como Theodor Adorno, Martin Heidegger o Rosalind Krauss, entre otros.

En el primer capítulo, Rebentisch parte de la crítica puramente teatral al reconocer cómo uno de los conceptos clave del arte instalativo es el de la teatralidad, por lo que decide retrotraerse a la crítica a este concepto que protagonizó en los años 60 Stanley Cavell y su traslación a la práctica minimalista por el crítico Michael Fried. Los trabajos de estos críticos atacan directamente al concepto de teatralidad (o al de estetización) al considerar que la separación clásica entre escenario y la sala de espectadores oscura produce una cosificación amoral que distancia al espectador con el mundo y lo sitúa en una relación puramente voyeurística, de compasión y apropiación. Lo que aplicado por Fried para el arte minimalista tiene que ver con la forma con la que la "inclusión" o dependencia del observador y la "literalidad" latentes en las obras minimalistas niegan la "presentidad" en la que se apoya la autonomía del arte: "los materiales no representan ni significan ni aluden a nada: son lo que son y nada más" (57). Como para la crítica modernista el arte debe trascender su objetualidad a través de la forma, para ambos críticos la autonomía de la obra requiere de la prevalencia del objeto estético frente al sujeto observador, al que no se le permite más que reconocer su condición de testigo. No obstante, Rebentisch va a proponer un sentido diferente para el concepto de teatralidad, de tal forma que llega a afirmar que la teatralidad no es una característica propia y por tanto criticable de las obras de instalación, sino que es un rasgo estructural de todo el arte, en tanto que todo objeto estético tiene una presencia escénica doble, como cosa y como signo. Como consecuencia, Rebentisch se posiciona frente al objetivismo estético al afirmar no sólo que el problema de la autonomía no se resuelve otorgando una prioridad del objeto frente al sujeto, ni viceversa, sino reconociendo un "acontecer entre" sujeto y objeto, al que llama experiencia estética, que desestabiliza el "acceso comprensivo del sujeto al objeto estético" (43). Es decir, que para ella la teatralidad no establece ninguna jerarquía entre sujeto-objeto sino que reconoce una asimetría tensional y comunicativa que ocurre en ese entre, por la que el objeto siempre se sustrae a toda fijación definitiva de significado y mantiene con el sujeto una relación experimental. Y, sostiene, si bien "la inclusión del espectador" forma parte tanto de la modernidad como de la posmodernidad, lo que las diferencia es que el arte minimalista y de instalación evidencian de una manera más clara este problema de acceso al objeto y desestabilización del sujeto (que ahora es performativo, corpóreo y móvil), problema que en realidad siempre ha sido insalvable también para la obra moderna. Es decir, para ella el malentendido objetivista sobre la autonomía del arte se supera al entender a la autonomía como experiencia estética; es decir, al asumir que "el arte es autónomo, no a pesar sino a causa de la inagotabilidad de la experiencia" (70).

En el extensísimo segundo capítulo, Rebentisch se detiene sobre cómo el concepto de intermedialidad ha afectado a las modernas clasificaciones de las artes (convencionalmente encasilladas en géneros y categorías) y para el que ha existido un profundo rechazo desde los críticos objetivistas. En primer lugar, la autora comienza recogiendo las aportaciones de aquellos que piensan que la intermedialidad de las artes rechaza a su autonomía, bien porque crean que la autonomía tiene que ver con los recursos o medios específicos de representación (como Clement Greenberg), o porque se rechace 
la incursión de la "espectacularidad" en la industria cultural (Krauss) o porque se defienda que la especificidad del medio entronca directamente con la del género (Fried). No obstante, más allá de identificar la autonomía artística con la especificidad o reafirmación de una posible identidad de cada género, Juliane sigue las tesis de Luhmann para quien la obra de arte es ante todo un "medio social". De esta manera, afirma que la autonomía estética no es algo que dependa de la producción (previa) de la obra ni algo que tenga que ver con un "área de competencia única del artista", sino que la obra existe imprescindiblemente en el proceso de su observación, de su sustracción: "en el proceso de una experiencia de relación de objeto específicamente estética" (111). En este sentido, la intermedialidad no se enfrentaría a la autonomía sino que sería parte de su definición. Y esto es posible porque para ella la autonomía de la obra leída en clave de experiencia estética exige entender el medio artístico no como un recurso de representación específico de cada arte, sino como un llamado a interrelacionarse infinitamente: "el horizonte potencialmente infinito y abierto de las posibles formaciones de interrelación" (109). Cualquier otro intento de identificar la autonomía del arte con su medio específico o habilidad artística no es más que un intento de objetivación en el discurso público; una impresión de orden y unidad. Además, ella llega a demostrar cómo ha sido la crisis propiciada por la intermedialidad la que precisamente ha permitido la reflexión sobre las cualidades específicas de los distintos medios, y no al revés. En segundo y último lugar, Rebentisch aterriza en algunos casos concretos de obras intermediales (instalaciones teatrales, cinematográficas y sonoras) para demostrar cómo estas prácticas no desechan la idea de autonomía estética ni se alejan de la reflexión de los medios concretos, sino que los radicalizan y complejizan.

Por último, en el que supone el capítulo más corto y, quizás por ello, de precipitado cierre, la autora se refiere, con especificidad de sitio, a la doble reflexión sobre el espacio que tematizan la mayor parte de las obras de instalación: el lugar literal de exhibición y la dimensión social en las que se inscriben. Siendo altamente "políticas" (y "politizadas") estas obras, la propia crítica posmoderna ha creído conveniente rechazar la idea de arte autónomo modernista, por creerla apolítica y poco comprometida. No obstante, lo que va a replantear Rebentisch, una vez más, es que ese rechazo sólo se produce si entendemos autonomía según la concepción objetivista en este libro superada. Si, en cambio, nos situamos según la teoría de la experiencia que propone la autora, la simple y vaga referencia semántica al contexto social de las obras instalativas resulta insuficiente para reflexionar sobre su lugar doble. Más que rechazar la autonomía del arte, los trabajos con especificidad de sitio reflexionan, precisamente, en el modo en el que se produce su esteticidad. Entonces, a partir de una relectura de la relación arte-espacio en Heidegger, Rebentisch plantea que algunas instalaciones permiten una experiencia estética en la que se reflexiona sobre el encuadre institucional, social, económico y político al "intervenir formalmente" en una arquitectura dada. De esta manera, la reflexividad del contexto no es contraria a su autonomía, sino un aspecto esencial o fundacional de su definición: los lugares y sus límites no son marcados, fundados, hasta que la obra no los "hace lugar", no los funda estéticamente o los hace legibles frente a sí mismos. Para clarificar estas tesis, Rebentisch termina el capítulo refiriéndose a dos etapas de la especificidad de sitio: las prácticas de los años 70 , en las que la pérdida de la neutralidad del cubo blanco y del museo supusieron una forma de reflexionar sobre el lugar doble del arte y hacer explícita la crítica (interna) a las condiciones de mercantilización del mismo; y las de los años 90, en las que el arte 
atacó a la concepción ética y universal de la subjetividad estética anhelada por la "obra total", y empezó a referirse en cambio a contextos sociales concretos, a individuos situados socialmente y a la forma en la que definen de esta manera su acceso estético a la institución. Eso sí, este sujeto siempre se experimentará con el objeto como performativo, autorreflexivo. Si como antes comentaba Juliane la autonomía como experiencia estética debe entenderse como desestabilización de cualquier acceso comprensivo al objeto estético, el arte sólo va a establecer relaciones de significado siempre que se admita su carácter abierto no objetivable. Por tanto, la obra instalativa de especificidad de sitio carece, ante todo, de sitio.

En último término, el trabajo que nos plantea Rebentisch a los lectores y estudiosos del arte a partir de su obra es doble: pensar el motivo por el que estas líneas han tardado quince años en ser traducidas al castellano (como ocurre con muchos otros trabajos que abordan el tema de las artes expandidas); $y$, teniendo en cuenta estas tesis que alteran por completo la noción de autonomía artística, revisar la totalidad de prácticas de instalación en apogeo en estas últimas décadas para ver, de todas ellas, cuáles propician de verdad una experiencia estética autónoma en un sentido antiobjetivista. 


\section{LつCつCN7E}

RESEÑAS

\section{La herencia de otra época}

María Jesús Godoy Domínguez*

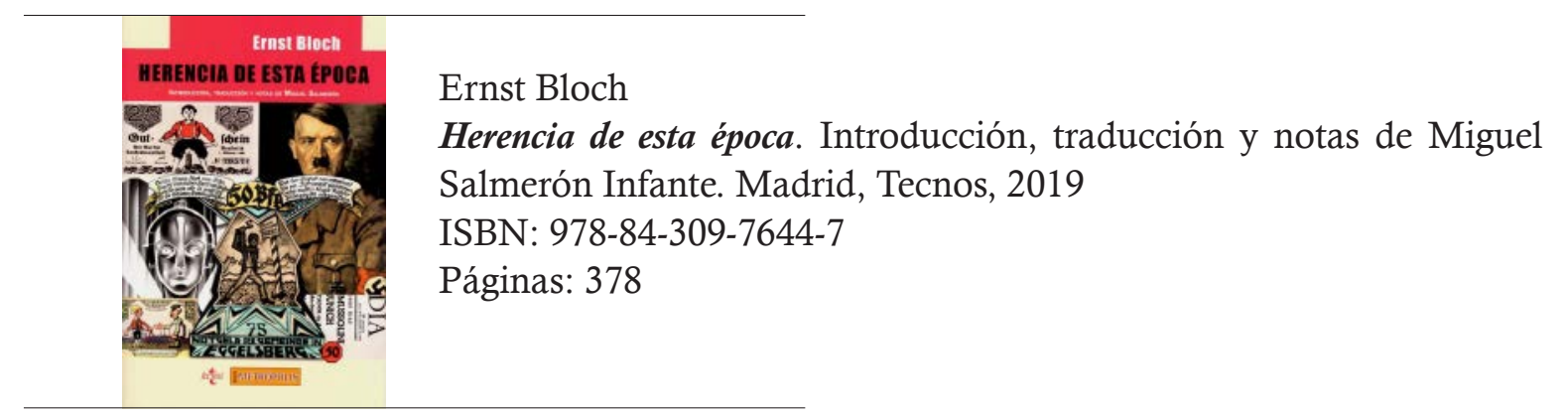

Este 2019 es un año de celebración para quienes sentimos cierta simpatía por la cultura germánica. Celebramos, por un lado, el centenario de la creación de ese centro de enseñanza y de ingente transformación de las artes que fue la Bauhaus y del que hoy en día seguimos siendo en gran medida herederos, al menos en el ámbito del diseño industrial y el diseño gráfico. Celebramos, por otro lado y en relación directa con ello, el centenario también de la Constitución con el que dio oficialmente comienzo ese período democrático de la historia de Alemania conocido como República de Weimar. Por si fuera poco, hemos de celebrar igualmente y, en especial aquí, la primera edición en castellano del libro que nos ocupa, Herencia de esta época [Erbschaft dieser Zeit], obra de uno de los referentes intelectuales en aquellos convulsos años de la Alemania de entreguerras como fue Ernst Bloch.

Ya el responsable de la edición -introducción, traducción y notas- nos garantiza una lectura fluida y erudita del texto. Se trata de Miguel Salmerón Infante, profesor de Estética y Teoría de las Artes y solvente germanista, a quien debemos otras varias traducciones dentro del mundo del pensamiento, como la Estética de lo feo de Karl Rosenkranz (Julio Ollero Editor, 1992; Athenaica, 2015) o Los fundamentos racionales y sociológicos de la música de Max Weber (Tecnos, 2015) y dentro también del mundo de los clásicos literarios alemanes (Goethe, Hölderlin y Kafka, entre otros). A ello hay que añadir una larga trayectoria investigadora, donde figuran precisamente dos estudios monográficos sobre Bloch (Arbor 2009; Bajopalabra, 2010).

De Herencia de esta época, debemos comenzar señalando que fue publicada originariamente en Zurich, en 1935, durante el primer período de exilio del autor judío por varias capitales europeas, una vez que el nazismo se instala en el poder; antes, por tanto, de su marcha definitiva a América en 1938, que lo alejaría de su patria por otros diez años. No podemos perder de vista esta circunstancia porque nos da una de las claves principales para entender el libro, como es su apego -en el sentido baudelairiano- al presente en curso y el análisis político que de él se desprende; algo de esperar en quien a su condición innata de pensador sumaría en los años veinte la de periodista. De ese 
modo, los hechos objetivos, la pura crónica, se hace acompañar de la valoración y el comentario subjetivo gracias a los cuales adquieren entidad y llegan a comprenderse. En definitiva, que hay que leer Herencia de esta época como documento histórico de una época vivida en primera persona -uno de los méritos precisamente de la obra es relatar hechos en el momento mismo en que estaban ocurriendo, la República de Weimar en primer lugar y, tras ella, la Dictadura nacionalsocialista- y como diagnóstico político del asalto de Hitler al poder en 1933, propiciado por el empobrecimiento y proletarización gradual de los alemanes con las capitulaciones de Versalles -recordemos que Alemania fue la gran perdedora de la Primera Guerra Mundial- y, en menor medida también, el Crack del 29.

Pero el libro funciona igualmente como manual de historia de la filosofía, pues en él se pasa revista, y se somete asimismo a duro examen, a corrientes de pensamiento como la fenomenología de Husserl, la ontología de Heidegger, el neokantismo, incluso el socialismo con el que el propio Bloch comulgaba en tanto marxista convencido. Este marxismo se entrelaza curiosamente en el filósofo con su credo judío, produciendo una confianza en la salvación y emancipación humanas -humanidad acotada aquí, como no podía ser de otro modo, al segmento social proletario- de un presente doloroso, mísero y alienante, cuya única responsable es la clase política burguesa y nacionalsocialista. Esta visión utópica y mesiánica de la historia, no le impide ver el que para él es el gran error del movimiento obrero de su tiempo, de sus correligionarios de izquierda: desdeñar, en nombre de un progreso mal entendido, el enorme potencial que el pasado y la herencia cultural encierran -desde la enseña nacional hasta la tradición literaria, pasando por el mito- para el avance y liberación del hombre; potencial del que ha sabido valerse, en cambio y muy astutamente, el fascismo para frenarlos en seco con su inherente carácter retrógrado.

Otra lectura que puede hacerse de Herencia de esta época es la estética, dada la incursión que hace Bloch en el debate de entonces en torno a la representación artística de la realidad. Dicho debate adquiriría en el caso del marxismo un cariz especial, puesto que se trataba de dilucidar qué arte podía servir mejor a la lucha de clases y el cambio revolucionario, el realista o el formalmente innovador. Mientras Luckács se mantuvo aferrado al realismo socialista, firme contra el intento de descomponer artísticamente la imagen del mundo -por burguesa y capitalista que ésta fuera-, Bloch optó sin embargo por la renovación de las vanguardias, por el expresionismo, que singularmente prolífico en suelo alemán, era el que mejor encarnaba una oposición política al nazismo al liberar al arte del culto a los clásicos del que se estaban apropiando el Führer y sus seguidores; expresionismo que no por casualidad formó parte de la muestra que bajo el título de "Arte degenerado" organizaron los nazis en 1937 a modo de escarnio público y condena del arte de vanguardia en general. En el "arte degenerado" justamente de pintores como Kirchner, Beckmann o Nolde, o de dramaturgos como Brecht -por quien Bloch sintió auténtica devoción-, veía el filósofo la semilla de la ansiada liberación, el puente entre un pasado trasnochado y un futuro prometedor cada vez más cerca de volverse presente.

En cuanto a la organización de la obra, aparte de un prólogo a la edición de 1935 y un postscriptum de 1962, donde queda perfectamente definida la posición del autor, consta de tres partes diferenciadas que incluyen el trabajo periodístico de Bloch de los años veinte, por lo que en realidad el libro puede leerse así, según la disposición original del filósofo o según la que quiera darle el propio lector, saltando libremente de un 
sitio a otro. La idea de montaje que Bloch asociara al arte expresionista se traslada a la propia conformación de la obra, que a la manera así prácticamente de un rompecabezas resulta al final un compendio de textos de muy diversa índole-reportajes, críticas, fragmentos, aforismos, como destaca Salmerón en la introducción-, con un mensaje, sin embargo, de conjunto que se resume en la frase con la que Bloch cierra magistralmente su prólogo: "E1 libro quiere contribuir a determinar la longitud y la latitud del viaje final del burgués para que realmente sea su viaje final". 


\title{
LつCつCN7E
}

RESEÑAS

\section{Del Theatrum Mundi al Gran Vidrio}

\author{
Miguel Salmerón Infante
}

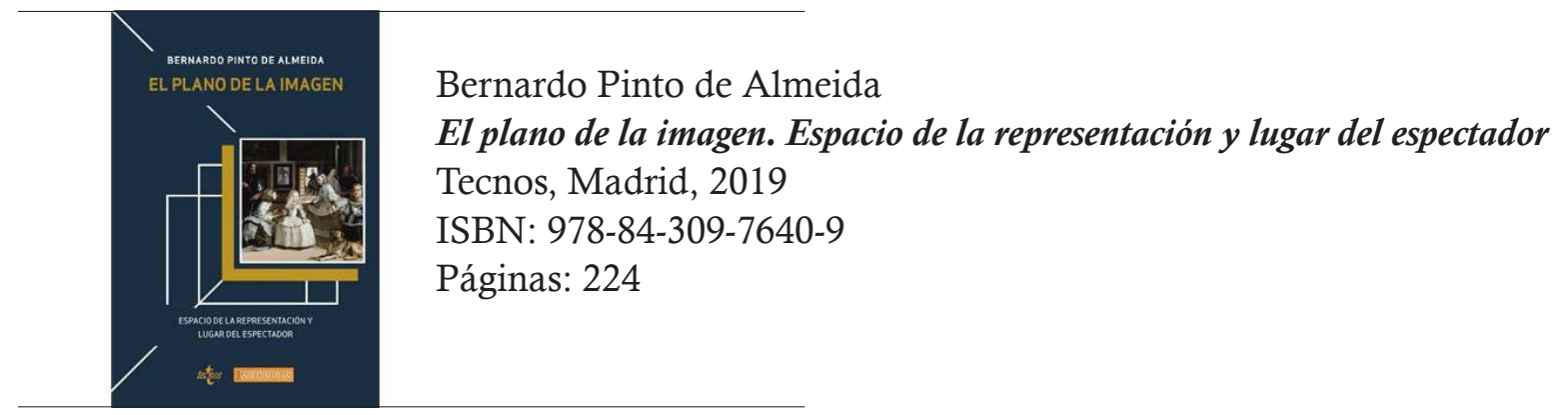

El libro que comentamos quiere ser una arqueología de la modernidad a través de la pintura. A tal efecto se lleva a cabo un recorrido que comienza con Velázquez y acaba con Duchamp, pasando por las estaciones intermedias de Manet y Cézanne.

En este recorrido son fundamentales dos aspectos: la configuración del espacio pictórico y el efecto de los cambios de éste en el papel que va adoptando el espectador. El lugar de esa reflexión es el plano de la imagen: "esa especie de lugar neutro...donde la imagen emerge como un devenir, constituyéndose como lugar de manifestación de una especie de inconsciente de la imagen" (46).

Según Pinto de Almeida, Velázquez introdujo un cambio paradigmático. La perspectiva artificialis derivada del modelo de Alberti, que prolongaba el espacio hacia un punto situado en el infinito, fue contestada por el pintor sevillano con la introducción de un plano de fondo que dotó de cierre al espacio.

Manet, gran admirador de la pintura española, fue el primero que atendió sistemáticamente a la realidad bidimensional del cuadro.

Cézanne afrontó el desafío de relacionar los problemas derivados de la representación de la naturaleza y los problemas culturales o estructurales de la representación.

Finalmente, Duchamp con la utilización expresa del vidrio, incorpora mediante la transparencia aportada por este material, lo interior aunado a lo exterior en el espacio de representación.

El autor parte de la tesis de la "discursividad del objeto". Según ésta, una obra de arte asume de por sí y en sí misma los presupuestos que la determinan.

La de Velázquez fue una época trágica en que el hombre comenzó a dudar tanto de sí, como del sentido de su presencia en el mundo. La mentalidad barroca toma la realidad por una farsa y el mundo como un gran teatro. Por ello, no hay mejor manifestación del espíritu de la época que Las Meninas. La familia de Felipe IV, acompañada de unos cuantos miembros de la corte es mostrada de un modo objetual y en su presente. Con este cuadro, Velázquez introdujo la unidad temporal, el instante y transformó el tiempo pictórico en tiempo del espectador. 
Asumiendo una tesis rotundamente formalista, el autor señala que la importancia de Manet radicó en tener ideas que sólo se podían expresar a través del medio que escogió para hacerlo. En su caso, la pintura. Manet inauguró el espacio vitrina, como Bataille proclamó: "la indiferencia de Manet es la indiferencia suprema". De ese efecto, también llamado "el silencio de la pinura" la manifestación más señera es Un bar del Folies Bergère (1882). Aunque Baudelaire atribuyera la condición de pintor de la vida moderna a Constantin Guys, el verdadero portador de ese título, debería ser Manet. Para el Baudelaire crítico de arte, la modernidad exige fe en el hombre común, en el hombre de la calle. Por ello el amor a la belleza en general no debe hacernos descuidar la belleza circunstancial. De ahí la estrecha relación de Manet con el mundo de la fotografía. El desnudo de mujer representado en Olympia (1863) es bello, pero parece provenir de una de esas fotos de prostituidas que alcanzaron gran difusión en su tiempo. Las carreras de Longchamp (1867), instantánea de una competición ecuestre, análoga a la de un daguerrotipo, muestra, a través de una obra, una escena correspondiente a gustos y estilos que la modernidad determinó como su propia estética, es decir de cómo quería verse a sí misma y que la vieran. La ejecución de Maximiliano (1867) es una cita apropiadora de El tres de mayo en Madrid o Los fusilamientos (1814) de Goya. A su vez, sirviéndose de un muro donde espectadores horrorizados observan la muerte del efímero emperador, da cuenta de la imposibilidad de la fotografía de su época de ofrecer una representación realista de la profundidad.

El capítulo sobre Cézanne se abre con sendas citas de D. H. Lawrence y Kasimir Malevich. El primero sostiene que el pintor fue el primero en intentar captar la manzana en su pura manzanidad, en su appleyness. El segundo, que Cézanne abre el camino hacia la forma de pintar no objetiva, no imitativa. También es importante al respecto la afirmación de Liliane Guerry según la cual, Cézanne se empeñó en su pintura en dar la imagen de aquello que vemos olvidando todo lo que apareció antes. Mientras que Monet pinto un objeto en momentos diferentes, como ocurre con la catedral de Reims, Cézanne pinta el mismo objeto desde diversos ángulos, la célebre Montaña de Sainte Victoire.

Finalmente, al abordar a Duchamp, Pinto de Almeida hace distingos entre dos modos de valorar la Historia del Arte. Entender a Cézanne como precursor del cubismo es propio de la Historia del Arte como continuidad. Entender a Cézanne como precursor de Duchamp es propio de la Historia del Arte como conspiración. La obra de Duchamp, como la de Velázquez, Manet y Cézanne, quiso hacer de la pintura algo más que un efecto de satisfacción de la retina, y aspiró a convertirse en una acción meditada sobre el espacio de representación.

Así, El gran vidrio o La novia desnudada por sus solteros (1915-1923) reduce el espacio de la bidimensionalidad a "lo "infradelgado", a la película, en suma, a la transparencia (finalmente conquistada), frente a la cual el lugar del espectador es definitivamente desplazado, una vez que puede pasar a recorrer el lugar de exposición viendo tanto el frente como el reverso del cuadro (si es que aún puede hablarse de cuadro, de frente y de reverso)" (199).

Resultan también sumamente interesantes las consideraciones del capítulo final donde se señala que el ready-made consagró el papel del museo como lugar de exposición artística, pues l'objet trouvé requirió para su legitimación la presencia, comparecencia y complicidad del espectador. 


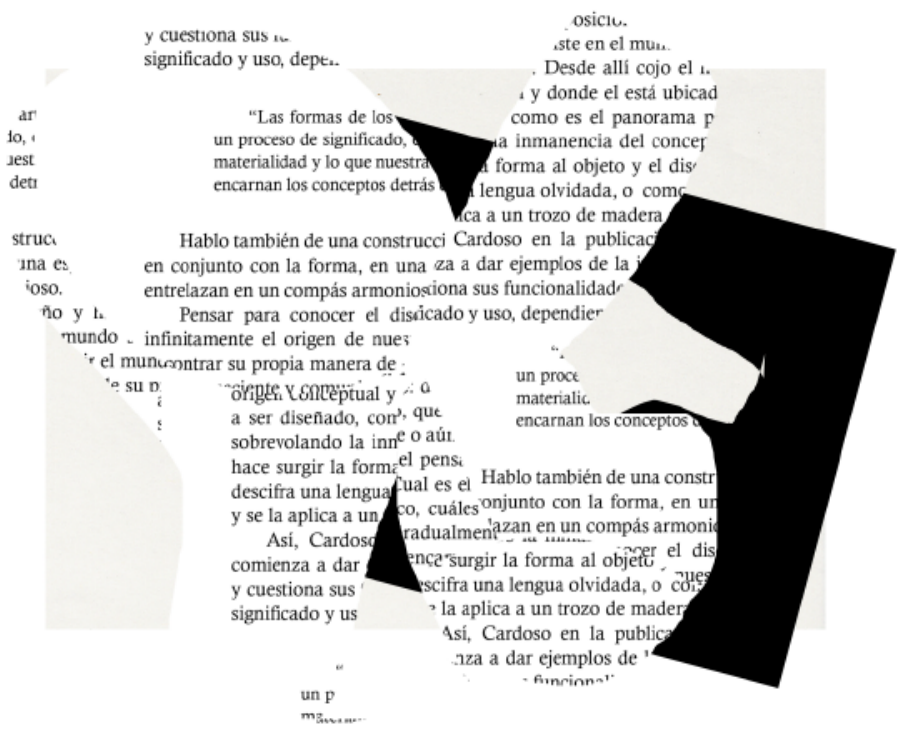

"Lo impreso exige una humildad de espíritu por cuya falta muchas de las bellas artes se tambalean ahora en experimentos de autoconciencia y sensiblería. No hay nada simple ni aburrido en lograr una página transparente. La ostentación vulgar es el doble de fácil que la disciplina".

Beatrice Warde, The Crystal Goblet, or why printings should be invisible (1930)

"El diseño que es objetivo, comprometido con el bien común, bien compuesto y delicado, constituye la base del comportamiento democrático".

Josef Müller-Brockmann, Grid and Design Philosophy (1981) 

EDITA

\section{SEyTA.}

SOCIEDAD ESPAÑLAA
DE ESTETICA Y TEORIA DE LAS ARTES

CON LA COLABORACIÓN DE

\begin{tabular}{|c|c|c|}
\hline 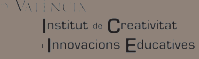 & $\begin{array}{l}\text { VNIVIRSIIN } \\
\text { II) VIIINCL Departament de Filosofia }\end{array}$ & 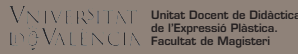 \\
\hline $\begin{array}{l}\text { ESTETICA } \\
\text { FLOSOFIA }\end{array}$ & 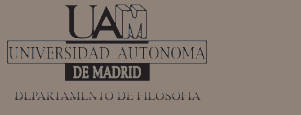 & $\begin{array}{l}\text { UAB } \\
\begin{array}{l}\text { Universitat Autònoma } \\
\text { de Barcelona }\end{array}\end{array}$ \\
\hline
\end{tabular}

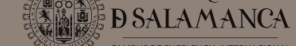

https://ojs.uv.es/index.php/LAOCOONTE/index 